2. MHE ECOLOGY

12 OF EVENAGED

HOREST PEANTAIIONS

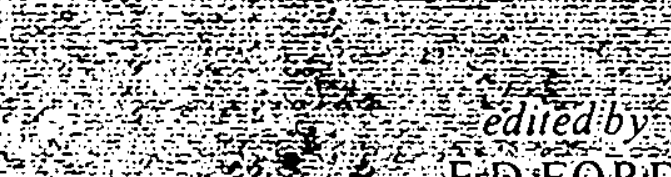

a

N

N

and

(n)

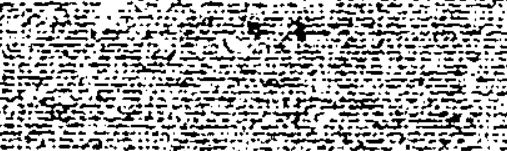

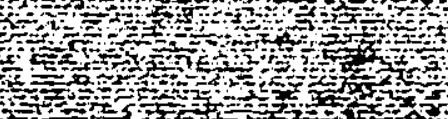

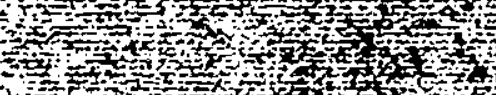

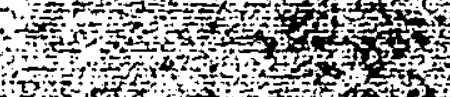

ond

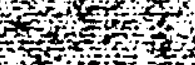

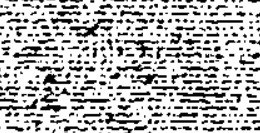

(n)

(n)

3

(n)

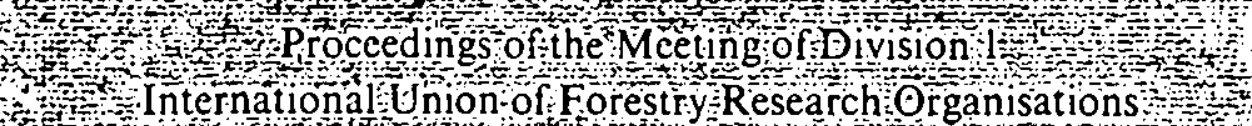

International Union of Forest y Research O $\mathrm{rganisations}$

30 Edinburgh September 1978 
634.0 .18 


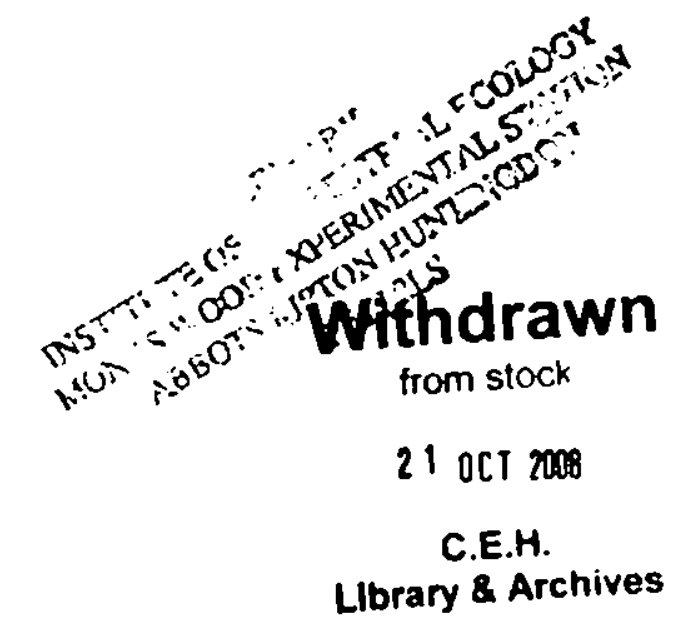

G200065530 

THE F.COLOGY

of

EVEN-AGED FOREST PLANTATIONS 



\title{
The Ecology of \\ Even-Aged Forest Plantations
}

\author{
Proceedings of the \\ Meeting of Division I
}

INTERNATIONAL UNION OF FORESTRY RESEARCH ORGANISATIONS

Edinburgh, September 1978

Edited by

E.D. FORD

Insticute of Terrestrial Ecology, U.K.

D.C. MALCOLM

University of Edinburgh, U.K.

and

J . ATTERSON

Forestry Commfsion, U.K. 


\section{Published b:}

\section{INSTITUTE OF TERRESTRIAL ECOLOGY}

Natural Environment Research Council

Copyright C 1979 . I by the Institute of Terrestrial fcology

L!O!I: YSOBO EXPERI:ACRTAL OTATION,

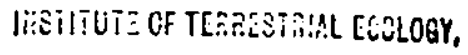

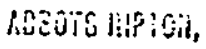

lia:::ji:ivg!!.

$$
\text { H } 3227
$$

6340.18

Further coples of this book

may be obtained from

Institute of Terrestrial Ecology, 68, Hills Road, Cambrldge, CB2 1LA, Uniced Kingdor. Telex 817201 


\section{PREFACE}

The initiative for Division I, 'Site and Silviculcure', of the International Union of Forestry Research Organisations (I.U.F.R.O.) to hold one of its regular full divisional meetings on the ecology of even-aged plantations came from Mr. R.C. Steele, Institute of Terrestrial Ecology, in consultation with the Division Coordinator, Professor D. Mlinsek. Over the past 60 years the United Kingdom has undertaken major afforestation through plantation schemes and so was an appropriate country in which to hold such a meeting.

The organising committee for the meeting was:

Chairman Professor F.T.last, Insticute of Terrestrial Ecology

Secrecary Dr. E.D. Ford, Insticute of Terrestrial Fcology

Mr. J. Atterson, Forestry Commission

Dr. D.C. Malcolro, University of Edinburgh

Mr.'D.T. Seal, Forestry Commission.

The programe of lectures and discussion was held at the Department of Forestry and Natural Resources, University of Edinburgh and at the liniversity's Pollock Halls of Residence. Visits were made to Ae, Dunkeld, Eskdalemuir and Glentress Forests by invilation of the Forestry Comission and the Economic Forestry Group. The programme incorporated the interests of the constituent Working Groups of Division I and was attended by 130 participants from 21 countries.

Further information on the activities of I.U.F.R.O. can be obtained from:

I.U.F.R.O. Secretar1at,

Schönbrunn, A-1131 Vienna, Austria. 



\section{ACKNOWLEDGEMENTS}

We are grateful to Mrs I. Bellos, Miss I. Schumacher and Miss D. Ziegler for their translations of the sumaries of papers into French and German and to our colleagues in I.U.F.R.O., H. Oswald, H.W. Zbttl and G.K. Kenk for their technical comments on these cranslations.

We wish to thank Mr. R.H.F. Wilson who drew the figures and particularly Mrs M.F. Cannell for her painstaking work in the preparation of the cypescript.

\section{EDITORS• NOTE}

This volume has been produced from camera ready copy of a typescript which itself was set by computer. The process lmposed some restrictions on the use of accepted conventions for abbreviations, symbols and units of measurement. As authors did not have the opportunity of correcting proofs responstbility for errors must rest with the editors. 

TABLE OF CONTENTS

\section{INTRODUCTION}

Introduction to the I.U.F.R.O. Division I Conference. D. MINSEK

Introductory address - An introduction to forestry in upland Britain.

G.D. HOLMES

THE PHYSICAL RESOLRCE

Site classification.

R.D.L. TOLEMAN

How do physical classifications contrast with site type classifications?

K. KRELTZER

Strategies for amelioration on poor sites.

J. PAIVANE.N

THE BIOLOGICAL RESOURCE

Variation belween and within tree spectes.

D.A. PERRY

The exploitation of genetic variation by selection and breeding.

R. FAULKNF.R

Biological opportunities for genetic improvement in forest productivity.

M.G.R. CANINELL

THE GROWTH OF PLANTATION FORESTS

An ecological basis for predicting the growth and stability of plantation forests.

E.D. FORD

The development of a flora in even-aged plantations.

M.0. HILL 
The developrent of populations of pests and pathogens in even-aged plantations - fungi. J.S. MURRAY

The development of populations of insects.

M. CROOKF:

NUTRITION

The nutrient budgets of even-aged forests.

H.G. MILIER

Decomposition and nutrient release in even-aged plantations.

O.W. HEAL

Biological weans of improving nutrient uptake in trees.

P.P. KORMANIK

Current fertilizer use in plantations.

J. ATTERSON

THE EFFECTS OF PLANTATIONS ON THE PHYSICAL RESOURCE Evaporation of water from plantation forest.

P.G. JARVIS and J. STEWART

Effects of forest plantations on the quantity, quality and tining of water supplies.

W.L. NUTTER

Soil changes under even-aged plantations.

D.G. PYATT and M.M. CRAVEX

THE EFFF.TS OF PLANTATIONS ON WILDLIFE

Plantation management and vertebrate wildlife.

J.A. ROCHELI.E and F.L. BUNNELL

Even-aged plantations as a habitat for birds.

D. MOSS

Even-aged plantations as a habitat for deer

in central furope.

E. KÖNIG and H. Gossow

The management of red deer in plantations.

A.B. COOPER and W.E.S. YUTCH 
FORFST DESIGN; THE FUTURE DEVELOPMENT OF EVEN-AGED

PLANTATIONS.

The future development of even-aged plantations:

Management implications.

E.J.M. DAVIES

The future developent of even-aged plantations:

Silvicul tural implications.

D.C. MALCOLM

Tropical forests - comparisons and contrasts.

P.G. ADLARD

FOREST PRACTICES AND RESEARCH REQUIREMENTS -

TODAY AND IN THE FUTURE

The way ahead in research and practice.

J.D. MATTHEWS, F.T. LAST and D.T. SEAL

OFFERED PAPERS

Maintenance of productivity in successive rotations

of radiata pine in South Australia.

R. BOARDMAN

Sociocconomic evaluation of the recreational use of fish and wildlife resources in Alberta, Canada. W.E. PHILLIPS and M.R. CARROLL

Variation in tropical tree specles.

P.J. WOOD 
FORESTRY IN GREAT BRITAIN

(Produced by the Forestry Commission) 

그.

$-$


September 3, 1978

\section{INTRODUCTION}

\section{Address by Coordinator of}

Division I

D. Mlinšek

Introductory address:

An introduction to forestry

in upland Britain

G.D. Holmes 



\section{ON ECOLOGY OF EVEN-AGED MONOCULTURES}

Introduction to the International Union of Forestry Research Organisations Division 1 , 'Site and Silviculture' Meeting at EdInburgh, September 1978.

\section{MLINŠEK}

Divisional Coordinator, Biotehniška fakulteta, Krekov trg 1 , 6100 Ljubljana, Jugoslavia.

At first glance the topic 'ecology of monocultures' may appear inappropriate, particularly if we recall the lengthy debates (e.8. Mitscherlich 1958; Wittish 1961) in the past about forest monocultures on the European continent. Monocultures do exist there today but often represent silvicultural formations of dublous value. At the 1975 Division I meeting in Ankara, Mr R.C.Steele proposed that we should examine this toplc and particularly that our venue should be the United Kingdom. We agreed then that this would be appropriate for the regular divisional meeting in 1978 . Today we are realising this idea thanks to the endeavours of Mr Steele and of the local organizing commlttec. On behalf of Division I, I would like to thank them all most sincerely. Particularly I would like to thank them for rendering possible continutey in the work of the Division as practised for a number of years, i.e. the holding of an annual divisional meeting .

While thinking about the 'ecology of even-aged monocultures' we find this topical area most appropriate. At our meeting we have in mind conifer monocultures in particular, yet I would like to draw your attention to the fact that an even-aged beech or oak stand, formed by a shelterwood system, also represents a monoculture and should not be excluded from our discussions.

Nowadays forest monocultures are a fact which cannot be avoided or ignored. From the historical and long-term point of view they frequently represent an obligatory, although often undesirable step in the development of a forest economy. They represent an imitation of agriculture by utilizing pioneer properties of individual tree species interesting from narrow, short-term economic point if view. In addition monocultures are strongly favoured by modern technology. The timber-hungry countrles without forests need monocultures primarily for their wood material - regardless of the timber quality. In the given state of world econoric development we 
have to accept this fact. Equally, we have to take into account the fact, innate to human nature, that we do not learn anything from the experience of others, but only from our own! Here I am referring to silvicultural experience with monocultures in Central Europe.

In the history of forestry we find that the monoculture concept of wood production comes in a wave-like form and frequency which cannot be avolded. The post-war period has been characterized by a huge wave that spread over all the continents, though only in a minor form over Central Europe. In many countries establishing monocultures represents a sign of progress in forestry, a first and essential step without which not further development, characterized by stronger considerations of ecology, can take place. This means that research on monoculture has to be activated, particularly as to its future development. It is a duty of research to study forest monocultures impartially and such impartiality will be quaranteed by an ecological approach - the researcher's realization that in the case of forest formations he deals with a typical black box system. Hence the name of the sessional topic 'ecology of monocultures'

We know a lot about establishing monocultures and there has been much research on this subject. However, it is now necessary to look at the future of monocultures in forestry, and it has to be appreciated, in order to avoid any possible misunderstanding, that there are differences between the ecological and economic points of view.

I hope that our discussions will evaluate viewpoints critically without digressing from the ecosystem starting points. Here I have in mind, for example, the fact that by means of different management methods man keeps reducing biomass in various ecosystems which brings about the most unfavourable consequences. Organized accumulation of blomass is one of the prerequisites for the functioning of a forest ecosystem. From this point of vlew, establishing monocultures with subsequent growth and organized accumulation of biomass is partly justified. But this could not be sald about the cases where we devastate natural forests with great quantities of bionass and replace them with the biomass of artificial forest monocultures.

Our efforts in establishing monocultures in areas where forests no longer exist, are positive from an ecological point of view. This holds true even more if we consider the fact that in forming forest ecosystems nature too uses various ways, even through the ploneer monoculture, with the basic starting goal to create biomass, i.e. Investment. In nature this stage is followed either by a slower or faster transformation of blomass - in some cases nature stays with pure pioneers. In any case nature butlds ecosystems that are more and more perfect. We, too, are facing the question 
whether it is purposeful to stay, at any price, with the pure, al ready established monocultures. The ecology of monocultures should draw actention to the future direction of forestry in monocultures, particularly in the cases where monocultures should perform new tasks of a soclal and procective nature.

The great accomplishments of foresters in deforested Great Britain are admirable. They are clearly evident from the book 'Forest Service' (Ryle 1969), describing the first forty-five years of Forestry combssion work, as well as from the paper presented by Mr George Holmes. The first step was to establish the material base of the forest, $1 . e$. to create biomass. It is possible to progress only after such a base has been created. And thus we read on p.292 of the above-mentioned book that '.... the recreational need will mean a partial breakaway from monoculture sooner or later'. This statenent is particularly attractive since we already know that practical forest management methods should combine wood production with other forest functions. It has to be stressed that in such cases wood production is not diminished.

We have to ask ourselves how to shape existing monocultures in the future in order to neet the new demands of a protective and soctal nature. This is a question of conversion methods which should not be rigorous in their nature. The better a conversion method is adapted to normal forest management, the greater its value. This finding is of the greatest importance considering the fact that the forest ought to rewain a natural counterbalance to artifictal, agricultural ecosystems and industry on a local, reglonal and global scale. Wherever we do insist on artificial monocultures, the following questions of an ecological and economic nature arise: how and to what extent is forestry capable of maintaining artificlal monocultures and what level of artficlality can forestry afford with regard to different site conditions?

Forestry certainly owes mankind help in the ecological crisis. It has been suggested that forestry wlll offer such help by substituting removals in natural forests by high wood production from planatations. I do not belleve such theories, al though they may be of local value. The task of forestry in environmental protection lies elsewhere.

The phenomenon of monoculcures in forestry cannot be avoided. It is necessary, however, to search for ways of diminishing the impact caused by artificlal monocultures. This is an area where ecological research can make an Important contribution, although we should not search for universal prescriptions. Examples and solutions from one site, e.g. specific to Great Britaln, way not be suitable for ecological, economic and soctal reasons elsewhere. Only general findings have untversal value and our discussions should contibute to such findings. 
In the changing world, artifictal monocultures can be both good and evil at the same time. Quite often the character of the newly established forest is dependent primarily on the forester's goodwll, zeal and professional qualification, and only in the second place on the money available for its establishment. And as I am deeply convinced that goodwll prevalls at our meeting, I have great expectations of our foint efforts in. the coming days.

\section{REFERENCES}

Mitscherlich,G.(1958). Bodenverschlechtung und Düngung in ertragskundlicher sicht. Der Forst- und Holzwirt, 13, 415-421.

Ryle,G.B.(1969). Forest Service - the first 45 years. David and Cnarles, Newton Abbott, Devon, U.K.

Wittish,W.(1961). Der Einfluss der Baumart auf den Bodenzustand. Al lgemeine Forstzeltschrift, 16, 41-45. 
THE ECOLOCY OF EVEN-AGED PLANTATIONS:

AN INTRODUCTION TO FORESTRY IN UPLAND BRITAIN

By G.D. HOLMES

Director General, Forestry Commission; 231, Corstorphine Road, Edinburgh, United Kingdom.

\section{SUMMARY}

The need for even-aged forests.

The present structure, productivity, and history of upland forests in Britain.

Rural land use and the prospects for more afforestation.

Ecological changes affecting soil, water, flora, fauna and the forest.

Ecological problems and the reconciliation of the needs of silviculture, environmental management, and operational efficiency.

The importance of research on questions including tree health, tree stabllity, regeneration, soll productivity and wildlife conservation.

The need for sound knowledge of the forest ecosystem as a basis for management decisions.

The value and scope for international debate and cooperation in research.

RÉSUMÉ

Cet exposé traite des sujets suivants:

Besoin de forêts composées de peuplements equiens.

Structure actuelle, productivite et histoire des forêts des Uplands de Grande Bretagne.

Utilisation de l'espace rural et prospectives de plantations nouvelles.

Changements écologiques ayant une influence sur le sol, l'eau, la flore, la faune et la forêt. problèmes d'ordre écologique et reconciliation entre les besolins de la sylviculture, de la gestion de l'environnement et de l'efficacité de la mise en oeuvre.

Importance des recherches sur des questions telles que la santé et la stabllité des arbres, la régénération, la productivite du sol et la protection de la faune sauvage. 
Besoin d'une connaissance solide de l'écosystème de la forêt en tant que base des decisions de gestion forestière.

valeur et nécessité d'un débat à l'échelon international et de la collaboration sur le plan de la recherche.

\section{USAMMENFASSLNG}

Die Arbeit behandelt folgende Themen:

Zweckmässigkeit glelchaltriger Wälder.

Gegenwärlige Struktur, Produktivität und Geschichte der Wälder im britischen Hochland. landwirtschaftiche Landnutzung und Aussichten weiterer Aufforstung.

Veränderungen von Boden, Wasserhaushalt, Flora, Fauna und ihre ökologischen Auswirkungen im Wald.

Ökologische Probleme und die Abstimmung von forstwirtschaftlichen, umweltpolitischen und betriebswirtschaftlichen Anforderungen.

Bedeutung der Forschung in Hinblick auf Forstschutz, Bestandesstabilitat, Verjüngung, Bodenfruchtbarkeit und Erhaltung des Tierbest andes.

Notwendigkeit einer grundlichen Kenntnis des Waldökosysters als crundlage

forstwirtschaftlicher Entscheidungen.

Nutzen und tmfang des internationalen Erfahrungsaustausches und der Zusamenarbeit in der Forschung.

\section{INTRODLCTION}

My prine aim is to introduce you to forestry in Britain by giving a very general picture of our forests, their recent history and place in the land use scene. I also intend to say something about afforestation achievements and a selection of what I believe are the key problems requiring research attention at the present time.

I warmly welcone IUFRO's initialive in holding a full Divisional meeting on the ecology of plantations bccause there is clearly a need for a betcer understanding of wan-made forests as ecosystems in order to provide a sounder foundation for future management decisions. I also welcome your meeting in Britain as I am sure that our experience of large-scale afforestation extending over a period of more than fifty years will provide a highly relevant and helpful background to your discussions. I an equally certain that your deliberations will be great value to British foresters and scientists. 


\section{THE NEED FOR EVEN-AGED PLANTATIONS}

Looking for a moment at the world situation, the need for man-made plantations is increasingly more apparent. The current consumption of wood is about 2500 million cubic metres/yr which is obtained from about 2500 million ha of productive forest land. The world population is now about 3800 million and no matter how successful the world may be in controlling population growth, it seems inevitable that the population will have increased to over 5000 million by 2000 and to sowe 8000 million by 2025. There w11, therefore, be ever increasing pressure on the land to produce both wood and food. Huch of the natural forest will be cleared for agriculture or agro-forestry, and the latter is unlikely to yield large quantitles of wood.

It is possible, given sufficient inputs of capital, manpower and research to increase the yield from natural forests two or threefold but man-made plantations can yield eight to ten times the current world average of 1 cublc metre/ha. Plantations can also be developed on land which is relatively poor, from the point of view of agricultural production. It seems certain, therefore, that high-yielding, even-aged plantations will provide a steadily increasing proportion of the world's growing demand for wood.

\section{FORESTRY IN BRITAIN}

The forest area of Britain per head of population is one of the lowest in Europe while the consumption of wood products is one of the highest. There is thus a very low level of self-sufficiency in wood products at about 8 per cent of consumption.

Although there have been intermittent attempts since the Middle Ages to increase timber production In Britain, a sustained national forest policy aimed at increasing the production of tirber to neet the nation's needs daces only from 1919 when the Forestry Commission was set up as a Government agency with the prime task of creating a reserve of growing timber for defence reasons.

Since that time, policy has evolved by a succession of Government Reviews and the strategic reserve policy of 1919 has given way to more commercial aims based on recognition of the continuing importance of an indigenous supply of wood to industry. At the same time, present policies place much greater emphasis on the social and enviromental benefits of forestry, notably employment, recreation, conservation and integration with agriculture.

$\frac{\text { Planting since } 1919}{\text { The planting }}$

achieverents since 1919 have been considerable. From 1919 to 1977 the area of productive forest doubled from 800,000 to 1.7 million ha, 1 .e. a rise from only 3.5 per cent to nearly 8 per cent of the land area of the 
councry. This expansion has consisted mainly of afforestation with coniferous species on bare heath 1 and, moorland and rough pasture of low value for agriculture, particularly in the uplands of Scotland, the north of England and Wales. It is also noteworthy that this has been achieved by, a combined effort of the public and private sections and that the forest estate of today is almost equally divided between the two (see Table 1). Thus, the planted area has increased by an average

Table 1. Area of productive forests in Great Brltain. 1977 (000's'ha)

Public

$$
\text { Conifers Broadleaves Total }
$$

$\begin{array}{lrrr}\text { (Forestry Comission) } & 791 & 50 & 841 \\ \text { Private } & 502 & 346 & 848 \\ \text { Total } & 1293 & 396 & 1689\end{array}$

of 15,000 ha/yr since 1919, but the greatest expansion has taken place over the last twenty-five years when the average rate of new planting has been about $29,000 \mathrm{ha} / \mathrm{yr}$ or nearly double the 1919-1977 average figure (see Table 2.).

Table 2. New planting - 25 years 1952-1977.

$$
\text { ( } 000^{\circ} \text { s ha) }
$$

Public

Private.

Total

(Forestry Comission)

Total area planted 425

The present species and age-class structure of forest in Britain can be broadly represented as in Figs 1 and 2 .

Future planting.

- Today, much of the debate on forestry policy turns on the question of new planting and how much further expansion should take place. Looking to the future, and even allowing for the substantial increase of forest area in recent years, we remain a poorly forested country and it is unlikely that Britain, even by the year. 2000 , will be able to supply more than about 14 per cent of its needs from home sources. Such is the likely growth of demand for wood products that the country must increase its total forest area to maintain even this degree of self-sufficiency after the turn of this century. This has spectal implications for the country's balance of payents and we have to consider the extent to which we should use resources now to create new plantations as an insurance for the future. In an effort to throw some light on this issue, we, in this country, recently set up a working group to look into the future demand for wood on a world scale and to relate 
HOLMES

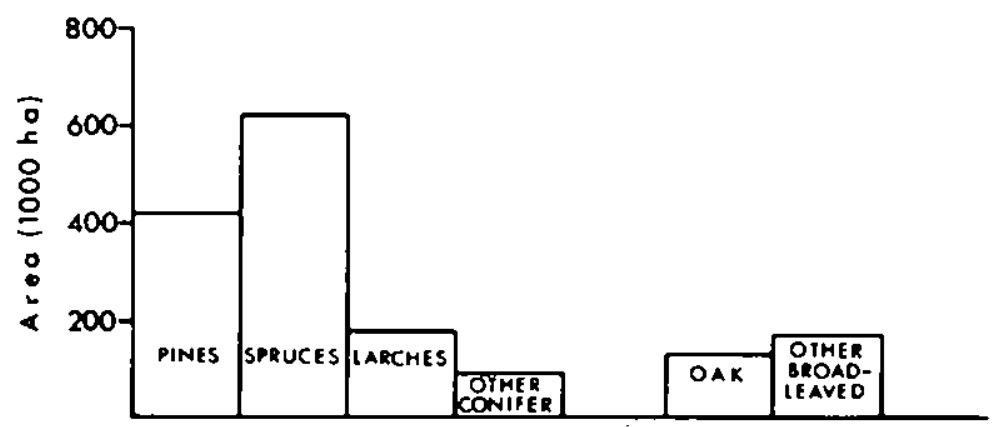

Fig. 1. Distribution of high forest specles groups in Great Britain. (March 1977).

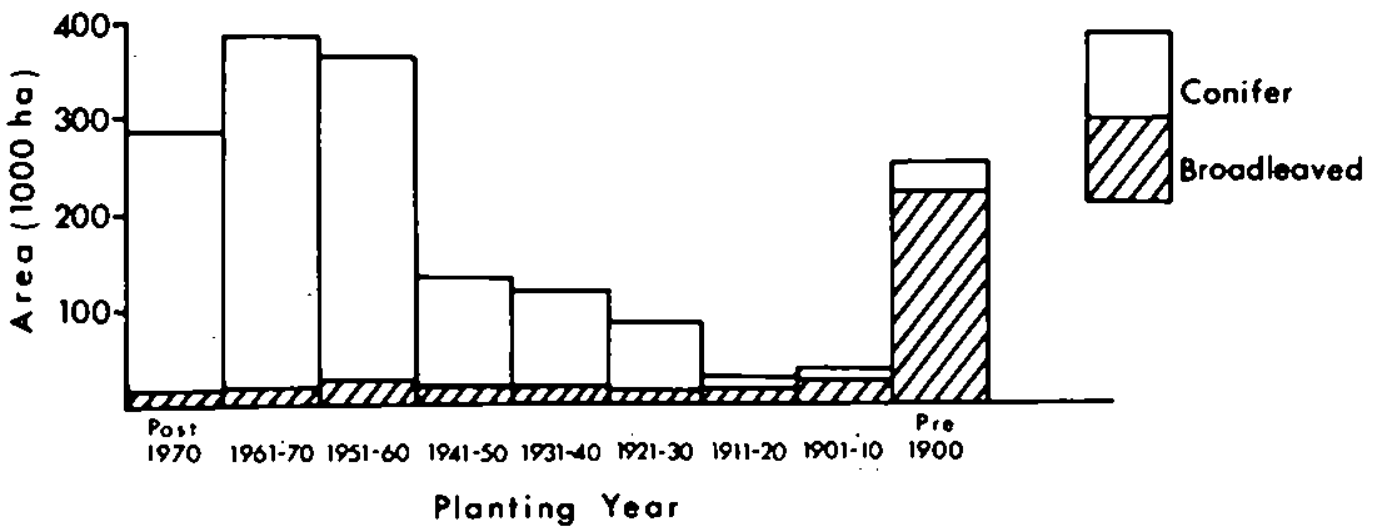

Fig. 2. Age class distribution of high forest in Great Britain (March 1977). 
their findings to the British scene. The group's report was published as a consultative paper earlifer this year and it is suggested that the world's forests will meet the increasing world demand for industrial wood until the turn of the century, without a serious rise in wood prices, but thereafter the continuing upward denand will result in a significant rise in the real price of wood. It is suggested that there should be a substantial continuling programme of new planting to help meet Britain's future needs.

of course, there are technical limits to the amount of land that can be afforested in Britain. Although many soil initations for tree growth can be ameliorated, there still remain areas which are incapable of growing econonic forest crops owing to climatlc conditions. Temperature, when linked with elevation, is importint. Increase in elevation results in reduced temperature and increased exposure and the combination of the two quickly becomes limiting to tree growth. In the uplands, planting rarely takes place above $550 \mathrm{~m}$, and in the more exposed parts of the west and north the planting 1 imit is about 300m.

As well as the physical limitations in the uplands, there are also economic limitations to the extent to which forestry can be practised in the fertile sites of the lowlands, where agriculture and urban developments have high values.

A balance has to be struck. Forestry in this country is really essentially an industry of the foothills and the uplands and this is where we must look to see any expansion.

Excluding areas with clinatic conditions unfavourable to tree growth, thin solls, arable and permanent 8 rassland, it is estimated that about 3 million ha of land in Britain could be planted with trees to produce economic crops of timber. Just over half of this ( 1.7 million ha) is in Scotland. In England and wales there are some 1.3 million ha of potentially plantable land, but constraints on the amount of new planting in kational Parks and in areas of outstanding natural beauty, could reduce the land available there to around 650,000 ha. Furthermore, there are considerable areas of common land in Fingland and wales which are not at present available for planting. Overall in Britain the main constraints on new planting are, of course, the requirements of agriculture.

views on how wuch of this potential area should be planted vary from zero to over 2 million ha. There is a strong case for more planting and how much is achieved will depend in the long run on public attitudes to landscape, to rural employment and lifestyle, and to the value placed on food production in the uplands compared wh wood production. It remains government pollcy that forestry should expand and workable procedures for consultation wh agricultural and environmental and other interests exist in order to ensure that when land is proposed for afforestation, a sensible 
allocation is made between the agricultural, forestry and other interests.

In the end, the alm 1s to achieve a pattern of 1 and use which secures the best contrlbution to the welfare of the nation. This aim is simple to express but to translate it into terms of arcas of 1 and by locations is extremely difficult and could be dangerously wisleading if one tried to do this precisely or by means of simplistic zoning scheves. Land can seldom, if ever, be categorised as being suitable for one and only one use. In practice, differences of interest and tradition, of aims and methods of management and of other factors play an important role in deciding which pattern of land use shall be adopted in a particular situation.

Wood production

New planting now will not affect production until the beginning of the next century and until that time output will be determined by the production goals and cutting plans for the existing forest area. Hardwood production is expected to remain at a level of about 1 million cubic metres/yr over the remainder of this century and although the value of this production is considerable, interest naturally centres on the growth of softwood production. Our latest sofwood production forecasts show an overall increase of 230 per cent over the 1976 value by the turn of the century (Table 3 ).

The Forestry Commission wlll produce nearly 75 per cent of British softwoods production by the turn of the century and the rate of increase is so rapid that both the public and private sectors face a major challenge for the fut ure if the timber becoming available is to be harvested and marketed effectively.

Some plantations wlll be managed on a non-thinning reglme inposed by the risk of windthrow but the majority will be thinned on a cycle of four to eight years and clearfelled on a rotation of forty-five to sixty-five years. Rotations are decermined largely by yleld class which, expressed as maximun mean annual increment, ranges for conifers. from 6 to 24 cubic metres/ha/yr, with a national average of 10 cubic metres/ha/yr.

Table 3. Softwood production in Great Britain.

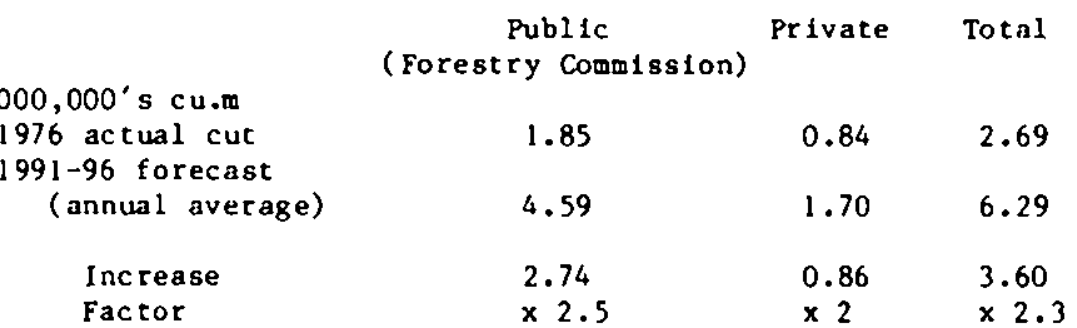




\section{ECOLOGICAI. CHANGE}

British forests in the uplands consist in the main of pure, even-aged plantations with a preponderance of conifers and young age classes, less than twenty-five years old.

This fact conjures up a picture of a collection of dull, uniform ecosystems; a picture which is not often confirmed in practice when one examines forests on the $g$ round. There are many reasons for this. In most areas, even though individual forests are made up of a serles of even-aged stands, there is almost always a range of age classes and species, and the stands are broken up by roads and felling coupes. In practice, therefore, there is much more diversity and variation of canopy and 'edge' conditions than wight at first be thought. Such diversity increases as the forest becomes older and regeneration fellings are carried out.

In establishing forests on bare upland it is hard to imagine a more dramatic change in the ecological conditions including the soll, the flora, the fauna, and not least the introduction of trees for the flrst time in many centuries. In general, the original site conditions were so inhospitable for the growth of trees that drastic interventions in the form of cultivation, drainage, weed control, fertilising and fencing have been necessary in order to establish productive forests.

I would like to comment on the nature of some of these ecological changes as I see ther; - again in the hope that I may provide some general background to your much more detalled discussions durfing the next few days. At the sane time; I would like to introduce the concept that when studying the ecology of plantations we are dealing with two complementary basic resources, namely:

THF. PHYSICAL RESOURCE - that is the soil and its physical enviroment, and

THE BIOLOGICAL RFSOURCE - that is the flora, fauna and - the trees themselves.

We need to understand how our management affects these resources and their interactions if we are to achfeve the best overall benefit to society and avoid haroful side effects. The so11.

The soll and its physical, hydrological and chemical properties are changed by plantation forestry, either prior to planting in order to make the site more sultable for cree growth or later during the life of the crop. Many of the solls of upland Britain are initially too wet and have inadequate aeration for the $g$ rowth of commerclal species. Ploughs of various kinds are used to provide a planting medium and to improve the drainage either by providing channels for more rapid run-off of water or by breaking up impeded soll layers to allow better vertical percolation. Unfortunately, some ploughing systems restrict the spread of surface, buttressing roots and any gain in crop stabllity from increased rooting 
depth may be more than cancelled out by lateral restriction to rooting. Windthrow is all too compon in upland forests.

Some sofls must be fertilised before tree growth is possible at all, while on many others fertilisers give worthwhile responses. in yield. Phosphorous fertilisers are the most frequently used; with additional potassium, especially on peat solls. - Spruces have a markedly higher need for fertilisers than pines on infertile soils.

Changes induced by the growth of the tree crop itself are becoming wuch betcer understood and in physical respects are frequently more significant than those produced by the initial ploughing. The forest canopy way intercept and evaporate up to 40 per cent of the rainfall and this imporlant effect on water yield from forested catchments needs to be taken into accounc in land-use planning. In sore solls with an initlal excess of water, much more favourable water and aeration conditions are created. However, the wet clayey solls of the uplands are proving to be the slowest to. respond in this way and the shallow rooting of spruces, especially with restricted laceral development, results in early wind damage.

The flora.

The flora has changed too. In the uplands, ploughing, draining and fencing initially encouraged plants of drier habitats and less grazing resistance. As the new forests have aged there has been a qualitative change from heath and grassland vegetation to more genuine woodland communities with ferns colonising the shaded areas and native tree species, such as rowan and birch, colonising the compartment edges. In the lowlands, changes in woodland flora have often been quantative rather than qualitative: mature.conifer crops frequently exhibit a similar range of plants to traditional broadleaf ones but with different quantities of each species. In particular, the abundant spring flora of deciduous woods is reduced in coniferous plantations but this is offset by the presence under older conifer crops.of a herb flora in late sumner when broadleaf shade would exclude much of it.

The fauna.

There have also been dramatic changes in the vertebrate fauna after the afforestation of bare land and wildife management is a vital part of forestry in Britain to protect the crop, to exploit animals for recreation, sport and meat, and to conserve a balanced population of animals and birds. The variety of fauna is ruch influenced by the diversity of the forest, and there are marked differences between the afforestation; thicket, pole-stage and mature forest stages of development. In the $1940^{\circ} \mathrm{s}$ and $1950^{\circ} \mathrm{s}$ large areas of young crops predominated in many forests and such a stage is relatively sterile of fauna. However, as windthrow and regeneration fellings proceeded in the 1960's and $1970^{\circ} \mathrm{s}$ these large areas have become a patchwork of young and older age 
classes moving closer to a balanced habitat progression where birds and animals can find suitable alternative habitats within a few hundred metres as the crop changes structure.

This new habitat provides for a considerable increase in the population of the more mobile and comzoner species - the less mobile and uncommon species require more active provision of suitable habitats, often more diverse in character than a plantation $c$ an provide. For example, research has shown that at least five ha of broadleaved woodland is required to sustain a bird population which differs in species composition from those found in surrounding conifer plantations.

The widespread use of exotic tree species introduces a major ecological change, and when we introduce genctically original trees into new environments, we can expect reaction from the existing inhabitants of these environments. These reactions are often of little consequence or may be favourable. Obviously also they may sometimes be damaing either to the new plantation or to the existing inhabitants themselves. Such potential 'ecological dangers' fron and to the new forest tend to acquire exaggerated and sinister images because we do not fully understand them. Fven so, it is clear that there are risks, especially to the new trees.

\section{THE MANAGEYENT SYSTEM}

our forecasts are created and managed for a purpose and there are three broad aspects that have to be considered in chis process:

Silviculture:

to ensure the best sustained growth of trees at an economic level to produce wood of industrial quality; this implies conservation of soil productivity and of the health and stability of the trecs.

Environmental management: to ensure the sustalned yield at an econoric level of the environmental benefits of forestry, including landscape, recreation values and conservation of flora and fauna.

Operation efficlency: to ensure that work is done in a manner that is safe and cost-effective.

In theory, the requirements of efficiency tend cowards large-scale, mechanised, simple and uniform methods of management and these may conflict with the environmental values, which tend to be : favoured by small, complex and diverse methods of work.

In practise, a compromise has to be struck, by choosing a management system appropriate to each region and ownership. I hope and belleve that in most parts of Britain we are developing systems of forest management wich are a reasonable and sensible compromise. We can measure our efficiency and product value in producing wood for the market and can even begin to measure our performance in terms of recreation 
values. It is much more difficult to measure and ascribe values to the long terw environmental and ecological implications of what we do for important questions such as conserving soll productivity, the vulnerability of our forests to damage by wind, pests and diseases, and the conservation of wildlife.

\section{ECOLOGICAL PROBLEMS}

I would like to refer briefly to some of the problems that arise and to some fields of current research which have a special significance for forest management in Britain today. Tree healch

Diversification of species and age classes reputedly reduces the risk of catastrophic damage from pests and diseases. Tree breeding programmes are beginning to take effect in practice and it is possible that the development of cheap ways of mass-producing genetically superior individual trees will open up the possibllity of clonal forests in the fairly near future. The prospect is that chrough selection and breeding and improved propagation methods the genetic base of our planting stock could be rapidly reduced. The full ecological consequences of planting programmes based on highly bred planting stock can never be fully assessed. However, I think that it is so important that $I$ hope you will find time to consider this question in the course of your discussions.

Tree stability

Windthrow is a persistent source of damage in British upland forests and current research is alred at both prediction and reduction of likely danage. Studies are proceeding on windflows in order to permit windthrow hazard classification on species and silvicultural systems, and on cultivation and edaphic factors that limit root growth. This is such a crucial area for future management that I must commend it to your attention.

Regeneration

Clearfelling of even-aged stands can present speclal problems in our uplands depending on the soll and climate. On heavier soils in high rainfall areas, surface waterlogging can follow clearfelling and cause establishment problems and the presence of stumps makes remedial treatments more difficult. Basic physiological research is being done in Britain on the effect of seasonal waterlogging together with applied research on remedial soll treatments. This too represents a field of research in which international debate and sharing of experience could be particularly relevant.

Soil productivity

In most cases our upland forests have been planted on land where only very small stores of nutrients had been accumulated by natural vegetation due to varlous factors including burning or erosion, and foresters have had to 
'recharge' the sites by manuring. Consequencly forest nutrition is an active and important field of study and fertilisers are used extensively at planting in order to establish fast growing species. Much of the attention today in Britain has curned to the prospect of improving the yield of established forests by fertiliser top-dressing regimes. The question of biological and economic limits to growth is posed. In some circunstances, large returns seem achievable by such means. We need better definition of these circumstances and of the implications of such treatmencs. We also need to know whether greater emphasis should be given to rescarch inco species and varieties capable of reasonable growth with a minimum supply of nutrients, i.e. the wtiole question of 'low' iniput versus 'high' input forestry.

Nature conservation

Our objectives and methods of wildife management pose important questions and $I$ am $g$ lad to see that you have devoted a considerable part of your timetable to this subject.

\section{CONCLUSION}

It has sometimes been suggested that there is a fundamental difference in out look on ecological matters between the foresters responsible for managing traditional, semi-natural, uneven-aged forests and those responsible for man-made plantations. I do not believe this to be so, and any differences there may be tend to reflect differences in objectives of management rather than differences to awareness or sensitivity on ecological questions.

A sound knowledge of the forest ecosystem is obviously important in all circumstances and espectally so for even-aged plantations. Furthermore, it needs to be stressed that new knowledge must be translated into terms which mean something to forest managers. In particular, if:there are undesirable features, the manager needs to know what these are and why they are undesirable in terms of productivity (e.g. site degradation, hazards to health, etc.), and environmental values (e.8. water, nature conservation and landscape).

In the end, the forest manager has to decide whecher his objectives or methods are satisfactory or should be changed. The scientists in each country must help ensure his decisions are based on knowledge and balanced judgment rather than on folklore or prejudice.

Your agenda for this week is very wide-ranging and it seens to me that some aspects of research lend themselves to international co-operation whereas others are so related to local conditions and to national policies and objectives that the scope. for international co-operation is limited. In general, I think it true to say that basic blological research and non-blological basic and applied research are the most likely to benefit from international co-operation as both tend 
not to be highly dependent on local conditions. It becomes practicable, therefore, to pool research resources and to deploy them more effectively.

It would seem that much of the agenda for the present Conference deals with aspects of research which are greatly influenced by local factors and in which the scope for international co-operation may be somethat 1 imited. The value of the Conference in these circumstances could lie not so much in assessing the detailed results or conclusions of research but rather in considering the concepts and wethodology. But even in these areas the main speakers will suggest analogies and stimulate ideas and rewarding discussion. There is, however, a more basic element in many of the topics to be dealt with and suggestions for effective International co-operation may well emerge during the course of the meeting. I wish your discussion every success. 
September 4, 1978

THE PHYSICAL RESOURCE

Chalrman: C.P. van Goor

Site classification

How do physical classifications

contrast with site type

classifications?

Strategles for amelioration

on poor sites.
R.D.L. Toleman

K. Kreutzer

J. Pälvånen 

Forestry Commission, Veftch's Close, Castlegate, Jedburgh, Roxburghshire TD8 6AY, U.K.

SURMARY

If consistent and rational silvicultural decisions are to be made when establishing even-aged plantations, a site classification is essential. The classification must be readily understood and be applicable by forest managers. It should be based on soll and climatic factors wich are the limitations to forest production when compared with the requirements of species. If species requirements are known, then these 1 imftations can be ameliorated. Forecasting of yleld based on site type must be imprecise where site limitations are aneliorated.

Yield forecasting is more precise on sites with few 1 imitations to growth and on which crops have been grown to a full rotation. The ultimate objective of a site classification must be to produce a site yield guide which incorporates silvicultural proposals designed for the target yield to be achieved. Such a guide may take a considerable time to devise, as the long term effects of site modification and improvement w111 only be apparent over a number of rotations.

RÉSUMÉ

Si nous voulons que les dectsions prises en matière de sylviculture soient logiques et rationelles au moent de la création de peuplements equiens, 11 est essentiel d'etablir $d^{\prime}$ abord une classification des stations. Cette classification doit être claire et capable d'être utilisée par des gestionnaires forestlers. Elle dolt ètre basée sur des facteurs liés au sol et au climat. Certains de ces facteurs sont souvent à un niveau insuffisant, comparés aux exigences de diffërentes essences, et Indiquent des stations 
marginales. Si les exigences sont connues, une amélioration de certaines stations est possible.

La prévision de la production basée sur les differents types de stations ne peut être très précise dans le cas ou l'amélioration de la station est possible et conduit a une mellleure croissance. La prévision de la production sera plus précise pour les stations ayant moins de contraintes limitatives et pour lesquelles la croissance a déjà été suivie pendant une révolution complete. L'objectif numéro un d'une classification des stations sera d'établir un guide des lialsons production - station, qul comporteralt également des règles sylvicoles, conformes aux objectifs de production retenus. Le temps nécessalre á établir un tel guide sera considérable, pulsque les effets à long terme de la modification et de $1^{\prime}$ anél loration d'un terrain ne seront ressentls qu'après une ou plusieurs révolutions.

\section{ZUSAMMENF ASSUNG}

Wenn bei Begründung gleichalcriger pflanzungen konsequente und rationelle waldbauliche Entscheidungen $z u$ treffen sind, ist eine Standortsklassifikation unerlässlich. Die Klassifizierung muss für den Forstmann leicht verstàndlich und anwendbar sein. Sie sollte auf Boden- und Klimaeigenschaften beruhen. Aus ihnen können sich oft Standortsbeschränkungen ergeben, wenn man dle Bedürfnisse der Baumarten berücksichtigt. Wenn die Ansprüche der Baumarten bekannt sind, kann man veränderliche Standortselgenschaften entsprechend verbessern. Ertrafsvoraussagen nach dem Standortstyp sind zwangsläuf 18 ungenau, wo wachstumsbeschränkende Faktoren verbessert und danit das Wachstum gefördert werden kann.

Die Ertragsvoraussage wird genauer sein für Standorte mit geringen Einschränkungen, und wenn die volle Untriebszeit erreicht 1st. Die Standortsklassifikation sollte letzlich auf die Frstellung standortsgebundener Ertragstafeln abzichen, die auch waldbauliche Richtlinien zur Erreichung des Ertragszlels geben. Zur Ausarbeltung solcher Unterlagen ist beträchtliche zeit erforderlich, da slch die Langzeitwirkungen von Standortsveränderung und -verbesserung erst nach wehreren 
Umtriebsperioden zeigen.

\section{INTRODUCTION}

The objective of this paper is to examine the requirement for a site classification in even-aged plantations, and to consider the site features that $c$ an be used. A number of existing classifications will be cited, but a comprehensive comparision is not possible due to the extensive number of systems in use. Indeed, site assessment is such a broad subject that a I.U.F.R.O. working party under Dr Burger and Dr Kreutzer is examining the different methods of classification and their various objectives.

The term 'even-aged plantation' is imprecise. It can cover the establishment of exotlc or indigenous conifers and broadleaved species on bare land, abandoned scrubland with secondary regrowth, low production forest and high production forest. It also covers the regeneration of natural, uneven-aged forest, particularly where a preferred spectes is favoured and the re-establishment of felled, even-aged, mature plantations.

The most important requirement in establishing any of these even-aged plantations is that the preferred species must have a potentlal for successful growth. Where a specles has a wide tolerance and where the site is relatively homogenous, the chance of successful growth will be high. If sltes are diverse and species tolerances narrow, a plantation over an extensive area will produce a wide range of growth rates.

In early British plantation forestry, whenever even-aged plantations were established, a site classification was necessary, however empirical, to match the requirements of the species with characteristics of the site. The closer the species requirements were met, the 8 reater was the potential for success on the plantation. Very often in early plantations species requirements were imperfectly known and so many were unsuccessful. A nutritional site limitation was one that showed itself early in the life of the crop, but physical or climatic limitations often appeared much later.

European foresters have long recognized the value of site classification, primarily through phyto-sociological site mapping with some pedological influence. British foresters adopted a site classification based on vegetation communities and related to it observed yields of various spectes (Anderson 1950). Wood (1955) examined the ecology of conifers in northwest America and related observed site conditions there to those in Britain and suggested sultable British sites based on the conditions of natural stands of our exotic plantation trees. Macdonald et al. (1957) reviewed the ecology of exotic forest trees in Britain, giving indications of suitable sites, based on site limitations.

British even-aged plantations are characterized by 
establishment on bare ground, but other Furopean, tropical, Australasian and American foresters have frequently established even-aged plantations on logged-over forest. Their objective has usually been to increase the yield of the natural forest by selecting a preferred indigenous or exotic species. The advantage of this type of even-aged plantation is that, based on the natural phyto-sociological and pedological features, the forest site type can be classified prior to establishment.

THE NEED FOR SITE CLASSIFICATION IN F.VEN-AGED PLANTATIONS.

Because climate is the most doninant, single feature of site classification, as expressed by conbinations of warmth and cold, a measure of growing season length, precipitation and exposure, it follows that regions of either equable or consistent climates tend to have less wide variations in site types. Regions that have an inconslstent climate tend to have wide variations of site type, which is compounded if there are also wide ranges of lithology and physiography. The latter description fils western, maritime land masses and is typified by the British uplands.

Even-aged plantations have been established using one of two broad policies. The atcributes of the site were assessed, either subjectively or objectively, and species most sulted to, or most tolerant of these site features were planted. Al ternatively an assessment of site features which identified limitations was made. The site limitations were then ameliorated to a greater or lesser degree, depending on the relationship between cost and forest yleld improvement and a single preferred spectes planted.

The first policy can be regarded as 'low input' and sceks to stimulate the natural forest which has a moderate range of climax species, each with its own site tolerances. This low input, multi-species, even-aged plantation will produce trees of uneven sizes, with different qualities and different potential utilization. This type of production does not easily fit current timber use requirements. Its drawback, together with the greater yleld potentlal of single spectes, high Input, even-aged plantations, has resulted in the dominance of the single over the multi-specles afforestation.

The second policy is 'high input', where a preferred spectes, which must have moderately wide site tolerance, is ensured of success through the major modiflcation of site limitations. This type of single specles, even-aged plantation al so seeks to be even-sized, evenly grown and hence unfformly managed, to produce an unvarying product at any particular stage of the rotation.

However, a common feature of both policles was the need to recognize the characteristics of the site and hence the inftations. In sore cases a species was matched to a site, 
while in others the site was adapted to the requirements of the species.

Af forestation In the British uplands in the past was traditionally of the 'low input' type, using many species, but in the last thirty years it has increasingly becooe high input', using fewer species, wainly sitka spruce, or on the poorest sites, lodgepole pine. A major reason for this change in policy was that the Britlsh upland plantations prior to the $1930^{\circ} \mathrm{s}$ were priwarily in areas with few site linitations, 1.e. sheltered valley bottoms and mid-slopes on which a wide range of spectes could be planted. From the 1940's onwards, wore and more of the 1 and avallable for afforestation was at higher elevations, which provided sites with increasing limitations to growth. Very few species could tolerate these 1 initations and many site features had to be anellorated to ensure the silvicultural and commercial success of the plantation.

The objective of devising a site classification for even-aged plantations must be to ald forest managers in making rational and consistent silvicultural decisions, that will ensure the success of a crop and, if possible, Indicate for a given intensity of input, what the expected ylelds or rate of success of the crop will be. In upland plantations it is apparent that a site classification based only on soll parameters, although facilitating rational silvicultural decisions, has been less successful in predicting yield. This is due to the dominance of the climatic element.

prior to afforestation, the objective of a site classification is to optimize the cholce of species and to ensure an acceptable growth rate. As plantations develop, crops reveal differing growth rates which can be related to site type. Gradually yleld prediction based on site type becomes more rellable. After one or two rotations, in which a range of silvicultural practices has been examined for a number of specles over all site types, a rellable site yield gulde can be evolved. A predicted yield can then be achleved if a specific, site-related silvicultural regime is followed.

Where planting is carrled out on prevlously forested land and where the preferred species is indigenous, a site classification will glve an accurate egtimate of yield. However, it is normal practice to improve the site by ameliorating site limitations and the natural forest yleld of a species might be much lower than under even-aged plantation condtitions. Therefore, a land capability classification for forestry based on natural forest conditions wll only indicate a base level of yleld. This will be subject to sllvicultural improvement.

FACTORS USED IN SITE CLASSIFICATION.

A forester is primarily interested in site classification with a related yield potential as an ald to forest management. 
He is not interested in the classification of soil, vegetation, or land form per se. Factors used in a stte classification which is intended for a practical application by forest managers, must be readily understood and should be easy to assess. Silvicultural practices may then be related to a site classification and this will ensure that a relatively standard set of treacments will be applied to similar crops over a wide area.

Site factors fall into two groups:

Soll characteristics: nutrient avallabilicy, water availability, aeration, rootable depth, vegetation type, terrain type.

2. Climatic characterist1cs: warmth or coldness, wetness or

Soll characteristics dryness, exposure to wind.

Mutrient availability - The principle elements for successful tree growth are nitrogen, phosphorus and potassium (N, P and $K)$. Although values of $N, P$ and $K$ can be determined in a soil, it has proved not possible to forecast either yield or the success of a crop in relation to $K$, $P$, $K$ concentrations, except for extreme values. In upland Britain, on mineral and organo-mineral soils, there is some relationship between the soil nutrient availability and the chemical composition of the rock: quartzose and granitic rocks tend to have the lowest values. Special problems are found on other lithologies, such as low phosphorus availability in soils derived from basic igneous rocks, while high $\mathrm{pH}$ values are found in soils over calcareous rocks. Solls derived from stony or coarse cextured glacio-fluvial or littoral deposits often have low N, P, K availability.

In organic soils, nutrient avallabllity has been related to total content of $N, P$ and $K$ in the upper horizons, which Itself is correlaced with the bare ground vegetation. On such sites, nore consistent estinate can be made of yield, or more importantly, the nutrlent input required for a successful crop. The current classification of bogs used'in the Forestry commission, is based on the bare ground vegetation, and a slivicultural policy of increasing nutrient input is applied where the vegetation type indicates low $\mathrm{X}, \mathrm{P}, \mathrm{K}$ values (Toleman 1973).

Water avallability - Water avallability is related to climate, lithology, soil type and depth. In a moist, maritime climate it is only in exceptional years that trees suffer visibly from drought (Burdekin 1977; Fourt \& Hinson 1970), and this would usually only occur with a combination of shallow loamy solls over permeable bedrock. In drier climates water availability can become a limiting factor. It is evident in the Pacific northwest that avallable soll moisture plays an important part 
in a yield related site classification in drier zones (bood 1955).

Aeration - In very wet climates an excess of soil water can lead to periodic or permanent waterlogging, resulting in poor soil aeration. The intensity of anaerobic conditions in the soil is related to the precipitation and perceability of the soil and bedrock. Poorly drained or gley soils are extensive in wet, mild, maritine and cold, wet, continental climates and they frequently develop a considerable depth of surface peat.

The lack of aeration in the soll prevents deep root penetration and where this occurs in windy climates, extensive uprooting will occur. Shallow rooting in poorly drained soils does not necessarily imply a lack of soll nutrients and vigorous growth is often a feature of such sites. It has been traditional to drain waterlogged sites, but many gley solls are of a clayey texture with a very low permeability. There is an insignificant inprovement in soil aeration as a result of drainage, apart from the superficial horizons, which in any case are affected by water removal by the tree crop. Cleys of a loany texture should be separated in a classification as, with greater permeability, effective drainage and improved acration should be possible.

organic soils are nornally waterlogged but do have varying rates of permeability. Fibrous or relatively undecomposed peats are more permeable than amorphous or well-decomposed ones, and drainage may improve peat aeration and encourage decomposition. The principle reason for atcmpting to Improve soil aeration is to encourage deeper root penetration, so making the crop less susceptible to uprooting.

Rootable depth - Restricted rooting can occur In shallow suils over impermeable bedrock, or where there is mechanical restriction in a subsoll horizon, 1.e. on indurated layers which are relict pernafrost phenosena forwed during the periglacial clinatic conditions of the late stages of an Ice Age. Both freely drained and poorly drained solls can have a strongly indurated layer at depths of $20-50 \mathrm{cr}$ from the surface. The layer may be discrete and $20-30 \mathrm{~cm}$ thick, but commonly it exceeds $60 \mathrm{~cm}$. Roots cannot penetrate the Indurated layer due to the small pore space and firmness. Induration is greatest in loamy solls, resulting in high bulk deensity, but decreases with increasing clay content. The identification of indurated layers and their extent is irportant, as the shallower, discrete cype can be shattered by deep ploughing, so encouraging more extensive root penetration.

Vegetation type - Certain types of bare ground vegetation, besides indicating a site characteristic, may themselves compete with the early growth of tree crops. In upland Britain the infitial competition between heather (Calluna vulgaris) and 
many tree species, especially spruce, is well-known. In extreme cases spruce growth can be almost totally checked. The very lush growth of weeds on fertile lowland sites is only a limited problem, as the trees themselves are not checked and, once established, will grow rapidly.

vegetation has been used as a means of site classification. This $1 \mathrm{~s}$ based on the concept that the vegetation present is a result of prevalling environental factors and consequently different plant associations delineate different sites. However, vegetation boundarles are not permanent and in even-aged plantation forestry, natural or semi-natural vegetation declines, until recolonization takes place after thinning and felling.

Terrain type - Features of the terrain, such as ground bearing capacity, ground roughness and slope, seldom affect the growth rate or yield of plantations, but do have an fmportane relationship to all sllviculcural harvesting operations requiring mechanization. At establishment, the type of plough and ploughing equipont selected can be influenced, and at harvesting, the type of extraction equiprent.

The Forestry comission's current classification recognizes three terrain factors, which are sub-divided into five classes (Table 1 ).

In dry climates, terrain can influence soll molsture and wet, receiving sites may be separated from dry, shedding ones. Cilmatic characteristics

Warmth and coldness - In natural forests at high altitudes a timber line is associated with increasing climatic coldness and a reduction in growing season. Even-aged plantations are normally established well below such a timber line, as at these upper elevations yleld is low. However, in wet, marltime climates and within a range of elevations in which plantations can be established, there is a strong relationship between yield and alticude (Malcolm 1971; Mayhead 1973). Also, the potential for crop response to ploughing or fertilizing is

Ground conditions

(Soll bearing capacity)

1. very good

2. $800 d$

3. average

4. poor

5. very poor
Ground roughness

(Presence of surface obstacles)

very even
slightly uneven
uneven
rough
very rough

Slope $\left(\operatorname{gradlent}\right.$ in $\left.^{\circ}\right)$

level

gentle moderate steep very steep

Table 1. Forestry Commission ierrain classification. Units of these factors and their scales are described in more detall by Rowan (1977) and are based on Scandinavian practice. 
greater at lower elevations.

Wetness and dryness - Climatic dryness, i.e. potential evapotranspiration (see Jarvis of Stewart, this volume), is not a problem in wet, waritime reglons, but it becomes increasingly important in warmer, continental areas, particularly those with long, dry perlods. Climatic wetness is an important factor in the development of a soll from a parent material. The soll processes of organic incorporation and accumulation, clay translocation, leaching of soil nutrients, gleying, podzolization and weathering are all relaced to the amount of precipitation and its seasonal distribution. In climates of moderate rainfall with dry periods, where a soll potential water deficit (PWD) may develop, an established plantation can intercept and evaporate sufficient precipitation to have a marked effect on soll moisture and aeration. However, there is little effect in higher rainfall areas that do not experience a seasonal soll PWD.

Exposure to wind - Maritime climates have a high average wind speed, which at upper elevations is the major limiting factor to tree growth. It has an effect through physical uprooting and physical damage to the crown of the tree. Measurements of wind speed are difficult to make. Anemometers are expensive both to Instal and maintain and are seldow installed in isolated hill areas where afforestation has been carried out. ocher recording methods have been devised, though none have galned wide acceptance. Tatter flags (Lines \& Howell 1963) have been used by the Forestry commission to ald in determining upper planting 1 loits and a method of relative topographic exposure has been devised to produce wind exposure or 'topex' maps (Pyatt, Harrison \& Ford 1969). Recently an Ind frect technique has been developed. Models constructed on a proposed afforestation area are exposed in a wind tunnel and relative alr flows over different parts of the surface measured. Although data are limited for wind flows over upland areas the Forestry commission has used the avallable data to produce a wind zonation of Britain.

\section{EXAMPLES OF SITE CLASSIFICATIONS WITH THEIR OBJECTIVES}

Britain

It has been stated that the objective of a site classiffcation must be that it alds forest managers to make rational silvicultural decisions. When the Forestry Commission adopted a site classification in 1961, it was decided to base it on soil types. Although inftially this was related to the existing soll classification used by the Soll Survey of Great Britain, as more information became avallable, so soll attributes of silvicultural value were distinguished, e.8.

- textural class of poorly drained solls;

- depth of soll to bedrock;

- presence and depth of indurated horlzons; 
- thickness of surface organtc horizons;

- presence of surface rock or boulders;

- competing vegetation types;

- depth and continuity of ironpan;

- nutrient availability in deep peats as indicated by vegetation type.

Conversely soil features of only pedological differences were less important. For silvicultural considerations at a national level, the soll types are assembled into soil groups, e.8.

freely drained solls:

brown earths podzols

imperfectly and poorly drained soils: ironpan solls,gley solls, bogs

other mineral solls:

calcareous soils

littoral soils

skeletal soils

man-made soils.

As soil mapping extended over upland Britain, it became evident that a higher category could be introduced into the classification. Thls is the 'site reglon', which was defined as having a fairly narrow range of lithologic type within which there was a characteristic and consistent range of climate, terrain type, soil type and tree growth rate, and hence silvicultural practices could be expected to be fairly consistent. Some of the more extensive 'site regions' could be further subdivided inco wetter and $d r i e r$ western and eastern sub-types. Contrasting examples of the differences between soll type distribution in two 'site regions' is shown when comparing the Scottish border carbontferous 'site region' wh th the northeast scotland 'site region'. In the former, clayey textured gley solls and bogs account for up to 90 per cent of the solls, while in the latter there is a dominance of freely drafned brown earths and podzols.

A site classification based on soil types is effective for making silvicultural decisions when establishing a plantation. For example, poorly drained mineral, organo-mineral and organic solls will require adequate cultivation and drainage. Organic solls will require varying inputs of fertllizer, dependent on the nutrient status of the peat. Indurated solls and solls with an Ironpan layer will require cultivation.

To ald in forecasting crop yleld and risk of uprooting, additional climatic features must be superimposed on the soll-based site classification. Since exposure to wind is difficult to measure, elevation zone has been used as a substitute. In hilly and regular terrain, e.g. mid-Wales and the southern uplands of Scotland, the topex method of exposure 
assessment has been valuable. Pyatt, Harrison \& Ford (1969) describe this method and relate it to the windthrow hazard that crops experience on the various site types. As crop yield is also related to elevation, an overlay of soll map, topex map and elevation zone map $c$ an glve the following information: 1. Initial inputs of drainage, fertilizing and cultivation to aneliorate soll type 1 imftations.

2. Relatively accurate estimates of yield if the inputs are at an optimum level.

3. Relatively accurate estimate of risk.

Crops on shallow or poorly drained solls at high altitudes have a higher probability of windthrow before they reach their intended final helght. Windthrow is precipitated and accentuated by thinning and the Forestry conmission accepts that in such exposed sites normal thinning prescriptions (Hamilton \& Christie 1971 will not be carried out and the crops will have a shorter rotation.

The windthrow hazard classification (Booch 1977) is based on four sice feacures (Table 2). A score is given to each $v a l u e$ and the sum of these is regarded as the score range. Wind throw hazard classes 1 to 6 are sub-divisions of the score range. The mean crop top height at the onset of windthrow is given below. Windthrow is defined as over 3 per cent of the living trees in a plantation uprooted.

$\begin{array}{cc}\text { Wind throw } & \text { Top height of crop } \\ \text { hazard } & \text { at onset of } \\ \text { class } & \text { wind throw (m) } \\ 1 & 25 \\ 2 & 22 \\ 3 & 19 \\ 4 & 16 \\ 5 & 13 \\ 6 & 10\end{array}$

At present the Forestry Commission is devising a management policy to take account of this classification. Provisionally, normal thinning will be carrled out in classes 1,2 and 3 . Selective thinning will be carried out in class 4. Selective chlnning will be restrictively carried out in class 5 , while class 6 will have no thinning.

The Forestry Commission is at present using a provisional forest site yield guide for upland Britain (Busby 1974) in which sites are identified by elevation, wind zone and soil group. A preferred fertllizer reglme is given and a yield is forecast. However, as many crops on the poorest sites have not yet been grown to final rotation and as the response to wid-rotation fertllizing has not been accurately quantifled, the forecast yields remain rough estimates.

Although forest managers require a site classffication on which to base sllvicultural decisions, sentor management and 
Table 2. Forestry Commission windthrow hazard classification (Booth 1977).

\begin{tabular}{|c|c|c|c|}
\hline Wind Zone & $\begin{array}{l}\text { Elevation } \\
\text { above sea } \\
\text { level (m) }\end{array}$ & $\begin{array}{l}\text { Fxposure, } \\
\text { using } \\
\text { topex scale* }\end{array}$ & Soil type \\
\hline $\begin{array}{l}\text { 1. Consistently } \\
\text { high wind } \\
\text { values. } \\
2 . \\
3 . \\
4 \text {. } \\
5 \text {. Consistently } \\
\text { low wind } \\
\text { values } \\
\text { A map of wind } \\
\text { zones in Great } \\
\text { Britain is } \\
\text { avallable. }\end{array}$ & $\begin{array}{lc}\text { 1. } & 0-60 \\
\text { 2. } & 61-140 \\
\text { 3. } 141-190 \\
\text { 4. } 191-225 \\
\text { 5. } 226-255 \\
\text { 6. } 256-285 \\
\text { 7. } 286-315 \\
\text { 8. } 316-360 \\
\text { 9. } 361-405 \\
\text { 10. } 406-465 \\
\text { 11. } 466-540 \\
\text { 12. above } 540\end{array}$ & $\begin{array}{l}\text { 1. } 0-9 \\
\text { 2. } 10-15 \\
\text { 3. } 16-17 \\
\text { 4. } 18-19 \\
\text { 5. } 20-22 \\
\text { 6. } 23-24 \\
\text { 7. } 25-27 \\
\text { 8. } 28-40 \\
\text { 9. } 41-70 \\
\text { 10. } 71-100 \\
\text { 11. above } 100\end{array}$ & $\begin{array}{l}\text { 1. Rooting } \\
\text { unrestricted. } \\
\text { 2. Rooting } \\
\text { restricted at } \\
\text { about } 25-45 \mathrm{~cm} \text {. } \\
\text { 3. Rooting very } \\
\text { restricted } \\
\text { less than } 25 \mathrm{~cm} \text {. }\end{array}$ \\
\hline
\end{tabular}

*Pyatt, Harrison \& Ford (1969).

research workers require to know the extent of site types, so that their national importance for research work and financial implications can be assessed.

A soil survey carried out on the Forestry Commission estate in 1971 showed the following distribution of soll groups:

- freely drained soils

$28 \%$

- Iroperfectly drained solls

$14 \%$

- poorly drained mineral and organo-mineral sołls $39 \%$

- bogs

- others

$14 \%$

$5 \%$

A survey of ground awalting planting in 1972 showed that current afforestation $1 \mathrm{~s}$ on land dominated by the poorest site types and those at greatest risk to whdthrow. Current and future afforestation will be of sites with major 11mitations that require a moderate to high cash flow for site amelioration to maintain adequate growth rates.

Canada

In the extensively forested Pacific northwest, the British columbia Forest Service used a site classification (Spilsbury \& Sinth 1947) based on vegetation communities, which were Indicative of soll molsture status and related to tree growth rates. However, in southeast Alaska where rainfall is higher and soll molsture is not a limiting factor, the classification was not applicable.

The Canadian Land Inventory produces a series of interpretive maps, amongst which is one on 'land capability 
for forestry'. Seven classes of land are recognised each wh th a reducing productivity assessed frow the natural forest stands. It is emphasised in the classification that productivity is based on the natural state of the land whout improvements and that with site amelioration productivity will increase. The classes of 1 and are described as having increasing 1 imitations to the $g$ rowth of commerclal forests and as the limftations are identifled, they can be amellorated when even-aged plantations are established.

Subsequently the Britlsh Columbla Forest Service modified this system (Kesner 1970); first, to provide a classification and inventory of the land in terms of bedrock and surface geology, solls and vegetation and secondly, to interpret the se features for land use and forest managent purposes such as assessing potential productivity, specles suitability, natural regeneration potential, chinning, fertilizer requirements suitability for road construction and erosion.

Hungary

During the last thirty years Hungary has embarked on a extensive afforestation and reforestation programe. A classification of forest regions and forest types has been devised and silvicultural operations have been related to them (D.G. Pyatt, personal communication). Site requirements of the major specles have been determined, so not only can the correct choice of species and silvicultural method be adopted by site type, but a rational nationwde silvicultural policy can be developed.

The wajor site factors recognised are:

1. Climate - expressed as dryness or wetness and indicated by the mean $J$ uly atmospheric huldity in four classes.

2. Topography - as an influence on soll water; there are seven classes of land, from water shedding to water receiving.

Soll - 6011 type Identification follows accepted pedological practice, although certain features of silvicultural importance are emphasized. It includes nine groups and forty-three types.

4. Soll defects, 1.e. physical l1mitations - features recognised are depth of soll over bedrock, depth to water table, depth to salt accumulation, extreme stoniness, high pH and subsoli compactness.

Ground vegetation - to some extent reflects soll and wicro-climatic conditions and was used for site identification before being replaced by the present system.

In addition to these major site factors soll analytical data are collected:

1. $\mathrm{pH}$ value.

2. Hydrolytic acidity

3. Calcium carbonate content 
4. Soda - alkalinity

5. Hydroscopic molsture content

6. Liquid 1 imit

7. Capillary conductivity

8. Partfcle size

9. Humus content

For each of the forest regions, descriptions of geography, geology, topography, distribution of tree species, forest solls and forest types are prepared. Forest management prescriptions specific to each region are devised and yield potential is estimated from data collected from sample plots of all the major species on each site type. For each sice type and based on the national silvicultural policy, a manual 1 ist suitable spectes with an indication of yield and rotation length.

\section{REFERENCES}

Anderson,M.L.(1950). The selection of tree spectes. Oliver \& Boyd, Ed inburgh.

Booth,T.C. (1977). W1ndthrow hazard classification. Research Information Note 22/77, Forestry Commission, Edinburgh.

Burdekin,D.A.(1977). Dying beech. Research Information tiote 31/77. Forestry Commission, Edinburgh.

Busby,R.J.N.(1974). Forest site yield guide to upland Britain. Forestry Commission, Forestry Record 97 . Her Majesty's Stationery of $f$ ice, London.

Fourt,D.F. \& Hinson,W.H.(1970). Water relations of tree crops: a comparison between Corsican pine and Douglas fir in southeast England. Journal of applied ecology, $\underline{7}$, 295-309.

Hamilton,G.J. \& Christie,J.M.(1971). Forest management tables (metric). Forestry Commission Booklet 34. Pp.1-201.

Kesner,N.(1970). Mapping and interpretative system for the forested lands of British Columbia. Research notes 554 , British Columbia Forest Service, Victoria, B.C., Canada.

Lines,R. \& Howell,R.S.(1963). The use of flags to estimate the relative exposure of trial plantations. Forestry Commission, Forest Record \#51. Her Majesty's Stationery of $f$ lce, London.

MacDonald,J., Wood,R.F., Edwards,M.V. \& Aldhous, J.R.(1957) Exotic forest trees in Britain. Forestry Combsion, Bulletin $\$ 30$. Her Majesty's Statlonery offlce, London.

Malcolm,D.C.(1971) Site factors and growth of sitka spruce. $\mathrm{Ph} . \mathrm{D}$. thesis, Fd inburgh University.

Maythead,G.J.(1973). The effect of altitude above sea level on yield class of Sitka spruce. Scottish Forestry, 27, $231-237$

Pyatt,D.G., Harrison,D. \& Ford,A.S. (1969). Guide to site types in forests of North and mid-Wales. Forestry Commission, Forestry Record 69. Her Majesty's Stationery 
Office, London.

๒

Rowan,A.A.(1977). Terraln classification. Forestry Comission, Forest Record 114 . Her Majesty's Stationery office, Lond on.

Spllsbury,R.H. \& Smith D.S.(1947). Forest site types of the Pacific Northwest. Technical Publication 30, British Columbla Forest Service, Victoria, B.C., Canada.

Toleman,R.D.L.(1973) A peat classification for forest use in Great Britain. Proceedings of the International peat symposium on classification of peat and peatlands. Glasgow, U.K.

Wood,R.F.(1955). Studles of Northwest Amerlcan forests in relation to silviculture of Great Britain. Forestry Comossion Bulletin 25 . Her Majesty's Stationery of fice, London. 

HOW DO PHYSICAL CLASSIFICATIONS CONTRAST WITH SITE TYPE CLASSIFICATIONS?

\section{BY K. KREUTZER}

Institut für Bodenkunde und Standortslehre der Forstlichen Forschungsanstalt Hünchen, Amalienstr. 52, 8 München 40 , W. Germany.

\section{SUMMARY}

The different methods of site classification can be subdivided into environmental and mensurational ones.

Enviromental methods.

Enviromental methods characterize and classify sites primarily using the site's physical conditions such as properties of the soil, topography and climate. Vegetation is also frequently used as a supplementary indicator, in as much as it is indicating the water, temperature and nutrient supply of the site. As an additional ald the productivity of existing stands can sometimes be used. A special type of enviromental method is one that uses vegetation as the only indicator of slte properties.

The alms of the environmental methods are directed to provide a survey or basis for better answers to a large varlety of questions concerning the site, such as choice of tree species, productive capacity, threats, pathogen attacks, erosion protection, and watershed protection.

Mensurational methods.

Mensurational or forest site cype classification methods, however, characterize and classify the sites primatily using the productive capacity of the site. These methods apply suitable attributes of avallable stands. If the sites to be evaluated are not sufficiently stocked, productive capacity can be determined with the help of enviromental features being correlated with an expression for the-productive capacity. 
RÉSUMÉ.

Les différentes méthodes de classification des stations peuvent être divisés en deux groupes: celles qui sont liées à l'environnement physique et celles qui reposent sur la mesure de la productivité de la station.

Méthodes liées à l'environnement physlque. Ces méthodes classent et caractérisent les stations en tenant compte tout d'abord des facteurs physiques, c'est à dire des propriétés du sol, de la topographic et duclimat. On utilise aussi souvent la végétation comme facteur supplémentaire, dans la mesure ou elle peut etre un facteur indicatif du résime hydrique et thermique et de $1^{\prime}$ apport en élements nutritifs de la station. En outre, on peut aussi utiliser la productivité des peuplements existants. Une méthode spéciale utilise exclusivement la végetation comme seul facteur indicatif des propriétés des stations. Les méthodes liées à l'environnement ont pour but d'étudier ces facteurs et d'établir une base solide qui répondra a un grand nombre de questions concernant la station, par exemple, le choix des essences, leur productivité, les dangers, les attaques pathogenes, la protection contre l'érosion et la protection des cours d'eau. Methodes liées à la mesure de la productivité. Par contre les méthodes l lées à l'évaluation de la productivité ou méthodes de classification des types de stations classent et caractérisent celles-ci cout d'abord par leur capacité de production. Ces wéthodes donnent des nows caractéristiques aux peuplements exlstants. Si les terrains à évaluer sont nus ou insuffisamment bolsés, leur capacité de production peut être déterminée à l'aide de facteurs du milieu corrélés avec une expression de la capacité de production.

\section{ZUSAMMENFASSUNG}

Die verschiedenen Verfahren der Standortsklassifizierung lassen sich in zwei Gruppen gliedern; die eine geht aus von der Erfassung der Utweltfaktoren, die andere von der Messung der Wuchslelstung.

Standortskundliche Methoden.

Hierbei werden die Standorte vor allem durch die physischen Bedingungen, wie Bodeneigenschaften, Relief und KLima 
charakterisiert und klassifiziert. Auch die Vegetation wird häufig als zusāzlicher Indikator benutzt, da sie das Wasser-, Wärmeund Nährstoffangebot des Standorts anzeigt. Als zusätzliche Hilfe kann manchmal die Huchsleistung vorhandener Baumbestande dienen. Eine besondere Methode dieser Gruppe nimnt die Vegetation als alleinigen Indikator der Standorlseigenschaften. Die ziele der standortskundlichen Verfahren bestehen in der Schaffung einer Übersicht oder Grundlage standortskundlicher Kenntnisse zur besseren Beantwortung von Fragen im Hinblick auf Wahl der Baumarten, Produktionskapazitat, drohende Gefahren, Schädlingskalamitàten, Erosionsverhinderung und Schutz von Wassereinzugsgebleten . Wachstunskund iche Methoden.

Diese verfahren charakterisieren und klassifizieren die Standorte vor allem an Hand der gemessenen Produktionskapazität des Standorts. Man verwendet geeignete charakteristische Merkmale vorhandener Baumbestānde. Wenn die zu beurteilenden Standorte nicht oder nicht genügend bestockt sind, lasst sich die Produktionskapazität über die Beziehungen von Unweltfaktoren mit Daten der huchsleistung ermitteln.

\section{DEF INITIONS}

Before we examine methods of site classification in more depth, it is Important to give some definitions.

Site

The term 'site' is applied wth somewhat varying meanings. In older literature it was understood to mean the growing place of plants or plant communities as characterized by certain natural provisions, but today it is applied more precisely by plant ecologists. 'Site' is the totality of environmental conditions which have an effect on plants or plant communties in their growing place. 'Site' does not include the influence of competition amongst plants or temporary influences, such as a solitary fertilization which has no long-lasting effects.

In forest ecological research 'forest site' is simflarly defined as in plant ecology, as the totality of environmental conditions significant for the development of forest trees and these are principally determined by topography, cllmate and so11.

Contrary to this environmental definition

English-speaking people frequently apply the term 'forest 
site' with consideration for the yield obtainable on the growing place, e.g. 'stle classes' are yield classiflcation units. Thus Gessel (1976) writes: "Most foresters understand site as an expression of the ability of forest environment to produce a given yield of species or a combination of species". In land management the meaning of the term is narrowed down even more to productivity or at least potential productivity.

These somewhat diverging opinions come rogether in the one point that the yield of a stand is determined by a variety of growth factors. Apart from genotype, we are interested in all factors exterior to the plant such as nutrient and water supply and temperature. In most cases we cannot make a direct, quantitive calculation of the environmental factors which determine growth and so are dependent on assessing site features indirectly.

Site factors

'Site factors' are defined as the properties of a growing place which are relevant to organlsms living there. These are partly interchangeable and can be divided into the following groups:

- Climatic factors: precipitation, air temperature, solar radiation, wind patterns. Here the seasonal distribution as well as the total annual quantity is important.

Topographical factors: elevation, orography position, steepness and form of slope, aspect.

Edaphic factors: soll conditions which decerofine the water and nutrient supply, potential root depth, and soil temperature.

Biotic factors: activity of micro-organisms, influence of pathogens, wildlife.

In their interplay site factors determine the supply of

water, nutrients, warmth etc. to the growing plant and so determine the composition and growth of vegetation, the growth relations and yield capability of the tree species and the blotic and ablotic threats to stands. Moreover, site factors are relaced to nearly all forest managenent operations e.g. soil preparation, regeneration, herblcide use, thinning and harvesting techniques. Furthermore site factors influence a series of additional forestry activities which go beyond the mere production of wood, particularly those of erosion protection, water protection, landscape aesthetics and recteation. Many of these operations may themselves have an effect on 'site factors'.

Site unit

'Site un 1t' in environmentally based methods refers to a collection of growing places characterized by a similar combination of 'sice factors', and so with a similar basis for the choice of tree species, and for assessing productive capacity and threats to the forests. 'Site units' may sometimes be subdivided into top soil or hums form 
categories.

productive capacity

'Productive capacity' of a site means. the potential organic production of a distinct plant community within a distinct time span and grown over a specific rotation period. In forestry, 'productive capacity' is always related to distinct stand types and treatments. For cooparisons between sites it is helpful to use the most productive stand types or, as in the case of mensurational soil site studies, at least stands of the same type and similar treatment should be used. Site index

'Site index' is an expression of the productive capacity of the site and is derived from atcributes of stands of given type and treatment. There are various site indices, e.g. top height at index age, the growth intercept, $1 . e$. the five year height growth above breast height, mean annual height growth and waximum height of old trees. The most frequently used site index is top height at index age 50 or 100 .

\section{THE PROBLEM OF RELATING SITE INDEX TO THE PRODUCTIVE CAPACITY} OF THE SITE.

This is an important problem in mensurational classification methods, and so I would like to go into it in pore detail. The following questions arise:

a) What stand types should be used?

b) What stand treatments should be considered?

c) What measure should be used for productive capacity and how far is it reflected by site indices?

Even-aged or nearly even-aged pure stands of the main economic tree species are suitable as indicator stands, because changes in their growth behaviour and stand parameters in relation to age are well documented and are listed in yield tables. A site index can only be determined for one species at a time; a site cannot be characterlzed by taking data frow stands of different specles. Similarly errors may also occur when there are prominent racial differences within the ind icator specles wich influence growth. Only stands of the same race should be used. Problers may also occur in interpolating frow pure to wixed stands since synergistic effects between tree species do exist to influence the yield markedly.

Different methods of chinning and stand regeneration influence the development of stand parameters and only stands which have had similar treatments should be used as indicators for different sites. However, on occasion the same stand type treated in the same way may react differently on different sites. Our knowledge is not extensive enough to consider such questions sufficiently whin the framework of site evaluations and this may produce errors. 
Productive capacity is usually expressed in cerms of economic timber volume and excludes other components of stands such as branchwood, leaves, roots etc. Biological production would be betcer expressed as blomass or chemical energy content rather than tinber volume but investigations into production of these quantities are too fragmentary for general application. According to our present knowledge the best measure of productive capacity is maximum mean total increment of stem volume per hectare per year. Developroent of mean colal increment per hectare per year for Scots pine on a widespread soil type in northeastern Bavaria is shown in Fig. 1 and one can see that the maximun could be a good measure with which to evaluate site. However, these typical sile and stand maxima are not directly measurable and so we have to use correlated, easily measurable atcributes.

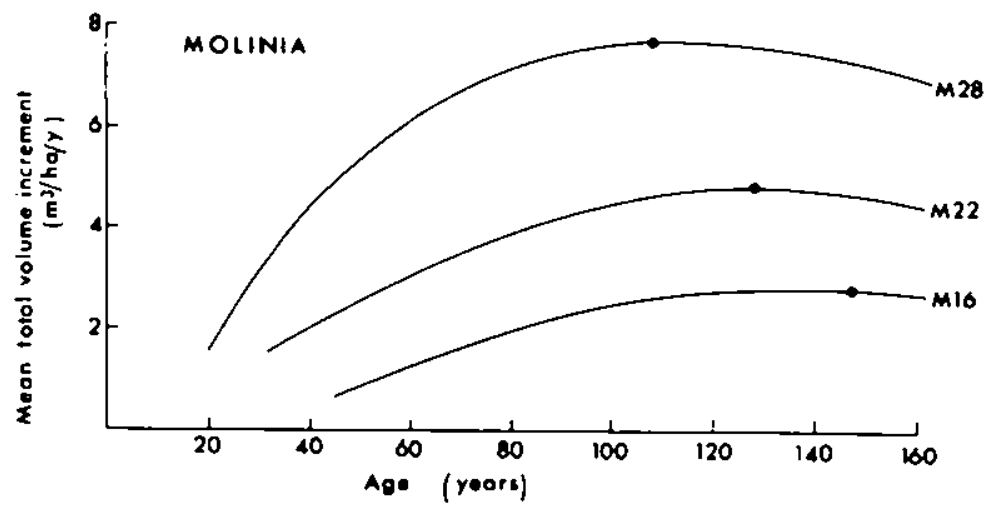

F1g. 1. Mean total volume increment of Scots pine (Pinus sylyestris) in northeastern Bavaria on mapping unit' moist sands-Molinia.

Two such attributes are stand age and height. We may determine the height at distinct Index ages from height 8 rowth curves (e.8. from yield tables). When taking this term as site Index 1t should be based on the dominant, or the dominant and co-dominant trees of the stand because their heights are less influenced by the thinning processes. Furthermore, the quality and suitabllity of the helght:age curve patterns should be critically considered (Carmean 1975). In America, harmonfzed yield tables often based on insufficient data have been 
developed for large tracts of land and have led to serious aistakes in site evaluation. Carmean recommended the elaboration of height:age curves better sulted to individual sites and suggested stem analyses and internode studies as important alds in their construction. In Europe, we have carried out similar deliberations which have led to regional and local yield tables.

But even though the site index 'top height at index age' is well derived and close to reallity, we have to ask whether this site index accurately reflects the maximum mean cotal

increment. An answer is given in Fig. 2 Using the data of the new Bavarian yield tables for spruce (Assmann \& Franz 1965) the maximum mean total increment is plotted against site index, 1.e. 'site class based on age $100^{\prime}$. Considerable variation in maximum mean total increment appears at the same site class and thls is caused by differences in basal area growth. This in turn reflects differences in diameter 8 rowth and/or number of trees per unit area and as stand treatments are identical one can suppose that propertles of the site are wainly responsible for this.

Such variation is not restricted to differences between regions and caused by climatic differences as earlier researchers suggested (Wiedemann 1939, 1941). Changes of the specific yield level* take place within relatively small areas because of their differing site conditions. Assmann's students have given very impressive evidence of that (Franz 1967, 1971; Schmidt 1971, 1973).

Two solutions are avallable to overcone this, problem of evalution. One is based on the technique of corrected or levelled yield tables (Fig. 2) (Assmann 1962, 1966; Assmann \& Franz 1965; Johnston \& Bradley 1963; Magin 1963, 1965; Franz $1967,1971)$. To evaluace the yield capability of a stand, additional stand attributes besides stand height and age are introduced. Assmann of Franz used stand basal area and the diameter of the tree of mean basal area. New developments are underway.

The other solution is by preselection and stratification of sites. This is a particularly useful technique where physiographic site maps are available which contain site units as a mapping basis. To estimate productive capacity, separate yield studies based on these site units are carrled out. The accuracy of the results depends on the quality of site

* Assmann (1966) understands yleld level to be the total growth achievement depending on helght developent. He differentiates between the general yield level at a given height and the specific one at a given site quality as the height at a distinct age. We modified the latter definftion by plotting the maximum mean total increment per hectare per year at height and age deterwined quality. 
classification and mapping. Subjective influences may become important particularly when qualitative estimations of nutrient and water regimes are uncritical and training and education of mapping personnel is very important, as are the development of suitable methods to deduce water and nutrient supply. Despite these difficulties good results have been obtained by this technique particularly for widespread site units and this demonstrates the practical value of such yield studies (Günther 1955; Moosmayer 1955, 1957, 1960; Franz 1967; Horndasch 1969).

Similar questions arise with other site indices. The 8 rowth intercept method is particularly useful when younger stands are inportant as site indicators, whereas the maximum height of old trees is mainly applied in areas which are not easily accessible and yield estimations are carried out using aerial photographs. Both methods are known as substitute techniques and their accuracy is even more problematic than yield estimates through the direct assessment of height and age.

\section{THE PROBLEM OF SITE PREDICTION}

One of the main practical aims of site evaluation research is to develop suitable methods for predicting the productive capacity of growing places where indicator stands are missing. In this instance determining good correlations between productive capacity and site properties is of spectal importance and understanding the causal relationships does not play a primary role.

Frequently, a first objective of enviromental classification is to divide the landscape into environmentally defined site units which acts as a framework for detailed yield studies. This division is not made on the basis of measured first yields. It is postulated that all growing places within the same site unft show the same or at least a similar potential yield capacity for the same tree species, whecher they'are stocked with this species or not. Such yield studies on individual site units enable comparisons of the productive capacity to be made between them as well as between different stand types and treatments within site unfts. All findings related to a site can be usefully transfered to other locations in the same unit.

Naturally problems arise when mappings are incorrect or when relevant environmental differences affecting tree growth are not taken into account. This often occurs within mapping units established purely on a vegetational basis. The reasons are obvious since the composition and vigour of plant communities arc influenced by stand type and density. In most cases vegetation only indicates the relationships of a relatively shallow root zone and moreover it reacts ephemerally to short-term changes in environmental conditions. 


\section{KREUTZER}

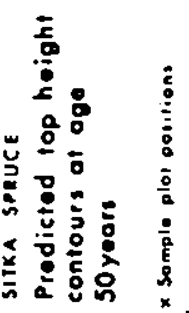

$\underbrace{1}$

4.

- 嵌 00

c $0 \infty^{\infty}$

要 2

茫出

可出

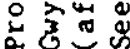

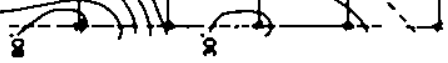

$\dot{m}$

in

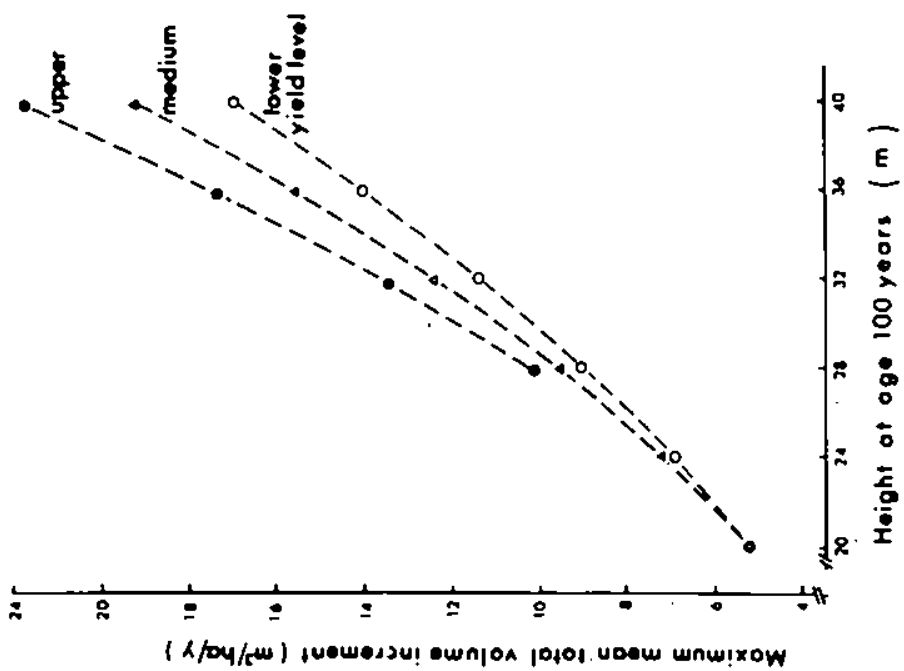

$\stackrel{\infty}{-1}$

苗

$\rightarrow>$

要焉

운등 웅

แ

- जำ

궈

웟

叫 0 ต

원

웅

t.

둥

㑒

冒导通

응 岂

ตั

( A/oy/w) fuowessu! ownjon poto1 voow wnw!xoW

$\stackrel{\sim}{\sim}$ 
In southern Germany a conbined, multi-level, physlographic vegetational method has proved to be quite practical. Firstly a regional classification is made and then wthin regions short distance differences between sites are taken into account. If necessary, these site units are further subdivided into top soil or humus type categories.

The mensurational forest site type classification methods offer another possibllity of predicting the productive capacicy of sites. Their development was mainly advanced in the U.S. (e.g. Carmean 1975). These methods use regression procedures in order to calculate the site index with the aid of correlated factors of soil, copography and climate. They are based on intensive field rescarch of site factors and yield parameters on suitable stands from sample plots which are equally distributed to represent the various relationships within a defined research area. Multiple regression equations mostly include site index as a dependent variable, and a series of site factors are included as independent variables. Nowadays computer techniques provide the derivation of well suited equations for such purposes, but equations should be proved at a series or test stands before they are used in practice.

An equation of Page (1970) for Sitka spruce in a welsh research area can be taken as an example:

$Y=119.82-0.042 \times 1+4.28 \times 2+3.92 \times 3+2.62 \times 4-0.13 \times 5-59.83 \times 6+27.04 \times 7$

where $\mathrm{Y}=$ top height at 50 years

$\mathrm{Xl}=$ elevation $(\mathrm{ft})$

$X 2$ = shape of slope (numerically converted)

$\mathrm{X} 3$ × shape of contours (numerically converted)

X4 = "hue' of soil at 6 " depth (according to the Munsell colour notation)

X5 - percentage moisture content of soll at $6^{\prime \prime}$ depth (soil at field capacity, dried for $24 \mathrm{~h}$ at $105^{\circ} \mathrm{C}$ )

$\mathrm{X} 6$ = bulk density of soil at $6^{\prime \prime}$ depth

$x 7$ - bulk density of soil at $12^{\prime \prime}$ depth.

This equation explains a great part of the total variation of the site index within the study area at a high statistical significance.

Fquations of this kind are not only used for ldentifying site quality and predicting yield at certaln growing places, but also serve as a basis for classification and mapping of the landscape into units representing different site classes. Using the above equation, site Index maps were constructed for Sitka spruce in Gwydyr forest (Fig. 3). Site factors contalned in the equation as Independent varlables were registered every $10 \mathrm{~m}$, ste indices were calculated, plotted and then isohypes of site indices were drawn. 
If corresponding equations have been derived, maps $c$ an be made in the same area for different tree species, and yields compared on the same sites. The accuracy of these maps depends on:

1. How far the site index represents the real productive capacity. Somettmes from a pragmatic point of view it is sald that the time spent on a very exact estimation of productive capacity is not worth the benefit of a very precise yield prediction.

2. The practicability of the method is decisively determined by how easily the Independent variables can be identified

in the field. Here there is also a pragmatic consideration; possibly in order to have a quicker process in the field, a less accurate estimation of the site index is accepted using only equations which contain easily identifiable site factors.

3. The application of yield prediction equations is only sensible when certain restrictions are accepted. These are :

- that sites should fall within the environmental boundary conditions of the study area, and

that values of site properties should fall within

the ranges used in establishing the relationships.

ESTIMATION OF CAUSAL RELATIONSHIPS BETWEEN THE ENVIRONMENT AND THE PRODUCTIVE CAPACITY OF THE SITE.

This problem is significant for both sciencific research and for practical forestry. Relevant questions are:

What changes in yield are to be expected when the supply of certain nutrients is improved, for example by fertilization?

What changes in productive capacity result when new harvesting methods such as complete tree utilisation decrease the nutrient storage?

How does lowering the ground water level, or, conversely, Irrigation affect the productive capacity?

Strictly, neither environmental nor mensurational methods can give exact evidence of causal relationships. However, these nethods are suitable for developing better insights and working hypotheses wich in some cases these can even stand up to experimental arguents.

Mensurational forest site cype studles can be developed to investigate causal relationships by including a wide range of variables which can improve incerpretation of variation in yield. Amongst these may be the contents of distinct nutrients in the soil volume of certain horlzons, the $\mathrm{C} / \mathrm{N}$ ratios in the litcer or distinct hums layers and the nutrient contents in the needles. 
The development of computer techniques has aided research into causal factors. Besides simple correlation matrices connected with association analysis and clustering techniques, stepwise and full regression models and more complex techniques such as factor and princlpal component analysis, are available. The latter in particular opens new ways for causal research, because "a large quantity of data can be reduced to comprehensible proportions whthout disturbing any of the relationships involved and by examining the vectors that are heavily loaded on the components, it may be possible to interpret the latter in an ecologlcally meaningful way" (Malcolm 1976). Additionally, the single components can be used as regressor variables with productivity as the dependent

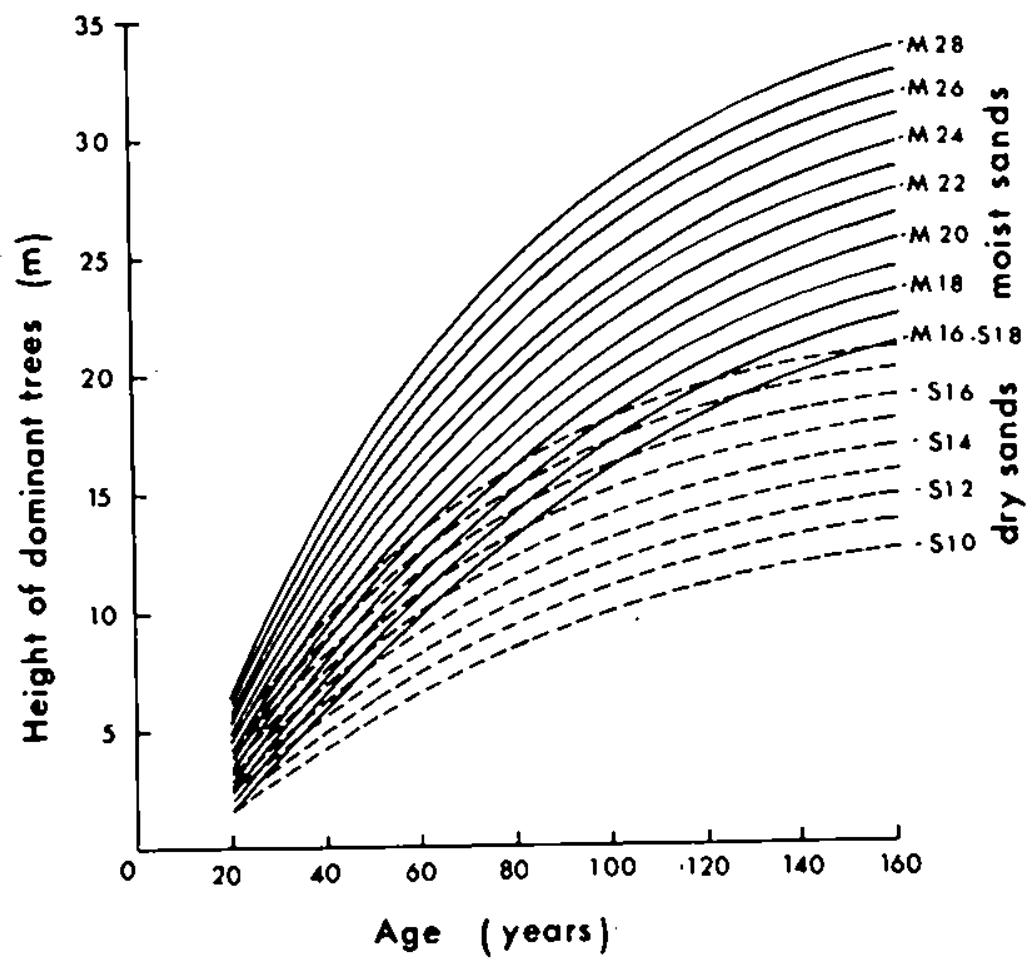

Fig. 4. Helght growth curves of Scots pine (Pinus sylvestris) on two mapping units in northeastern Bavarla. 
vartable.

Present computer techniques make it prowising to create and validate complicated models of ecosystems, so that simulation techniques can be used for causal research. Such studies are underway for instance at the Institute of / Soil Science and Forest Nutrition in coettingen and at the Institute of Forest Ecology in Stockholm.

Causal research $c$ an be aided by environmental site survey methods too. An example 1 s given by Schmidt (1971). He studied the yield relationships of Scots pine in a northeast Bavarian region, where the climatic conditions are rather uniform. His studies were based on site maps, whose mapping units used substrate type and water regime. To that a study of the pines' nutrition conditions were added, using needle analysis and an investigation of soll physical conditions.

Fig. 4 shows the pattern of the height growth curves on the 'dry sands' (dotted line) and on the 'moist Molinia sands' (continuous lines) whose rooted zone is influenced by caplllary water ascending from ground water level. Each mapping unit is characterized by a particular fan of the helght age curves. The curves of the 'dry sands' approach a maximum early in the $11 \mathrm{fe}$ of the stand, whereas those of the 'moist Molinia sands' approach a maximum later. Each single curve, equidistant within lts fan, represents a site quality curve, with the height at age 100 as site index. There is a recognizable variation within the same mapping unit, the causes of which are currently under investigation. Some preliminary results are shown in Fig. 5. St te quality is recorded on the abscissa and the maximum mean total increment on the ordinate. The lines represent single mapping untts, including the two extreme examples used in Fig. 4. For the same value of site quality i.e. height at index age, the maximum mean total increment of the scots pine stands is higher on the sites with a worse water supply than on those with a better one, 1.e. for the same site quality class stands with worse water supply had a higher basal area increment. To a large extent the needle analyses explained chis phenomena, nitrogen nutrition conditions, were mainly responsible for site quality class variation within the same mapping unit. No influence of other nutrients was found. Those quantitative relations between 8 rowth and nitrogen nutrition, as well as those between growth and water supply can be considered to be causative for volume increment within the boundary conditions of the other factors.

Obviously water supply considerably determines the shape of helght growth curves and hence also determines tree form. on sites where there is a water deficlt trees diminish their helght growth earlier than on sites well-supplied with water possibly because the hydraulic gradient between root space and crown influences the potentlal maximum height: Nutrient supply 


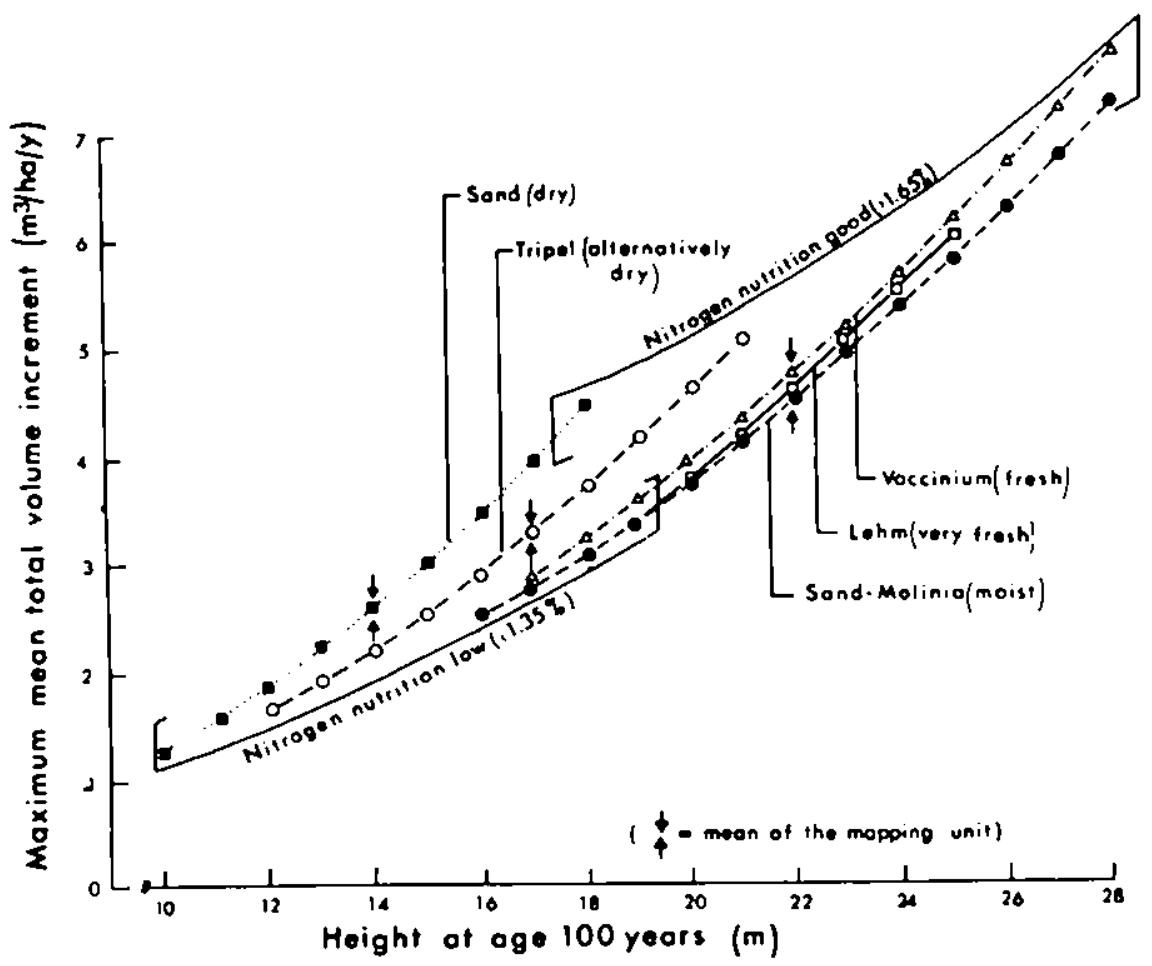

Fig. 5. Volume production of Scots pine (Pinus. sylvestris) in northeastern Bavaria on different mapping units.

seems to have less effect on the shape of the height growth curves, its variation mainly opens the fan.

These relationships still need to be examined further, but the results of Franz (1971) and Moosmayer (1960) from south German spruce stands can be explained in a simflar manner .

\section{CONCLUSIONS}

The two methods of site classification are different in approach but may lead to slmilar results with regard to yield prediction, site mapping and suggestions as to which are the basic requirements for tree growth. The methods are complementary rather than contradictory.

Environmental methods are based on extensive pre-selections and stratifications of the landscape into site 
units and site phases with slallar enviromental conditions. They may be used to Investigate the influence of site on productive capacity and the relative performance of different species. Environmentally based site classifications are also of relevance in assessing erosion hazards, harvesting methods, disease threats, etc. The main problems of environmental classifications are:

1 They wust be related to forest management and sllviculture. Though aany environmental surveys from soll scientists or plant sociologists produce important subdivisions of the landscape and contain valuable Information, they are often overcharged with specific academic objectives and do not meet the utilltarian requirements of foresters.

11 Their mapping units must be sufficiently precise to define areas that comprise forest sites with similar potential for tree growth, forest yield capabllities and susceptlbility to hazard. But in order to remain practical the definitions should not be too narrow.

1ii Maps wust be constructed to a scale and based on a sampling that enables different site types to be shown as distinct units.

These problems may be overcome by coordinated teamwork of soll scientists, ecologists, plant sociologists and foresters. Environmentally based classification and mapping can be of value to a large varlety of empirical studies and comparisons as well as permitting the extrapolation of results found at one point to other locations of the site unit.

The problems assoclated with mensurationally based classifications are:

1 The site Indices used are based on data from even-aged pure stands. Any increase in yield in mixed stands caused by synergistic effects between tree species are not predictable.

11 For even-aged pure stands site indices should reflect the real productive capacity as timber volume and including the yield effects of different site-typical growth curves.

111 The varying effects of different stand treatments should be excluded, for they introduce inaccuracies into the yield prediction equations.

Iv The site properties must be quantifled and sometlmes only numerlcal conversions $c$ an be used.

$\checkmark$ Yield prediction equations have to combine precision and practicability.

Preselections and stratifications of stands and sites

are often requited to resolve these problems. This may be considered to be an approach towards environmental methods, for sites are stratifled with regard to distinct site features and corresponding yield prediction equations are established. 
The main advantage of the mensurational site studies, or soil site studies as they frequently are called, are:

i. They show, a priori, the econoric value of the sices or mapping units.

if They point out various environmental features which are closely related to the yield capability of the stands.

11 They make evident the ragnitude of yield potential associaced with each significant enviromental feature.

Application of these methods is valuable in areas where site evaluation is focussed on the yleld of even-aged pure stands. However, mapping units defined by site indices alone are not satisfactory in all respects, because they are an expression of the integration of environmental features of the site. The same site index can be the result of a very different interplay of site factors and therefore it is unfit for expressing the variety of silvercultural possibilities and constralnts existing of the sites of the rapping unit. We have to consider that the ecological amplitudes of different tree species are different with respect to the various combinations of site factors. Furthermore, it is of importance to know which growth factors within a distinct mapping unit are 1 imiting growth and which can be improved.

Certainly such shortcomings may be resolved by using significant environmental features from yield prediction equations and introducing them into the definitions of mapping units. However, this may also be considered as an approach towards environmental methods.

Mensurational site type methods are of value when atcempting an environmentally based classification:

1 As a preliminary to environmental classifications, they can provide additional information in defining mapping units;

ii subsequent to environmental mapplings they may give evidence of slte Index variations within and between mapping units.

Further applications of mensurational methods in forest practice could be:

1 To achieve prellminary reviews of correlations between productivity and site conditions especially in remote regions, where forest experience is rather limited. Aerlal photography may be used, possibly together with preceeding geological, climatic or other environmental stratifications if such data bases are available.

11 To gain better insights into causal relations. Here rany possibilities of combinations wh thenvironmental methods exist for forest practice as well as for forest research. 


\section{REFERENCES}

Assmann,E.(1962). Die Fortentwicklung unserer Ertragstafeln. Aligemeine Forstzeitschrift, 17, 817-820;839-41.

Assmann,E.(1966). Die Schätzung jetziger und künftiger Ertragsleistung. Forstwissenschaft $l$ iches Centralblatt, $85,355-371$.

Assmann,E. \& Franz,F.(1965). Vorlaufige Fichtenertragstafel für Bayern 1963. Forstwissenschaftiches Centralblatt, $84,13-43$.

Carmean,W.H.(1975). Forest site quality evaluation in the United States. Advances in Agronomy, 27, 209-269.

Fourt,D.F., Donald,D.G.M., Jeffers,J.N.R. \& Binns,W.0.(1971). Corsican pine in southern Britain. Forestry, 44, 189-207.

Franz, F.(1967). Ertragsniveau-Schätzverfahren für die Fichte an Hand elnmalig erhobener Bestandesgrössen. Forstwissenschaft liches Centralblatt, $86,98-125$.

Franz, F.(1971). Grundlagen und Verfahren standortsbezogener Leistungsschätzung. Forschungsberichte forstliche Forschungsanstalt, $2,384 \mathrm{pp}$. (incl. $68 \mathrm{pp}$ of tables).

Gessel, St.(1976). Site in relationship to forest tending. Paper at I.U.F.R.O. meeting in Osslach, Austria, 1977.

Günther,M.(1955). Untersuchungen iber das Ertragsverosgen der Hauptholzarten im Bereich verschledener Standortselnheiten des Wirttembergischen Neckarlandes. Mitellungen des vereins für forstliche St andortskartlerung, 4, 5-31.

Hornd asch, M. (1969). Die $e^{-}$Standortserkund ung Fortenwicklung. Annual Report of the Bayerischen Forstuereins, pp.40-68.

Johnston, D.R. \& Bradley,R.T.(1963). Forest management tables. Commonweal th Forestry Review, 42, 217-227.

Magin, R.(1963). Standortsgerechte Ertragsermittlung als Te1l der Forsteinrichtung. Allgemeine forstzeitschrift, 18 , 128-130.

Magin,R.(1965). Zustandserfassung und Ercragsregelung im Rahmen einer zeitgemässen Fortsteinrichtung. Allgemeine Forstze itschrift , 20,781-784.

Malcolm, D.C. (1976). Site factors and the growth of Sitka spruce. Proceedings Section 21 of the 15th IUFRO Congress, Gainesville, Florida. Published In Wageningen. pp. 269-83.

Moosmayer,H.U.(1955). Die Wuchslelstung, der Flchte und Buche auf den whitigsten Standortseinheiten im Forstamt Könfgsbronn. Mittellungen des vereins für forstliche Standorts kartlerung, 4, 52-60.

Moosmayer,H.U.(1957). Zur ertragskundlichen Auswertung der Standortsgliederung in Ostéll der Schwäbischen Alb. Mitrellungen des vereins für forstiche Stand ortskartierung, $\underline{7}, 1-42$. 
Moosmayer,H.U.(1960). Die ertragskundliche Auswertung der Standortskarten it Hinblick auf die praktische Forsteinrichtung. Mitceilungen des Vereins for forstliche Standortskartierung, 10, 13-24.

Page,G.(1970). Quantitative site assessment: some practical applications in British forestry. Forestry, 43, 45-56.

Schlenker,G. \& Kreutzer,K.(1976). Verglelch von Klassifikationssystemen für forstliche Standortskartierungen. Proceedings IUFRO World Congress, Division I, Oslo. pp. 219-37.

Schidt,A.(1971). Wachstum und Ertrag der Kiefer auf wirtschaftich wichtigen Standortseinheiten der Oberpfalz. Forschungsberichee forstliche Forschungsanstalt, $1,245 \mathrm{pp}$. (including $58 \mathrm{pp}$ of tables).

Schidt,A.(1973). Ertragsniveau und Standort dargestellt am Beisplel der Kiefer. Forstwissenschaftliches Centralblatt, 92, 268-274.

Wiedemann,E.(1939). Untersuchungen der Preussischen Versuchsanstalt über Ertragstafelfragen. Mitteilungen aus Forstwitschaft und Forstwissenschaft, $4,1-40$.

Wledemann,E.(1941). Vorschlage für einheitliche Ertragsklassen. Der Deutsche Forstwit, 33/34, 313-317. 
BY JUHANI PÄIVÄNE,N

Metsäteho, Opastinsilta 8B, 00520 Helsinki 52, Finland.

\section{SUMMARY}

Site preparation is an action taken for the primary purpose of improving the survival and growth rate of a new stand. It includes prescribed burning, herbicide application, and various mechanical treatments. Amelforation measures, such as cultivation in particular, but also dralngage and fertilization, can be said to 'prepare' the site where a new stand is to be established. Cultivation is the use of equiprent to loosen and mix the soil in order to improve its structure and thus the overall growing conditions for trees. The purpose of drainage is to remove excess water from sites and so enhance the survival and growth of forest crops and fertillzers are applied to the forest stands for the purpose of accelerating their growth rate.

This paper deals with amelioration including drainage, cultivation and fertilization both on mineral and organic solls, mainly for stand establishment. It concentrates on results galned from research and practice in Northern Europe and, in particular, Finland.

RÉSUMÉ

La préparation d'un terrain c'est d'abord, essayer d'amélforer le taux de survie et de croissance d'une nouvelle plantation. Cela comprend le brûlage contrólé, l'application d'herbicides et divers traitements mécantques. Des mesures d'amélioration, tels que le labour en particulier, mais aussi la fertilisation et 1 assainissement, forment en quelque sorte la preparation du terrain avant l'établissement $d^{\prime}$ une nouvelle plantation. Le labour consiste en l'utilisation d'un certain équipement pour défoncer et mélanger le sol afin d'en améliorer la structure et par la les conditions générales pour la crolssance des arbres. La raison du 
travall d'assainissement est d'élfolner l'excédent d'eau du terrain et, par la, d'ameltorer la survie et la croissance de la foret. Les engrais sont utilises afin d'accélérer le taux de croissance d'une plantation.

Dans cet exposé on traite de ces amél forations - assainissement, labour, fertilisation - que ce solt sur sols minéraux ou organiques, en vue de l'établissement d'une plantation. On examine les résultats de recherches et la pratique en Europe septentrionale et en particulier en Finl ande.

\section{ZUSAMMENFASSUNG}

Die Vorbereftung der Kulcurflächen dient in erster Linie zur verbesserung der überlebensund Wachstumsrate des neuen Restandes. Das schliesst ein kontrolliertes Brennen, Anwendung von Herbiziden und verschiedene Arten. mechanischer Bodenbearbeitung . Bodenbearbeitungsuassnammen, wie vor allero Pflügen, aber auch die Drainage und Düngung, sind als 'Vorbereitung' des Standorts für den neuen Bestand anzusehen. BeIm Pflugen wird der Boden durch verschiedene Gerate gelockert und durchischt, was seine Struktur und die Wachstumsbedingungen insgesamt verbessert. Durch die Dralnierung soll Überschusswasser dem Standort entzogen und damit die überlebens- und Wachstumsrate der Bäume vergrössert werden. Düngemittel wiederum sollen das Wachstum des Bestandes beschleunigen.

Diese Arbelt befasst sich wit Stand or smel iorationsmassnahmen, einschllesslich Drainierung, Pflügen und Dïngung auf Mineralbóden und organischen Böden zur Bestandesbegrindung. Im Mittel punkt stehen Ergebnisse aus Forschung und praxis, die in Nordeuropa, Insbesondere in Finnland, gewonnen wurden.

\section{DRA INAGE}

Water relations of poorly dralned solls

All water present in the soll, at water contents between saturation and permanent witing point, is avaliable to plants; it is not prevented from being taken up by the plants due to being chemically or physically bound to the soll matrix. Superfluous water in the soll may, however, lopair 
aeration to such an extent that low oxygen and high carbon dioxide concentrations inhibit growth. In the case of undrained peatlands and water-logged mineral solls, the ground water cable is frequently located at, or very close to, the ground surface and in such cases the pore space of the soll is completely filled with water. If water moves very slowly then anaerobic conditions may prevall in the soil. Root development may be 1 imited by factors other than the lack of aeration, particularly in the case of saturated organic soils, eg. due to the development of toxic concentrations of ferrous iron, sulphides and manganese.

There is little general information avallable concerning the minimum air space required by the roots of trees growing on peat. Paavilainen (1967) found that roots of pine trees growing on pine swamps did not penetrate to a depth greater than that at which the alr space of the peat dropped below 10 per cent and this value is used as the upper ilmit of available water (Pãivanen 1973). It is of course open to adjustment because of the lack of information on the minimum air space required by the roots of other tree species growing on peat. The water content corresponding to pF 4.2, which has usually been considered as being the permanent wilting point, is used as the lower $1 \mathrm{imlt}$ of avallable water.

The quantity of water available to plants growing in peats with different bulk densities is shown in Fig. 1 for different hypothetical equilibria of soll water. In interpreting Fig. I 1t must be kept in mind that soll water under fleld conditions will rarely reach a static equilibrim; chere is continuous movement of water in one direction or another.

In undecomposed peat the minimum air space is obtained at a matric suction below pF 1 , the corresponding value being $p F$ 1.5 for peats at an advanced stage of decomposition. For the latter peat and at equilibrium conditions, the ground water table should be some $32 \mathrm{~cm}$ below the layer of observation. All the water which enters this minimum alr space is superfluous.

A number of studies have been carrled out to solve the question of the optimum drainage for forestry purposes (e.g. Heikuralnen, Pålvānen \& Sarasto 1964). However, this probably varies with the size and the stage of development of the tree e.8. germinating seed, seedling, young tree, mature tree ctc. It is not exactly clear how close a relationship there is between tree growth and soll water tension but somewhat above pF 2 can be considered to be optimum for tree growth (Heikurainen 1967). An average drainage depth of some $45 \mathrm{~cm}$ may provide the best growing conditions for tree roots.

The most important task of drainage is to adjust the water content of the soll to a level which ensures sufficient aeration. Studies carried out in Finland have ind icated that there is no risk of overdrainage in forests grown on peatlands (På1vànen 1973), at least not without fertilizer application 
Drainage techniques

Recommendations for ditch depth and spacing at present in use for different sites in Finland are:

Site

Spacing Density Depth Size

Tree-covered peatlands

shallow peat solls

(and wet mineral soils)

m

m/ ha

m $\quad \mathrm{cu} . \mathrm{m} / \mathrm{m}$

deep-peat soils

of gond quality

deep-peat soils of

poor quality

Open peat lands

bogs

$\begin{array}{llll}50 & 200 & 0.65 & 0.55 \\ 40 & 250 & 0.75 & 0.70 \\ 30 & 333 & 0.75 & 0.70 \\ 30 & 333 & 0.80 & 0.75 \\ 25 & 400 & 0.80 & 0.75\end{array}$

(Hutkari\& Paarlahti 1967).

On open peatlands water furrows are also used. Drainage ditches are spaced 25-40 m apart, and the furrows are placed perpendicularly to them at 3-5 w spacing. The furrows are 25-50 cro deep and are made by rotary ditchers or planting ploughs. Water furrows shorten the duration of high ground water and contribute to the lowering of the water table particularly at wide drainage-ditch spacings (Päivänen 1974). Since precipitation, the hydraulic conductivity of peat, and the tree stands on the area, to be dralned vary within wide limits, the combinations of ditch spacing and ditch depth used are different in different parts of the world.

Forest ditches in Finland were dug wanually until 1953 when mechanized forest drainage commenced with the introduction of forest ditch ploughs. A standard ditch may be ploughed into firm peat soll at the rate of 500-600 m per hour.

The relative length of ditches made by ploughing has decreased during the last decade and the most common machine at present in use is a tractor digger or backhoe (Fig. 2) which has a work output of 70-90 to forest ditch per hour. About 90 per cent of all forest ditches dug annually are made with tractor diggers, and the total number of units working in forest drainage is about 700 .

During the past few years rotary ditchers have been used though only for furrowing and site preparation prior to afforestation on deep peat sites. Some of these machines are capable of making elther vertical-walled, narrow ditches or ordinary open ditches. In open peatlands standard forest ditches can be dug by rotary ditchers at a rate of 60-200 per hour. 
PÄIVANEN

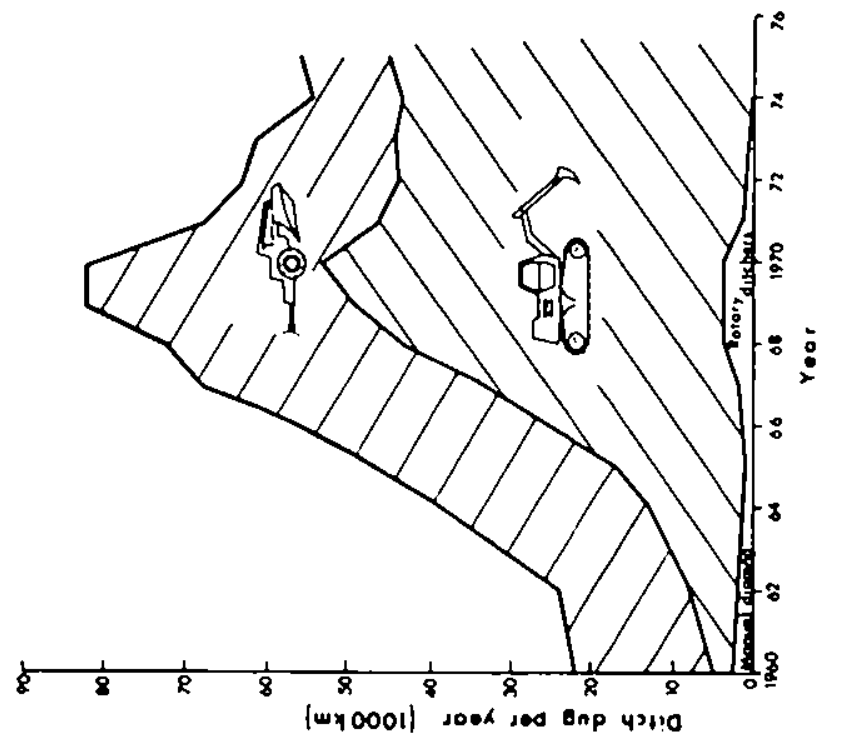

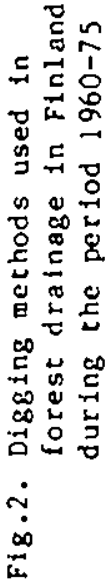

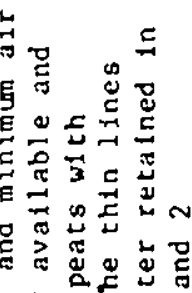

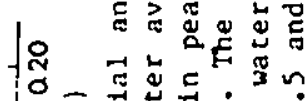

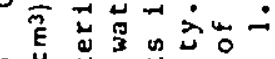

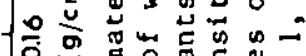

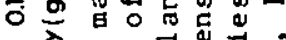

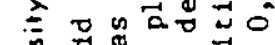
○ 以

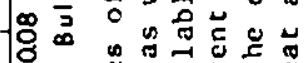
出

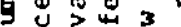

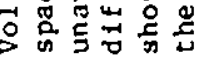


Effect of drainage on tree growth

Several studies have shown the response of trees to drainage (see e.g. Heikurainen 1964). Continuation of the post-drainage effect on growth has been studied on naturally tree covered peatlands (Seppäla 1969; Heikuraien \& Seppála 1973). Growth seems to increase gradually even after the imediate effect obtained following drainage and we can be sure that during the first rotation drainage will be adequate. Altogether we have enough data to calculate the suftability of various peatlands for forest drainage (Hefkuratnen 1973)

Because there are numerous naturally tree-covered peatlands in Finland, tt has not been as important to study the afforestation of peatlands, as the effect of drainage on the growth of tree stands already growing on the site at the time of draining. However, afforestation problems and the early growth of seedlings and transplants have been studied to some extent (Kaunisto 1972, 1975). It is concluded that afforestation of open peatlands is not a biological problem, since it is quite possible for young trees to grow well on peat, but rather a question of economics as is discussed later. In other countries more has been published about tree planting on peat (Zehetrayer 1954; Braekke 1974; Savill, Dickson \& Wilson 1974; Thorson 1974).

\section{CULTIVATION}

Necessity for cultivation

Very often the main purpose of cultivation has been to ald the work of afforestation. After cultivation the work output in planting is twice as high as without site preparation. The other objective of cultivation has been to improve survival and early growth of a new stand. From the point of view of soil improvement the ultimate aim is, however, to reach long-term favourable effects but the factors associated with cultivation are numerous and complex (F1g 3.) (Mä1könen 1976).

In northern countries low soll temperature is one of the limiting factors to the early growth of trees through its effect in reducing root developoent and the activity of soll organisms (Söderströn 1975). By cultivation, the humus layer is removed from the planting position or is mixed into the mineral soll and the temperature of the soll can be increased. However, extreme temperature fluctuations, ie. a high maximum during the day and low minimum at night ought to be avolded.

The humus layer on mineral soll reduces fluctuations in the water content of the soll, and on coarse mineral soils lack of water is a limiting factor for the early growth of trees, so that on such sites only a light scariflcation is recommended.

Lack of water may also be the princlpal limiting factor for transplants on other sites. Durfing transportation from 


\section{PÄIVÄNEN}

nursery to planting sites the roots nay be damaged and the general physlological condition of transplants may be lowered. This, together with a dry spell, may be fatal for the newly planted trees. The water retention capacity of the soil is greater, the finer the texture or the poorer the structure of the soll. Cultivation tries to improve soll structure by increasing the total pore space and particularly the air space of the soll. This is known to be favourable for root development and to Increase the 8 rowth of the established stand later on. So there is an obvious contradiction between the requirements for soll aeration and for soil moisture.

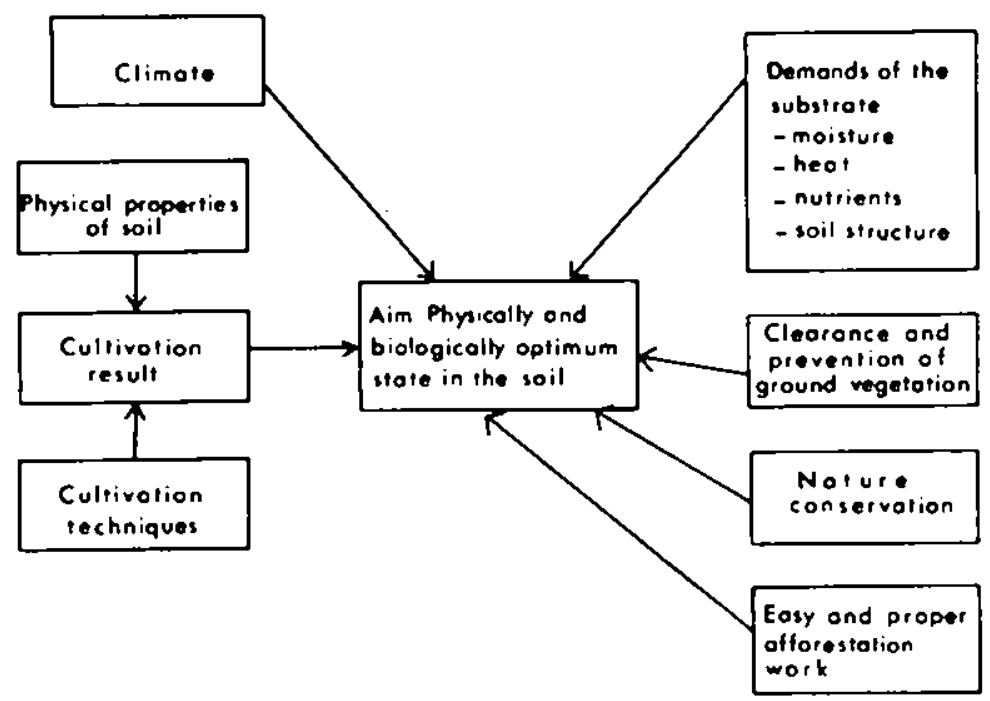

F18. 3. Factors associated with cultivation

(after Mälkönen 1976).

This can be avolded by developing cultivation methods that sat1sfy both these needs. Mixing the humus layer and the underlying mineral soll, and then ridging and compressing the mixture is one such method. The organic matter increases the water retention capacity and, when mixed with the mineral soil, lmproves the structure and so the aeration. Another method could be based on intensive culcivation where a thick enough layer of mineral soll is ploughed over so that $10 \mathrm{gg}$ ing 
slash from the previous rotation will be buried underneath However, at present, sultable cultivation equiprent for this technique is not available.

In addition to the above-mentioned, the following goals can be considered for cultivation:

- to reduce competition from ground vegetation

- to prevent damage from insects, and

to increase the relcase of nutrients confined to the

organic matter.

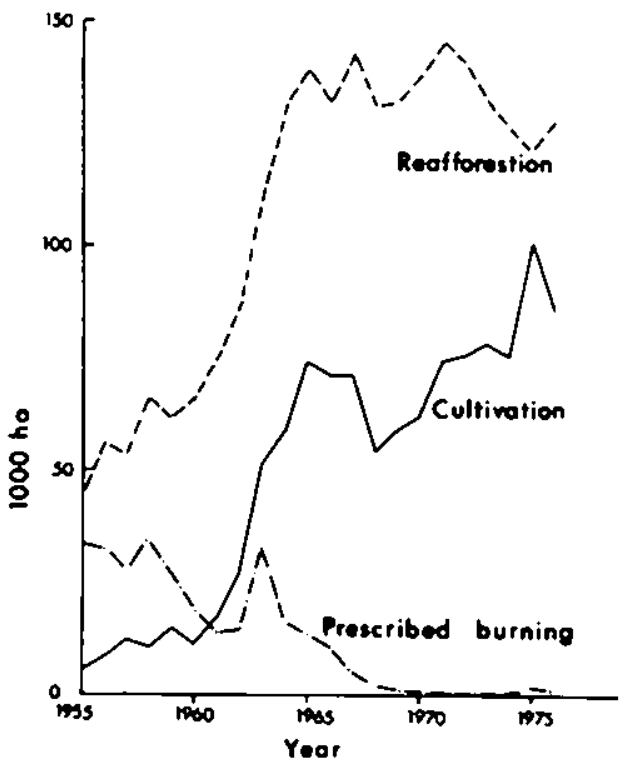

Fig. 4. Reforestation, cultivation and prescribed burning In Finland during the period 1955-76.

\section{Cultivation techniques}

As a site preparation technique, cultivation has increased remarkably in Finland over the last two decades (Fig. 4), whilst prescribed burning has diminished and is now almost non-existent. There are several reasons for this. Prescribed burning is a labour-intensive operation and one which fire laws and insurance requirements do not favour. At the same-time, technical developments have made it possible to mechanize site preparation work. Until the middle 1960's, scarification was the most commonly used technique. The action of scarlfiers is confined to exposing the mineral soll underlying the humus layer. In Sweden, scartfiers have been 
developed to cultivate and shape the scarified spot, whilst in Finland they have been replaced by forest disc ploughs which nake two continuous oineral soll furrows. Reforestation ploughs are used particularly in northern finland where, because evapotranspiration rates are never very high, even in summer, and are exceeded by precipitation, the soil needs draining. Trees are either planted in the exposed mineral soil on both sides of the furrow or, on wetter sites, in the furrow slice. Disc ploughs and afforestation ploughs are drawn by wheeled tractors, though, to a swall extent, afforestation ploughs are also drawn by crawler - tractors. The work out put of disc ploughs and afforestation ploughs is about 0.9 and 0.5 ha per hour, respectively.

On open-drained peatlands rotary ditchers are used which are operated on the chain, disc cutter or spiral principles. Fiffect of cultivation on tree growth

Cultivation costs can often be recovered at the time of planting as a result of reduced planting costs. Also the effect of appropriate soll preparation on survival and early 8 rowth of planted crees is evident (Milkönen 1972; Thomson \& Neustein 1973; Pohtila 1977). Not only does cultivation lead to an amelforation of soll structure but nutrients available to the trees are increased due to an increase in organic matcer decomposition. Whilst there are too few experiments old enough with which to assess the long-terw effects of cultivation, we can assume that, at least with intensive treatments, prolonged advantageous results can be expected.

\section{FERTILIZATION}

On mineral solls, the lack of nutrients is not usually a limiting factor for stand establishment (Leikola \& Rikala 1974). On clearfelled areas nutrients in the waste wood are returned to the nutrient cycle, and the nutrlent status of the soll may be better than it ever was during the whole rotation (Kubin 1977). If whole tree harvesting methods become general the situation may change.

Open peatlands may be poor in nutrients. On a practical scale, the dralnage and afforestation of open peatlands has been small in Finland. However, numerous expertments have been laid out in order to ascertain the best method of fertilizer application when fertilizing is carried out in connection with stand establishment. When directly sown, seedlings of Pinus sylvestris respond best if the topmost peat layer is rotavated and fertilizers are worked into the shredded peat (Kaunisto 1972 ). When planting pine seedlings on poor organic soils raw phosphate can be applied into the planting hole (Paavilainen 1966). Only small quantities of a mixed NPK fertilizer ought to be used and the fertilizer should not be thrown very near the transplant (Seppáa 1971). Large quantitles of fert1lizer broadcast at the time of planting increase mortaltty 
(Helkurainen \& Lalne 1976). The duration of the inftial fertilization effect after afforestation is only 5-7 years. Refertilization with nitrogen alone is not recommended for Scots pine on oligotrophic peatlands (Kaunisto \& Paavilainen 1977).

Afforestation experiments on open peatlands are still too young to allow conclusions on the profitability of this kind of activity. Compared with other amelioration techniques the afforestation of open, nutrient poor peatland is 1 ikely to be unprofitable even with the help of draining and prolonged fertilization.

\section{DISCUSSION}

A range of site preparation methods is in general use for improving survival and growth rate of the stand to be established. By cultivation we hope to maximize both advantages at the time of planting or direct seeding, as well as to secure a good start for the seedlings and co ameliorate soll properties over the long-term. The aims are similar for drainage and fertilization but until now only short-terts advantages have been shown conclusively. However, with drainage on naturally tree-covered peatlands long-term effects have been demonstrated. Long-term effects of cultivation, fertilization and refertllization are likely, although as yet not proved.

\section{REFERENCFS}

Braekke, F.H. (1974). The effect of fertilization and drainage intensity on height 8 rowth of Scots pine and Norway spruce in north Norway. Proceedings of the International Symposicm on Forest Dralnage, Jyväskylä-Oula, Finland. pp.207-18.

Heikuralnen,L. (1964). Improvement of forest growth on poorly drained peat soils. International Review on Forest Research, $1,39-113$.

Helkurainen, L. ( 1967$)$. On the possibilities of optimum drainage in peat lands. Proceedings XIV Congress IUFRO Section 23, pp. 264-77.

Helkurainen,L.(1973). A method for calculation of the suitability of peatlands for forest drainage. Acta forestalia fennica, 131, 1-35. (In Finnish with English sumary).

Heikurainen, L. \& Laine,J.(1976). Effect of fertilization, drainage, and temperature conditions on the development of planted and natural seedlings on pine swamps. Acta forestalla fennica, 150, 1-38. (In Finnish with English summary).

Helkurainen,L. Seppalä, K.(1973). Reglonality and contínulty of stand growth in old forest drainage areas. Acta forestalla fennica, 132, 1-36. (In Finnish with English 
sumnary) .

Hefkurainen,L., Pålvănen,J. \& Sarasto,J.(1964). Ground water table and water content in peat soll. Acta forestalla fennica, $77.1,1-18$.

Hulkar1,0. \& paarlahti,K.(1967). Results of field experiments on the ecology of pine, spruce and birch. Communicationes Instituti Forestal is Fenniae, 64.1, 1-135.

Kaunisto,S.(1972). Effect of soll preparation and fertilization on the growth of young pine plantations on peat. Proceedings $4 \mathrm{th}$ International Peat Congress, Volume III, pp. 501-508.

Kaunisto,S.(1975). Rotavation and fertilizer placement in connection with direct seeding of Scots pine on peat. Greenhouse experivents. Communicationes Instituti Forestalis Fenntae, 85.4, 1-58. (In Finnish with English sumary).

Kaunisto,S. \& Paavilainen,E.(1977). Response of Scots pine plants to nitrogen refertilization on oligotrophic peat. Communicationes Instut 1 Forestal is Fenniae, 92.1, 1-54.

Kubin,E.(1977). The effect of clear cutting upon the nutrient status of a spruce forest in northern Finland $\left(64^{\circ} 28^{\circ} \mathrm{N}\right)$. Acta forestalla fennica, 155, 1-40.

Leikola,M. \& Rikala,R.(1974). The effect of fertllization on the initial developoent of pine and spruce on mineral soils. Folla forestalia, 201, 1-19. (In Finnish with English summary).

Målkönen,E.(1972). Soge aspects concerning cultivation of forest so1l. Folla forestalia, 137, 1-11. (In Finnish with English summary).

Mālkönen,E.(1976). Markberedningens ekolog1 och Inverkan pa planteringsresultatet. Forskningsstiftelsen Skogsarbeten, Redogorelse 6, 11-15.

Paavilainen,E.(1966). Initial development of root systems of Scots pine transplants in Erlophorm vaginatum swamp. Communicationes Instut forestalis Fenniae, 61.6, 1-17. (In Finnish with English summary).

Paavilainen,E.(1967). Relationsh1p between the root system of Scots plne and the alr content of peat. Communicationes Instut 1 Forestalia Fenniae, 63.6, 1-21. (In Finnish with English summary).

Pälvänen,J.(1973). Hydraul tc conductivity and water retention in peat spolls. Acta forestalla fennica, 129, 1-70.

Paivanen,J.(1974). The effect of ditch spacing and furrowing on the depth of the ground water table and on the development of a Scots pine plantation on small-sedge bog. Silva fennica, $8,215-224$.

Pohtila,E.(1977). Reforestation of ploughed sites in Finnish Lapland. Communicationes Instuti Forestalis Fenniae, $91.4,1-98$. 
Sav111,P.S., Dickson,D.A. \& Wilson,W.T.(1974). Effects of ploughing and dralnage on growth and root development of Sitka spruce on deep peat in Northern Ireland. Proceedings of the International Symposium on Forest Drainage, Jyväskylä-Oulu, F1nl and. Pp.241-252.

Seppäla,K.(1969). Post-drainage growth rate of Norway spruce and Scots pine on peat. Acta forestalia fennica, 93, 1-89. (In Finnish with English sumary).

Seppäla,k.(1971). On the quantity of ferc1lizer and application methods used in afforestation of open bogs. Silva fennica, $5,61-69$.

Söderstrow, V.(1975). Ecological effects of ploughtng wineral soll before planting on clearfelled areas. Sveriges Skogsvardsforbunds Tidskrift, 73, 443-472. (In Swedish with English summary).

Thompson,D.A.(1974). A brief review of drainage in deep peat in the Forestry commission. Proceedings of the International Symposium on Forest Drainage, Jyväskyla-Oulu, Finland. pp.253-259.

Thonson,J.H. \& Neustein,S.A.(1973). An experiment in intensive cultivation of an upland heath. Scottish Forestry, 27, 211-221.

Zehetmayer,J.W.L.(1954). Experiments in tree planting on peat. Forestry Commssion Bulletin 22 . 
September 5, 1978

THE BIOLOGICAL RESOURCE

Chaiman: L. Roche

Variation between and within rree spectes.

D.A. Perry

The exploitation of genetic variation by selection and breeding.

R. Faulkner

Blological opportunities for genetic improvement in forest productivity.

M.G.R. Cannell 

VARIATION BETWEEN AND WITHIN TREE SPECIES

By

David A. Perry

Department of Forest Sclence, School of Forestry, Oregon State UnIversity, Corvalils, Oregon 97331, U.S.A.

\section{SUMMARY'}

Genetic variation in forest trees has three primary components: among populations, among Individuals within populations and among specles. Variation among populations has been widely studied. Much variation is apparently adaptive with some tratts, such as phenology, temperature optima for photosynthesis, seed welght, DNA content, and drought resistance, varylng with climatic clines in photoperlod, temperature and rainfall. Clinal varlation may be environmentally correlated in quite localized areas, i.e. up a single mountain slope or from one aspect to another. Nonclinal variation also occurs, most commonly in response to edaphic factors. Considerable variation among populations is not obviously correlated with environmental factors. Much of this may be due to historical factors producing isolation and drift.

Recent studies have found considerable genetic variation within populations. The indications, but whout soldd evidence, are that at least a portion of this may be adaptive, especially with respect to pest resistence and competition avoldance. On the other hand, effectlve pollen dispersal is apparently highly localized, suggesting that 1 solation and drift produce at least some of this variabllity.

Differences among specles are well known and impossible to detall here. A major segregating factor has been adaptive strategy as manifested in successional status, leading to differences in silviculturally significant tralts such as shade tolerance, efficlency of nutrient cycling and possibly pest resistance.

Ample genetic variation exists, or may be created through newly developing technologies, 
to yield significant genetic gains in individual tree growth. Possible approaches Include selection for temperature optima, efficlency of water and nutrient utilization, optimal mesophyll density, crowns that efficiently gather light, lower light respiration, and phenolog tes that fully utilize the growing season.

Because foresters probably will never deal with cultivated systems in the agricultural sense, 1t seems prudent not to decrease the natural buffering capacity of forests through drastic reductions in genetic diversity. Therefore, I suggest that genetic manipulation should focus both on individuals and communities. Much more study of ecosystem dynamics is needed but perhaps communities which are properly designed mixtures of genotypes can be both stable and productive.

\section{RÉSUMÉ}

Les variations génét lques des arbres forestiers peuvent etre primitivement classés en trois composantes: variation entre populations, variation entre individus au sein d'une population et variation entre espèces. Nombreuses ont été les etudes sur les varlations entre les populations. Apparamment, les variations sont en grande partie du genre adaptatif avec certains traits, tels que phénologie, température optimale de photosynthèse, poids des graines, contenu en DNA et résistance a la sécheresse variant avec les gradients climatiques, la température et la pluie. Les variations clinales peuvent etre corrélées avec des facteurs du milleu dans certaines zones limitées par exemple le long $d$ 'un versant, ou d'un versant a l'autre. Les variations qui ne sont pas clinales sont liées, le plus souvent, à des facteurs édaphiques. Mals une grande partie des varlations entre populations $n$ 'est manifestement pas liée à des facteurs dumilieu. Elle seralt plutôt liée à des facteurs historlques qui produisent soit un 1 solement, solt une dérive.

Des études récentes ont montré qu'11 y avalt au sein des peuplements des variations génétiques considérables. Elles ont indlque, mals sans preuves solides, qu'au moins une partie de cette varlation avalt un caractère adaptatif, 
surtout la résistance aux parasites et l'aptitude a éviter la coapétition entre espèces. $D^{\prime}$ un autre côté, la dispersion effective du pollen est trés localisée. Cela suggéreralt que $l^{\prime}$ isolement et la dérive seraient au moins une source partlelle de cette variation.

Les différences entre les espèces sont bien connues et ll est impossible de les énumérer ici. Un des facteurs de différenciation les plus importants est la stratégle d'adaptation qui s'est manifestée dans la succession des peuplements amenant des différences significatives dans le comportement sylvicole, tel que la tolérance d'ombre, l'efficacité du cycle des éléments nutritifs et peut-être la résistance aux parasites.

Il existe une vaste variation génétique, ou du moins celle-ci peut être créée par des technologies nouvelles, qui amèneraient des apports génétiques significatifs pour la croissance d'un individu. Les approches possibles comporteraient une selection pour des températures optimales spéctfiques de certaines stations, pour l'utilisation efficace de $l^{\prime}$ eau et des élements nutritifs, pour une densité du mésophylle optimale, pour des cimes qui recueulllent avec efficacité la lumiẻre, pour une photorespiration plus basse et pour des phénologles qui ut 11 lsent pleinement la saison de végétation.

Bien que les forestiers ne seront jamals amenés à traiter des systèmes culturaux au sens agricole du terme, 11 seralt prudent de ne pas diminuer la capacité de régulateur naturel des forêts qui est due, en large partie, la diversité génétique. Par consequent, je suggère que les mantpulations génétiques portent aussi blen sur les individus que sur les populations. Une étude plus approfondie de la dynamique des écosystèmes serait certes utlle mals il.se pourrait aussi que les peuplements issus d'un cholx. efficace d'essences différentes puissent être à la fois stables et productifs.

\section{ZUSAMMENFASSUNG}

Genet1sche Verschiedenartigkeit be1 Waldbāumen hat dre1 Hauptkomponenten: die zwischen Populationen, die zwischen Elnzelexemplaren innerhalb von populationen und die zwischen 
Baumarten.

Die Verschiedenartigkelt $z$ wischen Populationen Ist 8 ründlich erforscht worden. Häufig ist die Verschiedenartigkeit offenbar das Resultat elner Anpassung an bestimme Gegebenhelten, wie beisplelsweise Phänologie, Temperaturoptimum für Photosynthese, Saatgewicht, DNA-Gehalt and Dürreresistenz, die sich mit den klimatischen Abstufungen in der Phocoperlode, der Temperatur und dew Niederschlag ändern. Stufenweise Unterschiede mögen sogar in engem Raum von der Unwelt abhänging sein, wie zum Beisplel auf einem elnzigen Berghang oder von einer Exposition zur anderen. Es $8 \mathrm{ibt}$ auch nicht-abgestufte Unterschiede, weist als Reaktion auf edaphische Faktoren. Vieles in der verschledenartigkeit innerhalb von populationen 1st nicht offensichtlich von Umweltfaktoren äbhang 18. Das ist zum grossen Tell auf hlstorlsche Cegebenhelten zurückzufthren, die Isollerung und Abwanderung verursachen.

Jünere Studien haben eine beträchtliche gener 1 sche Verschiedenartigkelt innerhalb von Populationen festgestellt. Auch wenn es keine handfesten Beweise gibt, sprechen doch die Anzeichen dafur, dass zumindest ein Teil davon Ergebnls elner Anpassung 1st, besonders 1m Hinblick auf die Schädlingsresistenz und die Vermeidung von Konkurrenz. Andererseits ist elne effektive Pollenverbreitung weitgehend räullch begrenzt. Dies lässt verwuten, dass Isollerung und Abwanderung wenigstens in einem gewissen Mass die Varlabilität erzeugen.

Unterschiede zwischen Baumarten sind hinrelchend bekannt und es ist hier nicht möglich, darauf im einzelnen einzugehen. Eln wichtiger trennender Faktor ist die Anpassungsetrategle gewesen, die sich io Sukzessionsstand wanlfestlert. Dies führe zu Unterschieden in waldbaulich bedeutenden Elgenschaften, wie belspielswelse Schat tentoleranz, Wirksamkeit des Nährstoffumsatzes und möglicherweise Schädlingorealatenz.

Entweder 1st relchlich genetische Verschiedenartigkelt vorhanden, oder ole kann durch neu entwlckelte Techniken geschaffen werden, um signifikante genetische Gewinne fur das Wachstum des Einzelbaumes zu erzielen. Mögliche Ansätze schliessen eine Selektion ein, 
die abzielt auf bestime standortspezifische Temperaturoptima, wirksame Wasser- und Nahrstoffierwertung, optimale Mesophylldichte, Kronen mit wirksamer Lichtausnutzung, geringere Respiration bei Tageslicht und Phånologien die die Wachstumsperiode voll ausnutzen.

Da man es in der Forstwirtschaft wahrscheinlich nie mit Kultivierungssystemen im landwirtschaftlichen Sinn zu tun hat, scheint Vorsicht angebracht, damit die naturliche, vor allem durch genetische verschiedenartigkeit bedingte Pufferwlrkung von waldern nicht abnimmt. Deshalb schlage ich vor, genet1sche Manipulationen sowohl auf Individuen als auch auf Gemeinschaften auszurichten. Die Dynamik des Ökosystems ist noch sehr viel grüdlicher zu erforschen, aber vielleicht konnen cemeinschaften aus richtig zusamengestellten Misschungen von Baumarten stabll und gleichzeitzig auch produktiv sein.

\section{INTRODUCTION}

This brlef review of genetic differences in trees discusses some ways these differences might affect future silviculture. Fifteen years ago Allard \& Bradshaw (1964) suggested that no one had the competence to review all published information on plant genotype-environment interactions. Even narrowing the field from all plants to just trees, I am quite willing to take refuge in that statement coday. The unfortunate consequence of this 1s, that this review will not mention many pertinent papers. This is my error, and in no way reflects on the quality of unclted work. Any apparent blas towards North American conlfers should be considered, I hope charitably, as random drift introduced by choosing a reviewer from a small, lsolated population.

Perhaps I should warn of another blas. I am an ecologist, not a plant breeder. Therefore, to me, two questions must be asked about manipulation of forest gene pools. How much can we change? And, more 1mportantly, how much should we change? Unfortunately very little research is avallable to guide us in answering the latter question and discussing $1 \mathrm{t}$ can be frustrating. It is a question, however, that wust be addressed.

Hy arguement is developed in two phases: (1) a summary of what is known about genetic variation in forest trees, starting with differences among populations, then moving to whthin-population varfabllity, and finally some brief statements about variation among species; (11) a discussion of ways in which forest yleld may be improved through genetic selection at both the organisom and community level. 
VARIATION WITHIN SPECIES: AMONG POPULATIONS

Patterns of variation correlated with environment

Stern \& Roche (1974) and Wright (1976) summarized information concerning clinal variation in forest tree species. Clines generally occur along the three primary axes of latitude, longitude and elevation, reflecting vartous changes in photoperiod, thermoperiod and precipitation. The adaptive characteristics of a single population result from a complex combination of those factors, and other influences not so easily measured.

Adaptation to climatic varlation appears to be accomplished primarily through the developmental cycle of a plant (Heslop-Harrison 1964). One of the central problers of provenance transfer, especially in high latitudes, is symchronization of development with the seasonal cycle (Langlet 1967; Campbel1 1974a). Discussing British Columbla spruces, Roche (1969) wrote:

'In so far as there is a difference in the photothermal regime between any two reglons, the genetic constitution of the populations occupying those reglons wlll differ, and one of the most important external manifestations of this difference is the time of cessation of growth and initiation of dormanc $y^{\prime}$.

Both latitude and elevation correlate with critical daylength for growth cessation in Norway spruce (Heide 1974). Phenological clines have been demonstrated in a number of other species: laticudinal in the genus Populus (Pauley \& Perry 1954; Hoffman 1953), Scots pine (Sarvas 1969), Jack pine (Giertych \& Farrar 1962; Mergen, Warren \& Furnival 1967), lodgepole pine (Cannell 1976), ponderosa pine (Madsen \& Blake 1977), Sitka spruce (Falkenhagen 1977), and red oak (Kreikel et al. 1976); elevational in western white pine (Barnes 1967) and lodgepole pine (Hagner 1970a); and elevational-longitudinal in Douglas fir (Irgens-Möller 1968; Campbell \& Sorensen 1978).."

Most, if not all, wide ranging plant spectes are probably differentiated along climatic clines ( $c$. Hiesey \& Milner 1965 ) but this is sometfmes difficult to demonstrate. Local climates may not correlate smoothly with easily measured varlables such as latitude or elevation and other complicating factors, which I will detail later, may come into play.

vaartaja (1959) studied photoperlodic adaptation in eighteen tree specles from nine genera, finding latitudinal differentiation in only eight species. Intergenetic differences were pronounced. Three of five species of spruce, but none of five plne specles, showed photoperlodic differentiation. Vaartaja's results with certain specles conflict with findings of his own and of other researchers, indicating the difficulties involved in generalizing about these phenomena. 
Between-population variation may differ considerably frow one part of a species range to another. Reck (1973) investigated the phenology and growth patterns of forty-two Douglas fir provenances. Inland sources were clearly differentiated, whereas provenances from the Pacific coast, an area of relatively uniform climate, were not. Similarly, Squillace \& Silen (1962) found latitudinal clines among inland populations of ponderosa pine, but not among coastal populations. The correlation between the weight of ponderosa pine seed and clinatic factors differs strikingly among regions (We11s 1964). These patterns may simply be artifacts of low sampling intensity rather than real biolgical phenomena.

Many trafts, other than those related to phenology, show parterns of clinal variation. For yellow birch, wearster \& Barnes (1977) found strong south-north clines of decreasing helght, increasing seed welght, earlier inftlal germination and increasing total germination. In other specles, seed weight seems to be negatively correlated with molsture supply and length of growing season (e.8. Wells 1964, Perry o Lotan 1978), which probably is an adaptation for producing large seedlings in a relatively short time.

Differences have been found among populations within various spectes in drought resistance (Ferrell \& Woodard 1966), Bilan, Hogan \& Carter 1977; Eickme1r, Adams \& Lester 1975; Dijkstra 1974; Krelkel et al. 1976); frost resistance (IlI ingworth 1975; Van den Drtessche 1977; Langlet 1967); optimum temperature for photosynthesis (Slatyer \& Ferrar 1977) and characteristics of bark reflectance (Covington 1975). Gerhold (1959) and May \& Means (1977) found that chloroplast structure differed along elevational gradients.

In a classic experiment, Thoday \& Boam (1959) showed that strong selection would maintaln genetic differences between populations of Drosophila despite intense gene flow. This result seems to apply equally well to trees. Non-clinal transitions between soll types, to be discussed later, are well known. However, populations may vary over short gradients in elevation and abrupt changes in aspect as well. The most striking example was given by Fryer \& Led18 (1972) who found that the optimum temperature for photosynthesis in Balsam fit over an elevational gradient varled closely wh the adiabatic lapse rate. Growth and phenology of Douglas fir were shown to differ significantly smong populations 150 m apart (vertical) along an elevational transect (Hermann \& Lavender 1968). Douglas fir on south slopes are, in some cases, more drought resistant than those on neighbouring north slopes (Ferrell \& Woodard 1966). Later, however, I will discuss findings by Rehfeldt (1974) that urge caution in extrapolating these results.

The adaptive benefit for some trafts that vary clinally 
is obscure. For example, Douglas fir populations vary latitudinally in mycorrhizal formation (Wright \& Ching 1962). DNA content and nuclear volume of cells varies latitudinally in several conlferous species (Miksche 1967; Szlklai, El-Lakany \& De-Vescovi 1976). Wareing \& Matthews (1971) suggested that greater production of enzymes compensates for lower rates of enzyme action at low temperatures.

Stern \& Roche (1974, p.117 ff) d1scuss discont1nuous, also termed ecotypic or raclal variation in plants, most of which relates to edaphic factors. Differential ability to extract nutrients, or tolerance of low avallability has been found between populations on granitic and ultramific solls (Jenkinson 1974), calcareous and acldic sites (Ladiges \& Ashton 1977; Holst 1974), and swampy and upland sites (Musselman, Lester \& Adams 1975; Sannikov, Sannlkov \& Grishina 1976). Not surprisingly, rooting characetristics seem to play a role in edaphic adaptation (Schmidt-Vogt 1971; Ladiges \& Ashton 1977). Provenance differences in needle nutrient concentration (Van den Drlessche \& Webber 1975; Woessner et al. 1975; Falkenhagen 1976) and fert1lizer response (Bramlett $\&$ Belanger 1976) may represent adaptation to edaphic factors (Giertych (1969) reviewed earlier publications).

Patterns of variation without obvious environmental correlation Much variation among populations cannot be attributed easily to differential selection along environmental gradients. This often appears as 'nolse' superimposed upon broad environmentally related trends. For example, Wells (1964) found that 32 per cent of progeny:enviroment correlations in ponderosa pine were significant when calculated with data from an entire region, but only 3 per cent when data from separate ccotypes whthin reglons were used. Small-scale stochasticlty in population traits was also noted by Rehfeldt (1974), who found patterns of differentation in Rocky Mountain Douglas fir to be essentially randow wh thespect to topography. Sampling error may account for some of this. Other explanations include:

(1) Some phenotypic traits in a population may exist independently of natural selection (Stern \& Roche 1974). Others may not be influenced by the environmental $\mathrm{gradient}$ that was studled. For example, growth rate is an often studled tralt which, in many cases, may have little bearing on a plant's ability to survive and reproduce, particularly in harsh enviroments (Namkoong 1969).

(2) In species that pioneer disturbed sites, founder effects (random shifts in genetic composition due to establishment of a population by only a few parents) may produce differences between populations.

(3) Major perlods of selection occur infrequently in ploneers suggesting that some populations may be adapted to 
weather conditions which have since changed.

(4) Past glaciation led to large scale biological migration, so many populations way now exist on sites to which they have yet not fully adapted (Wright 1973).

(5) Historical factors may result in isolation and drift, leading to rapid differentiation. Comparing the Rocky Mountaln and Pacific Coast varleties of ponderosa pine, Hells (1964) wrote

-.... differences between the two varleties stem from wore ancient causes that are not reflected in ... weather records of the past seventy years".

For a discussion of the possible relation between diastrophism and eplsodes of evolution see Axelrod (1967).

(6) Populations may adapt to environmental differences in diverse, but equally effective ways (Heslop-Hatrison (1964).

(7) Adaptation occurs in response to a set of enviromental factors, and the adaptive significance of a character may becone evident only when the full set of relevant niche parameters is considered (Stern \& Roche 1974).

(8) Some important environmental factors may be normally overlooked. For example, Elllot (1974) found that predation by squirrels living in stands of lodgepole pine has selected for certain seed and cone characteristics. Factors affecting squirrel populations may then be reflected in tree phenotypes.

Some tratts that seem to vary randowly have clear selective advantage. Pest resistence differs widely within species. For example, Scots pine varies in its resistance to Zimmerman pine moth (Wright, wilson \& Bright 1975), loblolly pine to rust (Wells 1966), European larch to various insect pests (Sindelar \& Hochmut 1972) and ladgepole pine to Crumenula sororla (Hayes 1975). Provenance or clonal differences in resistance to pollutants have been found in lodgepole pine (Lang, Neumann \& Schutt 1971), Japanese larch (Vogl, Schönbach \& Hadlcke 1968), Norway spruce (Braunn $1977 \mathrm{a}, \mathrm{b}$ ) and trembling aspen (Karnosky 1977).

Terpene content varies considerably among populations of some conifers (Van Rudloff 1972; Thielges 1972; Gansel \& Squillance 1977; Faulkner et al. 1977). The adaptive value of differing terpenes 18 not apparent and much of the varlation may be due to gene flow between specles (eg. Zavarin, Critchfield \& Snajberk 1969). However, terpenes probably play an important role in interaction with pests. Faulkner et al. (1977) found Fomes annosus to be absent from most sitka spruce in which alpha-pinene formed at least 35 per cent of the root resin. The role of chemicals as mediators of ecosystem structure and dynamice 16 virtually unknown, although Interesting work 18 in progress (eg. Melnwald et al. 1978). 
Hendry (1976) hypotheslzed that dietary chemicals may substructure insect populations in ecological and evolut lonary time, although Miller et al. (1976) offered a counter argument. Other subtle ecosystem interactions are mediated by chemical factors as well - see the discussions by Smith (1976) and Karimbayeva sizova (1977) on the role of root exudates in rhizosphere ecology.

One of the most interesting phenomena of forest genetics is the fact that local populations, especially those on severe sites, are often not optimal elther in 8 rowth, which may not be a trait selected for, or other adaptive characteristics (Namkoong 1969; Campbell 1974a). Sirllarly, many populations have superlor growt characteristics even when transferred far from their native location (eg. Glertych 1976; Illingworth 1975). Height of five year old lodgepole pine at two different planting sites, one of which was quite severe, was highly correlated $\left(r^{2}=0.88\right.$ and 0.92$)$ with the site index of the parent stand, even though the sampled provenances spanned about $1500 \mathrm{~km}$ (Perry \& Lotan 1978; Perry \& Steinhoff, unpublished data). In that study, height was also correlated closely with length of the growing season at the native location, suggesting that favourable environments may permit the evolution of genotypes which are vigorous and which are also highly buffered agalnst enviromental change.

\section{VARIATION WITHIN SPECIES: WITHIN POPULATIONS}

One of the most critical yet least understiood questions in population genetics relates to the adaptive nature of varlability within populations (cf Simpson 1975). Electrophoretic studies have revealed large amounts of enzyme polymorphism within populations of most studied organisms; whether this variability is selectively neutral or not, is vigorously debated (Gillesple \& Langley 1974; Ne1, Fuerst \& Chakrakorty 1976; Gilpin et al. 1976).

Saki \& Park (1971) found lsozyme differences between groups of trees separated by only a few hundred meters and wth no obvious environmental gradient included, which they attributed to isolation and drift, 1.e. pollen dispersal was very localized. Significant variation within populations has been found in the growth characteristics of several spectes (Hagner 1970b; Clausen 1975; Wells \& Snyder 1976; Dietrichson 1969; Eriksson et al. 1976; Led 1g \& Clark 1977; Perry \& Lotan 1978). Family dffferences have also been shown in stress response (Perryet al 1978 ) and nutrient relations (Burdon 1971).

Varlablity in growth characteristics within populations occurs primarlly in young seedlings, tending to disappear with time (Namkoong, Usanis \& Silen 1972; Namkoong \& Conkle 1976; Perry \& Lotan 1978). Namkoong et al. (1972) suggested that this is due to the relatively large micro-enviromental 
diversity encountered by young seedlings, with a consequent selective premium for differential growth strategy. As trees grow and micro-environments become less important, diversity in growth strategy also becomes less important. Among lodgepole pine populations, famlly related phenotypic variance correlates closely with differential family response to changing environments, suggesting that variability has an adaptive component (Perry \& Lotan 1978). Famllies may also follow differing growth patterns as a mechanism for dividing resources in time (Perry 1978).

Desplte much speculation little is actually known about the role of genetic diversity in ecosystem regulation. Mono-specific forests are more susceptible to pest outbreaks than diverse ones (Vouté 1964) and In an elegant laboratory experiment, Plmentel \& Bellotti (1976) demonstrated that diversity is indeed an important pest regulator. Intraspeciffc as well as interspecific diversity probably play important regulatory roles. Shaw \& Little (1977) found that foliar components of dietary importance to spruce budworm varied locally in balsam fir, Hunt \& Von Rudloff (1977) showed that leaf - oll - terpene varlation was greater within than between populations of western white plne. Observations of this type do not, of course, prove a regulatory function. However, recent studies investigating both insect and tree hosts suggest a great deal of genotype : specific interaction (Claridge \& Whlson 1978; Edmunds \& Alstad 1978). Levin (1975) concluded that pest pressures have played a large role in maintaining open recombination systems in climax species.

Indirect evidence suggests that within-species diversity varles inversely with between species diversity. Levins (1968) predicted on theoretical grounds that increasingly uncertain enviroments would result in broader niches, one component of which could be genetic diversity within species, with consequent decrease in between-species diversity. That species diversity decreased with increasing site severity, within certain limits, has been demonstrated both for animals (MacArthur 1975) and forest plants (Brünig 1973; Glenn-Lewin 1977), although this is not always the case (eg. Zobel et al. 1976). Factors such as rapid crown closure on good sites (del Moral 1972) may confound matters by introducing a time dimension.

Little work has been done on within-population variabllity as a function of environment, although Heslop-Harrison (1964) felt that it should be greater at the margin of the species distribution because of low inter-spectific competftion. May o Means (1977) reported that the variability of Englemann spruce chloroplasts increased up an elevational gradient. Clausen Hesey (1958) found a similar relationship in the helght varfabllity of Achillea spp. I have found a close correspondence between phenological 
varlability within lodgepole pine populations and the elevation of their native habltat, although these stands spanned a considerable latitudinal gradient, with consequent confounding effect on the climate-elevation relation. On the other hand, Stern \& Roche (1964) concluded that the studies they cited indicate greater varfability in central rather than marginal populations; they argue that inter-specific competition produces variabllity. These two viewpoints may be compatible. Where physical factors are highly variable and dominate the selection regime, certain sets of adapative traits will be diversified. As blological factors become increasingly important (in relatively benign habitats), diversifying selection acts on other sets of traits. For example, the greatest diversity of genes for pest resistance are usually found in the centre of the species range (Levin 1975). Links between enzyme and phenotyplc varlab1lity are not well established (see, however, Mitton 1978), but Tigerstedt (1973) did find that differences in lsozyme variability between central and marginal populations of Norway spruce depend on the enzyme pattern studied.

Do we then expect populations from harsh sites to be the most highly buffered agalnst physical factors of the environment? This may often be the case, and prudent management demands that, in the absence of specific evidence to the contrary, we assume that it is (Morgenstern \& Roche 1969). However, some data do not f1t the model. Relative growth of Norway spruce provenances is highly consisent across a wide varlety of environments, with non-local sources out-performing locals on many harsh sites (Giertych 1976). I have seen similar trends in lodgepole pine, although the seedlings are too young to draw conclusions. Clearly much still must be learned about the population ecology, but current evidence suggests that certain populations, often from the center of the species range, are genetically superior not only in growth, but also in overall buffering capacity. On the other hand, fitness for a given site may ultimately be deterwined by the ability of a genotype to survive infrequent climatic events, and short term studies tell us little about this.

\section{VARIATION BETWEEN SPECIES}

Rather than review the information about differences between tree species, I will brlefly and generally discuss brọad differences in adaptive strategies as they relate to silviculture, focussing more on what is not known that what 1s.

Temperate and boreal forests have evolved under an environmental reglme of perlodic disturbance. Thus time has produced a rough dichotomy in adaptive strategy, distingulshed in forestry as ploneer and climax species and in current 
ecological theory as $r$ and $K$ selected species (Stearns (1976) reviewed life history tactics). Two distinguishing characteristics of these groups are especially pertinent here: (1) genetic systems or devicés for regulating variability (Darlington 1939) and (2) a degree of adaptation to physical factors on the one hand and biotic factors on the other.

Adaptive strategles form a continum between the ephemeral pioneer and climax species, with pioneer tree species falling socewhere in between. Thus applying theoretical results directly to trees is misleading although some generalizations seem possible. At least three arguments can be made that greater genetic diversity occurs in long-lived pioneers relative to climax species:

(1) Because of low interspecific competition, pioneers can colerate more genetic deaths and, therefore, can afford to produce more varlability (Grant 1963).

(2) Because of low interspecific competition, pioneers occupy relatively broad niches, mediated by both genetic diversity and phenotype plasticity (Levins 1968).

(3) Because major eplsodes of selection may occur decades apart in ploneers, $1 . e$. at the time of seedling establishment, they must maintain the ability to cope with relatively large changes in climate.

on the other hand, sound arguments support less recombination in pioneer species (e.8. Pickett 1976). Resolution of these two lines of argument may lie in the organisation of variation within populations, with climax specles tending toward individual buffering and pioneers toward populational buffering, thereby preserving homozygosity in individuals without foregoing diversity in the population. From a practical standpoint, these questions bear directly on the potential for gains through selection and the degree to which a given gene pool should be narrowed. However, I at aware of little research to assess the validity of these speculations.

The genetic systems of specles differ, although why is not always clear. Red pine, for example, is genetically quite uniform, which Fowler \& Morris (1977) attributed to historical factors. Wright (1976) discussed the considerable differences among pine species in the effectiveness of mass selection techniques. Trends within species wight tell us something about differences between species. Lotan and I compared varlabilities between open- and closed-cone progeny of lodgepole pine, which probably evolved in very different environments, and among populations from relatively severe and benign habitats (Perry \& Lotan 1978). We found differences, but they were inconsistent so we could not draw conclusions about causal factors. Considerable work is needed before we understand the forces that shape the genetic systems of species. 
Odum (1969) discussed numerous functional and structural differences between developmental stages and mature ecosystems. Many of these may be important to silviculture but here I will mention one in particular which 1 will discuss in more detall in the next section. Ploneer species generally occupy habltats whth, at least in the beginning, greater resource availability (Gadgll \& Bossert 1970) and less interspecific variability, thus they are often poor competitors. Sowe coniferous specles, as a means of indirect competition, may in fact have evolved mechanisms for retarding decomposition of organic material and consequent release of nutrients (first suggested to me by Don Despain, a blologist at Yellowstone National Park). In contrast, ang losperms seem to cycle nutrients very rapidly. Later I discuss how this might be used to silvicultural advantage.

Pest resistence is another difference between pioneer and climax species which may have silvicultural importance. Ploneer species persist because of periodic disasters, and thus have little evolutionary incentive to develop resistance to epidemic pest outbreaks, in fact, they may have evolved to encourage them. For obvious reasons climax specles must develop a greater degree of pest resistance. Grant (1963) suggested that much diversity in tropical forests was due to selection for pest resistance.

\section{UTILIZATION OF GENETIC DIVERSITY}

Crop breeders speak In terms of ideotypes, 1dealized plant models with optlmum potential for growth under a given set of enviromental conditions (e.g. Donald 1968; Frey 1970). Within the concext of the physlological basts of yleld, this is a sensible approach and one which, as long as we understand its limitations, has much to offer forest tree breeders. Several authors have recently discussed plant factors most amenable to genet1c manipulation for increased yleld (Wareing \& Matthews 1971; Gordon 1975; Nasyrov 1978). At 1ts first level, the model is very simple: yield is a funtion of photosynthes16, less respiration, integrated over a growing season. Let us consider each of these separately.

\section{(1) Photosynthesis Improving the quantum yield of}

photosynthesis would have enormous payoff, but seems rather remote at this time (Gordon 1975). However, differing chloroplast structure among genotypes of a species suggests that such an advance is not out of the question. Alternatively, several indirect approaches seem feasible to increase gross carbon fixation. First, genetic varlation for process-orlented traits, e.g. temperature optima, efficiency of mineral or water utflization and decreased wesophyll resistance might be explotted within populations to narrow the range of 'maladapted' Individuals on a given site. Wareing \& 
Mathews (1971) suggested breeding for individuals with optimal incercellular space distribution within the mesophyll, high rates of enzyme activity and the abllity to maintain high rates of photosynthesis at low temperatures. Secondly, structural characteristics deterwining the number and orientation of leaves could be important targets of selection, 1.e. canopies should be designed as optical systems (Nasyrov 1978; Horn 1971; numerous references clted by Monsi, Uchiuina \& 01 kawa 1973). Wareing \& Mathews (1971) pointed out that species in genera such as Ables, Thuja and Tsuga, with long crowns, dense follage and low light compensation points, are highly productive, both as single trees and in dense stands. For example, on the Oregon coast a twenty-six year old stand of stern hemlock is producing dry matter at a rate of 36 metric tons ha/yr (Fujfmorl 1971). Within-specles variability in crown structure (see Stern $\&$ Roche 1974) provides an additional source of $r a w$ materlal. Finally, leaf senescence 1s iroportant in the loss of photosynthetic capacity and, though poorly understood, is amenable to genetic modification. Nasyrov (1978) produced a mutant of cotton in which leaf senescence was delayed with consequent increase in productivity. Klm (1976) attrlbuted the high productivity of an Fl hybrid of loblolly and pltch pine to increased photosynthetic life of needles.

(2) Respiration "Perhaps the most prowising basic modification of the photosynthetic process is the suppression of resplration in the light (Gordon 1975; see also Marx 1973). Differences in $C 4$ and $C 3$ plants are well known. More relevant to forestry is the possibility of differing rates of photorespiration among C3 genotypes. Wilson (1972) did, in fact, find genetic variation in photorespiration within Lolium sp, suggesting that similar searches within, or among, tree specles may be productive.

(3) Full ut1lization of the growing season. Substantial gains seem possible here, both by selection within populations and by transfer across clines. In several specles of pines, genotypes moved north of thelr native location outgrew local provenances (Wells \& Wakely 1970a, 1970b; Morgenstern \& Te1ch 1969). However, experience with Scots pine in Sweden has been the opposite, with greatest volume gains made by moving provenances southward and down in elevation (Eriksson et al. 1976). This is primarily due to increased survival, reflecting the fact that large numbers of individuals within provenances are apparently unft for the climate at their howe location (Hagner 1970b). Warelng \& Maththews (1971) suggested an 
actuarial approach to provenance transfer, using weather records to balance gains in productivity against the probability of loss due to early or late frost. Campbell (1974b) used predictions of timing of vegetative bud burst to examine response of seedlings to seed transfer. He concluded that east-west transfers were likely to be more maladaptive than north-south transfers. The Swedtsh experience suggests that intra-populational vartability should be included in analyses such as these.

Radiation and chemicals have been extensively used to induce mutants in crop breeding (see frey 1970 for a review), and powerful new techniques are being developed for genetic manipulation (eg. Hoskins et al. 1977; Carlson \& Polacco 1975). We may be standing on the threshold of a quantur leap in our ability to shape the genetic system of the organisms which serve us, a power that carries considerable $r$ isk.

At this juncture it is appropriate to ask if, in forestry, we wish to follow in the footsteps of crop geneticists. I suggest that we do not and that, while the concept of the organismic ideotype can be used advantageously, our primary focus should be on the ideotypic communtty. The reason for this is simple. We deal with ecological systems, of which autecological considerations form only one component. In traditional agriculture, high inputs of cultural energy maintain a simplified system state dominated by autecologlcal factors. The system has no internal buffering, and it is stable only as long as the external energy source, based on fossil fuel, lasts. Even if high levels of cultural input became feasible in forestry an unlikely eventuality, comfitment to genetic 'uniformity' seems unwlse to me for two basic reasons. First, cultural treatments are poorly suited to protect populations against unpredictable, e.8. temporal environmental variation (Allard \& Bradshaw 1964). Second, the track record of pest control in forests through approaches such as spraying, has not been good.

The relation between stability and diversity of ecosystems is a subject of considerable debate (see coodman 1975 for a revlew), much of which stems from an inadequate definition of both diversity and stability. If we define buffering capacity, like Allard \& Bradshaw (1964), as 'stability in those aspects of phenotype, especially yield and quality, that are Important economically', the role of genetic diversity seems incontrovertible (Allard \& Bradshaw 1964; Edmunds \& Alstad 1978; Schal \& Levin 1976; Clausen \& Hiesy 1958; M1tton 1978).

Populations may be buffered. in two ways, individually and as a population. In the former, buffering is a property of individual organisms, whereas population buffering arises in interactions among different coexisting genotypes' (Allard \& Bradshaw 1964). To the extent that population buffering is important, any factor which narrows the genetic base of a 
population carries with it the risk of decreasing that population's abllity to absorb environmental change. Very little research among tree species bears on this question. Owino (1977) concluded that eleven sets of loblolly pine families were average to below average in genotyplc stability, 1.e. buffering capacity. Significantly, the study showed no difference in the buffering capacity of wide and local crosses, suggesting that heterozygosity did not influence genotypic stability. I found fifty lodgepole pine familles from five populations to vary considerably in genotypic stabllity (unpublished data) and in stress resistance (Perry et al. 1978), suggesting that population buffering may be important in this species.

Does a commitment to genetic diversity in forest stands necessarily imply losses in yleld? I think not. Growth in the ideotypic community might be enhanced through three modes: structure in space, structure in time and wat I w111 call 'process complementation'. Cordon (1975) suggested that - efficient occupancy of space allocated to each individual in a stand becomes the criterion by which genotypes should be chosen for intensive culture'. Mixtures including at least one shade-tolerant specles hold promise. Alan B. Berg (School of Forestry, Oregon State Unfversity, Corvallis 1978, personal communication) planted western hemlock beneath a thinned stand of fifty-year-old Douglas $f(r$; the hemlock is growing rapidly and growth of the Douglas fir has not decreased detectably. Niche separation in the rooting zone has been found in successional annuals (Parrish \& Bazzaz 1976), and it may play a role in decreasing competition among tree genotypes as well.

Resources can be partitioned in time as well as space. Th16 should manifest 1 tself as a differential growth pattern efthet in one growing season or across a span of several years. Seasonal phenology shows considerable genetic variation, both between specles which occupy the same site (Marks 1976; Parrish Bazzaz 1976) and at the family level within populations (Kaufman 1977; Perry 1978); however, it has not been established as representing competition avoldance. Delayed bud set, especlally at high elevations or latitudes obviously carries risk. However, ind ividuals native to severe climates may have considerable frost tolerance, even during perlods of active growth. I have seen actively growing lodgepole pline seedlings unaffected by temperatures well below freezing. In any event, evolution has certainly used the actuarial approach of Wareing \& Mathews (1971), balancing risk of loss against potential gain. In at least some specles, familles vary in long-term growth patterns (Namkoong \& Conkle 1976; Perry 1978). As in the case of seasonal vartation, however, any selective advantage this might confer through competition avoldance is yet to be demonstrated.

Process complementation 18 the enhancement of some rate 
limiting step or process whthin ecosystems. The most pertinent example is nutrient cycling. Many ecologists believe that mixed forests alntain a higher soil fertility than monocultures (cf. Powers 1974). Conifers and other specles, e.g. buckwheat, which exude relatively large amounts of acids, are apparently able to obtain nutrients unavallable to other species (Fisher \& Stone 1969; McLachlan 1976; Graustein, Cromack \& Sollins 1977). Nutrient cycling, however, is generally more efflcient in deciduous communities. Mixtures of hardwoods and conifers cycle nutrients more quickly than coniferous monocultures, thereby lmproving stand productivity (Tappeiner \& Alm 1975; Rakhtsyeyenka \& Kabashnikana 1975). Thus, the ideotypic comunity may develop a synergism in nut rient relations, conifers improving the 'pumping' step and angiosperms the cycling, with benefit to both components.

Incorparating nitrogen-flxing species within forest ecosystems will become increasingly froportant. In Washington, a mixed stand of red alder and Douglas fir had twice the biomass of adjacent Douglas fir monocultures (Miller \& Murray 1977). Berg \& Doerksen (1975) found that red alder that seeded into a thinned stand of Douglas f1r added from 200 to 800 $\mathrm{kg} / \mathrm{ha} \mathrm{N}$ in seventeen years. In our laboratory, we are attempting to select nftrogen-fixing genotypes suited for interplanting in young, pre-comercially thinned conifer st and $s$.

The silvicultural potential of genetically diverse forests as opposed to monocultures will undoubtedly vary with site conditions. That potential cannot be adequately assessed until we have a much fuller understanding of the structure and functions of forest communtiles. However, it seems 1ikely that, given silviculturalists with knowledge and loagination, the ideotyplc community has much to offer forestry.

\section{REFERENCES}

Allard,R.W. \& Bradshaw,A.D.(1964). Implications of genotype environment interactions in applied plant breeding. Crop Sclence, $4,503-8$.

Axel rod,D.I. $(1 \overline{9} 67)$. Drought, diastrophlsm and quantum evolution. Evolution, $21,201-209$.

Barnes, B.V.(1967). Phenotypic variation associated with elevation in western white pine. Forest Science, 13 , 357-364.

BerB,A.B. \& Soerksen,A.(1975). Natural fertilization of a heavily thinned Douglas fir stand by understory red alder. Oregon State University, Forest Research Laboratory, Corvalis. Research Note 56. 3 pp.

Bllan,M.V., Hogan,C.T. \& Carter, H.B.(1977). Stomatal opening, transpiration and needle motsture of loblolly pine seedlings from Texas seed sources. Forest Science, $\underline{23}$, 457-462. 
Bramlett,D.L. \& Belanger,R.P.(1976). Fertillzer and phenotypic selection increase 8 rowth and flowering of young Virgina pine. Forest Science, 22, 461-467.

Braun,G.(19777a). Causes and criteria of resistance to air pollution in Norway spruce. 2. Reflexive resistance. European Journal of Forest Pathology, $7,129-151$.

Braun,G.(1977b). Causes and criterla of resistance to alr pollution in Norway spruce (Plcea abies). 3. Tolerance of toxic waterials (Internal resistance). European Journal of Forest Pathology, 7, 236-249.

Brü18,E.F.(1973). Species richness and stand diversity in relation to site and succession of forests in Sarawak and Brunel (Borneo). Amazoniana, 4, 293-320.

Burdon,R.D.(1971). Clonal repeatabilities and clone:site interactions in Pinus radiata. Silvae Cenetica, 20, 33-38.

Campbell,R.K.(1974a). A provenance-transfer nodel for boreal regions. Reports of the Norwegian Forest Research Inst 1 tute, $31,541-566$.

Campbell,R.K.(1974b). Use of phenology for examining provenance transfers in reforestation of Douglas fir. Journal of Applied Ecology, 11, 1069-1080.

Campbell,R.K. \& Sorensen,F.C.(1978). Effect of test environment on expression of clines and on deliditation of seed zones in Douglas fir. Theoretical and Applied Genetics, 51, 233-246.

Cannell,M.G.R.( $(1976)$. Shoot apical growth cataphyll initlation rates in provenances of pinus contorta in scotland. Canadian Journal of Forest Research, $6,539-556$.

Carlson,P.S. \& Polacco,J.C.(1975). Pliant cell culture techniques and genetic aspects of crop improvement. Science, $188,622-625$.

Clar Idge,M.F. W Wilson,M.R.(1978). British insects and trees: a study in 1 sland biogeography or insect/plant coevolution? American Naturalist, 112, 417-456.

Clausen,J. \& Hiesey,W.M.(1958). Experimental studies on the nature of species. IV. Genetic structure of ecological races. Carnegle Institute, Washington D.C. Publication $4615.321 \mathrm{pp}$.

Clausen,K.E.(1975). Early results of a yellow blrch progeny test. Proceedings IUFRo working party on progeny testing, November 1974. pp. 16-23. Southeastern Forestry Experiment Station, Asheville, North Carolina.

covington,W.W.(1975). Altitudinal variation of chlorophyll concentration and reflectance of the bark of Populus tremuloides. Ecology, 56, 715-720.

Darlington,C.D.(1939). The evolution of genetic systems. Cambridge University Press, Cambridge. 265 pp.

Dietrichson,J.(1969). Growth rhythm and yield as related to provenance, progeny and enviroment. Second World 
Consultation on Forest Tree Breeding, Section $2 / 3$, IUFRO and FAO, Rome.

Donald,C.M.(1968). The breeding of crop ideotypes. Euphytica, $17,385-403$.

Dykstra,G.F.(1974). Drought resistance of lodgepole pine seedings in relation to provenance and tree water potential. British Columbian Forest Service, Research Note $62.9 \mathrm{pp}$.

Edwunds,G.F.,Jr. \& Alstad,D.N.(1978). Coevolution in insect herblvores and conlfers. Sclence, 199, 941-945.

Elckme1r,W., Adams.M. \& Lester,D.(1975). Two phys1ological races of Tsuga canadensis in Wisconsin. Canadian Journal of Botany, 53, 940-950.

Ell lot,P.F.(1974). Evolutionary responses of plants to seed eaters. Pine squirrel predation on lodgepole pline. Evolution, 28, 221-231.

Eriksson,G., Anderson,S., Eiche,V. \& Persson,A.(1976). Varlation between and within populations in a provenance trial of pinus sylvestris at Nordanas, lat. $64^{\circ} 19^{\circ}$, long. $18^{\circ} 09^{\frac{1}{}, \mathrm{al} t} \cdot 400 \mathrm{~m}$. Studia Forestalia Suecica, $133^{\text {, }}$ $1-46$.

Falkenhagen,E.R.(1976). Varlation in follar macronutients of one-year-old sitka spruce seedlings of ten provenances. Northwe st Sclence, S0, 209-212.

Falkenhagen, E.R. (1977). Genetic varlations in 38 provenances of Sitka spruce. Silvae Genetica, 26, 67-75.

Faulkner,R., Fletcher,A.M., Johnstone,R.C.B. \& Forest,G.I. (1977). Report on forest research. British Forestry Commission, London. $27 \mathrm{pp}$.

Ferrell,W.K. \& Woodard,E.S.(1966). Effect of seed origin in drought resistance of Douglas fir (Pseudotsuga menziesil (Mirb.) Franco)). Ecology, 47, 499-503.

Fisher,R.F. \& Stone, E.L. $(19 \overline{69})$. Increased avallabllity of nitrogen and phosphorus in the root zone of conifers. Soll Sclence Soclety of America Proceedings, 33, 955-961.

Fowler,D.P. \& Worris,R.W.(1977). Cenetlc diversity in red pine: evidence for low genic heterozygosity. Canadian Journal of Forest Research, $7,343-347$.

Frey,K.J.(1970). Improving crop y'elds through plant breeding. 'Moving off the yleld plateau'. (Ed. by R. Munson) pp. 15-58. Special Publication 20 American Society of Afronomy Madison, Wisconsin.

Fryer,J.H. \& Ledig,F.T.(1972). Micro-evolution of the photosynthetic temperature optimum in relation to the elevational complex gradient. Canadian Journal of Botany, $50,1231-1235$.

Fufimori,T.(1971). Primary productivity of a young Tsuga heterophylla stand and some speculations about blomass of forest communities on the Oregon Coast. U.S. Forest Service, Pacific Northwest Forest and Range Experiment 
Station, Portland, Oregon.- Research Paper PNW-123. 11 pp. Gadgil,M. \& Bossert,W.H.(1970). Life historical consequences of natural selection. American Naturalist, $104,1-24$.

Gansel,C.R. \& Squillace,A.E.(1977). Geographic variation of monoterpene in cortical oleoresin of slash pine. Silvae Genetica, 25, 150-153.

Gerhold,H.D.(1959). Seasonal varíation of chloroplast pigments and nutrient elements in needles of geographic races of scotch pine. Silvae Genetica, $8,105-132$.

Giertych,M.M.(1969). Growth as related to nutrition and competition. Second Horld Consultation on Forest Tree Breeding, Section 2/4, IUFRO and FAO, Rome.

Giertych,M.M.(1976). Summary results of the IUFRO 1938 Norway Spruce (Picea abies (L.) Karst)) provenance experiment height growth. Silvae Genetica, 25, 154-163.

Giertych,M.M. \& Farrar,J.L. (1962). A provenance study of jack pine seedlings. Silvae Genetica, $11,111-114$.

Gillespie,J.H. \& Langley,C.H.(1974). A general model to account for enzyoe variation in nacural populations. Genetics, 76, 837-884.

Gilpin,M., Soule,M., Ondricek,A. \& Gilpin,E.A.(1976). over-dominance and U-shaped gene frequency distributions. Nature, $\underline{263}, 497-499$.

Glenn-Lewin, D.C. (1977). Species diversity in North American temperate forests. Vegetatio, 33, 153-162.

Goodman,D.(1975). The theory of diversity. Stability relationships in ecology: Quarterly Review of Blology, $50,237-266$.

cordon,J.C.(1975). The productive potential of woody plants. Iowa State Journal of Research, 49, 267-274.

Grant,V.(1963). The origin of adaptations. Columbia University Press, New York.

Grauste1n,W., Cromack,K.Jr. \& Sollins,P.(1977). Calcium oxalate: occurrence in solls and effect on nutrient and geochemical cycles. Science, 198, 1252-1254.

Hagner,M.(1970a). A genecological investigation of the annual rhythm of Pinus contorta Dougl. and a comparison with Pinus sylvestris L. Studia Forestalia Suecica, 81 . 26 pp.

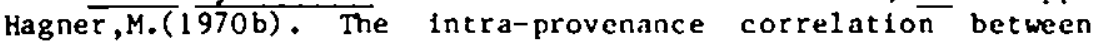
annual rhythm and growth of single trees of pinus sylvestris L. Studia Forestalia Suec1ca, $82,34 \mathrm{pp}$.

Hayes,A.J.(1975). The mode of infection of lodgepole pine by Crumenula sororta Karst. and the susceptibllity of different provenances to at tack. Forestry, 48, 99-113.

Heide,0.M.(1974). Growth and dormancy in Norway spruce ecotypes (Picea abies). I. Interaction of photoperiod and temperatures. Physlologia PIantarum, 30, 1-12.

Hendry,L.B.(1976). Insect pheromones: Diet related? Sclence, $192,143-145$.

Hermann, R.K. \& Lavender,D.P.(1968). Early growth of Douglas 
fir from various altitudes and aspects in oregon. Silvae Genetica, 17, 143-151.

Heslop-Harrison,J.(1964). Forty years of genecology. Advances in Ecological Research, 2, 159-247.

Hiesey,h.l.. \& Milner,H.W.(1965). Physiology of ecological races and species. Annual Review of Plant Physlology, 16, 203-216.

Hoffman,D.(1953). Photoperlodisr in tree breeding. Zeftschrift für Forstgenetik und Forstpflanzenzuchtung, $2,44-47$.

Holst,M.J.(1974). Performance of Japanese larch and the Dunkeld hybrid larch at Petawawa Forest Experiment Station. Forestry Chronicle, 50, 109-110.

Horn,H.S.(1971). The adaptive geometry of trees. Princeton University Press, Princeton, New Jersey, U.S.A. 144 pp.

Hoskins,B.B., O'Connor,J.T., Shannon, T.A., Widdus, R. \& Daniel11,J.F.(1977). Application of genetic and cellular manipulations to agricultural and industrial problems. BioScience, 27, 188-191.

Hunt,R.S. \& von Rudloff, E.(1977). Leaf-oll-terpene vartation in western white pine populations of the Pacific Vorthwest. Forest sclence, 23, 507-516.

Illingworth,K.(1975). Logdgepole pine provenance research and breeding in British Columbia. Proceedings of a Symposium on management of lodgepole pine ecosystems, pp. 47-67. Washington State University Press.

Irgens-Moller,H. (1968). Geographical varlation in growth patterns of Douglas fir. Silvae Genetica, 17, 106-110.

Jenkinson,J.L.(1974). Ponderosa pine progenies: differential response to ultraspectfic and granitic solls. U.S. Forest Service, Pacific Southwest Forest and Range Fixperiment Station, Research Paper PSW-101. 14 PP.

Kar lobayeva,L.Y. \& Sizova,T.P.(1977). Ef fects of root exudates of pine and spruce seedlings on developing mycoflora in rhizosphere of the conifers. Mikologija 1 Fitopatologlja, $11,191-198$.

Karnosky,D.F.(1977). Evidence for genetlc control of response to sulfur diozlde and ozone in populus tremulnides. Canadian Journal of Forest Research, $\overline{7}, 437-440$.

Kaufman,C.M.(1977). Growth of young sīash plne. Forest Sc lence, $23,217-226$.

Kim,J.H.(1976). Studies on the productivity and the productive structure of the forests: II. Comparison between the productivity of Plnus rigida and of Pinus rigitaeda plantation. Korean Journal of Botany, $19, \overline{85-91}$.

Krelkel,H.B., Bagley,W.T., Deneke,F.J., Funseh,R.W., Roth.P., Jokela,J.J., Merritt,G., Wright,J.W. \& Will lams,R.D. (1976). Ceographic varlations in Quercus rubra in north central U.S. plantations. Silvae Genetica, 25, 118-122.

Ladiges,P.Y. \& Ashton,D.H.(1977). A comparison of some populations of Eucalyptus viminalis Labill. growing on 
calcareous and acid soils in Victoria, Australia. Australian Journal of Ecology, 2, 161-178.

Lang, K.J., Neumann,P. \& Schutt,P.(1971). The effect of seed source and fertilizing on so2-sensitivity of Pinus contorta seedilings. Flora, 160, 1-9.

Langlet,0.(1967). Regional intra-specific variousness. Proceedings $14 \mathrm{th}$ IUFRO Congress Division III, Section 22-AG22/24. Pp. 423-58. Munich.

Ledig,F.T. \& Clark,J.G.(1977). Photosynthesis in a half-sib family experiment in pitch pine. Canadian Journal of Forest Research, ?, $510-514$.

Levin,D.A. (1975). Pest pressure recombination systems in plants. Anerican Natural ist, 109, 437-451.

Levins,R.A.(1968). Evolution in changing environents. Princeton University Press, Princeton, New Jersey. 120 pp.

MacArthur,J.W.(1975). Environmental fluctuations and species diversity. 'Ecology and evolution of communities'. (Ed. by M.L.Cody and J.M.Diamond), pp.74-80. Belknap Press, Cambridge, Massachusetts.

Madsen,J.L. \& Blake,G.M.(1977). Ecological genetics of ponderosa pine in the northern Rocky Mountains. Silvae Genetica, 26, 1-8.

Marks,P.L.(1976). On the relation between extension growth and successional status of deciduous trees of the northeastern U.S. Bulletin of the Torrey Botanical Club, $102,172-177$.

Marx,J.L. (1973). Photorespiration; key to increasing plant productivity? Science, 179, 365-367.

May,D.S. Means,K.S.(1977). Chloroplast pigments as units of selection in Picca engemannil. American Midland Natural1st, $98, \overline{283-295}$.

McLachlan,K.D. $(19 \overline{76})$. Comparative phosphorus responses in plants to a range of avallable phosphorus situations. Australian Journal of Agricultural Research, 27, 323-341. Meinwald,J., Prestwich,G.D., Nakanishi,K. \& Kuko,I.(1978). Chemical ecology; studies from East Africa. Science, 199, $1167-1173$.

Mergen,F., Worrall,J. \& Furnival,G.M.(1967). Genotype environment interactions in 50 sources of jack pine seedlings. Proceedings 14th Congress IUFRO Division III, Section 22, PP. 459-466. Munich.

Miksche,J.P. (1967). Variation in DNA content of several symosperms. Canadian Journal of Cenetics and Cytology, $9,712-722$.

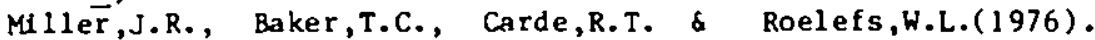
Re-investigation of oak leaf roller sex pheromone components and the hypothesis that they vary with diet. Sclence 192, 140-143.

Miller,R.E. \& Murray,M.D.(1977). The effects of red alder on 
growth of Douglas fir. U.S. Forest Service. Pacific Northwest Forest and Range Experiment Station, Olympla, Washington. Un published manusc ript.

Mitton,J.B.(1978). Relationship between heterozygosity for enzyme loci and vartation of morphological characters in natural populations. Nature, 273,661-662.

Monsi,M., Uchiuima, 2. \& Oikawa, T. (1973). Structure of follage canopies and photosynthesis. Annual Review of Ecology and Systematics, 4, 301-327.

Moral,R.del (1972). Diversity patterns in forest vegetation of the Wenatchee Mountains, Washington. Bulletin Torrey Botanical $\mathrm{Club}, 99,57-64$.

Morgenstern,E.K. \& Roche,L.(1969). Using concepts of selection to delimit seed zones. 2nd World Consultation of Forest Tree Breeding, Section $2 / 16$ IUFRO, August 7-16, Washington, D.C.

Morgenstern,E.K. \& Teich,A.H.(1969). Phenotypic stabllity of height growth of jack pine provenances. Canadian Journal of Genetics and Cytology, 11, 110-117.

Musselman,R.C., Lester,D.T. Adams,M.S.(1975). Locallzed ecotypes of Thuja occidentalis L. In Wisconsin. Ecology, 56, 647-655.

Namkoong,G.(1969). Nonoptimal local races. Proceedings loth Southern Conference on Forest Tree Improvement, pp. 149-153. Texas A \& M University, College Station, Texas.

Namkoong,G. \& Conkle,M.T.(1976). Time trends in genetic control of helght 8 rowth in ponderosa pine. Forest Sclence, 22, 2-12.

Namkoong, G., Usanis, R.A. \& Silen,R.R.(1972). Age selected variation in genetic control of height growth in Douglas fir. Theoretical and Applied Genetics, 42, 151-159.

Nasyrov,Y.S. (1978). Genetic control of photosynthesis and Improving of crop productivity. Annual Review of Plant Physlology, 29, 215-237.

Ne1,M., Fuerst,P.A. \& Chakrakorty,R.(1976). Testing the neutral mutation hypothesis by distribution of single locus heterozygosity. Nature, 262, 491-493.

Odum,E.P.(1969) The strategy of ecosystem development. Sclence, $164,262-270$.

Owino,F.(1977). Genotype $X$ environment interaction and genotyptc stability in loblolly pine. 2 Genotypic stab1lity comparisons. Silvae Genetica, 26, 21-24.

Parrish,J.A.D. \& Bazzaz,F.A.(1976). Underground niche separation in successional plants. Ecology, 57, $1281-1288$.

Pauley,S.S. \& Perry,T.0.(1954). Ecotypic varlation of the photoperiodic in Populus. Journal of the Arnold Arboretum, 35, 167-188.

Perry,D.A.(1978). Minimization of intraspecific competition through differential growth patterns in trees. 
Proceedings 8 th World Forestry Congress, Jakarta, Indonesia. In Press.

Perry,D.A. \& Lotan,J.E.(1978). Variation in lodgepole pine Pinus contorta var. latifolia): Greenhouse response of wind-polilinated familles from flve populations to daylength and cemperature-so11. Canadian Journal of Forest Research $\underline{8}, 81-89$.

Perry,D.A. Lotan,J.E., Hinz,P. \& Hamilton,M.A.(1978). variation in lodgepole pine: family response to stress induced by polyethylene glycol 6000. Forest science. In press.

Pickett,S.T.A.(1976). Succession: an evolutionary Interpretation. American Natural ist, 110, 107-119.

Pimentel,D. \& Bellott1,A.C.(1976). Parasite-host population systems and genetic stability. American Naturalist, 110 , 877-888.

Powers,R.F.(1974). Mineral cycling in temperate forest eco-systems. Proceedings Northern Callfornia Section of the Society of American Foresters. Nov.7-8, Redding, Callfornia and Feb. 20-22, Eureka, California.

Rakhtseenka,I.N. \& Kabashnikava,H.I.(1975). Biolog1cal activity of solls under pure and mixed stands of pine and birch during the growing season. English Abstract in Forestry Abstracts, 38, 4005. Abstract 3999.1977.

Reck,S.(1973). Differences in 8 rowth behaviour between Douglas fir provenances. Forst- und Holzwrt, 28, 334-6.

Rechfeldt,G.E.(1974). Local differentation of populations of Rocky Mountain Douglas fir. Canadian Journal of Forest Research, 4. 399-406.

Roche,L.(1969). A genecological study of the genus picea in Britigh Columbia. New Phytologist, 68, 505-554.

Rudloff,E.von(1972). Chemosystematic studies in the genus Pseudotsuga. I. Leaf ofl analysis of the coastal and Rocky Mountain varieties of the Douglas fit. Canadian Journal of Botany, 50, 1025-1050.

Sak1,K.I. \& Park,Y.G. $(\overline{1971)}$ Genetic studies on natural populations of forest crees. III. Genetic differentation whin a forest of Cryptomeria japonica. Theoretical and Applied Genetic $6,4 \overline{1}, 13-17$.

Sannikov,S.N., Sannikov,N.S. \& Grishina,I.V.(1976) Population structure of Pinus sylvestr1s in the Transurals. Lesovedente, $\underline{1}, 76-81$. In Russian. English abstract in Forestry Abstracts, 37, 445. Abstract 4952 .

Sarvas,R.(1969). Genetical adaptation of forest trees to the heat factor of the climate. Second Horld Consultation of Forest Tree Breeding, Section 2/15 August 7-16, Washington D.C. FAO \& IUFRO, Rowe.

Schaal,B.A. \& Levin,D.A.(1976): The demographic genetics of Llatris cylindracea Michx: (Compositae). American. Natural 1 st, 110, 191-206. 
Schidt-Vogt,H.(1971). Wachstum und Wurzelentwlcklung von Schwarzerlen verschtedencr Herkunft. Allgemeine Forstund Jagdze1tung, 142, 149-155.

Shaw,G.G. \& Little,C. H.A.(1977). Natural varlation in balsam fir foliar components of detary importance to spruce budworms. Canadian Journal of Forest Research, 7, 47-53.

Simpson,G.G.(1975). Review of A.V. Yaklokov. Variäbility of mammals. Sclence, 189, 987-988.

Sindelar,J. \& Hochmut,R.(1972). Variability in the occurrence of some insect pests on various provenances of European larch (Larix decldua Mill). Silvae Genetica, 21, 86-93.

Slatyer,R.0. \& Ferrar,P.J.(1977). Altitudinal variation in the photosynthetic characteristics of snow gum, Eucalyptus pauciflora Sieb. ex Spreng. III. Effects of growth temperatures under controlled conditions. Australian Journal of Plant Physlology, 4, 289-299.

Smich,W.H.(1976). Character and significance of forest tree root exudates. Ecology, 27, 324-331.

Squillace,A.E. \& Silen,R.R.(1962). Racial vartation in ponderosa pine. Forest Science Monographs, 2,27 :

Stearns,S.C.(1976). Life history tactics: a review of the ideas. Quarterly Review of Biology, 51, 3-47.

Stern,K.\& Roche,L.(1974). Genetics of forest ecosystens. Springer Verlag, New York. 330 pp.

Szikla1,0., El-Lakany,M.H. \& De-Vescov1,M.A.(1976). On the clinal variability in nuclear characteristics of Douglas fir, its possible causes and applications. Egyptian Journal of Genetics and Cytology, 5, 146-152.

Tappeiner,J.C. \& Alm, A.A.(1975). Undergrowth vegetation effects on the nutrient content of 11 tterfall and soils in red pine and birch stands in northern Minnesota. Ecology, 56, 1193-1200.

Thtelges, B.A. $(\overline{1972})$. Intraspecific variation in foliage polyphenols of Pinus (subsection sylvestris). Silvae Genetica, 21, $114 \overline{-119 .}$

Thoday,J.M. \& Boam, T.B.(1959). Effects of disruptive selection. II. Polyworphism and divergence without Isolation. Hered1ty, 13, 205-218.

Tigerstedt,P.(1973). Studies of 1soenzyme varlation in marginal and central populations of Picea abies. Herid1tas, 75, 47-60.

vaartaja;0.(1959). Evidence of photoperiodic ecotypes in trees. Ecolog1cal Monographs, 29, 92-111.

Van den Drlessche,R.(1977). Survival of coastal and interior Douglas fir. seedlings after storage at different temperatures, and effectiveness of cold storage in satisfying chilling requirements. Canadian Journal of Forest Research, $7,125-131$.

.Van den Drfessche,R. \& Webber,J.E.(1975). Total and soluble nitrogen in Douglas fir in relation to plant nitrogen 
status. Canadian Journal of Forest Research, 5, 580-585. Vog1,M., Schönbach,H. \& Had1cke,E.(1968). Fxperimentelle uncersuchungen für relative Rauchharte tm Rahen eines Provenienzversuchs mit der japanischen Larche. Archiv für Forstwe sen, 17, 101-115.

vouté,A.D.(1964). Harmonious control of forest insects. International review of forest research I (Ed. by J.A. Romberger and P. Mikola). pp. 325-83. Academic Press, New York.

Wareing,P.F. \& Matthews,J.D.(1971). Physlological and genetical factors determining productivity of species. Proceedings 15th IUfRo Congress, Gainesville, Florida. pp. $136-43$.

Wearstler,K.A. \& Barnes,B.V. (1977). Genetic diversity of yellow birch seedlings in Michigan. Canadian Journal of Botany, 55, 2778-2788.

Wells, $0.0 .(1964)$. Ceoographic variation in ponderosa pine. II. Correlations between progeny performance and characteristics of the native habitat. Silvae Cenetica, $13,125-132$.

Wells,0.0.(1966). Variation in rust resistance among pine seed sources and species in a Mississippi planting. Forest Science, $12,461-463$.

Wells,0.0. \&nyder,E.B.(1976). Longleaf pine half-sib progeny test. Forest Sc1ence, 22, 404-406.

Wells, 0.0 . \& Wakely,P.C. $(1 \overline{970} \mathrm{a})$. Varlation In long leaf pine from several geographic sources. Forest Sclence, 16 , $28-42$.

Wel1s,0.0. \& Wakely,P.C.(1970b). Varlation in shortleaf pine from several geographic sources. Forest Science, 16, $415-423$.

Wilson,D.(1972). Variation in photorespiration in Lolium. Journal of Experimental Botany, 23, 517-524.

Woessner,R.A., Davey,C.B., Crabtree,B.E. \& Gregory,J.C. (1975). Nutrient content of the above-ground tissue of 12-week old loblolly pine intraprovenance and interprovenance crosses. Canadian Journal of Forest Research, $5,592-598$.

Wright,E. \& ChIng,K.K.(1962). Effect of seed source on mycorthizal formetion on Douglas fir. Northwest Science, $36,1-6$.

Wright,J.W.(1973). Genotype-environment Interaction in north-central U.S. Forest Science, 19, $113-124$.

Wright,J.W.(1976). Introduction to forest genetics. Academic Press, New York. $463 \mathrm{pp}$.

Wright,J.W., Wilson,L.F. \& Bright,J.N.(1975). Genetic variation in resistance of Scotch pine to Zimmerman pine moth. Great Lakes Entomolog1st, $8,231-236$.

Zavarin,E., Critchfield,W.B. \& Snajberk,K.L.(1969). Turpentine composition of plnus contorta $x$ pinus banksiana hybrids and hybrid derivatives. Canadian Journal of Botany, 47, 
1443-1453.

Zobel,D.B., McKee, A., Hawk,G.M. \& Dyrness,C.T.(1976). Relationships of environment to composition, structure, and diversity of forest communties of the central western Cascades of Oregon. Ecological Monographs, 46, 135-156. 
THE EXPLOITATION OF GENETIC VARIATION BY SELECTION AND BREEDING.

BY R. FAULKNER

Forestry Commission, Northern Research Station, Roslin, Mid lothlan, U.K.

\section{SUMMARY}

A brief historical review is provided of factors leading to the plus tree concept; this is based on observations on crown and sten-forn characters. Most breeding programes are concerned with wood production in which volume, stem-form, branching and wood density are the most Important traits. Problems of wutiple-trait selection and selection indices are discussed against the background problems of time, physical avallable resource and breeding strategy. Methods of Indirect selection are unsultable for plus tree selection.

Herltability values for specified tralts and spectes and their lititations are discussed together with some of the main reasons why responses to phenotyplc selection have been low in the past. Response to genotypic selection, based on sexually and asexually produced planting material is generally high for form but not vigour.

Reliable juventle-mature correlations in progenies are of great potential value to the breeder who seeks to maximlze gain per unit of time. At present there are very few progeny tests old enough to enable the breeder to do this and most evidence on timber volume production is based on provenance test data. Some of the dangers to be expected in predicting future volume production are highlighted and the value of data obtained from seedling plants raised under controlled or semi-controlled enviroments wll be mainly related to factors such as early-frost susceptibllity and the ability to develop, and amounts of, free growth.

The value, use and problems associated with the 
production of inter- and intra-specific hybrids are discussed in addition to a brief reference to the commercial production of seed from orchards.

The value and uses of vegetatlvely produced planting material are described and attention is drawn to the problems of selecting young plant material and predicting performance from the aspects of plant shape and vigour. Mixed-cloned families based on recreated hybrids from single-pair matings with known superior performance values are likely to provide a satisfactory way of getting genetic improvement quickly into the forest.

RÉSUMÉ

Bref historique des facteurs qui ont amene le concept de 'l'arbre plus'; celui-cil est basé sur l'observation des caractéristiques de la cime et de la forme du tronc. La plupart des programmes d'amélioration concernent la production du bois, dont les caractéres les plus 1mportants sont le volume, la forme du tronc, l'aspect des branches et la densité du bois. Les problèmes de sélection selon plusieurs caractéristiques et les indices de sélection sont discutés en tenant compte des problèmes de temps, des ressources physiques disponibles et des stratégies d'amélioration. Des méthodes de sélection indirecte ne conviennent pas à la sélection 'd'arbres plus'. L'exposé traite aussi de l'hérédité de certains caractéres et de certaines especces et leurs limfitions, ainsi que certaines des raisons principales qui expliquent les déboires dans le passé $d$ une sélection phénotyplque. Les résultats d'une sélection génotyplque, basée sur des Individus prodults de façon sexuée et asexuée sont, en général, favorables quant a la forme, mals mauvais quant a la vigueur de l'individu.

Des bonnes corrélations entre les stades juvéntles et adultes sont d'une importance capitale pour celui qui cherche à anéliorer le rendement par unité de temps. En ce moment 11 y a encore très peu de tests juvéniles ayant assez de recul et qui permettraient a l'améliorateur d'établir ces relations, et la plupart des résultats sur la production en volume est actuellement basée sur les résultats 
des tests juventlës. Certains des dangers auxquels on peut $s^{\prime}$ attendre dans la prédiction de la production sont mentionnes. Les résultats obtenus avec des plants cultives en milleu contrôlé ou semi-contrôlé portent essentiellement sur la résistance vis à vis des gelées précoces et sur les facultés de développement et quantité de la croissance libre.

on traite aussi de l'usage et des problèmes associés a la production des hybrides inter- et intra-spécifiques. on se refere aussi, brièvement, a la production commerciale de graines provenant des vergers à graines.

On décrit aussí la valeur et l'utilité des individus produits végétativement et $l^{\prime}$ on fera remarquer les problèmes de sélection des jeunes individus et la prédiction de leur performance en tenant compte de la forme et de la vigueur des plants. Des peuplements formés d'un mélange de clones de familles basés sur des hybrides crées a partir de crolsements entre couples de performances supérieures connues, seront certainement à même d'apporter à la forêt une amélioration génétique rapide.

\section{ZUSAMMENFASSUNG}

Es soll hier, basierend auf Kronen- und Stammformcharakteristiken, ein kurzer historischer Abriss uber die Faktoren gegeben werden, die zur 'Plus-Baum'-Idee geführt haben. Die weisten Zuchtprogramme befassen sich wit der Holzproduktion, wobel volumen, Stammform, Astigkeit und Holzdichte die wichtigsten Merkmale sind. Die Probleme, dle in Bezug auf die Auswahlkriterien bel der Auswahl nach mehreren Merkmalen entstehen, sollen vor dem Hintergrund solcher Probleme wie zeit, verfügbare ititel und Anzuchtverfahren. diskutlert werden. Methoden der Indirekten Auswahl sind fur dle 'Plus-Baum' -Auswahl ungee ignet.

Zur Diskussion gestellt werden 'Vererbungswerte' für verschledene Merkmale und Baumarten und die Grenzen lhrer Aussage, sowie einlge der Hauptgründe, warum die Wirkung der Auswahl von phänotypen bisher so gering war. Die Wirkung der Auswahl von Genotypen, die aus sexuell und asexuell produzlertem pflanzenmaterlal stammen, 1st im allgemeinen 
sehr gut, wenn es um dle Bauform und weniger gut, wenn es um die bichsigkeit geht.

Zuverlāssige Daten liber dic Jugend-Reife Verhaltnisse bei der Nachkommenschaf $t$ sind von grossem potentiellen wert für den zuchcer, der eine zeitliche Gewinnmaximierung anstrebt. Gegenwărtig glbt es nur wenige, genügend alte Nachkommenschaf $t s p r u ̄ f u n g e n$, dle das dem ztichter ermöglichen kơnnten. Die meisten Zahlen über die Masse der Holzproduktion stuitzen sich auf Werte, die von Provenienzprufungen abgeleltet werden. Es wird auf die Gefahren hingewlesen, die die Voraussage zukinftiger Wuchsleistung beeinhal tet. Fraglich ist vor allcm, inwieweit Daten zuverlāssig sind, die von Sămlingen aus geschiltzter oder halbwegs geschlizter Umgebung stammen. Dies ist problematisch vor allem in Hinblick auf Frühfrostempfindlichkelt und in Bezug auf die Fähigkeit für 'freies Wachstum' (oder Johannistriebblidung) und dessen Quant1tät.

Diskutlert werden auch Wert, Nutzen und Probleme in Zusammenhang mit der Erzeugung von inter- und intraspezifischen Hybriden. Dariberhinaus wird auf die kommerzielle Produktion von Samen aus Bampflanzungen kurz hingewiesen.

Der Wert und die verschtedenen verwend ungsmoglichkelten von vegetativ produzlertem Pflanzenmaterial wird diskutiert unter besonderer Berücksichtigung der Probleme, dle bei der Auswahl jungen Pflanzenmaterials entstehen, und wie aufgrund von form und Wichsigkelt der Pflanzen ihr späteres verhalten vorausgesagt werden kann. Mit H1lfe gemischt-klonischer Famillem aus neu gezüchteten Hybriden, dle aus Einzelparen hervorgegangen sind und die hervorragende Verhaltenselgenschaften aufwelsen; sollte es möglich sein, schnell eine genetische Verbesserung des Waldes zu erreichen.

\section{INTRODUCTION}

Selection and breeding of individual forest trees on a scientific basis began in 1924 and lagged behind similar work on many other crop plants. For example, rice was in cultivation and influenced by selection for over 5000 years and has been systematically bred since 1905. Undoubtedly the delay to the start of tree breeding was due to the long breeding cycle of most tree species, physical difficulties of 
artiflcially pollinating flowers borne high above the ground or, in some cases working with small hermaphrodite flowers, e.g. Eucalypt us spp., and difficulties of cheaply and reliably propagating old trees by rooting cuttings or other methods of vegetative propagation. Where vegetative propagation is easy, it has been exploited and used to advantage, for example extensive clonal plantation forests were begun with vegetatively reproduced Cryptomeria japonica in Japan over 400 years ago (Toda 1974).

\section{THE PLUS TREE CONCEPT}

Opperman (1908) published his findings that undesirable shape in stem- and crown-form is inherited and Nicolai (1932) suggested the selection of special seed trees in pinus sylvestris, which he termed 'elite', from which separate seed collections should be made and later progeny performances recorded. One year later Bornebusch (1933), writing on beech breeding, recommended one-parent progeny-tests to estimate breeding values and Larsen (1934) introduced the concept of the clonal seed orchard thus: "I strongly urge therefore, taking up vegetative propagation and in conjuction with experiments on artificial pollination, the establishment of seed plantations for the supply of seed for practical use".

The term' plus tree' appears to have been introduced first around $\frac{1950}{195}$ the Royal Board of Private Forestry of Sweden (Anon.1951). Before this ellte tree was used as a synonym, a fact which has led to much confusions in the literature. Currently accepted defintions of these terms are: Plus tree: a phenotype judged (but not proved by tests) to be unusually superior in some quality or qualities, e.g. exceptional growth rate relative to site, desirable growh habit, high wood quality, exceptional apparent resistance to disease, insect attack or other adverse locality factors.

Elite tree: one that has been shown by testing to be capable of producing progeny with superior qualities and is, therefore, of superior genotype (Anon. 1971).

In a later publication, reporting on some early progeny test results, Larsen (1947) suggested that tree phenotypes are more environmentally conditioned than those of other crop plants, and also, because trees are cross-pollinated and are highly heterozygous, progeny testing would be essential to estimate the genotype for certain characters. Undoubtedly he had been convinced from observation that some characters, for example, crown-shape and stew-form, were highly inherited and that grafted trees would give an Indication of genotype but not necessarily enough to form definite opinions of an individual's sultabllity for breeding. Lindquist (1948) supported Larsen's proposal and reconmended that mother trees for use in elfte seed plantations (seed orchards) should be 
the "most extreme plus tree varlations", which he suggested should be trees wth an acceptable type of branching and crown and superior stem-diameter, helght growth and flower production. The criteria for selection were described for several spectes, and for scots pine he suggested that selected trees should contain fifty percent more volue than their three nearest dowinant trees.

In the perlod 1950-1970 many countries began tree breeding programmes. Most had the main objective of increased yields of high-quality wood through multiple-trait selection as described by e.8. Stonecypher (1970) and Dorman (1976). others were specifically aimed at improvement in yield or quality of other products, for example, pine resin yields in soucheastern U.S.A. (Squillace \& Dorman 1961). Plus tree selection, which is a form of mass selection, was an important aspect of these programmes and the criterfa for selection varled according to species, age of crop, objectives of the breeding work and avallable resources (Mathews \& McLean 1957; Mitchell 1956; Vidakovic 1966; Squillace 1968; Morgenstern et al. 1975). It soon was realized, that a high selection-intensity for several tratts was rarely feastble, particularly when tratts were independently inherited, or negatively correlated and, which was often the case, controlled by several gene-pairs (Mergen 1959;. Campbell 1964).

\section{PLUS TREE SELECTION CRITERLA}

Problems arise in describing the characteristics of plus trees which are usually related to growth rate and wood quality, and in establishing a classification systed in which points are awarded for the degree of excellence of each trait in the plus tree. Tralts are welghted according to their economic importance (Anderson 1966). Independent culling levels are often chosen in which a level of mertt for each trait is cstablished. Individuals falling below this level are excluded regardless of their superiority in other traits. Cech (1959) investigated five methods of selection used in the southern U.S.A. and formed the opinion that the estimator is more important than the method and, as might be expected, that numerical scoring systems are more effective than subjective, descriptive systems. In even-aged plantations the candidate plus tree is often compared with neighbouring dowinants for superiortty by measurements or by scoring (Fletcher \& Faulkner 1972). In nacural forests, where age and espacement between trees may be quite variable and where there may be family relationships and risks of inbreeding between candidate and adjacent comparison trees, such comparisons are less valuable. For this reason Ledig (1974) suggests that in wild populations there may be more gafn from individual tree selection than from comparative wethods.

In many animal and plant breeding programmes selection 
indices have been widely used to determine the economic value of a new cultivar. The procedure entails the combination of the econonic values of each trait, their herftabilities and correlations with other traits of economic importance (Stern 1964). This is relatively easy for those agricultural crops about which much is known of their genetic and economic attributes. But for the tree breeder, with 1 imited and not very reliable information on genetic paraneters, the problem will remain largely academic, the more so when coupled to the problem of giving probable economic welghtings for material to be marketed twenty-five to seventy-five years ahead. At tempts to use selection indices for tree species have been made (van Buijtenen \& Horne 1960; Baradat et al. 1970; Bunn 1975). The technique may, in the course of time and in some circumstances (Namkoong 1976), replace the method of independent culling levels currently practised by most breeders but this replacement will depend on the accuracy of estimates of genetic varlance and covariance matrices (Williams 1962). Tandem-selection, in which selection is practised on one trait per generation, followed by selection of all taits over several further generations, is tmpracticable for forest trees because of the time element.

If they can be established, strong phenotypic correlations between traits can be useful, particularly when one trail is easy to assess and the other difficult. However, phenotypic correlations are a function of genetic and environmental correlations and the strength of narrow-sense heritabilities obviously plays an important interactive role. Since estimates of genetic correlations between characters in older trees can only be established on the basis of growing families of known origin to near-rotation age, it is unlikely to featurye in breeding programmes for all but the fastest growing species. Of particular interest to breeders are phenotypic correlations between stem volume and branching characteristlcs, such as numbers per whorl and their diameter, as investigated in Pseudotsuga menzlesil by Campbel1 (1961, 1963).

Maximum genetic gain per unit of time is a primary objectlve of most breeding projects. It is dependent upon the genetic varlance, estlmated breeding values as expressed by the heritablity, the selection differential 1.e. the difference between the population mean and the average of the selected individuals (Stern 1964), and the length of breeding cycle and time at which future progeny performances $c$ an be reliably predicted. Burdon \& Shelbourne (1972) pointed out that for a given investment in a breeding programe, selection differentials must be maximized in order to maximize genetic gain. They showed that selection differential increases curvilinearly with the ratio of individuals screened to those selected. Thus the increase in selection differential falls 
rapidly in relation to the additional effort required. An accurate appraisal of breeding strategles depends on detailed calculations of the expected gain for varying proportions of the population selected for traits, each of which has different heritabllities. At present few breeders have sufficiently accurate information on the selection intensitles used in their programmes on which to base estimates of genetic gain.

Selection on the basis of factors influencing growth, such as photosynthetic rate, particularly at low temperatures, higher enzyme activity, leaf-area index, domancy control mechanisms, seasonal patterns of extension and radial growth, and ageing is complex (Wareing 1964; Wareing \& Matchews 1971) and cannot be directly practised in plus tree selection. In future such criterla may play a useful role in the selection of families in the seedling and juventle stages of growth (Richardson 1960; Ledis 1975, 1976; Cannell, Thompson \& Lines 1976).

\section{RESPONSE TO PHENOTYPIC SELECTION.}

Response to phenotyplc selection can only be determined from progeny or clonal tests from which estimates of the heritabilities of the characters under selection can be obtalned. Herltability values are not constant for a given character since they are the ratio of additive genetic variance $V_{A G}$ to total varlance, $1 . e$. environmental variance $v_{a}$, non-additive genetic variance $V_{N A}$ and $V_{A C}$ itself.

$$
\text { Heritability }=\frac{V_{K A}+V_{N A}+V_{A G}}{V_{A C}}
$$

For this reason heritabllity values may vary mainly according to the site conditions under which a progeny test is conducted, within-plot competition and ablity to compete between trees and the age of the materlal under test.

The value of phenotyplc selection to a breeder is greatest when a crait is under the control of a single or very few genes and when heritability of the traits to be lmproved is moderate to high and persists from youth through to the end of the crop rotation. This has been shown to be generally the case in numerous conffers for tree-form characters such as stem straightiness, branch angle and length, and wood characters such as tracheld length, cell wall thickness and spiral grain (Ehrenberg 1970; Faulkner 1969; Harris 1970). In contrast, tree vigour, expressed by stem diameter and height growth, generally has a low, narrow-sense heritability indicating polygenic control of the trait or that environmental factors may play an over-riding role in tree growth rate. Forest sites are intrinsically variable and before 1945 were seldom amellorated by treatments such as drainage, deep cultivation and fertilization. For this reason 
plus tree selection in old crops, even when very high selection intensities were practised, often proved unrewarding. Where difficult site conditions have been ameliorated or where sites are inherently more uniform, selection for vigour offers higher prospects for success. For these reasons it can be assimed that as improved silvicultural techniques for the rapid establishment of plantations are developed and put into practice, so heritability values will be raised.

From 5-10\% of plus trees selected in even-aged plantations frequently show height gains of about $15 \%$ in progeny tests. Somewhat lower height gains are reported from plus trees selected in older crops. This may be due to the fact that they were established on variable sites and raised under silvicultural regimes very different from those currently practised or, alternatively, that inaccurate age determinations were made on plus trees in natural stands, perhaps compounded by microsite variation which favoured the rapid establishment and fast development of certain individuals.

A further complication affecting plus tree selection can be the year when flowering begins and the periodicity and amount of flowering thereafter. It is well-known that heavy seed and pollen production adversely affects diameter growth and that trees which grow extremely well to normal rotation age with moderate flower crops, way later fall to meet selection standards if they produce bountiful and regular seed crops in relation to their neighbours when approaching senescence. For this reason plus trees should only be selected in crops up to but not beyond the expected rotation age, when grown in plantations under current silvicultural practices.

Finally, plus trees should only be selected in large plantations derfved from extensive seed collections involving many parents. This minimizes the risk of relatedness and the undesirable consequences of inbreeding which may only become manifest in subsequent generations.

\section{RESPONSE TO GENOTYPIC SELECTION}

The majorlty of well-designed progeny tests have been established since 1960 and reliable information on heritability values for some characters is now beginning to emerge. Most relates to characters which are easily assessed in young trees, such as height and diameter growth, frost-hardiness, resistance to certain pests and diseases, stem form and branching characters (I11y 1966; Ehrenberg 1963, 1966). Regression of parent tree/family data has been atterpted by only a few workers, e.g. Illy (1967). Strong correlations for vigour between parent tree and progeny are unlikely and are rarely strictly comarable because of ageing and local dfferences in competition and site treatments. 
Similarly crown-shape is strongly influenced by conpetition and stand management treatments, but stem and branch strafghtness have been strongly correlated in young progeny material.

Several workers have established correlations between the perfurmances of vegetatively propagated ramets, both grafts and rooted cuttings, of plus trees and thelr parents but these are unlikely to be of much practical value since age of parent, method of raising cuttings, origins of the sclonwood or cuttings on the parent tree, precocity in flowering, ease of rooting and grafting and speed of asserting apical dominance in the ramet can all have a profound influence on the shape of the propagated material and its growth performance. Wellendorf (1970) atcempted to establish parent/graft correlation for Pinus sylvestris and established a relationship for height.

\section{JUVENILE-MATLRE CORRELATIONS}

To maximize genetic gain per unit of time tree breeders have to shorten the generation cycle and, therefore, reliable predictions of future performances of individuals, families and clones are essential (Squillace \& Gansell 1974). Theoretical ways for making predictions have been suggested by Nanson (1967, 1976).

Due to the long rotation of most forest crops there are very few published data on juvenile-adult correlations for many commercially important characters: most information has been gathered for tree height and wood qualicy characters from provenance experiments rather than progeny tests. Western Furopean provenance experience shows that height 5-10 years after planting, when trees are about $1.5 \mathrm{~m} \mathrm{tall}$ and have recovered from planting shock and are not affected by weed comptition, is strongly correlated with total wood volume production and height at 25-60 years (Nanson 1976). Selection of 'super seedlings' with very high selection intensitics (1 in 200,000) is not a reliable method for predicting future helght growth in pines (Ellestein 1955; Callaham \& Duffield 1962) and may be more closely linked with intial seed size and very rapid gerwination. In Britain, glasshouse-grown two-year-old Picea sitchensis seedlings provided correlations of $r=0.5$ co $\overline{r 00.6}$ with forest-8rown plants, one to four years after planting. In a typlcal pinus sylvestris progeny test consisting of sixty-one open-polilnated progenies, the correlation coefficlent matrix for helght was:

lst yr

lst yr 1.000

$3 \mathrm{rd} \quad 0.832$

$6 \mathrm{th} \quad 0.543$

$3 \mathrm{rd} \mathrm{yr}$

0.506

1.000

0.849

$10 \mathrm{th}$

0.409

0.755

0.671

6 th yr

$1.000 \quad 10 \mathrm{th} \mathrm{yr}$

0.962

1.000

0.860

0.942

$15 \mathrm{th} \mathrm{yr}$

1.000 
Toda (1974) struck a note of caution in predicting longterw fucure performances frow young plant material and cited a commercially used Cryptoneria clone in Japan which grew very rapidly for only the first twenty years, after which growth declined. He also reported that stem diameter is a better predictor of volume performance than height growth for pine, spruce and larch up to $30-40$ years old. Namkoong \& Conkle (1976) reported good helght growth correlations between ages three and twenty-nine for seven provenances of pinus ponderosa in a twenty-nine year experiment. Family variances within provenances were often swaller than environmental variances; differences were not well. correlated between earlier and later phases of growth and sometimes correlations were negative. Typical slgmold curves were reported, indicating exponential growth after planting followed by constant 8 rowth and then declining growth towards maturity probably due to more intense competition or perhaps the onset of heavy seed production. Family average growth curves were fairly close up to twenty years, indicating that family differences during the adolescent stage are not accumulated and for this reason Namkoong suggested that changes in growth rate may be better selection criteria than total size.

Early test on which to base helght growth predictions are of course less reliable for crops grown on sites subjected to episodic or unpredictably extreme climatic conditions, for example conditions favouring heavy accumulations of wet snow leading to branch breakage, exceptional drought, frosts, hurricanes, hallstorms, disease and insect attacks or varlous combinations of these hazards. Results from early tests on first rotation crops of exotic species and of indigenous species with origins other than local ones, must always carry a greater risk of unreliability than tests based on indigenous materlals of local origin.

7obel \& Rhodes (1956) working with individual trees of Pinus taeda established highly significant correlations between wod spectfic gravity of the juvenile core (first eight rings around the pith core) and mature tree wood; and between wood specific gravity of stem sections and adjacent branch sections. This suggests that estimates of young trees could be obtained from a tree branch - an obvlous advantage in progeny test work where trees cannot be sacrificed. By predicting potential rate of camblal activity from mean tracheid dlameters and leaf characters together with ring wdths in first year conffer seedlings, Denne (1976) suggested that rate of wod production could be separated from length of growing-season. Wedel, Zobel \& Shelbourne (1967) Investigating knot-wood in 7-8 year old Pinus taeda, reported high uniformity in branch diameter, number of branches per whorl, branch angle and knot volume percent within open-pollinated 
families and also significant correlations between branch-dlameter, bole diameter and the number of branches, and branch diameter and branch angle. Branch diameter increased with increasing bole diameter, steeper branch angles and a decreasing number of branches.

The use of fully or partially controlled glasshouses is valuable for ralsing young plants of species which show responses to photoperiod. Such plants can be periodically measured to assess growth responses to varying daylengths from which plant susceptibility to early and late frosts can be predicted (Ekberg et al. 1976). In pines, patterns of shoot 8 rowth and their adapative roles have been described by Lanner (1976), who mentions that 'free' growth, the precoclous expansion of new buds or the supplementary initiation and coergence of follage after the spring flush, beyond the seedling stage is related to mildness of climate; for obvious reasons flexibllity in shoot growth behaviour can allow great gains in growth rate. In young plants of some picea species 'free' growth after the spring flush contributes to total height; it is affected by photosynthesis and temperature and decreases with age (Pollard \& Logan 1976). Different comblnations of these variables in different years and localities could account for some of the more variable results between years for some progeny performances and so reduce the value of early testing for some species.

Branch angle, stem circularity, stem straightness and branch numbers per whorl are all tedious to assess and few research workers have made repeated assessments of these characters over a period of time. Ehrenberg (1970) reports fairly good correlations of stem and branching characters in young and older pines.

In clonal material correlations between stock plant and ramet for stem and crown characters are normally very good, as evidenced by the ease of early visual recognition of some poplar clones and of conlfer garden 'cultivars' when. grown on a wide variety of sites.

Rellable early tests. for disease resistance have not been developed on any scale, except for resistance to Cronartium fusiforme in pinus elliottil and p. taeda, which can be tested by using 3- $\overline{5}$ year old seedlings (Griggs \& Dinus 1977); Ceratocystis ulmi on elms and resistance to Aplano bacterium populi in poplars. It seems probable that biochemical methods are likely to be used to a greater extent in the future for predicting resistance to certain insects and diseases.

THE PRODUCTION OF HYBRIDS

Most countries include a hybridization programme in their breeding strategles. This is often at the inter-specific level, for example Larix kaempfer $1 \times$ L. decidua and between Populus species in many European and American countries; 
Eucalyptus species in Australia; Plnus rlglda $\times \underline{p}$. taeda in Korea; and between five-needled pines In America. Fl hybrid vigour 16 a frequent but rarely attained objective and resistance to diseases or climatic injury is often a more important reason. Other programes are based on intra-specific (provenance) hybridization. In Scandinavia there is much interest in the production of hybrids between Scandinavian and eastern European sources of picea ables and in Britain between coastal and inland origins of pinus contorta in order to develop varieties which are both vigorous and stable under infertile and exposed situntions. In the course of time it is expected that outstanding hybrids derived from single pair matings will be used commercially, as is already the case with poplars. When vegetative propagation presents few difficulties, the mass production of hybrids is easy. Most Fl hybrid seed has to be obtained by artificial pollination due to poorly matched flowering times of the parent species. Quite often the seed has a low percentage germination due to a low seed set, or physlologlcal barriers associated with fertilization, adverse effects of pollen handling and storage methods, pollination techniques and unsultable methods of isolating the female flowers before and after pollination. In conifers seed production from artificial pollinations is usually between ten and fifty percent of that obtained by wind pollination under normal forest or seed orchard conditions.

\section{SEXUALLY DERIVED PLANTINC MATERIAL}

In the majority of cases forest planting stock is obtained from seed. Before 1940 most forest enterprises used seed frow unselected sources, but since then the importance of seed or 18 in (provenance) has been recognized and seed from selected stands of superior phenotype has been more widely used. As a consequence both national and international seed and plant certification schemes have been developed for marketing purposes (Barber 1975).

By combining performance information from progeny tests and information on amount, periodicity sex ratio and dates of flowering of plus and elite parent trees, the tree breeder can design and plan a programme of clonal or seedling orchards for the mass production of seed of improved genetic quality for a varlety of planting regions (Weit \& Zobel 1975).

\section{VEGETATIVELY DERIVED PLANTING MATERLAL}

Vegetatively produced planting stock used efther as single or mixed clones, offers a fast method of introducing material of the highest genetic quality into comerce. It has been extensively used for many years for the establishment of poplar plantations throughout the world, for Cryptomerta in Japan (Toda 1974) and on a more linited scale for pinus radiata in the southern hemisphere. Hore recently, 
vegetatively produced planting stock has been used for Picea abies in west Germany and chere are plans to use vegetatively produced, intra-specific hybrids of $\underline{p}$. ables more extensively in Scandinavian countries. In Brítaln Larix $x$ eurolepis hybrids are being produced vegetatively and are likely to be used commercially within the next five years. Grafts are too expensive to produce for use as nomal planting stock and current and projected schemes are based on rooted cutings. Active research and development programmes for micro-propagation, using cell- and tissue- cultures, are to be found in many countries, notably in the U.S.A. and France (Boulay 1977).

Unt1l well-designed long-term tests have been carried out to compare the behaviour of clonal and seedling conifer materlal; there will always be doubt about the real value and role of vegetatively propagated stock.

In the Pinaceae rootability of cuttings declines rapidy on plants over five years old. Therefore, a decision to accept a parent for clonal work must be made on evidence derlved from early tests. As stated earlier, good correlations with future performance on the basis of height growth are seldow attalnable until the plant is 5-7 years old, at a time when rootability declines rapidly. This provides an obvious dilema for the breeder wishing to introduce into commerce large stocks of material frow a few, highly selected clones, produced from selected phenotypes in his best families. Furchermore, cuttings satisfactorily rooted from older and therefore larger plants, as in the case of larch (John 1977), will probably behave differently when taken from different parts of the tree due to topophytic (posttional and may be irreversible) and cyclophytic (ageing) effects. Both phenomena can result in different degrees of plaglotroplc growth, the times taken to achleve orthotropism, earlier seed production and consequent loss of volume growth. In a five-year-old $p$. radiata experiment, comparing seedlings with cuttings, Sweet \& Wells (1974) showed that seedling relative growth rate values, corrected for co-variance on plant slze, were higher than those for cuttings. Shelbourne of Thul in (1974) have reported poor repeatabllity between tests of the same clonal material at the same age.

Kleinschoidt (1974) described a commercial programme for the propagation of picea ables based on cuttings from a mixture of over 1000 clones, These were derlved from selected, open-pollinated famllies from stands or clonal orchards or frow controlled crosses. His predicted gains are suspect, however, on the grounds that selections are made on young familles grown in nurseries, where selection may favour trees which are tallest on account of late growth in autimn, orlginal seed size and strong growth responses to favourable nursery conditions. To avold this problem and to obtain 
naximum gain, it is necessary to first test numerous single pair matings and when satisfied as to which are the best combinations, repeat the crosses to provide enough plants for adequate multiplication by vegetative means. Plant mixtures of twenty or more 'cloned families' would be genetically heterogeneous as a mixed population and would produce a more stable output in a range of environments Such variation should enable trees of different genetic constitution to use the aggloweration of ecological niches effectively on wany sites with a lower probability of risk from episodic harmful events.

\section{REFERF.NCES}

Anderson,E.(1966). The selection of plus trees in Sweden. Sumarski ilst, 1-2, 21-37.

Anon(1951). Directions for seed collecting and trading in forest seeds and plants. Issued in 1950 by the Royal Board of Private Forestry in Sweden. David Broberg. Stockholm.

Anon(1971). "Terminology of forest sclence, technology, practice and products". (Ed. by F.C.Ford-Robertson). Society of American Foresters, Washington D.C.

Baradat,Ph., Illy,G., Maugé,J.P. \& Mend tbourne,P.(1970). Sélection pour plusiers caractères sur indice programmes de calcul. Application a la condult de verger graines test de descendance. Compte rendu d'activaté 1970 de l'Assoc lation Forêt-Cellulose, 46-69.

Barber,J.C.(1975). Seed certification. "Seed orchards". (Ed. by R.Faulkner), pp.143-148. Forestry Commission, London. Bulletin 54 .

Bornebusch,C.H.(1933). Dedanske B/ga Foraedling. Dansk Skovforeningens T1dsskrift, 292-295.

Boulay,M.(1977). Recherches sur la propagation du Douglas par culture en vitro. Annales de Recherches Sylvicoles 1976. Association Foret-Cellulose, 83-145.

Buijtenen,J.P. van \& Horne,W.M. (1960). A selection index for aspen based on genetic principles. Progress Report 6. Lake States aspen genetic and tree improvement group weeting, Appleton, Wisconsin, U.S.A.

Bunn, E.H.(1975). Genetics and tree improvements. Report Forest Research Institute, New Zealand Forest Service 1974. pp.12-15.

Burdon,R.D. \& Shelbourne,C.J.A.(1972). Breeding populations for recurrent belection: conflicts and possible solutions. New Zealand Journal of Forestry Science, 1 , $124-193$.

Callaham,R.Z. \& Duffield J.W.(1962) helght of selected ponderosa pline seedlings during 20 years. Proceedings Forest genet1cs workshop, Macon, Georgla. pp.11-13.

Campbell,R.K.(1961). Phenotypic variation and some estimates of repeatability in branching characteristics of Douglas 
f1r. Silvae Genetica, 10, 109-118.

Campbell,R.K.(1963). Phenotypic correlation among branch and upper crown attributes in Douglas fir. Forest Science, 9, $444-451$.

Campbell,R.K.(1964). Recommended traits to be improved in a breeding program for Douglas fir. Forest Research Note \$57. Weyerhaeuer Co., Centralla, Washington, U.S.A.

Cannell,M.G.R., Thompson, S. \& Lines,R. (1976). An analysis of inherent differences in shoot growth within some north temperate conlfers. "Tree physiology and yield improvement". (Ed.by M.G.R.Cannell and F.T.Last), Pp. 171-205. Academic Press, Lond on and New York.

Cech,F.C.(1959). Superior tree selection. A conparison of 8 rading systems. Proceedings $5 \mathrm{th}$ Southern forest tree improvement conference. pp.49-52.

Denne,M.P.(1976). Predicting differences in potential wood production from tracheld diameters and leaf cell dimensions in conifer seedlings. "Tree physiology and yield improvement". (Ed. by M.G.R.Cannell and F.T. Last), pp 283-289. Academic Press, London and New York.

Dorman,K.(1976). The genetics and breeding of southern pines U.S. Department of Agriculture Forest Service. Agriculture Handbook, 471, 339-351.

Ehrenberg,C.E.(1963). Genetic varlation in progeny tests of Scots pine. Studia Forestalla Suecica, 10.

Ehrenberg,C.E.(1966). Parent-progeny relationship in Scots pine (Pinus sylvestris) . Studla Forestalia Suecica, 40.

Ehrenberg, C.E.(1970) Breed Ing for stem quality. Unasylva, 24, 23-31.

Ekberg,I., Dormling,I., Erikson,G. Wettstein,D. von (1976). Inheritance of the photoperlodic response in forest trees. "Tree physiology and yield improvement", (Ed. by M.G.R.Cannell and F.T. Last), pp 207-2!. Academic Press, London and New York.

Ellerstein,B.W.(1955) Selection of plne super seedlings

an exploratory study. Forest Sclence, $1,111-114$.

Faulkner,R.(1969) Some characters of secondary importance to stem straightness in the breeding of conifers. proceedings 2nd World consultation of forest tree breeding, Washington D.C., $1,269-283$.

Fletcher,A.M. \& FaulknerR.(1972) A plan for the Improverent of Sicka spruce by selection and breeding. Research and Development Paper \#85. Forestry Commission, London.

Cris8s,M.M. \& Dinus,R.J.(1977). Patterns of fusiform rust increase and their implications for selection and breeding. Proceedings 14th Southern Forest tree Improvement conference, 43-52.

Harris,J.M.(1970) Breeding to improve wood quality. Unasylva, $24,32-36$.

Illy, $\overline{G .}(1967)$. Recherches sur l'amélioration génétique du 
pin maritlme. Annales des Sciences Forestieres, 23, $771-948$.

John,A.(1977). Vegetative propagation of hybrid larch in Scotland. Symposium on vegetative propagation of forest trees - physlology and practice. Instituce for Forest Improvement, Stockholm. pp. 129-136.

Kleinschmidt,J.(1974) A programme for large scale cutting propagation of Norway spruce. New zealand Journal of Forestry Science, $.4,359-366$.

Lanner,R.M.(1976) Patterns of shoot development in pinus and their relationship to growth potential. "Tree physlology and yield improvement". (Ed. by M.G.R.Cannell and F.T.Last), pp.245-251. Academic Press, London and New York.

Larsen,C.S.(1934). Forest tree breeding. Royal Vecerinary and Agricultural College Yearbook for 1934, Copenhagen, p.112.

Larsen,C.S.(1947). Estimation of the genotype in forest trees. Royal Veterinary and Agricultural Yearbook for 1947 , Copenhagen. pp.87-128.

Ledig,F.T.(1974). An analysis of methods for the selection of trees in wild stands. Forest sclence, 20, 2-16.

Led $18, F . T .(1975)$. Increasing the productivity of forest trees. "Forest tree Improvement - the third decade". Proceedings 24th Annual Forestry Symposium, Pp. 189-208. Loulsiana State University, Division of Continuing Education, Baton Rouge, U.S.A.

Led 18, F.T.(1976). Physlological genet1cs, photosynthesis and 8 rowth models. "Tree physlology and yield Improvement". (Ed. by M.G.R.Cannell and F.T.Last), Pp.21-54. Academic Press, London and New York.

Lindquist, B.(1948). Genetics in Swedish forestry. Svenska Skogsvardsforeningens Forlag, Stockholm.

Matthews', J.D. \& McLean,C. (1957) Improvement of Scots pine in Britain by selection and breeding. Paper 7 th British Commonwealth Forestry Conference, Australia and New Zeal and. PP 1-13.

Mergen.F.(1959). Forest tree breeding research. Unasylva, 13 , 129-37.

Mitchell,A.F.(1956). The selection of plus European larch trees. Scottish Forestry, 10, 68-80.

Morgenstern,E.K., Holst,M.J., TrIch,A.H.\& Yeatman,C.W.(1975). Plus tree selection. Revlew and outlook. Department of the Environment, Canadian. Forest Service, Publication $\$ 1347$.

Namkoong,G.(1976). A mulciple index selection strategy. Silvae Genetica, 25, 192-199.

Namkoong,G. \& Conkle,M.T.(1976). Time trends in genetic control of height growth in ponderosa pine. Forest Sclence, 22, 1-12. 
Nanson,A.(1967). Modele théorétique pour l'étude des tests précoces. Biométric-Praximétric, 8, 84-107.

Nanson, A.(1976). Juvenile-mature relationships mainly in provenance and progeny tests. Proceedings I.U.F.R.O. joint meeting on advanced generation breeding, Bordeaux 1976, pp.99-119. Institut national de la Recherche Agronom ique, France.

Nicola1,F.(1932). Anregung zur Individual- und Rassenzucht. Bericht des Westpreussischen botanisch-zoologischen vereins, $54,1-12$.

opperman, A. (1908). In: Det forstlige forsфosvaesen 1 Danmark $\underline{2}, 29-256$.

Pollard,D.F.W. \& Logan,K.T.(1976). Inherent variation in free growth in relation to numbers of needles produced by provenances of picea mariana. "Tree Physlology and yleld improvement". (Ed. by M.G.R. Cannell and F.T. Last), PP. 245-251. Academic Press, London and New York.

Richardson,S.D.(1960). The role of physiology in forest-tree improvement. Paper at the 5th world Forestry Congress Seattle 1960. New Zealand Forest Service Reprint $\$ 23$.

Shelbourne,C.J.A. \& Thulin,I.J.(1974). Early results from a clonal selection and testing programe with radiata pine. New Zealand Journal of Forestry Science 4 , 387-398.

Squillace,A.E.(1968). Selection of superior trees. Proceedings 9 th Southern conference on tree iroprovement, pp. 7-9. U.S. Department of Agriculture Forest Service.

Squillace,A.E. \& Dorman,K.W.(1961). Selective breeding of slash pine for high oleoresin yield and other characters Recent advances in Botany, $2,1616-1621$.

Squillace,A.E. \& Gansell,C.R.(1974) Juvenile : mature correlations in slash pine. Forest Sclence, 20, 225-229.

Stern,K.(1964). Population genetics as a basis for selection. Unasylva, $18,21-9$.

Stonecypher, R.L.(1970). Multiple traft breeding. Unalylva, 24, 48-51.

Sweet,G.B. \& Wells,L.G.(1974). Comparisons of the growth of vegetative propagules and seedlings of Plnus radiata. New Zealand Journal of Forestry Research, $4,399-\overline{409}$.

Toda,R.(1974). Vegetative propagation in rélation to Japanese forest tree Improvement. New zealand Journal of Forest Sclence, $4,410-417$.

Vidacovic,M. $(1 \overline{9} 66)$. Selection of plus trees. Sumarski List,

Wareing, P.F. $(1964)$. Tree physiology in relation to genetics and breeding. Unasylva $18,61-70$.

Wareling,P.F. \& Matthews,J.D.(1971). Physlological and genetical factors determining productivity of spectes. Proceedings 15th I.U.F.R.O. Congress, Gainesville, Florida, pp. 136-143. I.U.F.R.0. Munich. 
Wedel,K.W. von, Zobel,B.J. \& Shelbourne,C.J.(1967). Knotwood in loblolly pine. North Carolina State University Cooperative tree improvement progran. Technical Report $\$ 36$.

Welr,R.J. \& Zobel,B.J.(1975). Advanced generation seed orchards. "Seed orchards". (Ed. by R.Faulkner), pp. 118-216. Forestry Commission, London. Bulletin 54 .

Wellendorf,H.(1970). Resemblance in helght growth between original trees and clones of scots pine. Forest tree Improvement, $\frac{1}{2}, 25-45$.

Wlliams,J.S. ( 1962$)$. The evaluation of the selection index. Blometrics, $18,375-93$.

Zobel,B.J. \& Rhodes,L.R. (1956). Specific gravity estimations of mature loblolly pine from juventle wood and seedling $11 \mathrm{mb}$ sections. Forest Science, $\underline{2}, 107-12$. 

BIOLOGICAL OPPORTUNITIES FOR GENETIC IMPROVEMENT IN FOREST PRODUCTIVITY.

BY M.G.R. CANNELL

Institute of Terrestrial Ecology, Bush Estate, Peniculk, Midlothian, Scotland.

\section{SUMMARY}

The genetically varlable attributes that influence forest productivity can be divided Into three groups.

First, there are attributes which can be, and are being, improved, nomally as the unplanned consequence of selection for genotypes which produce the largest, highest-quality Individuals in the shortest time. These include adaptive traits, enabling trees to more fully exploit avallable growing seasons, and more effectively deal with or endure adverse features of the environment (especially water stress). These adaptive tralts are becoming understood from studies on provenances, and could be used as early selection criteria. Individual tree 'vigour' and, in a sense, 81 antisw, are belng favoured, by selecting for rapid establishment, rapid individual tree crown development, root regeneration and 'site capture', possibly favour ing competitive types and enhancing early sawlog production. And, most of all, stem quality defects are being minimized or el iminated.

Secondly, there are attributes which could be improved, but which are not being fully exploited. It 18 often considered too costly, too rlsky or potentially counterproductive to attempt to tallor genetically more uniform populations to particular sites or cultural enviroments. These judgements need to be regularly reviewed. Opportunities for genetic improvement in blomass ylelds may be particularly large under intensive culture; because of lessened need for mutually-depressing competitive traits, and smaller investment of assimilates in 
non-harvested branches and roots. More attention might also be given to selection for delayed ageing, avoiding early flowering genotypes, and employing new technologies to induce parent trees co flower.

Thirdly, there are attributes which do not seem readily amenable to genetic improvement, even though attempts may be wade to improve them. Foremost among these attributes may be fundamental changes in the potential radiant energy conversion efficlencles of well-adapted closed forest stands. It is pointed out that (a) In temperate regions, natural, coniferous forest stands are potentially already among the most productive biomass producers of all terrestrial crops, (b) contrary to common belief there are few precedents in agriculture for substantial genetic improvements in yield resulting from selection for greater photosynthetic efficiency of crop stands, including vegetative crops like grasses (Alberda 1971), and (c) it may be particularly difficult to improve the per hectare biomass productivitles of forest stands as long as we need to select for rapidly growing competitive individuals, because compromises have to be made between traits desired for rapid site capture and competitiveness, and craits desired for maximum community productivity after full site capture.

RÉSUMÉ

Les attributs varlables sur le plan génétique qui influencent la productivité de la forêt peuvent se diviser en trois groupes:

Premierement, 11 existe des attributs qui peuvent être, et sont, améllorés; en général, ces amélforations sonts la conséquence, non planifiée, d'une sélection de génotypes quí produisent, dans le temps le plus court des individus les mellleurs en qualité et en dimension. Ces attributs comprennent les facteurs d'adaptacion, qui permettent aux arbres d'exploiter au maximum les salsons de végetation et de lutter le plus efficacement possible contre les facteurs adverses de la nature (surtout contre le manque d'eau). La connaissance que $l^{\prime}$ on a des facteurs d'adaptation provient des études des provenances et peuvent être utilisés comme 
preniers critères de sélection. La 'vigueur' d'un arbre, et dans un certain sens, le gigantisme, sont favorisés par la bélection pour une reprise rapide, un développement raplde de la cime de l'arbre, une régénération rapide des racines et une exploftation rapide du potential de la station, favorisant eventuellement le pouvoir compestitif et arrivant ainsi rapldement a produlre des bois de sciages. Et surtout les défauts de qualité du tronc sont minlmisés, ou même éliminés.

Deuxièmement, 11 y a les attributs qui seraient a même d'etre amélforés mals qui n'ont pas encore été complètement explottés. On a souvent pensé qu'essayer de créer des peuplements génétiquement plus uniformes pour des stations ou des milieux particuliers, etalt un procéde trop côteux et trop r1squé, qui irait mête à 1 'encontre du résultat désiré. On se dott de réviser ce jugement régultèrement. Les possibllités permettant une amélloration génétique du rendement en blomasse peuvent être très importantes dans le cadre d'une culture intensive parce que la competition entre individus est moins 8 rande et 1 'investissement en prodults de photosynthèse dans les branches et les racines non recoltées est plus falble. on devralt aussi porter plus d'atention à la sélection portant sur un viellissement retardé et éliminer les génotypes qui fleurlssent trop tôt et sur l'utilisation de techniques nouvelles pour Indulre la floraison chez des arbres-mères.

Troislèmement, 11 existe des attributs qui ne semblent pas être amêliorables, bien que $l^{\prime}$ 'on alt essayé. L'attribut le plus important parmi ceux-ci est celui qui amènerait un changèent fondamental dans l'efficacité de la conversion potentlelle de l'énergle de radiation dans des peuplements fermés et bien adaptés. Il faut remarquer que (a) dans les réglons temperées les peuplements naturels de résineux sont déjà parmi les meilleurs producteurs de blomasse de toutes les productions terrestres, (b) contralrement à l'opinion commune, 11 y a peu de précédents en agriculture quil montrent une amélloration génétlque importante du rendement, qui résulterait d'une sélection basée sur une plus grande efficacitè de 1 a photosynthèse dans les peuplements, y compris les pratries 
(Alberda 1971) et, (c) 11 serait particulièrement difficlle d'amellorer la productivité de blomasse par hectare dans les peuplements forestiers si $l^{\prime}$ on continue à cholsir des essences a crolssance rapide et compétitive, car on dolt trouver un compromis entre, d'une part, l'utllisation plus rapide du potentiel de la station et une certaine compétition, et d'autre part une productivité maximale de l'ensemble du peuplement après une occupation compléte de la station.

\section{ZUSAMMENFASSUNNG}

Die genetischen Eigenschaften, welche die Produktivitat elnes Waldes beelnflussen, lassen bich in drei Gruppen gliedern.

Erstens 8 ibt es Eigenschaften, die sich verbessern lassen und die auch wirklich verbessert werden. Normalerwelse geschieht das als ungeplante Folge der Selektion von Genotypen, die in der kürzesten zelt die grossten und qualitativ besten Einzelexemplare hervorbringen. Zu diesen Eigenschaften gehört auch die Făhigkeit der Anpassung, aufgrund derer die Brume die Wachstumsperioden intensiver nutzen und widrigen Unwel tbed ingungen (besonders Wasserknappheit) standhalten konnen. Diese Merkmale der Anpassungsfahlgke $1 t$ werden aus

Provenienzstudien $\mathrm{klar}$ ersichtlich und konnten als erste Selektionskriterien denen. In der Selektion auf raschen Bestandesschluss, rasche Individuelle Entwlcklung der Baumronen, Regenerationsfähigkett der Wurzeln und 'Eroberung des Standorts' hin werden die Wuchskraft von Baumindividuen und in gewissem Sinn auch Riesenwuchs bevorzugt. Man versucht nach Molichkeit, wettbewerbsaktive Typen besonders zu fordern und damit elne frühe Sảgeholzproduktion zu steigern. Vor allem aber werden Qualitâtsmângel bei den Baumstămmen auf ein Minimum reduziert oder sogar ganz verhindert.

An zwelter Stelle stehen Elgenschaften, die zwar verbesserungsfahig sind, aber nicht voll genutzt werden. Es gilt hă 18 als $z$ kostsplel18, zu rlokant oder der Produktivität möglicherwelse abträgllch, wenn man verbucht, genetisch gleichformigere Populationen für bestimite Standorte oder loweltbedingungen zu 
schaffen. Solche Anstchten sollten in regelmässlgen Abständen neu iberdacht werden. Be1 Intensiver Bewitcschaftung gibt es besonders viele Moglichkelten genetischer Verbesserung der Biomasseerträge, da wenlger Bedarf besteht für gegenseitig unterdrückende und rivalisierende Elgenschaften und somit weniger Assimilate den nicht genutzten Zweigen und Wurzeln zugefthrt werden. Man könnte auch der Selektion it Hinblick auf eine Verzbgermg des Alterns mehr Aufmerksamke1t schenken, Indem man frühblühende cenotypen vermeldet und neue Methoden anwendet, um die Muterbăme zum Blūien zu bringen.

Drittens glbt es Elgenschaften, die nicht ohne weiteres genetisch $z$ verbessern zu sein scheinen. Dennoch kōnnten entsprechende Versuche unternommen werden. Grundsatzliche Veränderungen in der potentiellen Fählgkelt von gut angepassten, geschlossenen Waldbeständen, den Ausnutzungsgrad der Strahlungsenergie zu stelgern, konnen an erster Stelle in der Re the dieser Eigenschaften stehen.

Es wird darauf hingewlesen, dass (a) in gemảssigten Zonen natürliche Nadelwaldbestände heute schon potentiell zu den produktiviten Erzeugern von Blomasse unter allen Landpflanzen gehōren; (b) Im Gegensacz zur allgemeineñ Auffassung es in der Landwirtschaft nur wentgé Beispiele für substantielle genetische Verbesserungen des Ertrags 8 lbt, die durch die Selektion Im Hinblick auf grōssere photosynthetische Effizienz von Pflanzenbeständen, elnschliesslich vegetativ vermehrter Pflanzen, wle Gräser (Alberda 1971), erzlelt wrien; und (c) es sich als besonders schwier 18 erweisen kann, den Blomasseertrag der Waldbestände pro hektar zu verbessern, so lange wr nach rash wachsenden resistenten Elnzelpflanzen selektleren müsen, well Kompromisse notig sind zwlschen Merkmalen, die wegen rascher Standortseroberung und Resistenz erwinscht sind und Herkmalen, die wegen 1hrer optimalen allgemeinen Produktivität nach der vollen Eroberung des Standorts winschenswert sind.

\section{INTRODUCTION}

The ylelds of modern varieties of most fleld and horticultural crops are several-fold those of their widd 
progenitors, partly as a result of selection and breeding. Could the growth rates and ylelds of forest plantations be increased similarly by breeding, bearing in mind that forest trees are only at the threshold of domestication? What are the blological constralnts and limits on forest productivity set by their physiology and the way they are grown?

This contribution gives some personal viewpolnts on these questions based on considerations of (a) the physlological basis of yield of forest trees - their strengths and weaknesses as productive systems, and (b) the yield-determining processes that have been lmproved by selection and breeding in field crops (Wallace, ozburn \& Munger 1972; Ivins 1973; Evans 1975).

To provide a framework I shall examine four broad categories of attributes which have to be improved in order to increase forest productivities - attributes affecting

(a) adaptation,

(b) the speed of 'site capture' to full canopy cover after planting and each thinning,

(c) the efficiency of 'site utilization' in teros of -dry nater productivity per hectare per year after full site capture, and

(d) the proportion and value of the dry matter that is harvested.

\section{ADAPTATION}

The blological potential for improving forest ylelds by selecting species and provenances which are better adapted for volume growth than local populations is well-known. Many locally native forest populations, like primitive cereals and ma1ze (Evans \& Dunstone 1970; Mangel sdorf, MacNeish \& Galinat 1964) seem to exploit environmental resources rather conservatively, sacrificing rapid growth for long-term stress tolerance, ensuring survival over an evolutionary time scale, always in the face of competition from other specles. Similarly, native provenances of trees often appear to under-utilize the growng season avallable to then in their localities, or they may seem to be 'over-sensitive' to mild levels of water stress. These may have been destrable strategies during their evolutionary history, but during the 20-30 years history of provenance research they have seered over-cautious. There is a prodiglous literature on the benefits of provenance transfer from long-season, wet or otherwise favourable climates, to shorter-season, less-favourable climates (e.8. Wright 1976; Farmer 1976). The fastest growling provenances are often from areas with somewhat longer seasonal perlods of shoot, bud or camblal growth or, in the case of pinus taeda, for instance, are from areas with more frequent or reliable sumer rainfall (Wells 1969).

But all Individuals within a forest population are not 
equally well-adapted. Progenies selected within provenances differ in their abllties to endure or exploit particular environmental conditions. Kleinsctoit \& Sauer (1976) found more variation in shoot growth phenology among clones within provenances of Picea ables than between provenances, and van Buijtenen, Bilan $\bar{l}$ Zimmerman (1976) found considerable variation in drought resistance among familles belonging to certain provenances of Pinus taeda. Thus, during the early generations of recurrent selection, there is considerable scope to loprove the adaptive tralts of the best provenances. This selection could be done most effectively, and perhaps at an early age, if we gained and used information on the physiological and morphological basis of provenarce differences.

Provenance differences in phenology can be traced to particular cemperature and photoperlodic thresholds for budburst budset and bud development (e.8. Campbel1 1974; Ekberg et al. 1976). Desirable genotypes may have enhanced temperature or photoperiodic sensitivities at particular thresholds or way be indifferent to photoperlod. In fact, the shoot apices of plcea spp. may already be indifferent to photoperfod during bud development (Pollard \& Logan 1977), in which case temperature chresholds for growth and frost hardiness may be all 1mportant. It is noteworthy that the photoperiodic requirements of malze, soybean, potato and some rice varleties have been relaxed during selection to enable them to utilize the full growling seasons at temperate latitudes. In these, and many other annual field crops, temperature thresholds for vegetative growth seems to 1 latt yields (Monteith \& Elston 1971).

Provenance differences in crown form can be traced to a few rules governing the branching patterns (Cannell 1974; Cochrane \& Ford 1978). Differences in drought resistance can be traced to particular avoldance or tolerance mechanisms, and so on.

The blological potentials for forest productivity are set not only by how well the trees are adapted to particular natural environments, but al so how well they are adapted to the management system nder whlch they w11 be grown. Most tree breeders select genotypes which wll grow well in a range of climates, at various nutrlent levels and wh current site preparation and forest management. This may be wise, but the history of agriculture suggests that we could be missing large and perhaps profitable opportunities for genetic improvement $1 f$ we do not explore the potential genetic gains under intensive culture, ignoring, for the moment, the high costs of support energy. The outstanding feature of many field crop improvement programmes has been the synergism between new varieties, fertilizers, weed control and an increase in planting density. The prime achlevements of cereal breeding 
have been adaptations to fertilizers and close spacing. Without them, genetic fmprovenent by selection would probably have been swall. Indeed, Zohary (1969) reported that the grain yield from mixed stands of the wlld progenicors of wheat, barley and oats in the Middle East were similar to the yields of wheat in England, and rice in Japan, during the Middle Ages, that is, before the age of artificlal fertilizers. A few researchers who are examining biomass and pulp production by trees with intensive culture, report very high yleld of particular genotypes using high rates of fertllizers and close spacing (Schultz 1975; Anon 1976).

Unfortunately, the information on exploftable interactions between tree genotypes and their cultural environments is scanty. Researchers are only just beginning to explore the responses of large single-famlly blocks to varlous management regimes (Bridgwater \& Stonecypher 1978). There is, however, evidence that phosphate-responsive varieties of pinus taeda and Pinus elliottil could be developed for phosphate deficient sites, and certain specific crosses within these species are exceptionally responsive to nitrogen fertilizers (Goddard, Zobel \& Hollis 1976). Campbell \& Wilson (1973) found no full-6ib $x$ spacing interactions among young Pseudotsuga menzies11, but Snyder \& Allen (1971) and Adams, Roberds \& Zobel (1973) found evidence that competitive ability had a genetic component in Pinus elliottil and pinus taeda, respectively.

An important trait which could be regarded as adaptive, is the length of the 11 fe cycle. Different species, families and even clones mature at different ages, which partly determines the shapes of their height: age progress curves and times of maximum current annual increment (Muckadell 1959; Wareing \& Matthews 1973). The onset of these genetically determined ageing processes (Inherltance studied in fruit trees, e.8. Visser 1976) 1s usually signalled by increased cone production and a loss of apical dominance. Some species (e.g. Plnus virginlana) and some provenances (e.g. Lulu Island, B.C. Pinus contorta growing in Britain) are undesirable because of early ageing. Less obvioui famlly differences in ageing may not becowe apparent for many years, and should, where possible, be observed on their parents. There could be dangers in selecting heavily flowering plus trees, particularly if they are not very old.

How far it is wise to go in fine-tuning the adaptive traits of forest trees, 16 a matter of judgement. Improvements in the fitness of varieties to particular natural or man-modifled environments carry with them deteriorations in their abilities to cope whth opatial and temporal variations: adaptation and adaptabllity are antagonistic (Simmonds 1962; Tigerstedt 1974). Most tree breeders prefer to breed for widely adapted types which are genetically heterogeneous and 
physiologically adaptable. These types will perform as expected in a wide range of niches and environments and w111 exercise least selection pressure on potential pests and pathogens. Risks and breeding costs will be modest, but there will inevitably be sacrifices in potential genetic gains as long as some genotypes remain poorly adapted. The traditional approach of foresters is, in many respects, like that of subsigtence farmers: almed at some yield in most years on most sites, and satisfled with a modest overall optimum yield rather than striving for the maximum possible. A modest step towards adaptive fine-tuning, involving little further breeding costs, would be to assign single families to uniform sites and cultural treatments to which they respond (Bridgwater \& Stonecypher 1978). Further steps would be to grow single blocks of full-sib families or clone wixtures. These steps should not be rejected for reasonably uniform sites, bearing in wind that even single clones can be phenotypically plastic (Bradshaw 1965). Thus, some tree genotypes can acclimatize more readily than others to changes in temperature and light intensity (Led1g 1976; Ledig, Clark \& Drew 1977). A few potato clones are highly adaptable, and growers of tea and rubber have managed extensive areas with genetically homogeneous perennial crops for many years. We should also be aware, however, that many studles have shown that cereal cultivar mixtures slightly outyleld completely pure stands (Simmonds 1962) and that coffee (an Inbreeding spectes), which is genetically homogeneous, was wiped out of Sr 1 Lanka by leaf rust.

\section{SITE CAPTURE}

A coniferous forest crop may spend half the total rotation 'capturing' and 'recapturing' the site, that is, exploring the soll profile and bullding up a full follage canopy after planting and after each thinning. Consequently, forests, like annual crops, probably assimilate carbon and accumulate dry matter at rates which are proportional to the amount of intercepted radiation over the life of the crop (Montelth 1977). It 16 important, therefore, to increase the speed of 'slte capture'. On fertile, lowl and sites hardwoods will restore their follage canoples rapidly, and if they are copplced their soll enviroments are explored almost continuously. With conffers, however, we wust endure the prolonged perlod of early crown development. of new saplings, and accept that the soil profile has to be re-explored with new roots when a tree 18 felled.

It 18 important to realize that the biological attributes which limit the speed of site capture are those which 1 inft the growth rates of trees as individuals. Many of these attributes are different from those influencing the per hectare productivity of closed forest stands (Cannell 1978). 
It is equally important to realize that almost all forest tree breeders evaluate the growth of genotypes on the basts of the mean sizes of individuals, normally in rows, before or after canopy closure. They do not, and cannot, evaluate families on a per hectare basis in blocks large enough to allow the spatial processes of competition to operate (Ford 1975), because of the cost and the environmental heterogenelty of forest sites. Because they select for rapld individual tree growth, tree breeders are successfully improving many attributes favouring rapid site capture, Involving rapid exploration of surrounding environmental resources, and increased competitive abllity. These improvements will be inevitable consequences of selecting for fast-growing individuals, and will be highly desirable for half the rotation. During the other half, when the sites are fully captured, Incensified inter-tree competition could have two effects. On the negative side, 1t could concelvably depress per hectare productivity (FIg. 1). This is because, to maximize volume production per hectare, a large proportion of the trees should produce large volumes per year by using environmental resources efficiently, and not by robbing them from their neighbours (Donald 1968; Ford 1976; Cannell 1978). On the positive side, intensified inter-tree competition may spread tree size frequency distributions (producting some large dorinants) and so enhance the chances of producing some large trees of high value early in the rotation (FIg. 1). According to Schwantiz (1966) one of the important steps in the evolution of crop plants has been a transition to gigantism, often involving hybridization or an increase in ploidy. Large cereal grains, maize cobs, beans and beets, like large trees, are more valuable than small ones. Selection for gigantisw in trees may be a worthwille pursuit in itself, irrespective of its possible negative effect on per hectare volume productivity.

What are the biological attributes which regulate the speed of site capture? First, they will include the size of the embryonic capltal and other factors which influence seedling size in the nursery and after outplanting (e.g. Sweet \& Wareing 1966; Perry 1976). The value of $W$ in the equation $W=W_{0}{ }^{r t}$ depends on the starting value $W$ as well as the relative growth rate, $\underline{r}$, and time, $\underline{t}$. So-called 'superseedlings' of Pinus taèda, $\underline{P}$. elliottil añd $\underline{p}$. echinata, selected in the nursery, can be $2 \overline{0}-2 \overline{00}$ per cent greater in individual-tree volume at age ten than trees gorwn from average-sized seedlings (Zarger 1965), and differences in the initial size of Pinus radiata cuttings can lead to 4-5-fold overestimates of genetic $\overline{\text { gain at }}$ age four (Burdon \& Sweet 1976). Maternal, seed size, nursery and ' $C$ ' effects could be exploited to speed the rate of site capture. 
Secondly, among the factors influencing $r$ in the above equation, is the rate of leaf area expansion. In general, plants which invest a large proportion of their dry matter in photosynthetic tissue and distribute that tissue over a large surface area (often producing 'thin' leaves) to increase $11 \mathrm{ght}$ Interception, tend to succeed as individuals (Jackson 1963; Potter \& Jones 1977). Relative leaf growth rates are important decerminants of the time taken. to develop fully light-intercepting crop canopies. Within conifer specles there are striking differences in branching and crown form which Influence the rate of build-up in photosynthetic tissue after planting and thinning. The components have been considered (Campbell 1963; Miller 1965; Cannell 1974) and are contalned in crown expansion factors in single-tree computer models (Arney 1972; Mitchell 1975). Unfortunately, we cannot select rigorously for rapid crown development because of its undesirable impacts on stem knot size, wind stabllity and resistance to snow breakage. Very coarsely-branched, wide-crowned trees are rejected in favour of trees with moderately full crowns of fine branches, recognizing that there is a strong relationshlp between bole size and crown size (e.8. Waring et al. 1977). Also, genotypes which display current-year needles as late sumer flushes may be superior on favourable stes to genotypes which store all their needle primordia in buds until the following year.

Thirdly, inherent differences in root morpholoy and mycorrhizal developont may be lmportant. In droughty or competitive situations early growth after transplanting may be limited by the speed of access to water and nutrients, rather than the speed of radlant energy capture. In these situations, brecders, selecting fast-growing progenies, may be selecting for increased root growth (e.8. Plnus taeda, Cannell, Bridgwater \& Greenwood 1978). If so, this seems somewhat wasteful because trees, like land races of fleld crops (Jennings 1976) may already invest heavlly in roots as a survival strategy in competitive habltats. Young conifers send up to 50 per cent of the1r fixed carbon below ground (Webb 1977). It would be better if some of this dry matter were employed in shoot growth, but apparently this is not possible as long as there is a need for rapid root regeneration after transplanting. It would be interesting to know whether known genetic differences in root: shoot relative growth rates (Led 18 \& Perry 1965) could bring about interactions between genotypes and planting techniques or environments. If so, this would be another instance where genet1c improvements were conditional upon Improvements in tree culture.'

So far, I have spoken of attributes which influence light, nutrient and water 'capture'. To these must be added attributes which improve the efficiency with which light is intercepted, carbon fixed and water and nutrients used, 
remembering that we are considering these tralts for individuals and not for forest stands. The ideal light interception characteristics of isolated plant canopies (Charles-Edwards \& Thornley 1963) are different from those of crop canopies (Duncan et al. 1967). High rates of light-saturated photosynthesis which are desirable for isolated plants may be less Important in crop stands because most leaves are then; shaded. And we should be aware that light-saturated photosynthetic rates, or net assimilation rates, have not been improved much during the evolution of many field crops (Evans 1976 and see below), possibly because high photosynthetic rates are assoclated with sall mesophyll cells, small leaves and slow leaf relative growth rates which mean slow rates of 'site capture' (Charles-Edwards 1978).

Nevertheless, potential genetic improvements in the growth rates of individual trees, resulting from improvements in rates of site capture combined with better adaptation, appear to be considerable. Widely spaced trees of some new poplar clones grow twice as rapidly as old ones (van Goor. $\delta$ Koster 1969). And many conifer breeders confidently predict 50 per cent genetic galns over 2-4 generations of recurrent selection for lndividual-tree heights and bole volumes, attainable without intensive culture or intensive explotitation of genotypes $x$ environment interactions. However, such figures for gains in yleld may apply in full, as galns per hectare, only during the perlods of site capture, and they are, of course, modest compared with the several-fold genetic gains in, for instance, wheat and rubber yields since their domestication (rubber: Ferwerda 1969).

\section{SITE UTILIZATION}

Once the site has been fully captured the productivity of a forest depends on how effectively fintce resources of 1 ight, water and nutrients are utilized by the commity. As mentioned above, whilst it is destrable to have some vigorous, competitive Individuals to rapidly produce some large high-value stems, intense competition throughout even-aged stands could well depress per hectare productivity of dry matter and wood volume (F1g.1). The need to compromise between vigorous, competitive, ploneer-like individuals, and those which contrlbute to high per hectare productivitles after full sice capture, could severely limit potential genetic gains in per hectare volume production averaged over complete rotations.

This dilemma becomes clearer when we consider the traits that need to be compromised. First, there is the compromise between reasonably wide, spreading crowns giving rapid site capture and tall, narrow crowns whlch apparently intercept light most effectively in closed canoples (Jahnke \& Lawrence 1965) and produce the greatest stem volume per unit of crown 
volume or surface area (Assman 1970; Hamllton 1969). Secondly, there is the compromise between characteristics giving maximum photosynthetic rates at light-saturation, desirable on open-grown trees, and maximum shade adaptation, light absorptivity and photochemical efficiency, more important for shaded needles in conifer stands with leaf area indices often greater than ten (see Cannell 1978). Thlrdly, there could be compromises between below-ground nutrient-capture and drought-avoidance mechanisms desirable for open-grown individuals, and adaptive traits needed to utilize, mobllize and recycle nutrients effectively, and contend with water stress, in forest stands. In general, the compromises are between traits 1deally expressed by what Donald \& Hamblin (1976) called 'Asolation/competition' ideotypes and 'crop' identypes. The 'isolation/competition' ideotype for cereals is a lax, free-tillering, leafy plant, able to explore its environment as extensively as possible, whereas the 'crop' cereal ideotype is small, with few, erect leaves, minimum leaf display and few tillers (Fig. 1). In conifers the differences between 1deotypes may be more subile, but the effect on genetlc advance may be the same. That is, selection for fast-growing individuals may not increase stand productivity during the years when the site is fully captured. Selection for yield on the basis of spaced plant performance is believed by some agricultural crop breeders to be an ineffective way of increasing yields (e.g. 8rasses, Lazenby \& Rogers 1960-65; cereals, Syme 1972; Fischer \& Kertesz 1976; beans, Hamblin \& Evans 1976). Similarly, selection of high-yielding competitive individuals in mixed-genotype stands $c$ an favour genotypes which perform poorly in pure stands (Fig. 1; Hamblin \& Rowell 1975).

However, we should not be complacent about genetically improving the potential per hectare dry matter productivities of closed forest stands. Plantations of well-adapted, but genetically unimproved temperate-zone forests, especially conifers, which are well-supplied with nutrlents and water, are already physiologically capable of producing as much dry matcer as any hlghly-bred annual or perennial field crop employing $\mathrm{C} 3$ photosynthesis at the same latitude (Fig. 2). In north-temperate reglons this is $30-40 \mathrm{Mt} / \mathrm{ha} / \mathrm{yr}$ or above-ground dry matter - equal to $\mathrm{C} 4$ crops in these reglons. In certain sub-tropical reglons the maximum for forests may be nearer 50 $\mathrm{Mc} / \mathrm{ha} / \mathrm{yr}$ - less than C4 troplcal grasses (Dawkins 1963; Bevege 1976; Fig. 2). Revlews by Westlake (1963), Art \& Marks (1971), Loomis Gerak1s (1975), Gordon (1975), Kira (1975), and computer models of de Wit (1968) and Monteith (1977), all lead to the conclusion that unimproved coniferous forest canopies are very effective solar energy converters (Cannell 1978). An optimistic interpretation of these figures would be that the potential productivity of genetically improved coniferous 


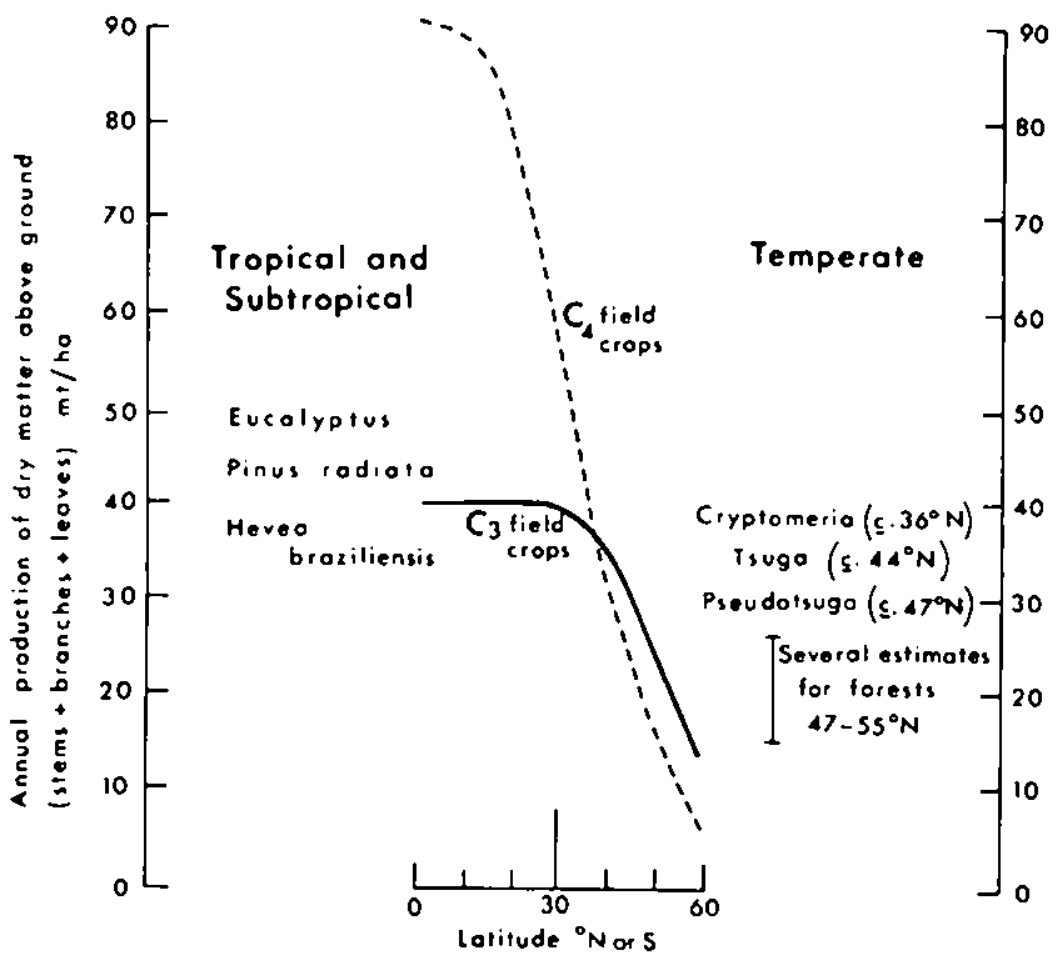

F18. 2. Maximum annual total above-ground dry matter production recorded for field crops (including perennials) with $\mathrm{C} 3$ and $\mathrm{C} 4$ photosynthesis (after Loomis \& Gerakis 1975), compared with maximum recorded for forest plantations (estimated or taken from Dawkins 1964; Templecon 1968; Westlake 1963; KIra 1975; Cannel1 1978). Maximum productivities of temperate hardwoods are less than those of conlfers (Day \& Monk 1977). 
forests may be much greater than that of other C3 crops because of their high capacilles for winter photosynthesis (Fry \& Phillips 1977), thelr high leaf area indices (e.g. Grier \& Running 1977), high energy conversion efficiencies of shaded follage, and large cambial sink capacities. On the other hand, attempts to genetically improve the photosynthetic efficiency of field crops in a fundamental sense have been singularly unrewarding (Evans 1975). Conputer rodels constructed by Monteith (1977) and Charles-Edwards (1978) for field crop stands indicate that it would need about a 4- to 5 -fold increase in 1 ight-saturated photosynthetic races to bring about a 50 per cent increase in annual dry matter productivity. Genetic variation in photosynthetic rates per unit leaf area within crop species has rarely been positively correlated with productivity, and these rates, or relative growth and/or net assimilation rates, have been negatively correlated with yields among evolutionary races or: among modern varieties of wheat (Evans \& Dunstone 1970), maize (Duncan \& Hesketh 1968), sorghum (Downes 1971), sugar beet (Watson \& Witcs 1959), sugar cane (Bull 1971), ryegrass (Rhodes 1972), tomatoes and cotton (Evans 1975). The maximum crop growth rates, and radiant energy conversion efficlencles, are remarkably similar for a wide range of $\mathrm{C} 3$ crops in Britain and the Netherlands (Greenwood et al. 1977; Sibma 1968; Monteith 1977). It may be very difficult to achieve, say, a 50 per cent improvement in the potential dry matter productivity of well-adapted forest stands in the present-day $\mathrm{CO}_{2}$ environment by selection within the natural pool of variation in $\mathrm{C} 3$ photosynthesis.

I specify the present-day $\mathrm{CO}_{2}$ environnent because global atmospheric $\mathrm{CO}_{2}$ concentrations are increasing by about 1 $\mathrm{vpo} / \mathrm{yr}$, which, according to Monteith (1977) could produce an 11 per cent increase in crop growth rates by the end of the century, without any credit to forest researchers! I also specify the natural pool of variation. According to Charles-Edwards (1978) there is no compelling evidence that crop growth rates can be increased in Britain by selection within the existing genetic variation in leaf photosynthetic characteristics. On the other hand, there could be fundamental biochemical weaknesses universally limiting energy conversion by $C 3$ photosynthesis and existing mitochondrial respiration, which could conceivably be overcome by genetic or cherical modification (Oliver \& Zelitch 1977; Day 1977; Radner \& Kok 1977). Lastly, I specify C3 photosynthesis becausese all forest trees examined so far are $\mathrm{C} 3$ plants (except mangrove, Schaedle 1975; and possibly larch, Fry \& Phillips 1976), and in tropical regions potential productivities are greatest with C4 photosynthesis. Crops with $\mathrm{C}_{4}$ photosynthesis can wake se of high irradicances, at high temperatures (PEP carboxylase has a temperature optimum exceeding $30^{\circ} \mathrm{C}$ ) and have high water use 
efficiencies. In temperate regions, however, $C_{4}$ photosynthesis is at a premium only in sumer (Monteith 1978). Over the whole year, especlally for crops with high leaf area indices and substantial winter photosynthesis, C3 crops are often wore productive than C4 crops (Loomis \& Gerakis 1975; Gifford 1974; Moore 1974).

Let me make clear that most closed forest plantations are not producing to the limits of their photosynthetic potential (perhaps 30-40 Mt/ha/yr of above-ground dry matter, about 2.5 per cent solar energy conversion, in north-temperate regions) and selection and hybridization can produce betrer-adapted genotypes which are more likely to approach this potential especially with inputs of support energy. My point is that we should not be complacement about the prospects of genetically improving this potential energy conversion efficiency of forest stands, particularly if we need to select for big trees.

PROPORTION AND VALUF, OF THF, DRY MATTER THAT IS HARVESTED.

Diversion of assimilates to the harvested sink (grain, tuber etc.) has been a highly significant feature in field crop improvement. Evans (1976) stated that "the evolution of crop plants has been primarily the evolution of the sink organs". Donald \& Hamblin (1976) concluded that "most of the progress in breeding high-yielding cereal cultivars secms to be related to higher harvest indices ( $H I$, the proportion of the aboveground dry matter that is harvested) with Ifttle change in biological yleld (total dry matcer produced)". In the early $1900^{\prime} s$ the HI of wheat varteties was 32 per cent, whereas for current dwarf wheats it is 49 per cent (Wallace, Ozburn \& tunger 1972), Phaseolus bean varleties have HI's ranging frow 55 to 67 per cent (Wallace, Ozburn \& Munger 1972), potatoes from less than 50 per cent for wild progenitors to 84 per cent for modern varletles (Watson 1971), and rubber clones from 3 per cent to 11 per cent (Templeton 1968), and oll palm progenies from 25 per cent to 55 per cent (Corley, Hardon \& Tan 1971). Thus, by changing the HI alone it has been possible to increase crop yields by between 20 and 250 per cent!

ovington's (1957) study of Pinus sylvestris in England showed that about 40 per cent of the net total dry matter (Including needles) produced above-ground by a forest crop is accumulated in the boles and somewhat less than 40 per cent will be recovered and converted into marketable products. If this index could be increased to 50 per cent, this could represent a 25 per cent increase in y1eld whthout any increase in total blomass production.

There are certainly considerable genetic differences in dry matter distribution within tree species - in root-shoot allometry (Led18 \& Perry 1965; Cannel1, Bridgwater \& Greenwood 
1978) in stem-branch, and bole-crown ratios (Matchews et al. 1975; Thompson 1974) - large enough to increase the above-ground harvest index of indivual trees to maybe 50-60 per cent. However, this potential cannot be fully exploited to increase forest yields as long as these depend greatly on the speed of site capture. As mentioned above, with current forestry practice, it is important to maintain, even enhance, the capacity for rapid crown and root developrent after transplanting and thinning. Consequently, there is unlikely to be much improvement in bole ylelds over entire rotations resulting from decreased investment in other tree parts.

one could, however, envisage carefully-planted, regularly thinned, closely-planted plantations, where there was a lesser need for rapid crown development, with inputs of fossil fuels permitting reduced investment in roots and reserves. Under these circumstances, genetic selection for higher harvest indices could increase stem pulpwood yields very considerably, both directly, and maybe indirectly, because the boles require less respiratory maintenance than do additional roots, branches and leaves. It is noteworthy that stem wood production per unit of foliage increases anyway after canopy closure (Mitchell 1975, his p.9 and Fig. 7), either because the trees become photosynthetically more efficient and/or because an increased proportion of the annual dry matter increment goes to the boles (Cannell 1978).

An obvious way to increase the harvest indices of forests is to include the branches, stumps and even structural roots in the harvest (Young 1973; Eskilsson 1974) or 1roprove the technology of harvesting and utilization (e.8. King \& Smith 1974). These approaches need not be discussed here.

Fielding (1960) stressed that up to 16 per cent of the above-ground dry watter produced by 7-year-old pinus radiata can be used to produce stroblli, seeds and pollen, and other workers have recorded decreased stem girth increment in heavy-coning years Rohmeder 1951). However, provided there is some effort to avoid very precoctous or fecund genotypes (Gerhold 1966), it would be misleading to exaggerate the potential for genetic gain in stem yields by selecting for reduced use of assionilates in flowering and opposed to selection for delayed ageing. If 15 per cent of the annual dry matter increment were taken by cones over one third of the rotation, this would average out as a reduction in vegetative growth of only 5 per cent, even if we assume that the cones are non-photosynthetic and have the same respiratory losses per unit welght as new vegetative tissues. But we know that green fruits, cereal ears, cotton bolls and sexual structures on ocher plants $f 1 x$ considerable amounts of external and respiratory $\mathrm{CO}_{2}$, and that the presence of fruit sinks often enhances photosynthetic rates. In my view, in trees, the association between flowering and ageing is likely to be wore 
Important in breeding programmes than the direct lopact of flowering on the harvest index.

By far the most Important gains in harvest index resulting from current tree improvement programmes will be gains in the proportion of stem wood which has a high merchantable value. Glaistone (1975) and Matthews (1975) elaborated the dramatic gains to be made by diminishing crook, sweep, taper, knot sizes, spiral 8 rain and other quality defects. There may not be much roon for altering the proportion of stem to bark, at least in P. taeda (Matziris o Zobel 1973), but most other wood quality characteristics are genetically varlable and usually highly heritable. First-generation seed-orchard progenles should contain a much smaller proportion of defective genotypes than unimproved stock. Selection for plant form in fleld crops (e.8. in brassicas) and ellmination of defects (e.g. shattering cereal inflorescences) has been very successful during their domestication (Evans 1976) and wll undoubtedly be one of the success stories of forest tree breeding, particularly with pines.

\section{REFERENCES}

Adams,W.T., Roberds,J.H. \& Zobel, B.J.(1973). Intergenotyplc interactions among familles of loblolly pine (Pinus taeda L.). Theoretical and Applied Genetics, 43, 319-322.

Alberda,T.(1971). Potential production of grassland. "Potential crop production". (Ed. by P.F. Wareing and J.P. Cooper), pp.159-171. He Inemann, London.

Anon.(1976). Intensive plantation culture. U.S. Department of Agriculture Forest Service. Ceneral Technical Report NC-21. Northeast Central Forest Experimental Station, St. Paul, Minnesota.

Arney,J.F.(1972). Computer simulation of Douglas fir tree and stand 8 rowth. Unpublished Ph.D. thesis. Oregon State University, and Canadian Forest Service, Victoria. Internal-Report BC-27.

Art,H.W. \& Marks,P.L.(1971). A summary table of blomass and net annual primary production in forest ecosystems of the world. "Forest blomass studles". Life Sciences and Agricultural Experiment Station, University of Maine and Orono, U.S.A. Miscellaneous Publications, 132, 6-32.

Assman, E. (1970). The principles of forest yield study. Pergamon Press, Oxford.

Bevege,D.I.(1976). A green revolution in the high yield forest: rational sllviculture or new technology? Australian Forestry, 39, 40-50.

Bradshaw,A.D.(1965). Evolut lonary significance of phenotypic plasticity in plants. Advances in Genetics, 13, 115-15S.

Bridgwater,F.E. \& Stonecypher,R.W.(1978). Genotype $x$ enviroment interaction: implications in tree breeding 
programs. Proceedings of 5th North American forest biology workshop, Universtty of Florida, Galnesville. (in press)

Bulftenen,vanJ.P., Bilan,M.V. \& Zimmerman,R.H.(1976). Morpho-physlological characteristics related to drought resistance in Pinus taeda. "Tree physlology and yield improvement". (Ed. by M.G.R. Cannell and F.T. Last), pp.349-359. Acadenic Press, London and New York.

Bul1, T.A.(1971). The C4 pathway related to 8 rowth rates in sugar cane. "Photosynthesis and phocorespiration". (Ed. by M.D. Hatch, C.B. Osmond and R.0. Slatyer), pp.68-75. Wiley, New York.

Burdon,R.D. \& Sweet,G.B.(1976). The probler of interpreting inherent differences in tree growth shortly after planting. "Tree physiology and yield improvement". (Ed. by M.G.R. Cannell and F.T. Last), pp.483-502. Academic Press, London and New York.

Campbell,R.K.(1963). Phenotypic correlations among branch and upper-crown stem attributes in Douglas fir. Forest Sclence, $9,444-451$.

Campbell,R.K.( 1974$)$. Use of phenology for examining provenance transfer in reforestation of Douglas fir. Journal of Applied Ecology, 11, 1069-1080.

Campbeli,R.K. \& Wilson,B.C.(1973). Spacing-genotype interaction in Douglas fir. Silvae Genetica, 22, 15-20.

Cannell,M.G.R.(1974). Production of branches and follage by young trees of Pinus contorta and Picea sitchensis: provenance differences and their simulation. Journal of Applied Ecology, 11, 1091-1115.

Cannell,M.G.R.(1978). Improving per hectare forest productivity. Proceedings of 5th North American forest biology workshop. University of Florida, Galnesville, U.S.A. (in press).

Cannell,M.G.R., Bridgwater,F.E. \& Greenwood,M.S.(1978). Seedling growth races, water stress responses and root-shoot relationships related to elght-year volumes among families of plnus taeda L. Silvae Genetica (in 11 t. .).

Charles-Edwards,D.A.(1978). An analysis of the photosynthesis and productivity of vegetative crops in the United Kingdow. Annals of Botany, 42, 717-731.

Charles-Edwards,D.A. \& Thornley,J.H.M.(1973). Light Interception by an isolated plant. A simple model. Annals of Botany, 37, 919-928.

Cochrane,L.A. Ford,E.D.(1978). Growth of a Sitka spruce plantation: analysis and stochastic description of the development of the branching structure. Journal of Applied Ecology, 15, 227-244.

Corley,R.H.V., Hardon,J.J. \& Tan,G.Y.(1971). Analys1s of growth of oll palm (Elaeis guieensis Jacq.). 1. 
Estimation of growth parameters and application in breeding. Euphytica, 20, 304-315.

Dawkins,H.C. (1963). The productivity of tropical high-forest trees and their reaction to controllable enviroment. Unpublished Ph.D. thesis. Conmonwealth forestry Institute, $O x$ ford, England.

Day,F.P. \& Monk,C.D. (1977). Net primary production and phenology on a southern Appalachian watershed. Amertican Journal of Botany, 64, 1117-1125.

Day,P.R.(1977). Plant genetics: Increasing crop yield. Science, 197, 1334-1339.

Donald,C.M. $(19 \overline{98})$. The breeding of crop 1deotypes. Euphytica, $17,385-403$.

Donald,C.M. \& Hamblin,J.(1976). The blological yield and harvest Index of cereals as agronomic and plant breeding criteria. Advances in Agronomy, 28, 361-405.

Downes,R.W.(1971). Relationship between evolutionary adaptation and gas exchange characteristics of diverse Sorghur taxa. Australian Journal of Blological Sciences, 24, 843-852.

Duncan,W.G. \& Hesketh,J.D.(1968). Net photosynthetfc rates, relative leaf growth rates, and leaf numbers of 22 races of malze grown at eight temperatures. Crop science, $\underline{8}$, 670-674.

Duncan,W.G., Loomis,R.S., Williams,W.A. \& Hanau,R.(1967). A model for simulating photosynthesis in plant communities. Hilgard 1a, 38, 181-205.

Ekber8,I., Dormling, I., Eriksson,G. \& Wettste1n, von D.(1976). Inheritance of the photoperlodic response in forest trees. "Tree physlology and yleld improvement". (Ed. by M.G.R. Cannell and F.T. Last), pp.207-221. Academ lc Press, London and New York.

Eskllsson,S.(1974). Whole tree pulping. 3. Pulp properties. Svenska Papperst1dning, 77, 165-174.

Evans,L.T.(1975). Crop physlology, some case historles: Cambridge Untuersity Press, London and New York.

Evans,L.T.(1976). Physlological adaptation to performance as crop plants. Philosophical Transactions of the Royal Soctety, London, B.275, 71-83.

Evans,L.T. \& Dunstone,R.L.(1970). Some physlological aspects of evolution in wheat. Australian Journal of Blological Sclences, $23,725-741$.

Farmer,R.E.(1976). Relationships between genet1c difference in yleld of deciduous tree species and varlation in canopy size, structure and duration. "Tree physlology and yield improvement". (Ed. by M.G.R. Cannell and F.T. Last), PP. 119-137. Academic Press, London and New York.

Ferwerda,F.P.(1969). Rubber (Hevea brazlllens1s (W1d.) Mull. Arg.). "Outlines of perennial crop breeding in the tropics". (Ed. by F.P. Ferwerda and F.WIt), pp.427-458. 
Miscellaneous Papers f4. Agricultural University, Wageningen, Netherlands.

Fieldings,J.M.(1960). Branching and flowering characteristics of Monterey pine. Bulletin 37 . Forestry and Timber Bureau, Australia.

Fisher,R.A. \& Kertesz,2.(1976). Harvest index in spaced populations a:d grain weight in microplots as indicators of yielding ability in spring wheat. Crop Sclence, 16, 55-59.

Ford,E.D.(1975). Competition and stand structure in some even-aged plant ronocultures. Journal of Erology, 63, $311-333$.

Ford,F.D.(1976). Competition, genetic systers and fmprovement of forest yicld. "Tree physlology and yield improvement". (Ed. by M.G.R. Cannell and F.T. Last), Pp. 463-472. Academic Press, London and New York.

Fry,D.J. \& Phillips,I.D.J.(1976). Photosynthesis of conifers in relation to annual growth cycles and dry matter production. I. Some $\mathrm{C} 4$ characteristics in photosynthesis of Japanese larch (Larix leptolepis). Physiologia Plantarum, 37, 185-190.

Fry,D.J. \& Philips,I.D.J.(1977). Phocosynthesis of conifers in relation to annual growth cycles and dry matter production. II. Physiolog1a Plantarum, 40, 300-306.

Gerhold,H.D.(1966). Selection for precoctous flowering in Pinus sylvestris. U.S. Department of Agriculture Forest Service, Research Paper NC-6.

Gifford,R.M.(1974). A comparison of potential photosynchesis, productivity and yield of plant species whth differing photosynthet1c metabolism. Australian Journal of Plant Physiology, 1, 107-117.

Gladstone,W.T. $(19 \overline{7} 5)$. Tree improvement programs of forest industries. "Forest tree Improvement - the third decade". (Ed. by B.A. Thielges), pp.65-71. 24th Forestry Symposium, Louisiana State University, Baton Rouge, U.S.A.

Goddard,R.F., Zobel,B.J. \& Hollis,C.A.(1976). Responses of Pinus taeda and Pinus elliottil to varied nutrition. "Tree physiology and y Cannell and F.T. Last), pp. 449-462. Academic Press, London and New York.

Goor,C.P. van \& Koster,R.(1969). New poplar clones. Populier, $\underline{6}, 43-47$.

Gordon,J.C.(1975). The productive potential of woody plants. Iowa State Journal of Research, 49, 267-274.

Greenwood,D.J., Clcaver,T.J., Loquens, S.M.H. \& Niendorf,K.B. (1977). Relationship between plant we ight and growing period for vegetable crops in the U.K. Annals of Botany, $41,987-997$.

Grier,C.C. \& Running,S.W.(1977). Leaf area of mature 
northwestern coniferous forests: relation to site water balance. Ecology, 58, 893-899.

Hamblin,J. \& Evans,E.M. (1976). The estimation of cross yield using early generation and parental yields in dry beans (Phaseolus vulgaris L.). Euphytica, 25, 515-520.

Hamblin,J. \& Rowell,J.G.(1975). Breed Ing implications of the relationship between competitive ability and grain yleld In a barley cross. Euphytica, 23, 535-542.

Hamilton,C.J.(1969). The dependence of volume increment of individual trees on dominance, crown dimensions and competition. Forestry, 42, 133-144.

Ivins,J.D.(1973). Increasing productivity. Crop physiology and nutrition. Philosophical Transactions of the Royal Soctety, Lond on, B.267, 81-91.

Jackson,J.F.(1963). The relationship of relative leaf growth rate to net assimilation rate and its relevance to the physiological analysis of plant growth. Nature, London, 200, 909 .

Jahnke,L.S. \& Lawrence,D.B.(1965). Influence of photosynthetic crown structure on potential productivity of vegetation, based primarily on mathematical models. Ecology, 46. 319-326.

Jennings,P.R.(1976). The amplification of agrirultural production. Scientific American, 235, 181-194.

King,N.J. \& Solth,C.A.(1974). Problems of wood waste. Forest and Home grown Timber, 3, 46-48.

Kira,T.(1975). Primary productivity of forests. "Photosynthesis and productivity in different environments". (Ed. by J.P. Cooper), pp. 5-40. Cambridge University Press, London.

Kleinschit,J. \& Sauer,A.(1976). Varlation in morphology, phenology and nutrient content among picea abies clones and provenances, and its implications for tree ioprovement. "Tree physiology and yield improvement". (Ed. by M.G.R. Cannell and F.T. Last), pp.503-517. Academlc Press, London and New York.

Lazenby,A. \& Rogers,H.H.(1960-65). Selection critería in grass breeding. Parts I-IV. Journal of Agricultural Science, $59,51-66 ; 62,282-298 ; 65,65-78$ and $79-89$.

Ledig,F.T.(1976). Physlologlcal genetics, photosynthesis and growth models. "Tree physlology and yield improvement". (E.d. by M.G.R. Cannell and F.T. Last), pp.21-54. Acaderic Press, London and New York.

Ledig,F.T. \& Perry,T.0.(1965). Physiological genetics of the shoot-root ratio. Proceedings of the Society of American Foresters, Detrolt, Mchigan. pp.39-43.

Led 1g,F.T., Clark,J.G. \& Drew,A.P.(1977). The effects of temperature treatment on photosynthesis of pitch pine from northern and southern latitudes. Botanical Gazette, $138,7-12$. 
Loomis,R.S. \& Gerakis,P.A.(1975). Productivity of agricultural ecosystems. "Photosynthesis and productivity in different environments". (Ed. by J.P. Cooper). Cambridge University Press, London.

Mangelsdorf,P.C., MacNeish,R.S. \& Galinat,W.C.(1964). Domestication of corn. Sclence, 143, 538-545.

Matthews,J.A., Feret,P.P., Madgewick,H.A.I. \& Bramlett,D.L. (1975). Genetic control of dry matter distribution in twenty half-sib familles of Virginia pine. Proceedings 13 th Southern forestry tree improvement conference. pp. 234-241.

Matchews,J.D.(1975). Prospects for improvenent by site amelioration, breeding and protection. Philosophtcal Transactions of the Royal Society, London, B.271, $115-138$.

Matziris,D.I. \& zobel,B.J.(1973). Inheritance and correlation of juvenile characteristics in loblolly pine (Pinus taeda L.). Silvae Cenetica, 22, 38-45.

Miller,W.E.(1965). Number of branchlets on red pine in young plantations. Forest Science, $11,42-49$.

Mitchell,K.J.(1975). Dynanics and simulated yield of Douglas fir. Supplement to Forest Science 21. Monograph 17.

Monteith,J.L.(1977). Climate and the efficlency of crop production in Britain. Philosophical Transactions of the Royal Society, London, B 281, 277-294.

Monte1th,J.L.(1978). Reassessment of maximum growth rates for $\mathrm{C} 3$ and $\mathrm{C} 4$ crops. Experimental Agriculture, 14, 1-5.

Monte1th,J.L. \& Elston,J.F.(1971). Microclimatology and crop production. "Potential crop production". (Ed. by P.F. Wareing and J.P. Cooper). He ineman, London.

Moore,P.D.(1974). Mi sunderstandings over C4 carbon fixation. Nature, London 252, 438-439.

Muckadell,M.S. de (1959). Investigations on aging of aplcal meristems in woody plants and its importance in silviculture. Forstlige Forsogsvaesen I., Denmark, 25, $309-455$.

oliver,D.J. \& Zelitch,I.(1977). Increasing photosynthesis by inhibiting photorespiration with glyoxylate. Sclence, $196,1450-1451$.

Ovington, J.D.(1957). Dry matter production by pinus sylvestris L. Annals of Botany, 21, 287-316.

Perry,T.0.(1976). Maternal effects on the early performance of tree progenies. "Tree physlology and yleld Improvement". (Ed. by M.G.R. Cannell and F.T. Last), pp.473-481. Academic Press, Lond on and New York.

Pollard,D.F.W. \& Logan,K.T.(1977). The effects of light intensity, photoperlod, soil moisture potential and temperature on bud morphogenesis in picea species. Canadian Journal of Forest Research, $7,4 \overline{15-42} 1$.

Potter,J.F. \& Jones,J.H.(1977). Leaf area partitioning as an 
important factor in growth. Plant Physiology, 59, 10-14. Radner,R. \& Kok,B.(1977). Photosynthesis: limited ylelds, unl imlted dreams. Bioscience, 27, 599-605.

Rhodes,I.(1972). Yield, leaf area Index and photosynthetic rate in sone perennial ryegrass (Lolium perenne L.) selections. Journal of Agricultural Science, Cambridge, $78,509-511$.

Rotmeder,E.(1951). Beftrage zur Kelmungsphysiologie der Forstpflanzen. Bayerischer Landwirtschaftsverlag, Minchen.

Schaedle,M.(1975). Tree photosynthesis. Annual Review of Plant Phys10logy, 26, 101-115.

Schultz,R.P.(1975). Intensive culture of southern pines: maximum ylelds on short rotations. Iowa State Journal of Research, $49,325-337$.

Schwanitz,F, $(19 \overline{66})$. The or igin of cultivated plants. Harvard University, Cambridge, Massachusetts, U.S.A.

Sibra,L.(1968). Growth of a closed green surface in the Netherlands. Netherlands Journal of Agricultural Science, $16,211-216$.

Simmonds, N.W.(1962). Variablitty in crop plants, its use and conservation. Biological Review, $37,442-465$.

Snyder,E.B. \& Allen,R.M.(1971). Competitive ability of slash pine analysed by genotype $x$ environment stability method. Proceedings $11 \mathrm{th}$ Southern forest tree improvement conference. pp.142-147.

Sweet,C.B. \& Wareing,P.F. (1966). The relative growth rates of large and small seedlings in forest tree specles. Supplement to Forestry. pp.110-117.

Sywe,J.R.(1972). Single-plant characters as a measure of field plot performance of wheat cultivars. Australian Journal of Agricultural Research, 23,753-760.

Templeton,J.K.(1968). Partition of assimilates. Proceedings Natural Rubber Conference, Kuala Lumpur, Malaysia.pp. $1-4$.

Thompson,S.(1974). Shoot growth and dry matter production in two contrasting provenances of Plnus contorta Dougl. Unpublished Ph:D. thesis, University of Aberdeen, Scotl and.

Tigerstedt,P.M.A.(1974). The application of ecological genetics principles to forest tree breeding. Silvae Genetica, 23, 62-66.

Visser,T.(1976). A comparison of apple and pear seedlings wh th reference to the juventle perlod. II. Mode of inher1tance. Euphyt 1ca, 25, 339-342.

Wallace,D.H., Ozburn,J.L. \& Munger,H.M.(1972). Physiological genetics of crop yleld. Advances in Agronomy, 24, 97-146.

Wareing,P.F. \& Matthews,J.D.(1973). Physlological and genetic factors determining productivity in species of forest trees. Proceedings of $15 \mathrm{th}$ Congress of I.U.F.R.O., 
Gainesville, Florida, U.S.A. pp.136-143.

Waring,R.H., Gholz.,H.L. Grier,C.C. \& Plummer,M.L.(1977). Evaluating stem conducting tissue as an estimator of leaf arca in four woody angiosperas. Canadian Journal of Botany, 55, $1474-1477$.

Watson,D.J.( $1 \overline{97} 1)$. Size, structure and activity of the productive systems of crops. "Potential crop production". (Ed. by P.F.hareing and J.P. Cooper), pp.76-88. He ineman, London.

Watson,J.D. \& Witts,K.J.(1959). The net assimilation rates of wild and cultivated beets. Annals of Botany, 23, 431-439.

Webb,W.L.(1977). Seasonal allocation of photoassimllated carbon in Douglas fir seedlings. Plant Physiology, 60, 320-322.

Wells,0.0.(1969). Results of the southwide pine seed source study through 1968-9. Proceedings 10 th Southern forestry tree improvement conference, Houston, Texas. pp. 117-129.

Westlake,D.F.(1963). Comparisons of plant productivity. Biologlcal Review, 38, 385-425.

Wit,C.T. de (1968). Plant production. "Agricultural sciences and world food supply". (Ed. by S.J. Wellensiek). Miscellaneous Publications \#3. Landbouwhogeschool, Wageningen, Netherlands.

Wright,J.W.(1976). Introduction to forest genetics. Academic Press, London and New York.

Young,H.E.(1973). Blomass nutrient elements harvesting and chipping in the conplete tree concept. 10th Research conference, A.P.I.-T.A.P.P.I., College Relations Group, Polnt Clear, Alabama. 20 pp.

Zarger,T.F.(1965). Performance of loblolly, shortleaf and eastern white pine superseedlings. Silvae Genetica, 14, 177-208.

zohary,D.(1969). The progenitors of wheat and barley in relation to domestication and agricultural dispersal in the old world. "The domestication and exploitation of plants and animals". (Ed. by P.J.Ucko and G.W.Dimbleby), pp.47-66. Duckworth, London. 
September 5, 1978

THE GROWTH OF PLANTATION FORFSTS

Chairman: R.C. Sceele.

An ecological basis for predicting

the growth and stability of

plattation forests.

E.D. Ford

The development of a flora in even-aged plantations.

i1.0. Hill

The development of populations

of pests and pathogens in

even-aged plantations - fung $i$.

J.s. :!urray

The development of populations of insects.

4. Crooke 
AN E.COLOGICAL BASIS FOR PREDICTING

THE GROWTH AND STABILITY OF PLANTATION FORESTS.

BY E.D. FORD

Institute of Terrestrial Ecology, Bush Estate, Peniculk, Midlothian, EH $26 \mathrm{OQB}, \mathrm{U} . \mathrm{K}$.

The widespread establishment of even-aged forests is one further stage in the intensification of forest management which has taken place in response to a continuous increase in the demand for forest products. Two problems are foreseen in the future management of these plantations which will require further evolution in silvicultural techniques.

(1) The growth rate of plantations must be increased and accurate predictions made of likely timber yleld. Where the crop cycle is long this has to be acheived against a background of continuous variation in the conditions of growth and in the response of trees. The varlation due to (1) long and short term cycles in the weather; (1i) the changing response of trees with different age at different levels of amelioration, is discussed. Classical yield table techniques are not suitable as a basis for predicting plantation 8 rowth under more intensive management systems. The potential of individual tree models to predict both the total yield of the forest and the distribution of different sizes of tree within it are examined.

(2) As plantations age, the standing yield of timber is increasingly at tisk from such hazards as fire and wind throw. These are not to be seen as inevitable 'catastrophies'. Their incidence is a function of spectes, site and silvicultural system. The potential for developing a model of the ecological basis of wind throw is examined.

It is suggested that whilst there is considerable research into the component processes of forest growth and cree:site interactions, there are few invest lgations into the design of new silvicultural systems for 
high production or the avoldance of hazards to production

RF́SUMÉ

La création de plus en plus étendue de forêts équiennes n'est qu'une étape dans l'intensification de la gestion forestière, doe a la demande accrue de prodults forestiers. La gestion future de ces plantations fera face a deux problètnes qui nécessiteront un developperent plus grand des techniques sylvicoles.

(1) Le taux de croissance des plantations dolt être augmenté et la prevision des productions dolt devenir plus exacte: dans le cas d'une longue révolution il faudra tenir compte des variations continuelles des conditions de croissance des arbres et de leurs réactions. Nous traitons dans notre exposé des varlations dûes (i) aux cycles climatiques longs et courts, (1i) aux changements de réactions des arbres selon l'åge et les différents niveaux d'amélioration. Les tables de production classiques sont mal appropriécs a la prévision de la production d'une plantation gérée intensivement. Nous examinons la posstbilité d'étabirir des modéles-arbres permettant de prévoir la production totale du peuplement ainsi que les tallles des différents arbres qui la corposent.

(2) A mesure que la forêt viefllit, le bols sur pled dolt lutter de plus en plus contre les $r$ isques $d^{\prime}$ incendie et les chablis, qu' on ne dolt pas considérer comme des 'catastrophes'. Ces incidents sont fonction à la fois des espèces, des stations et des systemes sylvicoles. Nous indlquons la possibilité de développer un modẻle basê sur le phénomène écologlque du chablis.

Nous suggérons que, malgré des études considérables sur les divers procédés de la croissance d'une forêt et les interactions arbre/station, il y a un manque de recherches dans le domalne des modeles de sylviculture centrés sur une haute production ou sur les mantères d'éviter les risques pour la production.

\section{ZUSAMMENFASSUNG}

Als Reaktion auf die ständige Zunahme der 
Nachfrage nach Waldprodukten ist die verbreltete Begruindung gleichaltriger Bestande elne weitere Phase in dem Entwicklungsprozess zu einer intensiveren Waldbewirtschaftung .

In der zukünftigen Bewitschaftung dieser Bestande lassen sich zwei Probleme voraussehen, del elne itere Entwicklung von Technicken in der Forstkultur erfordern:

(1) Man wuss das Wachstum von Beständen beschleunigen und genaue voraussagen der wahrscheinlichen Holzerträge wachen. Das hat bei langen untriebszeiten unter Berlickslchtigung eines ständigen Wechsels in den Wachstumsbedingungen und des Wachstums selbst zu geschehen. Hier wid der Wechsel diskutiert, der bedingt ist (1) durch lang- und kurzfristige Wtterungsperioden und (11) durch die mit Alter und Genotyp wechselnden Reaktionen. Konventionelle Ertragstafeltechniken eignen sich nicht als Grundlage für die Prognose des Bestandeswachstums unter intensiveren Bewirtschaftungssystemen. Wir erfassen den Wuchsverlauf von Einzelbäunen als Modell, um sowhl den Cesamtertrag eines Waldes als auch die Ertragsverteilung in Abhängigkeit von der Baumhöhe zu erfassen.

(2) Mit zunehoendem Alter der Bestände ist die nutzbare hol zmasse immer wehr Risken wie Feuer und Windbruch ausgesetzt. Diese werden nicht als unvermeidliche 'Katastrophen' betrachtet. Ihr Auftreten ist eine Funktion der Baumart, des Standorts und der waldbaulichen Situation. Wir untersuchen die Molichkett, auf okologischer Basis ein Modell fur Windbruch zu encwlckeln.

Wir behaupten, dass es nur wenige Untersuchungen für die Entwicklung neuer waldbaultcher Systeme zur Ertragsste1gerung oder zur Vermeldung von Produktionsrisken glbt, whrend die Faktoren des Wachstumsprozesses von Bestânden und die Wechselbezlehung Raum-Standort gründlich erforscht sind.

\section{INTRODUCTION}

Increase in the demand for timber and timber products is not a new phenomenon, neither is the evolution of silvicultural systems designed to meet this demand. Fifty years ago silviculturalists felt the pressure for more wood threatened the destruction of forests and sought ways of 
managing ther to cope with this.

"Forestry is now passing through a critical stage. The depletion of natural forests that has taken place during the past hundred years in wany parts of the world gives genuine cause for alarm... If the problem of future timber supplies is to be solved, it is (also) of the utrost importance that the reduced forest area now avallable should be treated in such a way as to produce the highest possible sustained yield of timber ..." (Troup 1928). Also, in 1928, Toumey put forward a basic concept which he considered should be followed in sllvicultural practice. "Forest vegetation is composed of plant communities or units of vegetation developed and arranged in accordance with definite biological laws and is not an aggregation of trees and other plants brought together by chance" (In Toumey \& Korstlan 1947). Toumey's view of the forest as an ecological entity was strongly felt and he considered that his text on the foundations of silviculture "Is not an outgrowth of plant ecology but rather plant ecology is an outgrowth of $1 t^{\prime \prime}$.

The silvicultural systems of Troup and Tolmey have their origins in tending natural forest to produce a sustalned yleld without destroying the forest itself. Their considered "ecological" basls is that yleld is in balance with the site without recourse to large scale amelioration of site conditions. Since 1928 the demand for timber has concinued to increase. This, combined with the worldwide reduction in areas of accessible natural forest, has led to the establishment of substantial areas of plantations in a wide variety of climates and frequently on land not previously forested." Plantation forestry is subject to stringent demands requiring intervention during the growth of the crop to maintain or increase growth rates or to adjust the proportions of different timber sizes to be produced. This requires a further development in silvicultural systems which itself demands more detalled understanding of ecological processes underlying the growth and developoent of forests.

PROBLEMS OF GROWTH RATE AND THE DEVELOPMENT OF FOREST STRUCTURE IN A PLANTATION ENTERPRISE.

The culture of forest plantations involves more than just careful management of an existing ecosystem on conservative ecological principles - it is an excensive investment excrcise with the following characteristics.

(1) Plantations are frequently restricted to marginal 1 ands with solls and climates which are poorer and more varlable than those used for agriculture - these environments do not automatically support high yields and may present hazards such as wind throw, frosts etc.

(i1) Timber is a bulky product, so that a large proportion of the cost of producing it is incurred in its transport to 
processing mills. The plantation enterprise should be concentrated to minimize transport and investment costs, but yet must generate sufficient production to sustain the development of an industrial infra-structure (Boardman, this volume).

In commercial plantation forests with these characteristics there are three closely related problems of forest growth and developoent.

Achieving a predictable, high growth rate

Plantations are costly to establish in teros of land, roads and fencing, and so generally the higher the yield/area obtained, the greater the proficability. High growth rates also mean that processing plant can be supported from a smaller area of land, again minimizing costs. However, almost as important as achieving high growth rates, is the need to predict the yield of timber which will be obtained in order to develop the associated forest industry efficiently.

protecting the forest against hazards and predicting risk

In many cases an even-aged plantation produces a forest structure which is at risk to destruction by strong winds, fire, animals (Crooke; König; Cooper \& Mutch, this volume) and pathogens (Murray, this volume). Since the fncidence of such hazards is related to the structure of the forest, attempts can be made to assess risk and devise silvicultural systems to winimize it.

The development of a balanced forest structure

Conflicting requirements can arise in relation to the optimum size and spatial distribution of stands of different species and age within a forest. This topic is dealt with in some detail by Malcolm and Davies in this volume. Management options in forest design are critically affected by the capacity to increase and secure production which themselves are influenced by variations in site and topography.

ACHIF.VING A PREDICTABLF, HIGH GROWTH RATE.

Traditional methods of predicting forest yields require no detalled understanding of which factors control growth rates. A 'site lndex' is used to classlfy the productive capacity of each stand based on some aspect of the growth made up to the time of observation, most frequently height (Kreutzer, this volume). Future growth is predicted from a set of empirically constructed yield tables on two assumptions, (1) the productive capacity of the stand wlll not change, 1 .e. growth will follow a patern established from previous stands which have been similarly classified, and (ii) a particular, prescribed sllviculture is followed, which determines the frequency, severity and type of thinning during the course of growth. This technique of yield prediction originates largely from the work of German foresters of the nineteenth century in long-established forests (Assmann 1970) and is based on the 
precept that the removal of a timber harvest should be in balance with the 'site'.

over the years refinements have been made in the parameters used to measure site indices so that they relate more closely to productive capacity, e.8. In Britain production classes used in conjunction with general yield classes, to incorporate a measure of stand basal area as well as helght (Hamilton \& Christie 1971). Another development has been to stratify forest sites in relation to physiography and various measurable site factors before constructing yield tables. However, as Kreutzer (chis volume) has polnted out, whilst this approach has made predictions more accurate, it has also raised many questions about the relationships between various environmental factors and forest growth. One needs to know which variables to chose when making yleld class stratifications. These are exactly the questions that we must answer to understand how to increase the growth rate of established stands.

The stage has now been reached where we should question the extent to which this yield table technique is an appropriate model for yield prediction in plantation forestry. lielther of the two assumptions under which yield tables are constructed, are applicable to modern plantation silviculture! Plantations do not grow under uniform conditions and intervention may be required to accelerate (Davies, this volume) or maintain (Boardman, thls volume) timber production. The removal of yield as thinnings has now become a more variable operation in response to the advent of new machinery (Hamilton 1976a), fluctuations in the demand for timber of different sizes, or the development of systems with no-thinning (Godwin 1968) or pre-commercial thinning (Fenton \& Sutton 1968) sllvicultures. We need to consider how these characteristics of plantation forestry may be incorporated into techniques for predicting yleld.

Changes in 'sice' conditlons and tree response during the plantation cycle

plant growth is regulated by the amounts of radiation, water and nutrients received or available and by conditions of temperature and humidity. These are not constant over the plantation cycle, netcher is the level or type of tree response. There are three sources of vartation (1) long and short term changes in weather patterns, (11) continuous developments in stand microclimate and (i11) differences in response to environmental variation as the trees age or as the conditions for growth alter greatly. Let us consider these three sources of varlation in turn.

(1) Changes in weather patterns. In extrese climates the width of tree rings may be very closely related to variation in a single environmental factor e.8. annual precipitation in arid zones (Fritts 1965). In more temperate reglons, climatic 
variation may not be so dramatic but still has a major influence on tree growth. Over twenty-eight sites in colorado, Fritts et al. (1971) found that on average sone 60-65 per cent of the variation in tree ring widths of three species was related to variables representing the seasonal march of climate. Different environmental variables were important on different sites, and whilst 20 per cent of the sites showed less than 50 per cent of the variacion related to these variables, another 20 per cent showed more than 80 per cent of the variation so related.

Climatic cycles can have a substantial effect on growth. In a mature plantation of Pinus sylvestris, Miler, Milier $\delta$ Binns (1977) showed that tings had varied from 0.5 m to 1.25 min in a regular way between the seventy-fourth and eighty-ninth year. They detected three significant cyclical patterns with periods of $42.0,23.0$ and 4.4 years fertilization increased the amplitude of the vartation associated with these cycles.

The influence of short term, i.e. daily or weekly changes in the environment on tree growth has been largely ignored. Physiologisls have cended to stress either the influence which condicions in one year may have on a subsequent year's growth (Kozlowski, Torrie \& Marshall 1973), or the importance of trends in the developent of trees during a season (Denne 1976).

'Carry over' effects from one year to the next are well-known in agricultural experimentation and must. be taken into account when assessing the ylelds of crops under different treatments over a series of years (Patcerson \& Lowe 1970). In forests such evidence as exists suggests that these effects can be small compared with the effects of current season's weather. Over the twenty-eight colorado sites investigated by Fricts et al (1971) only 15 per cent of the variation in ring width was 'explained' by correlation with the previous year's ring width, compared to 60-65 per cent variation 'explained' by current weather. For trees it has yet to be proved that there is a direct physiological influence on yield by one season's condtions on the next year's yield. The influence which varlation in weather in one year has on growth in the next, seews most $11 \mathrm{kely}$ to be restricted to aspects of shoot elongation where bud development takes place a year in advance of extension. This may determine the number of needles which will be produced in the following year (Cannell, Thompson \& Lines 1976), but both the size of needles and the total length of shoot on which they are carried are influenced by the amount of photosynthesis made during the year of growth itself (Litte 1974).

Factors controlling the duration of the growth period are Important, particularly with regard to bud development and shoot elongation. Variation in response to these factors is a 
major source of exploitable genetic variation in growth (Perry, Cannell, this volume). However, within the limits set by the seasonal perlod of developront, growth fluctuates in response to changes in the environment. In a plantation of Sitka spruce in the Scottish uplands, cell production by the camblum during the production of early wood varled between zero and twelve cells per radial file of trachelds per day, being greatest on days with high solar radiation (Ford, Robards \& Piney 1978). In the same forest, the population of fine roots was found to decrease by up to 50 per cent over a fifteen-day period wh no rain, but after heavy rainfall the population increased almost to its original size within five days (Deans in press). The magnitude of these effects varied between soll horizons and depended upon their particular microclimates. These results suggest that fast 8 rowth requires alternation of sunny and wet periods each with a duration of no more than a few days. Whilst cambial activity may respond to individual days of high radiation, long unintertupted sequences wil lead to the development of high moisture tension whin the tree which checks cambial activity (Little 1975). The amplitude and frequency of weather changes may be as important to the achievement of high growth rates as the mean conditions and may explain some of the very high growth rates in wild, temperate climates (e.g. Tottenham \& Joyce 1975).

(1i) Development of stand microclimate. The extent to which plantation growth is sensitive to changes in the environment, will depend upon lts size and structure since this has a large influence on the microclimate of the stand. In a young plancation height increments were found to increase slowly until the branches from neighbouring trees overlapped. Increments then increased rapidly from year to year until competition between trees started (Cochrane \& Ford 1978) from which time annual helght increments osclllated around a mean. The precise environmental changes, which cause the acceleration of height increment and those which deternine the limit of mean annual helght increment are not known for this forest. The environmental factors which determine the size a forest canopy can attain and the size at which competition becomes important, have been variously specified as a balance between temperature and solar radiation (Nomoto 1964) and the ratio between incoming rain and potential transpiration (Crier \& Running 1977). Whilst such combinations of factors may be predominant at the extremes of wet or dry climates, some more complex balance may be struck in intermedfate zones between water balance, temperature and nutr1tion (Warling et al. 1978). Factors controlling maximum growth rate and the canopy size at which this maximum is achieved, are important areas for future research, since microclimate, e.g. Increasing 'interception loss' with increasing forest size, is strongly implicated and 
may possibly be manipulated through silvicultural techniques. Boardman (this volume) has pointed out that ifttle opportunity may exist for rapid acceleration of growth rate once canopy closure has occurred. Silvicultures which depend largely on maintaining a closed canopy for long periods of time and taking a substantial proportion of their yield as chinnings, 1.e. anticipating mortality, may not prove as flexible as those in which the rotation is short and final yield is a large proportion of total yield.

(111) Differences in tree response. Alterations in the physlological characteristics of trees as they age, are well-known (Moorby \& Waering 1963). Many of these are easy to predict and can be counted as intrinsic properties of the crop. Such ageing effects are likely to become important to strategies of increasing and predicting yield where differences are known to exist between and particularly within spectes. In a progeny trial with Ponderosa pine, Namkoong \& Conkle (1976) found indications of trends in helght growth which differed between the phases of plantation growth, planting site and family. More research on such differences is required to determine whether they are directly due ro differences in genotype or indirectly due to differences in stand structure and therefore in microclimate.

A wajor consequence of accelerating growth rates through a treatment such as fertilization, is the production of wide 8 rowth rings (Davies, this volume) and a possible change in wood properties. Cenerally, sale of timber for structural purposes is more profitable than sale for pulp and industrial processing, but such timber must meet certain speciflcations of strength. This is deterwined by the properties of knottiness, wood density, grain angle and the incidence of compression wood. Tree spacing, thinning and pruning can all influence these properties (Brazier 1977) but the silvicultural technique of most interest for its effects on quality is fertilization, since this has the general effect of increasing total growth. Litcle is known of the effects of fertilizing on knottiness, grain angle and the incidence of compression wood and more research is required on these aspects of growth and their importance in determining wood strength (Brazier 1977).

Brazler (1977) revlewed a number of reports ind 1cating that fertilization decreased wod density, which, by implication, would be expected to decrease timber strength Exceptions to this are very slow growing trees which were initially producing 'starvation wood'. Fertilization increases the proportion of early wood, the cells of which have a high 1 umen area:wall thickness ratio. Smith, Wellwood \& Elliot (1977) also reported this general result but suggested that climatic differences were important and could interact with fertilization to affect wood density. They also reported 
differences in response to fertilization between trees. Finally, fertilization sometimes alters the form of trunks and hence the 'form factor' used in prediction (Flewelling \& Yong 1976).

This examination of 'site' conditions and tree response leads to the following conclusions:

(1) Trees respond to variation in weather over a range of frequencies and abeliorative treatments may amplify the effects of such variation.

(ii) In temperate regions, unless irrigation is used or large reservolrs of soll molsture exist, the highest 8 rowth rates are likely to be achleved in conditions where there are rapid short term fluctuations in the weather.

(111) Where the growth process is largely controlled by the supply of a necessary resource, e.g. water, radiation, or nutrients, then forest growth rates will change warkedly with age as the stand structure influences the microclimate. Ameliorative treatments, such as fertllization or dralnage may accelerate these effects.

(iv) Low input silvicultural systems, may nelther respond adequately to 'ameliorative' treatments or if they do, way not produce timber of the same quality as originally intended.

The essential character of forest growth is that it is varlable and intensification of management is likely to make it more so. Current mensurational techniques for predicting yleld assume that the largest part of varlation can be expressed in terms of a growth curve, either empirically constructed from the growth records of prevfous stands (Hamllton \& Christie 1974a) or by attempting to fit varlous types of growth curves, e.g. logarfthmic (K1lpatrick 1978) or the Richards growth function (Rawat \& Franz 1974). Varlation is treated as error. Netther approach provides a satisfactory basis for yield prediction of intensively managed plantation. Rather we should consider forest growth as being produced by a series of impulses under changing conditions and the appropriate mathematical structure for this is multivariate time serles analysis (e.8. Box \& Jenkins 1970). Growth can be analysed by time serles techniques (Ford \& Robbards 1976; Ford, Robbards \& Piney 1978) and models for prediction using such techniques are increasingly in use in economics.

Manipulating and predicting the distribution of yleld by adjusting stand structure

The distribution of yield from a plantation, both in time and in cerms of the assortments of stem sizes, can be influenced by initial spacing (Hamilton \& Christie 1974b) and by the thinning regime adopted (Assmann 1970). When yleld tables are constructed by an empirical site index technique, 
e.8. Hamilton $\&$ Christie (1974a), it is necessary to spectfy quite closely the particular thinning regime to be used and wost frequently this has been some form of selective thinning. However, increasing interest in mechanical thinning (Hamilton 1976a), no-thinning (Godwin 1968), often combined with more intensive forest management and a range of harvesting techniques, have together stinulated attenpts to model the competition process between individual trees with the object of providing wore flexible predictions of growth and yield (Arney 1974; Munro 1974).

A number of curve fitting techniques have been applied to provide descriptions of stem size distributions in even-aged plantations, e.g. Baily \& Dell (1973). However, a more fundamental approach, modelling the influence that a tree's neighbours way have on lis growth, has recently been quite widely adapted. By concentrating on the growth of the Individual, this approach offers a framework whereby all the wajor direct influences on growth may ultimately be incorporated into one model. It is intended that individual trec models which simulate the mechanisms of growth and competition will provide flexible predictive models, beyond the scope of conventional yield tables (Munro 1974).

competition occurs for the resources used in growth and can be defined as a process. "When the immediate supply of a single factor necessary (for growth) falls below the combined demands of the Individual plants, competition begins" (Clements quoted in Donald 1963). These resources, v1z. 11ght, water and nutrients, exist in finite concentrations so competition is a spatial process and Its onset in a plant community depends upon the relative growth rates of the plants themselves. Thus, fertilization increases growth and accelerates the competition process (Yoda et al.1963). The competition process has five characteristics which must be considered when a model is being constructed.

(i) Two plants of the same size may not have the same status in a community. If one has bigger neighbours than itself, whilst the other has smaller neighbours, the two Individuals would not be expected to achfeve the same growth in future. 'Success' in competition is a matter of probabilities - it depends upon the relative sizes of neighbours - so competition should be regarded as a stochastic process.

(ii) Competition in a plant monoculture can only be assessed by observing the distribution of relative growth rates, RGR, e.g. for basal area, square $\mathrm{cm} / \mathrm{square} \mathrm{cm} / \mathrm{yr}$. We must ask: "Has there been a change in the effictency at which the growth machinery of the individual plant operates?" Little can be judged from the distribution of plant size in a community. This can take many forms (Ford 1975; Diggle \& Ford, unpublished) as a community ages. 
Absolute growth rate, e.g. for basal area, square centimeters/year, may not be a sensitive indicator of competition since it is greatly influenced by plant size. The necessicy for observing RGR was illustrated by examinting 8 rowth rates and RGRs of individual trees in a young Sitka spruce plantation in Scotland just reaching the stage when its annual production of needles was constant (Fig. 1). Ninety percent of the trees, 1.e. those with basal area between 53 and 240 square centimeters, had the same relative growth rates, although there were considerable differences between them in size and in growth rate. Only the smallest 4 per cent and the largest 6 per cent had substantially different RGRs and showed the effects of coropetition. In an unthinned plantation, differences in mean RGR between size classes accentuated as the stand grew (Ford 1975).

( $i$ ii) The intensity of competition changes as a stand develops. In tis simplest form this can be seen in differences found between young and old stands in calculated competition coefficients. These coefficients decrease with Increasing age (Thomas \& Stevens 1977).

(iv) The importance of competition in determining the distribution of final plant size may depend on the degree of site heterogeneity (Cannell et al. 1977) and genetic variability (Digble \& Ford unpublished).

(v) The competition process can influence the total amount of growth that a stand makes. Differences exist between trees within a stand in the amount of timber produced per unt of crown volume or crown surface area. In general, dominants and sub-dominants are more efficient than dominants, e.g. Hamilton (1969). But there are some suggestions that the largest trees in a stand can be less effictent than those slightly sinaller. Some indication of this effect can be seen in Fig. 1 where the mean RGR of trees in the category of second largest basal area is higher than those of the largest basal area. Simllar effects can be seen in some older unthinned plantations (Ford 1975). Differences in crown efficlency can also be produced by thinning treatments. In a series of experiments where selective thinning was malntained to remove increasing numbers of swall trees (Krammer 1966), the mean individual crown volume was largest in the most severely thinned stands but timber production per unit of crown volume was lowest.

Competition models for even-aged forest stands are at an early stage of development. There are two important problems which must be faced, (1) relative tree scatus must be represented accurately and (1i) descriptions of the total amount of growth to be 'shared' amongst trees must be made flexible if the effects of different environmental factors are to be assessed. 


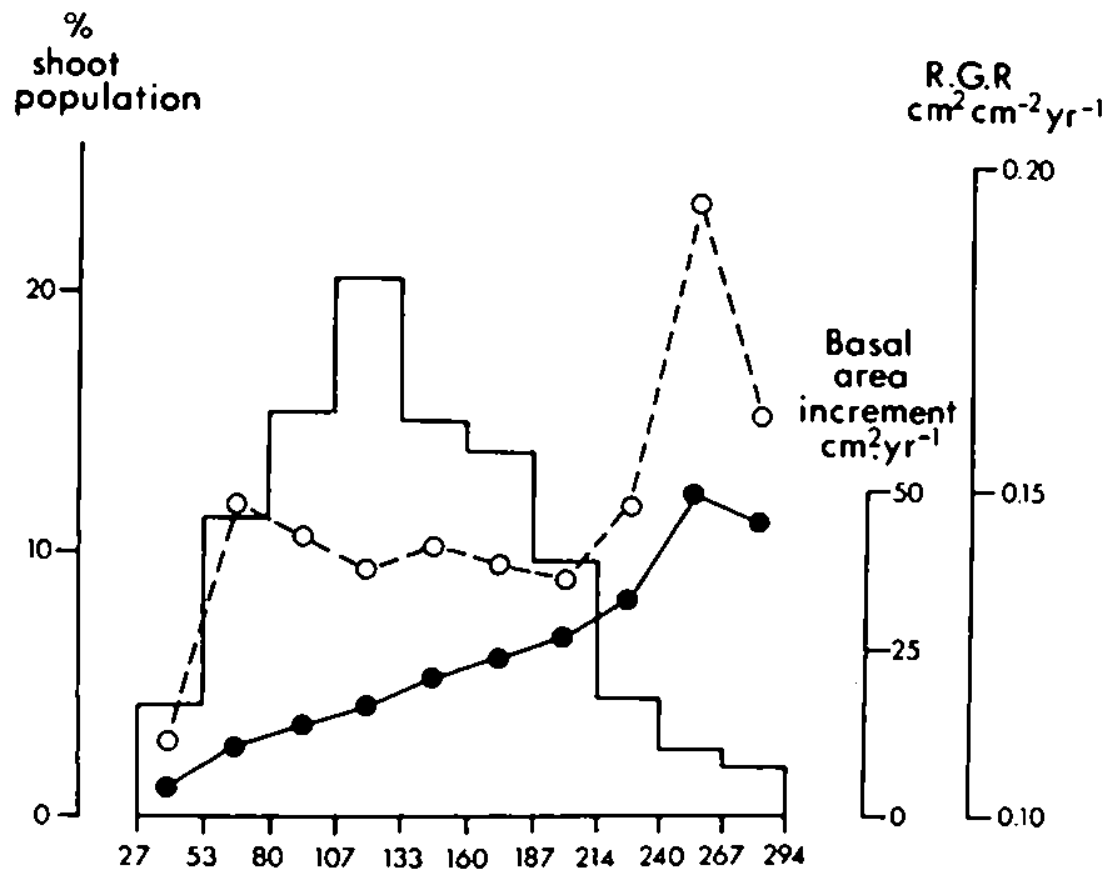

Basal orea

Fig.1. Frequency distribution of trees by basal area and the mean basal area growth rate (closed circles) and basal area relative growth rate (open circles) for each basal area category in a $14 \mathrm{yr}$ plantation of Sitka spruce.

Sowe techniques for describing relative tree status are described in Fig. 2, but rarely has more than 60 per cent of the variation in growth between individuals been accounted for. Parameters are required to express the degree of Influence which a plant may have on its nelghbours. In some models a zone of influence is estimated for each tree as a function of lts diameter (Bella 1971; Hegyl 1974) and interaction with other trees is calculated elther as a function of the distance between neighbours or by estimating a zone of influence and calculating interaction as the sumation of intersections, with a weighted influence in favour of large trees (Bella 1971) (Fig. 2). Nelther tree dlameter nor basal area are sufficlently accurate representations of tree size to 
be used in competition models. They are integrated values of all growth ande by the tree over the history of the stand and can only describe general differences between individuals; a more sultable measure would be basal arca increment over the last year as this would give a better indication of the changing status of individuals. Basal area or diameter can not be directly related to the competition process as can measures such as helght or crown size.

More functional measures of tree status have been used in stand simulations. Newnham \& Srith (1964) modelled competition as the extent to which a tree crown was intersected by neighbours; Ek \& Monserud (1974) used tree helght in confunction wh th an estlmated crown radius (Fig. 2), whilst Mitchell (1969) sloulated crown development directly as dependent upon branch growth which was in turn related to the proximity of nelghbouring crowns. However, these three models, in common with many others, use the form and size of open grown trees as a base line for estimating growth and development. They do not simulate competition at the process level in terms of the relative distribution of resources for growth and this they would have to do in order to predict the effects of treatments such as fertilization on the distribution of tree sizes within the stand.

A strategy for modelling forest growth

Difficulties have been encountered with models designed to predict both the distribution of yield and growth in relation to site factors. Frequently this has been because the requirements of management have been kept too closely in view when formulating model structures. Accuracy requires an effective simulation of physiological and ecological processes but for ease of use, rodels must not be too complicated. I suggest a three level modelling strategy for producing a more rellable yield prediction technique for forest plantations.

(1) Baslc growth models

Two are required, a physlologically based model of plant response to environmental variation and a population dynamics model of the competition process. The former should be modelled at the level of carbohydrate, water and nutrient balance of trees and should be able to predict the factors limiting growth as conditions vary. It should provide information on growth rate to a population model describing competition as a stochastic process. This second model should determine the rate of change of competition intensity as stands develop and the extent to which relative growth rates are determined by factors other than competition, particularly genetic variation.

(2) Growth-yield Linking models

Two models are required to link simulated growth of processes with yield prediction techniques. One to describe the distribution of yield over ind lvidual trees and how this 


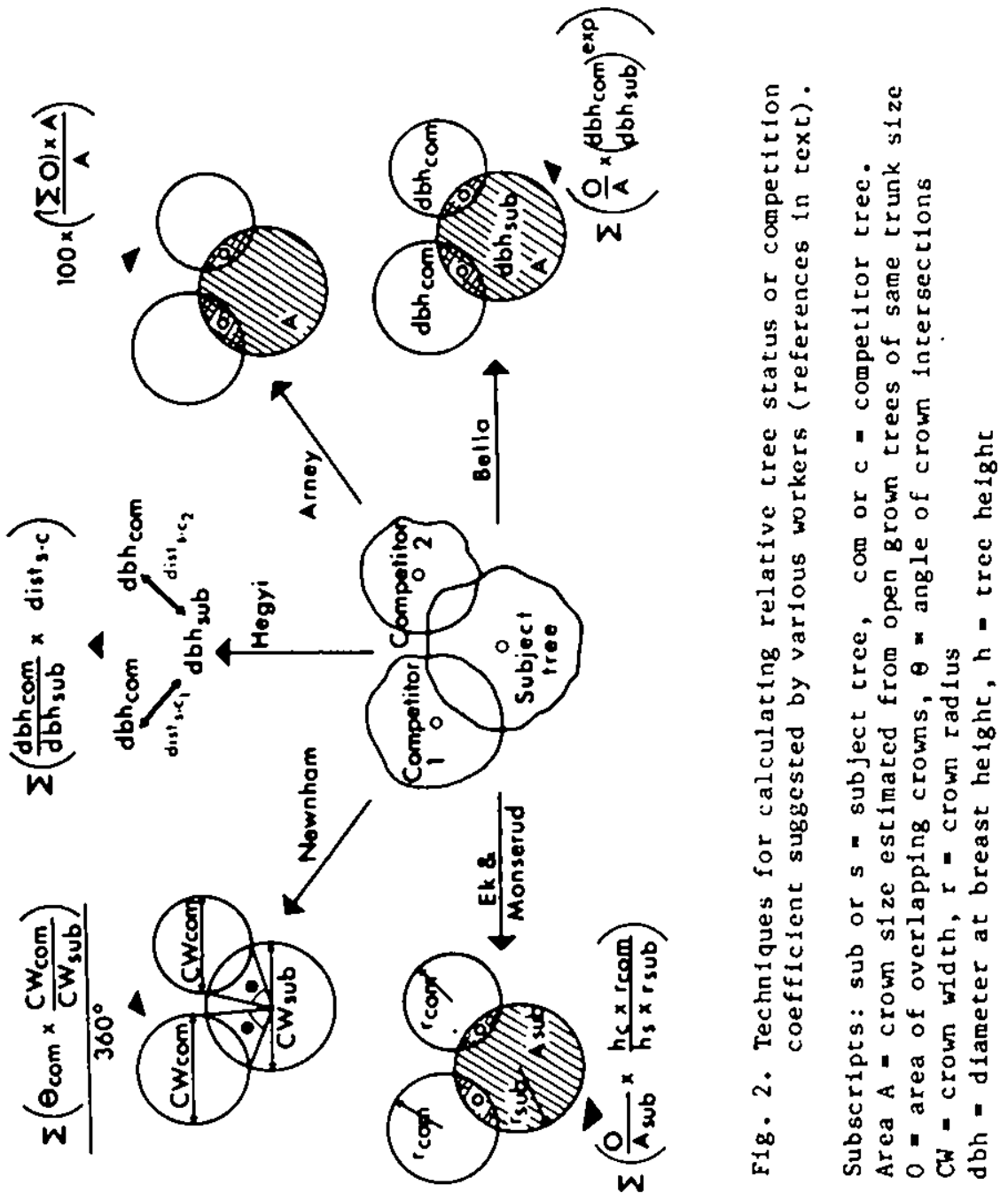


may vary under a range of conditions. Such a model would link physiological and competition models with the actual production of $t$ imber in terms of both total yield and quality. The second to describe the changes which can occur in stand microclimate as stand structure is manipulated. The object of this would be to provide the link between proposed silvicultural treatments and their effect on growth. Models in this category are the most neglected aspect of the science of yleld prediction.

(3) Yield models

The prime object of these should be to estimate the 'error' in prediction. They should be capable of examining the likely fate of a proposed silvicultural creatment under a range of future weather patterns and management options.

\section{HAZARDS TO PLANTATION DEVELOPMENT.}

The fate of many forests is regeneration through destruction, by wind or fire (Malcolm; Adlard, this volume). When such a process occurs in a plantation. it is considered to be a catastrophe and whilst this is certainly so as far as management is concerned, such catastrophies have ecological reasons and are not purely random events. The study of their ecology can provide insight leading to both control and prediction. Fire is a major hazard in dry climates, and atterpts have been wade to predict its occurrence in both scrub, e.g. Rothermel (1972) and forest, e.g. Davis \& Irwin (1976), Cunningham \& Martel (1973). Windthrow is a major hazard to plantation development in the United Kingdom (James \& Dier 1968), the Irish Republic (Gallagher 1974), New Zeal and (Irvine 1970; Wilson 1976), Australla (Cremer et al. 1978) and Germany (Hutte 1968).

Three groups of factors influence the occurrence of wind throw:

(1) the frequency and strength of the wind,

(11) the interception of wind by the tree crown to create a drag force,

(111) the resistance to windthrow offered by soll and roots.

Our knowledge of how these interact is Ilmited. Published studies have either analysed either a single factor, for example, resistance offered to windthrow by soll and roots (Fraser \& Gardiner 1967) or the incidence of windthrow over a forest in relation to site and management factors after a gale has taken place. Unfortunately the latter type of analysis is complicated by methodological problems. In most plantations the distribution of specles and soll types are confounded and certainly in the British Isles, soil type is confounded with copography. Most important of all, the cultural techniques used during establishment are confounded with age of crop. Consequently, the analysis of gale damage can be of very 
limited value, even to predict future windthrow, let alone advance understanding of the mechanisw itself. A further drawback is that the conditions which operate in aajor gales may not be closely related to those which are important in swaller but more frequent stoms. The latter may cause substantial loss of timber (Gallagher 1974; Irvine 1970) and it is protection against them which is more frequently sought by forest managers (Booth 1974b).

(i) The frequency and strength of the wind

The arrival of wind storms cannot be predicted accurately, but, like other weather phenomena, must be treated as a stochastic process. However, wind has a complex structure (Allen 1968; Meroney 1968) and we need to know more about the combinations of factors which produce windthrow, such as the relationship between the duration of high mean wind speeds and the incidence of strong gusts and between wind speed and rainfall. Without chis information detailed analysis of wind as a stochastic process in an attempt to predict risk may not be fruitful.

Hut te (1968), Irvine (1970) and 0 Cinneide (1974) have all suggested that storm damage is greatest in places where turbulence and wind speed are increased by rellef, particularly on lee slopes. Measurements of variation in wind speed over a landscape were made with anemometers and were found to be relaced to topographlc features (Hutte 1968). However, it is difficult to characterize the components of topography which effect wind microclimates. Flow round many regular objects can be predicted mathematically (Schlichting 1968), but flow over a specific natural topography cannot. In the U.K. attempts have been aade to assess varlations in wind speed in relation to topography by (a) using simple integrated measurements of wind run, e.g. tatter flags, (b) calculating 'topographic shelter', the sum of the horizon angles to the eight major compass points (Howell \& Neustein 1966), and (c) constructing models of forest topography for use in wind tunnels. However, Booth (1974a) concluded that a combination of these techniques had not been proved helpful in stability zoning although recent work has proved more encouraging (Booth, personal communication). Measurements of wind speed at different points over model forests in wind tunnels have correlated well with anemometer data from the forest itself, although tatter flags and anemometer data did not correlate. The scale models incorporated either an exaggeration of vertical helght or a roughened surface.

(i1) The interaction of wind with tree crowns

Susceptibllity to wind throw has been related to increase in tree height (e.g. 0 Cinneide 1974) and, under U.K. silviculture, to increased thinning intensity (e.8. Booth 1974b). However, some evidence (Irvine 1970; O Cinnelde 1974) suggests that windthrow risk peaks in plantations of middle 
age when thinnings are frequent and that older stands are more stable. The distuption which thinning causes to the surface of the crop is generally consldered to produce an uneven distribution of drag forces between the crowns (Mitchèrlich 1974; Cremer et al. 1978). Two sllvicultural techniques have been suggested to combat this problem and to produce a plantation with an undisturbed canopy as crop height approaches that of greatest windthrow risk. (a) No thinning throughout the life of the crop (Godwin 1968) comblned with an early final felling; (b) early non-commerclal thinning, designed to produce a short rotation crop which has an undisturbed canopy as the 'critical he1ght' approaches and produces a final yield of sawlogs (Fenton \& Sutton 1968 as applied in Irvine 1970; Moore 1976). Neither technique is fully tested and there is need for fundamental studies on these systems of the relationship between stand structure, the distribution of drag forces and windthrow.

over the past decade a number of micrometereologists have measured wind profiles over and within forest canopies (Jarvis, James \& Landsberg 1976). Most usually their objective has been to assess the importance of ventilation of the canopy in the transfer of heat, water vapour and carbon dioxide between the atmosphere and the crop. The logarithmic wind speed profile has usually been assumed, which for tall vegetation is

$$
U_{(z)}=\frac{U_{k}}{k} \ln \frac{z-d}{z_{0}}
$$

where $U(z)$ is the wind speed at height $z$,

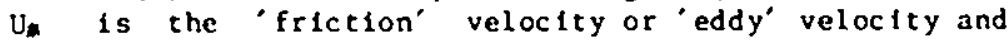
represents the rapldity with which morentum finds its way to the surface.

$k$ is a constant

$d$ is the zero plane displacement

$z_{0} 16$ the 'roughness length' of the surface.

$d$ and $z_{0}$ are parameters which glve some indication of the aerodynamic characterlstics of a surface. d Indicates the mean level of action at which momentum is absorbed by the individual elements of the plant commity: the level of action of the bulk aerodynamic drag on the community. The size of $z_{0}$ specifies the bulk effectiveness of the canopy as a momentum absorber.

However, although varlation in $d / h$ and $z_{0} / h$ have been found for crops with different structures, the potential of such parameters for analysing susceptibllity to whdthrow seems limited for the following reasons. (a) Large uniform areas of forest are required to determine $z_{0}$ and $d$ accurately. (b) $d$ and $z_{0}$ can be determined only for wind profiles obtalned under the limited conditions of no exchange of heat between the canopy and the atmosphere (but see Jarvis, 
James \& Landsberg 1976). (c) The use of the logarithmic profile to describe momentum exchange for vegetation greater than $2 \mathrm{~m}$ high is being increasingly questioned. The three-dimensional structure of tall crops (Ford 1976) may influence momentum transfer (Mulhearn \& Finnigan 1978). From a theoretical analysis, Perrier et al. (1972) considered that the logarithmic profile could only be applied to a tall row crop when the inter-row cavities were conpletely fllled wh follage. For other crop structures they described the wind proflle in terms of the different degrees of mixing of the wakes and vortices which develop behind individual roughness elements.

Papesch (1974) emphasised that more attention must be paid to the structure of the wind when considering the forces which act to produce windthrow. Wind does not provide a constant force but one which occurs in gusts. A wind can be described in terms of its turbulence structure, i.e. the relative amounts of energy which it contains as little gusts, high frequency energy, and large gusts, low frequency energy. Observations made across a forest edge showed a reduction in total energy as the wind passed from a grassland over the forest, but a relative concentration of energy at higher frequencies close to the natural sway period of the crees. This was due to interaction with the tree crowns.

Papesch (1974) developed a mathematical formulation for the relationship between the wind, tree crown and the movement of the tree combining both static parameters, such as mean wind speed, and dynamic description, such as the oscillation in wind amplitude. One interesting prediction from calculations with this model was that, under the same general conditions, when edge trees required a mean wind speed of 80 mph to blow them down, trees within the forest required a mean wind speed of only $62 \mathrm{mph}$. It is Indeed a common occurrence that edge trees are the only ones left standing after windblow. A greater fluctuation of the forces acting on trees just behind the forest edge was predicted from wind tunnel studies with static forest models by Fraser (1964).

Testing the analysis developed by Papesch requires (a) more comprehensive measurements of the frequency distribution of wind energy over forest canopies of different types (Bull \& Reynolds 1968), (b) more detailed analyses of the dynamic response of tree crowns to Increase in wind speed (Mayhead 1973), and (c) the developrent of methods to describe the configuration of the canopy surface (Ford 1976) and to apply these to the changes in shape which occur as the wind blows. With this information experiments to investigate the distribution of drag forces could be conducted in wind tunnels (see Marshall 1971 for an agricultural application) with more 'realistic' forests than have been used to-date. 
(ii1) The resistance to wind throw produced by soil and roots Early studies in the plantations of upland Britain indicated that windthrow occurred principally on shallow rooted crops growing in soils with impeded drainage, most typlcally peaty gleys (Fraser \& Gardiner 1967; Pyatt 1968). On gleyed solls closely spaced deep ditches were ploughed to dry the soil and enhance transplant growth (Taylor 1970). This technique has now been revised since tree pulling experfoents on gleyed solls indicated that lateral spread of roots between widely spaced ploughing ditches $(4.27 \mathrm{~m})$ was more effective in promoting stability than the soll increase in rooting depth which could be achieved with closely spaced ( $1.22 \mathrm{~m})$ ploughing ditches (Booth 1974b).

The relationship between root growth, sofl condilions and stability is complex. Cremer et al. (1978) measured soll sheer strength on well-dralned and poorly drained soils in a pinus radiata plantation near Canberra, Australia, shortly after a destructive gale. The mean relative sheer strength of the undisturbed poorly drained solls was 1.0 compared with 2.0 for und isturbed well-drained solls. However, within the root balls of blown trees the relative sheer strengths were respectively 5.3 and 3.2 for poorly and well-dralned sites. On the intrinsically mechanically weaker solls the root balls had grown firmer and to a larger diameter with better lateral attachment but poorer vertical hold. Cremer et al. (1978) did not identify the mechantcally weaker soil as being more prone to wind throw.

Shallow root growth is frequently attributed to the occurrence of some impenetrable zone in the soll or to waterlogging. However, concentration of roots at the surface of forest soils is the rule rather than the exception. (e.g. Eis 1974). Following a destructive gale in New Zealand, Irvine (1970) concluded that shallow rooting was prevalent among uprooted pinus radiata but that this was a response to the distribution of nutrients in the soll since these were located In the surface soll horlzons. Ford \& Deans (1977) analysed the growth of $f$ the roots in an eleven year old plantation of picea sitchensis on a peaty gley in Scotland. A distinctive and more active root population was found in the surface soil and those so11 horizons formed beneath turf upturned during ploughing. Most fine roots were found in soll wh the largest concentrations of avaliable nutrients. The importance of the upturned turf ribbon as a source of nutrients on gleyed sites and its role in root development has also been stressed by Savill (1976). Increasing the available nutrlent to a stand by fertilizing increases the total amount of root (Paavilainen 1967) and root thickening is also increased by increased nutrient concentration (Coutts \& Phillipson (1976). Further work is required to determine the effect which cultural techniques may have on the mineralisation process and how this 
may vary with soils of different basic nutrient status and physical characteristics.

Mineralization requires specific physical conditions (Heal, this volume) and may not proceed at a uniform rate in all parts of the forest soil and this could affect the distribution of root growth. Deans (in press) has shown that in a young plantation of Picea sitchensis in the southern uplands of Scotland with an annual rainfall $1800 \mathrm{~m} / \mathrm{yr}$, root mortality can occur during the sumer months and is associated with drying out of the soil. The distribution of water to the soil of this plantation is very localized, some 40 percent of water received during the summer months flows down stems (Ford \& Deans 1978), a phenomenon which may have a direct influence on root growth and may also influence the mineralization process in the soll. McColl (1973) has demonstrated that mineralization is enhanced by the passage of a wetting front through a soil horizon.

Before a silviculture can be specifically designed for windy areas, further research is necessary into all three of these factors:

(i) to define the frequency and spatial varlabllity of risk,

(ii) to search for variability which way exlst between canopies of different structure in the dissipation of momentum,

(iii) to formulate the relative importance of soll moisture, nutrlent concentration and physical impediment to the lateral and vertical spread of roots and to examine more precisely the influence whlch different root structures may have on stability.

Some interesting silvicultures for windy areas have been proposed. From different reglons both Irvine (1970) in New Zeal and and Moore (1976) in Ireland have suggested that widely spaced crops could be grown over short rotations without production thinning. Mitcherlich (1974) has suggested that on gentle terrain planting in strips with the youngest trees up-wind can improve stabilfty and both Fraser (1964) and Mitcherlich (1974) have suggested high pruning or early thinning of edge trees to reduce turbulence above the canopy just interior to the edge. Hengst \& Schulz (1976) have suggested that specific silvicultures be applied to match topography in a wind damaged forest, including the creation of a new network of forest roads with spectally structured stand margins and conversion of uniforn stands to mosaics of different species and ages. Following a comprehensive description of the linked catastrophies of windthrow and fire which occur in Lower Saxony otto (1976) described silvicultures for a range of soll types which would minimize risk. He particular stressed the advantages of wide spacing and species mixtures. 


\section{CONCLUS IONS}

The intensification of forest management with a general trend towards higher growth rates and realisation of yield, secure against wind and other hazards, have continuously produced research problems. In sore cases the solutions to a number of these problems imply a need to change the silvicultural system. For instance, a suggestion has been made in both the British Isles and New Zealand to increase spacing, shorten the rotation and abandon commercial chinning in conifer plantations. This silvicultural system has been proposed both to minimize risk from windthrow and to shorten the time in which saw timber can be obcalned. In implementation it is not a single alternative to high density crops which require thinning; interactions between spacing, quality of planting stock and pre-comercial thinnings must all be considerd (Bunn 1974).

When such radical proposals are made, it is profitable to consider them as a 'new' silviculture and to question other aspects of the cultural technique. Dawson (1975) emphasized that "Intensive culture is concerned with a number of culture treatments applied to the same stand, not just one or two practices as generally in "cimber stand improvement" . The large gains wade in agriculcural productivity have been through the application of not one, but a number of improvements working together. In this respect it is taportant to appreciate that from the economic viewpoint "the extremes of intense culture are quite expensive and are, in this sense, high r1sk" (Bentley 1975). This makes it all the more important to define the objectives of a plantation enterprise more closely than 'maximum sustained yield' (Elliott 1977). The opportunities for devising high yield silvicultures are greater when a range of specific objectives can be given rather than one general objective. Not only can the physiolog1st, breeder and ecolog1st work towards more closely defined endpoints, but particular advantage $c$ an be taken of natural varlations which occur both in the blological and the physical resources (Patterson 1975). Attempts to design bilvicultures to meet specific management objectives in specific climates and on spectfic solls would provide a stimulus to the furcher incorporation of plant physiological and ecological knowledge into the forest industry.

\section{RFFERENCES}

Allen,L.H.(1968). Turbulence and wind spectre whthin a Japanese larch plantation. Journal of Applied Meteorology, $7,73-78$.

Arney,J.D.(1974). An individual tree model for stand simulation in Douglas fir. "Growth models for tree and stand simulation" (Ed. by J.Frles), pp.38-46. Research Notes 30 , Department of Forest Yleld Research, Royal 
College of Forestry, Stockholm.

Assman,E.(1970). The princtiples of forest yield study. Pergamon Press, Oxford.

Bailey,R.L. \& Dell,T.R.(1973). Quantifying diameter distributions with the Weibull function. Forest science, $19,97-104$.

Bella, I.E.(1971). A new competition model for individual trees. Forest Science, 17, 364-372.

Bentley,W.R.(1975). Economic environgent of intensive culture. Iowa State Journal of Research, 49, 275-277.

Booth,T.C.(1974a). Topography and wind risk. Irlsh Forestry, 31, $130-134$.

Booth,T.C.(1974b). Silviculture and management of high-risk forests in Great Britain. Irish Forestry, 31, 145-153.

Box,G.F.P. $\delta$ Jenkins,G.M.(1970). Time series analysis forecasting and control. Holden-Day, San Francisco.

Brazier,J.D.(1977). The effect of forest practices on quality of the harvested crop. Forestry, 50, 49-66.

Bull,G.A.D. \& Reynolds, E.R.G.( $1 \overline{968})$. Wind turbulence generated by vegetation and its implications. Supplement to Forestry, pp.28-37.

Bunn,E.M.(1974). Production forestry in the 1980s. New Zeal and Journal of Forestry, 19, 181-190.

Cannell,M.G.R., Thompson, S. \& Lines,R.(1976). An analysis of inherent $d$ ifferences in shoot growth within some north temperate conifers. "Tree Physiology and Yield Improvement" (Ed. by M.G.R.Cannell and F.T.Last) pp.173-205. Academic Press, London and New York.

Cochrane,L.A. \& Ford,E.D.(1978). Growth of a Sitka spruce plantation: analysis and stochastic description of the development of the branching structure. Journal of Applied Ecology, 15, 227-244.

Coutts,M.P. \& Philipson,J.J.(1976). The influence of mineral nutrition on the root development of trees. I. The growth of Sitka spruce with divided root systems. Journal of Experimental Botany, 27, 1102-1111.

Cremer,K.W., Myers,B.J., Duys, F.P. van der \& Cra18,I.E.(1977). Silvicultural lessons from the 1974 windthrow in radiata pine plantations near Canberra. Australian Forestry, 40, 274-292.

Cunningham,A.A. \& Mortel,D.L.(1973). A stochastic model for the occurrence of man-caused fires. Canadian Journal of Forest Sclence, 3, 282-287.

Davis,J.B. \& Irwin,R.L. (1976). FOCUS: a computerlzed approach to flre management planning. Journal of Forestry, 74 , 615-618.

Dawson,D.H.(1975). Are culcural methods avallable to maximize yields? Iowa State Journal of Research, 49, 279-280.

Deans,J.D. (in press). Fluctuations of the soll environment and fine root growth in a young sitkia spruce plantation. 
Plant and Soil.

Denne,Y.P.(1976). Effects of environmental change on wood production and wood structure in picea sitchensis seedlings. Annals of Botany, 40, 1017-1028.

Diggle,P.J. \& Ford,E.D. Competition in plant monocultures as a spatial stochastic process. Unpublished manuscript. Institute of Terrestrial Ecology, U.K.

Donald,C.:.(1963). Competition among crop and pasture plants. Advances in Agronomy, 15, 1-118.

Eis,S.(1974). Root system morphology of western hemlock, western red cedar and Douglas fir. Canadian Journal of Forestry Research, 4, 28-38.

Ek,A.R. \& Monserad,R.A.(1974). Trials with progran FOREST: growth and reproduction sinulation for mixed species even- or uneven-aged forest stands. "Growth nodels for tree and stand simulation" (Ed. by J.Frics) pp.56-73. Research Wotes $\$ 30$, Department of Forest Yield Research, Royal College of Forestry, Stockholm.

Elliott,D.A.(1977). Plantation forestry: the future - a state forester's viewpoint. New Zealand Journal of Forestry, $22,229-232$.

Fencon,R.T. \& Sutton,W.R.(1968). Silvicultural proposals for radiata pine on high quality sites. New zealand Journal of Forestry, 13, 220-228.

Flewelling,J.W. \& Yong,Y.C.(1976). Tree volume table growth relationships possibly affected by fertilization. Forest Science, 22, 58-60.

Ford,E.D.(1975). Competition and stand structure in some even-aged plant monocultures. Journal of Fcology, 63, $311-333$.

Ford,E.D.(1976). The canopy of a Scots pine forest: description of a surface of complex roughness. Agricultural Meteorology, 17, 9-32.

Ford,E.D. \& Deans,J.D.(1977). Growth of a Sitka spruce plantation: spatial distribution and seasonal fluctuations of lengths, weights and carbohydrate concentrations of fine roots. Plant and soll, 47, 463-485.

Ford,E.D. \& Deans,J.D.(1978). The influence of canopy structure on the pattern of rainfall distribution to the floor of a Sitka spruce plantation. Journal of Applied Ecology, 15, 807-819.

Ford,E.D. \& Robards,A.W.(1976). Short term variation in tracheld development in the early wood of picea sitchensis. "Wood structure in blological and technical research" (Ed. by A.J.Bolton, D.M. Catlin and P. Baas), pp.212-221. Leiden University Press, Netherlands.

Ford,F.D., Robards,A.W. \& Piney,M.D.(1978). Influence of environmental factors on cell production and differentiation in the early wood of picea sttchensis. 
Annals of Botany, 42, 683-692.

Fraser,A.I.(1964). Wind tunnel and other related studies on coniferous trees and other crops. Scottish Forestry, 18, $84-92$.

Fraser,A.I. \& Gardiner,J.B.H.(1967). Rooting and stability in Sitka spruce. Bulletin of the Forestry Comissiont40.

Fritts,H.C.(1965). Tree-ring evidence for climatic changes in western North America. Monthly Weather Review, 93 , $421-443$.

Fritts,H.C., Blasing,T.J., Hayden,B.B. \& Kutzbach,J.E.(1971). Multivarlace techniques for specifying tree growth and climate relations and for reconstructing anomalies in paleoclimate. Journal of Applied Meteorology, 10 , 845-864.

Gallagher,G.J.(1974). Windthrow in state forests of the Republic of Ireland. Irish Forestry, 31, 154-167.

Godwin,G.E.(1968). The influence of wind on forest ranagement and planning. Supplement to Forestry, pp.60-6.

Grier,G.C. \& Running,S.W.(1977). Leaf area of mature northwestern coniferous forests: relation to site water balance. Ecology, 58, 893-899.

Hamilton,G.J.(1969). The dependence of volume increment of individual trees on dominance, crown dimensions and competition. Forestry, 42, 133-144.

Hamilton,G.J.(1976a). Different thinning methods and their influence on yield. Proceedings $16 \mathrm{th}$ I.U.F.R.O. Congress Oslo, Division IV. pp. 324-32.

Hawilton,G.J.(Ed.)(1976b). Aspects of thinning. Forestry Comission Bulletin "55. Her Majesty's Stationery Office, london.

Hamilton,G.J. \& Christie,J.M.(1971). Forest Management Tables (metric). Forestry Commisstion Booklet 34. Her Majesty's Stationery of fice, London.

Hamilton,G.J. \& Christie,J.M.(1974a). Construction and application of stand yield models. "Growth models for tree and stand simulation" (Ed. by J.Fries), pp.222-239. Research Notes 30 , Department of Forest Yield Research, Royal College of Forestry, Stockholm.

Hamilton,G.J. \& Christie,J.M.(1974b). Influence of spacing on crop characteristics and yield. Forestry Comission Bulletin 152 . Her Majesty's Stationery of fice, London.

Hegyi,F.(1974). A simulation model for managing jack pine stands. "Growth models for tree and stand simulation" (Ed. by J.Fries), pp.74-90. Research Notes \#30, Department of Forest Yield Research, Royal College of Forestry, Stockholm.

Hengst,E. \& Schulz,W.(1976). Beispiele zur Herstellung der raumlichen Ordnung als Massnatme für elne Erhôhung der Betriebssicherheit im Fichtenwald (Informationsartike) mit Depotangabe). Wissenschaftiche Zeitschrift der 
Technischen Lniversităt Dresden, 25, 313-314.

Howell,R. \& Neustein,S.A.(1966). The influence of genorphic shelter on exposure to wind in northern Britain. Report of Forestry Research 1965, Forestry Comission, Her Yajesty's Stationery of $f$ ice, London.

Hutte,P.(1968). Experiments of windflow and wind damage in Cermany; site and susceptibility of spruce forests to storm damage. Supplement to Forestry, pp.20-27.

Irvine,R.E.(1970). The significance of windthrow for pinus radiata management in the Velson district. New zealand Journal of forestry, 15, 57-68.

James,J.F. \& Dier,H.V.S.(1968). Wind damage in Forestry Compission forests and its influence on management. Supplement to Forestry, pp.78-83.

Jarvis,P.G., James,G.B. \& Land sberg,J.J.(1976). Coniferous forest. "Vegetation and atmosphere" Volume 2. (Ed. by J.L.Monteith), pp.171-240. Academic Press, London and New York.

Kilpatrick,D.J.(1978). Growth models for unthinned stands of Sitka spruce in Northern Ireland. Forestry, 51, 47-56.

Kozlowski,T.T., Torrie,J.H. \& Marshall,P.E.(1973). Predictability of shoot length from bud size in pinus resinosia Alt. Canadian Journal of Forest Research, $\underline{3}$, 34-38.

Kramer,H.(1966). Crown developwent in conlfer stands in Scotland as influenced by initial spacing and subsequent thinuing treatment. Forestry, 39, 40-58.

Little,C.H.A.(1974). Relationship between the starch level at bud break and current shoot growth in Abies balsamea. Canadian Journal of Forest Research, 4, 268-273.

Litcle,C.H.A.(1975). Inhibition of cambial activity in Abies balsanea by internal water stress: role of abscisic acid. Canadian Journal of Botany, 53, 3041-3050.

Marshal1,J.K.(1971). Drag measurements in roughness arrays of varying density and distribution. Agricultural Meteorology, $\underline{8}, 269-292$.

Mayhead,G.J.(1973)- Some dras coefficients for British forest trees derived from wind tunnel studies. Agricultural Meteorology, 12, 123-130.

McColl,J.C.(1973). Environmental factors influencing ion transport in a Douglas fir forest soil in western Washington. Journal of Ecology, 61, 71-83.

Meroney,R.N.(1968). Characteristics of wind and turbulence in and above model forests. Journal of Applied Meteorology, $7,780-788$.

Miller,H.G., Miller,J.D. \& Binns,W.O.(1977). Growth of Scots pinc under nutritional and climatic stress. Plant and So $11,48,103-114$.

Mitchell,K.J.(1969). Simulation of the growth of even-aged stands of white spruce. Bulletin $\$ 75$, School of Forestry, 
Yale University. $48 \mathrm{pp}$.

Mitcherlich,G.(1974). Sturmgefahr und Sturmsicherung. Schweizerische zeitschrift fur Forstwesen, 125, 199-216.

Moorby,J. \& Waring,P.F.(1963). Ageing in woody plants. Annals of Botany, 27, 291-308.

Moore,D.G.(1976). The oceanic forest. Irish Forestry, $\underline{33}$, 4-15.

Mulhearn,P.J. \& Finnigan,J.J.(1978). Turbulent flow over a very rough, randon surface. Boundary-Layer Heteorology, $15,109-132$.

Munro,D.D.(1974). Forest growth models - a prognosis. "Growth models for cree and stand simulation" (Ed. by J.Fries), pp.7-21. Research Notes 30, Department of Forest Yield Research, Royal College of Forestry, Stockholm.

Namkoong,G. \& Congle,M.T.(1976). Tlme trends in genetic control of helght growth in ponderosa pine. Forest Science, 22, 2-12.

Newnham,R.M. \& Smith,J.H.G.(1964). Development and testing of stand models for Douglas fir and lodgepole pine. Forest Chronicle, 40, 494-502.

Nomoto,N.(1964). Primary productivity of beech forest in Japan. Japanese Journal of Botany, 18, 385-421.

0 Cinneide,M.S.(1974). Quantltative assessment of the relative inportance and cooperative effects of factors influencing forest instability. Irish forestry, 31, 135-144.

ot to,H.-J.(1976). Forstliche Erfahrung und Folgerungen aus den Waldkatastrophen in Niedersachsen. Forst- und Holwirt, $31,285-295$.

Paavilainen,E.(1967). The effect of fertilization on the root systems of swamp pine stands. Folla Forestalia Fennica, $31,1-9$.

Papesch,A.J.G.(1974). A simplified theoretical analysis of the factors that influence windthrow of trees. Proceedings of the Sth Australasian Conference on Hydraulichs and Fluid Mechanics. University of Canterbury, Christchurch, New 7eal and $\mathrm{pP} \cdot 235-42$.

Patterson,D.B.(1975). Silvicultural practices on extenstve areas of complex sites. Scottish Forestry, 29, 140-144.

Patterson,H.D. \& Lowe,B.I.(1970). The errors of long-term experiments. Journal of Agricultural Science, 74, 53-60.

Perrier,E.R., Robertson,J.M., Millington, R.J. \& Peters,D.B.(1972). Spatial and temporal variation of wind above and within a soyabean canopy. Agricultural Me teorology, 10, 443-465.

Pyatt,D.G.(1968). Forest management surveys in forests affected by wind. Supplement to Forestry, pp.67-77.

Rawat,A.S. \& Franz,F.(1974). Detalled non-linear asymptotic regression studies on tree and stand growth with particular reference to forest yield research in Bavaria (Federal Republic of Germany) and India. "Growth Models 
for Tree and Stand Simulation" (Ed. by J.Fries), pp.180-221. Research Notes "30, Department of Forest Yield Research, Royal College of Forestry, Stockholm.

Rothermel;R.C.(1972). A matheratical model for predicting fire spread in wildland fuels. U.S. Department of Agriculturé Forest Service Research Paper INT.115. Intermet Forest and Range Fixperimental Station, Ogden, Utah, U.S.A.

Savill,p.S.(1976). The effect of drainage and ploughing of surface water gleys on rooting and windthrow of Silka spruce in Northern Ireland. Forestry, 49, 133-141.

Schlichting,H.(1968). Boundary layer theory. MkGraw-Hill, Lond on ( 6 ch ed.). $747 \mathrm{pp}$.

Smith,C.J., Wellwood,R.W. \& E.lliot,G.K.(1977). Effects of nitrogen fertilizer and current climate on wood properties of Corsican pine (Pinus nigra var. maritima (Ait.) Melv.). Forestry, 50, 117-138.

Taylor,G.G.M.(1970). Ploughing practice in the Forestry Commission. Forest Record 773, Her Majesty's Stationery of fice, London.

Thom,A.S.(1975). Momemtum, mass and heat exchange of plant communities. "Vegetation and atmosphere" Volume 1. (Ed. by J.L.Monteith), pp.57-109.

Thomas,C.A. \& Stevens,R.D.(1977). The Influence of competition from nearby trees on the selection of western hemlock plus trees. Final Report Contract 0SS7-02040, Science Sector, Science Procurement Branch. Supply and Services Branch, Government of Canada.

Tottenham,R. \& Joyce,P.M. (1975). Sitka spruce yleld class 500 ! Irish Forestry, 32, 30-33.

Toumey,J.W. \& Korstian,C.F.(1947). Foundations of silviculture. John Wiley \& Sons, New York.

Troup,R.S.(1928). Silvicultural systems. Oxford Universicy Press.

Wareing,R.H., Emminghar, W.H., Grolz,H.L. \& Grler,C.C.(1978). Variation in maximum leaf area of coniferous forests in oregon and tis ecological significance. Forest Science, $214,131-40$.

Wilson,H:H.(1976). The effect of the gale of August 1975 on forests in Canterbury. New Zealand Journal of Forestry, $21,133-140$.

Yoda, K., Kira,T., Ogawa,H. \& Hozumi,H.(1963). Self-thinning in overcrowded pure stands under cultivated and natural conditions. Journal of the Institute of Polytechniques, Osaka City University Series D, 14, 107-129. 
THE DEVELOPMENT OF A FLORA IN F.VEN-AGED PLANTATIONS

By M.O. HILL

Institute of Terrestrial Ecology, Bangor Research Station, Penrhos Road, Bangor, Gwynedd, Wales, U.K.

\section{SUMMARY}

When a conifer plantation is established there is a big change in the ground flora as the canopy closes. Under crops of Abies spp, Picea spp and Tsuga* Spp, which generate heavy shade, vascular plants are largely eliminated during the thicket stage, and at least with the short rotations that are necessary in most of upland Britain, do not reappear in quantity before clearfelling. Bryophytes often increase, though under very dense canopies even these may be absent. Under the lighter canopies of Larix spp and pinus spp a larger flora persists and there may often be an almost complete cover of vascular plants in the later stages of the rotation. The flora in western European conifer plantations is intermediate in composition between that of boreal forest and that of deciduous woodland. The fern Dryopteris dilatata is a particularly characteristic feature. On clearfelling there is often a rapid increase of vascular plants. The composition of the reappearing flora and the speed of its re-establishment depend on the amounts of seed present in the soll and on the vegetation present on the site at the time of clearfelling. In many plantations there are large populations of viable seeds in the surface layers of the soll, densities of 1000-5000 seeds per sq.m being typical, though those in peat are wuch lower. Seeds of plants with wind dispersal seldom survive in the soll, and have to be replentshed each year. Many plant species survive in marginal habitats in

* Nomenclature follows Clapham, Tutin \& Warburg (1962), Dallimore \& Jackson (1974), and Saith (1978). 
forests, notably on roadsides and beside streams. A moderate to large number of lowland species immigrate on roadsides, thereby diversifying the flora of upland areas in Britain. However, many plants of barshes and bogs are eliminated in afforested areas, so that on balance there is little change in the number of species present.

RÉSUMÉ

L'établissement d'une plantation de conifères amene un changement important de la végétation (au niveau du sol) a mesure que la voûte des arbres se referme. Dans le cas des essences (tels que picca, Tsuga* et Abies) qui

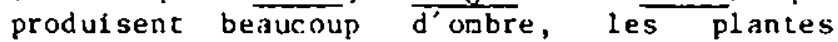
vasculalres sunt largement elfminees au stade de fourré, et à cause des courtes révolutions, souvent nécessaires dans les régions élevées de Grande Bretagne, elles ne reapparaissent pas en quantité avant la coupe à blanc. Le nombre des bryophytes augmente souvent mais si le couvert est très épais, ils peuvent mêne être absents. Sous le couvert plus léger des Larix et des Pinus, la végétation persiste d'une waniere plus importante et on peut souvent trouver une couverture presque complete de plantes vasculaires vers la fin de la révolution.

La composition de la flore des peuplements de coniferes d'Europe occidentale est comprise entre celle des forêts boréales et celle des forêts de feuillus: I a fougere Dryopteris dilatata* y est très caractérlstique. Les coupes al blanc sont suivies $d^{\prime}$ un accroissement rapide de plantes vasculaires. La composition de cette flore et la rapidité de sa réinstallation dépendent de la quantité de graines présentes dans le sol et de la végetation existante au monent des coupes à blanc. On peut trouver dans de nombreux peuplements un grand nombre de gralnes viables dans les couches superficielles du sol, des densités de 1000-5000 graines/m.carré étant typiques, mais elles sont plus faibles dans les sols tourbeux. Les graines des plantes qui sont disséminées par le vent ne survivent que rarement dans le sol et doivent être réapportées chaque année. Beaucoup d'espèces survivent dans des stations marginales en foret, surtout au bord des routes et des cours 
d'eau. Un grand nombre d'espèces provenant de la plaine émigrent vers le bord des routes, amenant ainsi une certaine diversification de la flore de montagne en Grande Bretagne. Cependant de nombreuses espèces provenant de stations marécageuses sont éliminées dans les reboisements, ce qui nous montre qu' en fait, il $n^{\prime} y$ a pas de grand changement dans le nombre des espèces présentes.

\section{USAMMENFASSUNG}

Eine Nadelbaumpflanzung führt zu einem grossen Wandel in der Bodenflora, sobald sich das Kronendach schliesst. Abies spp, picea spp und Tsuga ${ }^{\star}$ spp beschatten so stark, dass Gefässpflanzen während des Dickungsstadiums weitgehend eliminiert werden und, zumindest bei den kurzen Umtriebszeiten, die fast überall id britischen Hochland niztlg sind, auch bis zum Kahlschlag nicht mehr in nennenswertem Umfang auf tauchen. Bryophyten breiten sich oft stärker aus, aber unter sehr dichtem kronendach konnen sugar sie fehlen. Unter dem lichteren Kronendach von Larix spp und Pinus spp halt sich cine umfangreichere Flora. In späteren Stadien der Umtriebszcit bildet sich oft eine fast geschlossene Decke von Gefăsspflanzen aus. Die Flora westeuropälscher Nadel baumpflanzungen liegt in ihrer zusammensetzung zwischen der eines borealen Nadelwaldes und der von Laubwăldern. Fin besonders charakteristisches Merkmal ist der Farn Dryopteris dilatata*. Nach dem Kahlschlag komm es oft zu einer raschen Vermehrung der Gefisspflanzen. Die Zusammensetzung der wieder auftauchenden Flora und die Geschwindigkeit ihrer Ausbreitung sind abhängig von der Menge noch its Boden lagernder Samen und der vegetation, dic zur teit des Kahlschlags am Standort wähst. In vielen Pflanzungen liegen grosse Mengen lebensfähiger Samen in den obersien Bodenschichten. Dabie sind 1000-5000 Samen pro Quadratmeter durchaus typisch. In Torfböden liegt die 7ahl allerdings "liedriger. Vom Wind verbreitete Samen überleben selten in Boden und müssen jedes Jahr neu anfliegen.

viele Pflanzenarten überleben in den Randgebieten der walder, hauptsächlich an Strassenrandern und an Flüssen. Eine mittlere bis grosse $2 a h l$ von Tieflandarten wandert 
entlang der Strassenränder ein und bringt so Abwechslung in die flora des britischen Hochlandes. Viele Marsch- und Moorpflanzen sind jedoch in Auf forstungsgebleten ausgestorben, so dass sich insgesamt die Artenzahl wenis andert.

\section{VASCUIAAR PLANTS ANO BRYOPHYTES IN PLANTATIONS OF DIFFERENT} TREE SPECIES.

In British plantations, the heaviest shade is cast by the canopy of Western herlock (Tsuga heterophylla). There is virtually no ground flora, except perhaps invery old stands after heavy thinning; even bryophyces are excluded. Under hemlock, therefore, the development of the 8 round flora is restricted to the establishing phase before canopy closure.

Sicka spruce (picea sicchensis) casts a shade that is less dark, and although vascular plants are normally scarce or absent, a bryophyte cover of perhaps 5-10 per cent is usual (Fig. 1). After plantling, higher plants decline rapidly as the canopy closes (ten to flfteen years); there is litcle regrowth later. During establishment of the second rotation, higher plants are generally less abundant that they were at the same stage in the first rotation. The difference is due in part to ineffective recolonization of bare ground and in part to the presence of slash which suppresses the growth of most vegetation. Sprawling plants such as Rubus fruticosus and Corydalis claviculata can sometimes cover larger areas of slash effectively, but these plants are absent on the peatier soils where Sitka spruce is often planted.

The development of a bryophyte flora follows a tolally different pattern. Bryophyles, mostly mosses, increase from the first, and may continue to increase after canopy closure. There is, however, much variation in the pattern of bryophyte developont, depending on the condition of the crop and the dampness of the ground. Generally, the more successful the crop and the drter the ground, the fewer are the bryophytes. During establishment of the second rotation, perhaps because of reduced competition from higher plants, bryophytes are distinctly more numerous than at the same stage in the first rotation.

Norway spruce (Picen ables) casts a slightly less dense shade than sitka spruce, with the result that there is a more abundant ground flora. Brâkenhlelm (1977), working in Smaland, South Sweden, followed the developwent of the ground flora in even-aged plantations of Norway spruce on abandoned arable 1 and over a perlod of cen years. The general pattern was slollar to that under Sitka spruce in Britaln, with higher plants decreasing and bryophytes increasing during the first ten years, followed by a rapid decline of higher plants as the canopy closed, and somewhat inconsistent changes in the bryophytes. There were, however, marked differences later. In 


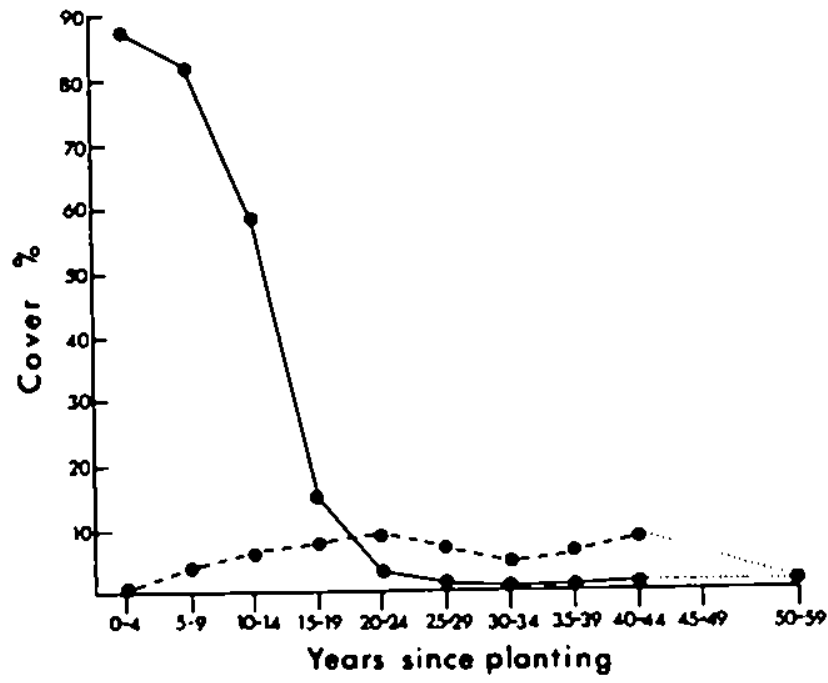

Fig. 1. Cover of vascular plants (solid line) and bryophytes (dotted line) in relation to age of crop in plantations of Picea sicchensis in upland Britain.

particular, a woodland flora Including some vascular plants began to establish itself when the crop was cleaned by felling of hardwoods and subordinate spruce at about twenty years. The vascular plants increased appreciably at the time of first thinning, about thirty years, but as the canopy reclosed they decreased agaln. Woodland bryophytes, on the other hand, also increased at this time, but did not die back as the canopy reclosed.

Pines (Pinus spp) and larches (Larlx spp) cast a ligher shade than spruces, so that a larger ground flora is normally present through the rotation ( $F 18.2)$. The cover of bryophytes is similar to that found under spruces. Unlike the pattern under spruces, there is a large increase in the cover of the ground flora towards the end of the rotation.

The flora of broad-leaved plantations will not be considered here, except to remark that although vernal species such as Anemone nemorosa and Endymion nonscrlptus may becone abundant on better solls in lowland areas, these plants do not generally increase under broad-leaved crops on the peatier solls of upland Britain. For example, the ground flora was examined in a Forestry Commission experiment at Clocaenog Forest, North Wales, where forty-three year-old stands of 


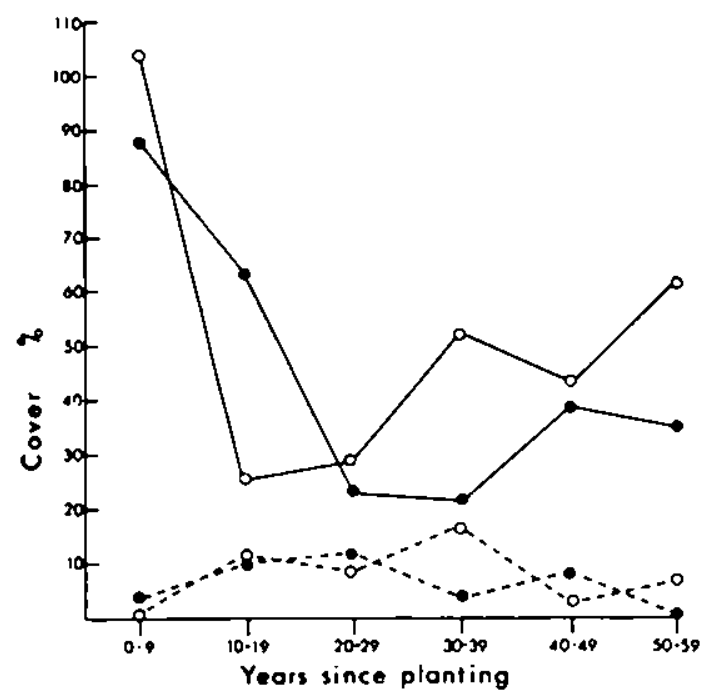

Fig. 2. Cover of vascular plants (solid lines) and bryophytes (dotted lines) in relation to age of crop in plantations of pinus spp (closed circles) and Larix leptolepsis (open circles) in upland Britain. There is some irregularity in these curves due to random variation in a rather small sample of observations.

Pinus contorta and Betula spp could be compared. Both the ground flora species present and their cover were similar. The soil was a peaty gley intergrading with a brown earth.

\section{COMPOSITION OF THE FLORA}

On the geographical scale the composition of the flora under planted conffers depends both on climate and on the species available in the surrounding area to imigrate. On a local scale it depends on soil, spectes planted, stage of the rotation, and on the past history of the site.

The climate determines not only which plants can grow on the forest floor, but also which tree specles are suitable for planting as crops in the first place. It is, however, worth noting some differences between northwest furope and more continental regions further east. Heather (Calluna vulgaris) and ferns (especially Dryopteris dilatata) are perhaps the most characteristics species in many forest of northwest Europe. Heather is not shade-tolerant, but is common in plantation forests before closure of the canopy, reappearing from seed when the crop is clearfelled. The fern Dryopter1s 
dilatata is often the only vascular plant to achieve appreciable cover in British conifer plantations, and it has been noted as a characteristic plant of Douglas fir (Pseudotsuga menziesii) plantations in Holland (Sissingh 1975).

Further to the east, as for example in Brakenhielo's Swedish plantations, heacher and ferns are less proninent or absent, but a wider variety of typical woodland plants occur. Bräkenhielm (1977) noted that Luzula pilosa, Melampyrum sylvaticim, Oxalis acetosella and viola riviniana soon established themselves after the crop was cleaned or thinned. To some extent this difference reflects not only the climate, but also the avallability of a suitable local flora to occupy the ground and a soil that was relatively good after years of agricultural use. The area of Sweden in which Brakenhielm made his observations is very diverse, with.fields, meadows, lakes and woodland forming an intimate and complex mosaic of habitats. Consequently there is a large avallable flora in the immediate vicinicy of the plantations, and, in particular, a woodland flora that has not been eliminated by years of grazing as in so much of upland Britain.

In accordance with the greater cover of plants under pines and larches than under spruces, there is also a greater variety of specles. Vascular plants that are particularly characetristics of pine and larch plantations on more fertile soils in Brftain are bramble (Rubus fruticosus) and bracken (Pteridium aquilinum). These species are almost totally eliminated by Sitka spruce once it has closed its canopy. Bracken seldom reappears even after thinning. On heathier soils the grass Deschampsia flexuosa and bilberry (Vaccinfura myrtillus) prevail and may survive in very small quantities even under sitka spruce; though really successful thickets will eliminate them.

Both the overall cover of bryophyces and the diversity of species are similar under spruces and pines. There are, however, a few bryophytes that do not normally survive under Sitka spruce in Britain though they are frequent under those crop species with lighter canopies. Of these the most notable are Hylocomium splendens and pleurozlum schreberi, large pleurocarpous mosses that are often abundant in the boreal forest, and which are common before afforestation in the British uplands (H11l o Jones 1978). This is in contrast to Brakenhielm's Norway spruce plantations in Sweden, where Pleurozium schreberi was one of the woodland plants that invaded af ter the crop was chinned.

The soll is one of the biggest influences on the composition of the flora. Where it is initially acid and Infertile, few species of vascular plants occur. In Britain, the almost ublquitous Deschampsta flexuosa, Dryopteris dilatata and vaccinium myrtillus would often be the only 
vascular plant specles present. On more fertile solls there is a much richer flora, and a greater variety of woodland plants may invade, including oxalis acetosella, Rubus fructicosus and Sorbus aucuparia. Bryophytes, however, which grow mainly on the litter and stumps, are less affected by soll quality than by available moisture. They are not notably more plentiful on darp soils and on northfacing slopes than on dry soils and on south-facing slopes.

\section{INFLLFNCE OF THE DEVELOPING PLANTATION ON GROUND VEGETATION}

The strungest influence of all on the composition of the ground flora is the crop. Before the canopy closes, 1 ight-demanding plants including weeds and pasture specles can thrive. After the canopy has closed, only the most shade-tolerant species can survive under spruces. Even under pines and larches many formerly abundant plants such as Calluna vulgaris and most grasses othen than Deschampsia flexuosa vanish.

While light intensity is clearly the strongest single influence on the ground flora, its effects are difficult to separate from other influences correlated with the density of the canopy. In particular where the canopy is denser, less rain can penetrate, and there is a greater fall of litter. Rool competition can also be expected to be greater. In a series of experiments to assess the effects of tree-root competition and of litter in a pinus strobus forest in New Hampshire, Toumey (1929) severed the roots round some experimental plots, and removed the litter from a part of them. Removal of litter led to a large increase of vascular plants. Severing the roots led to a large increase of soll moisture during the summer, and to an appreciable increase of vascular plants.

Toumey concluded that 1 ight was not the factor controlling the entrance of natural vegetation under his experimental conditions. This conclusion, somewhat polemical at the time, is of course unjustified. No factor can be said to be incffective unless it has been varied under concrolled conditions. Nevertheless, his experiments aptly illustrate the combination of adverse influences that the ground vegetation in a conifer forest has to contend with. The full combination of adverse influences is often necessary for suppression of the ground vegetation. If any one of them is relaxed, the vegetation can develop. Bryophytes often show this clearly, growing vigorously on stumps that are left after thinning of the crop, but being almost cotally absent on the forest floor where they are soothered by accumulating litter. The effect of root competition is probably less in wet regions such as the British uplands than in Toumey's experimental plots. Drought can be appreciable even in the west of Britain, but is certainly not as severe as in more continental regions. 
Competition for mineral nutrients is presumably the main influence of root competition in wetcer clinates.

Because of the other influences of the crop it is unrealistic to speak of a unique critical value for the intensity of light below which vegetation will not grow. In addition various authors thresholds for the cover of vegetation below which plants may be considered to be "absent" have rarely been stated precisely. Measurements of relative illumination have varied, some authors making their observations on sunny days, and others on days when the sky is overcast. In general, the grey-day relative illumination is to be recommended as a measure of shade, as it depends little on the angle of the sun; for a comparison of the relative illumination under spruce with and without an overcast sky; see Eber (1972).

Even if authors had been consistent, and even if other environmental condition were comparable, the relation between relative 11 im ination and the cover of the ground flora would not be exact, as the flora is seldom in equilibrium with the canopy. In Brăkenhielm's (1977) observation of Norway spruce plantations in South Sweden there was an increase in the ground flora after thinning, and a subsequent decrease as the canopy reclosed. Boch during the expansion and during the subsequent die-back there would be a 1 ag, so that the cover of the ground flora would depend on the prevlous few years of illumation as well as on current illumination.

In spite of these sources of variation, and in spite of possible differences in thresholds below which species are considered to be absent, the observation of various furopean authors are broadly consistent (Table 1). Vascular plants do not occur below about 10-20 per cent relative illumination. On a proportional basis the lower linit of illutination for bryophytes varies more widely, between 2 per cent and 9 per cent. The reason for the greater variability of the bryophyte threshold is the greater sensitivity of bryophytes to local Influences, notably the accumulation of litter and the effects of desiccation. The most discordant value in Table $l$ is due to Eber (1972). Here, the anomaly may be due to a difference of soll and slope, as Eber was working on steeply sloping, calcareous ground, whereas the other observations relate to acid or neutral solls on more level ground where litter would accumulate more thickly.

At all events, whether the main limiting factor is light, molsture or smothering by litter, the broad etopicical relation between relative 11 lumination and the ground flora can explain the differences found between spruces on the one hand, with Abies spp and Pseudotsuga menziesil resembling spruces in this respect, and plines and larches on the other. In spruce plantations the relative fllumation is normally between 1 per cent and 10 per cent until they are over sixty years of 
Table 1. Minimum relative illuminallon (grey-day) for growth of vascular plants and bryophyces under conifers. (Values are drawn from observations in the literature. Values for $\mathrm{Clocaenog}$ Forest in Vorch wales are based on my own observalions).

\begin{tabular}{|c|c|c|c|}
\hline & & Minimurn & Minimum \\
\hline Author & Crop & $\begin{array}{c}\text { illumination } \\
\text { for vascular } \\
\text { plants }\end{array}$ & $\begin{array}{l}11 \text { umination } \\
\text { for } \\
\text { bryophytes }\end{array}$ \\
\hline
\end{tabular}

$\begin{array}{llcc}\text { Cousens (1974) } & \text { Pinus sylvestris } & 17 \% & 9 \% \\ \text { Eber (1972) } & \text { Picea abies } & 6 \% & ? \\ \text { Koie (1938) } & \text { Pinus spp } & 10 \% & 2 \% \\ \text { Rheinheimer (1957) } & \text { Picea abies } & 20 \% & 5-7 \% \\ \text { Rheinheimer (1959) } & \text { Picea abies } & ? & 7 \% \\ \text { Schluter (1966) } & \text { Picea abies } & 12-15 \% & ? \\ \text { (Clocaenog Forest) } & \text { Picea and Pinus } & 12-13 \% & 2-8 \%\end{array}$

age; whereas in pine and larch plantations after thinning, values between 10 per cent and 40 per cent are typical.

\section{DIFFERENCES BETWEEN CONIFYR PLANTATIONS AND NATURAL WOODLAND}

Most conifer plantations in western furope are in the climatic. zone that would naturally support broad-leaved forest. As a result, their ground vegetation consists largely of species that also occur in nearby broad-leaved woodland. For example, in a detalled study of changes resulting from afforestation of some rough grazings in South wales, Hill \& Jones (1978) found only two species occuring in plantations that were not present in nearby oak (Quercus petraca) woods. Both were bryophytes that produce abundant spores, plagiothecium curvifoliun and polytrichun longisetum, and presumably could have reached the area from considerable distances. Otherwise the origin of the flora was clearly local.

From the point of view of the wild flora, plantation forests differ from natural wodland in two major respects: the uniformity of the thicket stage and shortness of the rotation. When a crop reaches the thicket stage simultaneously over a wide area, species may be eliminated completely that would otherwise re-occupy the ground during later stages of the rotation. This means that opportunities for true woodland species in plantations are much reduced, as they lack suitable refuges during, the establishment and thicket stages. There is perhaps more resemblance to a fire-succession. But in regions such as western North America where fire-successions have been extensively studied, the trees often reach ages of eighty to 
Table 2. Comnonest plants of coniferous plantations in upland Brilain.

Data for this Table are derived frow an unpublished report submitted by the Institute of Terrestrial Ecology to the Nature Conservancy Council. The two categories do not correspond to precise levels of frequency, but the plants in Category $A$ have frequency approximately 40-100\% in $200 \mathrm{sq} \cdot \mathrm{m}$, and plants in Category $B$ have frequency approximately 20-40\%. The establishment stage $(0-20$ years) of the flrst rotation has been excluded, but the establishment stage of the second rotation is included, this being regarded as a closer approximation to what will be present in a normal forest. Equal representation has been giver: to each of the age-classes $0-20$ years, $20-40$ years and $40-60$ years.

A. Almost ubiquitous

Deschampsia flexuosa Dryopteris dilatata Vaccinium myrlillus Dicrantur scoparium
Hypnum jut land icum Pl ag fo thecium und ul atum Lophocolea cuspidata

B. Other very common plants

Calluna vulgaris Chamaenerion angustifolium Galiun saxatile Molinta caerulea Rubus fruticosus Sorbus aucuparia
Campylopus paradoxus Dicranella heteromalla Eurhynchium praelongum Mnium hornum Pleurozium schreberi Hypogymia physodes

V. vitis-idaea and Deschampsia flexuosa constant and sometimes co-dominant. Otherwise the commonest flowering plants are Linnaea borealis, Luzula pilosa, Melampyrum pratense and Triental is europaea. On clearfelling, Descharopsia flexuosa becomes dominant, with abundant Epilobium angustifolium, Luzula pilosa and Rubus idaeus.

100 years or more. By that age most spruce plantations in the British uplands would have been windblown. The crop cannot be harvested at wuch more than fifty years of age and this short rotation is highly inimical to the establishoent of a true woodland flora.

In spite of these differences there are marked resemblances between the flora of conifer plantations in the northern deciduous zone of Europe and that found in the boreal forest. The comoner species in British upland forests (Table 2) include two, Dryopteris dilatata and Hypnum jutlandiciro, that are largely absent from the North European boreal forest; but the ocher specles are all frequent or common there. 
According to Sjörs ( 1965 ) Vaccinium myrtillus is dominant in the field layer under Norway spruce in the boreal forest of Sweden, with

\section{RFGENFRATION OF THE GROUND FLORA FOLLOWING CLEARFELLING}

Because of poor development of the ground flora in many plantation forests, the revegetation of sites that have been clearfelled is particularly dependent on seed surviving in the soil, and on the few vascular plants that may have survived the rotation. Hoodland plants nomally dic back. In Britain this usually means Dryopteris dilatata, which often does not actually die but merely survives unhealthily without increasing, and several species of woodland bryophytes. The moss Plagiotheciun undulatum is not very tolerant of desiccation, but Hypum jutlandicun, which is al so very comon in mature plantations, can grow equally happily on dry heathland and is not adversly affected by removal of the tree canopy.

After clearfelling there are four main sources of the regenerating flora: viable seed surviving buried in the soil; seed entering the area after clearance; seed distributed by plancs surviving on the site, and vegetative spread of the surviving green plants. Where there has been a succesful crop of a dense-canopied species such as sicka spruce, seed surviving in the soil is generally the main source of propagules for the regenerating flora, at least awa from the edges of felled compartments. Near the edges, many relatively light-demanding plants such as bracken (Pteridium aquilinum) may survive, so that in the season after clearance the centre of the compartment can be almost bare, while there is a dense growth of vegetation round the edge. Pteridium is almost colally dependent on vegetative spread, and does not reappear in areas from which it has been eliminated.

Some of the vlable seed present in the soll at the time of clearfellings is of recent origin; some, often the majority, has survived for many years in the soll. These two categories can usually be told apart by the fact that the recently arrived seeds are mainly in the litter, whlle the seeds that have been present for longer are mainly in lower horizons. Peter (1893, 1894) working in the vicinity of Gottingen, was the first to demonstrate the remarkable longevity of seeds in forest solls although there had been several earlier, anecdotal reports. Using a simple technique of germinating seeds from boxes of soil in the greenhouse, he found that where plantations had been established on old arable or pasture land, the seeds of arable or pasture weeds remalned abundant in the soll for up to fifty years. In plantations established for more than 100 years the flora of the previous land-use was largely eliminated though there was sometimes a small population of weed species in the surface 
layers of the soil. These he attributed to the use of the woodland by local farmers for sheltering livestock. Sone small-seeded plants, chiefly of the genera Hypericum and Juncus, were present in the deeper layers of the soll, and these had perhaps survived for much longer. The seeds of true woodland species were very poorly represented in the soils, with the result that densities of vlable seeds were much less in old plantations and ancient woodlands than in plantations established within the previous fifty years.

Peter's experiments were conducted with a care and thoroughness that have not been surpassed, and his conclusions have been amply confirmed by subsequent observers. My colleague P.A. Stevens, using essentially the same technique, has examined soil seed populations in British upland forests on several types of soil. He found seed densities typically in the range 1000-5000 seeds/sq.m on brown earths and peaty gleys, but much lower, typically 40-100 seeds per sq.w, on deep peat (P.A. Stevens, personal communication). Seeds of many species survived readily through the dark stage of the rotation, i.e. for about thirty-five years; but tree seeds (Betula, picea and Pseudotsuga) appeared always to be of recent origin. In general the larger seeds survived less well than smaller seeds, and many grasses were scarcely represented in samples taken from older plantings. In particular, Deschampsia flexuosa did not appear to survive for long as soil seed, so that when it invades a clearfelled area, it has to do so from plants surviving on the site. Under larch and plne it is usually present before clearfelling, but it may be largely eliminated by well-grown sicka spruce:

Among the small-seeded plants that showed good survival as soil sed, the most notable were Calluna vulgaris, generally in large numbers, Carex spp, Digitalis purpurea, Erica tetralix, Galium saxatile, Juncus spp, Luzula spp and potentilla erecta. The reappearance of these species on clearfelled areas, is therefore often to be expected. Also, the grasses Agrosti's canina, A. tenuis and Deschampsia cespitosa often reappear after clearfelling, and their seeds probably survive considerable periods of burial.

In addition to plants whose seeds survive on the site, certain plants with airborne seeds are capable of colonizing the area from outside. In Britain these are mainly Epllobium spp and Compositae; in many parts of North America and the Soviet Union, grasses of the genus Calamagrostis are often abundant. Chamaenerion angustifolium is generally the most plentiful windborne colonist of clearcut areas in Britain, though it often grows poorly and fails to become abundant on the poorer peaty soils. plants with windborne seeds are particlarly characteristic of fire-successions elsewhere, as some individuals are able to disperse over long distances, and are, therefore, at an advantage where seeds buried in the 
surface soil have been destroyed.

Dispersal of berries by birds is undoubtedly responsible for some regeneration of Rubus spp, Sorbus aucuparia and Vaccinium myrtillus. However, the seeds of these plants are often buried in the rineral soil, and clearly have considerable longevily. Where seeds are introduced from outside this is most probably by roosting birds while the crop is still standing. It is quite possible that birds serve mainly to introduce these species in the first place, but that the bulk of their regeneration is from plants already present in the soil before the crop closed its canopy.

Depending on the speciles of crop and on 1 ts management there may be an appreciable flora al ready present on the site to serve as a source of seedlings after clearfelling. Deschampsia flexuosa is markedly affected in this way, frequently being the most abundant plant of clearcut areas which had supported a final crop with a canopy broken by endenic wind throw, disease, etc. Grasses such as Agrostis spp and Molinia caerulea may spread vigorously from a few existing plants and brambles (Rubus fruticosus) and bracken (Pteridium aquilinum) nay spread vegetatively.

\section{OUTLOOK FOR THE GROUND FLORA IN FUTURE ROTATIONS}

In Britain, most plantation forests are still in their first rotation; large areas still remain to be planted in Scotland. Moreover, methods of silviculture and the choice of crop species have changed so much in the past fifty years that it is not possible to be sure what will happen in future rocations from a knowledge of what has happened to-date. Least known are the changes that may take place in populations of buried viable seeds. Existing populations of buried seeds were mostly derlved from the flora that preceeded afforestation. At the end of the next rotation the original seeds will almost all be dead, and numbers may not be replenished during the open phase before closure of the canopy of the second crop. If so, then the seed population may gradually drop, so that successive crups may be progressively more free of weeds.

This, however, is certainly not the outlook for the more fertile soils. One of the sites where the buried seed population was examined by P.A. Stevens, was on a brown earth in Gwydyr Forest, North wiales, on a site that had always been woodland. The burled seed population was here exceptionally large, about 5000 seeds/sq.m, of which 4000 seeds/sq.m were of Digitalis purpurea. After clearfelling, Digitalis germinated abundanty, and will cvidently leave a vast population of buried seeds to appear when the next crop is clearfelled. Digilalis is a species that can be expected to increase in future rotations, extending to areas that were formerly grassland as well as occurring in old woodland sites.

on peats, however, few seeds survive in the soil. 
Deschampsia flexuosa is normally the principal colonist after clearfelling though if it has been largely elininated by the previous crop, and has not al ready colonized windthrown areas, it may perhaps fall to establish a large population before the next crop closes its canopy. If so, then the ground flora on peats may eventually be very sparse.

There is much uncertainty in this prediction. Windthrow is proving to be more of a problem in Britain than had been anticipated. Patches of windthrow allow populations of mature plants to develop in planted blocks towards the end of the rotation and may eventually result in a more fine-grained pattern of age-classes than we have at present. If so, then a large ground flora may survive even on peats.

\section{RF.GENERATION OF TRE.ES FROM1 SEED}

An important category of windborne seeds not mentioned above is tree seeds. In British forests this usually means the seeds of birches (Betula pendula and $B$. pubescens) and conifers. As with windborne seeds of herbaceous species, tree seeds do not survive for long in the soil, and are mostly replenished each year. They regenerate more readily in mineral soils than on peats, especially if there has been some disturbance.

Available data on the regeneration of conifers in Britain are rather scattered, and there are still many gaps in our knowledge. The subject has been ably reviewed by Brown of Neustein (1972), who draw attention to the role of small mamals in destroying the secds. However, much of our knowledge is still anecdotal, and the effect of other vegetation on regenerating trecs is little understood. Grasses and heather are consiciered to have an adverse effect on regeneration, whilst Polytrichum and Vaccinium are reputed to make a good seed bed (Robertson 1976). The factors controlling natural regeneration require further study.

\section{FLORA OF MARGINAL HABITATS IN PLANTED FORESTS}

There has been a widespread fear among nature conservationists in Britain that the extensive new plantations would impoverish the flora of the uplands, and it is true of course that much of the existing vegetation is destroyed when a forest is established. Although many species survive in the soil as seed, and although a small number fmigrate, nevertheless if only the planted blocks themselves were considered, there would be an appreciable loss of species diversity in planced forests.

But, in addition to destroying existing habitats, afforestation also creates new ones, notably the rides and roads. Rides in my experience are rather a poor habitat for plants, as they are not disturbed enough to keep the vegetation open, with the result that they are nomally 
dominated by a thick mat of coarse-growing plants such as Agrostis canina, Calluna vulgaris, Holcus mollis or Molinia caerulea. The coarse-growing dominant plant then excludes smaller plants, preventing establishrent of a diverse flora. It is possible that rides have not yet had enough time for a characteristic flora to develop. In particular, until clearfelling of the first rotation, they nay experience very little disturbance. After disturbance a characteristic flora may begin to inmigrate, though conpletion of the proccess could take several rotations.

Roadsides, on the other hand, are disturbed from the first, and are nomally kept open by various management practices such as mowing. They are colonized by a wide variety of plants, including many that are scarce or absent in upland areas before afforestation (D.F.Evans, personal comunication) but mainly those characteristic of roadsides and hayfields in the lowlands. In Dalby Forest, North Yorkshire, where the roads are surfaced with limestone, the flora of the verges is particularly rich and includes a wide varicty of immigrating specles.

The flora of streamsides in forests varies greally, depending on the size of the stream and the closeness of planting. At one end of the scale, small streams are commonly canalized and trees planted right up to their edge. Their flora is largely obliterated. Large streams and rivers often have roads running alongside then and have a flora effectively unmodified by afforestation.

The habitats that are worst affected by afforestation are marshes and bogs. Not only are they commonly drained for planting but many spectes of base-rich marshes are low-growing and dependent on heavy grazing for their survival. When the grazing animal is excluded many small plants such as Drosera rotundifolia, Pinguicula spp, Valeriana diolca and numerous bryophytes are more or less el iminated. Some may survive here and there on damp verges beside forest roads, but in general they die out.

The result of these various influences, some leading to an increase of the flora, others to a decrease, is that the overall effect of afforestation on the number of specles present in an area is small. However, marshes and bogs are interesting habitats; and in areas where extensive afforestation is taking place it would be advisable to excercise restraint in planting thew up. In that way, it should be possible to maintain the diversity of flora and habitat that many of us value.

\section{ACKNOWLEDGEMENTS}

The work on which this paper is based, was done for the Nature Conservancy Council and financed under NERC/NCC contract F3/03/78. I am grateful to my colleagues D.F. Evans 
and P.A. Stevens, of the Institute of Terrestrial Ecology, Bangor, for permission to quote some of their unpublished results.

\section{REFERF.NCES}

Brakenhiclm,S.(1977). Vegetation dynamics of afforested farmland in a district of southeastern Sweden. Acta Phytogeographica Suecica, 63, 1-106.

Brown,J.M.B. \& Neustein,S.A. $(1972)$. Natural regeneration of conifers in the British Isles. "Conifers in the British Isles". Proceedings Royal Horticultural Society 3rd Conffer Conference, London, 1970. pp.29-39. Royal Horticultural Society, London.

Clapham,A.R., Tut In,T.G. \& Warburg,E.F.(1962). Flora of the British Isles. 2nd edition. Cambridge University Press, London .

Cousens,J.(1974). An introduction to woodland ecology. Oliver $\&$ Boyd, Edinburgh.

Dallimore,W. \& Jackson,A.B.(1974). A handbook of Coniferae and Ginkgoaceae. Revised by S.G. Harrison. Edward Arnold, London.

Eber,W.(1972). Ueber das Lichtklima von Waldern bel Göttingen und seinen Einfluss auf die Bodenvegetation. Scripta Geobotanica, $3,1-150$.

Hill,M.O. \& Jones,E.W.(1978). Vegetation changes resulting from afforestation of rough grazings in Caeo porest, south Wales. Journal of f.cology, 66, 433-456.

Kole,M.(1938). The soll vegetation of the Danish conifer plantation and its ecology. Danske Videnskabaernes Selskabsskrifter, Series 9, 7, 1-85.

Peter,A.(1893). Kulturversuche mlt 'ruhenden' Samen. Nachrichten von der königlichen Gesellschaft der Wissenschaften zu cöttingen, 17, 673-691.

Peter,A.(1894). Kulturversuche $\overline{m 1 t}$ 'ruhenden' Samen. II. Mittheilung. Nachrichten der königlichen Gesellschaft der Wissenschaften zu Göttingen, Mathematische-Physische Klasse, $4,373-393$.

Rheinheimer,G.(1957). Ueber die Standorte der Moosvegetation in Nadelholzforsten bei Hamburg: Mittellungen der Statsinstitut für allgemeine Botanik, $11,89-136$.

Rheinhelmer,C.(1959). Veränderungen der relativen Beleuchtungsstãrke und der Bodenvegetation in einem Fichtenforst. Berlcht der Deutschen botanischen Gesellschaft, 72, 246-250.

Robertson,S.U.(1976). The possible role of natural regeneration in Scottish forestry. Scottish Forestry, 30, $134-142$.

Schlüter,H.(1966). Licht- und Temperaturmesungen an den Vegetationszonen einer Lichtung in Fichtenforst. Flora, Abtellung B, 156, 133-154. 
Sissingh,G.(1975). Niederländische Nadelforsten und ihr Humus als Substrat für ihre vegetation. "Vegetation und Substrat". (E.d. by H. Dierschke), pp. 317-41.J. Cramer, Vaduz.

Sjòrs,H.(1965). Forest regions. Acta Phytogeographica Suecica, $50,48-63$.

Solth,A.J.F.(1978). The moss flora of Britain and Ireland. Cambridge University Press, London.

Toumey,J.T.(1929). The vegetation of the forest floor; 1ight versus soil moisture. Proceedings $4 \mathrm{th}$ International congress of plant sciences, Ithaca, 1926. (Ed. by B.M. Duggar), vol. l, pp.575-590. Ceorge Banta, Menasha, Wi sconsin, L.S.A. 
THE DEVEIOPMFNT OF POPUI.ATIONS OF PESTS AND PATHOCENS IN EVEN-AGED PI.ANTATIONS - FUNGI

By James S. Murray

Department of Forestry, University of Aberdeen, St. Machar Drive, Aberdeen AB9 2UU, U.K.

\section{SUNQARY}

From the point of view of establishment and persistence of palhogenic. fungi in even-aged plantations, it is convenient to divide the rotation into four stages: establishment, thicket, pole stage and mature.

In the establishment stage, the pathogens may be derived from the nursery and be taken into the field with the planting stock. Many common uursery pathogens can continue their attacks in this way, some being important only on the young stages. For this reason disease control in the stand may begin with disease control in the nursery or stoolbed. Plantations established by direct seeding are affected mainly by pathogens existing in the field.

In the thicket stage, microclimatic conditions favour external pathogen aclivity such as spore casting, germination and possibly primary infection. The intense competition between trees which develops during this stage favours pathogens which call attack stressed trees. Thus diseases of the foliage and bark are comon in the chicket stage.

In later stages compelition between trees is relieved by thinning and the betcer ventilated canopy offers a less favourable enviroment to follage discases. However, the more numerous interventions by the forester during the last two stages may greatly affect the disease sicuation and result in an increasing importance of root fungi and decay with age. Throughout the rotation pathogen establishment and activily is affected mainly by the following groups of factors:

- past history of the site and former crop residues; 
- pathogens carried on nursery stock;

- changing microclimalie of the sland during the rotation;

- activily by man, including managerenc decisions and silvicultural operations.

Thus, a considerable part of the background to the disease situation is under the control of the forester. The extent to which he would be prepared to manipulate it, depends on how far such actions would compromise other objectives of management.

RÉSURE:

Si on examine $1^{\prime}$ apparilion et le maintien des champignons pathogenes dans les peuplements équiens, il est souvent pratique de diviser la révolution en quatre étapes: stade de fourré, stade de gaulis, stade de perchis et stade de futaie.

Pendant le stade de fourré, les pathogenes, issus des pépinières, peuvent être transportés sur le terraln au mowent de la plantation. Un grand nombre de pathogènes usuels peuvent, de cetce maniere, continuer leurs attaques, certains $n^{\prime}$ étant dangereux que chez des arbres très jeunes. Par conséquent, le contrôl des infections dans les plantations doit debuter dans les pépinieres. Les plantations établies par seris à la volée sont surtout affectécs par des pathogenes existant déjà dans le terrain. Pendant le stade de gaulis, les conditions du microclimat existall favorisent l'activité pathogène externe telle que 1 'expulsion des spores, la gemination et peut-être les infections primaires. La competition tres intense entre les arbres à ce stade, favorise les pathogènes qui peuvent attaquer les arbres affalblis. Ainsi des infections du feulllage $e t$ de l'écorce sont habituelles pendant le stade de gaulis.

Pendant les stades subsequents la compétition entre les arbres est amoindrie par les éclaircles et un couvert plus aéré offre aux Infections du feuillage un milieu moins favorable. Cependant les incerventions de plus en plus nombreuses du forestier pendant ces dewx derniers stades peuvent avolr une influence considérable sur l'état des infections et peuvent amener avec I'age l'importance des champignons de racines et de 
la pourriture du tronc.

Tout au long de la révolution, l'établissement et l'activité des pathogènes sont affectées par les groupes de facleurs suivants:

- passé du terrain et résidus des anciens peuplements,

- pathogènes accompagnant les stocks de pépinières,

- changement du microclimat pendant la révolution

- activité de l'homme gestion et sylvicul ture,

Ainsi, une part importante des facteurs d'infection est sous le contrôl du forestier. Il pourra en tenir compte dans la mesure ou ils n'entreront pas en conflit avec d'autres objectifs de gestion.

\section{ZUSAMMENFASSUNG}

Bei der Betrachtung des Aufkommens und Überdauerns pathogener Pilze in gleichaltrigen Pflanzungen ist es zweckmàssig vier Alcersitufen 7.4 unterscheiden: Kulturstadium, Dickung, Stangenhol $z$ und Al tbestand.

Im Kulturstadium können die pilze aus dem Pflanzgarten stament und mit dem Pflanzmaterial in die Kultur gelangt sein. Viele verbreitete pflanzgartenschädlinge setzen so ihren Befall fort, wobei einige nur im jüngsten Kulturstadiun von Bedeutung sind. Die Infektionskontrolle des Bestandes sollte daher schon im Pflanzgarten oder Satbeet beginnen. pflanzungen, dic durch direkte Aussaat begründet wurden, werden hauptsächlich von in der Schonung vorkommenden Schadpilzen betroffen.

In Dickungsstadium fördern die mikroklimatischen Bedingungen die externe Infektionsaktivităt, wie Sporenverbreitung, Keimung und unter Umständen primärc Infektion. Der in diesem Stadium harte Konkurrenzkampf unter den Bäumen begunstigt den Befall der unterdrückten Bälme. Krankheiten der Blätter und der Rinde sind daher it Dickungsstadium verbreitet.

In späteren Bestandesleben wird der Konkurtenzkampf unter den Bäumen infolge Durchforstung genildert, und der besser belüftete Kronenraum ist Blattinfektionen weniger forderlich. 
Andererselts jedoch kann es durch die häufigeren forstlichen Fingriffe wahrend der beiden letzten Bestandesphasen vermehrt zu hurzelinfektionen und Holzzerstorung rit zunchmendem Alter der Batume kommen.

wahrend des Bestandeslebens werden fintritt und Aktivitat der Infektionen hauptsächlich von folgenden faktorengruppen beeinflusst:

- Vorgeschichte des Standorts und Rückstände des Vorbestands,

- Infektionen mit dem Pflanzmaterial,

- Anderung des Bestandesmikroklimas wàhrend der Uncriebszeit,

- menschliche Eingriffe einschliesslich betriebswirtschaftlicher Entschetdungen und waldbaulicher Massnahmen.

Die Vorgeschichte einer Pilzinfektion unterliegt also zu einem betrachtichen Teil der Koncrolle des Forstmannes. In welchem Unfang er hier Einfluss ausüben kann, hāngt vor allem davon ab, inwleweit solche lassnahmen wit anderen 7ielsetzungen in Einklang zu bringen sind.

\section{INTRODUCTION}

The establishment and persistence of pathogenic fungi in even-aged plantations and the damage they cause, depend on several factors. Some of these are associated with particular stages of growth of plantations as shown in Table 1. The stage of growth may also modify the local environment within the canopy and affect pathogen development. It may also affect the physiology of the trees and their predisposition to attack. A particular pathogen may depend on a special living or non-living factor that is itself dependent on the stage of growth of the crop. And, lastly, stages of growth are of ten associated with silvicultural operations which can affect tree susceptibility.

$\begin{array}{lll}\begin{array}{l}\text { Age related } \\ \text { liability to }\end{array} & \text { Structure } & \\ \text { infection } & \text { canopy } & \text { Silvicultural } \\ & \text { operations } \\ & \text { Environmental } & \text { Competition } \\ & \text { factors: } & \text { within the crop. } \\ & \text {-humidity } & \text { Predisposition. } \\ & \text {-temperature } & \\ & \text {-shade. } & \end{array}$

Table 1. Stage of growth of plantations. 
Thus, where land is to be under continuous forestry, it may be convenient to regard the successive rotations as long cycles during each of which a changing picture of pathology is presented. Table 2 portrays a rotation with some of the important influences which call affect the course of pathology during it. From this point of view it may be convenient to divide the rotation inco four stages of growth: establishment, thicket, pole and wature, and consider examples of disease assoclated with each stage.

\section{THF. F.STABLISHHENT STAGF.}

Even-aged plantations way be established by direct seeding, or, more commonly, by planting rooted stock. Certain pathogens are known to be speclally damaging on young crops during and shortly after the establishment stage. The longer such pathogens can be excluded from the crop, therefore, the less damage they may eventually cause. An important factor in this consideration is the source of the inoculum. There are three main sources: presence on the planting stock, presence on the site and incoring to the site.

Some pathogens way be present in the nursery and be taken inco the field on the planting stock. Many of the familiar nursery discases in Britain are in this category, Meria laricis Vuill. on larch; Didymascella thujina (Durand) Maire on Thuja; Microsphaera alphitoides Criff. and Maubl. on oak, and Phytophthora spp. on various hosts. Some of these, such as M. laricis and D. thujina are much more damaging in the early stages of plantation growth and cause only little damage in the later stages. They are especially damaging on trees recovering from the shock of transplanting into the field.

Recently, Skilling (1977) stated that in the case of Scleroderris lagerbergii Grem. in red and jack pine plantations in northern U.S.A. and Canada, damage was limited almost exclusively to trees less than ten years old and that most of the originally affected plantations were infected by nursery stock.

Therefore, where establishment is by nursery plants, control of disease in the plantation begins in the nursery and measures aimed at preventing losses in the nurbery may have a bonus in also reducing them in the plantation. Particularly important among such control measures are those which aim at disease avoidance either by siting nurseries remote from inoculum sources or by avoiding continuous raising of stock in the same nursery so that pathogens are annually transferred from older to younger stock. Such avoidance measures are particularly important in the case of host-11mited pathogens.

Most of the above cases concern nursery stock raised from seed, but infected, vegetatively produced stock might be used as well. Such stock, rooted and unrooted sets, way often suffer small wounds from pruning or accldental damage when 


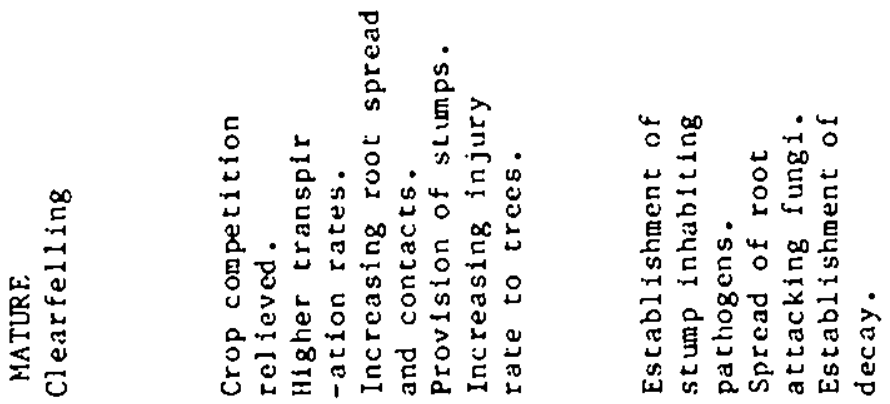

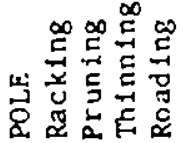

歨

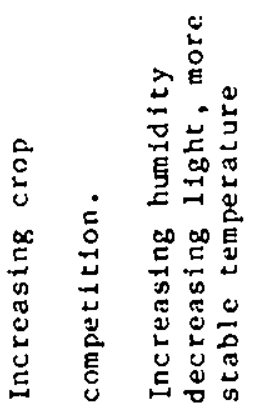

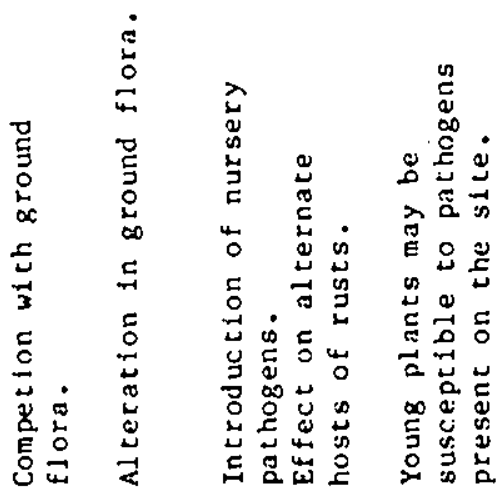

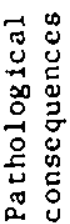

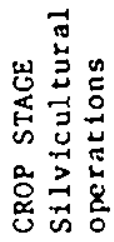

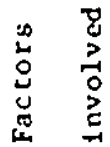

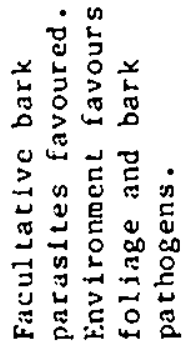

的嵒

오로 $\underset{0}{0}$ : 政

몽 ป 
being woved to the píanting sice.i The shock of transplanting often leads to a reduction of the moisture content of the bark, allowing facultative parasites to use the wounds as entries and to kill areas of bark. Cytospora chrysosperma (Pers.) Fr. and Dothichiza populea Sacc. and Briard. have both been recorded attacking poplar sets in this way. Another example is the use of sets of Salix alba as planting stock. The stool beds used may be infected with Erwini salicis (Day) Chester, causing water mark disease, so that the pathogen may be introduced into a plantation which wight otherwise have remained free of il (Gremmen 1977).

In this respect, pathogens which are present in the host for some time before causing obvious symptoms are especially dangerous since infected plants may not be culled in the nursery. Cronartium ribicola Fisch, which causes blister rust of five-needled pines, is especially prevalent on young stock from one-year old seedlings upwards. Typically it invades needles on which few symptoms appear and takes some lime to grow down to the shoots. Lse of such infected stock for establishing plantations has led both to carly losses and introduction of the pathogen to new areas. Work on lophodermium (Millar, personal communication) has shown that apparently healchy individual needles of Scots pine nursery stock can contain mycelia of up to three Lophodermiun species differing in their pathogenicity. The physiological effect of planting out stock carrying such latent infection is not known but it has been surmised that the consequent stress may favour the more pathogenic forms of Lophodermium present in the needles and lead to the frequent epidemics reported at establishment stage.

When plantation establishment is by direct seeding such nursery originated diseases are for the main part avoided. Reported pathogens conveyed on or in the seed are few. Geniculdendron pyriforme Salt, may kill seed of Sitka spruce especially at temperatures around $10^{\circ} \mathrm{C}$ and Ciberia batschiana (Zopf) Buchwald may kill acorns. The former is an example of a pathogen of apparently limited distribution in the world which could be farther spread by direct seeding and the latter one of general occurrence in oak woods in Europe. Certain seed-borne pathogens may attack other parts of the tree as, for example Gloeosporium quercinum Westd. which can attack acorns and also cause leaf spots on oak. The ability to atrack other parts of the tree increases the risk of persistence in plantations of such seed-introduced pathogens.

Where the pathogen is not carried on the planting stock, it may still infect the young stages if it is present on the planting site or possesses a stage in its life history allowing it to be easily vectored from a remote source.

Residues of previous crops, especlally stums and root systems, may carry pathogenic root fung 1 . This residue, which 
may persist for some considerable time, can be a serious cause of loss both where plantation follows plancation and where plantations replace existing natural forest. Modern sile preparation practices which remove such residues or bring ther up to the surface may be important in breaking the chain of persistence in this class of disease because very of ten the fungi involved cannot survive in the soil without such woody masses.

older, lightly infected trees may be the source of inoculum, which can produce a serious and sometimes lethal infection of the young plants. Scirrhia acicola (Dearn.) sigg., the brown spot fungus, is a good example of this. It is widely distributed in pine stands in the south and west l.s.A. where it can cause mortality and loss of growth of the young stages, but declines in importance as the plantations age. Another example is Nectria ditissima Tul. which causes canker on young beech raised under the uniform system and where the sources of infection are branch cankers on the older trees (perrin 1975). The regularly distributed mother trecs are ideally placed to distribute infection to the young stands, and the first step advocated by perrin in control of the canker is the elimination if such cankered adult trees.

Many foliage pathogens show a similar behaviour, damaging, mainly young stages. Bissel \& Gadgil (1975) describe the relationship betwecn damage of Pinus radiata due to Dohistroma pinf hulb. and age of crop in liew 7ealand. The $1-10$ year age classes are mainly affected, with some stands up to fifteen year also atlacked, very occasionally trees up to twenty-two years are infected and trees older than this are entirely resistanc. The authors emphasize that controls of $\underline{D}$. pini by spraying in the plantations is economic by virtue mainly of two features: the efficiency and persistent effect of a well-timed spray and the short period during the rotation when the spraying is required. Since not all pine species in New Lealand show Increasing resistance with age to D. pini this factor is tending to reduce the acreage of them planted in favour of $\mathrm{P}$. radiata.

In many cases the reasons for a relationship between age of crop and disease intensity are not known, especially where changes in the physiology of the host with age are concerned. In some cases, however, the reason is obvious. The snow moulds cypified by Herpotrichia 11 igra Hartig. are dependent on snow cover, which must often be relatively deep. Apart from the lower branches of larger trees, these moulds are most damaging at the young stages of the plantation when trees can be covered for some time and are unimportant beyond the thicket stage. Rhizina undulata Fr. may kill young stock shortly after planting out on areas which have been burned during site preparation (Seaby 1977).

A silvicultural operation may affect the probability and 
scale of disease altack. Moriondo (1975) showed that severe at tacks by Cronartiun flaccidum (Alb. and Schw.) Wint. on pine plantations in Italy may be due in part to the presence of the alternate host, Vincetoxicur officinale, necessary for the maintenance of the discase cycle, in the vicintty of the affected plantations. He further showed that v.' officinale could act as a pioneer species well able to colonize sites where the ground was prepared for planting. In Italy, the natural distribution of pine species pillus pinaster, $\underline{p}$. pinea, $\underline{P}$. : nigra and $\underline{P}$. sylvestris is outside of the natural $\bar{d}$ istribution of $v$. officinale. The managenent decision to greatly extend the area of pine plantations into regions where $\checkmark$. officinale was present and the silvicultural decision to prepare planting siles have resulted in severe losses due to the rust with intensities as high as 50-100 per cent for plantations in every zone between the Appenines and the eastern seaboard.

In another case, Miller (1972) working with fusiform rust, (Cronartium fusiforme Hedg. and Hunt.) on Pinus elliottif showed that the degree of preparation before planting significantly increased liability to individual tree infection, number of lethal galls and number of galls per tree. His site preparation involved different grades of ploughing and harrowing before planting.

\section{THE THICKET STAGE}

This stage of growth is a period when competition between trees is incensifying and when canopy closure and density 8 reatly affect the microclimate of the stand. The humidity in parcicular tends to increase and remain at high levels for considerable periods consequent on reduced wind speeds, increased interception of rain and exclusion of insolation. The Increasing competition may result in a proportion of the crop being predisposed to infection by certain pathogens. Competition for water may result in the more suppressed individuals having low bark moisture contents and being liable to infection by bark facultalive pathogens. Bier (1959) showed that for a number of host - parasite combinations a threshold value existed of about 80 per cent for bark turgidity, below which certain facultative bark pathogens extended and above which they did not. Further work by Bloomberg (1962) reinforced the importance of bark moisture in this respect.

During the thicket and on into the young pole stages 1 ight intensity within the stand decreases. Anderson (1972) showed experimentally that cankers developed and enlarged more rapidly on stems of quaking aspen, Populus tremuloides, when they were shaded although the basis of the association is not known. The results fit well with observations associating high canker intensities with dense stands, and by inference with stages in the rotation when light values are low. 
Other workers have recorded high incidence of particular diseases in the thicket and young pole stages. Hopkins (1963), in a survey of cankers caused by Atropellis piniphila (heir) Lohm. on lodgepole pine in Alberta, showed a peak for initiation of cankers on stem tissues in the 10-14 year age class. He showed that the pathogen could enter undamaged stem bark directly. He postulated that during the course of forest developrent, stem tissue changed in its likelihond of infection: an initial period of low likelihood being followed by a period of high likelihood succeeded, by one of low likelihood. He suggested that the first pertod of low likelihood in the upper crown could be due to the microclimate associaced with that region and that the low likelithood of the third period was associated with host resistance resulting fron the thick bark. The high humidilies associated with the thicket and young pole stages would explain why disease figures became high at that stage.

\section{THE POLE STAGF.}

At the pole slage in crop development the crop has passed chrough a long period when the forester may have intervened litcle in its development apart from carrying out cleanings for density and mixture regulation. At the pole stage when the crop is about 10 mo in height, the forester starts to carry out a series of operations which may comprise creating racks, brashing, thinning and pruning. These operations, togecher with changes in microclimate and crop physiology, may affect the likelihood of disease incidence.

As the canopy grows upwards and lower branches die, the increasing exposure of follage in the wind results in lower humldities in the crown and shorter periods when leaf and bark surfaces remain wet. This would be expected to be unfavourable to the germination and infection stages of many pathogens. Castellani (1966) has shown that heavy attacks by varssonina brunnea (E. \& E.) Sacc. on poplar in Italy are associated with climatic conditons which result in a water film on leaf surfaces lasting for a certain time and that the distribution of serious attacks by the disease is associated wh theather patterns involving rainfall, cemperature and humidity. Similarly, Cronartium ribicola has been reported by Boyce (1961) to need forty-eight hours of saturated air and temperatures of not over $18^{\circ} \mathrm{C}$ for the processes involving production of promycelia, casting, germination of sporidia and penetration of the pine needle. Such requirements also dictate the pattern of spread of the rust in western North America. The changes in microclimate associated with the more exposed, elevated canopy of the pole stage would be expected to be unfavourable to pathogens with such demands. The further opening of the canopy following thinnings would intensify such wicroclimatic effects. 
Increasing size of trees is associated with extending root systems and may involve root contacts and root grafting, especially in pure stands. This favours those root diseases transtissible by direct contact or grafting and is particularly important where the root fungus finds difficulty in surviving in unsterilized solls. In spreading pacches of such root attack there is usually one clone of the fungus associated with each patch. According to Childs (1963) Portia weiril (Murr.) Murr. spreads mainly by root contact when attacking Douglas fir in western North America, though actual root grafting is not necessary, and experiments have shown that $P$. weirii cannot survive in unsterilized soil. Many other root pathogens show a similar life history.

Bikshi, Reddy of Singh (1976) have described the same life history of Ganoderma lucidum (Leyss.) Karst. in plantations in India stressing that the spread is greatly slowed down or stopped in natural forests where there is a mixture of resistant and susceptible hosts and the continuity of the susceptible root wat is broken. Severe damage has occurred in pure plantations of susceptible specles, especially where they have replaced natural forests where the pathogen was present in the root systems. The importance of the developing root wat is exemplified also where Armillaria mellea Vahl ex. Fr. is unable to form rhizomorphs in certain solls and is dependent for spread on a continuous root system in the plantation. Wilt fungi may also be transmitted through root grafts. This method of spread is well-known for oak wilt, Ceratocystis fagacearm (Bretz) Hunt., in North Anerica and for Dutch elm disease due to Ceratocystis ulmi (Buisw.) C. Mor.

The silvicultural operations carried out from the pole stage onwards may affect the disease situation. Brashing may cause wounds and encourage bark pathogens. Van vloten (1952) showed experimentally that large annual cankers on stems of Japanese larch were caused by the invasion of brashing wounds made in winter by phomopsis pseudorsugae (Phacidlopycnis pseudotsugae (Wils.) hahn.) and similar danage may follow removal of branches of Douglas fir in wincer (Zycha 1962).. In New zealand, Gilmour (1964) carried out four surveys of Diplodia pinea (Desm.) Kickx. infection of bark of Pinus radiata termed Diplodia whorl canker and showed $1 t$ could be initiated by green pruning wounds. In this case, unlike Phacidiopycnis, the damage was independent of season of pruning. An added consequence of the Diplodla infection was the entry of decay through the lesions.

During thinning operations workers tend to be in the woods for prolonged periods and the ground is often open enough in the later pole stages for lunchtime fires to be lit. Such fire sites may be colonized by Rhizina undulata which may then cause dying of groups of trees in plantations of susceptible conifers (Murray \& Young 1961). This is analogous 
to the killing of newly planted stock emanating from burned areas at the time of site preparation already referred $t o$ and represents the second phase in the rotation when such activity by Rhizina is possible. The activity is enhanced by the provision of stums as food sources at the same time.

The pole stage with its repeated thinning operations and provision of stums is especially significant in the entry of root and decay fungi to the stand. The iroportance of the conifer stump, as an entry for Fomes annosus (Fr.) Cje., especially on first rotation sites, is well-known and protection of such stumps against fomes has domina d much of the recent research work on this pathogen. It is likely that provision of sturps is generally favourable to the whole class of root and but rot fungi which can exploit their parasitic ability in colonizing a still living stump in advance of saprophytic competitors and then lead a saprophytic existence In the large mass of woody material provided. Such stums offer both points of colonization and means of persistence to these organisms.

Where thinning operations are neglected and intense competition develops in the stands, a disease problem may arise subsequent to insect attack. Cilmour (1964) has described attaks by Sirex noctilia $F$. on stands of various conifers in New \%eal and. In pine species particularly and especially pinus radiata, the less dominant trees in unthinned stands were badly affected by the Anylostereum sp. carried by Sirex and injected by it when ovipositing. The fungus causes a crown wilt and in inconspicuous white decay of the timber.

At the pole stage the proportion of heart wood in stem and root becones significant and this combined with the increasing number of Injuries to trees from operations in the forests, may affect the incidence of decay fung $i$ in the trees. The thinning slages represent the first time during the rotation that butes and root systems may be signiffcantly mechanically danged. The injuries depend on many factors but in general greater and heavier mechanization of harvesting has resulted in deeper wounding of buts and surface root systems. Many studies, especially in countries with older confferous plantations than Britain, have shown that a wide varlety of decay fungi can enter such wounds. In Britaln, Pawsey $\&$ Gladman (1965) analysed a large number of such wounds in spruce plantations and demonstrated the importance of these as entries for a number of decay fungl of which Stereum sanguinolentum $\mathrm{Alb}$, and Schw. ex Fr., was the most important. S. Sanguinolentum has been described as a primary colonizer of wounds, being able to tolerate the inhibitory conditions associated with freshly exposed wood, especially heart wood, but being unable to compete with organisas established on older wounds. Thus spectes such as $\underline{s}$. sanguinolentum are early colonizers of wounds. This is important where rotations are 
short, as in many coniferous crops. With other decay fung 1 there may be various intervals between provision of a wound entry and its colonization. Lavallie (1965) showed that on Picea mariana, Fomes pini (Thore) lloyd infected wound s that had been exposed for at least a year and possibly longer. various writers have described the late entry of fomes igniarius (L. ex Fr.) Kickx. into wounds. In a case described by Ftheridge (1961) investigating the succession of organisms in Populus trenuloides the fungus was not isolated until nineteen years and longer after the wound was available.

In the above cases there is often a simple and obvious relationship between disease incidence and stage of the crop. In other cases the relationship is obscure. Murray, Millar \& van der Kamp (1969) showed that Peridermium pini (Pers.) Lev. in northeast Scotland was extremely rare in plantations below ten years of age but that the incidence rose as the crop attained the pole stage. The reason for the pole stage being so badly affected is not known and in this respect the rust differs from other species such as cronartiun ribicola where losses in young stages due to juvenile susceptibility are severe.

THF. MATURF. STAGE

In the fourth stage of the rotation the trees reach a degree of malurity in which height and diameter growth decreases, crowns broaden and branches become stouter. In regularly thinned plantations the canopy is high with spaces between adjoining crowns. At this stage the well-ventilated environment in the crown is not generally favourable to leaf and needle infecting pathogens and their attacks are more dependent on fluctuating climatic conditions than at earlier stages. However, infections especially by obligate or strong parasiles, do occur. Hycosphaerella alphicoides often defoliates relatively old oak plantations in Furope and this may be associated with the high water content of the conidia of wildews, in general enabling them to germinate and invade tissue al lower humidities than many other pathogens. Lophodermella sulcigena (Rostr.) v.Hohn., again an obligate parasite, may cause conspicuous browning of older trees of Pinus nigra and similarly Rhabdocline pseudotsugae Syd. may cause thinning of crowns of Douglas fir but - such -atlacks on the older stages are more sporadic than on thicket stages.

Diseases of the bark may be found in the older stages, especially where trees are damaged or predisposed by ocher agencles. Possibly the best known in Britain is beech bark disease. Parker (1974) describes it occurring in stands from twenty-five years of age upwards but some of its worst effects are in older woods. The disease is a good example of the syndronic type of injury often suffered by the older stages. The rain fungus involved, Nectria coccinea Pers. ex Fr., 
invades bark damaged by the scale insect Cryptococcus fagi Bacr. and is itself followed by a variety of organisms including ambrosia beetles and decay fung 1 with Bjerkandera adusta (Willd. ex $\mathrm{Fr}$,) Karst. a very common species. In the worst cases the trees die and remain standing or are snapped off where decay has developed in the ster. In the last decade the increasing incidence of beech bark disease has affected the management of large areas of beech forest in northern France raised under the uniform system.

In the older stages of plantation growth, the trees are likely to have suffered many types of wounds. Some are due to natural causes but, due to the many harvesting and extraction operations carried out since the start of the pole stage, many are caused by man. Snow and wind breakage of crowns, death of branches by shading, especially in shade intolerant species such as oak, fire and animal damage, felling grazes to stems and wounds on butts and root systems following harvesting and road making operations, all offer avenues of infection for decay fungi which probably constitute the most iaportant group of damaging fungi at this stage. A factor of importance is the date when the injuries were caused. The earlier. in the rotation the injury and the izore pioncer the decay fungus, the greater the damage. The shorter rotations now favoured for many coniferous rotations have tended to reduce such decay losses which are posslbly more serious in broadleaved plantations with their longer rotations than in coniferous ones.

\section{CONCLUSION}

A large proportion of the factors controlling the incidence and impact of pathogenic fung 1 is concerned with the particular stage of the rotation. This relationship is probably best seen in even-aged plantations. In uneven-aged plantations and in natural regeneration stands ralsed by a relatively long regeneration pertod, the more complex canopy development would tend to obscure the relation between disease incidence and stage of growth.

Because of this; even-aged plantations are likely to prescnt simpler problems in understanding disease initiation and development than other types of forest stand: But even in this situation, although something may be known about the more obvious causes and pathological effects associated with the different stages of plantation development, a great deal of the more subtle and indirect relationships remain to be discovered.

Many of the controlling factors are affected by management decisions and silvicultural measures. It is probably no exaggeration to say that every managerial decision has an effect on the disease situation. Such decisions begin with the choice of site to be planted and the provision of 
planting stock and continue until the end of the rotation. There is no doubt that a proportion of disease control lies within the hands of the forest manager, although occasions arise when there is a conflict of interest between disease control and some other desirable objective.

Because of the association between crop development and disease and the relatively siople sitation in even-aged stands, the latter seem to offer the best situation for management to take a part in disease control.

\section{REFERENCES}

Anderson,G.W.(1972). Development of Hypoxylon mammatum cankers on artificlally shaded aspen stems. Forest Science, 18, 316-318.

Bakshi,B.K., Reddy,M.A.R. \& Singh,S.(1976). Ganoderma root rot mortality in Khair in reforested stands. European Journal of Forest Pathology, $6,30-38$.

Bassett,C. \& Gadgil,P.D. $(1 \overline{9} 75)$. Control of Dothistroma needle blight in New 7ealand. Second World Technical Consultation on forest diseases in insects. New Delhi. pp. $1-9$.

Bier,J.E.(1959). The relation of bark woisture to the development of canker diseases caused by native facultative parasites. Canadian Journal of Botany, 37, $781-788$.

Bloomberg,W.J.(1962). Cytospora canker of poplars: Factors influencing the development of the disease. Canadian Journal of Botany, 40, 1271-1280.

Boyce,J.S.(1961). Forest pathology. McGraw-Hill, New York.

Castellani,E.(1966). Report on two little-known poplar diseases. "Breeding pest resistant trees" (Ed. by H.D. Gerhold, E.J. Schreiner, R.E. McDerwat and J.A. Winteski), pp 89-96. Pergamon Press, Oxford.

Childs, T.W. (1963). Poria we1ril root rot. Phytopathology, 53, $1120-1136$.

F.theridge,D.E.(1961). Conditions affecting branch infection in aspen. Canadian Journal of Botany, 39, 799-816.

Gilmour,J.W.(1964). Survey of Diplodia whorl canker in Pinus radiata. Research leaflet 5 New Zealand Forest Service, $\overline{\mathrm{pp} \cdot \mathrm{l-4} \text {. }}$

Gremmen,J.(1977). The benefit of sllvicultural measures to prevent damage and disease in forest trees. European Journal of Forest Pathology, 7, 158-164.

Hopkins,J.C.(1963). Atropellis canker of lodgepole: etlology symptoms, and canker development rates. Canadian Journal of Botany, 41, 1535-1545.

Lavallie,A.(1965). Modes d'entrée des caries du tronc de 1'éplnette, natre. Phytoprotection, 46, 163-168.

Miller,T.(1972): Fusiform rust in planted slash pines: influence of site preparation and spacing. Forest 
Science, $18,70-75$.

Moriondo,F.(1975). Some features of pine blister rust Cronartium flaccidum (Alb. and Schw.) bint. in Italy. Second world Techinical Consultation on forest diseases and insects. New Delhi. pp.1-13.

Murray,J.S., Millar,C.S. \& Kamp,B.J. van der (1969). Incidence and importance of peridermium pini (Pers.) Lev. in Northeast Scotland. Forestry, 42, 166-184.

Murray,J.S. \& Young,C.W.T.(1961). Group dying of conifers. Forest Record 146 , Forestry Commission, L.K.

Parker,F.J.(1974). Beech bark disease. Forest Record \$96, Forestry Commission, U.K.

Pawsey,R.G. \& Gladman,R.J. (1965). Decay in standing conifers developing from extraction damage. Forestry Comission Forest Record lo. 54. Her Mesty's Stationery office. $25 \mathrm{pp}$.

Perrin,Re(1975). Le chancre du hetre à Nectria ditissima. Rapport annuel, Laboratoire de pathologie forestière, INRA-CNRF, France. Pp7-8.

Sk1lling, D.D.(1977). The development of a rore virulent strain of Scleroderris lagerbergi in New York State. Furopean Journal of Forest Pathology, $7,297-302$.

vloten, H. van (1952). Fvidence of host-parasite relations by experiments with Phomopsis pseudotsugae Wilson. Scottish Forestry, $6,38-46$.

Zycha,G.(196,2). 7ur Astung der Douglasie bei Schmuckreisegewinnung . Forstarchiv, 33,78 . 
THE DEVELOPNENT OF POPUI.ATIONS OF INSECTS

\section{By Myles Crooke}

Department of Forestry, Liniversity of Aberdeen, St. Machar Drive, old Aberdeen, $A B 9$ 2UU, U.K.

\section{SURMARY}

This paper considers the succession of different pests which may occur during the various growth stages of even-aged coniferous plantation crops. Only the temperate regions are considered and most of the specific examples quoted are British. The main conclusion reached is that the different growth stages do indeed have characteristic species or groups of pests which are likely to give most trouble. Sometimes, however, a completely unexpected and unpredictable outbreak may occur. other time scales apart from the rotation length itself, the creation of the total plantation resource and the $r$ ise and fall of the individual infestation, are briefly mentioned.

\section{RÉSUMÉ}

Dans cet article nous considérons la succession des differents effectifs de nuisibles qui affectent et accompagnent les différentes stades de croissance des forêts résineuses equiennes. Les examples donnés appartiennent au région temperées et la plupart sont typiquement britanniques. Nous arrivons a la solution suivante à savolr que des espèces ou groupes de nuisibles sont caracteristiques des différentes stades de l'évolution des peuplements. Pourtant, 11 se peut qu'une affection entièrement imprévisible et innattendue se développe. Nous mentionnons brièvement d'autres échelles du temps, qui ne sont pas directement liées à la longueur de la révolution, à importance des plantations et aux gradations de certatnes attaques individuelles. 


\section{ZLSAMMENFASSUNG}

Dieser Beitrag befasst sich mit der Sukzession verschiedener Schaderreger, die in entsprechenden Altersklassen gleichalter Nadelwälder auftreten kơnen. Berucksichtigt wird nur dic genassigle Klimazone und die Mehrzahl der Beispicle bezieht sich auf Britannien. Die wichtigste Schlussfolgerung ist, dass die verschiedenen Altersklassen tatsächlfch unter charakteristischen Schädlingen oder Schälingsgruppen leiden. Gelegentlich kommt es jedoch zu völlig unerwarteten Gradationen. Neben der Umtricbszeit sind andere 7.eitefnheiten erwähnt, (die Einfluss auf die Schádingspopulation haben mogen), wie die Gesamtdauer einer Massenvermehrung und die Verjüngungsperiode eines Bestandes.

\section{INTRODUCTION}

This paper deals with the developient of populations of forest insects in even-aged plantations. It is restricted to consideration of such population changes arongst pest spectes in conifer crops in the temperate zone with most of the examples being drawn from the United Kingdon scene with which the author is most familiar. It is clear that such plantations have a likelihood of supporting epidemic numbers and of being damaged by certain characteristic groups or species of pests at different times and stages of growth during the rotation. It is equally clear that any individual plantation may suffer damage from only a few, or one, or none, of the various groups or species of insects which $c$ an in succession erupt at different times during the existence of such a crop. It is highly probable that an analogous situation exists with respect to other phytophagous insects assoclated with other types of trees in different climatic regions, but this is not examined. There will, of course, be changes too in the densities of other groups such as parasites, predators and soll insects during the course of the rotation but these aspects are also omitted from consideration.

\section{ESTABLISHMENT}

The dominant factor influencing the level of insect damage in newly established crops is whether or not the area has recently carried a previous tree crop. In afforestation areas where there is no such recent history of tree cover the probability of insect damage to the newly planted crop is very low, in fact, almost non-existent, even though Chrystal (1937) does record instances where, in the welsh border countics, the species Aphelia viburnana F. and Fupithecia nanata Hubn. 
having almost totally destroyed their normal food supplies of bilberry (Vaccinium myrtillus L.) inflicted considerable damage to young Furopean and Japanese larches (Larix decidua Mill. and L. L. kaempferi (Lamb.) Carr), Douglas firs (Pseudotsuga menziesil (Mirb.) Franco), and Scots pines (Pinus sylvestris L.) There are similar records from Germany (Gauss 1960). In restocking areas, on the other hand, high populations of such damaging insects as Hylobius abietis L. and Hylastes spp. inevitably arise where the felling of the previous crop results in an abundance of stumps and slash providing breeding sites. In such situations damage can be intense and because epidemics are such a regular feature, the plants used for restocking Britain are routinely protected by being dipped in insecticide. According to King \& Scott (1975), restocking of coniferous forests by the Forescry Comission covers 3600 ha/yt and this figure will double by 1990 . The use of insecticidally dipped plants on such large areas could be avoided by delaying replanting, since the pest population naturally declines three or four years after the felling of the previous crop. Such an approach is undesirable, however, because it not only lengthens the rotation but also creates weeding problems.

THICKET

In the thicket stage a variety of pests begin to make their appearance with sap-sucking insects, defoliators and shoot border probably the most prodinent.

of the sap-suckers, the Adelgids are the most common and al though the results of their activilies are obvious as with for example, the discolouration and deformation of Douglas fir needles, caused by Adelges cooleyi Gill., the practical effect of their atcacks is typically of little importance. A major exception to this is A. nordmannianae (F.ck.) which so cripples the European silver firr, Abies alba Mill., in its young stages of growth that the cultivation of this tree has been almost totally discontinued in Britain despite the fact that it has many desirable silvicultural characteristics (Varty 1956). Another sucking insect which becomes comon in thicket stage crops, in this stage of Sitka spruce, Picea sitchensis (Bong) Carr., is the green spruce aphid, Elatobium abietinum Walk. which causes marked loss of older needles. Populations of both E. abietinum and Adelges spp. persist into stages of plantation development later than the thicket one.

Most species of defoliators are of limited importance at this stage in the growth of the crop, but here again there is one major exception namely, the pine sawfly, Neodiprion sertifer Geoffr., which produces very noticeable needle loss from scots and wore particularly lodgepole pine (Pinus contortal Dougl.) crops of about 2 to $3 \mathrm{~m}$ in height. The gregarlous caterpillars concentrate their attack on the older 
needles and in severe attacks the whole of the inner crown is stripped. Control has been achieved here and elsewhere (e.g. Bird 1953) by incroducing a virus disease which brings about a population collapse, accelerating the natural decline in numbers which occurs after a few years of high density.

The attack of shoot borers often becomes apparent during the thicket stage. For example, the dead twigs produced by the feeding of the larvae of Argyresthia laevigatella (H.-S.) on larix spp. may be numerous and conspicious but the economic irportance of this type of damage is slight. On pinus spp., however, the pine shoot moth, Rhyacionla buoliana Schiff., is a major pest producing various types of main stem distortion including forking and posthorn deformations. There have been recent heavy attacks in Eire, whilst in Canada Scots pine being grown for Christmas trees and $\underline{p}$. resinosa have suffered damage. Where attacks are repeated over a number of years very few leaders escape undaraged (Scott 1972).

\section{POLE AND THINNING}

During this phase of growth the predominant entomological possibility, now being increasingly realised in Britain, is that of large scale attacks by defoliators. These outbreaks may be caused by either introduced or native pests and it is somewhat surprisingly, the latcer which have so far inflicted most damage.

Commencing in the 1950's the pine looper, Bupalus piniarius L., has erupted on a number of occasions in different parts of the country and has had to be controlled with various insecti- cidal treatments (Crooke 1959; Bevan 1961). It is possible to predict the 11 kelihood of epidenics by monftoring the numbers of overwintering pupae in the soll and, if required, of the egg state in the pine crowns, so that creatments can usually be applied before serious damage is infliced on the affected crop. The pupal indices derived from annual surveys are of interest in revealing population trends in relation to time and Table l shows sequences of pupal counts from three forest areas.

The counts for Elveden, Thetford Forest, East Anglia, exemplify a situation where the population levels have been consistently low for some twenty years. The counts for Rendlesham, Thetford Forest, East Anglla, also have been low for most of that time but they did peak to $41.8 / \mathrm{sq}$.m in 1959 before dropping back to more normal levels. The population collapse that occurred in 1960 was due to a combination of an abnormally low field fecundity on the part of the moth and a very high level of parasitism of those eggs which were laid. The figures for Cannock Chase, Staffordshire, demonstrate a much more volatile situation where on average the densities have exceeded normal, enderic levels and where on two occasions in 1954 and in 1963, insecticidal intervention was 
$\leftarrow$

Table 1. Annual pupal indices for B. piniarius.

Year

1954

1955

1956

1957

1958

1959

1960

1961

1962

1963

1964

1965

1966

1967

1968

1969

1970

1971

1972

1973

1974

1975

1976

1977

1978
No. of pupae/sq.m

Mean for highest compartment
Rendlesham

4.4

3.2

8.2

6.4

6.6

1.8

0.6

0.6

0.8

1.2

2.4

1.2

0.8

0.8

2.8

3.2

2.4

0.8

0.0

0.8

$-$

1.2

0.4

0.0

0.8
41.8

0.6

0.4

1.2

3.2

10.0

3.6

0.8

0.4

4.0

2.4

2.8

0.4

0.4

0.4

0.8

0.4

2.4

4.0

3.6
Cannock

$281.9 *$

1.6

0.6

3.2

2.6

6.8

34.6

25.4

22.4

81.2 *

4.8

2.0

1.2

5.2

12.4

18.8

9.6

2.8

11.2

44.8

18.0

5.6

10.0

17.2

34.8

* Insecticidal treatment applied.

Figures for earlier years are number of pupae/sq.yard which, at lower population levels, do not differ appreclably from number of pupae/ $6 q \cdot m$.

required to reduce population numbers to acceptable levels. These sequences of figures show the short term and erracic fluctuations in pest population densities which may occur at any time during the approximately forty year period when the crops are in a vulnerable stage. The fact, however, that population trends of $B$. piniarius move in the same direction in the same year in forests in a given region or even throughout most of Britain, suggests that the underlying factors influencing population change are climatic,e.g. In 1959 virtually all forests in Britain recorded an increase in 
population density. Thesc may operate either directly by providing favourable conditions c.g. for adult flight and oviposition or larval feeding (Hussey 1957), or indirectly through mediation of the physiological condition of the host plant (White 197/4).

The larch feeding sawfly, Anoplonyx destructor Bens., is a common:and sometimes spectacular defollator in thinning stage stands (Crooke 1953). Much of the larval feeding, however occurs very lace in the growing season and has no effect on tree health or timber increment. The species is mentioned here, not because it is of any forest importance but because it illustrates rather well the change of status that may occur consequent upon the introduction of an insect to a region outwith its natural range. When Benson (1952) described the species from British material he stated that it was a rare insect on the continent of turope being known only from Finlatid, its native home. Thus, managerial practices in Britain have not prevented $A$. destructor from becoming endemic:. This is true of other sawily pests such as Gilpinia hercyniae HLg. on spruce and Cephalcia alpina Klug. on larch, which have reached damaging numbers on thinning stagc stands, mainly in wales (Billany, Borden \& Brown 1978; Brown \& Billany 1977). It seems clear therefore, that these types of incidents have become more frequent in the fairly recent past and tay be expected to recur in the future in thiming stage plantations.

During pole and thinning stages bark beetles become more common. The introduction of thinning operations and the fact that increasing tree height predisposes to wind damage provide favourable breeding conditions. Unless there is a natural catastrophe on a large scale, e.g. the storm damagc to woodlands in scotland caused by the gale of 31 January 1953, it is ustually possible to restrict bark beetle damage to low levels by sensible management practices. The situalion may, however, be complicated with species such as Ips cembrae Heer. Which is associated with larch and which.can disseminate varlous fungi capable of causing dieback and death of affected trees.

\section{FINAL, FELLING}

Most plantations in Britain are regenerated by clear felling followed by replanting and not by any system of natural regeneration. The production of much felled timber can favour the multiplication of bark beetles and of timber borers such as Trypodendron lineatum (Oliv.) and Hylecoctus dermestoides (L.) (Bletchly \&. White 1962), but if the felled material is removed from the forest quickly these problems can be avoided.. Sometimes, however, because of marketing hold-ups this cannot be done and it may be necessary to resort to chemical protection of the logs (Bevan 1962) Also of course, as mentioned earlier, the final felling of the mature crop provides favourable breeding conditions in stums for pests 
which can affect the young trees used for replanting.

\section{THF. UNEXPECTED}

Desplte the fact that there is a more or less clearly defined and well-established succession of different types of insect attack affecting plantations at different stages of growth, the possibllity nevertheless exists of some unexpected and unforeseeable infestation taking place. This possibility has recently been demonstrated in a most rearkable way by the outbreak of the pine beauty moth, Panolis flammea (D.+S.), on lodgepole pine crops in the north of Scotland. This outbreak which necessitated insecticldal treatment of some 4600 ha in 1978 appears to have had its observable origins in 1973 when larvae of this species were common in plantations of the Forestry Commission's Shin, Rumster and Naver forests (Stoakley 1977). The pine beauty is a well-known defollator of Scots pine crops, usually of more than twenty-five years of age in Central Europe. In the Scottish outbreak the attack was on a different species of host tree, occurred at an unusually early stage in the growth of the crop, took place near the northerly limit of the insect's range, and developed in a location where soll and cllmatic conditions are very different to those of areas where previous infestations have been recorded. The combination of all these abnormal factors made the incident entirely unpredictable. Another remarkable feature is the relative rapidity with which the situation developed. The first plantings of lodgepole pine in the area in question took place in 1958. It is possible, but not definttely established, that the pine beauty was present prior to 1958 in very small numbers on the few Scots pine which grow in Calthness and Sutherland. Thus the whole course of the establishment of the pest in the plantations and lis increase in numbers to damaging levels was compressed into a brief period of time: the first planting in 1958, first larvae found quite commonly in 1973, some defollation in 1974, no reports for 1975, defoliation apparent in June 1976, control unsuccessfully attempted in 1977 with a Bacillus thuringiensis preparation applied over 540 ha, and insecticidal treatment of 4600 ha in 1978 (results not yet known).

\section{CONCLUSION}

Three time scales operate in respect of the development of insect populations in plantations. The first and longest is that of the creation and maturation of the cotal plantation estate. During this usually long and rather ill-defined period opportunities arise, first, for the introduction of non-1ndigenous pest species and, second, for the dissemination of both native and exotic pests. Accompanying these processes in time is the establishment of increasingly large areas of plantations which potentially can support epidemics of 
different types of pests as the crops successively reach ages favourable to these pests. In Britain it is convenient to think of the start of this period as being around 1920. Before then there had of course, been much plantation establishment using mainly either the native scots pine or trees incroduced from elsewhere in Europe and this had had its effects upon the establishment, and spread of the forest insect fauma (e.g. Crooke 1957). The end of the first world thr however, saw the introduction of the major planting programmes to recreate forests." felled for wartime timber requirements. These programmes have continued up until the present and have become increasingly. dependent on conifers introduced from North America. Against this time scale and keeping in mind the essential features of forestry practice, it was possible to make some guesses or predictions about fucure development in the patcern of forest insect damage in the country as a whole (Crooke 1958) and in the main it appears that these have been real ised:

The second time scale is the life of the individual platitition itself and it is this aspect of the subfect which has formed the raln content of thls paper. The third time scale, which has been hinted at but not explored, is that concierned with the beginning and end of the single epidenic. In some cases the ecological factors contributing to the 'graduation' are obvious and well understood (e.g. $\underline{H}$. abietis); in other cases the changes in insect denslty during the course of the infestation can readily be recorded but are only imperfectly accounted for by ecological explanation (e.p. B: piniarius); and in yet others the ecological underlying influences operating on the arisal and terrination of the outbreak are little if at all appreciated (e.8. P. flammea). It is in this epidemiological area that much future research will have to be conducted.

\section{RFFFRENCES}

Beuson, $R, B,(1952)$. A new Anoplonyx destructive to larch in Britain. Bulletin of Entomological Research, 43, 543-547.

Bevan,D.(1961). Insecticidal control of the pine looper in Britain. I I Population assessment and fogging. Forestry, $34,14-24$.

Bevan,D.(1962). The ambrosia beetle or pinhole borer, Trypodendron lineatum 0l. Scottish Forestry, 16, 94-99.

Billany,D.J., Borden,J.H. \& Brown,R.M.(1978). Distribution of Gilpinia hercyniae (Hymenoptera, Diprionidae) eggs within Sitka spruce trees. Forestry, 51, 67-72.

Bird,F.T.(1953). The use of a virus disease in the biological control of the Furopean pine sawfly. Canadian Entomologist, $.85,437-446$.

Bletchly,J.D. \& White,M.G.(1962). Significance and control of altack by the ambrosia beetle Trypodendron lineatum 
(Oliv,) (Col. Scolytidae) in Argyllsire forests. Forestry, 35, 139-163.

Brown,R.M. \& Billany,D.J.(1977). The web splinning larch sawfly Cephalcia lariciphila Wachtl. (-C. alpina Klug.). Report on Forest Research, London, pp. 35 .

Chrystal,R.N.(1937): Inscets of the British Woodlands. Frederick Warne + Co. Ltd., London and New York.

Crooke,M.(1953). Some notes on Anoplonyx destructor Bens. Bulletin of Entomological Research, 44, 77-81.

Crooke,M.(1957). A bricf review of the conifer feeding sawflies. Zeitschrift für angewand te Entomologic, 41, 179-183.

Crooke,M.(1958). Some aspects of forest entomology in Britain. Proceedings 10th International Congress on Entomology (1956), 4, 233-239.

Crooke,M. $(195 \overline{9})$. Insecticidal control of the pine looper in Great Britain. I. Aerial spraying. Forestry, 32, 166-196.

Gauss,R.(1960). Tortrix viburnana F. erneut als Forstschadding. Zeitschrift für angewand te Entomologie, $47,46-51$.

Hussey,N.W.(1957). Effects of the physical environment on the development of the pine looper, Bupalus piniarius. Report on Forest Research, London, pp. $\overline{11-128}$.

King,C.J. \& Scott,T.M.(1975). Control of the large plne weevil and bark beetles of the genus Hylastes. Forestry, 48 , $87-97$.

Scott,T.M.(1972). The pine shoot moth and related species. Forestry Commission Record, 83.

Stoakley,J.T.(1977). A severe outbreak of the pine beauty woth on lodgepole pine in Sutherland. Scottish Forestry, 31, 113-125.

Varty,I.H.(1956). Adelges insects of silver firs. Forestry Commission Bulletin 26. Edinburgh.

White,T.C.R.(1974). A hypothesis to explain outbreaks of looper caterplliars with spectal reference to populations of Selidosema suavis in a plantation of plnus radiata in New Zealand. Decologia, 16, 279-301. 


\section{September 6, 1978}

\section{NUTRITION}

Cha 1rman: K. Parkin

The nutrient budgets of even-aged forestst

H.G. Miller

Decomposition and nutrient

release in even-aged

plantations.

0.W. Heal

Biological means of Improving

nutrient uptake in trees.

P.P. Korqanik

Current fertilizer use in

plantations.

J. Atterson 


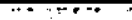


THE NUTRIENT BUDGETS OF EVEN-AGED FORESTS

BY HUGH G. MIILER

Macauly Insticute for Soil Research, Department of Pedology, Craigiebuckler, Aberdeen, $A B 92 Q J, U . K$.

\section{SUMMARY}

Nutrients are introduced to a forest in rainwater, by the trapping on tree surfaces of aerosols and dust, through adsorption of gases and by nitrogen fixation. The input from sources other than rainfall is difficult to assess but for some elements may be as large as that in rainwater, and it is probable that the total input from all sources is sufficient to compensate for losses through harvesting. Irrespective of the mode of introduction, nutrients are very efficiently retained within forests, to the extent that, provided sensible management practices are followed, high inputs in fertilizer or in sewage effluent are unlikely to contaminate neighbouring waterways. However, this same ability could mean that forest are peculiarly susceptable to air-borne pollutants.

Within the ecosystem nutrients are taken up and released by the trecs, the rate of transfer varying greatly with species, growth rate and size of the crop. Nutrients become progreesively immobilized both in the crees and in the humus, and immobilization of nitrogen way even reach such proportions that growth declines. In gencral. it seems that, provided the nutrient capital of the site is sufficient to enable establishment, nutrient deficiencies later in the rotation result from changes in the ability of the soil to supply nutrients, rather than from changes in demand by the crops.

Nutrients move within the trec as a result of (i) current nutrient uptake, (ii) the moving into temporary storage of recent uptake and its. subsequent mobilization during the growing season, (iii) the withdrawal from agelng 
tissues, and (iv) should there be an insufficient supply from the first three sources, the mobilization of nutrients accumulated during previous years. This latcer may represent use of stored excess nutrient, or may result in the sacrifice of older tissues.

RÉSUMÉ

Les éléments nutrilifs sont introduits dans la forêt par 1'eau de pluie; les cimes des arbres arrêtent les aérosols et les poussières, absorbent les gaz et les arbres fixent l'azote. L'apport d'eléments nutritifs provenant des sources autres que les chutes de pluie est difficile à évaluer mais dans certains cas 11 peut être aussi important que celui de l'eau de pluie et il est probable que l'apport total, provenant de toutes les sources, suffirait a compenser les pertes dûes aux coupes. Quelque soit le rode d'introduction. de ces éléments nutritifs, ceux-ci sont retenus d'une manière tres efficace par la forêt au point que, si $l^{\prime}$ on maintient une forme d'exploitation raisonnable, l'apport d'engrais ou d'eaux résiduaires ne seraic pas une source de contamination des cours d'eaux avoisinants. Cependant le procéssus decrit plus haut rendrait les forêts particulièrement susceptibles aux polluants portés par l'air.

Au sein de l'écosystème, les éléments nutritifs sont absorbés et relibérés par les arbres. Le taux de transfert varie beaucoup entre les différentes essences et l'age des peuplements. Les eléments nutritifs sont progressivement immobilisés par les arbres et par l'humus; l'tmobilisation de l'azote peut attelndre de telles proportions, qu'elle entraine un déclin de la croissance. En général, il semble que, si le capital d'éléments nutritifs de la station suffit à assurer la reprise à la plantation, les carences nutritives qui apparaissent plus tard résultent plutôt de l'incapacité du sol à fournir les éléments nutritifs, que des besolns accrus du peuplement.

Le mouvement des éléments nutritifs dans 1 'arbre est le résultat des cas suivants: (1) l'absorbtion courant d'éléments nutritifs, (2) le stockage remporaire des élétents nutritifs et leur mobilisation pendant la période de croissance, (3) le retrait d'éléments nutritifs 
de tissus âges et, (4) au cas où ces trois premiêres sources seraient insuffisantes, la mobilisation des éléments nutritifs accumulés antérieurement. Dans ce dernier cas 11 peut $s^{\prime a g i r}$ soit de l'utilisation d'un excédent d'éléments nutrltifs, soit du sacrifice de tissus plus âgés.

\section{ZUSARMENFASSUNG}

Nährstoffe gelangen in den wald im Regenwasser, durch Auskammen von Aerosolen und Staub, durch Adsorption von Gasen und Bindung von Stickstoff. F.s ist schwierig, den Nährstoffeintrag durch Gase, Aerosole und Staub abzuschatzen. Er dürfte jedoch bei manchen Elementen in ähnlicher Hohe wie der durch Regenwasser liegen. Insgesam sind die Gewinne aus allen quelien wohl ausreichend, um die verluste durch Ernte auszugleichen. Nährstoffe werden, unabhang $1 g$ von der Art ihrer Zufuhr, in den wäldern sehr wirkungsvoll gespeichert. Daher sind bei. richtiger Handhabung selbst hohe Zufuhren von Düngenitteln oder Abwasser möglich ohne Beeincrächti gung benachbarter Gewässer. Aus den gleichen Grund ist jedoch denkbar, dass der Wald besonders für Verschmutzung durch die Luft anfälig ist.

Innerhalb des ökosystems werden die Năhrstoffe von den Baumen aufgenommen und abgegeben. Die Unsatzrate ist abhängig von Art, Wuchsleistung und Alter der Baure. Die Nahrstoffe werden in zunehmenden Masse sowohl in den Bämen als auch im Humus festgelegt; dabei kann die Fixierung von Stickstoff solches Ausmass erreichen, dass das Wachstum zurückgeht. Im. allgemeinen wird bel ausreichend hohen Năhrstoffvortaten des Standorts Nährstoffuangel während der Umtriebsze1t. cher infolge Veränderung in der Nährstoffnachlieferung des Bodens aufreten als durch Verănderungen im Bedarf der Pflanzen. Die Nährstoffbewegung im Baum ist bedingt durch 1) laufende Nahrstoffaufnahme, 2) vorübergehende Speicherung und nachfolgende Mobllisierung während der Wachstumsperiode, 3) Rückzug aus alternden Geweben und 4) Mobilisierung von in früheren Jahren gespeicherten Nährstoffen ito Falle ungenugenden Angebots nach 1)-3). Letzteres kann bedeuten, dass gespeicherte überschussmengen aufgebraucht oder aber ältere Gewebe geopfert werden. 


\section{INTRODUCTION}

The fact that tree growth can be reduced if there is an insuffictent supply of any of at least twelve essential nutrient elements was clearlydemonstrated by early studies using pot culture (e.8. Aldrich-Blake 1930; Addors 1937; Mitchbel1 1939; Ludbrook 1940; Swith 1943) and defictencies of certain of these elements were subsequently identified under field condtions (sec reviews of Tamm 1964; Mustanoja \& Leaf 1965; Stone 1968; Baule \& Fricker 1970). The available literature on forest studies, however, is largely based on results from extensive fertilizer trials and contains confusing contradictions. In seeking to find some order, or framework, on which to build hypotheses, the published work on nutrient dynamics within forests, particularly studies of the full nutrient-cycle (e.g. Rerezov 1956; Ehwald 1957; Ovington 1959 and 1962; Will 1959 and 1964; Smith, Nelson \& Swltzer 1963; Miller 1963) has had to be studied. This, in turn, has led to a new generation of experiments, established mainly during the $1960^{\circ} \mathrm{s}$, that were designed to investigate, inter alia, the effect of management practices on nutrient cycles and their controlling influence on tree growth. Such studies have considered the effects of fertilizer applications either alone (e.g. Wittwer, Leaf \& Bickelhaupt 1975; Miller, Miller \& Pauline 1976; Turner 1977; Stone \& Kszystniak 1977) or combined with thinning treatments (e.g. Weetman 1962 and 1967) - the replacement of tree species (e.g. Llich et al. 1976; Nihlgard 1971), the effects of harvesting (e.8. Weetman \& Webber 1972; Malkönen 1974 and 1977), the effects of burning (c.8. Kimmins \& Feller 1976) and, more recently, the effects un, or of pollution (e.g. Tamm 1973, 1976 and 1977).

Alchough definitive results have still to appear from some of the more ambitious studies started in recent years, a considerable amount of information has become avallable over the past decade. This is, therefore, a convenient point at which to review our knowledge of nutrient cycles in forests and to consider (a) whether it can provide a framework within which to asses the significance of results from other studies on limited parts of the system and (b) whecher the picture that is emerging will give any practical assistance to the forest manager.

Nutrient cycles occur at three interrelated levels: (i) the geochemical cycle, which contributes nutrients to and removes them fron the forest site, (ii) the cycle transferring nutrients between zones of accumulation within the ecosystem and (iii) the physiological cycle within the tree.

\section{GEOCHEMICAL CYCLE}

Nutrient elenents enter a forest sice in rainwater, by the trapping on tree surfaces of aerosols and insoluble dust, through adsorption of such gases as sulphur dioxide, ammonia 
Table 1. Weights of sodium, calcium and potassium $(\mathrm{kg} / \mathrm{ha} / \mathrm{yr}$ ) in rainfall at two coastal and two inland sites in Scotland during 1977 (author's data).

$\begin{array}{crrrr}\text { Element } & \begin{array}{l}\text { West } \\ \text { Coast }\end{array} & \text { Inland } & \text { Inland } & \begin{array}{r}\text { East } \\ \text { Coast }\end{array} \\ \text { Na } & 41 & 23 & 21 & 45 \\ \text { Ca } & 10 & 9 & 8 & 10 \\ \text { K } & 1 & 4 & 2 & 2 \\ \text { Rainfall (m) } & 1530 & 1620 & 1020 & 1120\end{array}$

and oxides of nitrogen and by biological fixation of nitrogen. Input in rainwater has attracted attention for many years (e.g. Miller 1905; Freeman 1924; Ingham 1950; Madgwick \& Ovington 1959; Miller 1961; Actiwlll 1966; Dovland, Joranger \& Semb 1976). Values range widely, reflecting factors such as the amount of rainwater recelved and distance from the sea or from possible terrestrial sources of contamination (Table 1). A variecy of evidence points to the sea as the main source of most elements in rainwater and amounts generally decrease on moving inland ( $0^{\prime}$ Carrol \& McCarthy 1973; Turner \& Kel1y 1973; Probert 1976; Hingston \& Gallitis 1976). The sea is probably also the main source of soluble salts in trapped aerosols (Yaalon \& Lomas 1970; Hitchcock 1976) and rate of input of these to the forest varies not only with concentration in the air, but also with the nature and spatial arrangement of the receiving surfaces (Chamberlain 1975). Placing an inert wind-filter over a rain gauge results in an increase in the concentration of many elements in the collected rainwater (Nihlgard 1970; Clayton 1972; Azevedo \& Morgan 1974; Schlesinger \& Reiners 1974), the effect varying with location of the gauge (Table 2). This aerosol contribution is difficult to assess, but recent studies in pole-stage in Germany and Scotland (Table 3) suggest it is of comparable magnitude to the amount introduced in rainwater.

Over land masses and at a height of more than $2 \mathrm{~km}$ over oceans aerosols mainly consist of insoluble mineral (Rodhe, Persson \& Akesson 1972; Gether, Lunde \& Markal1 1976) and organic particles (Gether, Gjos \& Lunde 1976; Lunde et al. 1976) of continental origin (Delany, Pollock \& Shedlovsky 1973). A dramatic example of long distance transfer is the Sahara derfued dust that has fallen as 'red raln' as far north as the Isle of Skye (Pitcy.1968; Baln \& Talt 1977). In addition, there is a short-range transport of dust (Tamm \& Troedsson 1955; Miller \& Williams 1977) that is again almost entirely soil-derived. Virtually no information exists on the quality of nutrients introduced in dust frow all sources, but certalnly the amount of dry particles trapped by trees is 
Table 2. Weights of sodium, calcium and potassium collected in rain gauges beneath inert wind-filters polyethylene-coated wire mesh expressed as a percent of the weights of these clements collected in standard rain gauges. Results are taken from the four sites shown in Tables 1 and over the same year (author's data).

Element

West
Coast

Inl and

Inl and

Ease

$\mathrm{Na}$

425

185

100

Coast

$\mathrm{Ca}$

190

115

150

445

K

465

110

200

500

Table 3. Inputs $\left(\mathrm{K}_{8} / \mathrm{ha} / \mathrm{yr}\right)$ in rainwater and in. aerosols estimated for a beech stand in central Germany (Mayer \& Ulrich 1974) and for a coastal stand of Corsican pine in Scotland (Miller, Cooper \& Miller 1976).

$\begin{array}{lcrcc}\text { Germany } & \text { Na } & \text { Ca } & k & M g \\ \text { Rainwater } & 7 & 13 & 4 & 3 \\ \quad \text { Aerosol } & 3 & 6 & & \\ \begin{array}{l}\text { Scotland } \\ \text { Rainwater }\end{array} & 25 & 3 & & \\ \text { Aerosol } & 15 & 4 & 7 & 2 .\end{array}$

greater than that deposited on open ground (Chamberlain 1975; Slinn 1977). Tamr (1958) has suggested that dust may be an irportant source of phosphorus which, although initially insoluble, can be mobilzed by weathering.

Turbulent transfer to and impaction of gases on forest vegetation is now the object of a considerable amount of investigation in relation to the input of pollutant gases. Direct measurement of the inpur of gaseous compounds is very difficult. Deposition is usually assumed to be proportional to the concentration of the gas in the surrounding atmosphere, the constant of proportionality being called the deposition velocity'. Values for the deposition velocity of sulphur dioxide are around 0.4 to $0.8 \mathrm{~cm} / \mathrm{s}$ (Fowler \& lnsworth 1974; Bache 1977; Garland 1977), which is a ragnitude greater than the est imated deposition velocities of typical atmospheric. particles in dry air (Chamberlain 1975). Sulphur dioxide and gaseous ammonia may also be absorbed directly by the soil (Hall \& Miller 1911; Ingham 1950; Allison 1955; Paul 1976). Furthermore, Tamm (1953) has pointed out that the acid moss 
Table 4. Concentrations (mg/1) of elements in rainwater, soil leachates and drain-water collected over three months beneath a crop of Sitka spruce in east Scotland (author's data).

\begin{tabular}{|c|c|c|c|c|c|c|c|c|}
\hline & N & $P$ & $\mathrm{k}$ & $\mathrm{Ca}$ & Pg & Na & 5 & C! \\
\hline $\begin{array}{l}\text { Throughfall and } \\
\text { stenflow } \\
\text { leachate }\end{array}$ & 8.0 & 0.235 & 5.7 & 7.4 & 2.2 & 9.6 & 8.0 & 22 \\
\hline - below hurus & 3.1 & 0.044 & 2.3 & 5.3 & 0.8 & 7.0 & 5.1 & 7 \\
\hline $\begin{array}{l}\text {-below root zone } \\
\text { ater draining }\end{array}$ & 1.1 & 0.004 & 1.3 & 3.7 & 1.2 & 44.7 & 19.9 & 15 \\
\hline ron the site & 1.6 & 0.003 & 0.8 & 6.6 & 2.6 & 13.9 & 1.3 & 13 \\
\hline
\end{tabular}

flora of coniferous forests absorbs ammonia from the atmosphere, and as nitrogen in gosses is relatively readily rineralized on decomposition (Zöltl 1960) this ray be an important source for tree growth in boreal forests (Weetman 1967).

There is also an accretaion of nitrogen through biological fixation. The presence in a forest of leguminous or other nodulated species, such as Casuarina (Bond 1957) or Podocarpus (Becking 1965), has long been known to be beneficial (Tarrant \& Yiller 1963; Richards \& Bevege 1967; Gadgil 1971 and 1977), and large accretions of nitrogen have been recorded beneach pure stands of black locust (Ike \& Stone 1958) and red alder (Turner, Cole \& Gessel 1976). Moreover, Richards (1964) has pointed to many examples of nitrogen accretion in coniferous forests containing no nodulated species. Suggestions that this fixation may be associated with mycorrhizae are probably unfounded (Richards \& Voigt 1963; Harley 1969) and it seems to result from free-living organisms within the soll (Reddy \& Knowles 1965; Roskoski 1975) and, perhaps, in the phyllosphere (Jones 1970). By extrapolation from laboratory studies knowles (1965) estinated annual rates of nitrogen fixation of from $5-35 \mathrm{~kg} / \mathrm{ha}$, although more recent studies under field conditions seer to be suggesting that the lower figure is the more likely (see also Kormanik, this volume).

The forest floor and surface soll horizons are remarkably effective at retaining nutrients received in rainwater (Table 4). Comparisons of water reaching the forest floor with that of drainage from the bottom of the profile suggest a net retention of nitrogen and phosphorus within the soll (Cole \& Ballard 1970; Grier \& Cole 1972; Fredrikson 1972; Gessel, Cole \& Steinbrenner 1973; Nishimura 1973; Mayer \& Ulrich 1974; Heinrichs \& Mayer 1977; Likens et al. 1977; Staaf \& Berg 1977; Feller 1977) and although the soil may show a net loss of many cation species, Mayer \& Ulrich (1977) have calculated that, 


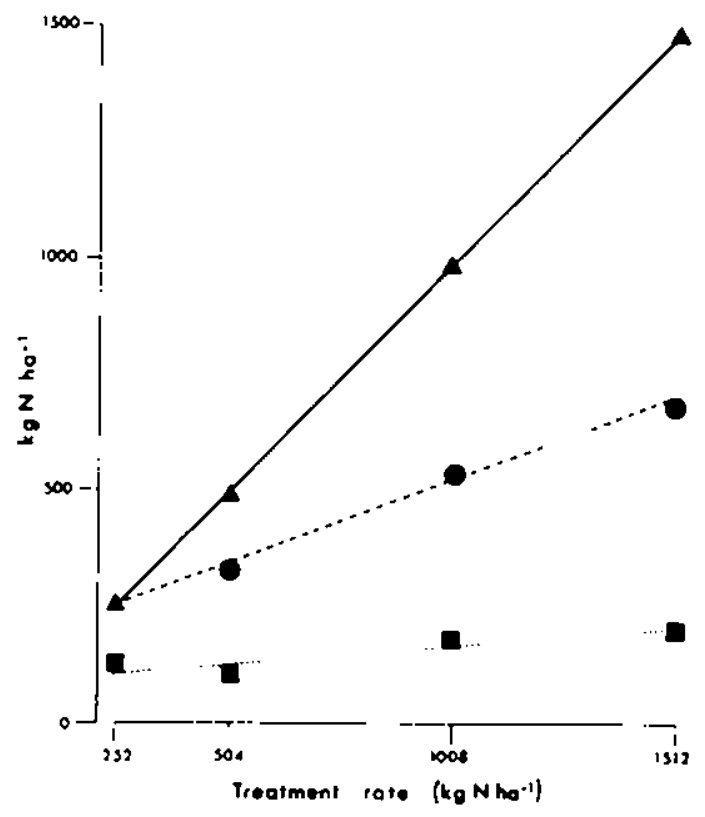

Fig. 1. Retention of fertilizer nitrogen within a crop of Corsican pine ( $\bullet$ ) and retention in the assoclated soil organic layers ( $\square$ ) in comparison to the weight of nitrogen applied ( 4 ). (Miller, Miller \& Pauline 1976).

when account is taken of increasing accumulation within the tree crop, only sodiun of those elements shown in Table 4 decreases in the ecosystem. In this respect forestry seems to be more effective than other forms of land use (Dilion 8 Kirchner 1975). Forests also have the ability to retain large amounts of fertilizer applied nutrients. Studies with is $\mathrm{N}$ suggest total recovery of nitrogen when applied at standard races to raw humus (Overrein 1970), and repeated sampling in a Corsican pine plantation before and after a three-year period of a nitrogen fertilizer application revealed very high rentention rates ( $F i g .1)$. Similar results have been quoted by Morrison \& Foster (1977) for urea fertilized jack pine. However, if a large amount of nitrate is applied, leaching losses may occur (Kreutzer \& Welger 1974). Fertilizer phosphorus is also recalned efficiently by most forests, although there is some recent evidence of leaching of this element in drained peat (Malcolm et al. 1977; Cuttle \& Malcolo, personal communication; see also Fig. 2), and potassium, although very moblle, is efficlently retained by 

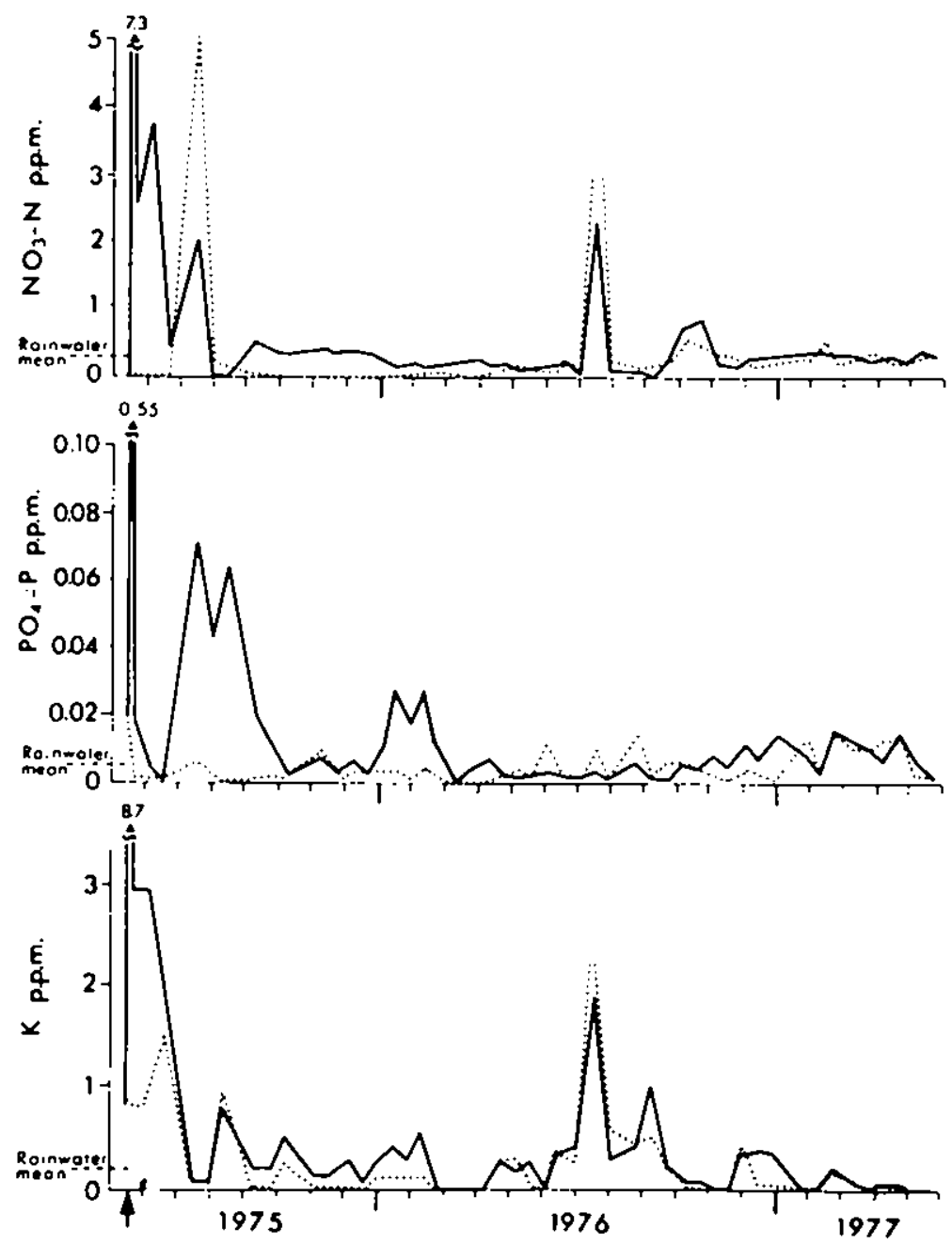

Fig. 2. Comparison of levels of nitrate, phosphate and potassium in ditch water on entering (.......) and leaving $(\longrightarrow)$ a Sitka spruce plantation ( $25 \mathrm{yr}$, top height $11.5 \mathrm{~m}$ ) to which amonium nftrate, rock phosphate and potassium chloride were applied at the outset of period (vertical arrow). Soll: peaty-gley. (The W.H.O. suggests that nitrate in drinking water should not exceed 11.3 ppo as nitrogen.) 
incorporation into the rapid cycle of this element (Miller et al. in press; Stone \& Kszystniak 1977).

Practlcal significance

In 1955 Rennie calculated that the nutrient drain associated with timber harvesting in managed plantations would lead to "soil degradation and seriously reduce production" (Rennie 1955). Subsequently ovington (1962) pointed out that the mean annual removal in cree trunks is largely balanced, at least for elements other than nftrogen and phosphorus, by the nutrient input in precipitation - an observation that has since been amply confirmed using more precise data (e.g. Weetman \& Webber 1972; Foster \& Morrison 1976). Whether the further drain associated with practices such as slash burning (Harwood \& Jackson 1975; Kimuins \& Feller 1976; McColl \& Grigal 1977) and complete- or whole-tree utilization (Keays \& Hatton 1976) would then be balanced by the inputs chrough impaction of acrosols and gases and chrough nitrogen fixation, remains an open question. Burning, which mainly releases nitrogen (Robertson \& Davies 1965; Kimins \& Feller 1976), is thought not to cause irreparable loss if properly managed (DeBell \& Ralston 1970; Wollum \& Davy 1975; Klemmedson 1976). Although there is less agreement about the consequences of harvesting the tree crowns as well as stems, recent data does confirm that this practice results in a marked increase in nutrient removal (Table 5 ), and it has been suggested that on sites of low fertility it may be necessary to balance the loss by fertilizer application (Weetman \& Webber 1972; Whice,E. 1974; Måkönen 1974 and 1976; Wells \& Jorgensen 1977). However, there is still too little information on the input of nutrients, other than that in direct precipitation, to obtain a clear picture.

Management practices, in particular clearfelling, may result in increased leaching of many nutrients (Cole \& Gessel 1965; Fredrlksen, Moore \& Norris 1975; Popovic 1975; Nykuist 1977). In the mixed hardwoods of New England it has been shown that, whereas in the undistributed stand nutrients were conserved and losses to lower soll layers were minimized, clearfelling was followed by a marked increase in the leaching of most elements: The reappearance of forest vegetation, however, was followed by rapid stabilizing of the nutrient cycles, leaching returning almost to pre-treatment rates (Likens et al. 1977; Bormann, Likens \& Melillo 1977; Likens et al. 1978). An essentlally simllar patern can occur following application of fertllizer, for although there is an overall high retention of applied nutrients, concentrations in water leaving the slte may increase for a period after application, largely as a result of the fertilizer that falls directly into the drainage ditches (F1g. 2). The most important effect of this is probably the pollution caused in neighbouring waterways (Tamm \& Wiklander 1972; Tamm 1973; Kreutzer \& Weiger 
Table 5. Comparison of the nutrient removal resulting from harvesting stem alone, with that resulting from removal of all above-ground components of tree for both Corsican pine and Sitka spruce growling in Scotland (author's daca).

$\mathrm{Kg}$ element per $\mathrm{M}^{3}$ of stem wood and bark

Pine

Spruce

$\begin{array}{lllllll} & \mathrm{N} & \mathrm{P} & \mathrm{P} & \mathrm{N} & \mathrm{P} & \mathrm{K} \\ \text { Stem alone } & 0.46 & 0.04 & 0.19 & 0.52 & 0.05 & 0.22 \\ \text { Whole Tree } & 1.38 & 0.12 & 0.62 & 2.17 & 0.23 & 0.78\end{array}$

1974; Bengston \& Kilmer 1975).

Recently the ability of forest solls to retain chemical elements, and so purify the water passing through them, has been explotted as a means of sewage effluent disposal (Sopper 1975). However, the obverse of this abllity is that forests are pecultarly susceptible to atmospheric pollution, and there is now considerable concern about the effects of increasing inputs of sulphur and nitrogen to forests (e.g. Likens \& Bormann 1974; Dovland et al. 1976). Sulphur, as sulphates and sulphites in acid rain, way have a direct effect on trees (Tam \& Cowling 1977) or an indirect effect through inducing changes in the soll (Ulrich 1975; Abrahamsen et al. 1976; Tamm 1976) - although there 1s, as yet, very little definitive information on elther. Certainly large amounts of sulphur can be Introduced into forests (Ulrich et al. 1976), but this has to be viewed against the normal rate at which sulphur cycles within the ecosystem and also the complex interactions that contribute to the buffering characteristics of a so11. Claims that tree growth has been reduced through acid rain (Jonsson \& Sundbers 1972) are difficult to confirm (Abrahamsen et al. 1976) and way have been confused with variations in growth in response to regular variations in climatic factors (Miller \& Cooper 1976). Indeed it is easier to substantiate suggestions that trees show a postitive growth response to enhanced inputs of nitrogen pollutants from the atmosphere (U1rich 1975). However, the proven ability of forests to retain most chemical elements means that pollution-derived inputs be viewed with concern, and their effects investigated.

\section{CYCLES WITHIN THE ECOSYSTEM}

Within the ecosystem, nutrients move between the three zones of accumulation represented by the living vegetation, the soll organic layers and the lower soil horizons.

Since rate of nutrient uptake by trees differs with specles and soll conditions (Table 6), and even within species shows a considerable variation both wh growth rate and 


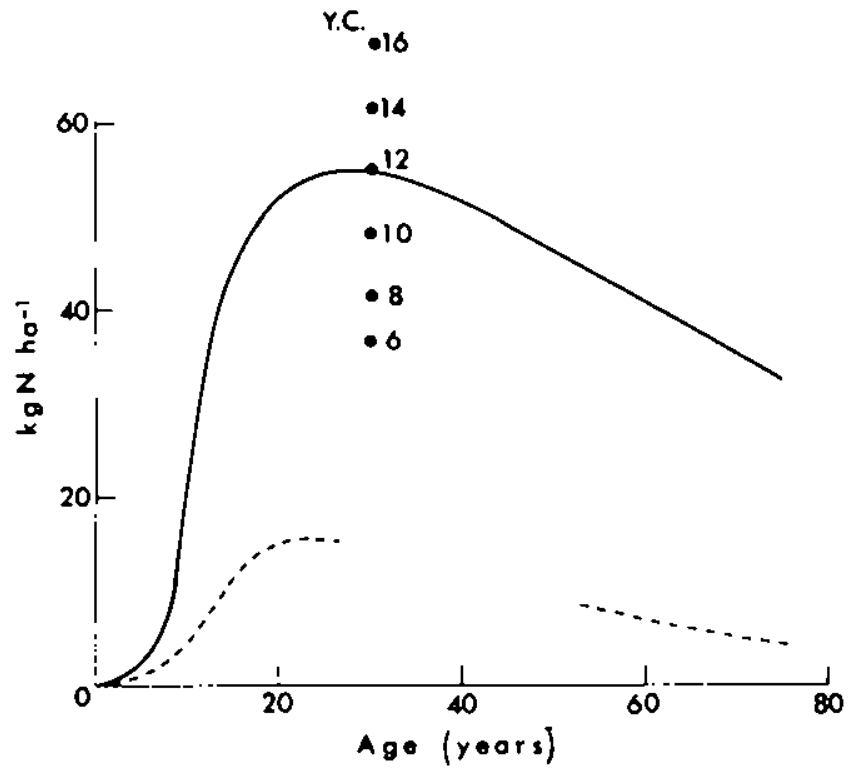

Fig. 3. Variation in nitrogen uptake with growth rate (Y.C.= yield class, Hamilton \& Christie 1971) and age for one growth rate; broken line shows rate of net increase in accumulation of nitrogen at this growth rate. Values predicted by models derived for Corsican pine (Miller, Miller, \& Pauline 1976 , together with unpub, results.)

developmental stage of the crop (Fig. 3), values of uptake, taken alone, have little meaning. As trees sirultaneously release nutrients, the net proportion of the uptake that remains to accumale within the crop is low and generally ranges from 8 to 38 per cent (Malkonen 1974, 1977; Miller, Miller \& Pauline 1976). Desplte this, the amount of nutrient, particularly nitrogen, that eventually accurulates within trees can be large, and on poor sites may represent a significant fraction of the total capital of the site.

Nutrients are released by trees through litter fall, crown leaching, root death and root exudation. Litcer fall is composed predominantly of dead leaves, the amount of which is broadly proportional to growth rate (Bray \& Gorham 1964; Miller, Cooper \& Miller 1976). Presumably the release of organic matter and assoclated nutrients by root systems is also proportional to growth rate, but little information exists. Orlov (1955) considered that in young contferous crops organic mater turn-over below ground is about half of that above ground. More recently $1 t$ has been suggested that the 
年

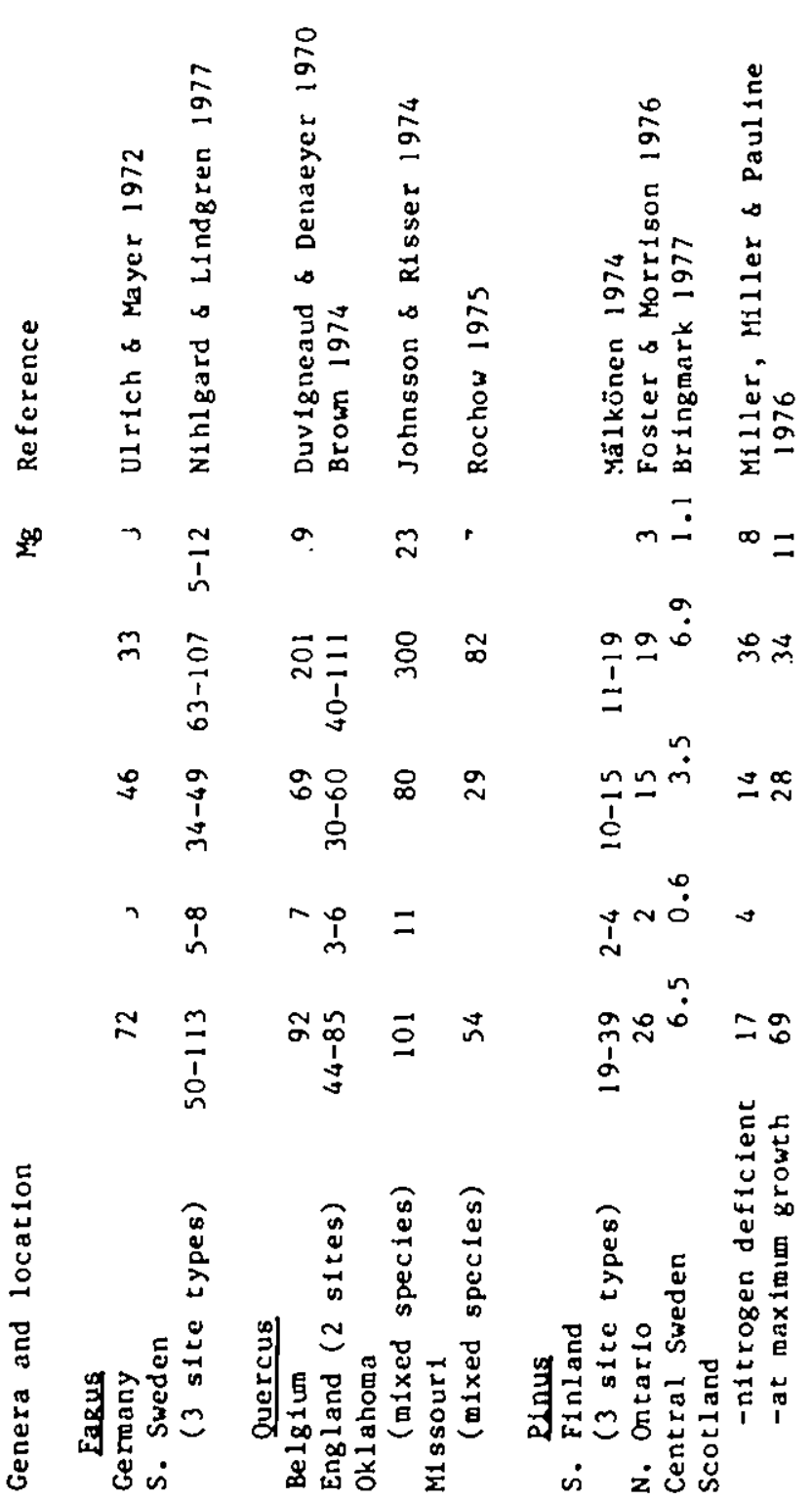


ratio of release of an element to total wefght accumulated is similar for the root system and the shoot syster (Newbould 1968; Andersson 1970; Whittacker \& Woodell 1971; Whittaker et al. 1974). Whether this also accounts for release in root exudates is not clear, but certainly, root exudation can release appreciable quantities of nutrients, in particular potassium and calcium (Smith 1976).

Table 7. Release in litter fall and through crown leaching measured in Corsican pine, $\mathrm{Kg} / \mathrm{ha} / \mathrm{yr}$ (Miller, Cooper \& Miller 1976).

$\begin{array}{lcccrr} & \mathrm{N} & \mathrm{P} & \mathrm{K} & \mathrm{Ca} & \mathrm{N} \\ \text { Litcer fall } & 35 & 3 & 8 & 18 & 3 \\ \text { Crown leaching } & \text { trace } & \text { trace } & 6 & 2 & 3\end{array}$

For some elements, release through crown leaching can be as important as that through 11 teer fall (Table 7). Rate of crown leaching varies with season, with the arount, nature and acidity of the incident precipitation, with element concentrations in the tree foliage and with species (Miller 1963; Eaton, Likens \& Bormann 1973; Mahendrappa \& Ogden 1973; Pảivänen 1974; Fairfax \& Lepp 1975; Wood \& Bormann 1975; Abrahamsen et al. 1976; Miller, Cooper o Miller 1976). Moreover, the relative magnitude of the leaching of different elements changes with species. Thus, Nihlgard (1970) found that whereas phosphorus and sulphur are not readily leached from beech, these elements are among the most easily removed from a Norway spruce canopy; a similar difference by the leaching of phosphorus has been noted between Corsican pine and Sitka spruce (Miller \& Williams 1973).

Accumulation of nutrients, particularly of nitrogen and phosphorus in the soil organic layers beneath many coniferous species can be comparable to, or even exceed, that accumulated within the trees themselves. Organic matter builds up very rapidly while the crop is young, probably reaching a maximum by the middle of the rotation (Page 1968). However, there are suggestions that there might be a continuing accrecion of nitrogen long after organic matter accumulation has stabilized (roster \& Morrison 1976). This immobilized nitrogen way be regarded, in the short-term, as an effective removal of nitrogen from the cycle within the forest and can cause the gradual development of deficiency conditions on sites already low in this nutrient, as has been shown in Germany (Zöttl 1960; Rehfuess 1968), Sweden (Tamm, Carbonnler \& Hagberg 1960), Finland (Siren 1955; Viro 1967), eastern Canada (Weetman 1962), Washington (Heilmann \& Gessel 1963; Turner 1977) and Scotland (Miller 1969; Miller \& Cooper 1973; Miller, Miller \& Binns 1977). Indeed, Heilman (1966) has suggested that the reduction in the availability of nitrogen beneath 
black spruce in Alaska has led to accumulation of a thick moss layer and eventual deterioration to a sphagnum bog.

The accumulation of organic matcer on the forest floor may also play a positive role (a) by acting as a reservoir of nutrients that will buffer the system against disturbances promoting loss of nutrients (Cosz, Likens \& Bormann 1976) and (b) as pointed out above, by retaining much of the nutrient input to the ecosystem.

During the early years of a plantation, much of the nutrient taken up is supplied from the mineral soil. With time, however, a cycle becomes established between the tree and soil organic horizons that, together with enhanced input through aerosol capture, reduces the dependence of the trees on nutrients from the lower soil horizons. Indeed, recent models of nutrient cycling in Corsican pine (Miller et al, in press) suggest that for potassium, which cycles rapidly and which is immobilized at a rate sufficiently low to be compensated for by atrospheric input, the mineral soll way supply only 7 per cent of the trees' uptake (Fig. 4). A similar situation exists for magnesilm. For nitrogen, however, the trees have to make continuing demands on soll reserves throughout the rotation (Fig. 4) and this al so seems to apply for phosphorus and calcium. Although in most solls the amount of potentially' 'avallable' nutrients is relatively large compared with the amount accumlated in the tree crop (Weetman $\delta$ Webber 1972; Foster \& Morrison 1976), and although trees are able to obtain nutrients from falrly intractable soll sources (Voigt 1965; Harley 1969), there are many soils, such as the peats of Britain and Ireland (Binns 1962; $0^{\circ}$ Carroll 1966) and the sandy outwash soils in New York State (Heilberg \& white 1950), in which one or more nutrient is in such low supply that fertilizers have to be applied if trees are to be established.

Once cstablished, trees interact with the soil, producing changes that probably vary with species. The effects induced by many broadleaved species are notably different to those Induced by coniferous species, the latter tending to lead to the developrent of a pronounced organic layer, and increased acidity and podzolization. Beneach spruce as compared to beneath adjacent becch, exchangeable cation contents in the surface horizons are usually lower, phosphate, aluminium and exchangeable hydrogen contents higher, while the rate of nitrification is depressed (N1hlgard 1971; Ulrich, Ahrens \& Ulrich 1971). There may also be a difference in soll structure; whilst roots of some coniferous species promote an Increase in large soll pores, the removal of sesquioxides associated with podzolization may lead co a loss of aggregate stability (Grieve 1978). However, the very variable nature of soil, even within a crop of the same species, means that it 15 difficult to make a precise assessment of the effects of a 

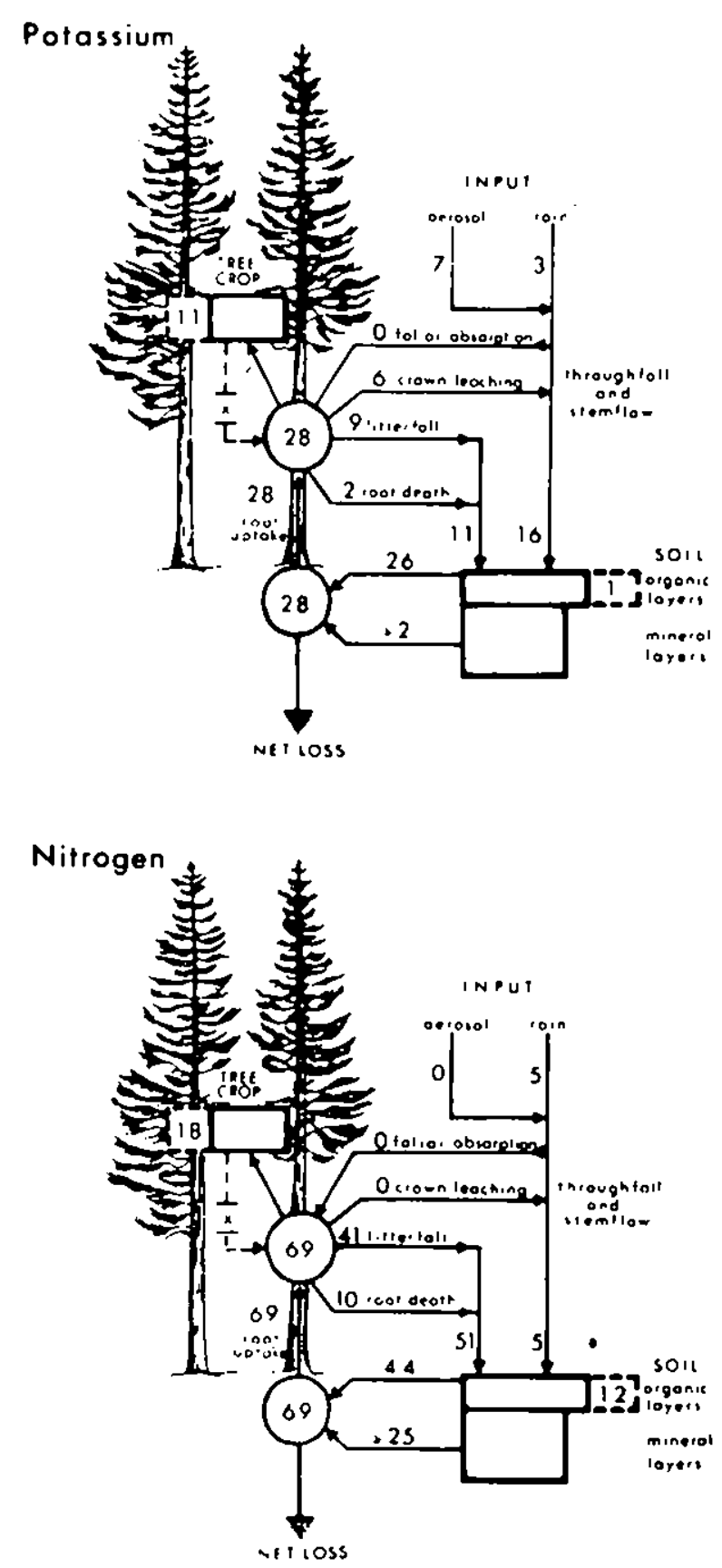
change of tree specles; indeed, Anderson (1976) has recently suggested that, desplte intial differences noticed in the soll beneath a range of confferous trees, subsequent development indicates convergence towards a uniform soil type. Although solls, beneath different tree species have been compared, there have been few opportunities to monitor the changes following afforestation of hare ground. Several authors have reported marked drylng and physical changes in peat beneath planted lodgepole pine (Binns 1962; Pyatt 1975; Boggie \& Miller 1976). Williams, Cooper \& Pyatt (1978) have shown that in such peat there is a decrease in exchangeable calcium, magnesium and potassium, presumably associated with tree uptake, and an increase both in exchange capacity and amount of exchangeable sodium, reflecting greater decompostition and catch of sea-derived aerosols beneath the trees.

Practical significance

knowledge of the accumulation of nutrients in the tree, humus and soil is necessary to understand the significance of the input and loss of nutrients from the ecosystems. At tempts to balance atmospheric input against nutrient drain on harvesting require information on the amount of nutrients accumulated in different organs at different stages of growth. Similarly, studies of the nutrient supplying ability of a soil can only be assessed against the known dewands of a tree crop.

The pattern of nutrient dewand by a tree crop can now be established with reasonable certainicy (Fig. 3). Although it reaches its peak at, or just before, the time of maximum current annual increment, deficiencies either appear soon after planting or in middle-age suggesting that, provided the nutrient capital of the site is such that trees can become established, variation in uptake is less significant than is variation in supply. Beneath wany coniferous crops the nutrient supplying ability of the soil, particularly for nitrogen and phosphorus, appears to alter as the trees age. This is probably due to immobllization in living vegetation and soll organic layers, although the posstbility of a build-up of a haroful microbial population cannot be discounted (Florence 1967).

Fig. 4. Calculated annual fluxes and rates of accumulation of $K$ and $N(\mathrm{~kg} / \mathrm{ha} / \mathrm{yr}$ ) required to maintain maximum growth rate $(20 \mathrm{cu} . \mathrm{m} / \mathrm{ha} / \mathrm{yr})$ of $40 \mathrm{yr}$ Corsican pine in Scotland. Zones of accumulation are shown by rectangles the annual rate of new accumulation being represented by the dashed portion. Moblle pools are depicted by circles. Link $x$ between accumulation and mobile pool in the tree represents potential mobilization from second level sources (see text). 
The deleterious effect of accumulation of a deep mor-hum layer has attracted the attention of silviculturalists since the outset of systematic forest management. Countermeasures include soll disturbance, increasing penetration of sunlight, liming, fertllization and burning. Because the feeding roots of most conifers are shallow, soll cultivation can only be uscd at the end of the rolation (Rehfuess \& Schmidt 1971; Ford \& Deans 1977) when nitrogen mineralization is, in any case, falrly rapid (Popovic 1975). The arount of sunlight reaching the soil, on the other hand, can be altered during the rotation by changing the thinning intensity and the advantages of this are probably worth more critical examination. Although lime will increase both the rate of organic mater decomposition and nitrogen mineralization (Williams 1972; Adams \& Dickson 1973; Adams \& Cornforth 1973), few positive effects on tree growth have been observed in recent experiments (Adams et al. 1978), despite clains for such an effect in older literature (Baule \& Fricker 1970), an exception being a response to heavy rates of 1 ime when rotovated into the surface layers of deep oligotrophic peat (Dickson 1977). It has also been suggested that application of nitrogen increases mineralization of native organic nitrogen (Chu \& Knowles 1966; Williams 1972) but the response is short-lived, as is that to added phosphate (Williams 1972). Fire or heat sterilization has frequently been reported to increase the avallability of nitrogen (e.g. Siren 1955; Weetman \& Nykvist 1963) and this does appear to be a useful treatment. It is interesting to note that the three 'catastrophic' factors of burning, reduction in canopy cover and soll disturbance, such as that resulting from wind-blow, appear to be most effective at mobilizing hums nitrogen.

\section{CYCLES WITHIN THE, TREE}

Trees can move nutrients from one organ to another, the best documented example being the withdrawal of nutrients from old follage prior to abscission. Viro (1955) estimated that about 85 per cent of the nitrogen, phosphorus and potassium in old needles of scots pine can be retranslocated into living tissues during senescence. Presumably the tree similarly conserves nutrients during the death of other tissues; Indeed, Merrill \& Cowling (1966) considered that the progressive decrease in nitrogen content of annual xylem increments on passing from the cambium to the heartwood was associated with the withdrawal of nitrogen from parenchyma cells prfor to death.

Most retranslocation, however, is not associated with death of tissues, but represents the accumulation of nutrients during dormant periods and their subsequent mobilization for use, often in a different part of the tree, during active growth. Studies with nitrogen (David \& David 1966; Durzan 
1963; Tromp \& Ovaa 1971) which is stored as protein but translocated as soluble amino actds, indicate considerable movement with a marked conversion into mobile forms just prior to bud-break. The appearance and disappearance of mobile nitrogen in the tree is even reflected in variations in the amount of wineral nitrogen lost through crown leaching during a year (Miller, Cooper \& Miller 1976).

Thus, there is a marked seasonal pattern of translocation between different organs of the tree that, together with uptake during the growth perlod, would normally account for all the nutrient required for new growth. Should these supplies, which Miller et al. (in press) have teroed supplies frow 'first level sources', be insufficlent, either through low availability in the soll or through some abnormal demand, such as for heavy conlng (Rehfuess 1970), then the tree will utilize nitrogen accumulated during previous growling seasons. This mobilization from 'second level sources' (Fig. 4) usually occurs at sub-optimum levels of nutrition and is at the expense of the proper functioning, or even continued existence, of older tree cissues - a sacrifice that is inevitably accompanied by a reduction in growth. For example, it has frequently been observed that nitrogen deficiency reduces the age at which needles senesce (e.g. Heilman \& Gessel 1963b; Miller \& Miller 1976a; Turner \& 0lson 1976). Mobilization from second level sources of a nutrient previously accumulated in excess of the then requirements for growth is less usual but this can happen following heavy fertilizer application. Indeed this is sufficient to explain alone the continuation of growth response in the years after fertilizers were last applied (Miller, Miller \& Pauline 1976).

Following fertilizer application all living components of the tree show an increased concentration of that nutrient (Table 8). The largest proportional increase occurs in lateral roots and foliage, but significant increases also occur in stem wood and stump. Accumulation even within the heartwood

Table 8. Changes in amount of accurulated nitrogen following application of nitrogen fertllizer ( $504 \mathrm{~kg}$ $\mathrm{N}$ ha/yr for these years) to 40-year-old Corsican pine (author's data).

$\begin{array}{lcc}\text { Tree component } & \begin{array}{c}\text { Xincrease in } \\ \text { N concentration }\end{array} & \begin{array}{c}\text { Increased we ight } \\ (\mathrm{kg} / \mathrm{ha}) \text { of } \mathrm{N}\end{array} \\ \text { Follage } & 280 & 250 \\ \text { Branches } & 210 & 45 \\ \text { Stem bark } & 225 & 55 \\ \text { Stem wood } & 185 & 45 \\ \text { Stump } & 190 & 10 \\ \text { Lateral roots } & 295 & 90\end{array}$


has been revealed by electron probe microanalysis of the medullary rays taken from deep inside Sitka spruce stens, which have shown higher phosphorus and porassium contents following application of rock phosphate and potassium chloride (J.D. Miller \& A.C. Birnie, pers. cont.). The increased accumulation of nitrogen in fertillzed Corsican pine (Table 8 ) can be regarded as an increase in the potential supply of this nutrient from second level sources, for it can be utilized at least until the concentration values fall back to pre-treatment levels. Clearly, as most of this accumulated nitrogen is located in the follage and lateral roots, anything promoting prenature death of these organs, such as drought or pollution will, apart from the obvious consequence, reduce the 'store' of nutrients avallable for subsequent growth. This danger is most severe early in the rotation when foliage, and to a lesser extent lateral roots, represent a large proportion of the total weight of the crop and the amount of available nutrient that can be accumulated in the relatively small quancity of woody tissue is significant in relation to the requirements for new growth.

Pracilical significance

Recent problems with certain species in diagnosing nutrient deficiencies from analysis of top-whorl foliage (e.g. Miller \& Willams 1972), coupled with the difficulty of obtaining foliage from this position on any regular basis, has encouraged investigations into the pattern of accumulation in other organs of the tree. A clear understanding of the sink-source relationships within the tree should enable identification of the organ, time of sampling, and type of analysis that most accu- rately reflects the nutrient status (Vanden Driessche 1974). Thus Florence \& Chung (1974) suggested that even when nitrogen and phosphorus deficlencies are not indicated in top-whorl follage, they are reflected by a gradient of these elements across age categories of needles - a result of more pronounced withdrawal of nutrients from older needles on defictent trees. Simllarly Lamb (1975) has shown that withdrawal of nitrogen and phosphorus from ageing green needles is more marked on poor than on fertile sites. In some studies follage from the lower crown, despite the difficulty of giving this a standard physiological identity, has proved to be a better Indicator of nutrient status than has top-whorl foliage (Carey, pers. comm.). Considerable success at diagnosing nitrogen deficiency has recently been achieved using analysis of newly fallen needle-ilter (Mahendrappa \& Weetman 1973; M1ller \& Miller 1976b), and as litter nitrogen levels may in turn be reflected by the levels In the accumulated humus, this might be a suitable material to analyse (Malm, Möller \& Nömmik 1974; Adams 1974; Miller et al. 1977; Van den Driessche \& Webber 1977 and 1978). Other organs attracting attention Include surface roots (Van den Driessche 
\& Webber 1978), outer sapwood (Alcubilla, Aufsess \& Rehfuess 1976) and, because of its successful use in rubbertree plantations (Bolle-Jones 1957), inner-bark (White, Alexander \& Clark 1972; Alcubilla \& Rehfuess 1975; Alcubilla et al 1976; Van den Driessche \& Webber 1977 and 1978).

With coniferous species, follage samples are usually taken early in the dormancy perlod, simply because at this time the concentration of nutrients in follage remains fairly constant over a few months (White 1954). However, nutrient stress in tissues may be mote marked during the growing season, when demands by the new growth are large (Smith, Switzer \& Nelson 1970; Waring \& Youngberg 1972). It has also been suggested that levels of total soluble nitrogen, monosubstituted guanidino cowpounds, arginine or proline may give the best indication of any disturbances in nitrogen metabolism (Durzan 1974; Van den Driessche \& Webber 1975, 1977 and 1978). However, routine sampling elther during the growing season or for such transient substances as free amino acids, would need careful control and standardization. Although these approaches probably justify more attention, they require a clearer understanding of the cycling of such components within the tree.

There is a growing awareness that changes or imbalances
in tree nutrition can be reflected in pathological disturbances other than those produced directly by nutrient deficiencies. Thus, white $(1969,1974)$ has postulated that changes, resulting from molsture stress, in the pattern of accumulation of free amino acids in follage can explain sudden increase in numbers of defollating caterplliars, and parry (1977) has shown that seasonal variations in populations of the aphid Elatoblum ablecinum on spruce closely paralelled changes in the amount of free amino acids. Similar explantations have been offered for attacks by the spruce budworm (Durzan 1968) and for some fungal diseases (Baule \& Fricker 1970; Baule 1973). Furthermore, there is the possibility that an insufficlent supply of trace elements at critical periods of the year can predispose the tree to damage by inorgantc agencles, such as frost, and it is now known that a deficiency of potassiun can adversely affect the water economy of the tree (Bradbury \& Malcolm 1977).

\section{CONCLUS IONS}

There can be $11 \mathrm{ttl}$ e doubt that integrated research on nutrient cycles within forest ecosystems in leading to an appreclation of nutrition as a system of functional processes. As a result it is now possible to generate and test the hypotheses that are basic to a proper understanding of tree nutrition and the clme is forseen when the manager wll be in a position to deduce, from fundamental principles, the 
nutritional consequence of any proposed action.

\section{ACKYOWLFDGEMFNTS}

I aw indebted to my colleagues J.D. Miller and J.M. Cooper for the collection and computation of much of the original experimental evidence presented.

\section{REFERENCES}

Abrahamsen,G., Bjor,K., Horntvedt,R. \& Tveite,B.(1976). Effects of acid preclpitation on conlferous forest. "Impact of acid precipitation on forest and freshwater ecosystems in Norway." (k.d. by F.H. Braekke), pp. 37-6.3. Sur Nedbors Virkning pa skog og Fisk Fagrapport FR 6/76, Oslo- As.

Adams,S.N.(1974). Some relations between forest 1 itter and growth of Sitka spruce on poorly drained soils. Journal of Applied Fcology, 11,761-765.

Adams,S.N. \& Cornforth,I.S.(1973). Some short-term effects of lime and fertilizers on a Sitka spruce plantation. II. Laboratory studies on litter decomposition and nitrogen mineral ization. Forestry, 46, 39-47.

Adams,S.N. \& Dickson,D.A.(1973) . Some short-term effects of lime and fertilizers on a Sitka spruce plantation. I. field studies on the forest litter and the uptake of nutrients by the trees. Forestry, 46, 31-37.

Adams,S.N., Cooper,J.E., Dickson, D.A., Dickson,E.L. \& Seaby,D.A. (1978). Some effects of lime and fertilizer on a Sitka spruce plantation. Forestry, 51, 57-65.

Addoms, R.M.(1937). Nutritional studies on Toblolly pine. Plant Physiology, 12, 199-205.

Alcubilla,M. \& Rehfuess, K.E.(1975). Voruntersuchungen uber die Eignung Bastanalyse zur Beurteilung des Ernährungszustandes von Fichten (Picea abies Karst.). Forstwissenschaft 1 1ches Centralblatt, $94,3 \overline{44-351}$.

Alcubilla,M., Aufsess, H. \& Rehfuess,K.E.(1976). St1ckstoffdünungsversuche in etner Flchtenwachsstockung (Picea abies Karst.) auf devastierter Kalkmerger-rendzina: Wirkungen auf die Nahrelementgehal te der Fichtengewebe und den Hohenzuwachs. Forstwissenschaftliches Centralblatt, 95, 306-323.

Aldrich-Blake,R.N.(1930). The plasticity of the root systems of Corsican pine in early life. Oxford Forestry Memolrs el2.

Allison,F.E.(1955). The enigma of soil nitrogen balance sheets. Advances in Agronomy, $7,213-250$.

Anderson,M.A.(1976). Effect of trees on soll. Report on Forest Research London, 1976. pp.22.

Anderson,F.(1970). Ecological studies In Scanian woodland and meadow area, southern Sweden. II. Plant biomass, prfmary production and turnover of organic matter. Botaniska 
not iser, $123,8-51$.

At tiwill,P.M.( $\overline{1966)}$. The chenical composition of rainwater in relation to cycling of nutrients in mature eucalyptus forest. Plant and Soil, 24, 390-406.

Azevedo,J. \& Morgan,D.L.(1974). Fog precipitation in coastal California forests. Ecology, 55, 1135-1141.

Bache,D.H.(1977). Sulphur dioxide uptake and the leaching of sulphates from a pine forest. Journal of Applied Ecology, $14,881-895$.

Rain, D.C. \& Tait,J.M.(1977). Mineralogy and origin of dust fall on Skye. Clay Minerals, 12, 253-255.

Baule,H.(1973). Fffect of fertilizers on resistance to adverse agencies. Proceedings F.A.0./I.U.F.R.O. International Symposium on forest fertilization, Paris 1973, pp. 181-214. Ministere de 1'Agriculture, Paris.

Baule,H. \& Fricker, C.(1970). The fertilizer treatment of forest solls. (Translated by C.L. Whitcles). B.L.V. Verlagsgesel lschaf $t$ m.b.H., München.

Becking,J.H.(1965). Nitrogen fixation and mycorrhiza in Podocarpus root modules. Plant and Soll, 23, 213-226.

Bengston, G.W. \& Kilmer,V.J.(1975). Fertilizer use and water quality: considerations for agriculture and forestry. "Forest solls and forest land management". Proceeding $4 \mathrm{th}$ North American forest soils conference (Ed. by $B$. Bernier and C.H.Winget), pp.245-265. Les Presses de l'Université Laval, Quebec.

Binns,W.0.(1962). Some aspects of peat as a substrate for tree growth. Irish Forestry, $19,32-35$.

Boggie,R. \& Miller,H.G.(197/6). Growth of pinus contorta at different water-table levels in deep blanket peat. Forestry, 49, 123-131.

Bolle-Jones, E.W.(1957). Follar diagnosis of mineral status of Hevea in relation to bark analysis. Journal of the Rubber Research Institute of Malaya, 15, 109-127.

Bond,G.(1957). The development and significance of root modules of Casuarina. Annals of Botany n.s. 21, 373-380.

Bormann,F.H., Likens,G.F. \& Mel1llo,J.M.(1977). Nitrogen budget for an aggrading northern hardwood forest ecosystem. Science, $196,981-983$.

Bradbury,I.K. \& Malcolm, D.C.(1977). The effect of phosphorus and potassium on transpiration, leaf diffusive resistance and water-use effictency in sitka spruce (Picea sitchensis) seedlings. Journal of Applied Ecology, 14, $631-641$.

Bray,J.R. \& Gorham,E.(1964). Litter production in forests of the world. Advances in Ecological Research, 2, 100-157.

Bringmark,L.(1977). A blo-element budget of an old scots pine forest in central Sweden. Silva Fennica, $11,201-209$.

Brown, A.H.F.(1974). Nutrient cycles in oakwood ecosystems in N.W. England. "The British Oak" (Ed. by M.G.Morris and 
F.H. Perring), pp.141-161. E.W. Classey, Berkshire, for The Botanical Society of the British Isles.

Chamberlain,A.C.(1975). The movement of particles in plant communities. "vegetation and the atmosphere. Volume 1 , Principles." (Ed. by J.L. Monteith). Academic Press, London.

Chu,J.P.H. \& Knowles,R.(1966). Mineralization and immobilization of nitrogen in bacterial cells and in soll organic fractions. Soll Science Society of America Proceedings, 30, 210-213.

Clayton,J.L.(1972). Salt spray and mineral cycling in two California coastal ecosystems. Ecology, 53, 74-81.

Cole,D.W. \& Ballard,T.M.(1970). Mineral and gas transfer in a forest floor - a phase model approach. "Tree growth and forest solls". Proceedings 3rd North American forest solls conference, Raleigh, N. Carolina, (Ed. by C.T. Youngberg and C.B. Davey), pp. 347-358. Oregon State University Press, Corvallis.

Cole,D.W. \& Gessel,S.P.(1965). Movement of elements through a forest soil as influenced by tree removal and fertilizer additions. "Forest soil relationships in North America". Proceedings 2nd North American forest solls conference. Oregon State Universicy, Corvalis, (Ed. by G.T. Youngberg), pp.95-104. Oregon State University Press, Corvallis.

David,R. \& David,H.(1966). Teneur en azotes protélques et solubles des bourgeons et phénomènes de migration des composés azotes se produlssant dans les rameaux du pin maritime. Compte rendu de l'Académie des sciences, Paris, Série D, 18, 1945-1948.

DeBell,D.S. \& Ralston,C.W.(1970). Release of nitrogen by burning light forest fuels. Soll Science Soclety of America Proceedings, 34, 936-938.

Delany,A.C., Pollock,w.H. \& Shedlovsky,J.P.(1973). Tropospheric aerosol; the relative contribution of marine and continental components. Journal of Geophysical Research, 78, 6249-6265.

Dickson,D.A.(1977). Nutrition of Sitka spruce on peat problems and speculations. Irish Forestry, 34, 31-39.

Dillon,P.J. \& Kirchner,W.B.(1975). The effects of geology and land use on the export of phosphorus frow water sheds. Water Research, 9, 135-148.

Dovland,H., Joranger, E. \& Semb,A.(1976). Deposttion of air pollutants in Norway. "Impact of acid precipitation on forest and freshwater ecosystems in Norway" (Ed. by F.H. Braekke), pp.15-35. Sur Nedbørs Virkning pa Skog og Fisk Fagrapport FR 6/76, Oslo-As.

Durzan,D.J.(1968). Nitrogen metabolism of Picea glauca. I. Seasonal changes of free amino acids in buds, shoot apices and leaves, and the metabolism of unformly 
labelled 14 C-L-arginine by buds during the onset of domancy. Canadian Journal of Botany, 46, 909-919.

Durzan,D.J.(1974). Nutrition and water relations of forest trees: a blochemical approach. Proceedings 3rd North American forest biology workshop, September 1974 (Ed. by C.P.R. Reid and C.H.Fechner), pp.15-63. Colorado State University.

Duvigneaud, P. \& Denaeyer-De Smet,S.(1970). Biological cycling of minerals in temperate deciduous forests. "Analysis of temperate forest ecosystems. Ecological studles 1" (Ed. by D.E. Reichle), pp.199-225. Chapman \& Hall, London.

Eaton,J.S., Likens,G.E. \& Bormann,F.H.(1973). Throughfall and stemflow chemistry in a northern hardwood forest. Journal of Ecology, 61, 495-508.

Ehwald,E.(1957). Ueber den Năhrstoffkrelslauf des Waldes. Sitzungesberichte der Deutschen Akademie der Land wi $r$ schaf $t w$ ssenschaften, 6. 56pp.

Fairfax,J.A.W. \& Lepp,N.W.(1975). Effect of simulated 'acid rain' on cation 1088 from leaves. Nature, Lond. 255 , $324-325$.

Feller,M.C.(1977). Nutrient movement through western hemlock western red cedar ecosystems in British Columbia. Ecology, 58, 1269-1283.

Florence,R.G. $(1967)$. Factors that may have a bearing upon the decline of productivity under forest monoculture. Australian Forestry, $31,50-71$.

Florence,R.G. Chuong,P.H.(1974). The influence of soll type on follar nutrients in Plnus radiata plantations. Australlan Forest Research, $6,1-8$.

Ford,E.D. \& Deans,J.D.(1977). Growth of a Sitka pruce plantation; spatial distribution and seasonal fluctuations of lengths, welghts and carbohydrate concentrations of fine roots. Plant and Soil, 47 , 463-485.

Foster,N.W. \& Morrison,I.K.(1976). Distribution and cycling of nutrients in a natural pinus banksiana ecosystems. Ecology, 57, 110-120.

Fowler,D. \& Unsworth,M.H.(1974). Dry deposition of sulphur dloxide on wheat. Nature, 249, 389-390.

Fredriksen,R.L.(1972). Nutrient budget of a Douglas fir forest on an experimental watershed in western Oregon. "Research on conlferous forest ecosystems", Proceedings of the Bellingham, Washington, Symposium (Ed. by J.F. Franklin, L.J. Dempster and R.H. Waring), pp.115-131. U.S. Department of Agriculture Forest Service, Portland, Oregon.

Fredriksen,R.L., Moore,D.G. \& Norris,L.A.(1975). The Impact of timber harvest, fertilization and herbicide treatment on streamwater quality in western oregon and Washington. "Forest solls and forest land management". Proceedings 
4th North American forest solls conference (Ed. by B. Bernier and C.H. Winget), pp.283-313. Les Presses de l'Université Laval, Qucbec.

Freeman,J.F.(1924). Nitrogen in the rainwater at different points in Kentucky. Journal of the American Society of Agronomy, 16, 356-358.

Gadgil,R.L.(197). The nutritional role of Lupinus arboreus in coastal sand dune forestry, 1, 2 and 3. Plant and Soil, $34,357-367 ; 35,113-126$.

Gadgil,R.L.(1977). Alternatives to the use of fertilizers. 'Use of fertilizers in New Zealand forestry'. Proceedings Forest Research Insticute Symposilm 19 (corpiled by R. Ballard), pp.83-94. New Zealand Forest Service forest Research Institute, Rotorua.

Garland,J.A.(1977). The dry deposition of sulphur dioxide to land and water surfaces. Proceedings of the Royal Soclety, Lond on A, 354, 245-268.

Gessel,S.P., Cole,D.W. \& Steinbrenner,E.C.(1973). Nitrogen balances in forest ecosystems of the Pacific. Northwest. Soil Biology and Biochemistry, $\frac{5}{1}, 19-34$.

Gether,J., Gj申s,N. \& Lunde,G.(1976). Isolation and characterization in precipitation of organic micropulluntants associated with long-range transport in a1r. Sur ledbors Virkning pa Skog og Fosk Fagrapport FR $8 / 78$, Oslo- $\AA_{\mathrm{s}}$.

Gether,J., Lunde,G. \& Markali,J.(1976). Particulate material in atmospheric fall-out and preciptcation over the south of Norway. Sur Nedbors Virkning pa Skog og Fisk Fagrapport FR 7/76, Oslo- As.

Gosz,J.R., Likens,G.E. \& Bormann,F.H.(1976). Organic matter and nutrlent dymamics of the forest and forest floor in the Hubbard Brook Forest. Oecologia, 22, 305-320.

Grier,C.C. \& Cole,D.W.(1972). Elemental transport changes occurring during development of a second-growth Douglas fir ecosystens. "Research on coniferous forest ecosystems". Proceedings of the Bellingham, Washington Symposium (Ed. by J.F. Franklin, L.J. Dempster and R.H. War1ng), pp.103-113. U.S. Department of Agriculture Forest Service, Portland, Oregon.

Grteve, I.C.(1978). Some effects of the plantation of conifers on a freely drained lowland soll, Forest of Dean, U.K. Forestry, 51, 21-28.

Hall,A.D. \& Miller,N.H.J.(1911). On the absorption of ammonta from the atmosphere. Journal of Agricultural Science, 4 , 1911-1912.

Hamilton,G.J. \& Christle, J.M.(1971). Forest management tables (metric), Forestry Comission London, Booklet 34 .

Harley,J.L.(1969). The biology of mycorrhiza (2nd edition). Plant Science Monographs (Ed. by N. Polunin). Leonard Hi11, London. 
Harwood,C.E. \& Jackson,W.D.(1975). Atmospheric losses of four plant nutrients during a forest fire. Australian Forestry, 38, 92-99.

Helberg,S.0. White,D.P.(1950). Potassium deficiency in reforested pine and spruce stands in northern New York. Soil Sclence Soclety of Amertca Proceedings, 15, 369-376. Heflman,P.W.(1966). Changes in distribution and availability of nitrogen with forest succession on northern slopes in interior Alaska. Ecology, 47,825-831.

Hellman,P.E. \& Gessel,S.P.(1963a). Nitrogen requirements and the biological cycling of nitrogen in Douglas fir stands in relationship to the effects of nitrogen fertilization. Plant and Soll, 18,386-402.

Hellman,P.W. \& Gessel, S.P.(1963b). The effect of nitrogen on the concentration and weight of nitrogen, phosphorus and potassium in Douglas fir trees. Soll Sclence Society of America Proceedings, 27, 102-105.

Heinrichs, H. \& Mayer,R. $(1977)$. Distribution and cycling of major and trace elements in two central European forest ecosystems. Journal of Environmental Qual1ty, 6, 402-407.

Hingston,F.J. \& Gailitis,V.(1976). The geographic variation of salt precipltated over Western Australla. Australian Journal of Soll Research, 14, 319-335.

Hitchcock,D.R.(1976). Microbiological contribution to the atmospheric load of particulate sulfate. "Environmental Blogeochemistry, Volume 1, Carbon, nitrogen, phosphorus, sulfur and selenium cycles" (Ed. by J.0. Nrlagu), pp. 351-367. Ann Arbor Sclence, Ann Arbor, Michigan.

Ike,A.F. \& Stone,E.L.(1958). Soll nitrogen accumulation under black locust. Soll Science Society of America Proceedings, $4,346-349$.

Ingham, G. (1950). Effect of materials absorbed from the atmosphere in maintalning soll fertility. Soil Science, 70, 205-212.

Johnson,F.L. \& Risser,P.G.(1974). Biomass, annual net primary production and dynamics of six mineral elements in a post-oak-blackjack oak forest. Ecology, 55, 1246-1258.

Jones, K.(1970). Nitrogen fixation in the phytosphere of the Douglas fir, Pseudotsuga douglasi1. Annals of Botany, 34 , 239-244.

Jonsson, B. \& Sundberg,R.(1972). Has the acidification by atmospheric pollution caused a growth reduction in Swedish forests? Rapporter och Uppsatser, Institutionen for Skogsprodukt ion, Skogshogskolan, 20.

Keays,J.L. \& Hatton,J.V.(1976). The ioplication of full-forest utilization on worldwide supplies of wood by the year 2000. World wood, $17,12-15$.

Kimmins,J.P. \& Feller,M.C.(1976). Effect of clearcutting and broadcast slashburning on nutrient budgets, streamwater chemistry and productivity in western Canada. Proceedings 
XVI I.U.F.R.O. Congress, DIvision I, Oslo, Norway. pp. 186-197.

Klemmedson,J.0.(1976). Ef fect on thinning and slash burning on nitrogen and carbon in ecosystems of young dense Ponderosa pine. Forest Science, 22, 45-53.

Knowles,R.(1965). The significance of nonsymbiotic nitrogen fixation. Soll Sclence Society of America Proceedings, $29,223$.

Kreutzer,K. \& Weiger,H.(1974). Untersuchungen tiber den Einfluss forsticher Düngungsmassnahmen auf den Nitratgehalt des Sickerwassers in wald. Forstwissenschaft $l$ iches Centralblatt, 93, 57-74.

Lamb,D.(1975). Patterns of nitrogen minerallzation in the forest floor of stands of pinus radiata on different solls. Journal of Ecology, $6 \overline{3}, 615-\overline{625}$.

Likens,G.E. \& Bormann,F.H. $(19 \overline{74})$. Acld rain: a serious regional environmencal problem. Science, 184, 1176-1179.

Likens,C.E., Borwann,F.H., Plerce,R.S. \& Reiner,W.A.(1978). Recovery of a deforested ecosyster. Sclence, 199 , 492-496.

Likens,G.E., Bormann,F.H., Pierce,R.S., Eaton,J.S. \& Johnson,N.M.(1977). The biogeochemistry of a forested ecosysten. Springer Verlag, New York.

Ludbrook,W.v.(1940). Boron deficlency symptoms on pine seedlings in water culture. Journal of the Council for Sclentific and Industrial Research in Australia, $\underline{13}$, 186-190.

Lunde,G., Gether,J., Gjos,N. \& Lande,M.B.S.(1976). Organ1c micropolutants in precipltation in Norway. Sur Nedbors Virkning pa Skog og Fisk Fagrapport FR 9/76, 0slo-Ass.

Madgwick,H.A.I. \& Ovington,J.D.(1959). The chemical composition of precipitation in adjacent forest and open plots. Forestry, 32, 14-22.

Mahendrappa,M.K. \& Ogden,E.D.(1973). Effects of fertilization of a black spruce stand on nitrogen contents of stemflow, throughfall and litterfall. Canadian Journal of Forest Research, $\underline{3}, 54-60$.

Mahendrappa,M.K. \& Weetman,G.F.(1973). N1trogen concentrations in the current foliage and in fresh litter of fertilized black spruce stands. Canadian Journal of Forest Research, 3, 333-337.

Malcolim,D.C., Bradbury,I.K. \& Freeza111ah,B.C.Y.(1977). The loss of nutrients from fertilized peat in an artificial system in the fleld. Forest Ecology and Management, $\underline{1}$, 109-118.

Milkonen,E.(1974). Annual primary production and nutrient cycle in some Scots pine stands. Communicationses Institut 1 Forestal is Fennlae, 84.5. $87 \mathrm{pp}$.

Malkonen,E.(1976). Effect of whole-tree harvesting on soll fertility. Silva Fennica, 10, 157-164. 
Mälkơnen,E.(1977). Annual primary production and nutrient cycle in a birch stand. Communicationes Instituti Forestalis Fenniae, 91.5 . $35 \mathrm{pp}$.

Malo,D., Moller,C. o Nomik,H.(1974). Codslingseffektens samband med văxtrăringsinnehall; wark och barr. Foreningen Skogstrisforäling och Institut for Skogsforbattring. Arsbok 1973. pp.48-75.

Mayer,R. \& Ulrich,B.(1974). Conclusions on the filtering action of forests froc ecosystem analysis. 0ecologia Plantaruo, 9, 157-168.

Mayer,R. \& Ulrich,B.(1977). Acidity of precipitation as influenced by the filtering of atwospheric sulphur and nitrogen compounds - its role in the element balance and effect on soll. Water, Afr and Soll Pollution, 409-416.

McColl,J.G. \& Grigal,D.F.(1977). Nutrient changes following a forest wildfire in Minnesota: effects in watersheds with differing solls. 01kos, 28, 105-112.

Merrill,W. \& Cowling,E.B.(1 $\overline{966})$. Role of nitrogen in wood deterioration: amounts and distribution of nitrogen in tree stems. Canadian Journal of Botany, 44, 1555-1580.

Miller,H.G.(1969). Nitrogen nutrition of pines on the sands of Culbin forest, Morayshire. Journal of the Sciences of Food and Agriculture, $20,417-419$.

Miller,H.G. \& Cooper,J.M.(1973). Changes in amount and discribution of stem growth in pole-stage corsican pine following application of nitrogen fertilizer. Forestry, 46, $157-190$.

Mille $\bar{r}$, H.G. \& Cooper,J.M.(1976). Tree growth and climatic cycles in the rain shadow of the Grampian mountains. Nature London, 260, 697-698.

Miller,H.G. \& Miller,J.D.(1976a). Ef fect of nitrogen supply on net primary production in Corsican pine. Journal of Applied Ecology, 13, 249-256.

Miller,H.G. Miller,J.D.(1976b). Analysis of needle fall as a means of assessing nitrogen status is pine. Forestry, 49, 57-61.

Miller,H.G. \& Williams,B.L.(1972). Research on forest so1ls and tree nutrition. Report on Forest Research, London $1972,143-147$.

Miller,H.G. \& Willams,B.L.(1973). Research on forest solls and tree nutrition. Report on Forest Research, London $1973,145-147$.

Miller,H.G. \& Williams,B.L.(1977). Nutritton and forest solls. Report on Forest Research, London 1977, 51-52.

Miller,H.G., Cooper,J.M. \& Miller,J.D.(1976). Effect of nitrogen supply on nutrients in litter fall and crown leaching in a stand of Corsican pine. Journal of Applied Ecology, 13, 233-248.

Miller,H.G., Miller,J.D. \& Binns,W.0.(1977). Growth of Scots 
pine under nutritional and climatic stress. Plant and Soil, 48, 103-114.

Miller,H.G., Miller,J.D. \& Pauline,0.J.L.(1976). Effect of nitrogen supply on nutrlent uptake in Corsican pine. Journal of Applied Ecology, $13,955-966$.

Miller,H.G., Cooper,J.M., Miller,J.D. \& Pauline,0.J.L. (in press). Nutrient cycles in pine: their adaptation to poor solls. Canadian Journal of Forest Research.

Miller,H.G., Williams,B.L., Miller,C.S. \& Warin,T.R.(1977). Ground vegetation and hurus nitrogen levels as indicators of nitrogen status in an established sand-dune forest. Forestry, 50, 96-101.

Miller,N.H.J.(1905). The amounts of nitrogen as anmonia and nitric acid, and of chlorine in the rainwater collected at Rothamstead. Journal of Agricultura Science, Cambridge, $1,280-303$.

Miller,R.B.(1961). The chemical composition of rainwater at Taita, New Zealand, 1956-58. New Zealand Journal of Science, $4,844-853$.

Miller,R.B. $(19 \overline{6} 3)$. Plant nutrients in hard beech. III. The cycle of nutrients. New Zealand Journal of Science, $\underline{6}$, $388-413$.

orlov,A.J.(1955). The role of feeding roots of forest vegetation in enriching soil with organic mater. Pochvovedenic, $\underline{6}, 14-20$.

overrein,L.N.(1970). Tracer studies on nitrogen imobllizationmineralization relationships in forest raw humus. Plant and Soil, $32,478-500$.

ovington,J.D.(1957). The volatile matter, organic carbon and nitrogen contents of tree specles grown in close stands. New Phycologist, 56, 1-11.

ovington,J.D.(1959). The circulation of minerals in plantations of Pinus silvestris L. Annals of Botany n.s., $23,230-239$.

ovington,J.D.(1962). Quantitative ecology and the woodland ecosystem concept. Advances in Ecological Research, 1 , 103-192.

Page,G.(1968). Some effects of contfer crops on soil propertics. Commonweal th Forestry Review, 47, 52-62.

Päfvanen,J.(1974). Nutrient removal from Scots pine canopy on drained peatland by raln. Acta forestalia fennica, 139, $19 \mathrm{pp}$.

Parry,W.H.(1977). The effects of nutrition and density on the production of alate Elatoblum abletunum on Sitka spruce. Decologia, 30, 637-375.

Paul, E.A.(1976). Nitrogen cycling in terrestial ecosystems. "Environmental Biochemistry. Volume 1. Carbon, n1trogen, phosphorous, sulfur and selenulm cycles" (E,d. by J.0. Nrlagu) pp. 225-243. Ann Arbor Sclence, Ann Arbor, Michigan. 
Pitty,A.F.(1968). Particle size of the Sahara dust which fell in Britain in July 1968. Nature London, 220, 364-365.

Popovic,B.(1975). Kalhuggningens inverkan pa markens kvavemineralisering speciellt nitratbildningen. Institutionen for Skogsproduktion, Avdelning for skogsekologi, Skogshogskolan. Rapporter och Uppsatser 24.

Probert,M.E.(1976). The composition of rainwater at two sites near Townrsville, Queensland. Australian Journal of Soil Research, 14, 397-402.

Pyatt,D.G.(1975). Classification and improvement of upland soils. Report on Forest Research, London 1975, 25-26.

Reddy,T.K.R. \& Knowles, R.(1965). The fungal flora of a boreal forest raw humus. Canadian Journal of Microbtology, 11, 837-843.

Rehfuess,K.E.(1968).

Zusamenhange zwischen

dem Ernahrungs-zustand und der Bonitat Nordostbayerischer Tannenbestände (Abies alba Mill.). Forstwissenschaftliches Centralblatt, $\overline{87}, 276-296$.

Rehfuess,K.E.(1970). Vergleich zwischen nadelanalytischen Merkmalen von Weisstannen (Abies alba Mill.) mit und ohne Zapfenbehang. Zeitschrift für Pflanzenernährung und Bodenkunde, $127,75-84$.

Rehfuess,K.E. Schmidt,A.(1971). Die Wirkung von Lupinenunterbau und Kalkamonsalpeterdungung auf den Ernährungszustand und den Zuwachs alterer Kiefernbestände in der oberpfalz. Forștwissenschaftliches Centralblatt, $90,237-259$.

Remezov,N.P. (1956). The role of the biological circulation of the elements in soils formation under forests. 6th Inter national Congress on Soll Science, Paris,E. Pp.269-274.

Rennie,P,J.(1955). The uptake of nutrients by mature forest growth. Plant and soil, 7, 49-95.

Richards,B.N.(1964). Fixation of atrospheric nftrogen in coniferous forests. Australian Forestry, 28, 68-74.

Richards,B.A. \& Bevege, D.I.(1967). The productivity and nitrogen economy of artificial ecosystems comprising various conbinations of perennial legumes and coniferous tree species. Australian Journal of Botany, 15, 467-480.

Richards,B.N. \& Voigt, G.K.(1963). Nitrogen accretion in coniferous forest ecosystems. "Forest soil relationships in North America" (Ed by C.T. Youngeberg),pp.105-116. Oregon State University Press, Corvallis.

Robertson,R.A. \& Davies,G.E.(1965). Quantities of plant nutrient in heather ecosystems. Journal of Applied Ecology, 2, 211-219.

Rochow,J.J.(1975). Mineral nutrient pool and cycling in a Missouri forest, Journal of Ecology, 63, 985-994.

Rodhe,H., Persson,C. \& Akesson,0.(1972). An investigation into regional transport of soot and sulfate aerosols. 
Atmospheric Environment, 6, 675-693.

Roskoski,J.P.(1975). Differential nitrogen fixation in wood litter. Bulletin of the Fcological Society of America, 56,12 .

Schlesinger,W.H. \& Reiners,W.A.(1974). Deposition of water and cations of artificial foliar collectors in fur krummolz of New England mountains. Ecology, S5, 378-386.

Siren,G.(1955). The development of spruce forests on raw humus sites in northern Finland and its ecology. Acta forestalia fennica, 62, 1-363.

Slinn,W.C.N.(1977). Some approximations for the wet and dry removal of particles and gases from the atmosphere. Water, Air and Soll Pollution, 7, 513- 543.

Smith, M.E.(1943). Micronutrients essential for the growth of Pinus radiata. Australian Forestry, $\frac{7}{c}, 22-27$.

Smith, h.H. (1976). Character and significance of forest tree root exudates. Ecology, 57, 324-331.

Smith,W.H., Nelson.L.E. S Switzer,G.L.(1963). The characterization of dry matter and nitrogen accumulation by loblolly pine (Pinus taeda L.) on poor soils. Soil Science Society of America Proceedings, 27, 475-478.

Smith,W.H., Switzer,G.L. \& Nelsom,L.E.(1970). Development of the shoot system of young loblolly pine. L. Apical growth and nitrogen concentration. Forest Science, 16, 483-490.

Sopper,t.F.e(1975). Wastewater recycling on forest 1 ands. "Forest solls and forest land management". Proceedings $4 \mathrm{th}$ North American forest solls coference, Quebec 1973 (F.d. by B. Bernier and C.H. Winget) pp. 227-243. Les presses de L'Université Laval, Quebec.

Staaf,H. \& Berg B.(1977). Mobllization of plant nutrients in a Scots pine forest mor in central seden. Silva Fennica, $11,210-217$.

Stone,E.L.(1968). Micro-element nutrition of forest trees: a review, "Forest fertilization - theory and practice". Proceedings Symposium of forest fertilization, Gainsville Florida, 1967, pp. 132-175. Tennessee Valley Authority. National Fertilizer Development Center, Muscle Shoals, Al abama.

Stone,E.L. \& Kszystniak,R.(1977). Conservation of potassium in the Plnus resinosa ecosystem Science 198, 192-194.

Tamm, C.0.(1953). Growth, yleld and nutrittion'in carpets of a forest moss (Hyloconlum splendens). Meddelanden fran Statens Skgskforskningsinst itut 43 .

Tarm,C.0.(1958). The atrosphere. "Encyclopaedia of plant physiology. Volume IV. Mineral nutrition of plants" (Ed. by W. Ruhland) PP. 233-242. Springer Verlag, Berlin.

Tamm,C.0.(1964). Determination of nutrient requirements of forest stands. International revlew of forestry research $\$ 1$ (Ed. by J.A. Romberger and P. M1kola), pp. 115-170. Tamm,C.0.(1973). Effects of fertilizers on the environemt. 
Proceedings F.A.0./I.U.F.RO. International Symposium on forest fertilization, Paris 1973. pp229-317. Ministère de l'Agriculcure, Paris.

Tamm,C.0.(1976). Acid precipitation: blological effects in soil and on forest vegetation. Amblo, 5, 235-238.

Tamm,C.O. \& Cowling,E.B.(1977). Acidic precipitation and forest vegetation. Water, Air and Soll Pollution, $\underline{7}$, 503-511.

Tamm,C.0. \& Troedsson,T.(1955). An example of the amount of plant nutrients supplied to the ground in road dust. Oikos, $\underline{6}$.

Tamm,C.O. \& Wilkander,G.(1972). Kvavehalten 1 grundvattnet oakr vid skogsgodsling och kalhuggning. Forskning oih Framste8, 7, 27-9.

Tamm,C.O. \& Hagberg,N.(1960). Recent results of fertilizer experiments in Swedish forests. Proceedings 5 ch World Forestry Congress, 1 , 558-561.

Tarrant,R.F. \& Miller, $\vec{R} \cdot E \cdot(1963)$. Accumulation of organic matter and soll nitrogen beneath a plantation of red alder and Douglas fir. Soll Sclence Soclety of America Proceedings, 27, 231-234.

Tromp,J. \& Ovaa,J.F.(1971). Spring mobilization of storage nitrogen in isolated shoot sections of apple. Physlologia Plantarum, 25, 16-22.

Turner,J.(1977). Effect of nitrogen avallability on nitrogen cycling in a Douglas fir stand. Forest Science, 23 307-316.

Turner,J. \& Kelly,J.(1963). Foliar chlorlde levels in some south eastern Australian plantations forests. Soll Science Socientt of America Proceedings, 37, 443-445.

Turner,J. \& Olsen,P.R.(1976), Nitrogen relations in a Douglas fir plantation. Annuals of Botany, 40,1185-1193.

Turner,J. Cole,D.W. \& Gessel,S.P.(1976). Mineral nutrient accumulation and cycling in a stand of red alder (Alnus rubra). Journal of Ecology, 64, 965-974.

Ulrich,B.(1975). Die Unwettbeelnflüssing des Năhrstof fhaushaltes eines bodensluren Buchenwaldes. Forstwissenschaftliches Centralblatt, 94, 280-287.

Ulrich,B. \& Mayer,R.(1972). Systems analysis of mineral cycling in forest ecos;stems. "Isotopes and radiacion in siolplant relationships including forestry'. Proceedings I.A.E.A./F.A.O. Vienna Symposium, December 1971. Pp,329-39. International Atomic Energy Agency, Vienna.

Ulrich,B., Ahrens,E. \& Ulrich,M.(1971). Soll chemical differences beneath beech and spruce sites - an example of the methods used. "Ecological studies. Analysis and synthes1s" (Ed. by H. El lenberg), 2, 171-190.

Ulrich,B., Mayer,R., Khanna,P.K., Seekemp,G. \& Fassbender,H.W. (1976). Input, output und interner tusatz von chem 1 schen Elementen bel einem Buchen- und elnem Fichtenbestand. 
Berichte der Gesellschaft für Dekologic, Göllingen, September 1976, pp 17-28.

$v$ an den Driessche, R. (1974). Prediction of mineral nutrient status of trees by foliar analysis. Botanical Review, 40, 347-394.

van den Driessche,R. \& Webber J.F. (1975). Total and soluble nitrogen in Douglas $f i x$ in relation to plant nitrogen status. Canadian Journal of Forest Research, 5, 580-585.

van den Driessche, R. \& Webber,J.E.(1977). Variation in total and soluble nitrogen concentrations in response to fertilization of Douglas fir. Forest Sclence, 23 , 134-142.

van den Driessche, R. \& Webber J.F.(1978). Seasonal variations in a Douglas fir stand in total and soluble nitrogen in inner bark and root and in total and mineralizable nitrogen in soil. Canadian Journal of Forest Research, 7 , $641-647$.

Viro,P.J.(1955). Investigations on forest litter. Metsatie-teellison tutkimuslaitoksen julkaisu.ja, 45 , 1-65.

viro, P.J.(1967). Forest manuring on mineral solls. Meddelelser fra det Norske skogforsoksvesen, 23, 11.3-1.36.

voigt,G.K.(1965). Biological mobllization of potassium from primary minerals. "Forest soil relationships in North America" Proceedings 2nd North American forest soils conference Corvallis 1963 (Ed. by C.T. Youngberg), pp. 33-46. Oregon State Universicy Press, Corvallis.

Waring,R.H. \& Youngberg C.T.(1972). Evaluating forest sites for potential growth response of trees to fertilizer. Northwest Science, $46,67-75$.

Weetman,G.F.(1962). F.stablishment report on a humus decomposition experiment. Woodlands Research Index 134 , Pulp and Paper Research Insticute of Canada, Montreal.

Weetman,G.F.(1967). Nitrogen deficient black spruce on raw humus solls in northern Quebec - response to thinning and urea treatment. Proceedings lith I.U.F.R.O. Congress, Hunchen, $4,608-618$.

Weetman, G.F. \& Nykvist,N.B.(1973). Some mor-humus, regeneration and nutrition problems and practice in north Sweden. Woodlands Research Index $t 139$, Pulp and Paper Research Institute of Canada, Montreal.

Weetman,G.F. \& Webber,B.(1972). The influence of wood harvesting on the nutrient status of two spruce stands. Canadian Journal of Forest Research, $\frac{2}{2}, 351-369$.

Wells,C.G. \& Jorgensen,J.E.(1977). Nutrient cycling in loblolly pine - sllvicultural implications. Proceedings 1977 Forest biology wood chemistry conference, Madison, Wisconsin. pp.89-93. Technical Association Pulp and Paper Industry, At lanta, Georgia.

White,D.P.(1954). Variation in the nitrogen, phosphorus and 
potassium concents of pine needles with season, crown position and sample treatment. Soll Science Society of Anerica Proceedings, $18,326-330$.

White,E.H.(1974). Whole-tree harvesting depletes soll nutrients. Canadian Journal of Forest Research, 4 , 530-535.

White,J.D., Alexander,.L.T. \& Clark,E.W.(1972). Fluctuations in the inorganic constituents of inner bark of loblolly pine with season and soll series. Canadian Journal of Botany, 50, 1287-93.

White,T.C.R. $(\overline{1969)}$. An index to measure weather induced stress of trees associated with outbreaks of psyllids in Australia. Ecology, 50, 905-909.

White,T.C.R.(1974). A hypothesis to explain outbreaks of looper caterplliars with special reference to populations of Selidosema suavis in a plantation of pinus radiata in New Zealand. Oecologia, 16, 279-301.

Whittacker,R.H. \& Woodell,G.M.(1971). Measurement of net primary production of forests. "Productivity of forest ccosystems". Proceedings Brussels Symposium 1969 on Ecology and conservation (Ed. by P. Duvigneaud), pp.191-205. U.N.E.S.C.O., Paris.

Whittaker, R.H., Bormann,F.H., Likens,G.E. \& Siccama,T.G.(1974). The Hubbard Brook ecosystem study: forest biomass and production. Fcological Monographs, 44, 233-252.

Will,G.M.(1959). Nutrient return in litter and rainfall under some exotic contfer stands in New Zealand. New Zeal and Journal of Agricultural Research, 2 , 719-734.

Will,G.M.(1964). Dry watter production and nutrient uptake by pinus radiata in New Zealand. Commonwealth Forestry Review, $43,57-70$.

Williams, B.L.(1972). Nitrogen mineralization and organic watter decomposition in Scots pine humus. Forestry, 45, $177-188$.

Williams,B.L., Cooper,J.M. \& Pyatt,D.G.(1978). Effects of afforestation with pinus contorta on nutrient content, acidity and exchangeable cat lons in peat. Forestry, 51, 29-35.

Wittwer,R.F., Leaf,A.L. \& Bickelhaupt,D.H.(1975). Blomass and chemical composition of fertilized and/or irrigated pinus resinosa plantations. P1ant and Soll, 42, 629-651.

Wollum,A.C. \& Davey,C.B.(1975). Nitrogen accumulation, transformation and transport in forest solls. "Forest solls and forest management". Proceedings 4th North American foreeest solls conference, Quebec 1973. (Ed. by B. Bernfer and C.H. Winget), pp.67-106. Les Presses de l'Université Laval, Quebec.

Wood,T. \& Bormann, F.H.(1975). Increases in follar leaching caused by acidification of an artificial mist. Amblo, 4 , 
$169-171$

Yaalon,D.H. \& Lomas,J.(1970). Factors controlling the supply and the chemical composition of aerosols in a near shore and coastal environment. Agricultural Meteorology, ?, 433-454.

20ttl,H.(1960). Dynamik der Stickstoffoineralisation 10 organischen Waldbodenmaterial. II. Einfluss des St icks to f f gehal tes auf Mineralstickstof fnachlieferung. Plant and Suil, 13 , 183-206. 
DECOMPOSITION AND NUTRIENT RELEASE IN

EVEN-AGED PLANTATIONS

BY 0.W. HEAL

Institute of Terrestrial Ecology, Merlewood Research Station, Grange-over-Sands, Cumbria, U.K.

\section{SUMMARY}

The decomposition sub-system is a complex interacting set of organisus and processes whose activitles are central to the availability of nutrlents to plants and to the waintenance of the nutrient captal of the ecosystem. Information on decomposition and nutrient release in plantations is sparse and much is inferred from accumulation patterns on the forest floor. This paper describes the general principles of the control of decomposition and nutrient release, and examines their application and implications to even-aged plantations.

Decomposition comprises katabolism, comminution and leaching, comonly measured by weight loss and respiration which are correlated with rates of nutrient release with an aproximate release sequence $K>M_{8}>C a>M n>C>P>N>S$.

Decomposition is a function of three factors: climate, soll and resource quality, acting through the heterotrophic organisms. The broad limits to decomposition, set by site conditions, are modifled by management and forest development.

Decomposition of different litters is related to the proportions of ethanol soluble and ethanol insoluble fractions and in some cases to initial nitrogen concentration. Two exponential curves provide a reasonable representation of the main phase of decomposition, followed by long-term decomposition of resistant humus fractions.

During decomposition nutrients are 'Immobilized' in micro-organisms and faunal tissues, but the concept of fmmobllization, wth wineralization at critical c:nutrient 
ralios, masks the short-term recycling of nutrlents through microbial turnover.

The temporal pattern of decomposition and nutrient release includes pedogenetic trends over millenia, successional changes over decades or centuries, and seasonal and diurnal rhythms. In plantations the successional sequence is very distinct with additional pulses incroduced by management.

There is little evidence of the variation in nutrient release during a crop rotation but phases of nutrient supply and demand are apparentiy not synchronized as closely as in mixed-aged stands. The proportion of the ecosystem nutrients retained in the forest floor and the turnover time increases with

latitude. The organic accumulation, while acting as a stabilizing influence in high latitudes, reduces nutrient flow to the trees. A manipulated increase in rate of lurnover is expected to increase primary production.

\section{RÉSLMÉ}

Le sous-système de la décomposteton est un systeme interactif d'organismes et de processus dont l'activité est indispensable à la disponibilite et au capital d'éléments nutritifs de l'écosystème. Les renseignements que $l^{\prime}$ on possède à présent sur la decomposition et la libération d'éléments nutritifs dans les plantations sont minces et nous basons nos connaissances sur les types d'accummulation trouvés dans les sols des forêts. Notre exposé décrit les princlpes genéraux du controle de la décomposition et de la liberation d'éléments nutritifs et nous examinons leur application et les conclusions que $l^{\prime}$ on peut en tirer dans le cas de forêts equilennes.

La décomposition comprend le katabolisme, le broyage et le lessivage qui se mesurent habltuellement par la perte de poids et la respiration, qui sont corrilées avec le taux d'éléments nutritifs libérés, selon 1 'ordre-type sulvant: $K>M g>C a>M n>C>P>N>S$.

La décompostion dépend de trols facteurs, climat, sol et qualité en ressources, qui agissent par l'incermédialre d'organismes hétérotrophiques. Les limites générales de la décomposition, dictéses par les conditions de la station, sont modifiées par la gestion et le 
développement des forêts.

La décomposition de litières différentes est proportionnelle à des fractions solubles et insolubles dans l'éthanol et dans certalns cas à la concentration initiale d'azote. La phase principale de décomposition, sulvie de la longue décomposition de fractions d'humus plus résistant, peut erre représentés par deux courbes exponentielles.

Pendant la décomposition, les éléments nutritifs sont 'immobilisés' dans des micro-organismes et des tissus de 1 a microfaune mais le concept mêne d'immobllisation, avec une mineralisation à des rapports critiques de C:éléments nutritifs, masque le recyclage a court terme des élément nutritifs par l'intermédiaire du cycle mlcrobien.

Du polnt de vue temporel, la décomposition et la liberation des elements nutritifs presentent des tendances pédogénét lques sur une pérlode de mille ans, des changements de succession sur des décennies ou des siecles et des rhythmes salsonniers et diurnes. Dans les plantations, l'ordre des successions est très distinct, montrant des pulsations supplémentalres dûe à la gestion.

Il n'est pas évident que la libération d'eléments nutritifs varle pendant une révolution mals on peut dire que lés phases d'offre et de demande d'élements nutritifs ne sont pas ausst étroitement synchronisées que dans les peuplements d'âge mixte. La proportion d'éléments nutritifs de l'écosystème retenus au sol de la forêt et la durée du recyclage augmentent avec la latitude. L'accummulation organique qui a un effet stabilisateur à des latitudes élevées rédult le flux d'éléments nutritifs vers $l^{\prime}$ arbre. Une augmentation de la rapldité du cycle - amenée artiflclellement pourralt augmenter la production primaire.

\section{ZUSAMMENFASSUNC}

Das Subsystem der Verwesung besteht aus elnem komplexen Zusammenwirken von Organismen und Prozessen, deren W1 rken von zentraler Bedeutung für die Pflanzenverfügbarkelt von Nährstoffen und für die Aufrechterhaltung des Nahrstoffuorrats im Okosystem ist. Kenntisise uiber Verwesung und Frelsetzung von Nährstoffen in Forstpflanzungen sind spärlich und vieles 
muss man aus Anhaiufungsmustern auf dem Waldboden ableiten. Dieser Beltrag beschreibt die Gesetzoässigkeiten, denen Verwesung und Freisetzung von Nährstoffen unterliegen und uncersucht ihre übertragbarkeit auf gleichaltrige Pflanzungen.

Verwesung umfasst Kataboliswus, Zerkleinerung und Auswaschung. Man wisst sie überlicherweise am Gewichtsverlust und der Atmung. Diese Grobsen sind korreliert mit den Nahrstoff-Freisetzungsraten (ungefahre Reithenfolge $K>M g>C a>M n>C>P>N>S$ ).

Verwesung ist eine Funktion der drel Faktoren Klima, Boden und Angrelfbarkeit für heterotrophe Organlsmen. Die durch Standortsbedingungen gesetzten Grenzen der Verwesung werden durch Bewirtschaftung und Waldentwicklung modifiziert.

Die Verwesung verschledener Streuarten ist abhäng ig vow Antell der Äthanol-18slichen und Äthanol-unlosilichen. Fraktionen; in einigen Fallen auch vor ursprünglichen Stickstoffgehalt. Zwe 1 Exponent 1 alkurven geben elne zutreffende Darstellung der Hauptphase der zersetzung, auf die dann der langfrlstige Abbau resistenter Humusfraktionen folgt.

wahrend der Verwesung werden Nahrstoffe in Mikroorganismen und tierlschen Geweben 'Immobilisiert'. Das Konzept der Immobllisierung, wit einer Mineralisierung bei $k r i t i s c h e n$ Kohlenstoff : Nährstoff Verhälenissen, verdeckt jedoch das kurzfristige Recycling von Nahrstoffen durch wikroblellen Utesatz.

Das zelischema der verwesung und der Frelsetzung von Năhrstoffen schliesst ein die pedogenetischen Tendenzen über Jahrtausende, Sukzessionswechsel über Jahrzehnte oder Jahrhunderte sowie jahreszeltliche und tagliche Rhythmen. In Pflanzungen sind Sukzessionsfolgen sehr ausgeprägt; sle sind zusätzlich beeinflusst durch Bewirtschaftungsmassnahmen. Es gibt wenig Anhaltspunkte für die Schwankungen in der Frelsetzung von Nährstoffen während der lintriebsze1t. Phasen der Nährstoffanlieferung und des Nahrstoffbedarfs sind jedoch offensichtlich nicht so gut aufelnander abgestimmt we in verschiedenaltrigen Bestanden. Der Antell der Năhrstoffe des Ö́kosystems, die im Auflagehumus 
enchalten sind, und die tusatzzeit nehmen wit dem Breitengrad zu. Die Anhaufung in organischer Form, die in hohen Breltengraden elnen stabllisierenden Elnfluss ausubt, reduzlert gleichzeltig die Nährstoffzufuhr zu den Baumen. Es ist zu erwarten, dass eine gesteuerte Zunahe der Unsatzate die Primärproduktion steigert.

\section{INTRODUCTION}

The decomposition sub-system in forests, as in other ecosystems, is not just a 'black-box', best left unopened and considered as a component wich accepts and releases elements. It is Pandora's box containing a complex interacting set of organisus and processes whose activities are central to the availability of nutrients to plants and to the maintenance of the nutrient captal of the ecosystem. The sub-system, therefore, demands our understanding, on the assumption that better understanding wll lead to better management, although much of the experience in agriculture suggests that a pragmatic approach to management can be very successful. Forestry, however, has not had the benefit of centurfes of experience from trial and error and of a century of intensive soil research. Thus management of nutrient processes in forests has the opporunity, and the need, to use the research tool more directly than has agriculture and also to make use of the understanding from research in agriculture and from basic science.

The information on decomposition and nutrient release in forest plantations 18 sparse and scatered. Therefore, I have adopted the approach of describing first the general principles of decomposition, then of examining their application to even-aged forests in order to describe the pattern of processes during a rotation, and finally of discussing some implications, including comparisons with other systems. The emphasis throughout is on the organic horizons of the forest floor and on conlferous plantations.

\section{DECOMPOS ITION}

The term decomposition has been used in a wide variety of senses, but here it is used to include three main processes: katabolism, comminution and leaching. Katabolisw, the disruptive processes of chemlcal change by organisms, involving the breakdown of carbohydrates, proteins and other organic compounds for heterotrophic anabolism with the associated release of simpler, insoluble, soluble or gaseous compounds or elements. Thus the katabolism of organic compounds by heterotrophlc organisws results in the incorporation of elements into their tissues, i.e. immobilization, and release of elements into the soll and 
aerlal environment, 1.e. mineralization. However, it must be emphasized that the tissues of the heterotrophs are themselves subject to decomposition wh subsequent mineralization of elements. Comminution is the reduction in particle size by a combination of biological and physical mechanisms and results in redistribution of organic mater in the soll. Leaching is the physlcal process of transport of water-soluble or fine particulate material from organic mater. The comblnation of the processes of katabolism, comminution and leaching results in measurable parameters of weight loss, change in chemical composition and release of gaseous and water-soluble material from the organic matter but the component processes are often Ind ist Ingui shable.

Weight loss is a common measure of decomposition which combines all losses and is blased towards the major organic substrates which constitute most of the organic matter. Resplration provides a direct measure of carbon katabolism whlch usually correlates well with welght loss and with the rate of release of nutrient elements, although each element has a different pattern and rate of release. Potassium is not organically bound and is released rapidly through leaching. Calcium and magnesium are mainly contained in plant structural components, are released more slowly and accumulate in fung 1 and fauna (Cromack et al. 1977). Phosphorus, nitrogen and sulphur are mobilized during katabolism, but, because their concentration in microbial tissue is higher than that in plant tissues, they tend to be retained within the microbial population and released slowly. Thus the release sequence tends to be $K>M g>C a>M n>C>P>N>S$, largely reflecting the denand by decomposers but with some variation in different litters, depending on the relative concentration of the elewents (Will 1967; Attiwell 1968; Wood 1974; Toth, Papp \& Lenkey 1975; Cosz, Likens \& Bormann 1973).

\section{FACTORS CONTROLLING DECOMPOSITION}

Although there is a wide variety of types of organic matter decomposing in various environments, within any ecosystem, the rate of decomposition is basically a function of three groups of factors: climate, soll and resource quality, the term 'resource' being used for organic matter composed of a number of chemical compounds, while the term 'substrate' is used in the blochemical sense of a chemical entity that reacts in a specific manner with an enzyme. These factors control the activities of the heterotrophic microflora and fauna and can be represented as a module (Fig. 1) which is repeated for different types of resource, e.g. needle, leaf, stem or root within an ecosystem and in different ecosystem (Bunnell \& Tait 1975; Swift, Heal \& Anderson, in press). The rate of decomposition in planted forests is determined by:

(1) The microclimate of the forest floor, which is basically 


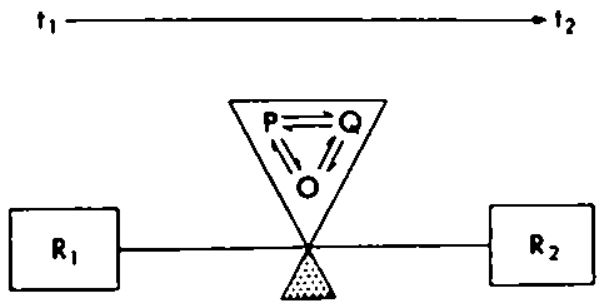

Fig. 1. Module of deconposition of organic matter. The decomposition of a resource from state $R_{1}$ to $R_{2}$ over time $t_{1}$ to $t_{2}$ is controlled by physico-chemical (P) factors of the environment and resource quality (Q) acting through heterotrophic organisms ( 0 ). (From Swift, Heal \& Anderson in press).

that of the local climate modified by the vegetation canopy, which varies with tree specles, planting density, 8 rowth rate and management.

(2) The soll on which the florest floor develops, the degree of soll influence 1 tself depends on the extent of site preparation and exposure of the mineral soll.

(3) The chemical and physical composition 1.e. resource quality of the organic mater input to the forest floor which is dependent on the intial vegetation, the type of tree and the associated management.

The rate of decomposition wll vary, therefore, during a forest rotation because the forest and its management modify she controlling factors and the amount of organic matter avallable for decomposition.

Cl 1mate

Al though there are no detalled studies of the influence of climate on decomposition through the cycle of an even-aged forest, a general picture can be drawn from the scattered data and from results in other systems. The model of the influence of temperature and molsture on microblal resplration by Bunnell et al. (1977) has proved reasonably applicable to a range of litcers, including aspen and dwarf shrub, in tundra, boreal forests and temperate bogs. It provides a succinct statement of the effect of the major cllmatic variables, with respiration rate of the litter $(\mathrm{R}(\mathrm{T}, \mathrm{M}))$ in $\mu / \mathrm{O}_{2} / \mathrm{g}$ expressed as : 


$$
R(T, M)=\frac{M}{a_{1}+M} \times \frac{a_{2}}{a_{2}+M} \times a_{3} \times a_{4}^{((T-10) / 10)}
$$

where $T$ is temperature in ${ }^{\circ} \mathrm{C}$; $M$ is moisture in per cent dry weight; a is the percentage moisture at which activity is at half its optimal value, thus representing availability of water for metabolisw by decomprser organisms; $a_{2}$ is the percentage moisture at which gas exchange is Ifolited to half its optimal value, thus representing the decreasing oxygen supply to organisros with increasing water content; $a_{3}$ represents the effect of substrate composition as the respiration rate in $\mu 0_{2} / \mathrm{g} / \mathrm{hr}$ at $10 \mathrm{C}$, when netther moisture nor oxygen are $1 \mathrm{Imitin}_{8} ; \mathrm{a}_{4}$ is the Q10 coefficlent deteroining the respiration response to temperature.

The model has been fitted to data from the litter, fermentation and humus layers of an aspen (Populus tremuloides) forest (Fig. 2). The calculated response surfaces show the retarding effect of both low and high molsture levels and also the decrease in respiration rate which occurs as the organic matter ages. Respiration rate of the three organic layers, measured seasonally, was influenced more strongly by temperature than by molsture, with the iroportance of temperature increasing with depth as the variability in moisture decreased (Van Cleve \& Sprague 1971). The site studied, a fifty year-old stand in central Alaska, is a silt loam in a cold, dry climate in which nolsture levels are moderate to low, but in forests on poorly drained soils and wet cllorates, the respiration rates will be inhibited by high moisture levels which retard oxygen diffusion. The principles of oxygen depletion in mineral solls (Greenwood 1968) probably apply to organic matter with the additional erophasis that the development of anaeroblc microsites $1 \mathrm{~s}$ related to the resplration rate and is, therefore, likely to be greatest in fresh and raptdly decomposing organic matter and to be temperature dependent. Thus respiration rates, commonly measured as oxygen uptake or carbon dioxide output, may omit a significant katabolic component of anaerobic respiration.

The rate of resplration by the microflora, although usually taken as a measure of carbon release, is also directly related to mineralization of the physiologically active plant nutrients (W1 tkamp 1966; Attiwell 1968; Wollum \& Davey 1975). The reduction - oxidation state of the elements, however, depends on the degree of oxygen depletion which is dependent not only on molsture content but also on microbial activity (Fig, 3).

The rate of decomposition of organic matter in the cycle of an even-aged plantation will, therefore, vary with the changing cemperature and molsture regimes. The forest floor temperature wll follow alr temperature but show reduced 

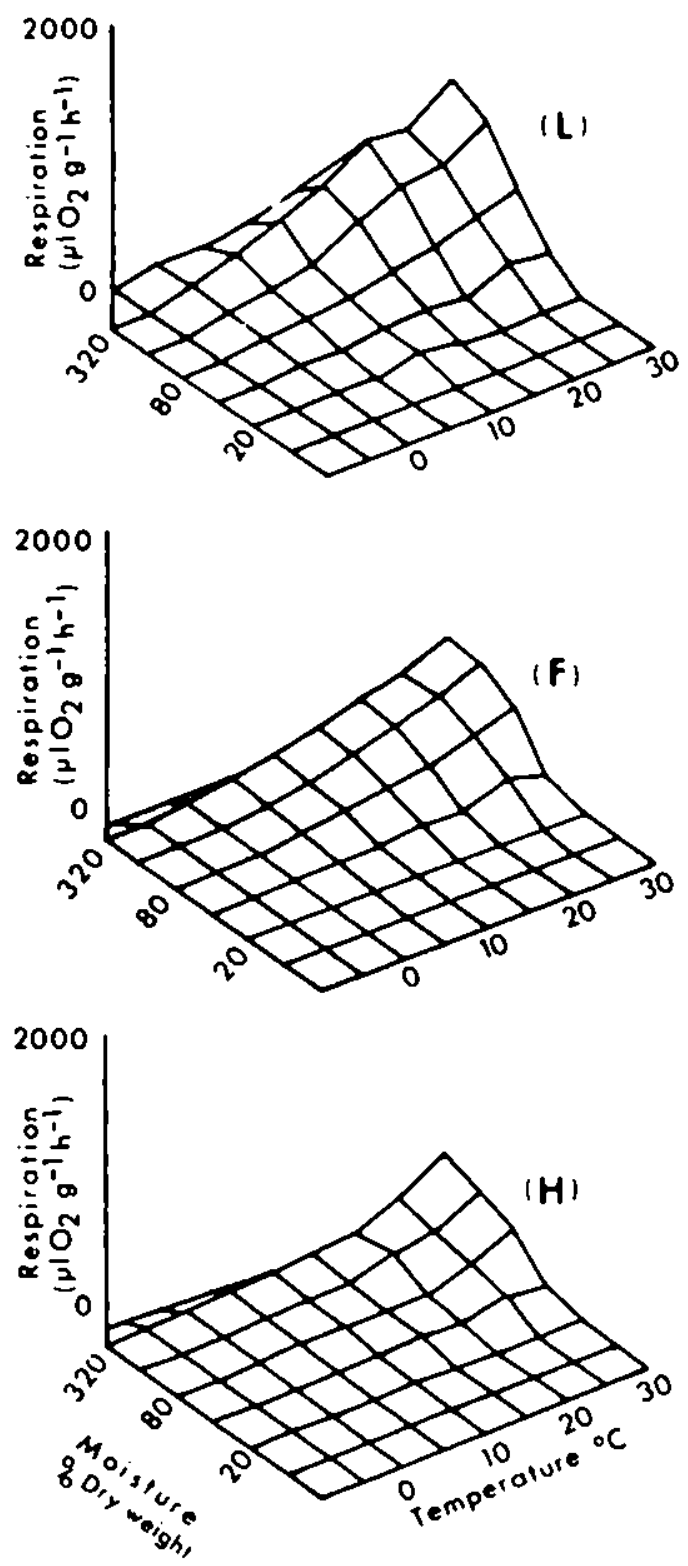

F1g. 2. Respiration rates of litter (L), fermentation (F) and humus ( $H$ ) layers of aspen (Populus tremulo1des) forest floor in Alaska, in relation to temperature and moisture. (From Bunnell et al. 1977). 


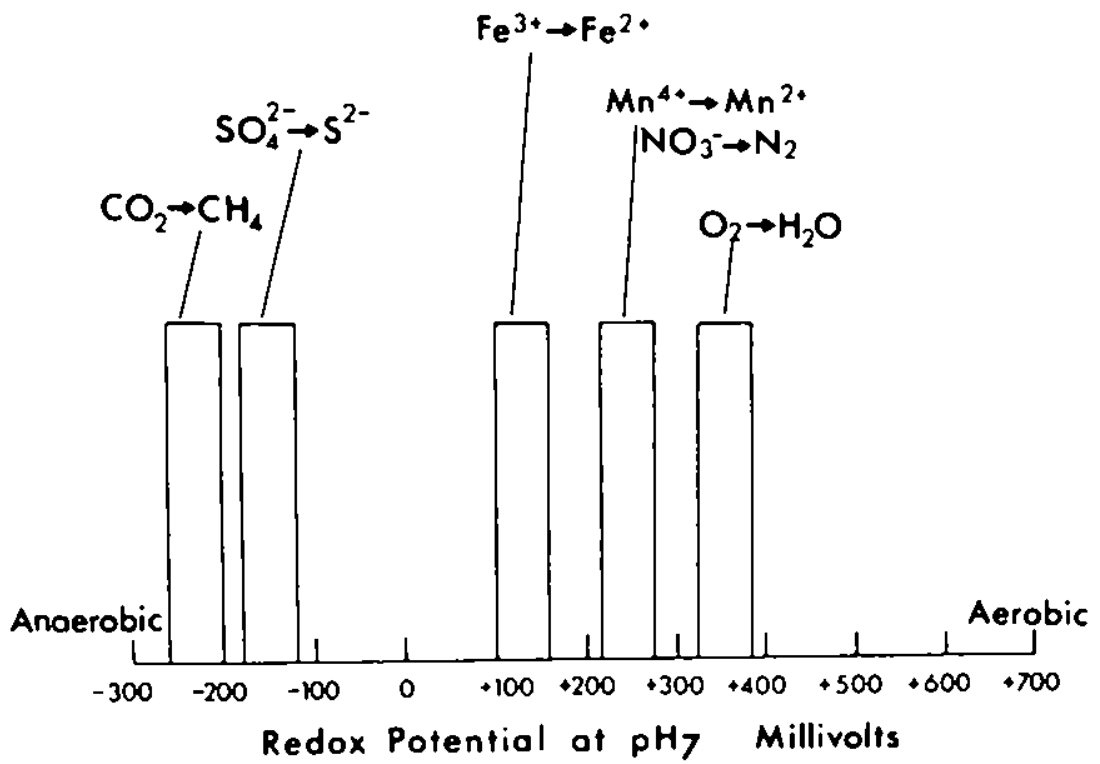

Fig. 3. Approximate crltical redox potentials at which various redox systems are reduced. (From Patric 1978).

diurnal and seasonal maxima and minima as the stand ages and canopy closes, although fluctuation will be increased at thinning (Hansen 1937; Odin 1974; Edgerton \& McConnel1 1976; Piene \& Van Cleve 1978). On mineral solls development of the organic layers will also reduce fluctuation because of their low therwal and water conductivity resulting from their low bulk density. The higher temperature minima and resulting longer decomposer season which occur as the forest develops will not compensate fully for the higher temperature maxima in unforested areas because the relationship of microbial resplation to temperature is basically exponential. In addition, freeze-thaw cycles which include nutrient release will also be depressed in the forest (Birch 1964; Witkamp 1969). The principle of reduced temperature fluctuations is reasonable but direct evidence is very $11 \mathrm{mmited}$. Piene \& Van Cleve (1978) found that thinning in a picea glauca forest in Alaska Increased the rate of litter decomposition as a result of higher temperatures and more favourable moisture conditions. However, Brown (1976) found no detectable difference in surface temperatures in cut and uncut strips of black spruce (Picea marlana) on a peat bog in Minnesota. He concluded that temperature related microbial activity was not 
expected to vary as a result of felling.

The varying effect of moisture during a forest cycle is more complex than that of temperature, as well as interacting with it, because of the balance between aerobiosis and anaerobiosis. The increase in evapotranspiration and canopy interception as the forest develops will reduce water input to the litcer surface and moisture levels in the soil. The degree of soil drying wlll vary with tree species, soll type, cultural technique and thinning (Hansen 1937; Lull \& Axley 1958; Haberland \& W1lde 1961; Binns 1968; Read, Arostrong \& Weatherall 1973; Pyatt 1973; Helvey 1975; Willians, Cooper \& Pyatt 1978). Molsture content and temperature will also vary spatially within a plantation, especlally in the pre-thicket stage, where ploughing has occurred, with greater temperature variation and lower moisture levels on ridges than in furrows. The changes in molsture content in organic horizons are reasonably predictable, but they are associated with more complex changes in other factors both in the organic and mineral horizons. Over the longer term, bulk density tends to increase as a result of decreasing molsture which causes a partially reversible compaction, especially in soils with a high organic content, while $\mathrm{pH}$ tends to fall and is related to alteration in the exchange capacity (e.8. W1lde 1964; Hawilton 1965; Pyatt 1973: Grieve 1978; Williams, Cooper \& Pyatt 1978).

Thus during the development of a forest the change in physical and chemical factors outlined above is expected to cause the following changes in the rates of decomposition and release of minerals:

(1) a gradual decrease at moist and dry sites because of decreasing fluctuation in temperature and decreasing moisture content as the canopy develops, reaching a constant level after canopy closure. At thinning, decomposition and relcase will increase for a few years with increased temperature and moisture and at felling the rate will rise considerably through the canopy removal.

(2) In wet sttes efther an increase or a dectease with tree growth, depending on the balance between the retarding effect of reduced amplitude of cemperature variation and the stimulating effect of increased aeration through lower molsture levels.

Soll factors

The Inftial soll conditions, like climate, set broad

limits to the rate of deconposition with a direct relationship to soll pH and concentration of minerals. Such a simplistic statement 16 inadequate, but there are surprisingly few studies which have examined decomposition in a wide range of soils and determined the influence of specific edaphic factors (Williams \& Gray 1974; Dickinson 1974). One reason for the lack of information is that many factors are correlated and it 
is virtually impossible to modify individual variables. In addition there is a strong interaction between climatic and soll factors which confounds analysis of decomposicion in field conditions (Heal \& French 1974).

Comparative studies have shown that decomposition of litter on the surface is correlated with $\mathrm{pH}$, phosphorus and calclum concentrations and is higher in solls with mull hurns than in those, with moder, mor of peat (Bocock \& Gilbert 1957; W1 tkamp \& Van der Drift 1961; Frankland 1966; Heal \& French 1974). Such studies correspond with results from research on particular processes such as cellulose decomposition, organic phosphate rineralization and nitrification (Alexander 1977). The chemical characteristics of the soil are intimately linked with physical characteristics, particularly texture and particle size, which have a great influence on adsorption characteristics, exchange capacity and $\mathrm{pH}$. The chemical and physical characteristics influence decomposition by their effects on the organisms and on the rate of enzyme activity, but they also affect retention of nutrlents in the soil and their availabilicy to decomposers. Because clay particles have a high ion exchange capacity, retention of nutrients is particularly related to the amount and composition of the clay fraction (e.g. Kolenbrander 1971). The soll moisture reglme is closely related to soll structure (Salter, Berry \& Williams 1966) through its associated aeration characteristics, the microsite phenomenon being applicable to $\mathrm{pH}$ and other physical factors as well as oxygen. The complex combination of soil factors which influence nutrient movements under varying soll condltions are well described by Nye \& Tinker (1977) and the dynamics of nutrients within ecosystems are defined in various computer simulations (Beek \& Frissel 1973; Innis 1978; Tanji \& Gupta 1978).

There is a vast 11terature on nutrient transformations in solls, espectally nitrogen and phosphorus in agricultural soils (Frissel \& Damen 1977), but the pattern of variation in decomposition and mineral release as related to different solls in forests is poorly documented. Durling the cycle of a conifer stand there is an accumulation of organic matter on the forest floor which reaches a maximum and may then decline in older stands (Ovington 1959; Page 1968, 1974; Kholopova 1972; Jorgensen, Wells \& Metz 1975). This accumulation, representing the balance between input and loss, is greater than under comparable deciduous stands and tends to have lower $\mathrm{pH}$, lower nitrogen content and a different balance of exchangeable nutrlents (Ovington 1953, 1954; N1hlgard 1971; Tappeiner \& Aln 1975). The changes in composition of the forest floor result in alterations to the lower horizons but the direction, degree, time-scale and consequences of such alterations are the subject of considerable debate (Stone 1975). The arguments will not be repeated here except to say 
that soil properties are affected by the chemical and physical composition of the incoming organic mater and its decomposition characteristics. Although not proven because of technical difficulties, such as accumulated sampling errors, comparability of sites and the range of variables to be measured, the theoretical and practical evidence indicates that conifers will cause soil changes which tend to reduce the rate of decomposition and nutrient release as coupared with deciduous species.

Resource quality

It is obvious that different resources, e.g. deciduous or coniferous leaf litcer or wood, have different rates of decomposition. Such variations occur between species, betwean different parts of the same plant, within the same species grown under differing soll conditions, and within the same plant as it matures and senesces. Thus, whlle it is convenient to define the resource as pinus contorta needles or Pseudotsuga nenziesil branches, such names are insufficient to describe the loportant physico-chemical characteristics which determine the rate of decomposition of that resource. Although our current understanding of the control of decomposition by resource factors is poor, four factors, which are often inter-correlated, are recognized:

(1) Carbon sources - a range of organic substrates act as carbon and energy sources for micro-organisms and their chemical composition controls their susceptibility to katabolism, e.g. Minderman (1968). The combination of carbon substrates whin a resource modifies its rate of decomposition (F1g. 4). Although many substrates are involved, the decomposition rate is largely determined by, or at least correlated with, the percentage of lignin (Van Cleve 1974). Bunnell, Tait \& Flanagan (1977) developed these principles and found that ethanol soluble components were katabolized at 5-10 tlmes the rate of ethanol insoluble components. From this they showed that a double exponential model, expressing both rapid and slow decomposing constituents, defined by the proportion of ethanol soluble and non-soluble fractions, provided a good fit between observed and predicted loss rates for a number of different litter types.

(2) Nutrient sources - the chemical elements of importance in plant growth are also ioportant in microbial and faunal growth, and are provided by katabolism of organic matter. The concentration of nutrient elements in fresh organic matcer is generally related directly to the rate of decomposition and mineral release as shown by the strong positive correlation between weight loss and initial nitrogen concentration (e.8. Witkamp 1966; Jensen 1974; van Cleve 1974). There is, however, an opposing trend, that during decomposition, the rate of decomposition 


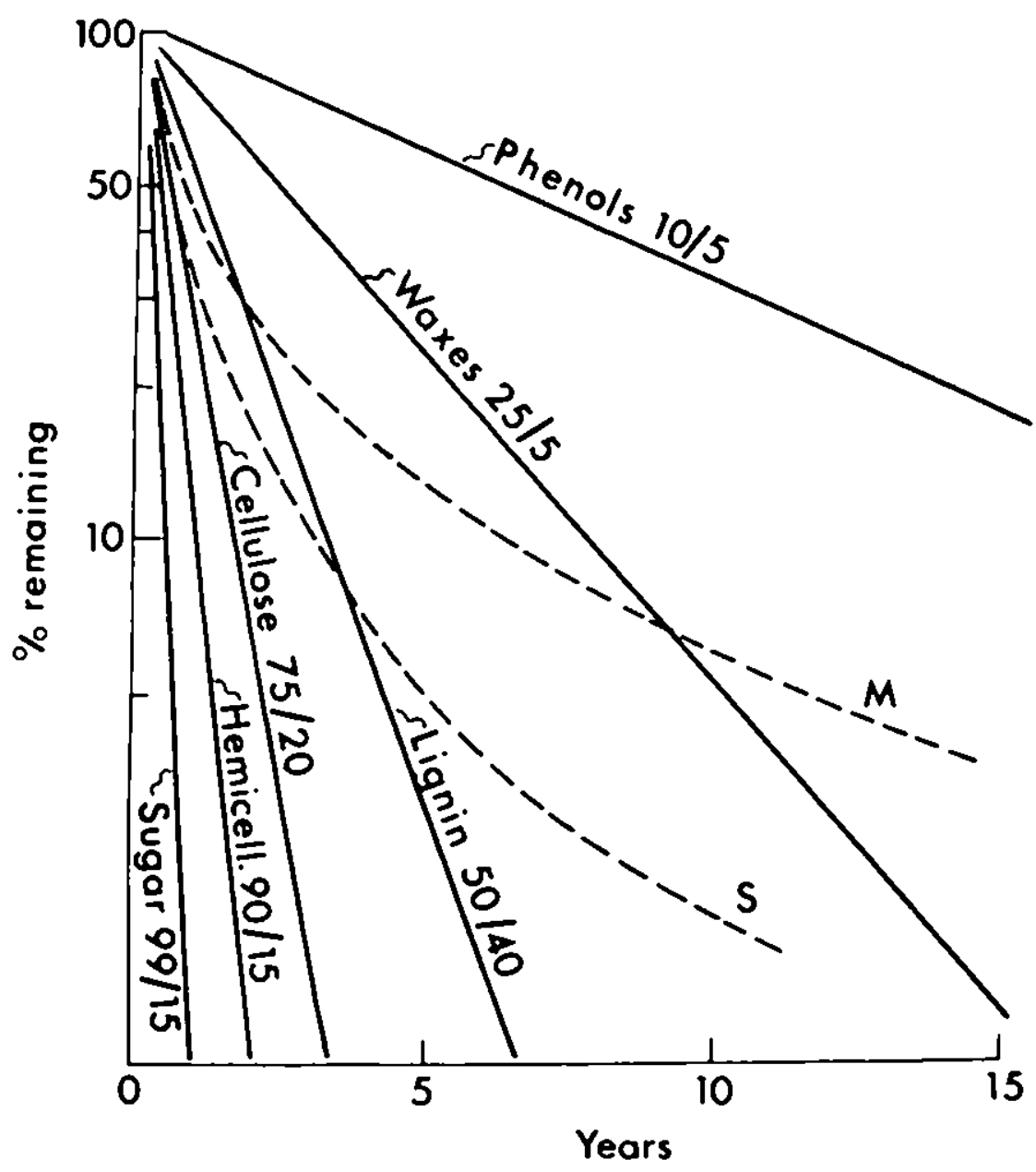

Fig. 4. Decomposition curves of substrates which constitute woodland litter. For each substrate the first number Indicates the percentage of the substrate lost in one year, the second number is the approximate percentage in weight of the original litter. The curve $S$ is the annual summation of the residual amounts of substrates remaining. The curve $M$ Is the approximate course of decomposition based on observed values. (From Minderman 1968). 
declines while the nutrient concentration often increases as a result of loss of gaseous carbon and immobilization of nutrients by the wicrobial population. The lowest rates of decomposition are found in 'humus' which has a high nutrient concentration, but the nutrients are conbined in complex organic molecules wich are the result of decomposition.

(3) Modifiers - chemical compounds, either present in the intial litter or produced by micro-organisms, whose presence in organic matter retards or stimulates microbial and faunal activity. A wide variety of compounds are involved but for technical reasons they have not been measured in comprehensive studies of decomposition. Their presence probably accounts for much of the variation in decomposition which is not explained by the composition of carbon and nutrlent sources. phenolic and quinonic compounds and cropolones extracted from conifer wood have been shown to be toxic to fungi (Scheffer \& Cowling 1966); polyphenols retard leaf litter decomposicion and inhibit earthworm feeding (King \& Heath 1967; Satchell \& lowe 1967) and may cause low rates of decomposition of roots (Sinha 1972); and of course Handley (1954) developed the hypothesis of the role of phenol tanned proteins in rull and mor formation. No general relationship between decomposition rate and concentration of modifier compounds has been described, but evidence suggests that conifers tend to have evolved these inhibiting compounds to a greater extent than wany other plants (e.g. Bauzon, van den Driessche \& Domergues 1969). Variation in decomposition of the same litter from different sites and ages may. be actributed to nutritionally induced differences in polyphenol complexing of litter materials, as in pinus radiata needles (Lamb 1976).

(4) Physical factors - the surface properties, coughness, particle size and other physical properties of the organic matter influence their rate of decomposition, particularly through their influence on moisture uptake and retention and on the resistance to attack by microorganisms and fauna. The main feature is the physical character of coniferous forest litter with its hydrophoblc surface and small surface area to volume. Thus, in comparison with most declduous leaf $11 \mathrm{tcc}$, they tend to have a low uptake but high retention of moisture, and retain their physical shape until late in the process of decomposition. These needle characteristics result in a lower leaching loss of soluble organic compounds and nutrients than in deciduous litters. Water soluble organic compounds thus decompose to a greater extent inside needles than inside leaf litter (Nykvist 1963). 
The four groups of factors which constitute resource quality combine to determine the relative rate of decomposition and nutrient release from different liters at a given site, with the environmental factors determining the absolute rate at different ricrosites. Although examples are cited in which a correlation exists between decomposition rate and concentrations of organic fractions or nutrients, there are many examples in which correlations were not detected (e.8. Melin 1930; Mikola 1955; Daubenmire \& Prusso 1953). Much depends on the range of resource qualicy which is examined, the range of chemical components determined and the extent to which interactions between factors are expressed.

The variation in rate of decomposition of different litters, as expressed by weight loss, has been determined in many comparative studies. These show a general pattern of decreasing rate over the series:

herb leaves > grass leaves > deciduous tree leaves > contfer needles > moss > declduous wood > conifer wood, (Mikola 1955; Daubenmire \& Prusso 1963; Bocock 1964; Voigt 1965; Mangenot 1966; W1tkamp 1966; Satchell \& Lowe 1967; Kira \& Shidei 1967; Attiwel1 1968; Yommaerts-Billiet 1971; Cosz, Likens \& Bormann 1973; Dickinson \& Pugh 1974; Heal \& French 1974; Swift et al. 1976; Heal, Latcer \& Howson 1978). Rates of loss have usually been measured for only the first year or two of decomposition but within this period the fastest rates are about ten times those of the slowest. There is considerable overlap between loss rates of the groups identified and it is particularly difficult to isolate the relative importance of different chemical and physical characteristics within groups. The initial state of the litter influences its subsequent decay rate, with faster rates recorded for green litter from which soluble fractions have not been resorbed before deach a factor relevant to the decomposition of brash. The decompostion of wood is also dependent on the proportions of bark, sapwood and heartwood, which vary considerably in chemical and physical composition and in decomposition rate (Gosz, Likens \& Bormann 1973; Kaar1k 1974).

The data on rate of decomposition of roots are very few but ind tcate slower rates than for leaf material of the sane species (Jenkinson 1965; Smith 1966; Malone \& Reichle 1973; Sinha 1972). The results are mainly for agricultural crops but are probably similar in non-cultivated species, with tree and shrub roots having rates comparable with those of above-ground wood (Kaarik 1974; Waid 1974; Heal \& French 1974). Root exudates constitute a very variable fraction of the total plant production, mainly as organlic aclds, sugars and amino acids whose rate of decomposition is probably high compared with other inputs (Smith 1969, 1970; Nye \& Tinker 1977).

Thus, during the $11 \mathrm{fe}$ of an even-aged plantation there is a changing pattern of quality of organic matter input, and 
Ground vegelation

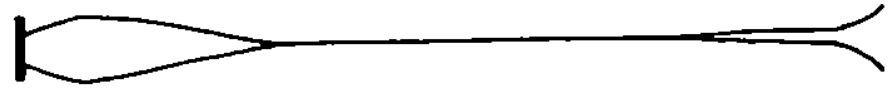

Needle

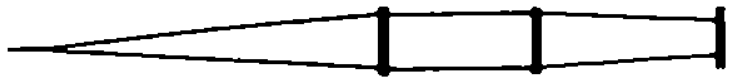

Twiglbranch

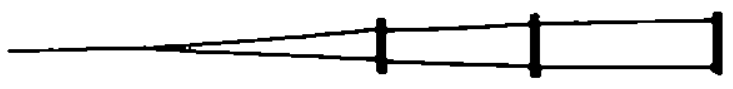

Wood

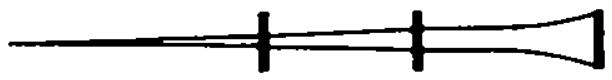

Rootistump
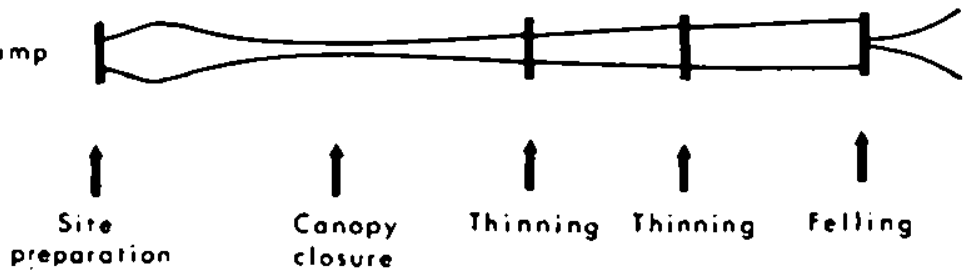

Fig. 5. Schematic input of varlous resources to the forest floor during a rotation. Bars represent major inputs of fresh material with relatively high soluble organic and nutrient content.

therefore, a changing rate of decomposition. The general phases of input are a gradual reduction in ground flora components compensated by needles and by $t w 1 g s$ and branches as the forest matures. The production of dead roots probably increases with time but data are very sparse. A series of inputs result from management practices with the particular characteristic that they usually comprise fresh plant material, needles, wood and roots, from which soluble organic materlal and nutrients have not been resorbed by the plant. At planting, fresh ground vegetation may be kllled as a result of sward inversion; brashing adds dead twgs and branches; thinning contributes green needles, fresh twigs, branches, stumps and roots, with a similar major input at final felling. Felling is followed by a perlod of negligible input until the ground flora redevelops, this being characterized by fast growing specles whose litter probably has a high decay rate. The general sequence of events, represented in Fig. 5, 18 recognized frow well-documented, quantitative measurements of 
above-ground input in plantations at varying stages of developrent (Bray \& Gorham 1964; Turner 1975; Miller, Cooper \& Miller 1976; Carey \& Farrell 1978), and occasionally for a complete age sequence for a species, e.g. Pinus sylvestris (Ovington 1959), P. radiata (W111 1964; Florence \& Larb 1974).

The varying types of organic mater deconpose at differing initial rates, but the composition changes with time as material is concentrated in alcroflora or converted to humus. The rate of decomposition of some of these residual fractions is very slow and as a result there are pools of organic mater and nutrients with different turnover rates. This is clearly expressed in the model developed by Jenkinson \& Rayner (1977) based on data from the Rothamsted field experiments and on measured organic matter fractions and rates of decomposition. The input $(1 \mathrm{tc} / \mathrm{ha} / \mathrm{yr})$ is separated into two fractions: 'decomposable plant material' and 'resistant plant material' in proportions 0.837 and 0.163 , respectively. Each of these fractions decomposes to produce 'soll biomass', 'physically stabilized organic matter' and 'chemically stabilized organic matcer' in proportions of $0.076,0.125$ and 0.0035 , respectively, with the release of carbon dioxide. These three fractions are repeatedly decomposed, yielding the same fractions at each step. The estimated half life of the fractions varied considerably and the predicted accumulation of the fraction when the model was run to 10,000 years assuming steady state (Table 1) was acceptably close to measured accumulations. The model indicates that small changes in input to the residual fractions, or changes in their curnover time, can cause large changes in the amounts of accurulated organic mater, and nutrients.

A change in. rate of decomposition and accumulation can result from input of residues which tend to produce more or less of specific humus fractions. Alternatively, a change in the acrobic / anaerobic balance during the forest development can modify the production of such conpounds. For example, Sinha (1972) showed that anaerobic decomposition of oat roots produced more fulvic acid and less humic acid and humins than did aerobic decomposition, the rate of decomposition of these fractions being in the sequence: fulvic acid $>$ humic acid $>$ humins (Campbell et al 1967).

\section{IMMOBILIZATION AND RELEASE}

The pool of organic matter with high rate of turnover may be stall but provides a rapid supply of recycled nutrients, while the larger pools of resistant organic matter with slow turnover provide a continuous supply of nutrients. The supply from the resistant organic matter, although representing a very small contribution from each year's input, represents a considerable accumulated release in any one year. The turnover of the microbial and faunal biomass are key factors in the 
Table 1. Turnover (half-life) and accumulation of fine fractions of organic matter in a cropped agricultural system at steady state (from Jenkinson \& Rayner 1977).

\section{Fraction}

Decomposable plant matertal Resistant plant material Soll blomass Physically stabilized o.m. Chemically stabllized o.t.

$\begin{array}{cc}\text { Half-11fe } & \text { Accumulation } \\ \text { (years }) & (t \mathrm{C} / \mathrm{ha})\end{array}$

$\begin{array}{cc}0.165 & 0.01 \\ 2.31 & 0.47 \\ 1.69 & 0.28 \\ 49.5 & 11.3 \\ 1980 & 12.2\end{array}$

mobllization of nutrients in the pools. The concentration of many elements in the decomposer organisms (Table 2) is much higher than in plant residues. As the carbon compounds are used as energy sources by the microflora, carbon is released as carbon dioxide or as anaerobic respiratory products, and only a small fraction is converted into microbfal tissue. In contrast nutrients are first mineralized from the plant residue, absorbed and converted into gicrobial tissue. The transfer of nutrients from plant to microbial compounds, comonly referred to as immobilization, results in the well-known fall in the $C: N$ or $C: e l e m e n t$ ratio. The decline in the ratio is considered to continue unt 11 it approximates to that of microbial tissue, at which stage the nutrient concentration is in excess of that required by the microflora and therefore the excess becomes avallable for plant uptake.

The changing concentration or ratios of elements indicate the stage at which there is net release of the element from the intimate mixture of plant restdue and microbial population. Critical levels approximate to 2 per cent for nitrogen ( $C: N \quad c .25: 1$ ), 0.1 per cent for phosphorus (C:P c.500:1), 0.20 per cent for sulphur ( $C: S$ c.250:1) and 0.10 per cent for potassium (C:K C.500:1) (Gosz, Likens \& Bormann 1973; Dowding 1974; Toth, Papp \& Lenkey 1975). Such generalizations are dangerous, however, because there is considerable variation between types of resource and in methods of analysis and release is inferred, not measured. The expression of concentration or ratio also ignores the state of the element, thus release wll depend on the avallability of the element, including carbon, to wicro-organisms, and also on the avallability of other elements.

The concepts of lomobilization and critical concentrations or ratios provide a conventent outline of the main sequence of events during decomposition and of differences between resources, but they mask the dynamic nature of the processes, particularly those involving the 


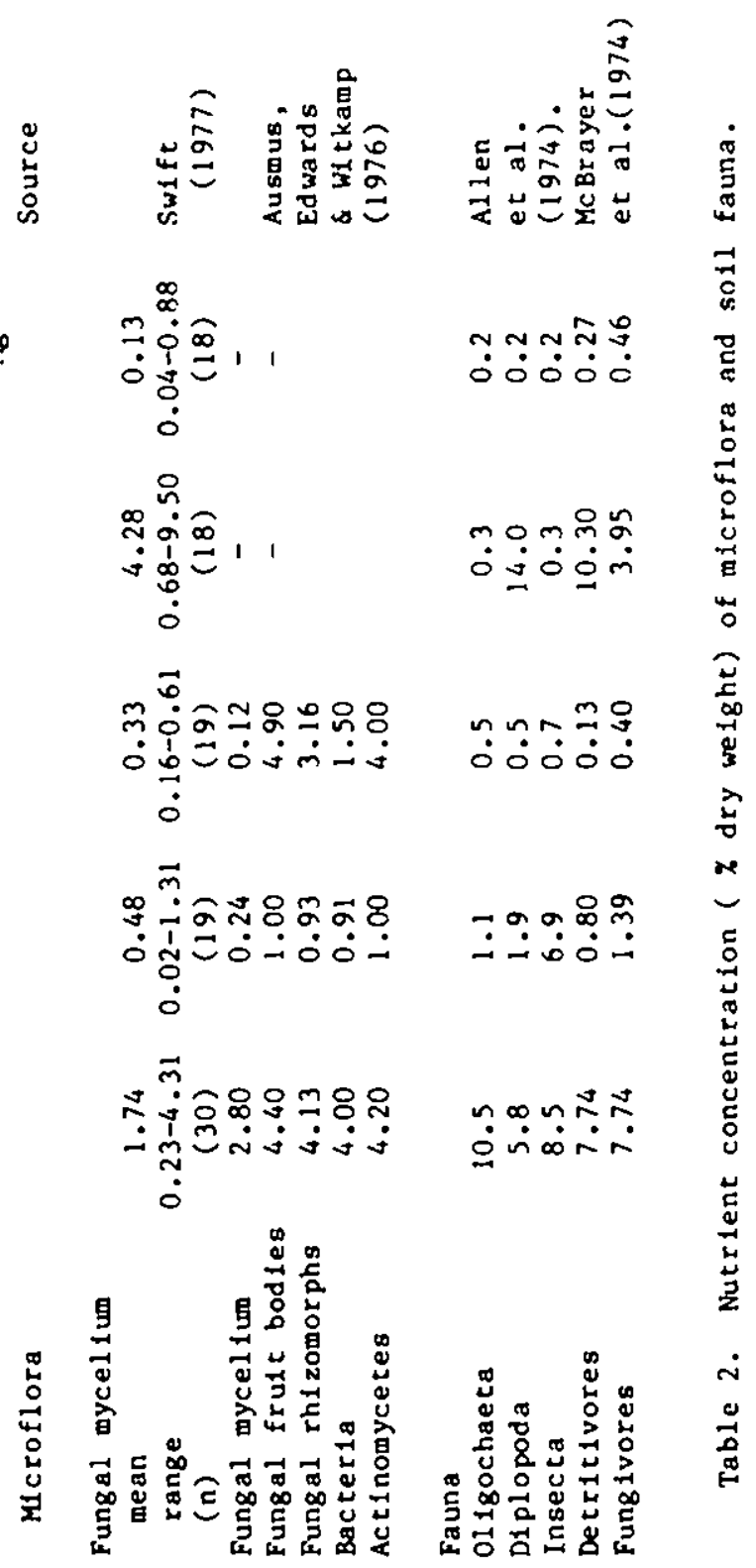


microflora. Measurement's of the standing crop of microflora in various resources have been used, in conjunction with nutrient concentrations of the microflora, to calculate the quantities of nutrients immobilized. The calculated percentage of the cotal nutrient which is immobilized varies greatly, e.8. 2-3 per cent for nitrogen and phosphorus in the forest floor of black spruce (Picea mariana) in Alaska (Flanagan \& Van Cleve 1977), but more than 100 per cent for sowe nutrients in the litter of Liriodendron tulipifera forest in Tennessee (Ausmus, Edwards \& Witkamp 1976). Methodological problems make accurate measurements very difficult, but these two studies show that nutrients are rapidly circulated through the microbial population which has generation times in days. Death and decomposition may be balanced by growth to give a falrly constant standing crop, but the nutrients are being circulated through inorganic pools which are capable of being utilized by fine plant roots permeating the litter. Both studies al so show warked growth in microbial populations and immobilization of nutrients in spring and early summer, wth a decline and presumably a release of nutrlents in late summer. The extent to which nutrients are retalned in dead microblal cells and mycelium is unknown and the presence of dark, apparently empty hyphae in acid organic solls argues for slow decomposition of at least the chitinous cell walls which have a high nitrogen content. However, Flanagan \& Van Cleve (1977) estimated that as a result of a decrease in microblal blomass, 90 per cent of which was fungal, there was a net release of $0.24 \mathrm{~g} / \mathrm{sq}$.m and $0.025 \mathrm{~g} \mathrm{P} / \mathrm{sq} . \mathrm{m}$. Within the forest floor in an eleven day period in summer. Ausmus, Edwards \& Wi tkamp (1976) showed similar fluctuations in the $L, F$ and $H$ layers.

The immobllization of nutrients by the microflora and possibly the mechanism of release is shown in the analysis of wood decomposition, for example (Ausmus (1977) and Swift (1977). Most nutrients in wood are gradually concentrated by fungi unt 11 30-50 per cent of the total calcium, magnestum and potassium, and 90-100 per cent of the nitrogen and phosphorus are contalned in mycelium (Fig, 6). Potassium, unlike other elements, shows a large initial decrease in concentration in wood as in other litters through leaching, whlle other elements are retained by the microflora. An increase in quantity of nutrient may result from nitrogen fixation or from import by fungl. Colonization by a sequence of fauna occurs after there has been considerable decomposition by fung 1 and is probably influenced by the concentration of nutrients in the microflora, which provide a more accessible nutrient source than the wood itself. Feeding by fauna then results in a net loss of nutrients from the wood, probably by a combination of leaching, movement of animals and comminution, which causes loss of fragments which are rich in nutrients. During the feeding by antmals nutrients are ingested, 

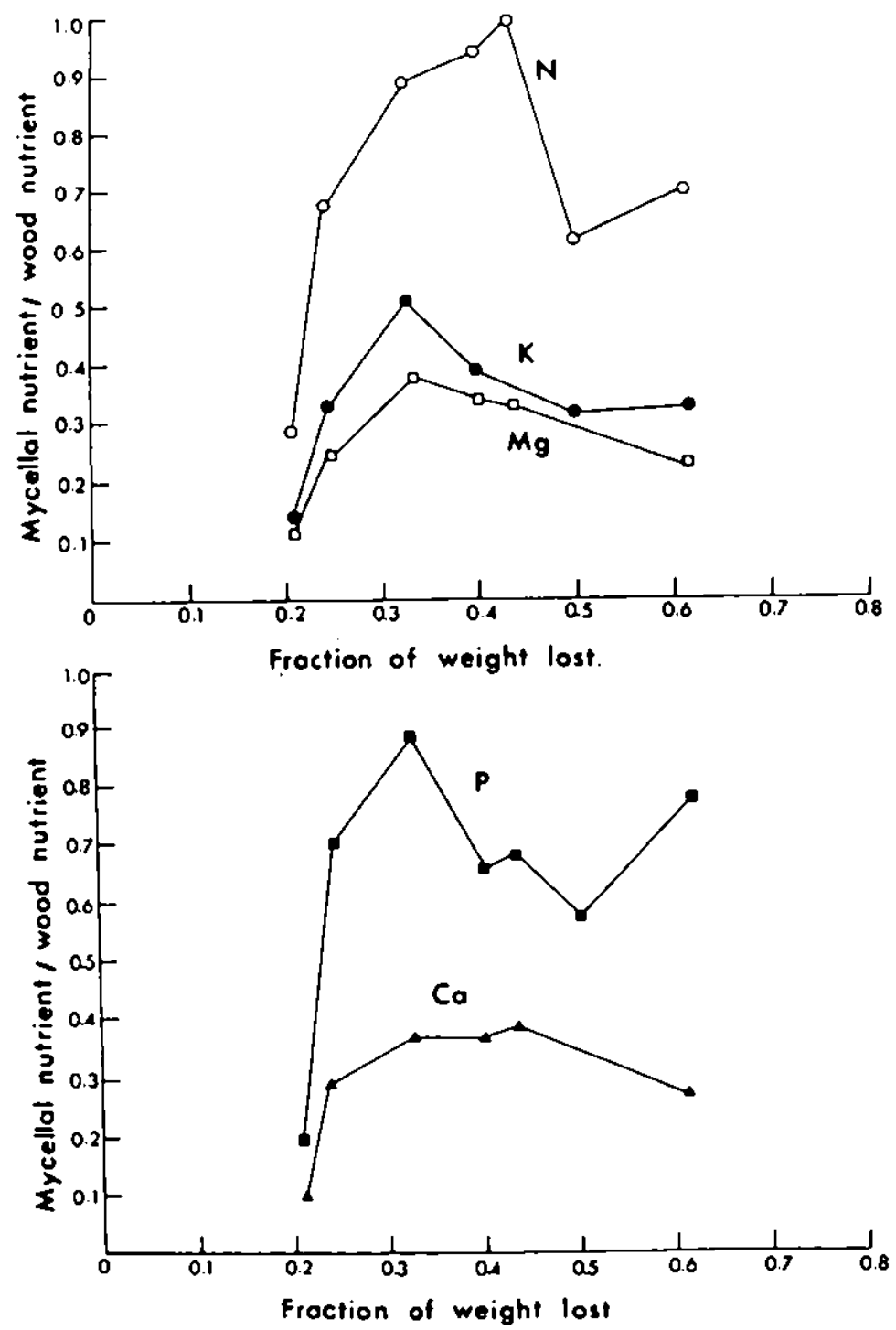

Fig. 6. The pattern of 1mmobilisation of branch-wood nutrients by mycelium of the white rot basidiomycete Stereum hirsutum in relation to state of decomposition. Mycelial nutrient is calculated from mycelial standing crop multiplied by mycelium nutrlent concentration and 1s expressed as a proportion of the branch-wood nutrient. (From Swift 1977.) 
mineralized and excreted as well as being Incorporated into tissue. Thus, there is a continual turnover of the inorganic and organic nutrient pools within the wood. The presence of plant roots within wood after faunal colonization, indicates that the nutrients are ut 11 ized by the vegetation and probably contribute to their net loss - at a time when the nitrogen concentration is about 0.5 per cent ( $C: N 100: 1)$.

The release of nutrients from bicroflora results from excretion, autolysis, decomposition by other microflora and grazing by fauna on both 1 ive and dead cells and hyphae. There is considerable evidence that suppression or elimination of fauna retards the rate of decomposition, directly through consumption and respiration and indirectly through reduced microbial activity (Edwards, Reichle \& Crossley 1970; Dickinson o Pugh 1974). Grazing on the wicroflora by protozoa and by nematodes decreases the microbial biomass but increases the rate of organic matter decomposition and the release of phosphorus and nitrogen in terrestrial and aquatic systems (Johannes 1965; Barsdate, Fenchel \& Prentk1 1974; Fenchel \& Harrison 1976; Coleman et al. 1977), although interpretation of experimental results on phosphorus release way be conflicting (Fenchel \& Harrison 1976).

Within an even-aged plantation, especially with conifers, changes in the physiconchemical conditions and in resource quality will influence faunal populations. Increase in acidity and of input of conlfer litter wll reduce earthworm populations if they were present initially, and the forest floor decomposition is usually dominated by micro-arthropods and enchytraelds and by fung 1 . The reduction in moisture level is likely to encourage faunal activity by increasing aeration on wet sites, but if waterlogging occurs as a result of felling, anacrobic conditions will again reduce the fauna. Although protozoa can modify bacterlal populations and processes, their influence on fungt is probably wuch more limited as few spectes are known to be funglvorous (Stout 1974) and their participation in nutrlent cycling is likely to decline during the development of a conifer plantation. Interaction within the microflora occurs and the most relevant aspect is the inhibition of litter decomposition by mycorrhizae. Gadgll \& Gadg1l (1975) showed that the weight loss of pinus radiata needles without plants or with non-mycorrhizal plants was significantly higher (44 per cent after six months) than in the presence of mycorrhizal plants ( 39 per cent). The difference is difficult to interpret but may result from the production of antiblotics which inhibit the growth of saprophytes or the greater competitive ability of mycorrhizal fung1, whose nutrlent uptake is not dependent on an assoctated energy source. Thus, organic matter decomposition may be retarded by the spread of mycorrhizas in the development of a plantation, while the mobllization of 
nutrients is maintained by the mycorrhizas.

\section{PATTERN AND IMPLICATIONS}

Decomposition and nutrient release comprise a complex series of interacting processes controlled by the physicochemical environment and resource quality and quantity. The balance between these processes and the input of organic matcer determines the rates of accumulation of organic matter and nutrients in and beneath the forest floor. In most ecosystems there are a series of trends occurring over different time scales - a pedogenic trend over millenia, on which is superimposed a successional sequence which may be repeated over decades or centuries, and a seasonal and even diurnal rhythm. In even-aged plantations the successional sequence is much more distinct than in mixed-aged situations, with the additional effect of distinct pulses introduced by management activities like brashing, thinning and felling.

The hypothesis, based on the review given in this paper, is that the general sequence of decomposition in conifer plantations will be:

(1) an initial pulse as a result of death of ground vegetation and sice preparation;

(2) a gradual decline as input from 8 round vegetation declines and conffer litter increases, and as soil temperature vartation and woisture content decline as the canopy closes;

(3) a pulse as a result of input of green needles, fresh wood and roots at thinning with associated short-term increases in temperature varlation and mofsture;

(4) a further decline as the proportion of wood input increases with stand age;

(5) a final pulse, greater than that at thinning, when felling provides a wajor input of fresh material and there is increased temperature and molsture response;

(6) the effect of the final pulse may be sustained by input from regrowth of ground vegetation into a favourable microclimate, until forest cover redevelops in a subsequent generation of trees.

Such a sequence is described in relation to specific management practices by Bunn \& W11 (1974) and Wollun \& Davey (1975). However, there is no direct evidence for or against the suggested sequence of events in terms of measured rates of decomposition and nutrient release over a rotation. The main corroborative evidence comes from the observed amounts of organic watter and nutrients accumulated over t1me or in response to particular practices. This evidence allows some inferences of rates of decomposition processes, particularly loss of carbon, but gives iftele Indication of the actual patcern of mineralization or of supply of nutrients to the 
The studies on effects of clearfelling appear to provide direct evidence with marked increases in nitrate output in stream water from felled, compared with unfelled, areas, additional varlation being related to management of the forest waste and forestry practice (Pierce et al. 1972; Verry 1972; Brown, Gahler \& Marston 1373; Likens \& Bormann 1974; Wiklander 1974; Fredriksen, Moore \& Norris 1975; Snyder, Haupt \& Belt 1975; Neary 1977). Although there are major varlations in concentration, many of these studles show an increase in nitrate output of about an order of magnitude after felling, with a return to base-line concentrations when ground vegetation is redeveloped. Actual changes within the forest floor and soll have recelved little attention, but Popovic (1974) showed an increased nitrification in solls as a result of felling, the rate being greatest in solls with $\mathrm{pH}$ above about 4.3 and $C: N$ below about $30: 1$. Tamm et al. (1974) point out that the change in nitrogen release is the result of loss of nutrient uptake by the trees which allows temporary accumulation of amonla, providing the necessary substrate for nitrification. Unless inhiblted by soll conditions, there will be an increase in nitrification and, in the absence of uptake by vegetation, the nitrate produced will be readily leached. Thus, there is a change in the product of nitrogen mineralization rather than a change in rate. The amount which is available for mineralization will, however, depend on the amount of organic residues from felling.

Loss of nitrate, and to a lesser extent phosphate, after felling is related to the change in demand, analogous to nutrient leaching under fallow conditions in agriculture. This raises the question of the synchronization of nutrient release from the forest floor and the nutrient demand by the growing crop. The apparent pattern of Increasing accumulation of organic matter and nutrients in the forest floor as the forest develops, implies decreasing release of nutrients, although some of the change is probably a redistribution of material within the soll profile rather than a change in absolute amount. The sequence of management practices from site preparation to felling results in a series of pulses of nutrient release. The initial pulse coincides with a small, locallzed dewand by the establishing forest; at thinning the pulse of nutrients from the forest floor probably accounts for some of the increased crop growth at a time when nutrient demand is maximal; at felling there is a release which does not coincide with forest demand. Thus, in even-aged plantations, both supply and demand are phased, but these two wajor cogs in the nutrient cxcle are apparently not fully synchronized. In contrast, the mlxed-aged forest has a spatial mosalc which allows greater opportunity for trees and other vegetation to benefit frow phases of nutrient input and release associated with individual trees. The mosaic in a 
mixed-aged forest will include seasonal variation in input and release when a range of specles are involved.

The importance of synchrony of nutrient supply and denand is only theoretical, and probably varies in different climatic regimes: In tropical regions a wajor proportion of the nutrient capital is maintained in the forest biomass, with a swall proportion in the forest floor which has a very short curnover time. With increasing latitude the balance changes, and an increasing proportion of the ecosystem nutrients are retalned in the forest floor, until in boreal forests there is a long turnover time (0lsen 1963; Duvigneaud \& Denayer-DeSuet 1969; Witkamp o Ausmus 1976). The forest floor, acting as both nutrient sink and source, provides a stability in high latitude forests which makes then less llable than tropical forests to suffer nutrient loss through man's activity. However, while acting as a stabilizing influence, the forest floor reduces the flow of nutrients to the trees, and any increase in the rate of nutrient turnover is expected to increase primary production. Fertilizers give some increase in growth, but efficiency of uptake is low compared with agricultural systems, partly because of the slow response rate of trees. Grazing is an alcernative practice which has the potential to increase the rate of nutrient turnover in the forest floor, and by maintaining a vegetation cover can retain nutrients during management disturbances. Some of the positive responses of trees to experimental grazing (Hedrick \& Keniston 1966) may result from increased nutrient avallability despite potential competition between trees and ground flora. Although current evidence of the value of grazing in forests is inconclusive (Adams 1975), there are logical reasons for examining this, and other alternatives to current management practices, which can increase and control nutrient circulation through the forest floor.

\section{REFERENCES}

Adams,S.N.(1975). Sheep and cattle grazing in forests: a revlew. Journal of Appl led Ecology, 12, 143-152.

Allen,S.E., Grimshaw, H.M., Parkinson,J.A.\& Quamby,C.(1974). Chemical analysis of ecological materlals. Blackwell, Oxford.

Alexander,M.(1977). Introduction to soll microblology. Wiley, New York.

Attlwell,P.M.(1968). The loss of elements from decomposing litter. Ecology, 49, 142-145.

Ausmus, B.S.(1977). Regulation of wood decomposition rates by arthropod and annelid populations. "Soll organisms as components of ecosystems." (Ed. by U.Lohm and T.Persson), pp.180-192. Ecologlcal Bulletin, Swed1sh Natural Science Research Council, 25 . 
Ausmus, B.S., Edwards,N.T. \& Witkamp,M.(1976). Microbial immoblitization of carbon, nitrogen, phosphorus and potassium: implications for forest ecosystems processes. "The role of terrestrial and aquatic organisws in decorposition processes." (Ed. by J.M. Anderson and A. Mac fadyen), pp.397-416. Blackwe11, Oxford.

Barsdate,R.J., Fenchel,T. \& Prentk1,R.T.(1974). Phosphorus cycle of model ecosystems: significance for decomposer food chains and effect of bacterlal grazers. 0ikos, 25 , 239-251.

Bauzon, D., Van den Driessche,R. \& Domergues,Y.(1969). L'effet litière. I. Influence en situ des litières forestières sur quelques caractéristiques biologiques de sols. Decologia plantarum, $4,99-122$.

Beck,J. \& Frissel,M.J.(1975). Simulation of nitrogen behaviour in solls. Pudoc, Wageningen.

Binns,W.0.(1968). Some effects of tree growth on peat. Proceedings 3rd International Peat Congress, Quebec 1968.

Birch,H.F.(1964). Mineralization of plant nitrogen following alternate wet and dry conditions. Plant and Soll, 20, 43-50.

Bocock,K.L.(1964). Changes in the amounts of dry matter, nitrogen, carbon and energy in decomposing woodland leaf litter in relation to the activities of the soll fauna. Journal of Ecology, 52, 273-284.

Bocock,K.L. \& Gilbert,0.J.W.(1957). The disappearance of leaf litter under different woodland conditions. plant and So11, $9,179-185$.

Bray,J.R. \& Gorham, E.(1964). Litter production in forests of the world. Advances in Ecological Research, $2,101-157$.

Brown,G.W., Gahler,A.R. \& Marston,R.B.(1973). Nutritent losses after clearcut logging and slash burning in the oregon Coast Range. Water Resources Research, 9 , 1450-1453.

Brown,J.M.(1976). Peat temperature regime of a Minnesota bog and the effect of canopy rewoval. Journal of Applied Ecology, 13, 189-194.

Bunn, E.H. \& WII, G.M.(1974). Management operations affecting nutrient cycling and fert\$lizer response in forest stands. Proceedings F.A.O./ I.U.F.R.O. International Symposium on Forest Fertilization, Par1s. pp.33-53.

Bunnell,F.L. \& Talt,D.E.N.(1975). Mathematical simulation models of decomposition processes. "Soll organisms and decomposition in tundra." (Ed. by A.J.Holding, O.W.Heal, S.F.Maclean and P.W.Flanagan), PP.207-225. Tundra Biome Steering Comitcee, Stockholm.

Bunnell,F.L., Ta1t,D.E.N. \& Flanagan,P.W.(1977). Microbial respiration and substrate welght loss. II. A model of the influences of chemical composition. Soll Biology and Biochewistry, $\frac{9}{,} 41-47$.

Bunnell,F.L., Tait, D.E.N., Flanagan,P.W. \& Van Cleve,K.(1977). 
Microblal respiration and substrate weight loss. I. A general model of the influences of abiotic varlables. Soll Biology \& Blocheristry, 9, 33-40.

Campbel1,C.A., Paul,E.A., Rennie,D.A. \& McCallum,K.J.(1967). Applicability of the carbon-dating method of analysis to soil humus studies. Soll Sclence, 104, 217-224.

Carey,M.L. \& Farrell,E.P.(1978). Production, accumulation and nutrient content of Sitka spruce litterfall. Irish Forestry, $35,35-44$.

Coleman,D.C., Cole,C.V., Anderson,R.V., Campion,M.K., Clarholo,M., Elliot,E.T., Hunt,H.W., Schaefer,B. \& Sinclair,J.(1977). An analysis of rhlzosphere saprophage inceractions in cerrestrial ecosystems. "Soil organisms as components of ecosystems." (Ed. by U.Lohm and T.Persson), pp.299-309. Ecological Bulletin, Swedish Natural Science Research Counc1l, 25 .

Cromack,K., Sollins,P., Todd,R.L., Fogel,R., Todd,A.h., Fender,W.M., Crossley,M.E. \& Crossley,D.A.(1977). The role of oxalic acid and bicarbonate in calciun cycling by fungi and bacteria: some possible implications for soil animals. "Soll organisms as components of ecosysters." (Ed. by U.Lohm and T.Persson), pp.246-252. Ecological Bulletin, Swedish Natural Sclence Research Council, 25 .

Daubentire,R. \& Prusso,D.C.(1963). Studies of the decomposition rates of tree 11tter. Ecology, 44, 589-592.

Dickinson, C.H.(1974). Decomposition of litter in soil. "Biology of plant litter decomposition." (Ed. by C.H.Dickinson and G.J.F.Pugh), pp.633-658. Academic Press, London.

Dickinson, C.H. \& Pugh,G.J.F.(1974). Biology of plant litter decomposition. Academic Press, London.

Dowd ing,P.(1974). Nutrient losses from litter on I.B.P. Cundra sites. "Soll organisms and decomposition in tundra." (Ed. by. A.J.Holding, 0.W.Heal, S.F.MacLean and P.W.Flanagan), pp.363-373. Tundra Biome Stecring Commitce, Stockholm.

Duvignesud, P. \& Denayer-DeSmet, S.(1969). Biological cycling of minerals in temperate deciduous forest. "Analysis of temperate forest ecosystems" (Ed. by D.E.ReIchle), pp.199-225. Springer Verlag, New York.

Edgerton,P.J. \& YcConnell(1976). Diurnal temperature regimes of logged and unlogged mixed conifer stands on elk summer range. U.S. Department of Agriculture Forest Service Research Note, PNW-277.

Edwards,C.A., Reichle,D.E. \& Crossley,D.A.(1970). The role of soll invertebrates in turnover of organic matter and nutrients. "Analysis of temperate forest ecosystems." (Ed. by D.E.Reichle), pp.147-172. Springer Verlag, New York.

Fenchel,T. \& Harrison,P.(1976). The significance of bacterlal grazing and wineral cycling for the decomposition of 
particulate detritus. "The role of terrestrial and aquatic organisms in decomposition processes." (Ed. by J.M.Anderson and A.Macfadyen), pp.285-299. Blackwe11, Oxford.

Flanagan,P.W. \& Van Cleve,K.(1977). Microbial blomass, respiration and nutrient cycling in a black spruce talga ecosystem. "Soll organisms as components of ecosystems." (Ed. by U.lotm and T.Persson), pp.261-273. Ecological Bulletin, Sweidish Natural Science Research Council, 25 .

Florence,R.G., \& Lamb,D.(1974). Influence of stand and site on radiata pine litter in. South Australla. New Zealand Journal of Forestry Science, 4, 502-510.

Frankland,J.C.(1966). Succession of fung 1 on decaying petioles of Pterldium aquilinum. Journal of Ecology, 54, 41-63.

Fredriksen,R.L., Moore,D.G. \& Norris,L.A.(1975). The 1mpact of timber harvest, fertilization and herblcide treatment on streamwater quality in western Oregon and Washington. "Forest soils and forest land management." Proceedings 4th North American Forestry Solls Conference, Quebec. (Ed. by B.Bernier and E.H.W1nget), pp.283-313. University of Laval Press, Quebec.

Frissel,M.J. \& Damen,J.P.N.(1977)(Eds) Cycling of mineral nutrients in agricultural ecosystens. Agro-Ecosystems, 1 and 2 .

Gadgil,R.L. \& Gadgil,P.D.(1975). Suppression of litter decomposition by mycorthizal roots of Pinus radiata. New Zealand Journal of Forestry Science, $5,33-41$.

Gosz,J.R., Likens,G.E. \& Bormann,F.H.(1973), Nutrient release from decomposing leaf and branch litter in the Hubbard Brook Forest, New hampshire. Ecologlcal Monographs, 43 , 173-191.

Greenwood,D.J.(1968). Measurement of microbial metabolism in soil. "Ecology of soll bacteria." (Ed. by T.R.Gray and 0.Parkinson), pp.138-151. Liverpool University Press, Liverpool.

Grieve,I.C.(1978). Some effects of the plantation of conifers on a freely drained lowland soll, Forest of Dean, U.K. Forestry, 51, 21-28.

Haberland,F.P. \& Wilde,S.W.(1961). Influence of thinning of red pine plantation on sofl. Ecology, 42, 584-586.

Harditon, C.D. (1965). Changes in the soll under pinus radiata. Australian Forestry, 29, 275-289.

Handley,W.R.C.(1954). Mull and mor formation in relation to forest solls. Forestry Commssion Bulletin 23 .

Hansen, T.S.(1937). Ecological changes due to thinning jack pine. University of Minnesota, Technical Bulletin, 124 , $1-77$.

Heal,0.W. \& French,D.D.(1974). Decomposition of organic watter in tundra. "Soll organisms and decomposition in tundra." (Ed. by A.J.Holding, O.W.Heal, S.F.MacLean and 
P.W.Flanagan), pp.279-309. Tundra Biome Stecring Committee, Stockholm.

Heal, O.W., Latter,P.M. \& Howson,G.(1978). A study of the rates of decomposition of organic matter. "Production ecology of British moors and montane grasslands." (Ed. by 0.W.Heal and D.F.Perkins), Pp.136-159. Springer Verlag, Berlin.

Hedrick,D.M. \& Keniston,R.F.(1966). Grazing and Douglas fir growth in the oregon white oak type forest. Journal of Forestry, 64, 735-738.

Helvey,J.D.(1975). Soll molsture depletion and growth rates after thinning ponderosa pine. U.S. Department of Agriculture Forest Service Research Note, PNW-243.

Innis,G.S.(1978). Grassland simulation model. Springer verlag, Berlin.

Jenkinson,D.S.(1965). Studies on the decomposition of plant material in soil. I. Losses of carbon from $14 \mathrm{C}$ labelled ryegrass incubated with soll in the field. Journal of Sol1 Science, 16, 104-115.

Jenkinson,D.S. \& Rayner,J.H.(1977). The turnover of soll organic matcer in some of the Rothamsted classical experiments. Soll Science, 123, 298-305.

Jensen, $v .(1974)$. Decomposition of angiosperm tree leaf litter. "Biology of plant litter decomposition." (Ed. by C.H.Dickinson and G.J.F.Pugh), Pp.69-104. Academic Press, London.

Johannes,R.E.(1965). Influence of marine protozoa on nutrient regeneration. Limnology and Oceanography, 10, 434-442.

Jorgensen,J.R., hells,C.G. \& Metz,L.J.(1975). The nutrient cycle: key to continuous forest production. Journal of Forestry, 73, 400-403.

Kaarik,A.A.(1974). Decomposition of wood. "Blology of plant litter decomposition." (Ed. by C.H. Dickinson and G.J.F.Pugh), pp.129-174. Academ1c Press, London.

Kholopova,L.B.(1972). Variation in some physical and chemical soll properties with age of pine plantations. Lesovadente 1972 , pp.38-48.

King,H.G.C. \& Heath,C.W.(1967). The chemlcal analys is of small samples of leaf material and the relationship between the disappearance and composition of leaves. Pedobfologia, 7 , 192-197.

Kira,T. \& Shide1,T.(1967). Primary production and turnover of organic matter in different forest ecosystems of the western Pactfic. Japanese Journal of Eçology, 17, 70-87.

Kolenbrander,G.J.(1971). Contribution of agriculture to eutrophication of surface waters with nitrogen and phosphorus in the Netherlands. Institute of Soll Fertility, Haren, Gronlingen.

Lamb,D.(1976). Decomposition of organic matter on the forest floor of pinus radiata plantations. Journal of Soll 
Science, 27, 206-217.

Likens,G.E. \& Bormann,F.H.(1974). Effects of forest clearing on the northern hardwood forest ecosystem and its biogeochemistry. Proceedings lst International Congress on Ecology, The Hague, Netherlands. pp.330-335.

Lul1,H.W. \& Axley,J.H. (1958). Forest soll molsture relations in the coastal plain sands of southern New Jersey. Forest Sclence, $4,2-19$.

Me Brayer,J.F., Reichle,D.E. \& Witkamp,M.(1974). Energy flow and nutrient cycling in a cryptozoan foodweb. Oak Ridge Nat Ional Laboratory, Oak Ridge.

Malone,C.R. \& Reichle,D.E.(1973). Chemical manipulation of soll biota in a fescue meadow. Soll Biology and Biochemistry, 5, 629-639.

Melin,E.(1930). Biological decomposition of some types of litter from North American forests. Ecology, 11, 72-101.

Mikola,p.(1955). Experfments on the rate of decomposition of forest litcer. Cocmunicationes Instituti Forestalis Fenniae, $43,1-50$.

Miller,H.G., Cooper,J.M. \& Miller,J.D.(1976). Effect of nitrogen supply on nutrients in litter fall and crown leaching in a stand of Corsican pine. Journal of Applied Ecology, 13, 233-248.

Minderman,G. $(1 \overline{968})$. Addition, decomposition and accumulation of organic matter in forests. Journal of Ecology, $\underline{56}$, 355-362.

Mommaerts-Bililiet,F.(1971). Aspects dynamiques de la disparition de la litière de feuilles. Bulletin Sociéte royale de botanique de Belgique, 104, 181-195.

Neary,D.A.(1977). Impact of timber harvesting on nutrient losses in stream flow. New Zealand Journal of Forestry, 22, 53-63.

Nihlgard,B.(1971). Pedological influence of spruce planted on former beech forest solls in Scania, South Sweden. Oikos, 22, 302-314.

Nye, P.H. \& Tinker,P.B.(1977). Solute movement in the soll-root system. Blackwell, Oxford.

Nykvist,N.(1963). Leaching and decomposition of water-soluble organic substances from different types of leaf and needle litter. Studia Forestalla Suecica, $\frac{3}{1-31}$.

odin,M.(1974). Some meteorological effects of clearfelling. Sveriges Skogsvards forbunds Tidskrift, $1,60-65$.

01 son,J.S.(1963). Energy storage and the balance of producers and decomposers in ecological systems. Ecology, 44, 322-331.

Ovington,J.D.(1953). Studies of the development of woodland conditions under different trees. I. Soll pH. Journal of Ecology, 41, 31-34.

ovington,J.D. $(1954)$. Studies of the development of woodland conditions under different trees. II. The forest floor. 
Journal of Ecology, 42, 71-80.

Ovington,J.D.(1959). The circulation of minerals in

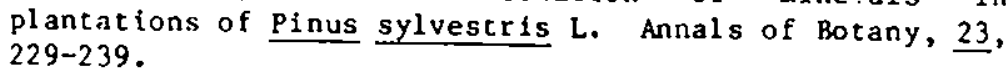

Page,G.(1968). The effects of conifer crops on soil properties. Commonweal th Forestry Review, 47, 52-62.

Page,G.(1974). The effect of forest cover on the properties of some Newfoundland forest solls. Canadlan Forest Service Publication 1332 .

Patrick.W.H.(1978). Measurement and predication of anaerobiosis in solls. "Nitrogen in the environment. I.Nitrogen behavlour in field soll." Academic Press, London.

Piene, H. \& Van Cleve,K.(1978). Weight loss of 11 teer and cellulose bags in a thinned white spruce forest in Interior Alaska. Canadian Journal of Forest Research, $\underline{8}$, 42-46.

Pierce,R.S., Martin,C.W., Reeves,C.C., Likens,G.E. \& Bormann,F.H.(1972). Nutrient loss from clearcuttings in New Hampshire. Proceedings of the symposium on watersheds in transition. American Water Resources Association, Urbana. pp.285-295.

Popovic,B.(1974). The effect of clearfelling on soll nitrogen transformation. Sveriges Skogsvardsforbunds Tidskrift,, 80-85.

Pyate,G.(1973). Physical and mechanical properties of sotl types. Report on Forest Research, London. 1973. pp.62-66.

Read,D.J., Armstrong, W. \& Weatherall, J.(1973). The effects of cultivation treatment on water potential and soll aeration in wet heathland with spectal reference to afforestation. Journal of Appl led Ecology, 10, 479-487.

Salter,P.J., Berry,G. \& Williams,J.B.(1966). The influence of texture on the moisture characteristics of soils. III.Quantitative relationships between particle size, composition and avallable water capacity. Journal of Soll Science, $17,93-98$.

Satchell,J.E. \& Lowe,D.G.(1967). Selection of leaf litter by Lumbricus terrestris. "Progress in soll biology." (Ed. by 0.Craff and J.E.Satchel1), pp.102-118. North Holl and Publishing Co., Amsterdam.

Scheffer,T.C. \& Cowling,E.B.(1966). Natural resistance of wood to microbial deterloration. Annual Review of Phytopathology, 4, 147-170.

Sinha,M.K.(1972). Organic matter transformation in solls. I. Humlfication of Cl4-tagsed oat roots. Plant and Soll, 36, 283-293.

Sufth,J.H.(1966). The use of 18otopes in soll organic matter studies. Pergamon Press, Oxford. pp.223-224.

Smlth,W.H.(1969). Release of organic materials from the roots of tree seedlings. Forest Sclence, 15, 138-143. 
Swith,W.H.(1970). Root exudates of seedling and wature sugar maple. Phytopathology, 60, 701-703.

Snyder,G.G., Haupt,H.F. \& Belt,G.H.(1975). Clearcutting and burning slash alter quality of stream water in northern Idaho. U.S. Department of Agriculture Forest Service Research Paper INT-168. Intermountain Forest Range Experimental Station.

Stone,E.L.(1975). Effects of species on nutrient cycles and soll change. Philosophical Transactions of the Royal Society, Lond on B, 271, 149-162.

Stout,J.D.(1964). Protozoa. "Blology of plant licter decomposition". (Ed. by C.H. Dickinson and G.J.F.Pugh), pp.385-420. Academ 1c Press, London.

Swift,M.J.(1977). The roles of fungi and animals in the immobllization and release of nutrient elements from decomposing branchwood. "Soll organisms as components of ecosystems." (Ed. by U.Lohm and T.Persson), pp.193-202. Ecological Bulletin, Swedish Natural Science Research Counc11, 25 .

Sw1ft,M.J., Heal,o.W. \& Anderson,J.M. (in press). Decomposition in terrestrial ecosystems. Blackwell,
Oxford.

Swift,M.J., Healey,I.N., Hibberd,J.K., Sykes,J.M., Bampoe,V. \& Nesbitt,M.E.(1976). The decomposition of branchwood in the canopy and floor of a mixed deciduous woodland. oecologia, 26, 139-149.

Tamm, C.O., Holmen, H., Popovic, B. \& Wiklander,G.(1974). Leaching of plant nutrients from solls as a consequence of forestry operations. Amb1o, $3,211-221$.

Tanji,K.K. \& Gupta,S.K.(1978). Computer simulation modelling for nitrogen in 1rrigated croplands. "N1trogen in the environment. I.Nitrogen behaviour in field solls." (Ed. by. D.R.Nielsen and J.G.MacDonald), pp.79-130. Academic Press, New York.

Tappelner,J.C. \& Alm, A.A.(1975). Undergrowth vegetation effects on the nutrient content of litterfall and solls in red pine and birch stands in northern Minnesota. Ecology, 56, 1193-1200.

Toth,J.A., Papp,L.B. \& Lenkey,B.(1975). LAtter decomposition In an oak forest ecosystem (Quercetum petraeae cerris) of northern Hungary studled in the framework of the 'Sikfokut project'. "Blodégradation et Humification." (Ed. by G.Kilbertus, O.Reisinger, A.Mourey and J.A. Cancela Da Fonseca), pp.41-58. Université de Nancy.

Turner,J.(1975). Nutrient cycling in a Douglas fir ecosystem with respect to age and nutrient status. Forestry Abstracts, 37,6003 .

van Cleve,K.(ig74). Organic matter quality in relation to decomposition. "Soll organisas and decomposition in tundra." (Ed. by. A.J.Holding, O.W.Heal, S.F.Maclean and 
P.W.Flanagan), pp.311-324. Tundra Biome Steering Committee, Stockholm.

Van Cleve,K. \& Sprague,0.(1971). Respiration rates in the forest floor of birch and aspen stands in interior Alaska. Arctic and Alpine Research, 3 , 17-26.

Verry,E.S.(1972). Effect of an aspen clearcutting on water yield and quality in northern Minnesota. Proceedings Symposium on watersheds in Transition, Fort collins. American Water Resources Association, Urbana.

Voigt,G.K.(1965). Nitrogen recovery from decomposing tree leaf tissue and forest humus. Soll Science Soclety of America Proceedings, $29,756-759$.

Waid,J.S.(1974). Decorposition of roots. "Biology of plant litter decomposition." (Ed. by C.H.Dickinson and G.J.F.Pugh), pp.175-211. Academic Press, London.

Wiklander,G.(1974). Effect of clearfelling on the content of nutrients in surface and ground water. Sveriges Skogsvards forbunds Tidskrif $\mathrm{t}, \frac{1}{1}, 86-90$.

wilde,S.A.(1964). Changes in soil productivity induced by pine plantations. Soll Science, 97, 276-278.

W111,G.M.(1964). Dry matter production and nutrient uptake by Pinus radiata in New zealand. Commonwealth Forestry Review, $\frac{43}{73}, 57-70$.

Will,G.M.(1967). Decomposition of Pinus radiata litter on the forest floor. I. Changes in dry mater and nutrient content. New Zealand Journal of Forestry Science, 10 , 1030-1044.

Williams,B.L., Cooper,J.M. \& Pyatt,D.G.(1978). Effects of afforestation with Pinus contorta on nutrient content, acidity and exchangeable cations in peat. Forestry, sl, 29-35.

Williams,S.T. \& Gray,T.R.G.(1974). Decomposition of litter on the soll surface. "Biology of plant litcer decomposition." (Ed. by C.H.Dickinson and G.J.F.Pugh), pp.611-632. Academic Press, London.

Witkamp,M.(1966). Decomposition of leaf litter in relation to environment, microflora and microbial respiration. Ecology, 47, 194-201.

Wi tkamp,M. $(1969)$. Environmental effects on microbial turnover of some mineral elements. I. Ablotic factors. Soll Biology and Biochemistry, $1,167-176$.

Witkamp,M. \& Ausmus, B.S.(1976). Processes in decomposition and nutrient transfer in forest systems. "The role of terrestrial and aquatic organisms in decomposition processes." (Ed. by. J.M.Anderson and A.Macfadyen), pp.375-396. Blackwe 11, Oxford.

witkamp, ,M. \& Drift,J.van der(1961). Breakdown of forest litcer in relation to environmental factors. Plant and So $11, \underline{15}, 295-311$.

Wollum,A.G. \& Davey,C.B.(1975). Nitrogen accumulation, 
transformation and cransport in forest soils. "Forest soils and land management." (Ed. by B.Bernier and C.H.Winget), pp.67-106. Université de Laval Press, Quebec.

Wood,T.G.(1974). Field investigations on the decomposition of leaves of Eucalyptus delegatensis in relation to environmental factors. Pedobiologia, 14, 343-371. 



\section{BIOLOGICAL MEANS OF IMPROVING NUTRIENT UPTAKE IN TREES}

\section{BY PAUL P. KORMANIK}

USDA Forest Service, Institute for Mycorrhizal Research and Development, Southeastern Forest Experiment Station, Forestry Sciences Laboratory, Carlton Strect, Athens, Georgia 30602.

\section{SUMMARY}

Nitrogen-fixing wicro-organisms and wycorthizal fungi play important roles in nutrient relationships in present-day natural forest stands and undoubtedly they will play significant roles in even-aged plantations in the future. Nodulated non-legumes, shrubs, al so can be important on forestry sites, which frequently have soll conditions not suitable for long-terw developnent of herbaceous legumes. Free-living, nitrogen-fixing organisms require abundane organic substrate and good soil moisture conditions, and nitrogen from them only becomes available after the organisms decay. These organisms exhibit a preference for mineralized nitrogen over atmospheric nitrogen, factors which limit their importance in agricultural solls but should not be a drawback in forest soils. Both groups of organisms working together may provide significant amounts of nitrogen for tree growth and stand development.

The importance of mycorthizae as absorbing structures may not yet be fully appreciated, but they are indispensable to many forest trees for $P$ uptake. The avallability of this element is normally too low in forest solls to support growth of trees lacking mycorrhizae. The methodology, however, for studylng the mycorrhizal contribution in biological nutrient uptake in the forest ecosystem has not been perfected. Because of the complex relationship among tree mixtures, fungal symbionts, and soll types, the techniques will be difficult to develop. Evidence on the importance of 
mycorrhizat in nutrient absorption by many agrononic plants is overwhelming and this uplake function by mycorrhizae on trees in furests will probably prove to be even more important than on plants growing in heavily fertilized agronomic soils. Forest solls that contain sufficient available $P$ to permit suitable growth of trees lacking mycorrhizae are rare.

The greatest immediate impact of mycorrhizal technology will be in nursery seedling production, plancation establishment and tree improvement programs, all three of these areas are closely integrated. There is mounting evidence that planted seedlings with heavily mycorrhizal root systems survive and grow significantly better than seedlings with few or no mycorrhizae.

RÉSUMÉ

Les microorganismes qui fixent l'azote et les mycorrhizes jouent un rôle important dans les cycles d'éléments nutritifs des forêts naturelles actuelles et continueront sans doute ce role dans les forets Equiennes de l'avenir. les non-légumineuses à nodule sont des arbustes. Elles peuvent être importantes dans les stations forestières qui ont souvent des sols ral adaptés au développenent à long terme des légumineuses herbacees. Les organistoes libres et fixateurs d'azote demandent des sous-sols organiques riches et des conditions d'humidité favorables. L'azote qu'ils libèrent $n^{\prime}$ est disponible que lorsque ces organismes se décomposent. Ces organismes préfèrent $1^{\prime}$ azote minéralisé à celui de l'atmosphere, ce qui limite leur importance dans les sols agricoles mais ne devrait pas être un inconvénient dans les sols forestlers. Ces deux groupes d'organismes devraient pouvoir travaliler de concert pour produire la quantité appréciable d'azote utile a la croissance de l'arbre et au développerent du peuplement.

Il se peut que nous ne comprenions pas bien 1'importance des mycorthizes en tant que structures absorbantes, mais nous savons qu'elles sont indispensables a l'apport de $P$ dans beaucoup d'arbres forestiers. Le taux de $p$ disponible est normalement trop bas dans les sols forestiers pour aider à la croissance 
d'arbres manquant de mycorrhizes. Cependant, les méthodes qui étudient la contribution des mycorrhizes dans le cycle des éléments nutritifs de $1^{\prime}$ écosystème - forêt ne sont pas très perfectionnees. Les techniques seront difficiles à développer a cause des relations complexes entre nélanges d'arbres, symbiotes et types de sols. Nous savons I importance des mycorrhizes dans l'absorption d'éléments nutritifs de nombreuses plantes agronomiques et le rôle des mycorthizes dans l'arbre forestier s'avérera encore plus important que chez les plantes poussant dans des sols agricoles très riches en engrais. Les sols foresticrs qui comportent suffisament de $P$ disponible pour permetcre une croissance favorable des arbres et qui manquent de mycorrhizes sont rares.

Li ou la technologie liée aux mycorrhizes aura la plus grande influence sera dans les pépinières, la création de plantations et les progranmes d'amélioration des arbres - ces trois champs d'utilisation étant étroitement liés. Il devient de plus en plus Evident et significatif que les plantes ayant des racines comprenant des mycorrhizes survivent et poussent plus favorablement qui ceux qui $n^{\prime}$ ont peu ou pas de mycorrhizes.

\section{ZUSAMMENFASSUSG}

Stickstoffbindende Mikroorganismen und Mykorrhizen spielen eine bedeutende Rolle in bezug auf die Nährstoffbeziehungen heutiger Naturwaldbestände und werden zwelfelsohne auch in zuküntigen gleichaltrigen Pflanzungen von Bedcutung sein.

Nichtleguminosen tit Knöllchenbakterien sind Sträucher. Sie können auf haldstandorten wichtig sein, wo die Bodenbedingungen of nicht für elne langzeitliche Entwicklung krautiger Leguminosen geeignet sind.

Freilebende stickstoffbindende organismen benötigen Substrate rit hohem organischen Anteil und gute Bodenfeuchtigkeltsbedingungen. Erst bei der Zersetzung der Organismen wird ihr Stickstoff frel. Diese Organismen bevorzugen Mineralstickstoff gegenüber Luftstickstoff, was ihre Bedeutung fir landwirtschaftliche Böden einschränkt, aber für Waldboden kein Nachteil sein sollte.

Wenn beide Organismengruppen zusamenarbeiten, 
können sie bedeutende Stickstoffrengen für das Wachstim der Bäume und die Fntwicklung des Bestandes anliefern.

Die Bedeutung von Mykorrhizen für die Nährstoffaufnatme wird vielleicht noch nicht genügend geschätzt, aber ohne sie wäre eine Phosphoraufnakme bel vielen Waldbätren unmöglich. Die Verfügbarkeit dieses Flements ist im Waldboden normalerweise zu niedrig für ausreichendes Wachstum von biumen ohne Mykorthizen. Eine Methodik, mit der man der Beitrag der Mykorrhizen zur biologischen Năhrstoffaufnahme in Waldökosystemen bestimmen konnte, steht noch nicht zur verfügung. Wegen der komplexen Beziehung zwischen verschiedenen Bäuen, Pilzsymbionten und Bodentypen wird es schwierig sein, entsprechende verfahren zu entwickeln.

Es gibt überwältigendes Beweisnatertal für die Wichtigkeit von Mykorrhizen bei der Nahrstoffaufnahe vieler landwirtschaftlicher Nutzpflanzen, und diese Aufnahmefunktion wird sich wahrscheinlich für Waldbäume als noch viel wichtiger erweisen als für Pflanzen in stark gedünten landwirtschaftlichen Böden. Waldböden, die genigend verfügbaren Phosphor für ein normales Wachstum von B̈̈umen ohne Mykorthizen auf weisen, sind selten.

Die grössten unmittelbaren Effekte wird die Mykorrhlza haben in der Sämlingsproduktion it Pflanzgarten, bei der Begründung der Pflanzungen und bei der Zuwachssteigerung von Bestïnden, wobei diese drei Gebiete alle eng miteinander verbunden sind. Es gibt umfangreiche Hinweise dafür, dass ausgepflanzte Simlinge mit starkem Mykorrhizabesatz weitaus besser überleben und wachsen als Sämlinge mit wenig oder ohne Mykorrhizen.

\section{INTRODUCTION}

The most important organisms for biologically improving nutrient relationships in plant communities are the nitrogen-fixing organisms and the mycorrhizal fungl. There is untversal agreement on the froportance of nitrogen fixers in the nutritional balance of plants, regardless of site. Nitrogen fixation is seen as the key to increasing the productivity of the blosphere. The absorption capacity of mycorrhizae, with many plants, surely must be ranked second in biological importance. However, universal agreement is lacking on the importance of mycorrhizal fungt because many sclentists 
view them as extraneous organisms whose importance to trees is limited to soils low in avallable nutrients.

Great emphasis has been placed on increasing agricultural productivity to sustain the world's increasing population. In comparison, litcle has been done to increase productivity on forested lands. Increas ed agricultural productivity can be attributed to greater mechanization and the development of superior hybrids and varieties coupled with increased use of fertilization and inoculation wth nitrogen-fixing bacteria. Most of the world's important food and grain crops are hosts for mycorthizal fungi and significantly benefit from mycorrhizae in teros of both nutrient and water uptake (Nicolson 1967; Gerdemann 1968; Smith 1974; Safir, Bayer \& Gerdeman 1971, 1972). Unfortunately, breeding programs seem to select against this important mycorrhizal symbiotic relationship that has been with plants since they evolved from their water habitat (Pirozynski \& Malloch 1975). Before a specific hybrid or variety is released, it is nomally tested under quite favourable water and fertility regimes for plant development but are artificial environmental conditions not conducive to optimum mycorrhizal development?

Throughout the world, foresters are gathering superior trees to be included in seed orchards and, in many cases, they have seed orchards well established. From these orchards will come seed for the plantations of the future. I think we should include in our selection criterla tests to identffy those mother trees whose progeny derive the greatest benefit from the mycorrhizal symbiosis and, thus, have an added advantage in blological nutrient uptake.

\section{NITROGEN-FIXING ORGANISMS}

It has been estimated that almost 100 million tons (about $10 \mathrm{~kg} / \mathrm{ha} / \mathrm{yr}$ ) of nitrogen are fixed annually by nacural processes worldwide in comparison to 25 atllion tons fixed by industrial methods (Nogsle \& Fritz 1976) and it is agreed that industrial production could never sustain the world's requirements to maintain present levels of plant production.

Rhizobium symbiosis with herbaceous legumes is of primary importance to agriculture. However, it is responsible for only about $0.5 \mathrm{~kg} / \mathrm{ha} / \mathrm{yr}$ of the nitrogen fixed at the earth's surface. Lichens and free-living heterotrophic bacteria account for about $3.5 \mathrm{~kg} / \mathrm{ha} / \mathrm{yr}$. The rest of the total is about equally divided between blue-green algae and nodulated non-legumes and woody legumes (Richards 1974).

At present $1 t$ secms likely that nitrogen fixation via Rhizobium will play only a minor role in forest plantation nutrition although it may be important on some of the more fertile forested sites where legumes could be planted between the rows in young plantations to help control weeds and at the same time contribute significant amounts of nitrogen for 
several years. Haines, Haines and White (1978) reported encouraging results in a young sycamore (Pseudoplatanus occidentalis) plantation in northern Alabama. After four years with a clover cover crop, Trifolium spp, the volume of a six-year old plantation was $52 / \mathrm{cu} . \mathrm{m} . /$ ha, without clover it was $14 / \mathrm{cu} . \mathrm{m} . / \mathrm{ha}$. It may also be feasible to introduce woody legumes into plantations to enhance nitrogen fixation. This approach may gain in importance if management is directed more towards total fibre yield rather than fibre yield for specific products such as paper.

Nodulated non-legumes (acinomycete symbiosis) have been reported in at least thirteen plant genera (Richards 1974) and may prove to be more signiflcant than Rhizobilm in plantations and forests of the future. These genera have a worldwide distribution and are represented by at least 300 species, about 100 of which have been exanined and found to develop nodules. Most of these nodulated plants are trees and shrubs which often grow on the relatively infertile sites usually avaliable to forestry and their contribution to nitrogen fixation can be significant. For instance, in acid peat bogs Gale palustris fixes about $9 \mathrm{~kg} / \mathrm{ha} / \mathrm{yr}$, but in artificial culture may greatly surpass the fixation by either red clover or other legumes. Alnus crispa has been shown to fix between 62 and $164 \mathrm{~kg} \mathrm{~N} / \mathrm{ha} / \mathrm{yr}$. In Africa, Casuarina equisetifolia has been reported to $\mathrm{fix}$ up to $58 \mathrm{~kg} \mathrm{~N} / \mathrm{ha} / \mathrm{yr}$ (Richards 1974).

Many nodulated non-legumes are woody shrubs that probably only compete with trees in young plantations. However, research is needed to determine if there are any blological advantages in encouraging their growth in the understory of plantations to take advantage of their ability to fix atmospheric nitrogen.

Nitrogen fixing nodules can fix 100 to 200 times more nitrogen than the free-living micro-organisos per unit of cell material. Asymbiotic organisms are limited in agricultural solls because they require an abundant supply of organic substrate and a good molsture supply. They also have a high affinity for mineralized nitrogen, such as ammoniun, which they utilize in preference to molecular nftrogen (Noggle \& Fritz 1976). In agricultural solls these requirements may 1 imlt their importance, but in forest solls they may not be critical. Jorgensen (1975) reported favourable fixation rates in coastal plain solls in South Carolina in conjunction with controlled burning experiments. From samples collected in June, before burning, he reported fixation rates of approximately $3 \mathrm{~kg} / \mathrm{ha} / \mathrm{yr}$ in mineral upland soils and 30 $\mathrm{kg} / \mathrm{ha} / \mathrm{yr}$ in swanp solls. Little if any of this activity could be attributed to blue-green algae. Jorgensen also reported that there is still no realistic assessment of the importance of anaerobic $\mathrm{N}_{2}$ fixation in practical forestry. Switzer \& Nelson (1972) found that during the first twenty years of a 
Pinus taeda plantation total nitrogen on site increased from

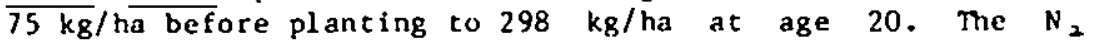
fixation rates reported by Jorgensen (1975) could easily be sufficient to meet the stand's need, and even lower fixation races would be of considerable significance in the nitrogen cycle.

Non-symbiotic fixation by blue-green algae may be significant in the world nitrogen balance but may only be significant in forest plantations under specific conditions. It is generally assumed that a combination of low light intensity, less than optimum soil moisture and temperature, and low pH in forest soils minimize the significance of these organisms in nicrogen fixation (Jurgensen \& Davey 1968). These authors, working with acid forest solls in both the Appalachian Mountains and the Atlantic Coastal Plain, reported a general absence of nitrogen-fixing algae. However, on wetter sices or desert areas where the $\mathrm{pH}$ is higher than six, blue-green algae way assume considerable local blological importance.

In North Carolina, Meyer (1977) studied nitrogen fixation on leaves and bark of a mature oak-hickory (Quercus-Carya) forest and on the needles of a pinus strobus stand. In the oak-hickory, fixation by bark and stem lichens was $1.9 \mathrm{~kg}$ $\mathrm{N} / \mathrm{ha} / \mathrm{yr}$ wille the phyllosphere fixed $0.16 \mathrm{~kg} \mathrm{~N} / \mathrm{ha} / \mathrm{yr}$ and these above-ground epiphytes contributed approximately 16 per cent of the annual nitrogen fixation in this forest. It was calculaced that the whice pine eplphytes fixed $0.92 \mathrm{~kg}$ N/ha/yr.

Lichens may play a role in biological nitrogen nutrition in plantations in tropical and subtropical forests where they are particularly abundant in those environments. For example, Harrelson (1969) reported nitrogen fixation rates by lichens in a Puerto Rican forest of $25 \mathrm{co} 75 \mathrm{~kg} / \mathrm{ha} / \mathrm{yr}$, and Forman (1975) reported 1 to $8 \mathrm{~kg} / \mathrm{ha} / \mathrm{yr}$ in a colombian rain forest. Further research is required to assess the contribution of lichens to the tocal nitrogen in the soll, both in tropical and subtropical forests as well as in other climatic zones.

\section{MYCORRHIZAE}

Most higher plants in nature develop mycorrhizae to varying degrees (Fig. 1). Wilhelm (1966) states that under field conditions plants do not, strictly speaking, have roots, they have mycorrhizae. Although much of the original basic mycorrhizal research has been done with agrononic plants, a significant portion of the recent awareness of the practical importance of mycorrhizae to plant growth and productivity can be traced to the application of the mycorrhizal technology in forestry (Marks \& Kozlowski 1973; Kormanik, Bryan \& Schultz 1977a, b; Marx 1975, 1977). Many professional foresters and scientists do not grasp the importance of this symbiotic 


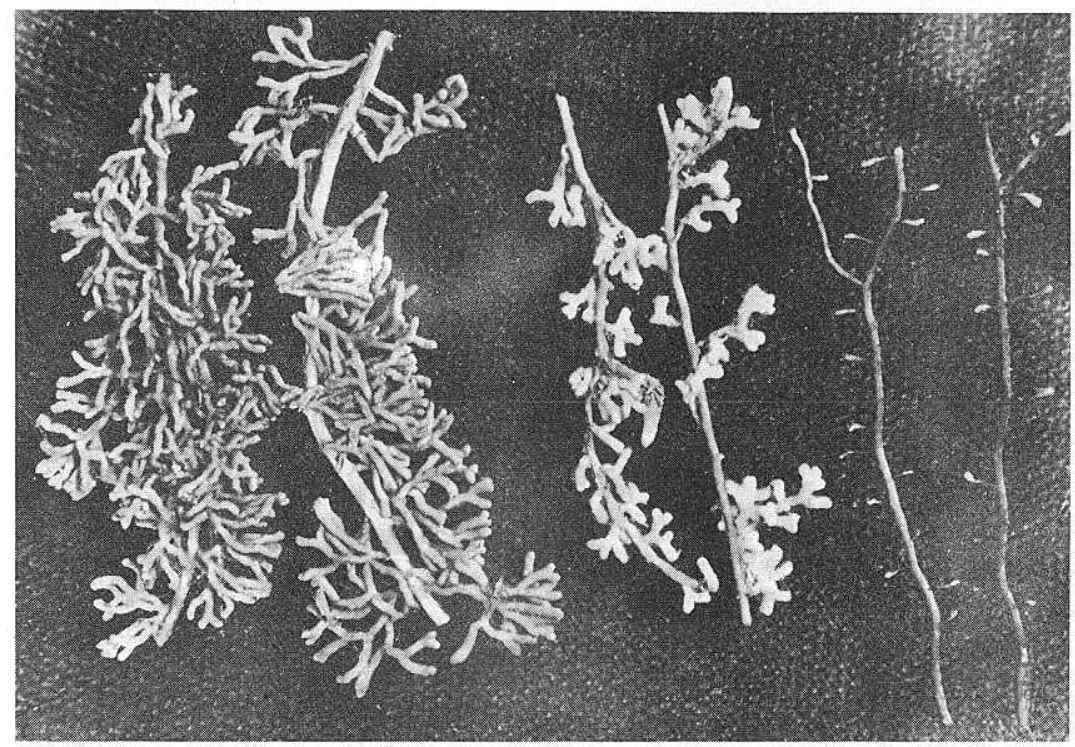

Fig. 1. Infection of a seedling pine root system by Pisolithus tinctorius (left), Thelephora terrestris (centre) and no mycorrhizal fungus (right).

relationship to trees. It is really not a question of how much better would the trees in the forest grow with mycorrhizae, but rather, would the forest exist at all without the mycorrhizae. Forest managers must become as aware of the importance of mycorrhizal symbiotic relationships as they are of photosynthesis. Photosynthesis may convert solar energy into chemical energy, but even the most photosynthetically efficient tree would not be self-supporting in a natural environment without the contribution of mycorrhizae.

In forestry, the two major types of mycorrhizae are ectomycorrhizae and endomycorrhizae. A third type, ectendomycorrhizae, is less frequently encountered, more poorly understood, and is currently considered of less ecological importance than the other two. Several general articles provide an understanding of these organisms (Nicolson 1967; Smith 1974; Marx 1975).

Ectomyorrhizae

The major distinguishing feature of ectomycorrhizae is the intercellular development of hyphae in the cortex resulting in the Hartig-net. Externally, ectomycorrhizae may appear as simple unforked roots, bifurcate roots, multi-forked (corralloid) roots, or even nodular-like roots that are readily visible to the naked eye. Most fungi that form ectomycorrhizae with forest trees are Basidiomycetes, which produce mushrooms or puffballs as reproductive structures. Certain of the Ascomycetes, such as truffles, are also 
symbiotic. The fruiting bodies of these fungi produce millions of spores which are readily and widely disseminated by wind and water.

Ectomycorthizae occur .naturally on wany of the important forest tree species of the world. All members of the gymosperm family Pinaceac, i.e. Pinus (pine), Picea (spruce), Ables ( $f$ ir), Larix (larch). Isuga (hemlock), and Pseudotsuga (Douglas-fir), as well as certain angiosperms, such as Salix (willow), Populus (aspen), Carya (hickory and pecan), Quercus (oak), and Fagus (beech), are ectomycorrhizal.

Endomycorrhizac

One major subtype of endomycorrhizae is commonly referred to as the vesicular-arbuscular or VA mycorrhizae. The vesicles and arbuscules are quite distinctive in the cortical zone of roots. Arbuscules consist of dense clusters of very fine dichotomously branched filaments wich may occupy the entire l men of a cortical cell. Vesicles develop later and appear as cerminal swellings either within or between cells. No characteristic external changes in morphology occur in roots infected with endomycorrhizal fungi.

The fungi which form endorycorrhizae are mainly Phyconycetes witich do not produce large, above-ground fruiting bodies or wind-disseminated spores. They are spread in the suil by root contact, moving water and animals. The spores are able to survive for many years in the soil when a suitable host is not present.

Many of the important angiosperm forest trees in the Uniled States, such as Liquidambar (sweetgum), Platanus (sycamore), Ulmus (elm), Juglans (walnut), Fraxinus (ash), Liriodendron (poplar), Acer (maple), and perhaps Alnus (alder) normally form endonycorthizae.

Ectend om ycorrhizae

This type of mycorthizac has the features of both ectoand endomycorthizae. Fctendonycorrhizae have a limiled occurrence and are found primarily on roots of forest trecs that are numally cctomycorthizal. Since little research has been done on these fungi, very little is known about the species of fungi involved or their importance to growth of trecs.

Influence of mycorthizae on plant nutrition

The role of mycorrhizac in plant development which has received the greatest attention is that relating to mineral nutrition, particularly phosphorus uptake. This interest in phosphates is justified both from the viewpoint of the fung $i$ and the plants. High levels of soluble phosphates in the soil seemingly depress mycorrhizal developrent, and low levels adversely affect plant growth. When referring to 'high' or 'low' levels of soll phosphace we must beg in to specify for what plant. Readily available soil $P$ of $100 \mathrm{ppm}$ may significantly reduce or almost eliminate endomycorthizae synthesis on one plant species but another species may be readily infected by $t$ he same symbiont at $200 \mathrm{ppt}$ or higher. 
However, it is unlikely that soluble phosphorus concentrations in any natural forest solls would ever be large enough to interfere with mycorrhizal synthesis of forest trees and thereby deter plantation establishment.

Greater soll exploitation by mycorrhizal roots as a means of increasing phosphate uptake is well established for both ecto- and endorycorrhizae. Current estimates place the nomal phosphate depletion zone around non-mycorrhizal roots at between 1 , and $2 \mathrm{~mm}$. Working with plants grown in contalners, Pearson. \& Tinker (1975) and Rhodes \& Gerdemann (1975) demonstrated that an endomycorrhizal root symbiont increased this zone to $7-20 \mathrm{~mm}$.

The main question is not whether mycorrhizae are involved and effective in phosphorus uptake, but whether this efficiency is due to exploitation of soil phosphates unavaliable to non-mycorrifizal roots or simply greater efficiency in capturing the avallable soluble phosphates. There is still no clear-cut answer to this question. Several investigators (Hayman \& Mosse 1972; Sanders \& Tinker 1971) report no difference in capacicy to solubilize phosphate. Contrary to speculation (Noggle \& Fritz 1976), these fungi have not been reported to digest plant litter in significant amounts and so feed back minerals to their hosts.

Results from studics on increased uptake of the other major and minor elements by wycorrhizal plants have been even more variable than those concerning phosphates. Sonetimes the elements $\mathrm{N}, \mathrm{K}, \mathrm{Ca}, \mathrm{Mg}, \mathrm{Fe}, \mathrm{Cu}, \mathrm{Mn}, \mathrm{Na}, \mathrm{Si}, \mathrm{2n}, \mathrm{Al}$ and $\mathrm{B}$ are present in greater concentrations in mycorrhizal plants than in non-mycorrhizal plants. In other cases, the concentrations of these same elements are higher in non-mycorrhizal plants, and sometimes no significant difference in concentrations between the two groups of plants is observed. The differential uptake of these elements, however, is not normally reflected in plant growth (Gray \& Gerdemann 1973). Characteristically, if mycorrhizal infection causes striking growth increases, the total amounts of all elements will be greater in the mycorrhizal plants, and the elements whose concentrations are affected most by mycorrhizal infection are very likely to be those 1 imiting growth (Kleinscholdt \& Gerdemann 1972).

Methodology must be developed for systematic study of mycorrhizae in older stands and plantations before quantitative data on nutrient cycling can be obtained; this will be extremely difficult, and such an effort has not yet been started. At present we must assume that nutrlent and even water uptake of forest trees is at least enhanced by mycorrhizae.

It is in the nursery phase and early plantation establishment where the greatest practical application of mycorrhizal technology may occur. In fact, the only quantitative data we have with forest trees involves nursery 
studies and outplanting trials that are less than five years old.

Such nursery work wust be complemented by carefully designed outplanting experiments on specific sites if in the future we hope to be able to write regeneration prescriptions instead of fust coopiling case histories. Much of the initial work at the U.S. Forest Service Institute for Mycorthizal Research and Developont, Athens, Georgia, indicated an advantage frow inoculating seedlings with a specific symbiont in the nursery for planting on adverse sites such as mining spoils and borrow pits. We thought at first that our results would be applied only on such sites. With considerable justification, we have gradually altered our chinking on this watter. Any area harvested by clearcuting is at least temporarily adverse for seedling growth. This adversity can be measured in terms of high cemperature, altered moisture regimes, excessive competition, etc. A seedling should be developed in the nursery that is very conpetitive during the critical early years of stand establishement. We feel that a heavily infected mycorrhtzal root system provides that competitive edge.

Nursery application

Periodic soil fumigation is desirable, if not essential, in a forest tree nursery. Ef fective fumigation eliminates destructive root pathogens and competing weeds, but it also eliminates mycorrhizal inoculum. The loss of ectomycorrhizal inoculum can be rectified early in the growing season if sufficient wind-disseminated spores are naturally avallable. Sufficient spores are usually avallable in the southeastern United States, but may not be in other parts of the world. To hasten this seedbed inoculation or to reinfest beds with specific ectomycorrhizal fungi, either spores or vegetative inoculum can be incorporated into the nursery beds. Both techniques have been used successfully (Theodorou 1967; Marx \& Bryan 1970; Marx 1977).

Nursery beds are reinfected more slowly by endomycorrhizal fungi since the spores are not wind-disseminated nor can vegetative inoculum be produced in aseptic culture. The seedling roots must penetrate below the zone of effective furigation where they come in contact with spores or infected root fragments. This is a slow process and too frequently results in inferior seedling production during the year of furlgation. Cover crops can be grown during the season of fumigation to build up endonycorthizal inocul un but selected herbicides that will not destroy the inoculum in subsequent years must be used in place of annual fumlgation. This cover crop rotation is being explored at the Mycorrhizal Institute in Athens, Georgla.

Seeding quality can be significantly improved by assuring early season development of mycorthizae. It has been 
repeacedly demonstrated that specific combinations of host and ectomycorrhizal fungus can result in seedlinzs with significantly inproved growth and survival not only on adverse mining spoils, but also on the more typical forested sites (Marx 1977). In one nursery in North Carolina, Marx, Bryan \& Cordell (1976) obtained growth increases of 100 to 150 per cent after one growing season with seedlings of pinus taeda, $\underline{P}$. strobus, and $\underline{P}$. virginlana following soil infestation and ectomycorthizal development by pisolithus tinctorius. In another test Marx \& Artman (1978), introduced vegetative wycelial inocula of $P$. tinctorius and Thelephora terrestris into fumigated soils in two nurseries in two different physiographic regions in Virginia. After one growing season, Pinus taeda seedlings with pisolithus and Thelophora ectomycorrhizae had 57 and 31 per cent greater fresh weights in the coastal plain nursery and 40 and 20 per cent greater weights in the mountain nursery, respectively, chan control seedlings. Soil inoculation with either fungus in both nurseries increased ectomycorrhizal development approximately 50 per cent over control seedings.

lursery inoculations with ectomycorrhizal symbionts has been tested extensively and the use of specific root symbionts for specific problem sites, as well as for routine reforestation, seems quite practical. Practical application of ecotomycorthizal fungi to nursery management is well advanced and should be put into practice as soon as the reliability of commercial inoculum is substantlated. Over 75,000 seedings have been planted out at the Mycorrhlzal Institute since 1974, and results encourage such practices for a wide range of sites (Marx 1977).

For example, on strip-mined lands trees frequently do poorly because the soll plis usually low and soll temperatures high. However, use of Pisolithus tinctorius as the primary root symbiont instead on the naturally occurring Thelephora terrestris has been successful on several such sites with $\mathrm{pH}^{\prime} \mathrm{s}$ ranging from 3.4 to 3.9 .

In one test on a coal spoil ( $\mathrm{pH} 3.8$ ) Pinus virginiana seedlings were first grown with elther pisolithus tinctorius or Thelephora terrestris ectomycorrhizae in our experimental nursery in Athens, Georgia. (Marx \& Bryan 1975). After two years only one percent on the Thelephora seedlings survived against 49 per cent of the Pisolithus seedlings, which also showed greater growth (Table 1).

There are numerous other examples of spectes of ectomycorrhizal fungi which have been shown to be quite benefictal under specific site or environmental conditions (Marx 1978).

As a silviculturlst, I belleve that nursery management practices that favour optimum root colonization by ectomycorrhizal fungl are a prerequisite to successful 
Table 1. Survival and growth of mycorrhizal Pinus $v i r g i n i a n a$ seedings after two years on coal spoil in the Southeastern United States.

\begin{tabular}{|c|c|c|c|c|}
\hline $\begin{array}{l}\text { Hycorthizal } \\
\text { condition } \\
\text { at planting }\end{array}$ & $\begin{array}{l}\text { Percent } \\
\text { survival }\end{array}$ & $\begin{array}{l}\text { He ight } \\
(\mathrm{cm})\end{array}$ & $\begin{array}{l}\text { Sted } \\
\text { diameter } \\
\qquad(\mathrm{cm})\end{array}$ & $\begin{array}{l}\text { Seedling } \\
\text { volume } \\
(\text { cu.col }) \star \star\end{array}$ \\
\hline Pisolithus & $49 *$ & $49 *$ & $1.6^{\star}$ & $130 *$ \\
\hline The lephora & $:$ & 19 & 0.4 & 3 \\
\hline
\end{tabular}

* Denotes significant differences $(P=0.05)$ between means for mycorrhizal treatments.

** Seedling volume (cu.ctr) $=$ (stem diameter) $x$ height.

plantation establishment. In my opinion, and one that is. shared by many foresters, careless planting and inferior root systems of pine seedlings are the leading causes of early plantation failure or poor development. Excessive nursery fertilization resulting in large top : root ratios and poorly developed ectomycorrhizal root systems should be discouraged. To-date the world fibre industry has been geared for softwood utflization, and until recently few hardwood plantations of endonycorrhizal host species were being established in the United States or ocher countries. Planting patterns have changed dramatically in the United States in the past decade because of technological changes in milling. Large acreages of hardwood plantations are beling established, and many of these hardwoods are endomycorrhizal host species. This trend of increasing hardwood utilization will probably be accelerated as other industrial uses of wood fibre compete with the paper industries.

In the past, hardwood plantations of species that are endomycorrhizal hosts have often been unsuccessful. Quality planting stock has been difficult to obtain, and poor stock probably was the cause of poor, early (during the first 3-5 years) growth of many plantations. Essential nursery sot1 fumigation probably played a major role in this because of the long delay before endomycorrhizal innocula returns to fumigated soil. After effective fumigation the newly developed seedling root of an endonycorrhtzal spectes must grow through 15 to $20 \mathrm{~cm}$ of soil before coming into contact with viable inoculum, elther infected root fragments or spores. Spore density at these depths is probably much less than it would be higher in the profile in the major root zone. It is our experience that until infection occurs, the roots of most endomycorrhizal tree hosts grow very poorly at the low 
phosphorus levels which do not have an adverse effect on the symbiont. Thus, the seedling may appear chlorotic and stunted and remain a few centimeters tall until late in the sumer when nycorrhizae form. By this time, 50 to 80 per cent of the effective growing season has passed, and the resulting seedlings are substandard for planting out the following year as is the usual practice.

Much of our endomycorrhizal research in Athens has been with Liquidambar styraciflua, but we have also run fertilizer/ mycorthizal interaction tests with Prunus serotina, Acer rubrum, Acer saccharun, Acer negundo, Juglans nigra, Fraxinus pennsylvania, and platanus occidentalis. Most of our experimentaliy grown seedlings have been destructively sampled, and only two rather small outplanting trlals have been installed. We have fertilized all species with rates of from $140 \mathrm{~kg} / \mathrm{ha}$ to $1120 \mathrm{~kg} / \mathrm{ha}$ of a commercial 10-10-10 fertilizer ( 10 per cent each for total $N$, available $P_{2} O_{5}$ and water soluble $\mathrm{K}_{2} \mathrm{O}$ ) plus top dressing during the growing season of $1680 \mathrm{~kg} / \mathrm{ha}$ of $\mathrm{NH}_{4} \mathrm{NO}_{3}$ (Bryan \& Kormanik 1977; Komanik et al $1977 \mathrm{a}, \mathrm{b}, \mathrm{c})$. At the highest fertilizer rate the solls have approximately 50 to $60 \mathrm{ppo}$ of avallable $\mathrm{P}$, amounts six to ten times higher than normally occur in our forest soils of the southeastern United States. The seedlings normally grow from sixteen to eighteen weeks before harvest.

Under these conditions non-mycorrhizal swectgum seedlings had an average height of $50 \mathrm{~mm}$, against 340 to $400 \mathrm{~mm}$ for mycorthizal seedlings, and this regardless of fercilizer applied. The mycorrhizal seedlings have been rather consistently seventy to eighty times heavier in total biomass than the non-mycorrhizal ones. Mycorrhizal seedlings of the other seven test species have been thirty to sixty times heavier than their non-mycorrhizal counterparts, and height differences are corparable to those with Liquidanbar styraciflua. Analyses of the responses of the seven species have not been compleced.

Thus far we have not picked up fertilizer effect in any of our experiments, but we have detected in each significant mother tree responses. The progeny from all mother trees we have tested consistently fall to develop when avallable soil $P$ in sterile soils is less than $60 \mathrm{ppm}$, yet all develop well with adequate soil infestation at these levels. However, in all of our experiments thus far analyzed, we have measured significant family responses in seedling biomass. Thus, while the great majority of all secdlings from all mother trees are reaching plantable size even in our shorter growing season, the progeny from specific mother trees produce a greater percentage of seedlings in the larger sizes. With Liquidambar styraciflua, as well as with most other hardwoods, seedling size has been positively correlated with field performance. We feel that standard tests could be developed to select superior 
trees on the basis of progeny performance in nursery beds if the level of $P$ was $15 \mathrm{ppo}$, a typical amount found under field conditions.

No direct assessments have been reported of the relative growth of outplanted endonycorrhizal and non-aycorrhizal seedlings. However, we observed dramatic differences in the degree of root Infection in Liquidambar styraciflua depending on the level of available $P$ in the nursery bed. With available $P<60 \mathrm{ppr}, 75$ per cent or more of $\underline{L}$. styrac $1 \mathrm{flua}$ seed 1 ing roots become infected, but at $>60 \mathrm{ppm}$ infection rate drops rapidly to an average of 15 per cent or less. Many forest tree nurseries have available $P$ levels of $>120$ ppo and this may result in the production of acceptable Liquidambar styraciflua seedling production without rycorthizae. This may be one reason for the poor early development of this species in plantations.

As with ectomycorrhizae, the greatest immediate benefit from endomycorthizae in even-aged plantation management will come in early establishment by providing the seedlings with competitive root systems. There is little published information on field performance of seedlings whose endomycorrhizal condition was known, but I feel no hesitation in stating my belief that endomycorrhizae are indispensable to those tree hosts which enter into a symbiotic relationship with them; endomycorrhizae are indispensable as absorbing organs in natural forested soil.

\section{CONCLUSION}

One cannot overemphasize the importance of nitrogen-fixing organisros in the nutrition of even-aged stands. Except perhaps in early stand establishment, it would appear to be economically impractical to apply nitrogen as a standard silvicultural treatment in any of its manufactured forms on forest lands. In even-aged stands we may see the growing importance of nodulated non-legumes and free-living nitrogen-fixing organisms because forest conditions provide a good environment for them. Harvest methods should provide an adequate substrate in forest solls so that temporary nitrogen tie-ups by free-living organisas are of no disadvantage. Lichens and phyllosphere organisros will contribute significant amounts of nftrogen under speclal conditions. Considerable work remains to be done to quantify the contribution of these sources of nitrogen fixation in the forest. Recent work indicates higher nitrogen contributions by lichens and non-syabiotic free-living organisms than has previously been reported for non-forested situations.

Second in importance only to nitrogen-fixing organisms in the biological nutrient relationships of even-aged stands are the mycorthizae. Plant scientists in general want to relegate these organisms as significant only in ecosystems where solls 
are low in available nutrients but they are equally 1mportant on our most fertile forested sites. For most host trees which form endomycorrhizae, it would probably take available elemental $P$ in excess of 60 ppm to result in tree growth without these important root symbionts and I question the existence of such $P$ levels in forest solls anywhere in the world. It is well-known that non-mycorrhizal plants grow well when supplied with inorganic mineral salts in soll or in hydroponics or sand cultures. But what is the relevance of these findings to forested situations? There is now anple cvidence that forest tree seedlings require wycorrhizae to function at $P$ levels most frequently found in natural solls. There is no scientific basis for assuming this requirement diminishes with tree age.

Developing a practical mycorrhizal technology on a worldwide basis offers no panacea for even-aged management now or in the foresceable future. Trees will not grow better simply because of what we are learning about this symbiotic relationship; they have always possessed and utilized mycorrhizae. However, mycorrhizal technology in the nursery can help to provide more competitive seedlings for outplanting on a variety of sites. Marx's extensive work with Pisolithus tinctorius certainly indicates that root systems can be 'tailored' with an aggressive fungus in nursery beds to meet specific outplanting conditions.

Unfortunately a great many plant scientists still resist exploring Harley's sound observation which I will quote from a conclusion by volght ( 1971$)$.

"One is forced to accept the fact that in a great many species of plants they (mycorrhizal roots) are the main organs of contact with the soil. In short, mycorrhizae have been selected in evolution against uninfected root systems in a large number of specles. Viewed in this way the original question of whether mycorthizal infection is beneficlal becomes secondary to the question of how these composite organs work and how they differ in any of their functions from uninfected roots."

\section{REFERENCES}

Bryan,W.C. \& Kormanik,P.P.(1977). Mycorrhlzae benefit survival and growth of sweetgum seedings in the nursery. Southern Journal of Applied Forestry, $1,21-23$.

Forman,R.T.T.(1975). Canopy 11chens with blue-green algae: A nitrogen source in a Columbian rain forest. Ecology, 56, $1176-1184$.

Gerdeman,J.W.(1968). Vesicular-arbuscular mycorrhiza and plant growth. Annual Review of Phytopathology, $6,397-418$.

Gray,L.E. \& Gerdemann,J.W.(1973). Uptake of sulphur-35 by vesicular arbuscular mycorrhizae. Plant and Soil, 39, 687-689. 
Haines,S.G., Haines,L.W. \& White,G.(1978). Leguminous plants increase sycamore growth in northern Alabama. Soll Sclence Soclety of America Journal, 42, 130-132.

Harrelson,M.A.(1969). Tropical eplphyllae and nitrogen fixation. Ph.D. Dissertation, University of Georgia, Athens. 103pp.

Hayman,D.S. \& Hosse, Barbara (1972). PIant growth responses to vesicular-arbuscular mycorthiza. III Increased uptake of labile P from so11. New Phytologist, $71,41-47$.

Jorgensen,J.R.(1975). Nitrogen fixation in forested coastal plain solls. U.S. Department of Agriculture Forest Service Research Note SE-130, 16pp.

Jurgensen,M.F. \& Davey,C.B.(1968). Nitrogen-fixing blue-green algae in acid forest and nursery solls. Canadian Journal of Microbiology, 14, 1179-1181.

Kleinschmidt,G.D. \& Gerdemann,J.W.(1972). Stunting of citrus seedlings in fumigated nursery solls related to absence of endomycorrhizae. Phytopathology, 62, 1447-1453.

Kormanik,P.P., Bryan,W.C. \& Schultz,R.C.(1977a). Endomycorrhizae: their importance in nursery production of hardwood seedlings. Proceedings 1976 SE Area Nurserymen's Conference, pp.16-21. Eastern session, Charleston, South Carolina, August 3-5, 1976.

Komanik,P.P., Bryan,W.C. \& Schultz, R.C.(1977b). Influence of endomycorrhizae on 8 rowth of sweetgum seedlings from eight wother trees. Forest science, 23, 500-509.

Kormanik,P.P., Bryan,W.C. \& Schultz,R.C.(1977c). Qualicy hardwood seedlings require early mycorrhlzal developaent in nursery beds. Proceedings 14th Southern Forest Tree Improvement Conference, Gainesville, Florida. pp.289-293.

Marks,G.C. \& Kozlowski,T.T.(eds)(1973). Ectomycorrhizae: their ecology and physlology. Academ Ic Press, New York $444 \mathrm{pp}$.

Marx,D.H.(1975). Mycorrhizae and establishments of trees on strip-mined land. The Ohlo Journal of Sclence, 75, 288-297.

Marx,D.H.(1977). The role of mycorrhizae in forest production. Tappi Conference papers. Annual meeting, February 14-16, 1977, Atlanta, Georgia. pp 151-161.

MarX,D.H.(1978). Ectonycorrhizal fungus inoculations: a tool for loproving forestation practices. International Workshop on Troplcal Mycorthiza Research, Forest Products Research Institute, 28 August - 6 Septerber, 1978, Kumasi, Ghana.

Marx,D.H. \& Artman,J.D.(1978). Growth and ectomycorrhizal developwent of loblolly pine seedlings in nursery soll infested wth Pisolithus tinctorius and Thelephora terrestris in Virginia. U.S. Department of Agriculture Forest Service Research Note. SE-256 6pp.

Marx,D.H. \& Bryan,W.C.(1970). Pure culture synthesis of ectomycorrhizae by Thelephora terrestris and Pisolithus 
tinctorlus on different conifer hosts. Canadian Journal of Botany, 48, 639-643.

Marx,D.H. \& Bryan,W.C.(1975). Growth and ectomycorrhtzal developrent of loblolly pine seedlings in funigated soll infested with the fungal symbiont Pisolithus tinctorius. Forest Science, 21, 245-254.

Marx,D.H., Bryan,W.C. \& Cordell,C.F.(1976). Growth and ectomycorrhizal development of pine seedings in nursery solls infested with the fungal symbiont pisolithus tinctorius. Forest Science, $22,91-100$.

Meyer,R.D.(1977). N1trogen fixation by epiphytes of an oak-hickory and a white pine forest. Master's Thesis University of Georgia, Athens. $67 \mathrm{pp}$.

Nicolson, T.H.(1967). Vesicular arbuscular mycorrhiza - a universal plant symbiosis. Science Progress, 55, 561-581.

Noggle,G.R. \& Fritz,G.J.(1976). Introductory plant physiology. Prentice-Hall, Englewood Cliffs, New Jersey, xiv + 688pp.

Pearson,v. \& Tinker, P.B.(1975). Measurement of phosphorus fluxes in external hyphae of endomycorrhizas. "Endomycorrhizas" Academic Press, London + New York. $626 \mathrm{pp}$.

Pirozynski,K.A. \& Maslock,D.W.(1975). The origin of 1 and plants: a natter of mycotropism. Biosystems, $6,153-164$.

Rhodes,L.H. \& Gerdemann,J.W.(1975). Phosphate uptake zones of mycorrhizal and non-mycorrhizal onions. New Phytologist, $75,555-561$.

Richards, B.N.(1974). Introduction to soll ecosystems. Longman Group Led., Essex, Harlow and Burnt Mi11. 266pp.

Safir,G.R., Boyer,J.S. \& Gerdemann,J.W.(1971). Mycorrhizal enhancement of water transport in soybean. Science, 171, $581-583$.

Safir,G.R., BoyerJ.S., \& Gerdemann,J.W.(1972). Nutrients status and mycorrhizal enhancement of water cransport in soybean. Plant Physlology, 49,700-703.

Sanders,F.E. \& TInker,P.B.(1971). Mechanisms of absorption of phosphate from so1l by endogone mycorrhizas. Nature, 233, 278-279.

Swith,S.E.(1974). Mycorrhtzal fungi. CRC Critical Reviews in Microblology, January: pp.273-313.

Switzer,G.L. \& Nelson,L.E.(1972). Nutrient accumulation and cycling in loblolly pine (Pinus taeda L.) plantation ecosystems: The first twenty years. Soll Science Society of America Proceedings, 36, 143-147.

Theodorou,C.(1967). Inoculation with pure culcures of mycorrhizal fung 1 of Radiata pine growing in partially sterilized soll. Australian Forestry, 31, 303-309.

Volght,G.K.(1971). Mycorrhizae and nutrient mobilization. "Ptycorrhizae" (Ed by E. Hacskaylo). Proceed Ings First North American Conference on Mycorrhizae, U.S. Department of Agriculture Forest Service Miscellaneous Publications 
1189. 255pp.

Withelw,S.(1976). Chemical treatments and inoculum potential of solls. Annual Review of Phytopathology, 4 , 53-78. 

BY J. ATTERSON

Principal Silviculturist, Forestry Commission Northern

Research Station, Rosli:i, Midlothian, U.K.

\section{SUMMARY}

The following subjects are dealt with: the most frequently found nutrient deficiencies, the rates and types of fertilizer currencly in use and their time and methods of application, species' responses, the economics of fertilizers use, advisory work and ferlilizer supply to the forest industry.

Nitrogen $(N)$ and phosphorus $(P)$ are the two main nutrients used in forestry throughout the world, typically at rates of $150 \mathrm{~kg} \mathrm{~N}$ and $50 \mathrm{~kg}$ $P$ element per hectare. Artificially produced $N$ conpounds such as urea and ammonlum nitrate usually are favoured because of their high $\mathrm{N}$ content, while crushed phosphate rock is a conmon type of $P$ applied because of its low $\cos t$.

Some species can be 'nutrlent demanding', such as Sitka spruce, while others, such as lodgepole plne, are tolerant of low nutrlent status of a site. The question of 'high input high yleld' versus 'low input - low yield' is raised. In the long term research on species, varieties and clones which can grow satisfactorily with low nutrient levels is required.

The cconomics of fertilizer use in plantation forestry are complex, and efficient and effective advice is essential. Methods of application can influence the cost and the effectiveness of the fertilization and more work is required to improve these. The relative costs of $N$ and $P$ fertilizers are likly to rise, making accurate advice on response and on the economics even more essential. 
RÉSLMÉ

Nous traitons des sujets sufvants: elléments nutritifs normalement insuffisants, types d'engrai utilisés et la quantite appliquée temps et méthodes d'utilisation, réactlons des espèces, dynanique éconoulque de l'utilisation des engrais et cravaux consultatifs et finalement fourniture d'engrais.

L'azote et le phosphore sont les deux éléments nutritifs communs, utilisés en forêt dans le monde entier, avec environ $150 \mathrm{~kg}$ de $\mathrm{N}$ et $50 \mathrm{~kg}$ de $P$ par hectare. Les conposés artificiels d'azote tels que l'uree et l'ammoniaque sont les plus courants a cause de leur taux élevé $d^{\prime}$ azote, tandis que le phosphate de roche broye est le type normal de phosphore utillsé à cause de son prix modique.

Certaines essences demandent beaucoup d'éléments nutritifs, comme l'épicéa de Sitka tandis que d'autres, tel le lodgepole pin se contentent de stations à taux d'éléments nutritifs peu élevé. Nous posons la question de 'taux élevé - rendement élevé', contre 'taux bas - rendenent bas'. Nous pronnons des recherches a long terme sur des essences, des variétés et des clones quí se contenteralent d'un niveau d'éléments nutritlfs. peu élevé.

La dynamique économique de l'usage d'engrais dans une plantation est complexe: un service consultatif efficace et compétent est nécessaire. Les méthodes d'utilisation peuvent influer sur le coût et l'efficacité d'application et il reste encore beaucoup de chemin a parcourir avant de parvenir a un perfectionnement. Le coot relatif d'engrais a base de $N$ et de $P$ augmentera sans aucun doute soulignant ainsi le besoin $d^{\prime}$ un système consultatif perfectionné en ce qui concerne les réactions à la fertilisation et sa rentabllité.

\section{USAMMENFASSUNG}

Folgende Themen werden behandelt: an welchen Nahrstoffen fehle es norwalerwe1se, welche Düngem 1 ttel und-mengen werden verwendet, wann und wie geschleht die Ausbringung, welche Reaktion zeigen die Baumarten, wie verhält es sich mit dem witschaftlichen Nutzen der Dünger anwend ung, der Beratungsarbe1t und schliesslich der versorgung mit Dingemitteln. stickstoff und Phosphor sind die zwei 
Hauptnährstoffe, die überall auf der Welt im Forst in Mengen von etwa $150 \mathrm{~kg}$ Stickstoff und $50 \mathrm{~kg}$ Phosphor pro Hektar verwendet werden. Unter den Stickstoffdingern werden gewönlich synthetische Stickstoffuerbindungen wie Harnstoff und Ammoniumnitrat wegen ihres hohen $\mathrm{N}$-Gehalts bevorzugt, während unter den Phosphordungern gemahlene Rohphosphate wegen ihres niedrigen Preises zur Anwendung kommen. Einige Baumarten, wie z.B. die Sitkafichte, kōnnen höhen Nährstoffbedarf haben, während andere, wie die Murray-klefer, mit niedrigem Nahrstoffangebot eines Standorts auskomen. Es erhebt sich die Frage, in wieweit die Regel gilt: 'hohe 7.ufuhr - hoher Gewlnn' oder 'geringe zufuhr - geringer Gewinn'. Langzeitversuche sind erforderlich mit Arten, Varietãten und Klonen, die einen geringen Nährstoff bedarf haben.

Die witschaftichen Aspekte der Dingeranwend ung in Forstpflanzungen sind komplex; fachönnische und effektive Beratung ist daher sehr wichtig. Die jeweiligen Anwendungsmethoden können die Kosten und die Wirksankeit der Düngung beeinflussen. Zu ithrer verbesserung ist noch einige Arbeit notwendig. Die relativen Kosten von Stickstoff- und Phosphordügern werden wohl eine genaue Beratung über die Auswlrkungen und wirtschaftlichke1t noch wichtiger machen.

\section{INTRODUCTION}

Fertilizers are now required on a large scale in forestry chroughout the world, in cold and hot climates, and in high and low rainfall areas. Table 1 gives a few of the more recent publications and Indicates the widespread use of fertilizers in forestry.

Initially, slow-growlng stands were selected for trials where a nutrient deficiency was the likely cause of the slow growth (Zehetmayer 1954; Gulnaudeau 1945). Later many workers started looking for responses in faster-growing areas (Gustavsen \& Lipas 1975). There can be few areas of plantation forestry anywhere in the world where fertilizers have not now been tried.

\section{NUTR IENTS}

An analysis of 'Forestry Abstracts' shows nitrogen as the nutrient most reported with phosphorus second. With the exception of decomposing organic soils, nitrogen is the only major nutrient which cannot be supplied directly by the soll. 
Table 1. Recent publications concerning fertillzer use in forestry in various countries.

Country

Britain

Canada

Denmark

Fast Gerroany

France

I rel and

Korea

New Guinca

New Zeal and

Russia

Sweden

Switzerland

Tropics and subtropics

U.S.A. -Florfda
Authors

Yayhead 1976

Weetman, Krause \& Koller 1978

Anon. 1976

Fiedler 1975

Barneoud \& Bonduelle 1973

Farrel1 1976

Chung 1977

Lamb 1977

$\mathrm{Kirkl}$ and 1977

Sudnitsyna 1976

Holmen 1978

Baule 1977

Schut z 1976

Anon. 1978 a

It is obtained from atmospheric nitrogen chrough fixation by soil and symbiotic organisms and by the oxidation of atmospheric nitrogen by lightning, the oxide subsequently being brought to earth by rain. If neither of these processes supplies sufficient nitrogen, then the application of nitrogen compounds would be Iikely to improve growth.

Nutrients other than nitrogen are obtained from soil minerals and from rainfall. The amount of phosphorus in rainfall, however, is much lower relative to the other major nutrients (Allen et al. 1968) and if the minerals in the soil are low in phosphorus, which is frequently the case, responses to added phosphorus would be likely. Most rocks in Britain are deficent in phosphorus and consequently agricultural crops and trees on almost all soils in this country respond when this nutrlent is added.

Potassium (K) can be limiting to tree growth but less frequently than nitrogen and phosphorus. However, the application of additional nitrogen and/or phosphorus can increase the $N / K$ and $P / K$ ratios in trees, indicating an fmbalance which is often revealed by $K$ deficlency symptoms. Responses to potassium on such sites would not have been obtained without the added nitrogen and/or phosphorus.

Calcium deficiency is uncommon in conifer plantations, although the addition of calcium as 1 ime has been tried in order to decrease litter actdity, increase litter breakdown and thereby release nutrients and improve tree growth. This technique has sometimes worked but can lead to other problems such as an increase in butt-rot. Bonneman (1970) found that liming of Norway spruce stands on pseudogleys had little effect on the growth of trees, the ground flora or the soll. 
With species other than conffers, calctum can be limiting. Eucalyptus grandis, which has a high calcfum and low phosphorus requirenent, has been found to respond to lime (Schutz 1976).

Magnesium deficiency can occur on certain soll types such as some in New 7ealand (Will 1966) where it is nomally corrected using magnesium salts or magnesium limestone.

Minor nutrients can cause deficiences in specific areas, for example boron and copper in New Zealand (Wil1 1971,1972), boron in Tanzania (Procter 1967), copper both in Holland (Oldenkanp \& Sinilde 1966) and in France (Bonneau 1972) and manganese in Souch Africa (Donald 1977). Fortunately most of these deficlencies can be corrected by the application of relatively low rates of element per hectare. Sonetimes soil fixation poblems arise necessitating the use of chelates or foliar sprays, e.g. iron deficiency on solls high in calcium (Karschon 1958).

\section{RATES OF APPLICATION}

Rates of application used in experiments vary depending on the site and species being treated, but those most frequently recommended are around $150 \mathrm{~kg} \mathrm{~N}, 50 \mathrm{~kg} \mathrm{P}$ and $100 \mathrm{~kg}$ $K$ element per hectare per application. Frequency of application can vary widely from one at the start of a rotation for phosphate on a site not too deficient in phosphorus, to every four years for nitrogen on infertile sands or inhospltable peats.

The standard rate used in British forests on any unimproved soll is $50 \mathrm{~kg} P$ per hectare as unground rock phosphate. This rate was found by experimentation over many years, on numerous stte types and with many species (Zehetmayr 1954,1960; Maytead 1979), to give a long lasting response on the beller sites and a reasonable response, say for six years, on the worst sites, e.g. unflushed acid peats. Applying rates higher than this gave no added yield on the betcer sites, while on the poorer sites other nutrients, most frequently potassium, had to be added later and could conveniently be mixed with phosphate rock for easier and more uniform application. The cost of a heavy, inttial dressing of phosphorus would also have attracted more compound interest.

\section{TYPES OF FERTILIZER}

The types of compound in use vary from crushed rock and natural organic materials to manufactured chemical compounds and mixtures and 'man-made' organic materials such as plastics, refuse and sewage. The best type is one which produces the largest response per untt cost in materials, transportation and application. In forestry fast-acting materials are not required and in many cases are undesirable as they can be lost through leaching or fixation or cause 
burning of plant tissue, Slower acting materials can be used and are frequently cheaper, e.g. crushed rock, industrial by-products, refuse or sewage.

An exception is $K$, where the high concentration of $\mathrm{NH}_{4} \mathrm{NO}_{3}$ and urea result in transportation and application economics. The lower $N$ concentration of industrial by-products, sewage, sludge etc. means that to achieve the usual application rates would require the transportation of bulky materials not readily distributed from the air. Urea has been widely used but under some conditions can be volatile, producing ammonium and nitrate radicals with can be lost from the site. This is a particular problem where the species being grown cannot absorb the ammonium radical directly. On the other had Bhure (1970) has shown in laboratory tests that when urea is applied to forest soils and litter, only small losses occur by volatilization. In Finland urea was found to be less effective than ammonium compounds (Gustaven \& Lipas 1975).

Types of phosphate rock can vary greatly in their total and citric-soluble phosphorus content; from less than 5 per cent $P$ to almost 14 per cent total $P$ with the citric-soluble fraction being from less than 10 per cent to almost 40 per cent of the total P. Mayhead (in press) has shown that when the total phosphorus applied to stands of both lodgepole pine and Sitka spruce was equal but different rocks were used, then height growth was correlated with amount of phosphorus in the citric-soluble fraction of the rock. Particle size of rocks did not influence height growth within the range used, i.e. from crude Gafsa rock of which only 2 per cent passed chrough a 0.075 m aperture sieve, to finely ground Kola and Nauru rocks, where 50 per cent passed through the same sieve. It would appear that in the acid soil conditions of these experimental sites, as long as the phosphate rock is not too coarse, phosphorus becomes avallable.

TIME OF APPLICATION

Many trees respond to fertilizer applied at time of planting. Later applications to established stands have been shown to be profitable in wany countries. In Britain, some stands which were not given phosphorus at planting responded dramatically to applications of this element (Dannat, Davies \& Mavish 1971).

The season of application of phosphorus, when applied as phosphate rock is unimportant, except perhaps where algal blooms could occur in reservolrs or waters used for fishing. In such areas application in the autum may be best. On a deficient site, delay of phosphorus application results in slow growth which is never made up after application and phosphorus should al ways be applied before or in the year of planting. 


\section{METHODS OF APPLICATION}

Before the $1960^{\circ}$ s most fertllizers were applied by hand, either as spot treatments to individual trees or broadcast, and inproved and cheaper methods for hand application have been devised over the years using for example, knapsack spreaders.

Mechanical methods were developed during the $60^{\circ} \mathrm{s}$ and $70^{\circ} \mathrm{s} u s i n g$ tracked or wheeled vehicles with mounted or towed spinners and blowers, and aircraft, both fixed-wing and helicopters. Machines on the ground are at a disadvantage in established plantations because of difficulty of access and are mainly used well before canopy closure. Other problems arise with then in effecting uniforwity of spread which necessitates application in narrow swaths which increased cost per unit area (Acterson \& Davies 1967; Ballard \& Will 1971; Virtanen 1975).

\section{SPECIES RESPONSE}

Frequently a choice of tree species is available for a given site in plantation forestry and if such a site has low levels of one or more nutrients, most tree species would respond to nutrient application. However, some may not, while of those which do, some will respond more in volume than ochers because of their inherently higher growth potential. In other words, some species appear to be more 'demanding' regarding nutrients e.8. Sicka spruce is more 'demanding' than lodgepole pine, which will produce more timber on poor sites than spruce (Zehetmayr 1954), but given sufficient fertilizer the spruce is capable of producing a larger voluse than the pine. Several recent experiments in Scotland indicate this, although results are not avallable as yet for a full rotation. In one experiment in Shin, Sutherland, lodgepole pine planted in 1969 is compared with sitka spruce on unflushed hill peat with a vegetation of cotton grass (Er1phorum), deer grass (Trichophorum), heather (Calluna) and peat moss (Spagnum). In chis cxperiment all plots were treated with phosphorus and potassium at $50 \mathrm{~kg} P$ per hectare and $95 \mathrm{~kg} \mathrm{~K}$ per hectare, broadcast before planting. After six years the helght of the trees indicated that the pine were on the yield class (YC) 13 curve, whereas the spruce were on the YC 15 curve and where the vegetation had been killed prior to planting, the pine did not respond but the spruce were on the YC 17 curve. There is no reason to suppose that such differences cannot be maintained throughout the rotation if the trees are kept healthy by subsequent fertllizer applications.

\section{ECONOMICS}

The fact that species response differs, leads on to the economics of fertilizer use and whether low-input, low-output species are more economic than high-input, high-output species 
on the poorer sites. Such a calculation obviously differs depending on the slte/species combination being consilered and on the relative costs of fertilizer and timber. The economics of fertilizer application to forest plantations is a complex subject because of the relatively long time scale between expenditure and harvesting and because there are in many cases interwediate returns from thinnings (Edwards 1974; Gagnon, Conway \& Swan 1976). The return from fertilizing can be from thinning heavier than norial, frow a higher total volume frow thinning plus clearfelling, or from an carlier final felling resulting in a lower total compound interest (Everard 1974). As such operations take place over many years and as compound interest has to be taken into account, such calculations $c$ an be misleading unless all the factors are known when comparing one set of calculations with another. The use of fertilizers in forestry should be considered nationally as part of the total energy of a nation because the continued provision of wood as a renewable basic resource is important to the economic well-being of many essential industries.

\section{ADVICF, TO MANAGERS}

Fertilizer application can be recommended following successful experimentation either where 1 t is essential for growth or to enhance growth. The economic justification of the former is simple but for the later wuch more detailed and accuratc estimates of volume production with and without fertilizer are essential. The most cost effective methods of estimating volume increment in fertilizer experiments are being investigated in several countries, including Britain. once fertilizer needs have been established for given site/species combinations, recommendations can either be as regimes based on a series of long-term experiments, or as individual prescriptions for given sites based on foliage appearance, recent helght and/or diameter growth, chemical analysis of trec tissue, usually follage, and a knowledge of likely responses for similar site/species combinations. The regime-type recommendations require a series of experiments which cover all major site/species combinations and run for a whole rotation, while the latter system requires a high input of advisor hours and a source of experfenced advisors. In Britain at present both systems operate: regimes are being recommended for the site-species combinations with the most predictable responses (Busby 1974), with an advisory service for other sites. The improvement of follage sampling lechniques and the search for alternative tissues to follage for chemical analysis, are subjects of current interest in Britain and several other countries.

\section{FERTILI7.ER SUPPLY}

Finally, the question of the avallability of fertllizer 
to the forest industry should be considered. Nitrogen should always be available, albeit at a price, due either to high transportation cost of low $N$ organic materials, such as industrial by-products, refuse or sewage, or high energy requirement when artificial nitrogen compounds are produced from atmospheric nitrogen. As the relative price of nitrogen fertilizer is likely to rise because energy costs will rise, research into nitrogen fixation and low nitrogen-demanding species, varleties and clones will be important in the long term. World rock phosphorus could be used up within 400 years according to data published by the Centre for Agricultural Strategy (Anon 1978b). Before this stage is reached and also because of the uneven world distribution of phosphate rock, the relative cost of phosphorus will undoubcedly rise considerably. As with nitrogen, low-phosphorus demanding species, varieties and clones should be investigated and developed. Nutrients other than nitrogen and phosphorus are not required in such large quantities throughout the world and should be available for use in forestry.

\section{CONCLUSIONS}

In the short term, a great deal of research is still required in most countries to determine optimum fertllizer races and regimes. Improved mechods of volume estimation are necesary to quantify such work.

Fertilizer application to forest plantations is and will continuc to be an accepted practice for a wide range of site/species combinations. However, because of a likely rise in the cost of fertilizers relative to the price of wood, research effort should be increased to find specles, varleties and clones or inter- or intra-specific hybrids which will grow with no or minimal fertilizer applications.

\section{RFFERENCES}

Allen,S.E., Carlisle,A., White,E.J. \& Evans,C.C. (1968). The plant nutrient content of rainwater. Journal of Fcology, 56, 497-504.

Anon (1976). Report of the fertilizing of Norway spruce etc. Dansk Skovforeningens Tidsskrift, 61, 167-253.

Anon (1978a). Annual Report for 1977 of cooperative research in forest fertilization - programe summary. University of Florida, U.S.A.

Anon (1978b). Phosphorus: a resource for U.K. agriculture. Centre for Agricultural Strategy Report $2.64 \mathrm{pp}$.

Atterson,J.(1966). Fertilizers in conlferous forests. Forestry and howe grown timber. Supplement to Timber Trades Journal actober 1966 , pp. 39-41.

Atterson,J. \& Davies E.J.M.(1967). Fertilizers - their use and methods of application in British Forestry. Scottish Forestry, 21, 222-228. 
Ballard,R. \& Will,G.M.(1971). Distribution of aerially applied fertilizer in New Zeal and forests. New 7eal and Journal of Forest Science, $\frac{1}{1}, 50-59$.

Barneoud, C. \& Bonduelle,P.(1973) Use of fertllizers in adult stands of Picea abies and Abies alba in North Fastern France. Rapport Annuel, Association Forêt-Cellulose 1972, pp. 279-329.

Baule,H.(1977). Fertilizer trials carried out during afforestation of former mountain pastures in Switzerland. Allgemeine Forstzeitschrift, 32, 1-7.

Bhure,N.D.(1970). Nitrogen losses by volatilisation from urea applied to forest soils. Bi-monthly research notes, $\underline{26}$, 42-43.

Bonneau,M.(1972). Results of fertilizer trials on Douglas fir in the west of the Massif Central. Revue forestière française, $25,35-40$.

Bonnemann,A.(1970): Growing spruce on solls with impeded drainage. Forstarchiv, 41, 217-221.

Busby,R.J.N.(1974). Forest site yield guide to upland Britain. Forestry Comnission Forest Record 197.

Chung, I.K.(1977). Experiment for comparing the effects of forest-use solid fertilizer and chemical fertilizer. Journal of the Korean Forestry Society, 34, 15-20.

Dannatt,N., Davies,E.J.M., \& McTavish,W.J.(1971). Kilmory 1971. An investigation into fertilizer response. Scottish Forestry, 25, 100-109.

Donald,D.G.M.( $\left.1 \frac{97}{97}\right)$. Silvicultural practices influencing harvesting. South African Forestry Journal, 101, 13-19.

Edwards,P.N.(1974). The profitability of large-scale aerial fert1lizing. Scottish Forestry, 28, 265-71.

Everard,J.E.(1974). Fertilizers in the establishment of conifers in wales and Southern England. Forestry Conmission Booklet $\# 41$.

Farrell,E.P.(1976). Forest fertilization in Ireland. Forestry Chronicle, 52, 194-196.

Fiedler,H.J.(1975). Fertilizing Picea abies stands in water catchent areas. Beitrage für Forstwirtschaft, 9 , 123-136.

Gagnon,J.D., Conway,J.M. \& Swan,H.S.D.(1976). An economic study of the Grand' Mère plantation 10 years after fertilizer treatment. Forestry Chronicle, 52, 26-29

Guinaudeau,J.(1954). An experiment in the use of fertilizers in forest plantings. Revue des eaux et forêts, $\underline{83}$, $34.3-351$.

Gustavsen,H.G. \& L1pas,E.(1975). Ef fect of nitrogen dosage on fertllizer response. Folia forestalia, 246, $20 \mathrm{pp}$.

Holmen,H.(1978). Forest fertilization in Sweden 1977. Kungliga Skogs- och lantbruksakadamiens tidskrift.

Karschon,R.(1958). Investigations on iron chlorosis in Eucalyptus gomphocephala. La-yaaran, $\underline{8}, 30-32$. 
Kirkland,A.(1977). Fertilizer use in forestry. New Zealand Journal of forestry, 22, 274-282.

Lamb,D.(1977). Relationships between growth and foliar nutrient concentrations in Eucalyptus deglupta. Plant and soil, $47,495-508$.

Mayhead,G.J.(1976). Forest fertilizing in Great Britain. Proceedings of the Fertiliser Society of London. 158 , $18 \mathrm{pp}$.

Mayhead,G.J.(In press). A comparison of different sources of rock phosphate on conifer growth. Forestry Commission.

oldenkamp,L. \& Smilde K,W. (1966). Copper deficiency in Douglas fir. Korte Mededelingen Bosbouwproefstation T.N.0., Wageningen, 77, 203-214.

Procter,J.(1967). A nutritional disorder of pine. Commonwealth Forestry Review, 46, 145-154.

Schutz,C.J.(1976). A review of fertllizer research on some of the more important conifers and eucalyptus planted in subtropical and tropical countries, with special reference to South Africa. Department of Forestry, Republic of South Africa, Bulletin $\$ 53$.

Sudnitsyna,T.N.(1976). Effect of fert1lizers on the growth of Scots pine plantations. Lesovedenie i lesovodstvo, $\underline{2}$, 43-50.

Virtanen,J.(1975). Evenness of spreading of forest fertilizers. Metsätieteellisen tutkimuslajtoksen julkaisuja, 86. 72pp.

Weetman,G. r., Krause,H.H. \& Koller,E.(1978). Interprovincial forest fercilization program. Canadian Forest Service Technical Report 22 .

Will,G.M.(1966). Magnesium deficlency: the cause of spring needle tip chlorosis in young pines on humus solls. New Zealand Journal of Forestry, $11,88-94$.

Will,G.M.(1971). The occurrence and treatment of boron deficiency in New zealand pine forests. New zealand Forest Research Institute, Research Leaflet \#32.

Will,G.M.(1972). Copper deficiency in radiata pine planted on sands at Mangawhai Forest. New Zealand Journal of Forest Science, 2. 217-221.

zehetmayer,J.W.L.(1954). Experiments in tree planting on peat. Forestry Commission Bulletin $\$ 22$

Zehetmayer,J.W.L.(1960). Af forestation of upland heaths. Forestry Connission Bulletin 32. 

September 7,1978

THF. F.FFECTS OF PLANTATIONS ON

THE PHYSICAL RE.SOURCE

Chairman: D.R. Johnston

Evaporation of water from
plantation forests.

Effect of forest plantations on the quantity, quality and timing of water supplies.

Soil changes under even-aged plantations.
- P.G. Jarvis and

J. Stewart
W.L. Nutter

D.G. Pyatt and

M.M. Craven 


\section{EVAPORATION OF WATER FROM PLANTATION FOREST}

* Department of Forestry and Natural Resources, University of Edinburgh, Mayfield Road, Edinburgh F.H9 3JU, U.K.

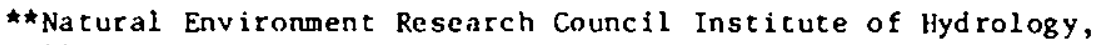
Walling ford, Oxon. OXlo 8BB. U.K.

\section{SURMARY}

The transplration and evaporation of water from plantation forest is analysed with the aid of the Penman-Monteith equation.

When the canopy is dry, the rate of transpiration is generally restricted to less than $0.3 \mathrm{~mm} / \mathrm{h}$ or $3 \mathrm{~mm} /$ day in summer and 0.03 molday in winter by the combined effects of saturation and stomatal conductance. When saturation deficits are sall the stomatal conductance is high, but when saturation deficits are large, stomatal conductance is low as the result of stomatal closure. Consequently transpiration uses only about 40 per cent of the available energy and Bowen ratios are large and often over 2 .

When the canopy is wet, evaporation is raptd because of the very high boundary layer conductance of forest canopies. Even though the available energy and the saturation deficits are very small, rates of over $0.3 \mathrm{~mm} / \mathrm{h}$ are reached. Thus, the rate of evaporation often exceeds the rate of input of available energy and the Bowen ratio is negative as a result of the addition of sensible heat to the canopy. Despice the much lower avallable energy and saturation deficits on rainy days than on sunny days, evaporation rates are often 2-3 times cranspiration rates because low stomatal conductance reduces transpiration on fine days and high boundary layer conductance enhances evaporation on wet days. Hence long tern rates of water loss from plantation forest by transpiration and evaporation depend upon the pattern of rainfall distribution and are much 
larger where frequent rainfall keeps the canopy wet for much of the time.

Because the stomatal conductance of forest is lower than that of grassland, transpiration rates from forest are lower than rates fron grassland in the same meteorological conditions despite differences in the albedos. However, rates of evaporation from wel forest canopies are very much higher than from wet 8 rasslands because the boundary layer conductance of forest is much higher than that of grassland. Thus, long-term rates of water loss from forest may be more or less than losses from grassland, depending upon the proportion of time the canopy is wet and hence the pattern of rainfall distribution.

More precise evaluation requires better information on the stomatal and boundary layer conductances of different types of forest at different stages of development, and on interception loss and duration of canopy wetness in different climatic regions.

RÉSUMÉ

La transpiration et l'évaporalion de l'eau dans les plantations forestlères sont analysées a 1 'aide de l'équation de Penman-Monceith.

quand le couvert est sec, le taux de transplration est en général ramené à moins de $0.3 \mathrm{~mm} / \mathrm{h}$ ou $3 \mathrm{~mm} /$ jour l'êté, et à $0.03 \mathrm{~mm} /$ jour l'hiver, dû à la combinaison du defficit de saturation et de conductance stomatale. Lorsque les deficits de saturation sont faibles, la conductance storatale est élevée, tandis que lorsqu' $t l s$ sont élevés la conductance stomatale est faible a cause d'une fermeture stomatiale.

Par conséquent la transpiration $n^{\prime}$ utilise que 40 per cent de l'énergle disponible et les rapports Bowen sont élevés et dépassent souvent 2.

Quand le couvert est moufllé, l'évaporation est rapide à cause de la conductance de la couche limite tres élevée des couverts forestiers. Même dans le cas ou l'énergie disponible et les déficits de saturation sont falbles, on arrive à des taux dépassant $0.3 \mathrm{~mm} / \mathrm{h}$. Ainsi, le taux d'évaporation excède souvent le taux d'absorption d'énergle disponible et le rapport Bowen est négatif à cause d'une léger apport de. chaleur au couvert. 
Malgré le fait que l'énergic disponible et les déficits de saturation sont plus faibles les Jours de pluie que les jours de beau temps, le taux d'évaporation est parfois deux a trois fois plus elevé que le taux de transpiration parce qu'une faihle conductance slonatale réduit la transpiration pendant les jours de beau temps et que la conductance élevée de la couche limite augmente l'évaporation les jours de pluie. Donc, 11 résulte que, dans les plantations forestières les taux a long terme de perte d'eau dûe à la transpiration et à 1 'évaporation dépendent de 1 a distribution des chutes de pluie et sont bien plus importants dans le cas ou le couvert reste mouillé la plupart du temps.

Puisque la conductance stonatale des forêts est plus faible que celle des prairies, le taux de transpiration des forêts est plus faible que celui des prairies, dans les mênes condilions nétéorologiques malgré des albédos différents. Cependant, le taux d'évaporation des forêts à couverts rouillés est bien plus important que celui des prafrles humides parce que la conductance de la chouce lílice des forêts est bien plus élevée que celle des prairies. Ainsi, le taux, a long terme, des pertes d'eau des forêts peut être, soit plus falble, solt plus élevé que celuí des prairles, le tout dépendant du temps pendant lequel le couvert est mouillé et, par conséquent, de la distribution des chutes de pluie. Une meilleure évaluation nécessite plus de renseignements sur les conductances des stomates el la couche limile des différentstypes de forés à des stades différents de développement, sur l'interception et le temps pendant lequel un couvert reste mouillé dans des région de climats differents.

\section{ZUSA:MMENFASSUNG}

Transplation und Evaporation von Forstpflanzungen wurden mit Hilfe der Penzan-Monteith Gleichung analysiert.

Bei trockenem Kronendach beschrankt sich die Transpiration aufgrund des Zusammenwirkens von Sättlgungsdefizit und Spaltöffnungsverhalten auf weniger als $0.3 \mathrm{~m}$ pro Stunde oder $3 \mathrm{mn}$ pro Tag in Sommer und 0.03 mn pro Tag im winter. Bef niedrigen Sättigungsdefiziten besteht hohe 
Regulierbarkeit der Spaltöffnungen, bei hohen Sätrigungsdefiziten ist sie jedoch sehr gering, da dann die Spal tenoffnungen geschlossen sind. Folglich werden nur 40 prozent der verfügbaren Fnergie durch die Transpiration ausgenutz $z$ und die Bowen-Quotienten sind gross, oft iber 2 .

Be 1 nassem Kronendach ist die Evaporation intensiv aufgrund der hochliegenden Grenzschicht des Kronenraums. Auch bei knappen Energieangebot und sehr geringem Sättigungsdeflzit werden Werte von über $0.3 \mathrm{~mm}$ pro Stunde erreicht. So ubersteigt die Evaporationsrate oft den Input an verfügbarer Energle und das Bowenverhältnis wird durch die zusätzliche wărme des Kronendaches negativ.

obwohl die verfügbare Energie und die Sätrigungsdefizite an Regentagen viel geringer sind als an sonnigen, liegen die Evaporationstaten oft zwei- bis dreimal höher als die Transpitationsraten, da die geringe Regulierbarkeit der Spaltöffnungen bei schönem Wetter die Transpiration reduzlert, während die hoch liegende Crenzschicht an Regentagen die Evaporation steigert. Die Langzeitraten des wasserverlusts durch Transpiration und rivaporation in Forstpflanzungen hängen sorit von der Art der Niederschlagsverteilung ab; sie sind viel grōsser, wo häufiger Niederschlag das Kronendach die melste teit nass hält.

Da die Spaltöfnungsregulierung la rorst unter denselben meteorologischen Bedingungen und trotz unterschiedlicher Albedo geringer ist als bei Grasland, liegen auch dic Transpirationsraten des forsts niedriger. Andererseits sind jedoch die Evaporationswerte bel nassem Kronendach sehr viel hobher als bei nasser Grasland, da die Grenzschicht in Wald viel höher liegt. So können also die Langzeitraten des Wasserverlusts ito Forst grösser oder kleiner sein als bel Grasland, je nachdem whe lange das Kronendach nass ist - was natürlich von der Art der Niederschlagsvertellung abhāngt.

$\mathrm{Zu}$ einer präziseren Darstellung wären bessere Information über die Spaltöffnungsregulierung und die Grenzschicht bei verschiedenen Forsttypen in verschiedenen Entwlcklungsstadien notwendig, ausserden über den Interceptionsverlust und de zeit der Kronenbefeuchtung in verschiedenen Klimazonen. 


\section{GENERAL PRINCIPLES}

The driving force for the movement of water from the soil through the trees to the atmosphere is provided by the evaporation of water at the liquid - air interface within the leaves. The phase change followed by the diffusion of water molecules through the stomata is here called transpiration $\left(E_{Y}\right.$ ) to distinguish it from the evaporation of intercepted water on the surfaces of the follage, twigs, branches and other parts of the trees $\left(E_{I}\right)$. E ls used when either or both $E_{T}$ or $E_{I}$ is intended.

The cranspiration of evaporation of water from the foliage depends strongly upon the avallable energy ( $A$ ), the saturation deficit of the alr (D), the wind speed (U) and, to a lesser extend, on air temperature $(\theta)$. In addition, cranspiration is strongly dependent upon the stomatal conductance $\left(8_{s}\right)$ of the needles and evaporation on the structural characteristics of the canopy which influence the boundary layer conductance $\left(B_{a}\right)$ in addition to the windspeed.

These variables were first put rogether through the application of the conservation of energy to exchange processes in crop canopies by H.L. Penman in 1948 and were first related explicitly in the manner used below by J.L. Montelth in 1965. As a result the following expression for transpiration has come to be known as the Penman-Monteith equation. It was first applied to the study of water loss from trees in plantations by A.J. Rutter in 1967.

$$
\begin{aligned}
\lambda E_{r}= & \frac{s A+c_{p} \rho D g_{a}}{s+\gamma\left(1+g_{a} / g_{s}\right)}\left(1 / /^{\prime} \mathrm{m}^{2}\right) \\
& 1 \mathrm{w} / \mathrm{sq} \cdot \mathrm{m}=0.0015 \mathrm{~kg} /(\mathrm{sq} . \mathrm{m} / \mathrm{h})=0.0015 \mathrm{~mm} / \mathrm{h}
\end{aligned}
$$

The physical parameters $c, \rho, \gamma$ and $\lambda$, respectively the specific heat of air, the density of air, the psychrometric constant and the latent heat of vaporization of water, are all weak functions of temperature (see Table A3 in Monteith 1973). The parameter $\underline{s}$ is the slope of the curve relating the saturated vapour pressure of water $\left(e_{s}\right)$ to temperature (i.e. $\left.\mathrm{de}_{S} / \mathrm{d} \theta\right)$ at the appropriate temperature and varies apprectably with temperature. For example, 1 t has values of $0.61,0.83,1.45$ and $2.44 \mathrm{mb} /{ }^{\circ} \mathrm{C}$ at $5,10,20$, and $30^{\circ} \mathrm{C}$, respectively (Montelth 1973, Table A4).

In the case of evaporation of intercepted water from.a completely wet canopy, rather chan the transplration of water which has passed through the plant, $g_{3}$ becomes very large indeed (Shutileworth 1976) and equation (1) becomes

$$
\lambda E_{1}=\frac{s A+c_{p} p D_{g_{a}}}{s+\gamma}
$$


Provided that the dependence of $\mathrm{ga}$ on windspeed is known, evaporation can be calculated from this equation wholly from weather station data.

The Penman-Monteith equation can be applied to single leaves or extensive canopies. When applied to canopies, an approximation is involved since the derivation assumes identical sources and sinks of water vapour and heat, whereas this is unlikely to be the case in a canopy. However, comparisons with more complex models show that this approximation does not lead to serlous error (Sinclair, Murphy \& Knoerr 1976; Shuttleworth 1976).

The equation can be applied successfully over perinds of weeks, days, hours or minutes provided that appropriate values of the variables are avaflable. Application over short periods of time, such as an hour, is usually limited by the availabllity of hourly meteorological data and hourly measurements or reliable estimates of stomatal conductance, $8_{\mathrm{s}}$.

The equation predicts that $E$ will increase with increases In either available energy or saturation deficlt or both. The influence of avallable energy and saturation deficit on $E$ appears in the numerator as additive. In the past this has led to the description of evaporation as having a radiation dependent component and a windspeed or saturation deficit dependent component. This is convenient but somewhat artificial since the maintenance of a saturation deficit depends upon the input of energy into the systero. However, the relative importance of avaialble energy and saturation defict in deriving fican readily be defined by the ratio of the two teras in the numerator of equation (1) or (2) as

$$
J=c_{p} \rho \quad D g_{Q} / s A
$$

Clearly the larger the boundary layer conductance, the larger will be the effect of saturation deficit on F. If both $8_{a}$ and D are large, the defictt term may greatly exceed the radiation term. This is commonly the case for tall, rough vegetation like plantation forest when the canopy is dry. For dry canopies of confferous plantations, J typically lies in the range $5-20$.

This leads to a useful simplification of equation (1). In the first place, if $\mathrm{J}$ is large and transpiration is much more dependent on saturation deficlt than on avallable energy, the radiation term can be neglected. Secondly, if the ratio $8 a / g_{s}$ is also large, as will be seen later, the sinall teris in the denowinator of equation (1) can be ignored. Thus the rate of transpiration can be approximated by

$$
E_{T}=\frac{C_{p} P}{\lambda \gamma} \cdot D \cdot g_{S}=K \cdot D \cdot g_{S}
$$


where $K$ is the factor for converting partial pressure of water vapour into mass concentration and has a value of $740 \times$ $10 \mathrm{~kg} /(\mathrm{cu} . \mathrm{m} \mathrm{mb})$ at a temperature of $20^{\circ} \mathrm{C}$ and atmospheric pressure of $1013 \mathrm{mb}$.

Equations (1) and (2) provide a means of determining the rates of transpiration and evaporation in particular circustances. To demonstrate how the properties of plantation forests interact with the environmental variables, it is also convenient to express evaporation in terms of the sources of energy available to drive it:

$$
A=\lambda E+C
$$

where $C$ is the convective exchange of sensible heat to or from the foliage. Two al ternative parameters are commonly used to describe the partitioning of available energy: - the proportion of the avallable energy used in evaporation

$$
\propto \quad \lambda F . / A
$$

- the Bowen ratio, which is defined as

$$
\beta=c / \lambda E
$$

From equations ( 5 ) and (7) $\lambda E$ can also be written as

$$
\lambda E-A /(1+\beta)
$$

TRANSPIRATION FROY DRY CANOPIF.S

Measured mean hourly rates of cranspiration from extensive plantations of Sitka Spruce in Scolland (Forest of Mearns) and Scots pine in Norfolk (Thetford Forest) can reach $0.3 \mathrm{~mm} / \mathrm{h}(200 \mathrm{~W} / \mathrm{sq} . \mathrm{m})$ but are more conzonly in the range 0.1 to $0.2 \mathrm{~mm} / \mathrm{h}(70-140 \mathrm{w} / \mathrm{sq} . \mathrm{m})$, depending on the weather and time of day. Dally rates can reach $3 \mathrm{~mm} /$ day in the sumer but are more commonly about $2 \mathrm{~mm} /$ day in summer and $0.3 \mathrm{~mm} / \mathrm{day}$ in winter.

These rates of transptration account for the utilisation of only a small proportion of the avallable energy. On average during the daytime only 40 par cent of the available energy is used for transpiration; values of $\alpha$ are within the range 0.3 to 0.5 for many hours of observations at Forest of Mearns, and Thetford Forest. The daytime Bowen ratios are rarely less than 1 and frequently in the range 2-4, rising to even higher values during drought or periods of high cemperature and low huldity. Such low rates of transpiration and the values of $a$ and $\beta$ are very different from what was expected ten years ago on the basis of experience with short vegetation such as agriculcural crops and grasslands. The transpiration rate from such vegetation when well supplied with water may equal or 
exceed the input of avallable energy; $\alpha$ for such vegetation is frequently in the rage 0.8 to 0.9 and $\theta$ in the range 0 to 0.5 (Penman, Angus \& van Bavel 1967). That is to say, the rate of transpiration froc short vegetation may commonly be two to three times larger than from plantation forest; or conversely, the rate of transpiration from plantation forest is only about $1 / 5$ to $1 / 3$ of the rate from crops and grassland.

To nake useful generallzations about water use by plantation forests, we need, therefore, to consider the reasons for the low measured rates of transpiration, low values of $\alpha$ and high values of $\beta$.

As expressed in equation ( 1 ), the main variables determining the rate of transpiration are:

- the available energy, $A$

- the saturation deficit, D

- the boundary layer conductance, $g_{a}$

- the stomatal conductance, is .

In principle, the rate of cranspiration could vary widely and reach very high values depending on the values of these variables In practice, however, the range is restricted by the combinations of values of the variables which occur. These combinations depend both on the environmental variables and on the morphological and physiological properties of the follage of the trees.

Avallable energy and saturation deficit

liet radiation over coniferous forest is about 75-90 per cent of the incident shortwave radiation (Jarvis, James \& Landsberg 1976). For dense canopies which intercept most of the radiation, such as Sitka spruce at 4000 trees/ha, with a leaf area index of about 9, little radiation reaches the soll and in the middle of the day only about 5 per cent of the net radiation goes into storage. Thus the avallable energy can reach about $600 \mathrm{~W} / \mathrm{sq} . \mathrm{m}$ in sumer. In more open stands such as Scots pine with a leaf area index of only 3 or 4 , much more of the net radiation reaches the soll and also goes into storage in the stems and branches. Consequently the energy available to evaporate water from the canopy is rather less, reaching only about $400 \mathrm{~W} / \mathrm{sq} . \mathrm{m}$.

The normal range of saturation deficics in temperace marltime climates is small. Over most of the British Isles, and particularly those parts in which forest plantations occur, saturation deficits only occasionally exceed $15 \mathrm{mb}$. The normal range of deficlts throughout the year over the main areas of afforestation is $1-10 \mathrm{mb}$. Of course much larger deficits of up to 30 mb do occur commonly in the summer in more continental areas where plantations are grown.

Stomatal conductance

The maximum stomatal conductance of Sitka and Norway spruce forests canopies is about $0.02 \mathrm{~m} / \mathrm{s}$. The maximum conductance for Scots pine, lodgepole pine and Douglas fir is 
somewhat less at about $0.01 \mathrm{~m} / \mathrm{s}$. However, measured conductances are usually less than these values, depending on the weather, the time of day and time of year. For comparison, the maximum stomatal conductances of crop canopies and grassland are somewhat larger ( 0.015 co $0.05 \mathrm{~m} / \mathrm{s})$.

The conductance of a canopy is the arithetical sum of the conductances of all the individual needles. Thus it depends upon the number of needles present, i.e. on the leaf area index, and on the conductance of the individual needles. The conductance of a needle varies with the species, and depends upon the age of the needle and its position in the canopy, as we 11 as upon the season, the time of day and the current wather. Because of the variation amongst needles in a canopy, the canopy conductance depends upon the proportion of needles of different properties which are present, i.e. on the partial leaf area indices of needles of different ages, position, branching etc.

The conductance of needles of conifers is low because of the occurrence of a meshwork of wax tubes in the stomatal antechambers (Jeffree, Johnson \& Jarvis 1971). 8s is also much reduced on a daily and seasonal basis by the pronounced sensitivity of the stomata of many conifers to saturation deficit. This sensteivity is particularly marked in Sitka spruce (Grace, Malcolio \& Bradbury 1975; Hatts, Neilson \& Jarvis 1976; Watts \& Neilson 1978).

Boundary layer conductance

In comparison with diffusion through the stomata, the curbulent transfer of water molecules across the needles and shoot boundary layers and through the canopy to the air above is very effective. Consequently the boundary layer conductance is very large in relation to the stomatal conductance and hence can vary widely with little or no influence on transpiration. Values of $g_{e}$ are typically 0.1 co $0.3 \mathrm{~m} / \mathrm{s}$ which can be compared with the values of $8 \mathrm{~s}$ of $0.02 \mathrm{~m} / \mathrm{s}$.

In addition, the large boundary layer conductance of plantation forest facilitates removal of sensible heat from the follage with the consequence that leaf temperatures of conifers are seldom very different from air cemperatures (Jarvis, James \& Landsberg 1976). As a result of cnhanced sensible heat transfer and low leaf temperatures, the transpiration rate is less than wight otherwise be expected, $\alpha$ is smaller and $\beta$ is larger. For comparison, $\beta_{a}$ of crops and grassland is an order of magnitude lower (see under Evaporation from wet canopies), leading to lower sensible heat losses and higher leaf temperacures, both of which tend to push the transpiration rate up and $\boldsymbol{\beta}$ down.

In the absence of stomatal control, when the canopy is wet, the boundary layer conductance is a major factor determining the rate of evaporation and is considered later. 


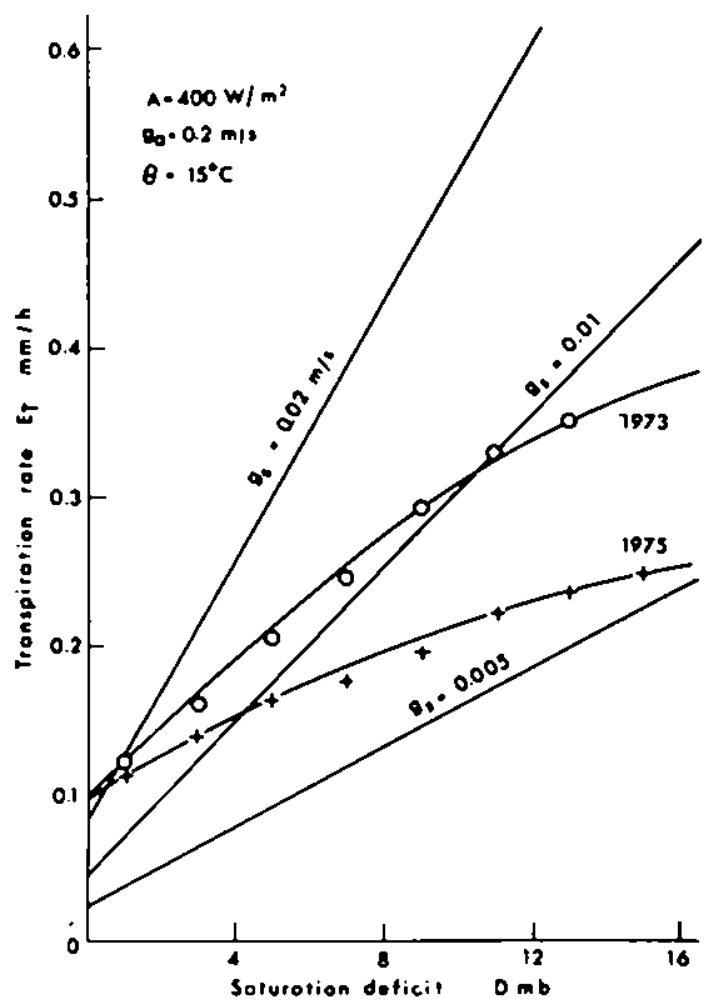

Fig. 1. The relation between transpiration rate and saturation deficit calculated from equation (1) for the conditions shown and three different values of $8_{3}$. The data points are medians of a large number of mean hourly values within saturation deficit classes for Sitka spruce at Forest of Nearns in June and July 1973 and 1975. The stand was thinned in 1974

\section{Conclusions}

From these figures and equation (1), we may estimate the rates of transpiration we would expect to find. For example, if 8 s were to be maintalned at $0.02 \mathrm{~m} / \mathrm{s}$ on a fine summer day when $A=600 \mathrm{~W} / \mathrm{sq} \cdot \mathrm{m}$ and $D=15 \mathrm{mb}$, a transplration rate of 0.9 $\mathrm{mm} / \mathrm{h}$, three times the maximum measured rate, would be expected, together with $\alpha>0.9$ and a low value of $\beta$ of about 0.1 .

The question arises as to why the measured transplration rates and values of $\alpha$ are so much lower than wight be expected 


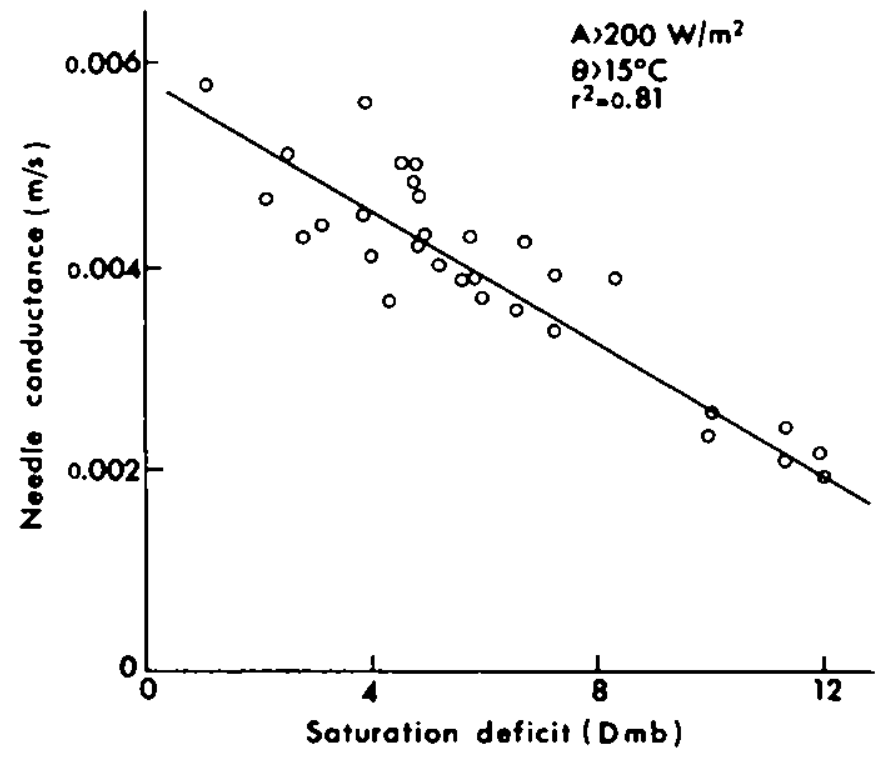

Fig.2. The relation between saturation deficit and stomatal conductance of 1-year-old needles of Sitka spruce in the upper part of the canopy, Forest of Mearns, sumer 1972. Needle conductance expressed on a unit needle area basis.

and the Bowen ratios so much higher. The answer is made most clearly evident by reference to the simplification in equation (5). Essentially, $E_{T}$ depends upon $8 s$ and D. Stomatal conductance is large in humid, cool weather when deficits are small, but because of the small defictts transpiration is not large in any case. On the other hand, in warm, dry weather when the deficits are large, the stonatal conductance is small, because the stomatal conductance itself depends upon the deficit. Stomatal conductance and saturation deficit are never both large at the same time. Consequently transplration never reaches the high rates expected.

Although the rate of transpiration does increase as $D$ increases ( $\mathrm{Flg} .1$ ), it does not increase to the extent that would be expected because $g_{9}$ does not remaln constant. During the course of a warm, sumer day, $B_{s}$ decreases as the saturation deficit gets larger (FIg, 2) and in extreme conditions may get so small that $\mathrm{CO}_{2}$ uptake becomes zero or negative. Thus there is feedback in the needle which effectively prevents large rates of water loss being attained. Laboratory experiments show that this decreases in $g_{S}$ results from the closing of stomata. Closure is not assoclated with 
the development of large water stresses in soll, tree or leaf mesophyll, but is a specific response of the stomata to saturation deficit.

Influence of stage of development

Transpiration from dry canopies depends upon the stonatial conductance of the canopy. This in turn depends upon the accimulation of leaf area and development of a closed canopy, as well as upon the changing rorphological and physiological characteristics of the needles and behaviour of the stomatia. So far as we know, systematic studies of stomatal conductance of canopies have been made on about ten stands of five different species at varying stages of development in the U.K. No systematic studies of stage of development of $g_{S}$ have been made or are in progress.

\section{EVAPORATION FROM WET CANOPIES}

The rate of evaporation of intercepted water from wet canopies can reach very high values. Rates are nomally in the range 0.1 to $0.3 \mathrm{~mm} / \mathrm{h}(70-210 \mathrm{~W} / \mathrm{sq} . \mathrm{m})$ but can exceed $0.5 \mathrm{~mm} / \mathrm{h}$ $(340 \mathrm{~W} / \mathrm{sq} . \mathrm{m})$ in the summer for short periods. The rate of evaporation often exceeds the rate of input of available energy, 1.e. $\alpha>1, \beta$ negative. For example, the average of 245 measurements of evaporation rate over 20 min periods from a wet Scots pine canopy at Thetford was $129 \mathrm{~W} / \mathrm{sq} \cdot \mathrm{m}$ and the corresponding average rate of available energy input was 102 W/sq.to (Stewart 1977).

At first sight this right appeat surprising since canopies are wet, dew apart, elther when it is raining or immediately after rain has ceased. In these circumstances it is usually cloudy so that the available energy is low. In addition, evaporation of the rain and intercepted water raises the huridity of the air and lowers its temperature, thus bringing the air closer to saturation. This combination of atmospheric conditions might be expected to result in low rates of evaporation of the intercepted water. The rates of evaporation are, of course, lower than would occur if saturation was not approached and irradiation remained high but they are nonetheless high for two reasons. In the first place, evaporation is not restricted by stomata, a large area of foliage and twig presenting a free water surface to the atmosphere at a temperature close to ambient. Secondly, because of the aerodynamic roughness of the canopy, curbulent mixing is very effective and the boundary layer conductance is very large $(0.1$ to $0.3 \mathrm{~m} / \mathrm{s})$, thus facilitating cransfer of water vapour into atmospheres of even very high humidity.

If hourly rates of over $0.3 \mathrm{wm} / \mathrm{h}$ were sustalned for twenty-four hours, very high dally rates of evaporation would result. However, the canopy rarely remains wet for long periods, because 1 t dries out so rapidly and when it does remain wet for long perlods, the humldity of the air 
approaches saturation so that the rate of evaporation is depressed. Consequently daily rates of evaporation rarely exceed 6 may.

Available energy and saturation deficit

In cloudy, ralny weather the available energy is swall, often lying, in the range 50 to $150 \mathrm{~W} / \mathrm{sq} . \mathrm{m}$. Nonetheless in the absence of restriction by the stonata, this can lead to an apprectable evaporation rate. Even if the air were to become completely saturated $(D=0)$, equation (2) gives the proportion of available energy involved in evaporation as

$$
\alpha=\lambda E / A=s /(s+\gamma)
$$

If the air were to be cooled to a dewpoint of $9^{\circ} \mathrm{C}$ for example, $\alpha=0,5$ and $E_{I}$ wight be $0.08 \mathrm{~mol} / \mathrm{h}$. In practice, al though the saturation deficit decreases as the air is cooled and humidifled by evaporation, the air does not become saturated because of the influx of air which has previously passed over areas of lower vegetation where there has been a sufficient input of sensible heat to maintain a small saturation deficit. Many observations at Mearns and Thetford indicate that while the canopy remains wet, even after rainfall has ceased, the saturation deficit of the air above is less than $1 \mathrm{mb}$, compared whth values of $10-25 \mathrm{mb}$ in good weather when the canopy is dry. During rainfall the saturation deficit is usually also about $0.5-1$ ob and evaporation goes on at simllar rates.

Boundary layer conduc tance

The large boundary layer conductance is without doubt the most important feature of forest canopies leading to high rates of evaporation. The boundary layer conductance is large because the plantation surface is rough in an aerodymanic sense. This roughness derives in part from the spire-like structure of the canopy and from the height of the trees. The boundary layer conductance al so depends on windspeed (Fig. 3) whlch is very rarely less than $0.5 \mathrm{~m} / \mathrm{s}$ at tree top height. For these two reasons, the boundary layer conductance of coniferous forest canoples is very large both in relation to the stomatal conductance and in comparison with the boundary layer conductance of crops and grassland (Fig.4). Typically, values of $g_{a}$ for plantation forests are in the range of 0.1 to $0.3 \mathrm{~m} / \mathrm{s}$. Consequently, the saturation deficit, even when less than $1 \mathrm{mb}$, contributes substantially to the evaporation rate from coniferous forest plantations.

Curves $B$ and C (Fig. 4) calculated from equation (2), show that even at small saturation deficits, rates of evaparation would be expected to exceed the avallable energy if the aerodynamic conductance is large enough. If the humidicy and temperature of the alr were not co adjust, evaporation would proceed at very high rates indeed as 


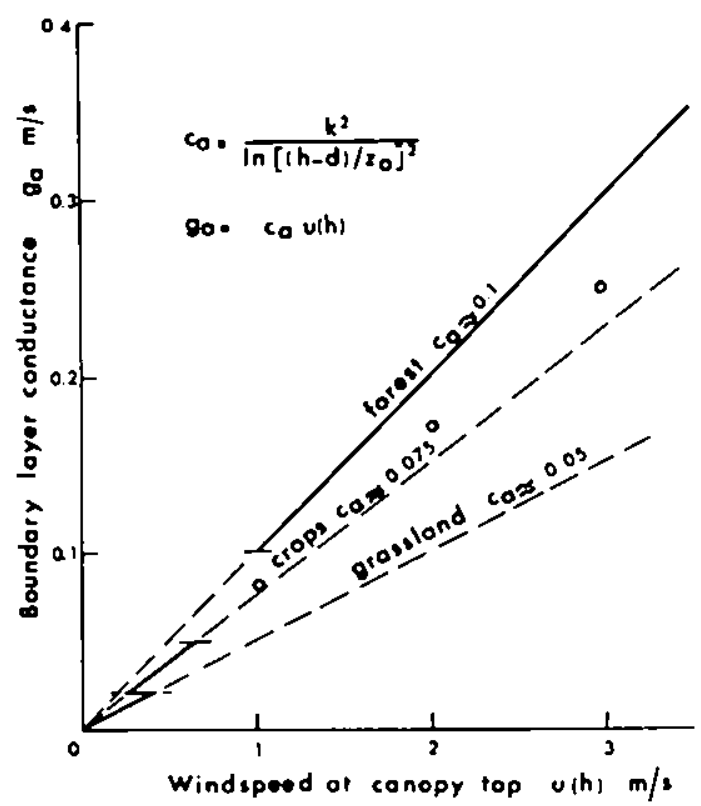

Fig. 3. The relation between boundary layer conductance and windspeed at the cop of the canopy for plantation forests, cereal crops and grassland. Crop heights of 16 , 1 and $0.3 n$ were assumed. $C$ is a non-dimenstonal canopy drag coefficient which is dependent upon the aerodynam $1 \mathrm{c}$ parameters $z$ and d (Jarvis 1976). Heavy 1 ines indicate typical ranges of values in the field. Data points are based on 66 mean hourly wind profiles measured with sensltive cup anemometers over sitka spruce at Forest of Mearns.

Indicated by curve A. However, these rates could not be supported without the abstraction of a great deal of heat from the ambient afr, thus reducing $D$ by cooling the air as well as by raising its humidity. The rate of evaporation of intercepted water will only become less than the avallable energy if the air approaches very close to saturation, or $\mathrm{ga}_{a}$ decreases (Curve $D$ ). If the alr were to becone saturated (Curve E), then evaporation would proceed at a rate which was some fraction of $A$ set by the dewpoint temperature as Indicated by equation (9). above.

The 245 measurements of evaporation from the wet Scots pine canopy at Thetford mentioned previously are shown in Flgure 5 in relation to the avallable energy (Stewart 1977). Also shown is the $1: 1$ line. The large number of points above the $1: 1$ line indicate that the evaporation rate was larger than the rate of input of avaliable energy in the majority of 


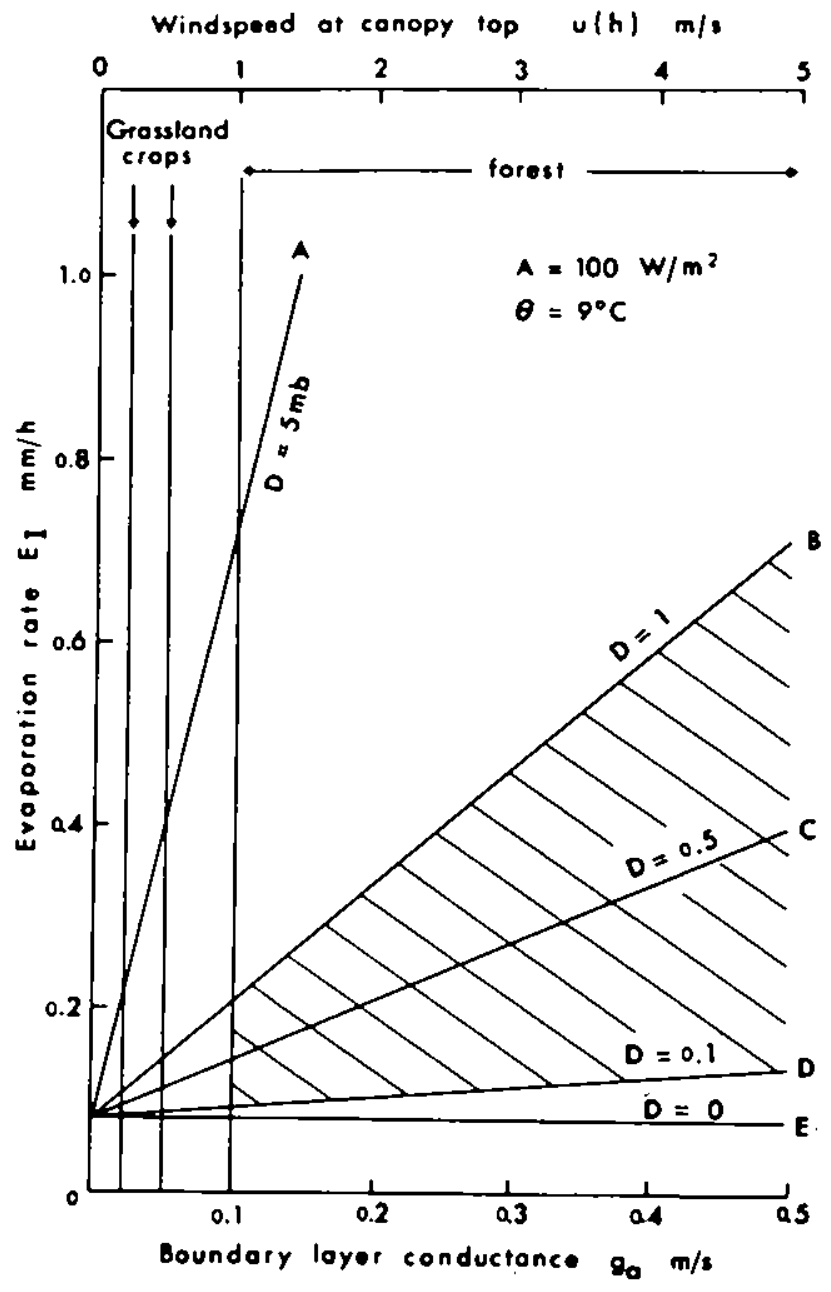

Fig. 4. The relation between evaporation rate, $E_{J}$, and boundary layer conductance calculated from equation (2) at a range of satuartion defic1ts, D. The letters on the curves are explained in the text. Upper lifits for the boundary layer conductance of grassland and crops are indicated by arrows at the top of the figure. The shaded area Indicates the range of evaporation rates from wet forest canopies 


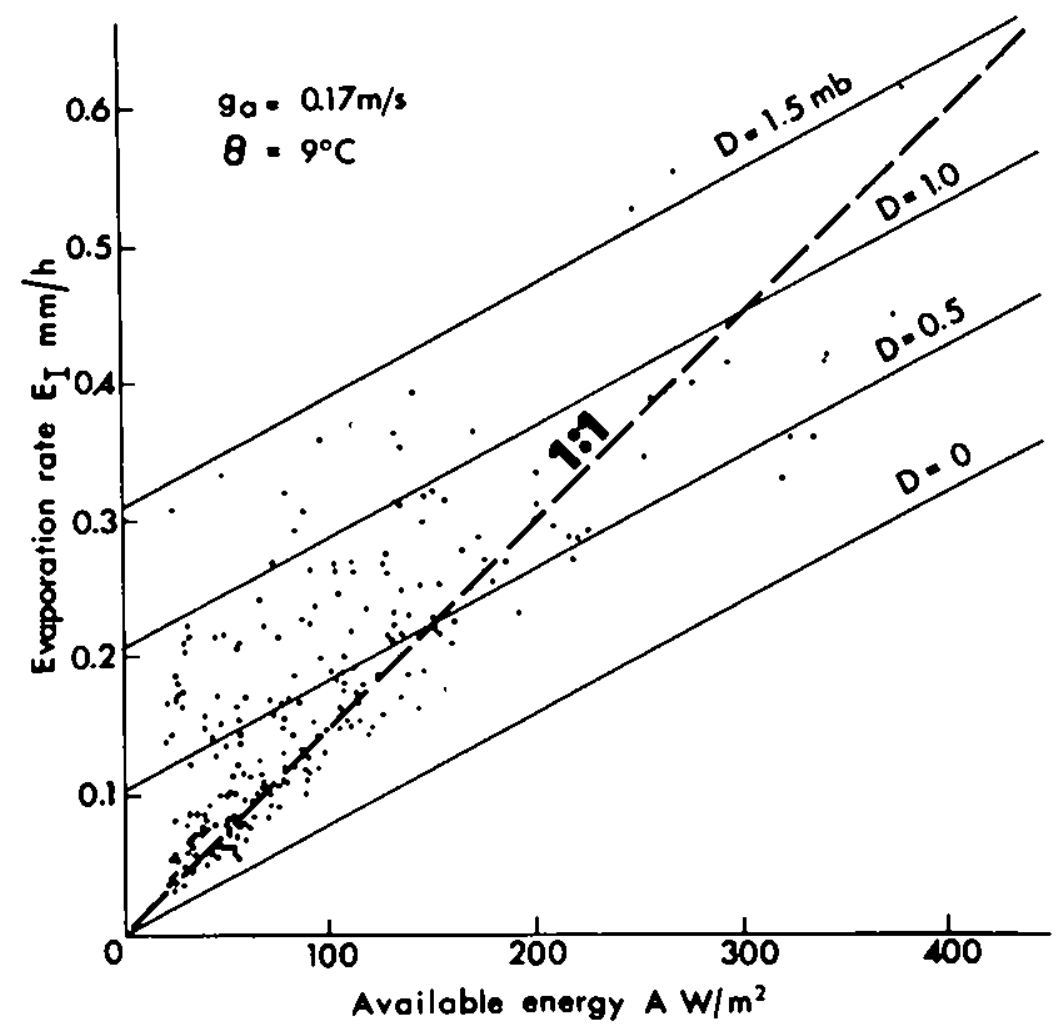

Fig. 5. The relation between evaporation rate and available energy ( $A>20 \mathrm{~W} / \mathrm{sq} \cdot \mathrm{m})$ for a wet Scots pine canopy at Thetford. The solid lines show the expected evaporation rates, calculated from equation (2) for the values of saturation deficit, $D$, shown by the lines. The dashed line $(1: 1)$ shows the line for evaporation rate equal to the avallable energy.

cases. The other four lines show the evaporaton rates to be expected for the values of $D$ given, and a temperature of $9 \mathrm{C}$. It is clear that $J\left(=c_{p} \rho \quad \mathrm{Dg}_{a} / \mathrm{sA}\right.$ ) has values of between 1 and 4 even when $D$ is 0.5 to $1 \mathrm{mb}$ and $A$ is 50 to $150 \mathrm{~W} / \mathrm{sq} \cdot \mathrm{m}$. Thus even at these small saturation deficits, the high boundary layer conductance is responsible for substantially raising the evaporation rate above what would be expected from radiation alone.

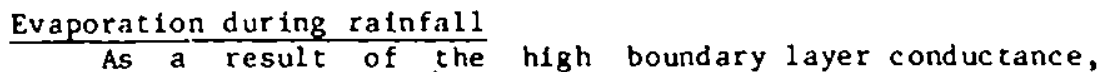
evaporation from wet canopies goes on at high rates into 
atmospheres of high humidity both when it is raining and after rainfall has ceased. It is not always appreciated that evaporation of intercepted water during rainfall accounts for a large proportion of the loss of intercepted water. This is illustrated with data provided by J.H.C. Gash (personal communication) in Table 1 which shows that about 30 per cent of the interception loss results from evaporation whilst rain is falling.

Table 1. The partitioning of the loss of intercepted water by evaporation from two plantations, one of Norway spruce in the Plynlimmon watershed and the other of Scots pine in Thetford Forest. The data were obtained from interception studies and micrometeorologlcal measurements and were kindly made avallable by J.H.C. Gash. For further details see Gash \& Stewart (1977) and Gash (1979).

Evaporation occurring

From small storms (mostly during rainfall)

During wetting up the canopy

From saturated canopy during rainfall

After rainfall ceases

From trunks

TOTAL
Plynlimmon Norway spruce
Thet ford Scots pine

\section{Comparison with transpiration}

Although large, the rates of evaporation are not so much larger than the rates of transpiration as might be expected simply from the absence of stomatal control, i.e. from equation (2) rather than equation (1), because, as the result of rain, the micrometeorological conditions are not the same as in fine weather. In ralny weather, cloud may reduce $A$ to less than $100 \mathrm{~W} / \mathrm{sq} . \mathrm{m}$, compared with values of 400 to 600 $W / s q . m$ in fine weacher, and $D$ is reduced to less than $1 \mathrm{mb}$, compared with values of 10 to $25 \mathrm{mb}$ in fine weather when the canopy is dry. A comparison between $E_{I}$ and $E_{T}$, with $8_{a} / 8_{s}$ taken as 20 , suggests that the rate of evaporation from a wet canopy would be over ten times that from a dry canopy in the same weather condltions. However, largely because of the small saturation deficits during and after rain, in practice the rate of evaporation from a wet canopy does not exceed two to 
Table 2. Typical values of mean hourly and mean daily rates of transpiration and evaporation from coniferous forest plantacions in sumer and winter. The figures are based on micrometeorological measurements on Scots pine at Thetford Forest and on Sitka spruce at Forest of Mearns, and on interception studies on Norway spruce at Plynlemmon (see Jarvis et al. 1976; Gash \& Stewart 1977; Stewart 1977; Gash 1979).

\section{Transpiration $F_{T} \quad$ Evaporation $E_{I}$} $\mathrm{mm} / \mathrm{h} * \mathrm{~mm} / \mathrm{day} \mathrm{mm} / \mathrm{h} \quad \mathrm{mb} / \mathrm{day}+$

$\begin{array}{lllll}\text { Sumer } & 0.15 & 2 & 0.3 & 6\end{array}$

$\begin{array}{lllll}\text { Winter } & 0.03 & 0.3 & 0.1 & 2.5\end{array}$

* for daylight hours only

+ in practice the canopy is rarely wet for $24 \mathrm{~h}$.

three times that from a dry canopy in summer (Table 2). Influence of stage of development

It might be expected that the surface roughness parameter of plantation canoples, and hence $g_{a}$, would vary with tree species, density of planting and stage of developrent of the stand. Up to 1975, fourteen published studles had been made on ten species in six countries by thiteen teans of investigators on fourteen stands of generally poorly defined structure and stage of development (Jarvis, James \& Landsberg 1976). No systematic studies of the influence of stand characteristics on the aerodynanic properties of forest canopies have ever been made, despite the importance of these characteristics in the exchanges of water, $\mathrm{CO}_{2}$, heat and momentum; the last being also of some slgnificance with regard to windblow!

\section{ANNUAL WATER LOSS}

As a result of the large differences in instantaneous rates of water loss from wet and dry canopies, long-term losses by evaporation and transpiration together (evapotranspiration) from plantation forest must depend upon the proportion of the time that the canopy is wet or dry, as well as upon the local climate and weather. Consequently, large differences in annual rates of evapotranspiration may be expected amongst areas with differing patterns of rainfall distribution with respect to time. If the rainfall is frequent, so that the canopy is almost continuously wet, very large amounts of water will be lost by evaporation. On the other hand, if the rainfall mostly comes in short, infrequent, heavy showers, or is very seasonal, the annual loss by evapotranspiration wll be smaller because of the ruch lower 
Table 3. The loss of water by transpiration and evaporation in 1975 from a plantation of Norway spruce in wid-Wales and Scots pine in Fast Anglia. The figures are based on micrometeorological and lysimetric measurements and data from automatic weather stations. Some of the data kirdly provided by J.H.C. Gash. Further information is given by Calder (1977), Gash \& Stewart (1977) and Gash (1979).

\author{
Plynlimion \\ Norway spruce
}

Gross rainfall, mm

Mean evaporation rate, $\mathrm{mm} / \mathrm{h}$

Mean rainfall rate*, m/h

Proportion of time the canopy is wet

Transpiration loss, mm

Evaporation loss, mm

$\begin{array}{ll}2002 & 650 \\ 0.13 & 0.19 \\ 1.76 & 1.38 \\ & \\ 0.48 & 0.13 \\ 340 & 350 \\ 550 & 210\end{array}$

890

560
Thet ford

Scots pine

Total loss, m

* for hours in which the rafnfall exceeded 0.5 mo.

rates of loss by transpiration from dry canopies than by evaporation from wet ones

There is very litele information available on the separate losses of water by transpiration and evaporation from forests in different climates, with which to support this hypothesis. Table 3 shows a comparison between such estimates for a Norway spruce plantation in the Plynlimmon watershed in mid-Wales and a Scots pine plantation in Thetford Forest in Fast Anglia, i.e. a comparison between a damp, occanic site in the west and a dry, more continental site in the east of the country. At both sites the transpiration losses in 1975 were very similar, but over twice as much water was lost by evaporation from the plynlimmon sice than from Thetford because frequent rain kept the canopy wet there for a much larger proportion of the time.

This comparison is not only between regions of the country but is also between species, and indeed between stands of quite different age structure. This is the best we can do at present. We do not have the information to wake comparisons between the same species in different regions, let alone the same species in stands at different stages of development or under different management regimes.

\section{COMPARISON BETWEEN PLANTATION FOREST AND GRASSLAND}

The main differences between plantation forest and grassland in characteristics affecting evapotranspiration lie 
in

- the solar reflection coefficient (albedo);

- the stomatal conductance;

- the boundary layer conductance.

The mean daily albedo of plantation forest is generally in the range 0.10 to 0.15 (Jarvis, James \& Landsberg 1976) in contrast with that of grassland and many crops which is about 0.25 . This difference gives rise to about 10 per cent more net radiation over forest than over grassland and probably an equal amount more available energy.

The maximum stonatal conductance for plantation forest is about $0.02 \mathrm{~s} / \mathrm{m}$ for dense canopies of spruce and about $0.01 \mathrm{~s} / \mathrm{m}$ for pines and perhaps some other coniferous species. Some crops and grasslands may have somewhat higher values but a figure of $0.02 \mathrm{~s} / \mathrm{m}$ is probably fairly representative for a sward well supplied with water. However, whereas the value for grassland may remain more or less constant during the day, unless drought intervenes, ${ }^{8} \mathrm{~s}$ for pine and spruce canopies may decline markedly during the day to much lower values leading to much lower transpiration rates.

The boundary layer conductance of plantation forest is typically within the range 0.1 to $0.3 \mathrm{~s} / \mathrm{m}$ whereas $\mathrm{Ba}_{a}$ for crops is about $0.03 \mathrm{~s} / \mathrm{m}$ and for grassland about $0.01 \mathrm{~s} / \mathrm{m}$. These large differences lead to substantial differences in the race of evaporation of intercepted water from forest and grassland.

The estirated effects of these variables on water loss from wet and dry canopies are shown in Table 4.

Table 4. A comparison between the characteristics and components of evapotranspiration of dry and wet canopies of Scots pine at Thetford Forest and grassland experiencing the same meteorological conditions during twelve hours of dayl ight on two days in June 1973. $\theta=15^{\circ} \mathrm{C}$. Adapted from Stewart (1978).

\begin{tabular}{lcccc} 
& \multicolumn{2}{c}{ Canopy dry } & \multicolumn{2}{c}{ Canopy wet } \\
& Scots plne & grass & Scots pine & grass \\
$\mathrm{A} \mathrm{MJ/sq.m}$ & 19.36 & 15.33 & 2.40 & 1.98 \\
$\mathrm{~g}_{\mathrm{s}} \mathrm{m} / \mathrm{s}$ & $0.01-0.003$ & 0.02 & - & - \\
$\mathrm{g}_{a} \mathrm{~m} / \mathrm{s}$ & 0.17 & 0.01 & 0.17 & 0.01 \\
$\mathrm{~J}$ & 4.21 & 0.30 & 0.99 & 0.07 \\
$\alpha$ & 0.49 & 0.80 & 1.21 & 0.64 \\
$\beta$ & 1.04 & 0.25 & -0.17 & 0.56 \\
Deficit term, rm & 3.09 & 1.14 & 0.59 & 0.03 \\
Radiation term, mm & 0.73 & 3.75 & 0.60 & 0.49 \\
Total, mm & 3.82 & 4.89 & 1.19 & 0.52
\end{tabular}

Dry canopy comparison

The higher stomatal conductance of the grassland leads to 
a wuch higher transpiration rate attributable to the radiation or available energy cerm than for the forest, despite the somewhat sollier amount of available energy. This is of a considerable degree by the much lower deficit term of the grassland than of the forest as a result of the differences in $\mathrm{ga}_{a}: \mathrm{J}$ is 4.2 for the forest whereas it is only 0.3 for the grassland. However, the partitioning of energy by dry canopies is more dependent on $g_{s}$ so that the daily total of cranspiration by the grassland is 28 per cent higher than by forest and 80 per cent of the avallable energy goes into cranspiration by the grassland as compared with only 49 per cent by the forest.

Wet canopy comparison

On days on which the canoples are wet all day, there is much less energy available because of the cloudy, rainy conditions.

The evaporation from the forest is twice that from the grassland, because the deficit term contributes as much as the radiation term, whereas the deficit term contributes almost nothing to evaporation frow the grassland. Consequently evaporation from the forest exceeds the input of available energy, whereas evaporation from the grassland is much less than the available energy. Thus is negative for the forest but +0.56 for the grassland.

\section{CONCLUSIONS}

Because of the high boundary layer conductance, rates of evaporation from wet plantation forest canopies are much higher than from grassland. On the other hand, the low stomatal conductance leads to lower rates of transpiration from forest than from grassland (Table 4). The figures in the table are for daylight hours only. It may be assumed that transpiration will be much reduced at night as a result of stomatal closure, as well as frow lack of energy. If the needle stomata were to remain partly open, night time transpiration might al so be appreciable. Evaporation from the canopy at night is likely to be at about the same rate as that attributable to the deficit term in day time, thus further enhancing the daily loss from forest, as compared with grassland. Thus, if wet and dry days occur with equal frequency, average dally rates of evapotranspiration olight be about 5 per cent higher from forest than from grassland. However, the rate of evaporation from the wet forest canopy is so rapid that the forest canopy does not remain wet for long between showers, except in the wetter, more humid, western parts of the U.K. where rainfall is frequent and often continuous for long periods. In these areas forests lose more water than grassland because of the large amount of rainfall which is intercepted by the canopy and thence evaporated. Where the pattern of rainfall is markedly discontinuous, the 
total evapocranspiration from forest is unlikely to exceed evapotranspiration from good quality grassland on deep soils, well supplied with water, because of the lower stomatal conductance of the forest. However, should the grassland experience drought, because of shallow rooting, or be composed of xerophytic specles with low stomatal conductance, the total evapotranspiration from the forest probably will still be higher. A more exact assessment must await better information on the comparative rates of evaporation and transpliation from forest and grassland in different climatic areas. In view of the considerable amount of information obtained on evaporation and transpiration from forest over the last fifteen years, it is perhaps desirable now that the emphasis be shifted somewtiat towards accurate estimation of evaporation and transpiration frow grassland and heathland in upland locations.

\section{REFERENCES}

Calder,I.R. (1977). A model of transpiration and interception loss from a spruce forest in Plynlimmon, Central wales. Journal of Hydrology, 33, 247-265.

Gash,J.H.C.(1979). An analytical model of rainfall interception by forests. Quarterly Journal of the Royal Meteorological Society. 'In préss.

Gash,J.H.C. \& Stewart,J.B. (1977). The evaporation from Thetford Forest during 1975. Journal of Hydrology, 35, 385-396.

Crace,J., Nalcolm,D.C. \& Bradbury,I. (1975). The effect of wind and humidty on leaf diffusive resistance in Sitka spruce seedlings. Journal of Applied Ecology, 12, 931-940.

Jarvis,P.G., James,G.B. \& Landsberg,J.J.(1976). Coniferous forest "Vegetation and the Atmosphere" Vol. 2 Case Studies (Ed. by J.l.. Monteith) pp 171-240. Academic Press, London, New York, San Fransisco.

Jeffree,C.E., Johnson,R.P.C. \& Jarvis,P.G.(1971). F.ptcuticular wax in the stomatal antechamber of Sitka spruce and its effects on the diffusion of water vapour and carbon dioxide. Planta, 98, 1-10.

Monteith,J.L.(1965). Evaporation and Environment. Symposia of the Society for Experimental Biology, 19, 206-234.

Monteith J.L.(1973). Principles of Environmental Physics, Arnold, London. 241 PP.

Penman, H.L.(1948). Natural evaporation from open water, bare soil and grass. Proceedings of the Royal Society, A 199 $120-145$.

Penman,H.L., Angus,D.E. \& Bavel,C.H. van(1967). Microclinatic factors affecting evaporation and transpiration. Agronomy, $11,483-505$.

Rutter,A.J.( $196 \overline{7})$. The analysis of evaporation from a stand of Scots pine. Proceedings International Symposium on Forest 
Hydrology (Ed. by W.E. Sopper and H.W. Lul1), pp 403-417. Pergamon Press, Oxford.

Shutcleworth,W.J. (1976). A one-dimensional theoretical description of the vegetation-atmosphere interaction. Boundary Layer Meteorology, 10, 273-302.

Sinclair,T.R., Murphy,C.E. \& Knoerr,K.R. (1976). Developuent and evaluation of simplified models for simulating canopy photosynthesis and transpiration. Journal of Applied Ecology, 13, 813-829.

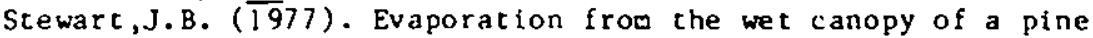
forest. Water Resources Research, 13, 915-921.

Stewart,J.B.(1978). A wicrometcorological investigation into the factors controlling the evaporation from a forest. PhD Thesis, University of Reading.

Watts,W.R. \& Nellson,R.F.(1978). Photosynthesis in Sitka spruce (Picea sitchensis (Bong) Carr.) VIII. Measurements of stomatal conductance and $\mathrm{CO}_{2}$ uptake in controlled environments. Journal of Applied Ecology, 15, 245-255.

Walls,W.R., Neilson,R.F. \& Jarvis,P.G. (1976). Photosynthesis in Sitka spruce (Picea sitchensis (Bong) Carr.) VII. Measurements of stomatal conductance and $\mathrm{CO}_{2}$ uptake in a forest canopy. Journal of Applied Ecology, 13, 62.3-638. 

EFFECTS OF FORFST PLANTATIONS ON THE, QUANTITY, QUALITY AND TIMING OF WATER SUPPI,IES.

By WADE L. NUTTER.

School of Forest Resources, University of Georgia, Athens, Georgia 30602, U.S.A.

\section{SUMMARY}

The role of forests and forest management in the regulation of the quantity and timing of water flow from foresied calchments has been well documented in the past fifty years. In general the annual volume of flow from forested catchments is less than that expected from other types of vegetation. Annual flow from coniferous catchmencs can be expected to be as much as 20 per ient less than that from hardwoods, due mainly to greater annual interception loss in the coniferous catchment. For some conifcrous species the annual transpiration loss also may be greater than that for hardwoods. Seasonal flows from conlferous catchments are usually less than from hardwoods; the greatest loss occurring during the dormant and early growing seasons. Flood flows, both peak and volume, are not expecied to be altered by conversion of forest stands to even-aged plantations.

The degree to which naciual water quality is altcred by land use practices depends on the climate soll, geology, topography and vegetation type. Evidence suggests that most nutrients are retained and recycled within a conlferous forest to a greater degree than in a hardwood forest and in forests to a greater degree than in grass or successional stage vegetation. Rapid revegetation of a site after forest harvest will generally result in only a small increase in nutrlent loss. Erosion is not a significant water quality factor under wel l-planned and executed forest management.

Many of the effects of even-aged plantations on che quantity, quality and timing of water flows 
are small or little different frow those expected from natural forests. The major effects will result from the more irtensive cultural practices common to even-aged plantation managenent. These effects can be minimized through careful and wise application of management practices.

\section{RÉSUMÉ}

Nous possédons depuis une cinquantaine d'années unc mine de renseignepents sur le roble régulateur des forêts et de la gestion forestlère en ce qui concerne la quantité et la distribution dans le lemps du régime des eaux. En général le débit annuel d'eau provenant des régions forestières est moins important que celui d'autres types de végetation. Le debit annuel provenant des forêts de conifères peut être de l'ordre de 20 per cent de moins que celui des forêts de feuillus à cause. d'une perte plus grande dûe à I'interception dans les forêts de conifères. La perte annuelle par évaporation de certains conifères peut être plus élevée quc celle de certaines essences feuillues. Le débil saisonnier des forêts de conifères est inférieur à celui des forêts de feulllus: les plus grandes pertes ayant lieu pendant la périnde de repos de la végétation et le début de la période végétative. On pense que ni le volue d'écoulement en général, ni les pointes de débit soient affectés par la conversion de peuplenents forestiers en plantations équlennes.

Le degré d'influence de l'occupation des sols sur la qualité naturelle des eaux dépend du climat, du sol, de la géologie, de la topographic el du type de végétation. Par expérience, on sait que la plupart des éléments nutritifs sont retenus et recyclés de façon plus avantageuse dans les forêts de coniferes que dans les forêts de feuillus, et aussi de façon plus avantageuse dans les forêts que dans les prairles ou d'autres stades de succession. La végélation qui apparait dans une station après la récolte $n^{\prime}$ amène qu' une falble augmentation de la perte d'éléments nutritifs. $L^{\prime}$ érosion n'est pas un facteur significatif de qualité des eaux dans le cadre d'une gestion forestière efficace.

La plupart des effets produits par des 
peuplements équiens sur la quantité, la qualité et le reglage du régime des caux ne diffèrent que peu ou presque pas de ceux des forés naturelles. Les effets les plus importants résultent de l'exploitation agricole intensive qui va de palr avec la gestion des forêts Equiennes. On peut minimiser ces effets en se bornant à appliquer des techniques de gestion prudentes et équilibrées.

\section{ZUSAMMENFASSUNG}

In den letzten fünfig Jahren ist sehr viel darüber geschrieben worden, welche Rolle walder und ihre Waldbauliche Behandlung bei Menge und zeitlicher verteilung des Wasserabflusses aus bewaldeten Einzugsgebieten spielen. Im allgemeinen liegl die jährliche Abflussrate aus bewaldeten Einzugsgebieten unter dew anderer Vegetationstypen. Aus Nadelwaldgebieten kann man Jahresmengen erwarten, die bis zu 20 prozent unter denen aus Hartholzeinzugsgebieten liegen. Dies wird hauptsächlich auf den grösseren jährlichen Interceptionsverlust in Nadelwaldgebieten zurückgefüht. Bei einigen Nadelholzarten ist auch u.U. der jährliche Transpirationsverlust grösser als bei Harthölzern. Die jahreszeltIichen Abflusse aus Finzugsgebiecen mit Nadelwaldbestockung sind nomalerweise geringer als aus denen von Hartholzern; der grösste verlust entsteht wăhrend der Ruhezelt und den frühen Wachstunsperioden. Bezuiglich des Auftretens von Hochwasser ist durch die lowandlung von Forstbestanden in gleichaltrige pflanzungén keine Anderung hinsichtich Menge und Intensität zu erwarten.

Inwiewelt die naturliche Wasserqualitat sich durch die jewell ige Landnutzung āndert, hängt von Klima, Boden, Ausgangsgesteln, Relief und dem Vegetationstyp ab. Die Erfahrung zeigt, dass die meisten Nährstoffe in einem Nadelwald in grōsserem Masse zurückgehalten und wieder aufgenomen werden als in elnem harthol zwald, und dass dieser Vorgang generell in waldern deutlicher ausgeprägt ist als bel Grasland oder anderen höherstehenden Vegetationsformen. Wenn ein Standort nach der Holzernte schnell wieder aufgeforstet wird, so füht das zu einem nur geringen zusătzlichen Nährstoffverlust. Bei gut geplantem und gut ausgefühtem waldbau wirkt 
slch die Erosion kaum auf die Wasserqualität aus.

Glefchaltrige Bestände beeinflussen Menge, Qualität und zeitliche vertellund der wassermengen kaum anders als Naturwälder. Am weisten wirken sich noch die intensiveren Kulturrassnahmen aus, die normalerweise bei gletchaltrigen Beständen angewand t werden. Durch ursichtige und kluge Kulturtechnlk kann dies auf ein erträgliches Minimum reduzlert werden.

\section{INTRODUCTION}

"It is not enough to know whether forests influence streamflow; it is necessary to know how much, at what seasons and under what conditions of climate, soll and topography and the varlations between different kinds of forest as well".

That statement was made in 1928 in the Wagon wheel Gap study report on the effects of forest 1 and use changes on streamflow (Bates \& Henry 1928). In the fifty years since that classic experiment and the Emmenthal, Switzerland study on differences in streamflow between pasture and forest land (Engler 1919), much has been learned about the influence of forests and other vegetation types on streamflow quantity and timing. The paired catchment experimental design pioneered in the wagon theel Gap experiment is the major design stlll used today in forest water yleld research. In more recent years research emphasis has shifted to understanding and interpreting components of the hydrological cycle to predict effects on forests and changes in forest 1 and use on the: quanticy and timing of streamflows. We have made progress. But if we were to turn Bates and Henry's statement into a question and ask, do we know enough, the answer is no. The biological and physical components of the forest ecosystem, vegetation type, climate, soll and topography interact in many different ways which are not precisely predictable. Predictability will improve as we learn the better to quantify the components and the Interactions between components.

In recent years there has also been greater emphasis on the effects of forests and forest land use changes on the quality of streamflows as concern over long-term site productivity and environmental issues has increased. Again the biological and physical components inceract in a complex way and experience is as yet too limited for us to make broad extrapolations and expect a high degree of predictability.

\section{FORESTS AND WATER YIELD}

Much of the forest hydrological research conducted over 
the past sixty years has been in natural forests, a few under continuing intensive management. There have also been a limited number of studies on effects of conversion from forest to non-forest vegetation and vice versa. Examination of the impacts of plantations on the hydrological cycle is very timely as the land area in incensively managed plantations grows at an increasing rate. For instance, in the coastal plain region of south Georgla and north Florida in the United States, 25 per cent of the $4 \times 10$ ha commercial forest is pine plantation. Since there is a paucity of research studies on the hydrological effects of even-aged forest plantations, extrapolations must be drawn from studies on natural stands under intensive management through application of our knowledge of the biological and physical processes.

Stated in its simplest form the hydrological balance for a forest catchment (Hewlett \& Nutter 1969) is:

$$
P_{g}-Q-E_{t} \pm \Delta S=0
$$

(Equation 1)

and

$$
E_{t}=I_{t}+E_{S}+T
$$

(Equation 2)

where $P_{9}$ is the gross precipitation, $Q$ the catchment discharge or streamflow, E $E_{t}$ the evapotranspiration and $\Delta S$ the change in soll and ground water storage within the catchment. The evapotranspiration $F_{t}$ is further defined as the sum of total interception loss $I_{t}$, evaporation from soll and water surface $E_{S}$ and transpiration $T$. The time period over which this balance applies may vary, although of greatest interest for purposes of this paper are annual and seasonal periods and the shorter periods during flood flows.

climate, physiography and vegetation are the major factors influencing the hydrological balance (Equation 1 ). Climate's major influence is in teros of precipitation patterns and net energy recelved; whether there is water available and sufficlent energy to evaporate 1t. Physlography and geological structure determine the permeability and water storage capacity properties of the soll and rock. Vegetation type, structure, denslty and vigour each influence evapotranspiration. Evapotranspiration is further influenced by precipitation patterns, the avallability of water in the soll to the plant and the energy to vaporlze the water. The outcome of all of these factors 1 s expressed in the rate, volume and pattern of streamflow from the catchent.

The importance of catchment physlography on the hydrological balance was demonstrated by Lul1 \& Sopper (1967) in the northeastern United States. They found that average annual and seasonal total streamflow was significantly different between seven major physiographic provinces. On the 
other hand, Woodruff \& Hewlett (1970) determined that the percentage of the precipitation appearing as stomflow, referred to as hydrologic response, from moderately sized catchents in the eastern United States was not highly correlated with any single catchment physical feature. This is not too surprising considering the complexity of the physical systen. There was a definite pattern; mapped physiographic provinces had unique hydrological responses. They did identify catchent storage capacity as one variable that is not readily measurable but which could probably account for a major portion of the difference in hydrological responses between physiographic provinces. Nutcer (1975) showed in a large physical model that, in addition to storage capacity, length and angle of slope influence the rate at which water will be delivered to the stream channel. Increasing slope angle or decreasing soll depth each tend to increase stormflow production and decrease the duration and volume of low seasonal flows. Increasing slope length tends to have an opposite effect. Soil depth and soll physical properties are direct indicators of the storage capaclty. Certainly there are exceptions to these generalizations, but the influence of physiography on catchment streamflow behaviour was demonstrated by the model study and highlighted a few problews associated with streamflow prediction from forest catchments.

In the simplest sense evapotranspiration is a function of the amount of water avallable and the amount of energy avallable to vaporize that water. How the water loss is partitioned between transplration, interception and direct evaporation from the soll and water surfaces has been a source of disagrecement among forest hydrologists.

One of the major sources of disagreement is the 1mportance of 1nterception. Burgy and Pomeroy (1958) studied interception and cranspiration losses from grassy areas and concluded that cooling of the leaf surface by evaporation of intercepted water resulted in a simflar reduction in cranspiration. Leyton \& Carlisle (1959) drew similar conclusions from interception studies in forests. In an excellent review of interception studies, Helvey (1971) presented sufficient evidence to conclude that concurrent interception and transplration losses do occur and that these losses are additive. The major reason is that energy avallable to a leaf surface is more efficlent in evaporating water from a wet leaf surface than from the internal cells of a leaf. Thus, for a given input of energy, interception loss from a wet leaf will be 8 reater chan transpiration loss.

vegetation type, structure and density are important factors in determining interception loss. Helvey's (1971) review of numerous interception studies reveals that interception loss and leaf surface area index are correlated; they are greatest in spruce-fir hemlock forests, intermediate 
In pine forests and least in hardwood forests. Age is important in determining stand structure and as a consequence, interception loss. For instance, In one study (Helvey 1967), the annual interception loss from white pine increased by 230 $\mathrm{mm}$ as 10-year old stands matured to 60-year-old stands. Delfs (1967) and Swank o Douglas (1974) reported differences in annual streamflow of 230 mnd and 200 , respectively, that were attributed to the increased interception of conifers compared to hardwoods. The number, structure and timing of precipitation events also influence interception loss. The greater the number of storas with sufficlent drying time between them, the greater the interception loss. Dormant season interception losses from hardwoods are less tnan from conifers. In sumary, forest interception losses $c$ an be significant, reducing the water reaching the soll to be used in maintaining plant growth or streamflow from 8-40 per cent of the gross preclpltation.

Vegetation type, structure and density are also Important factors in determining transplration losses. During the growing season, although the transpiration rates of hardwoods per unit of leaf area may be two or three times greater than conifers, the transpiration loss per tree is greater in conlfers because of the greater total leaf surface area (Swank \& Miner 1968). Penman (1967), through a theoretical study, Indicated that sumer evapotranspiration for conifers may be about 13 per cent greater than for hardwoods and during the winter may be twice as great. Although sowe of the differences in Penman's study are attributable to differences in interception, both between spectes and seasons, there is no doubt that transpiration loss is greater in conlfers. Root mass and depth are correlated with transpiration; shallow-rooted grass wll transpire less water than the deeper-rooted forest stands which can tap a greater volume of 8011 (Douglass 1967; Pyate \& Craven this volume).

To summarize, the role of evapotranspiration is one of considerable Importance in deterwining the quantity and timing of water flows from catchents. Since vegetation type, structure and density all strongly influence both transpiration and interception losses, manipulation of forest vegetation will affect the hydrological balance, both annually and seasonally. Control of evapotranspiration through forest management offers the greatest opportunity for increasing or at least influencing water supplies from catchments.

Studies on the effects of manipulation of forest stands on the hydrological balance are numerous and this paper wll only attempt to summarize the salient points. Studies on the conversion of vegetation types are not numerous but trends are identifiable. Hibbert (1967) reviewed much of the world literature describing results of forest cutting and/or conversion effects on water yield from catchments. He made the 
following generalizations that summarize the studies:

"1. Reduction of forest cover increases water yield.

2. Establishment of forest cover on sparsely vegetated land decreases water yield.

3. Response to treatment is highly variable and, for the most part, unpredictable."

There is little correlation between first year increase in water yield and the percentage reduction in forest cover. However, water yield increases for all studies to-date fall below a linear line between zero increase at no reduction in cover to 450 mincrease at 100 per cent cover reduction. In other words, studies the world-over have indicated that the maximum water yield increase expected following 100 per cent forest removal is 450 wherever preciptiation exceeds evapotranspiration. The increases in water yield following forest cover reduction are primarily due to reduction in transpiration and interception losses although at the same time soll evaporation increases due to greater soil moisture levels and more energy reaching the soll surface. Regrowth of forest vegetation resulcs in a decline in water yield (Hibbert 1967). The rate of water yield decline is directly related to the rate of regrowth.

Water yield generally decreases after forest cover is established on previously non-forested areas. The magnitude of water yield caused by establishing forest cover on non-forested areas, is about one-half the water yicld increase expected if the same amount of forest cover was removed by harvest (Hibbert 1967). Several reasons are possible for these dissimilar results. One may be that the range of observations for establishing forest cover is much smaller than studies on forest cover reduction and secondly, the afforestation sites are usually occupied by vegetation that is actively evapotranspiring before the forest is established.

Converting forests to other types of vegetation often results in increased water yleld. Croft \& Yonninger (1953) observed that replacement of an aspen forest with an herbaceous cover increased water avallable for streamflow by $100 \mathrm{~mm}$ or 8 per cent of the annual precipitation, and further removal of the herbaceous cover increased it by another 100 $\mathrm{mm}$. Conversion of a hardwood forest to heavily fertilized grass resulted in no increase in water yield for the first year (Hibbert 1969). As grass productivity declined, water yield increased each successive year. At the end of the fifth year, water yield fron the grass was about 1.5 times that expected from the hardwood stand. Dry matter production on the grass catchnent declined at the same rate as water yield increased. Fertllization of the grass after five years resulted in reduced water yield and increased dry matter production to the orfiginal first year levels.

The manner in witich water yield changes are distributed 
throughout the year following manipulation of the vegetative cover appears to be a function of precipitation pattern and form, e.g. snow, rain, soll depth, copography, nature of the manipulation and type of vegetation. On an area newly planted wth pine, increased interception loss in the dormant season decreased seasonal flow (Schneider \& Ayer 1961). When precepication is uniformly distributed throughout the year, initial increases in water yield may be greatest during the growing season. As the forest regrows, these increases diminish and way shift to other seasons (Hibbert 1967). The shift is particularly noticeable when a species change is involved. In a hardwood watershed planted with white pine, after fifteen years, the water yield in every month was less than that from the original hardwood forest (Swank \& Douglass 1974). The greatest reductions came during the dormant and early growing season whlch together represented $60-70$ per cent of the annual reduction in water yield. Interception losses in the dormant season were greater than they would have been under hardwood. In the early spring the pine leaves were intercepting water and actively transpiring while the hardwood leaves were still energing.

There are only a few studies on the effects of forest manipulation on peak flows and volume of stormflow. Hewlett \& Helvey (1970) observed that 100 per cent reduction of forest cover in a high precipitation mountain catchment increased peak flows by an average of 7 per cent and stormflow volumes by an average of 11 per cent. During a record storm the stormflow volume increased by 22 per cent. On the other hand, during small and incermediate storms there was little increase in peak flow and a moderate increase in total stormflow volune. Increases in stormflow volume were actributed to reduced soil water storage avallabilicy duc to reduced evapotranspiration. Complete forest removal in a mouncain catchment also resulted in moderate increases in peak flows and stormflow volume (Hornbeck 1973), subject to there being a considerable snow pack in winter. Peak flows and total volumes were increased (i) during the growing season due to higher soil water contents, ( 11 ) during the snow-melt season due to more rapid melting, and (iii) were the same in the domant season before snow-melt began because soll water contents were unchanged.

\section{FORESTS AND WATER QUALITY}

Water flowing from forested catchments is often considered to be of highest qualicy and sultable for most intended uses. There is, however, considerable varlation possible in the natural water quality since it reflects influences of vegetation type, climate, solls, geology and topography. Forest management activities can affect water quality markedly through increased erosion, increased rate of 
soll leaching and species conversion. Erosion is generally the result of non-judicfous management practices and can be controlled through better planning and application of current technology. Change in forest stand characteristics by harvesting or conversion may cause blological and chemical changes in the soil, changes in soll water levels and as a result, the cherical concentration of water leached to the stream.

An often cited study dealing with forest harvest and water quality is that made at Hubbard Brook, New Hampshire (L.S.A.). Borman et al. (1968) reported that following complete harvest of a hardwood forest catchment and subsequent treatment with herbicide to control regrowth, losses of nitrogen and spectific cations were drastically increased. Reasons cited were that (i) reduced evapotranspiration caused an increase in water movement though the sofl, (ii) reduced root systems decreased nutrient uptake, and (iii) the rate of mineralization was increased. Although not intended to simulate a practical forest management situation, the study has been widely quoted as applicable to forest management operations.

Neary (1977) revlewed the results of eight harvesting and water quality studles, including that at Hubbard Brook. He reported that the studies support the preaise that well-planned and managed practical harvesting operations produce relatively small increases in nutrient losses to streamflow, particularly where regrowth of vegetation is swift. Swank \& Douglass (1975) reported the nutrlent fluxes and streamflow quality in elght mature hardwood forests and sixteen other forests that had been altered by harvesting or changes in land use. They found that the nutrient cycles of young hardwood copplce reproduction forests were as closed as those in mature hardwood forests, 1.e. there was no difference in loss of nutrients. Conversion from hardwoods to white pine reduced the loss of most nutrients with the exception of nitrate-nitrogen which increased. Harvested forests returning to natural vegetation had elevated nitrate-nitrogen concentrations in the stream water for at least ten years after harvest. Partial defoliation by insects of a mature hardwood forest also caused a temporary increase in the export of nitrate-nitrogen.

Nitrate-nitrogen is one of the most mobile ions in ecosystems and species composition affects its export from catchments. Todd et al. (1975) reported that monthly averages of nitrate-nitrogen in stream water for grassed, whice pine and hardwood areas in natural succession were $0.8,0.2$ and $0.003 \mathrm{mg} / 1$, respectively. The populations of soll nitrifying bacteria in each ecosystem corresponded with the ragnitude of export; decreasing with decreasing export. The authors postulated that as the succession approaches climax, the 
nitrifying process is either inhibited, ammonia-nitrogen is better utilized by the vegetation, or both. Tamm et al. (1974) found nitrification to be greater in fertile solls and this was reflected in somewhat elevated levels of nitrate-nitrogen in ground water. They concluded that leaching from fertile sites following harvest will be somewhat offset by the wore intensive regrowth of vegetation. Nitrate-nitrogen leaching would be most pronounced where regrowth is delayed by regenetation practices such as application of herbicides, burning or scarification.

Forest burning increases the solubility of some cations, notably K, $C a$ and $M$ and the likelihood of their being leached to the streams. Total $N$ and $P$ are not directly increased by burning; however, soluble $P$ and nitrate may increase due to increased soll microbial activicy. Harvest and subsequent slash burning of a beech - podocarp forest increased the level of N, P, K, Ca and $M$ in the stream (Neary et al. 1978). Potassium export was large and was problably caused by a hot burn of slash concentrated near the stream channel. Most studies show minimal effects of fire on water quality unless all vegetation and the forest floor is destroyed and water travels to the stream directly over the soll surface. Logging of radiata pine followed by slash burning resulted in an increase in nutrient movement within the soll profile, but nutrient levels in the ground water were not increased (Webber \& Barton 1978). The volatility loss of nitrogen was considered to be more detrimental to site fertility than any leaching losses that occurred.

The effects of forest fertilization on water quality appear to be closely related to the method of application, the type of fertilizer applied and the nature of the soil and forest fertillzed. Tamm et al. (1974), after a. review of numerous fertilization studles, concluded that nitrate-nitrogen is the most critical problem and fertllization operations should be carried out to minimize its probability of movement to streams. Direct application of fertilizer to streams, particularly during aerial application, has often been the sole reason for fertilization affecting stream water qualicy (Nutcer \& Ike 1971; Moore 1974). The effects of direct application to the stream often last from a few days to several weeks. Except where readily leachable forms of nitrogen fertilizer are used, the application of fercllizer to forest stands has little effect on water quality when proper safeguards are employed and there is no direct movement of water over the soll surface to the stream channel. The use of pesticides and herbicides in the practice of forest management must follow similar precautions (Fredriksen, Moore \& Norris 1973). 
INTENSIVE PLANTATION MANAGEMENT FHFFCTS ON WATER QUANTITY AND TIMINS,

From the foregoing discussion it is evident that manipulation of forest vegetation, whether it is a partial or a complete harvest or conversion to another forest on non-forest species, directly affects the hydrological balance of catchents. There is little evidence regarding the effects of intensive managenent of even-aged plantations. By applying the results of the studies discussed and the known biological and physical processes that characterize the hydrological balance, the type and relative magnitude of even-aged plantation management effects on the hydrological balance of catchments can be est irated.

Even-aged plantations under intensive management are expected to be composed of genetically superior trees with greater growth rate, vigour and density than the natural vegetation they replace. The influences on the hydrological balance, all other factors being constant, are positively correlated with the extent to which vegetation occupies the site. A dense, vigorously growing plantation will increase the interception and transpiration losses because of greater above-ground biomass.

The evidence further suggests that the increase in transpiration and interception from fully-stocked plantations will decrease soil water levels under most climatic conditions. Rogerson (1968) has shown that the amount of preclpitation reaching the forest floor in a loblolly pine plantation increased by 2 per cent for every 2 sq.to reduction in stand basal area. Reduction of basal area by 50 per cent to an optinum density increased the net anuual precipitation to the forest floor by $100 \mathrm{~m}$ or 8 per cent of the annual precipitation. In regions of low precipltation during the growing season it is interesting to speculate whether less dense stands would have greater productlvity because of higher soil water avallability. Dahos (1971) reports that a precomnerclal thinning of lodgepole pine substantially increased productivity and soll water contents. As growth progressed the soll water contents decreased to pre-thinning levels.

The water yield from fully-stocked plantations will probably be less than from the natural vegetation, although exceptions are possible. Perelra (1973) reports that after crown closure annual water use by a pine plantation was equal to that of a natural bamboo forest in East Africa. On the other hand, a white pine plantation reduced water yield by 20 per cent, about 200 man, from that expected from the original hardwood forest (Swank \& Douglass 1974). A generalization might be that catchment water ylelds will be decreased if the plantation is more dense, has greater above-ground biomass and retains its leaves longer than the vegetation it is replacing. 
The same factors will result in changes in monthly or seasonal water yield, with the greatest differences expected in the growing season and in the dormant season where interception loss is increased over that for a natural vegetation.

When plantations replace non-forest vegetation, the recession of growing season streamflow will be more rapid than that of the original vegetation. Wicht (1967) reports that growing season flow frequently ceases when plantations replace natural, non-forest vegetation in South Africa. Water yield increases $c$ an also be expected when plantations are heavily thinned. Experience suggests that light thinnings will not generally increase water yleld because the newly avallable soll water resulting from initially reduced transpiration and interception loss will be used by the existing vegetation. In other words, depending on the extent to which the site is occupied by vegetation, a threshold level of vegetation removal must be reached before water yield increases occur. Harvesting at the end of a plantation rotation will lead to increased water yield. Following regeneration the water yield will steadily decline until it equals that pror to harvest (Swank \& Helvey 1970).

Decreased soll water levels under plantations may result in decrased stormflow volumes and peak flow resulting from small to moderate storms. It is unlikely that there will be any difference in flood response between plantations and natural forest when large storms occur, although plantations could have a substantial beneficial effect when they replace non-forests. So little experimental evidence exists on the effect of forest harvesting and/or conversion on flood flows, that only generalizations may be drawn frow the literature.

Although changes in the hydrological balance can be expected from the intensive managenent of even-aged plantations, the magnitude of the changes is difficult to predict. Upper bounds may be placed on the changes (Hibbert 1967) but rarely can the climatic, topographic, soll and vegetation factors of one experimental site be directly extrapolated to another. The magnitude of change in the hydrological balance may be substantial and readily detectable in small catchments. As catchment size increases and land use becomes a mosaic of plantations and other land uses, the downstream influence of the small catchment is diminlshed. The effects $c$ an be further reduced by scheduling management activities in a catchment so that water yleld increases from some plantations compensate for water yield decreases in others. A simple way to minfmize impacts is to manage a large plantation as a serles of blocks, all in varlous stages of development and water use.

When compared with natural forests, the influence of plantations on the hydrological balance will, in most places. not be severe. If plantations replace non-forests the 
magnitude of change in the hydrological balance way be substantial and reduce water supplies appreciably. On the other hand, Intensive management activities often assoriated with plantations can result in much more drastic changes in the hydrological behaviour of the catchment. Intensive networks of roads and trails and other activities that remove the soll's proteci ive cover result in more rapid and greacer flood peaks and often in increased volumes of stornflow as well. These effects can often be more damaging to downstream water supplies than silvicultural operations in plantations.

\section{INTENS IVE PLANTATION MANAGEMENT EFFECTS ON WATFR QLALITY}

The effect of intensive culture of even-aged plantations on water quality may be varled and depends on a number of site factors as well as the degree and type of management disturbance to the site. If the plantation species recycle more of the site nutrients than the original vegetation, fewer of the nutrients will be leached to the strean. In general, the establishoent of plantations will not adversely affect the concentration of dissolved minerals to stream water. Wherever plantations replace non-forest vegetation, an improvement in water quality can be expected because crosion losses from non-forest vegetation are generally greater than from forests. Erosion of particles to the stream channel increases both suspended and dissolved minerals and organic matter. Shorter rotations associated with plantations may cause a greater amount of nutrlents to be removed from a site, reducing the pool from which nutrients may be leached to the stream channel. This problem is magnifled when whole-tree harvesting practices are exployed in each rotation (Waide \& Swank 1977). If a site is quickly occupied by a vigorous regrowth of vegetation following harvest, only a slight increase in the leaching of nutrients may be expected. There appears to be some correlation between lengths of growing season and the amount of inftial leaching; the shorter the growing season, the greater the amount leached.

Perhaps the most disruptive of plantations effect on water quality is due to intensive management practices such as fertilization, chemical brush control, burning and regeneration practices. The judicinus use of, chemicals and fertilizer will minimize impacts, particularly if the formulations used are readily utilized or are of the slow release type, excessive application rates are avoided and application is not made directly to the stream channel or its immediacely adjacent area. Practices which remove vegetation or delay its regrowth such as burning and scarlfication, increase the possibility of increased nutrlent leaching to the strean.

Intensive harvesting practices associated with plantations that require an extenstve network of roads and 
trails and regeneration practices that bate mineral soil, can all lead to excessive erosion. The impacts of these practices, if not well planned and executed, will likely be greater than all other effects on water quality.

\section{RFFERENCES}

Bates,C.C. \& Henry,A.J. (1928). Forest and streamflow experiments at Wagon wheel Gap, Colorado, U.S. Weather Bureau Monthly Weather Review, Supplement No. 30.79pp.

Borman,F.H., Likens,G.E., Fisher,D.W. \& Pierce,R.S. (1968). therient loss accelerated by clearcuting of a forest ecosystem. Sctence, $159,882-884$.

Burgy,R.H. \& Pomeroy, C. $\bar{R}$. (1958). Interception losses in grassy vegetation. Transactions of the American Geophysical Union, 39, 1095-1100.

Croft,A.R. \& Monninger,L.V.(1953). Evapotrans- piration and other water losses in some aspen forest types in relation to water available for streamflow. Transactions of the American Geophysical Union, 34, 563-574.

Dahms,W.G.(1971). Growth and soll molsture in thinned lodgepole pine. U.S.Department of Agriculture Forest Service Research Paper, PNW-127, 32pp.

Delfs,J.(1967). Interception and stemflow in stands of Norway spruce and beech in West Cermany. "Forest Hydrology". Proceedings of an International symposium on Forest Hydrology, pp. 179-185. Pergamon Press, New York.

Douglass,J.E.(1967). Effects of spectes and arrangement of forests on evapotranspiration. "Forest Hydrology". proceedings of an International Symposium on Forest Hydrology, pp.451-461. Pergamon Press, New York.

Eungler,A.(1919). Untersuchngen ïber den Elnfluss des waldes auf den Stand der Gewasser. Mitteilungen der Schwelzerischen zentralanstalt für das forstliche Versuchswesen 12.625 pp.

Fredriksen,R.L., Moore,D.G. \& Norris,L.A.(1973). The lopact of timber harvest, fertilization and herbicide treatment on stream water quality in western oregon and Washington. "Forest solls and forest and management". Proceedings of the Fourth North American Forest Solls Conference, pp. 283-313. Laval UnIversity, Quebec.

Helvey,J.D.(1967). Interception by eastern white pine. Water Resources Research, 3, 723-729.

Helvey,J.D.(1971). A sumary of rainfall interception by certain contfers of North Anerica. "Biological E.f fects in the Hydrological Cycle". Proceedings of the $3 \mathrm{rd}$ International Symposium for Hydrology Professors, pp.103-113. Purdue University, West Lafayette, Indiana.

Hewlett,J.D. \& Helvey,J.D.(1970). Effects of forest cleat-felling on the storm hydrograph. Water Resources Research, $\underline{6}, 768-782$. 
Hewlett,J.D. \& Nutter,W.L.(1969). An outline of forest hydrology. Lniversity of Georgia Press, Athens, Georgia. $137 \mathrm{pp}$.

Hibbert,A.R. (1967). Forest treatment effects on water yield. "Forest Hydrology". Proceedings of an International Symposium on Forest Hydrology, pp. 527-543. Pergamon Press, New York.

Hibbert,A.R. (1969). Water yield changes after converting a forest catchment to grass. Water Resources Research, $\underline{5}$, $634-640$.

Hornbeck,J.W.(1973). Storn flow frov hardwood forested and cleared watersheds in New Hampshire. Water Resources Research, $9,346-354$.

Leyton,L. \& Carlisle,A.(1959): Measurement and interpretation of interception of precipitation by forest stands. International Association of Hydrology Symposiun, Publication 48, 111-119.

Lull, H,W, \& Sopper,W.E.(1967). Prediction of average annual and seasonal streanflow of physiographic units in the Northeast. "Forest Hydrology". Proceedings of an International Symposium on Forest Hydrology, pp.507-522. Pergamon Press, New York.

Moore,D.G.(1974). Impact of forest fertllization on water quality in the Douglas fir region - a summary of monltoring studies. Proceedings 1974 National Convention of the Society of American Foresters, Washington D.C. pp. 209-219.

Neary,D.G.(1977). Impact of timber harvesting on nutrient losses in streamflow. New 7ealand Journal of Forestry, $22,53-63$.

Neary,D.C., Pearce,A.J., O'Loughlin,C.L.\& Rowe,L.K. (1978). Management impacts on nutrient fluxes in beech - podocarp - hardwood forests. New Jealand Journal of Ecology.

Nutter,W.L.(1975). Moisture and energy conditions in a draining soil mass. Environmental Resources Center, Georgla Institute of Technology, Atlanta, Ceorgia, Report ERC $0875.77 \mathrm{pp}$.

Nutter,W.L. \& Ike,A.F.(1971). Evaluating effects of forest fertilization on water quality. Agronony Abstracts, American Soclety of Agronomy, Madison, Wisconsin, p.161.

Penman,H.L. (1967). Evaporation from forests: a comparison of theory and observation. "Forest Hydrology". Proceedings of an International Symposium on Forest Hydrology, pp.373-380. Pergamon Press, New York.

Pereira,H.C.(1973). Land use and water resources. Cambridge University Press, London. 246pp.

Rogerson,T.L.(1968). Thinning increases throughfall in loblolly pine plantations. Journal of soil and water Conservation, 23, 141-142.

Schneider,J. \& Ayer,G.R. (1961). Effect of reforestation on 
streamflow in central New York. U.S. Geological Survey Water Supply Paper 1602.61pp.

Swank,W.T. \& Douglass,J.E. $(1974)$. Streamflow greatly reduced by converting deciduous hardwood stands to pine. Science, 185, 857-859.

Swank,W.T. \& Douglass,J.E. (1975). Nutrient flux in undisturbed and manipulated forest ecosystems in the southern Appalachian mountains. Publication 117 de 'Association Internationale des Sciences Hydrologiques. Symposium de Tokyo. pp. 445-456.

Swank,W.T. \& Helvey,J.D. (1970). Reduction of streamflow increases following regrowth of clearcut hardwood forests. IASH-Unesco Symposium on the Results of Research on Representative and Experimental Basins, Wellington, New Zeal and.

Swank,W.T. \& Miner,N.H. (1968). Conversion of hardwood-covered watersheds to white pine reduces water yleld. Water Resources Research, 4, 947-954.

Tamm, C, O, Holmen, H., Popovic, B. \& Wiklander,G. (1974). Leaching of plant nutrients from soll as a consequence of forestry operations. Ambio, $3,2211-2221$.

Todd, R.L., Swank,W.T., Douglass, J.E., Kerr,P.C., Brockway, D.L. $\&$ Monk,C.D. (1975). The relationship between nitrate concentration in the Southern Appalachian mountain streams and terrestrial nitrifiers. Agro-ecosystems, 2 , $127-132$.

Walde,J.B. \& Swank,W.T.(1977). Simulation of potential effects of forest utilization on the nitrogen cycle in different southeastern ecosystems. Watershed Research in Eastern North America. A workshop to conpare Results Vol. II, Pp. 767-789. Solthsonian Insticution, Edgewater, Maryland.

Webber,B. \& Barton,P.G.(1978). Effect of logging and slash burning on the chemical properties of water passing through the soll profile. New zealand Forest Service, Forest Research Institute, Solls and Productivity Report No. 99 (Unpublished). $14 \mathrm{pp}+$ Appendices.

wicht, C.L. (1967). Forest hydrology research in the south African Republic, "Forest Hydrology". Proceedings of an International Symposium on Forest Hydrology; pp. 75-84. Pergamon Press, New York.

woodruff,J.F. \& Hewlett,J.D. (1970). Predicting and mapping the average hydrologic response for the Eastern United States. Water Resource Research, 6, 1312-1326. 
Forestry Commission, Northern Research Station, Roslin, Midlochian, U.K.

\section{SUMMARY}

Most of the soils of upland Britain are seriously affected by waterlogging. Afforestation reduces the supply of rainwater to the soll because of evaporation from the canopy. Ironpan solls have a perched water table above the pan but more permeable and betcer aerated layers beneath. In some examples the presence of the tree crop cures the waterlogging, in ochers preliminary breakage of the pan by cultivation is necessary. Aeration is then likely to be satisfactory throughout the profile. Gley soils have a high water table due to low permeability of the deeper layers and drainage treatments are only partially effective. The effects of spruce crops on the soil physical properifes are saall and we must look to other species more tolerant of the conditions to act as soll improvers. Deep peats of the blanket peat type are highly hurafied and undergo progressive drying after canopy closure. Strons shrinkage produces wide cracks which dramatically alter the drainage and acration properties of the peat.

RÉSUMÉ

La plupart des sols des hautes terres de Grande Bretagne sont moullleux. Le boisement réduit l'apport en eau de pluie au sol à cause de l'évaporation par le couvert. Les sols.d'alios ont une nappe perchee au dessus de $l^{\prime}$ al ios ma1s des couches plus perméables et mieux aérés au dessous. Dans certains cas, la présence d'un peuplement élimine le sol moullleux, dans d'autres, il est nécessaire de casser l'alios au préalable par un travail du sol. En conséquence, l'aération de tout le profil pédologique sera satisfalsance. Les sols à gley 
ont une nappe proche de la surface à cause de la faible perméabilité des couches plus profondes et les traitements par drainage ne sont pas entièrement satisfaisants. Les effets des peuplements d'eplcéas sur les propriétés physiques du sol sont roindres et l'on dolt se tourner vers d'autres essences, plus tolérantes des conditions du sol, qui seralent à même $d^{\prime}$ améliorer le sol. Des tourbières profondes, présentes sur les collines, forment beaucoup d'hums et sèchent progressivement apress la fermeture du couvert. Un retrécissement important produit de larges crevasses qui changent, de façon dramatique, le drainage et les propriétés d'aération de la tourbière.

\section{ZUSAMMENFASSUNG}

Die meisten Boden des britischen Hochlandes sind hydromorph beinflusst. Aufforstung reduziert den Wassergehalt des Bodens durch die Transpiration des Blätterdaches. In Böden mit ortstein wirkt dieser wasserstauend und darunter befinden sich meist durchlässigere und besser durchlüfete Horizonte. In einigen Fällen beseitigt das vorhandenseln von Waldbeständen den Wasserstau, in anderen ist es notwendig, die undurchlassige Schicht vorher mechanisch durch Bearbeitung zu beseitigen. Dies bewirkt auch eine Verbesserung des Luf thaushalts im ganzen Profil.

Gleye besitzen aufgrund der geringen Durchlässigkelt der tiefergelegenen Horlzonte einen hohen Wasserstau, Entwässerungswassnahmen sind nur tellweise wirksam. Da Fichtenbestande die physikalischen Eigenschaften des Bodens kaum verändern konnen, müssen wir andere angepasstere Gattungen als Bodenverbesserer heranziehen. Die măchtigen Torflagen des Deckenmoores sind stark humifiziert und enthalten ursprünglich viel Wasser, werden aber trockener, sobald sich das Blatterdach schliesst. Starke Schrumpfung lässt breite Risse entotehen, die die Entwässerungs- und Belüf tungsbed ingungen drastisch verändern.

\section{INTRODUCTION}

Afforestation is taking place in upland Britaln on solls which carried forest in earlier post-glacial times but which have been treeless for a period ranging from a few hundred to a few thousand years. During this latter period there have 
continued to be climatic fluctuations but there is little doubt that the absence of a tree cover has itself contributed greatly to widespread changes in soil conditions (Dimbleby 1962).

One of the most powerful effects of the removal of forest in our climatic conditions is to increase the supply of rainwater to the soll surface. This can have various effects including increasing the rate of weathering of rock fragments, increased leaching of soluble components, more prolonged anaerobism and the development of gley phenomena, and the faster accumulation of peat. More than three-quarters of the area of upland Britain which has been afforested carries solls which were previously seriously affected by waterlogging. These are three maln groups of soils: ironpan soils, surface-water gleys and deep peats (Pyatc 1970), alternatively termed stagnopodzols, stagnogley solls and peat soils (Avery 1973).

For afforestation to be successful on these solls some kind of site improvement is usually necessary, either physical, chrough cultivation or drainage; chemical, through the application of fertilizers; or biological, through control of competing weeds. When the tree crop has been established and particularly after the canopy has closed, the growth of the trees introduces further changes in site conditions. This paper is mainly concerned with the effects of afforestation on the moisture regime and aeration of these three main groups of sol1.

\section{IRONPAN SOILS}

Ironpan solls appear to be restricted to the most humid parts of the temperate zones of the world and to similar climatic conditions on tropical mountains (Fitzpatrick 1971; crompton 1956). They are particularly important in Britain where they represent some 20 per cent of the uplands,

A layer of peat, commonly 100-300 mn thick, occurs at the surface. Beneath this are the two characteristics horizons of the soll, a grey-coloured, mineral horizon with eluvial and gleying features ( $\mathrm{Eg}$ ), and a thin ironpan. Beneath the ironpan, the $B$ horizon or subsoll is brownish in colour and usually friable in consistence. Indurated material (fragipan) often occurs beneath the subsoil but may directly underlie the ironpan (horizon notation follows Hodgson (1974)). The $E_{B}$ horizon often has a greenish or olive hue as a conspicuous gley feature and foresters have for many years appreclated that these soils are wet or waterlogged at the surface for much of the year. Our understanding of subsoil conditions has been much less certain, partly because penetration of the subsoil by tree roots is very variable and partly because any investigation beneath the ironpan tends to destroy the effect of the pan as a barrier to water. In areas prior to 
afforestation soll plts or small boreholes often contain water even though they penetrate the ironpan. This is especially so where indurated materlal directly underlies the pan.

At Teindland (Speymouth Forest) in northeast Scotland research into afforestation methods has been in progress since 1926 (Zehetmayr 1960). The area is a so-called 'upland heath' with a vegetation dominated by Calluna vulgaris, with sone Trichophorum caespicosum and Sphagnum species which are indicative of the surface wetness. The peat layer is thin, usually less than $150 \mathrm{~mm}$, but a greenish gley colour is seen in the frestily exposed $E g$ hortzon. A strongly indurated layer about 300 thick underlles the ironpan beneath which the parent material is somewhat looser. The annual rainfall of 900 min is low for upland Britain.

The need for cultivation to break up the peat, the Eg horizon and ironpan was recognized by Mulr (1934), who was of the opinion that the Indurated materlal was more permeable than the horlzons above. Early attempts at cultivation were restricted in depth by the very stony nature of the soll, but it was soon found that pines and larches could be established successfully provided that a raised planting position was provided. Improved early growth was achieved with deeper and more complete ploughing treatments and in 1952 a key experiment was laid down with large replicated plots of six Intensities of cultivation, the deepest of which caused frequent breakage of the ironpan which lies at 350 depth. A later 'generation' of tine ploughs (Taylor \& Everard 1970) has been designed to disturb these soils to depths of at least 700 and and another experiment laid down in 1970, compares complete cultivations to depths which were sufficient to eliminate the ironpan and greatly.disrupt the indurated material. Farly results of the 1952 experiment confirmed previous experience that more rapld early growth of various tree species, especially Sitka spruce (Picea sitchensis (Bong.) Carr), was produced by the more intensive cultivation treatments (Henman 1964; Taylor 1970). After fifteen years, however, the growth advantage of the best treatments was sharply reduced (Thomson \& Neustein 1973) and this has stimulated further research into the soll condition under the trees.

In the 1952 experiment investigations of root development in relation to the culcivation have shown that the intensity of fine rooting is greatest in the overturned peat slice, decreases in the loosened or overturned mineral soll and is

Fig. 1. Moisture reglme of a heathland for 1977 (weekly data $26 \mathrm{Jan}-7 \mathrm{Dec}$ ). (a) tensiometers, (b) broken line is mean monthly rainfall on a weekly basis, (c) incerpolated iso-potential lines for the soll profile, derived from (a) and borehole water levels, (d) estimated deficits thin line for grassland, thick line forest. 
still less in the undisturbed Eg horizon. The undisturbed, Indurated materlal appears to have no roots. The loosened zone is 350 deep, with rooting extending to $400-450 \mathrm{~mm}$ depth. In the 1970 experiment, the general disturbance of the soil is to $500 \mathrm{~mm}$ depth, although the tine is recorded as having reached $700-900 \mathrm{~min}$. At six years of age the trees have not yet fully exploited to $500 \mathrm{~cm}$, so there is no indication whether culcivation has allowed penetration of the looser materlal beneath the forwer indurated layer.

Occasionally the question is asked whether the indurated material will gradually regain its hardness. The high bulk density $(1.75-2.00 \mathrm{~g} / \mathrm{cu} . \mathrm{cm}$ on a dry weight basis) has been produced by glacial or periglaclal processes (filzpatrick 1956) and the materlal has been further hardened by slight cementation (Pyate 1978). Cultivation reduces the bulk density to $1.0 \mathrm{~g} / \mathrm{cu} . \mathrm{cm}$ and the disturbed material breaks up inco fine fragments because it is extremely brittle. It is therefore difficult to see how cementation could recur without recompaction and that seems unlikely in waterial which is now much wixed with overlying horizons, including peat.

The soil water reglme under the tree crop has been compared with that under the open heathland. Several cultivation treatments have been examined beneath crops of Scots pine (Pinus sylvestris L.), and a mixture of lodgepole pine ( $\underline{p}$. contorta Dougl. ex Loud.), and Japanese larch (Larix kaeropferi (Lambert) Carr.), which are 10-13 m tall. Boreholes with perforaced liners and tensiometers have been installed to various depths above and below the ironpan (Pyatt 1978).

The difference between heathland and forest water regimes is very striking, but differences between cultivation treatments are negligible. Figures 1 and 2 show results for 1977 for one set of tensiometers typical of each vegetation type. The upper part of each figure shows the matric pocentials ('water pressures') recorded by each of five censiometers assessed at weekly intervals. The second part of the figure gives the weekly rainfall recorded in the open heathland. The broken line represents the mean monthly rainfall converted to a weekly basis. In the third part of the figure the tensiometer results are used together with borehole water level data to produce a chart of iso-potentials.

Under the heathland there was a perched water table in the upper 600 of the soil. Since the ironpan was at 350 , this implies that the indurated layer was only slowly

Fig. 2. Molsture reglee of Sitka spruce forest for 1977 (weekly data $26 \mathrm{Jan}-7 \mathrm{Dec}$ ). (a) censiometers, (b) broken line is mean monthly rainfall on a weekly basis, (c) interpolated iso-potential lines for the soil profile derived from (a) and borehole water levels, (d) estimated deficits, thin line for grassland, thick line forest. 
permeable. The soll was not waterlogged beneath the indurated layer at any time. Shallow boreholes contained water for much of the year but those penetrating beyond $600 \mathrm{~mm}$ depth were generally erapty. Lnder the forest waterlogging did not occur at ally depth.

The lowest part of Figures 1 and 2 are estimated soil moisture deficits (SMI)), that is the amount by which the cumulative transpiration exceeds the cumulative rainfall. This method of calculation is based on a technique developed for grasslands (Smlth 1967). See Jarvis and Stewart, this volume, for a critical survey. Sean monthly potential transpiration values for the locality are obtained from tables with a correction applied for the elevation of the particular site. The mean values are then corrected to the particular year using the monchly values of sunshine duration. The calculation of the SMD proceeds on a fortnightly basis, using actual rainfall for the site and half of the monthly transpiration. During the period of deficit the actual transpiration is allowed to fall below the potential transpiration according to a simple model of moisture avallabllity. The thin line represents the course of the SMD for an assumed short grassland. The thick line is obtained using the same transpiration values but only 70 per cent of the rainfall in each fortnight. In other words, this assumes an interception loss of 30 per cent of gross rainfall, without any adjustmenc to cranspiration. The validity of this assumption has not yet been widely tested (Jarvis \& Stewart, this volume). It is one of several possible ways of adjusting grassland transpiration values upwards to allow for the greacer total evapotranspiration of a forest, and 1 t is likely that tree species will have substantially different cranspiration rates as well as different interception rates.

The SYD for forest (thicker line) fits quile well with the observed moisture regime, indicating that the assumptions used in the estimates are probably of the right order of magnitude. The very small amount of drying in the heathland soil in comparison with the grassland SMD implies that the heathland vegetation transpires only slowly.

Soll aeration is also being assessed at these sites in 1978. Air or water samples are taken by hypodermic syringe from sampling probes at two depths above the ironpan and two below. Analysis of samples is by gas chromatography (Smith 1976).

Samples have been taken at three to four weeks intervals and so far results have been similar on each occasion. Under the heathland, the oxygen concentration in the layers above the ironpan was between $1-7$ per cent by volume. Beneath the pan the oxygen concentration was 15-17 per cent by volume. Under the forest the oxygen concentration was between 20-21 per cent by volume throughout the soil profile. 
The elimination of the perched water table and associated anaerobisa in ironpan solls after afforestation may not be so effective in regions of higher rainfall. At Newcastleton Forest in south scotland similar studies have been made in ironpan soils with 300-400 of peat where spruce crops (Picea spp) were planted on turfs between shallow furrows which did not break the ironpan. The rainfall here is 1400 $\mathrm{mol}$. Under the forest the soil above the ironpan is waterlogged for periods of several weeks during the winter. Although not waterlogged in the summer, it rematins wet long enough for very low oxygen concentrations to develop. This is in spite of tree roots having penetrated through to the non-indurated subsoil where good aeration persists. In general, therefore, the elimination of poor aeration in these soils requires thorough destruction of the ironpan as well as the drying effect of a tree crop.

\section{GLEY SOILS}

Fine cextured soils with very low permeability in the subsoil and with pale grey or blue-grey colours, often associated with ochreous moctling, are known as surface-water gleys. Peaty gleys have a surface layer of peat 50-450 thick, which is a response to even wetter condtions. The water table is high for uost of the year and aeration is poor except close to the surface. These soils are the rost extensive in upland afforestation, accounting for some 35-40 per cent of the area. They are ratnly planted with spruces which give a higher yield than other species, but netther Sicka spruce nor Norway Spruce (Picea abies (L.) Karst.) is capable of rooting below about 450 depth. The result is that premature windthrow is enderic in those forests with predominant gley soils.

Successful establishment of crops has been readily achieved using either individual turfs or plough ridges, which give the necessary improved aeration of the planting position. In an atcempt to promote rooting into the subsoll many types and Intensictes of deep drainage have been tried. In spite of some carly optimism (Fraser \& Gardiner 1967), the effects on the water table have generally been insufficlent to justify the cost (Neustein \& Thompson 1973). The most promising results have been achieved with closely-spaced mole channels (Hinson, Pyatt \& Fourt 1970) and research into this technique is continuing.

Plough furrows 300 deep at $1.8 \mathrm{~m}$ spacing do encourage somewhat deeper rooting than is achieved on individual turfs, but in terms of crop stability this is more than offset by the reduction in root spread caused by the furrows acting as barriers (Booth 1973). The current recommendation for ground preparation on these solls is therefore a compromise, double-mouldboard ploughing with furrows 450-600 min deep at 
4.5 m spacing. Deep drains intercepting the water from these furrows arc sited according to the topography rather than at some predetermined frequency (Thompson in press).

Comparisons of soil molsture content and bulk density under pole-stage spruce and in adjacent unplanted rides reveals that there is a small but significant removal of water from the subsoil under the forest, and that this effect carries over fron year to year. Lnfortunately, however, the resulting shrinkage of the clay is not yet resulting in cracking but is being taken up by subsidence with an increase in bulk density (Pyatt 1973).

Observations of the soll moisture regime using tensioneters and boreholes show that under the trees the rooted zone dries appreciably during the summer compared with adjacent grassland sites. Figure 3 contains results for 1976 for one of four forest sites and a comparable unplanced sice that were studied for three years at Newcastletion forest, Roxburghshire. Tensionecer and borehole data are combined into iso-potential charts.

The degree of drying achieved in the surmer beneath the spruce was sufficient to creace fissuring and the developrent of a betcer soil structure in the rooted zone, whether mineral soll or peat. The relatively small degree of drying in the subsoil was presumably due to poor capillary conductivity of the clay. 1976 was an unusually hot, dry summer, although it followed a wet spring. Drying reached a rather greater depth than in 1974 or 1975 but the general pattern was much the same.

The interception loss for a pole-stage stand of Sitka spruce during the summer months is about 40 per cent of 8 ross rainfall (Ford \& Deans, 1978). Using this figure and the same method of calculation as for Teindland-produces a SMD for forest which is too high to fit the observed soll moisture regime. It is possible therefore that the transpiration of Sitka spruce does not reach the values for grassland given by Smith (1967). Thus by setring an arbitrary $11 \mathrm{mit}$ of $1.5 \mathrm{mon} / \mathrm{day}$ for the transpiration of the spruce, about half that for grass in June, the SMD shown by the broken line is produced, a much closer fit to the soll data. The rainfall at Newcastleton is

Fig. 3. Moisture regimes for a grassland and a Norway spruce forest for 1976 (weekly data 1 Jan - 29 oct, monthly thereafter in the forest). (a) Broken line is mean monthly rainfall on a weekly basis, (b) and (c)

interpolated iso-potential lines for soil profile based on tensiometer and borehole data, (d) thin line is estimated deficit for grassland, thick line is for forest assuming same transpiration as grass, broken line is for forest with transpiration rate restricted to not more than $1.5 \mathrm{~mm} / \mathrm{day}$. 
$1400 \mathrm{mr}$ and the long lime that the canopy is wet must substantially reduce annual transplration.

During the years 1974, 1975 and 1976 at Newcastleton the non-forested gley soils had a water table at a depth of $0-200$ $\mathrm{mm}$ for 7-9 months of the year. Under the forest the water table fell to $150-400 \mathrm{~mm}$ and the duration was reduced to $6-8$ months. Without a change in the climate there is no prospect of a further reduction in the duration of high water table. Prospects for keeping the winter water table at a lower level seem to depend (a) on the extent to which mole drainage can be used, and (b) on whether al ternative species to spruces can be found which are capable of deeper rooting. Those worthy of immediate attention are lodgepole pine, which is very colerant of poorly acrated peat solls, and the alder species (Alnus). The hope would be that a species colerant of anacrobic conditions could speed up the process of drying the subsoil producing a non-recoverable shrinkage in the for of fissures, in other words a more or less permanent improvement in soil structure, permeability and the level of the winter water table. The silvicultural possibllities include 'pioneer' or soil-improving crops of these species or a more permanent 'stability mixture' of the deep rooting species with sitka spruce. The search has begun, but is hampered by the shortage of stands of lodgepole pine or alders suitable for study.

Yoanwhile there are signs that clearfelling of the first crop of spruce allows the water tables to rlse to very high levels during the first year or two when there is little or no transplring vegetation. inless replanting on these solls takes advantage of any raised posicions, survival may be poor. Conditions during replanting appear to be more diffleult for establishment than they were for afforestation.

\section{DEEP PEATS}

These are defined as organic accumulations exceeding 450 min in depth. In the last ten years deep peats have formed an increasing proportion of the sites planted by the Forestry Comisition and they now represent about 15 per cent of the total. Peats are classified for forestry primarily according to their nutrient supplying abllity which is reflected in the ground vegetation (Toleman 1973). The most important types of peat $c$ an be broadly described as the blanket peats or hill peats with a vegetation of Calluna vulgaris, Trichophorum caespitosum, Erlophorum vaginatum, E. angustifolium and various Sphagnum species. They vary in depth from 450 an to about $3 \mathrm{~m}$ and beneath a fibrous layer some 300 min thick are strongly humified ( 14 6-9 on the Von Post scale).

Peat is waterlogged or wet to the surface throughout the year and successful extablishment of a tree crop necessitates surface draining and planting on a raised turf or plough ridge. Closely spaced plough furrows and ridges have generally 
shown the best early growth; deep drains have produced little response in tree growth although a further lowering of the water table has been achleved (Taylor \& Everard 1969).

Since first reported by Binns (1959) it has becone increasingly evident that after afforestation, blanket peats becone progressively dried and develop wide shrinkage cracks in the humified layer. This process is a non-recoverable alteration in the peat and is obviously much the same as occurs when peat fuel is left to dry in the sun. Every year there is a large surplus of rainfall over transpiration except during dry sumer spells when irreversible dryling can take place.

A recent survey of the older peatland plantations indicates that drying is slight until canopy closes but then speeds up, and cracks can then develop within two or three years. Drying sufficlent to produce cracking takes place more rapidly under lodgepole pine than other species, but under the most suitable conditions does occur under scots pine, Sitka spruce and Japanese larch. Conditions favourable to rapid drying and cracklng are (i) relatively shallow peat, 1 .e. less than $2 \mathrm{~m}$, (ii) a high humification value and (iii) a relatively dry climate.

Soil molsture regimes under plantations and in adjacent unplanted areas were observed for three years at Inchnacardoch Forest, Inverness-shlre and for two years at Naver Forest, Sutherland. The crop at Naver has since been killed by the pine beauty moth (Panolis flammea), but before the defoliation was severe, the results shown in Figure 4 were obtained. The sites have relatively shallow blanket peat, $1 \mathrm{~m}$, and the degree of drying shown, both in terms of the permanent crack developoent and the moisture potentials reached each sumer, were much more striking than in peats of 2-4 $m$ depth in the same stand. Both planted and unplanted sites are ploughed, with furrows 250 mom deep from the original surface. Moisture assessments have not been made in the ridge itself. 1976 was unusually dry in spring and sumiser at Naver, and this is reflected in the long duration of the soll drying season, but molsture potentials as low as those shown, were also reached in 1977 before complete defoliation occurred.

During the winter the water table rose into the cracked zone, In this site at 300-900 depth, though not very far because of the rapid drainage. The majority of the dried material was therefore not subjected to prolonged immersion and this way be important in preventing rewetting. There is great silvicultural interest in the possibility of widening the choice of species in the second rotation and the devastation by pine beauty moth has sharpened this interest. Following clearfelling, or perhaps a defolfation, the water cables rises into the cracked zone for longer perlods and the possibility of some rewetting is increased. Certainly moisture 
potentials remain high throughout the profile because of the absence of transpiring vegetation.

Aeration has not yet been directly measured in the dried peats, but air-filled pore space exceeds 10 per cent by volume even in wincer so there is a likellhood that high oxygen concentrations will be maintained.

The speed with which low moisture potentials were reached in spring 1976 and the depth to which they occurred, suggest the possibility that the amount of water able to be held and made avallable to roots is now rather small. Preliminary calculations of water content changes do not suggest reason for concern but laboratory measurenents of water retention curves are beling made to check this.

The 'south coastal' provenances of lodgepole pine have shown a marked tendency to become unstable on deep peats and this certainly applies to blanket peat which has become cracked. Roots of pine, and other species, cross beneath the furrows into neighbouring planted strips but do not thicken beyond a few millimetres dlameter. 'South coastal' lodgepole pine often has a leaning or bent stem and when the weight of crown is increased by a thick layer of wet snow, the roots may be torn out, in spite of the anchorage of 600-800 mn of peat. Straight-stemed forms of lodgepole pine and ocher spectes have not showr this tendency, indeed there is reason to suppose that the stability of crops in windy conditions will generally be better on peats than on gleyed mineral soil (Booth \& Mayhead 1972).

Chemical changes in peat after afforestation will be important if they affect the avallabilfty of nutrients, especially nitrogen which is expensive as fertilizer. Williams, Cooper \& Pyatt (1978) have shown that drying and aeration of blanket peat enhances decoriposicion and produces an increase in cation exchange capacity. Exchangeable $\mathrm{Ca}_{a}^{2+}$, $\mathrm{Mg}^{2+}$ and $\mathrm{K}^{+}$are replaced by $\mathrm{Na}^{+}$and $\mathrm{H}^{+}$, and $\mathrm{pH}$ and base saturation fall. Incubation tests of the peat under aerobic and anaeroblc conditions Indicate that the amount of easily decomposed nitrogen substrates has been reduced (Williams, Cooper \& Pyatt, in press). No consistent changes in the total quantity of nitrogen, phosphorus and potassium have been found, partly because fertilizer applications of $P$ and $K$ have occured at some sites.

Progressive drying and the development of shrinkage cracks seem hardly ever to have been reported from other countries. Carey \&arry (1975) found the process to be well advanced in the afforested cut-over raised bog in central Ireland, but the upper layer of the material consisted of replaced turf peat which had probably dried in the sun. The phenomenon may not occur in Scandinavia, and observations by the author in Finland suggest that this is mainly due to the extremely low degree of humfication of the peat (H $1-2$ on the 
Nover Deep Peat 1976

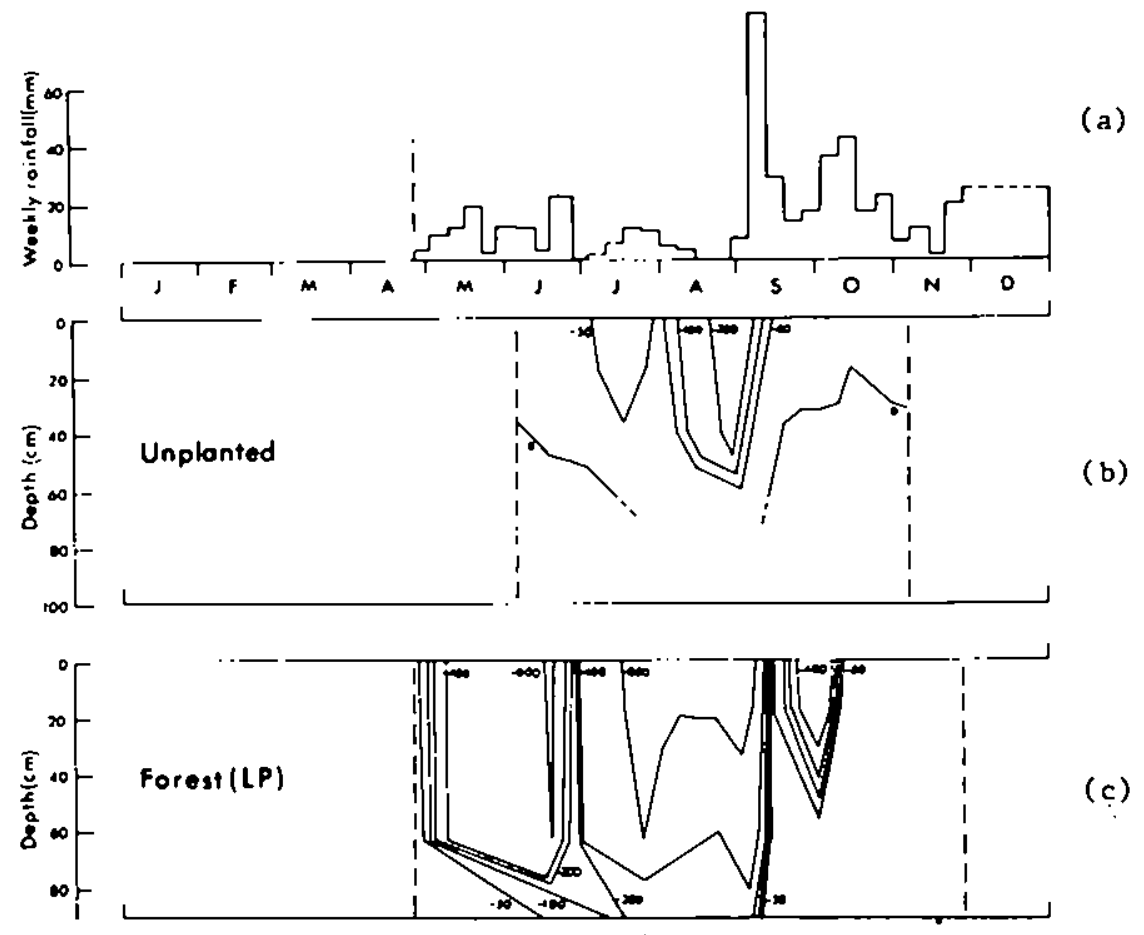

Fig. 4. Molsture regimes for unplanted and forested (lodgepole pine) peat ( 5 June - 6 Nov for unplanted, 26 Apr $11-27$ Nov for planted). (a) rainfall, avallable data, (b) and (c) interpolated iso-potential lines based on tensioneter and borehole data. 
Von Post scale).

\section{FUTURE PROSPECTS}

Changes in soil moisture regime have the same causes and are in the same direction in different soils but have very varied effects. As foresters we are entitled to think of these effects as etther beneficial or detrimental to long-term site productivicy. Most of the effects are at least potentially bencficial because these solls are initially too wet for maximum growth of our crops. Ironpan solls offer excellent prospects for a major improvement in moisture and aeration regimes. The growth of the forest will do much to put things right but deep ploughing lo eliminate the ironpan in peaty ironpan soils or to losen indurated material beneath the pan will show a benefit in crop stability. At present we cannot foresee any such cure for gley soils. But prospects are not as gloomy as they seened a few years ago. The forecasts of impending devastation by windthrow, based on damage that occurred in the early 1960's have been found to have been too pessimistic. Perhaps only the most susceptible stands were blowing down, perhaps we have been lucky with the winds. The realization around 1970 that the closely spaced ploughing of the period between 1940 and 1970 might lead to greater instabllity than we had experienced to-date, has been tempered by the greater stability achleved by unchinned crops.

The changes in some peat solls are drastic and may well be permanent. Gains in aeration and rooting depth may be offset by some loss in soil strength. Long term effects on moisture and nutrient availability are uncertain.

In general then, on the problem soils, our silviculture should have more varied possibilities in the second rotalion than in the first.

\section{ACKNOWLEDGEMFNTS}

The assistance of $M r$ D.T.Mclaren is gratefully acknowledged. The authors are indebted to Research Foresters D.L.Willmott and A.M.Walker and Ranger R.Anderson for fleld assessinents .

\section{REFERENCES}

Avery,B.W.(1973). Soll classification in the soil survey of England and wales. Journal of Soil Science, 24, 324-338.

Binns,W.O.(1959). The physical and chemical properties of deep peat in relation to afforestation. Ph.D. thesis, Aberdeen University.

Booth,T.C.(1973): Tree pulling. Report on Forest Research for 1973. pp. 72-73.

Booth,T.C. \& Mayhead,G.J.(1972). Tree pulling. Report of Forest Research for 1972.65pp.

Carey,M.L. \& Barry,T.A.(1975). Coniferous growth and rooting 
patterns on machine sod-peat bog (cutover) and trench 14 , Clonsast. Irish Forestry, 32, 18-29.

Crompton,E.(1956). The environental and pedological relationships of peaty gleyed podzols. Transactions of the $6 \mathrm{th}$ International congress on Soll Science. Paris F, PP. 155-161.

Fitzpatrick,E.A.(1956). An indurated horizon formed by permafrost. Journal of Soll Science, $7,248-254$.

Fitzpatrick,E.A.(1971). Pedology. Oliver \& Boyd, Edinburgh.

Ford,E.D. \& Deans,J.D.(1978). The effects of canopy structure on stemflow, chroughfall and interception loss in a young Sitkis spruce plantation. Journal of Applied Fcology, 15, 807-819.

Fraser,A.I. \& Gardiner,J.B.H.(1967). Rooting and stabllity in Sicka spruce. Forestry Commission Bulletin 40 .

Henman, D.W.(1964). Some early responses to increased intensity of heathland cultivation. Report on Forest Research for 1964 pp. 158-165.

Hinson,W.H., Pyatt,D.G. \& Fourt,D.F.(1970). Drainage studies. Report on Forest Research for 1970, pp.88-89.

Hodgson,J.M.(1974). Soil survey field handbook. Soll Survey Technical Monograph No 5, Harpenden.

Muir,A.(1934). The soils of Teindland State Forest. Forestry, $8,25-55$.

Neustein,S.A. \& Thompson,D.A.(1973). Drainage of soil with clay subso1l. Report on Forest Research for 1973. pp.67-68.

Pyatc,D.G.(1970). Soil groups of upland forests. Forestry Commission Forest Record 71 .

Pyatt,D.G.(1973). The effects of drainage treatments and tree crops on soil physical properties. Report on Forest Research for 1973. pp. 62-66.

Pyatt,D.G.(1978). Physical properties of soils with indurated material. Ph.D. thesis, Aberdeen l'niversity.

Smith,X.A.(1976). Aeration status of upland soils. Report on Forest Research for 1976. pp. 56-58.

Smith,L.P.(1967). Potential transpiration. Ministry of Agriculture, Fisheries and Food Technical Bulletin 16.

Taylor,G.G.M.(1970). Ploughing practice in the Forestry Comission. Forestry Commission Forest Record 73 .

Taylor,G.G.M. \& Everard,J.E.(1969). Dralnage of deep peat. Report of Forest Research for 1969. pp.87.

Taylor,G.G.M. \& Everard,J.E.(1970). Cultivation of Ironpan soils. Report on Forest Research for 1970. pp. 94.

Thompson,D.A. (in press). Forest drainage schemes. Forestry Commission leaflet.

Thomson,J.H. \& Neustein, S.A.(1973). An experiment in intensive cultivation of an upland heath. Scottish Forestry, 27, $211-221$.

Toleman,R.D.L.(1973). A peat classification for forest use in 
Great Britain. Proceedings International Peat Society Symposium, Glasgow. Paper no. 10.

Willtams,B.L., Cooper,J.M. \& Pyatt,D.G.(1978). Effects of afforestation with pinus contorta on nutrient content, acidity and exchangeable cations in peat. Forestry, $\underline{51}$, 29-35.

Willtam,B.L., Cooper,J.M. \& Pyatt,D.G.(1n press). Some effects of afforestation with lodgepole pine on rates of nitrogen mineralization in peat. Forestry.

Zehetmayer,J.W.L. (1960). Af forestacion of upland heaths. Forestry Commssion Bulletin 32 . 
September 7, 1978

THE. EFFECTS OF PLANTATIONS ON WILDLIFE

Chairman: J. Morton Boyd

Plantation management and vertebrate wildlife.

J.A. Rochelle and

F.L. Bunnel1

Even-aged plantations as a habitat for birds.

D. Moss

Even-aged plantations as a habitat for deer in central Europe.

F. König and

H. Gossow

The management of red deer in plantations.

A.B. Cooper and W.E.S. Mutch 

By JAMES A. ROCHELLE* and FRF.D L. BUNNELL+

* Weyerhaeuser Forestry Research Center, Centralia, Washington 98531, U.S.A.

+Faculty of Forestry, University of British columbia, Vancouver B.C., V6T IWS. Canada.

\section{SUMMARY}

A wide variety of forest types, containing numerous vertebrate species with specific habitat requirements occur in North America. In this paper we have attempted to treat species or groups of species which illustrate the major kinds of forestry - wlddife interactions that occur. Plantation management will affect populations to the extent that the combinations of resources required by a wildife species are available in a particular phase of plantation development. Against the background of nature's forests, man's activitles influence the availability of their resources mainly through: 1. modifying their distribution in space and time, and

2. increasing or decreasing their relative abund ance.

Thus, plantation management may enhance forage supplied during several stages in the life of the stand, but these perlods may be shortened relative to natural forest succession. Vegetative diverstcy is reduced in plantations since dominance of the site by crop trees is an objective. On industrial lands, rotation lengths are increasingly based on optimization of flbre ylelds in a context of highest financial return. Thus, rotation lengths are short with the result that forests older than 100 years will concinue to diminish in area and will not be replaced. Along with this change will occur a corresponding decrease in populations of species dependent on mature forest and specialized habltats, such as snags, 
i.e. large, standing dead trees.

In cases where wildife interferes with plantation managament, traditional methods of control such as population reduction or the use of repellents or physical barriers are cmployed, along with indirect controls through habitat manipulation. Maintenance of wildlife populations in managed forests is mainly being approached through planning to provide required resources through time and space. For species requiring large snags or old-growth timber, approaches to date center on either preservation of these kinds of habitat or extension of rotation periods on specified areas to maintain some habitats of this type. Management for suags is a reality in mixed-age forests, and snags are being preserved in some areas wien clearcuting is employed. The opportuntry exists to create small snags by killing plantation trees, and perhaps the feasibility of artificially providing larger snags warrants investigation.

Frameworks within whlch the complex interactions of forest managerent and wildife can be conceptualized and displayed are only recently available (Thomas et al 1976; Bunnell \& Eastman 1976). Although solutions are not readily avallable for all of the apparent conflicts between vertebrates and plantation management, some progress is being made. consideration of forestry and wildife trade-offs during the stage of development of management plans will identify further opportunities for integrated approaches.

RÉSUMÉ

11 y a en Amerique du Nord une diversité de types de forets où vivent de nombreuses especes de vertébrés aux habitâts spécifiques. Cet exposé traite des espèces ou groupes d'espéces qui peuvent servir a illustrer les differents genres $d$ 'actions réclproques entre forestrie et faune sauvage. La gestion d'une plantation aura sur les peuplements l'influence suivante: les combinaisons entre les ressources exigées par les differentes espèces animales ne sont disponibles que pendant un stade particulter du développement de la plantation. L'activite humaine peut influencer la disponibllité des ressources des forets de la maniere suivante: 
1. en en modifiant la distribution dans le temps et dans l'espace, et,

2. en augmentant ou diminuant $l^{\prime}$ abondance relative des ressources.

Ainsi la gestion des plantations peut améliorer la production en fourrage pendant plusieurs stades de la vie du peuplement, wals ces périodes peuvent être écourtées par rapport à la succession naturelle de la forêt. Dans les plantations il $y$ a une réduction de la diversité des espéces végétales puisque la station est occupée par des essences productives. Sur les terrains industrialisés, la durée de rotation est de plus en plus basée sur une optimisation des rendements en fibres en vue d'obtenir les meilleurs revenus. Ainsi la durée des révolutions est courte et par conséquent les forêts de plus de 100 ans continuent à dininuer et ne seront pas remplacées. Allant de pair avec ce développement on constatera la dimfnution des populations d'espèces qui dépendent de futales mûres et quil demandent un habitat spécialisé tels que les arbres secs.

Là où la faune sauvage entrave d'une façon ou $d^{\prime}$ une autre la gestion d'une plantation on utilise des méthodes de contróle traditionnelles, telles que la réduction de la population ou l'usage de barrières ou de royens répulsifs ainsi que des méthodes de contrôle indirectes en s'attaquant aux habitats. Le maintien des espèces anlmales dans les forêts gérées se falt principalement en s'assurant de pourvoir les ressources nécessafres dans le temps et dans l'espace. Dans le cas d'especes qui ont besoin de grands arbres secs ou d'anciens arbres, on essaie la préservation de ce genre d'habitats ou on prolonge la durée des révolutions dans des endrolts spéclfiques pour maintenir ce genre d'habitât. Dans les forêts inéquiennes 11 existe un véritable besoin de gestion quant aux arbres secs et ceux-ci sont épargnés dans les régions où l'on pratique les coupes-à-blanc. On a aussi la possibilité de créer des petits arbres secs en tuant certains arbres et on pourralt peut-être Etudier la possibilité de crécr artificlellement des arbres secs de plus grand taille.

On trouvera des exemples de la complexité des interactions entre gestion forestière et faune 
sauvage dans des ouvrages récents (Thomas et al. 1976; Bunnell \& Eastman 1976). Bien qu'il $n^{\prime} y$ ait pas de solutions toutes faites pour tous les conflits apparents entre vertébrés et gestions forestière, on ne peut nier les progrès quí ont été faits. La prisc en considération des influences réciproques de la forêt et de la faune sauvage au moment de l'établissement des plans de gestion, pourra ouvrier: des possibilités d'intégration pour l'avenir.

\section{ZLSAMMENFASSUNG}

In Nordamerika gibt es eine grosse Vielfalt von Waldtypen, in denen zahlreiche wirbeltiere mit besonderen Habitatansprüchen leben. In dieser Arbeit haben wir versucht, Arten oder Artengruppen $z$ u behandeln, die wichtige wald : Tier Wechselbeziehungen fllustrieren. Waldbauliche Yassnahmen werden in der Masse die Population beeinträchtigen, wie sie die Lebensbedingungen für eine wildart in elner bestimoten Fntwicklungsphase der pflanzungen verändern. Im Vergleich zu Naturwäldern wird das Vorhandensein der lebensnotwendigen Bedingungen von den Tätigkeiten des Menschen vor allem beinflusst durch:

(1) die Anderung ihrer Verteilung in Raum und Zeit;

(2) die Vermehrung oder Verminderung des Umfanges.

Deshalb kann efne Bewlitschaftung von Pflanzungen den Futtervorrat steigern, während mehrerer Stadien 1ro Leben des Bestandes, aber dicse Perioden können im Vergleich zu natürlichen Sukzessionen verkürzt werden. Verschiedenartigkelt der Vegetation in Pflanzungen ist zur Begünstlgung der Hauptbaumart reduziert. In Industriegebieten werden die Untriebszeiten zunehmend darauf abgestimmt, die Holzertrāge im Hinblick auf die hochsten finanziellen Gewinne zu optimieren. Die Untriebszeiten sind kurz, mit dem Ergebnis, dass walder, die alter als hundert Jahre sind, weiterhin an Unfang abnehmen und nicht ersetzt werden. Mit diesem Wechsel geht eine entsprechende Populationsverringerung solcher Tierarten einher, die auf alte walder und besondere Habitate wie stehende abgestorbene Bäune angewiesen sind. 
In Fallen, wo der Wildbestand die Bewirtschaftung der Pflanzung behindert, werden sowohl craditionelle Forstschutzmethoden, wie z.B. Reduktion des Bestandes, der Gebrauch von Abschreckungsmitteln oder Zäune, zusammen titt indirekten Massnahmen durch habitat-Management angewandt. Die Erhaltung von Tierbeständen im Wirtschaftswald wird vor allem dadurch angestrebt, dass man die notwendigen Lebensbedingungen oereftstellt. Für Tierarten, die grosse, abgestorbene Bäume oder Altbestände brauchen, konzentrieren sich die versuche bisher entweder auf Erhaltung solcher Habitace oder auf Verlängerung der Utriebszeit in bestimmten Gebieten.

Bewirtschaftung unter Belassung von abstindigen Büumen wird in ungleichaltrigen Bestanden gelibt und abgestorbene Bäume konnen beim Kahlschlag stehengelassen werden. Es besteht auch die Möglichkeit kleine Habitate zu schaffen, indem man gepflanzte Bäume zur Absterben bringt. Vielleicht sollten Untersuchungen ergründen, ob auch küntlich grössere 'Baumleichen' zu schaffen wären.

Frst seit kurzem verfugh man uber einen Rahmen, in dem die komplexen wechselbeziehungen von Waldbewirtschaftung und Tierleben begriffen und dargestellt werden können (Thomas et al. 1976, Bunnell \& Fastman 1976). Obwohl sich nicht für alle der offensichtlichen Konflikte zwischen wirbeltieren und Waldbewlitschaftung ohne weiteres Losungen anbleten, gibt es doch elnige Fortschritte. Die Berücksichtigung der gegenseltigen Beeinflussung von wald und Wild wird wàhrend der Entwicklung von Kulcurplänen weltere :golichkelten for gemeinsame Ansatze zeigen.

\section{INTRODUCTION}

Almost everywhere, forested land has the capacity to produce both wood fibre and animal tissue. Whilst we still know relatively little about the complexities of forestry-wildlife relationships in sub-tropical or tropical areas, we do know that in temperate regions the variety of resident wildiffe and, thus, the complexity of the relationship can be enormous. Bunnell \& Eastman (1976) noted that within British Columbla, Canada, about 70 per cent of the ninety-eight terrestrial manmal species utilized forests for part of their requirements. About 115 bird species were forest 
dwelling and 32 per cent of these were cavity-nesters, exploiling a particular aspect of forest structure. They also noted that many amphibian species and a few reptiles were preferential and possibly obligate, forest-dwellers. In much of furope the diversity of forest-dwelling vertebrates is less, in part due to a longer history of intensive human activicy. Nevertheless, parallels do exist among forestry-wildlife interactions on a global scale (Bunnell 1976a). While forest-dwelling species have evolved to withstand or even cxploit, dranatic changes in forest structure wrought by fire, storm or disease, the changes associated with intensive plantation managerent do not necessarily mimic such uncontrolled phenomena. The biological ability of forest-dwelling species to respond to intensive forest management is in many instances unknown. Equally important to management is the observation that potential conflicts between production of wood fibre and animal tissue inevitably have social as well as biological roots (Bunnell 1976 a; Bunnell et al. 1978).

We do not discuss the social dimensions of management in this paper. We present an approach to wildife research within the context of plantation management. Bunnell (1976b) noted that among 175 working parties and project groups then functioning within IUrRO, only four, or less than 3 per cent, incorporated the term 'management' in their title. This observation is consistent with the objectives of IUFRo, but may represent a syndrome hindering effective incorporation of research into management. In particular, it has potential implications for the expanding IUFRo merbership arong low income nations which frequently desire to transplant research results quickly (Bunnell 1976a, 1976b).

we suggest that wildife research within the context of plantation managenent should address three broad themes: 1 . documentation of forestry-wildlife trade-offs; 2 . methods of maincaining wildlife production, and 3 . methods of controlling 'danage' by wildlife.

The first theme we consider as addressing conditional or 'what-if' questions; e.8. what if the size of clearcuts is changed from 40 to 80 or 120 ha? What if the initial planting density is 1000 stems per hectare as opposed to 2500? We consider that the researcher has an obligation to document responses of wildlife to a broad range of trade-offs, racher than to document effects of a practice at a particular level of intensity. The manager then has the option of exploring the variety of 'what-if' alternatives that are congruent with a particular socio-economic background. The second theme recognizes that some plantation management practices may adversely affect particular wildlife species and encourages research on specific methods for malntaining that species e.g. artificial production of snags for cavity-nesters. The third 
theme al so considered specific methods, in this case to reduce numbers of those species encouraged by plantation management whose activities seriously reduce production of wood fibre e.g. Ursus americanus, Odocolleus spp or Aplodontia rufa.

Given the diversicy of wildi fe species and the diversity of forest cypes, some general model or conceptual framework is essential. We present a broad model in terms of the general requirements of wildife and the general effects of plantation forestry on wildlife. Al though a general model is essential to provide a framework for the complextly, it is important to acknowledge a common and debllitating atcribute of wildiffe research. Many wildlife researchers express their observations on a wildife species as though they were facts about the species, rather than facts about that species within a particular ecosystem. It is thus impossible to position their research results along any dimension of a generalized framework. Such results can be transplanced only through faith. Bunnell et al. (1978) have discussed the problem and ways in which research can be incorporated into a more generalized framework.

GENERAL REQUIREMFNTS OF WILDLIFE

Our experience with conflicts regarding wildilfe and forestry resources are similar to those of Thomas et al. (1976). Our conclusions are identical. Although we ray have chosen different words, they said it first;

"We concluded that lack of knowledge - though meager in some instances - was not the biggest problem. The biggest problem was the lack of conceptual framework to allow (1) consideration of all vertebrates in the planning process; (2) retention of the ability to emphasize management of a particular species and (3) identification of specific habitats requiring spectal attention in land alteration schemes".

(Thomas et al. 1976 p. 453).

At tempts to devclop a systen or conceptual framework useful in gulding management have repeatedly documented that the weakest link is our inabllity to predict effects on wildlife populations over time (Bunnell \& Fastman 1976; Thomas et al. 1976; Black, Scherzinger \& Thomas 1976). Thus, our approach has been to concentrate on changes that occur during succession within forest types. The approach has the advantage that it can be related readily co forest wanagement practices. The rationale for choosing components of the model has been expressed by Bunnell \& Eastman (1976). Briefly, all wildlife species have requirements which, while particular for each species, are broadly analogous. Thus, while the Pacific mole (Scapanus orarius) feeds largely on earthworas, the Pinyon fay (Gymorhinus cyanocephalus) on pine seeds and the black-talled deer (Odocolleus hemlonus columblanus) on browse, each is 
Table 1. Resources required by wildlife (modified from Bunnell \& Eastman 1976).

Resource

Finergy

Nutrients

Water

Temporary shelter

(from wind, snow, heat)

Escape cover

Habitation

(dens and cavities)

Space
Resource attribute

Amounc Distribution
Irigested Structural Horizontal Vertical

$\mathrm{x}$

$\mathrm{x}$

$\mathrm{X}$

feeding to obtain energy, nutrients and water. Even diverse wildife species have similar needs, but each is adapted to obtaining their needs in particular packages, be those packages earthworns or conifer seeds. We have attempted to express wildife requitements at the simplest level that will encompass all basic needs. In their general form, we consider there to be seven basic needs (Table 1). Because animals are mobile, but show physical and behavioural limits to their mobility, we are concerned not only with the amounts and forms of packaging in the resources utilized, but also with their vertical and horizontal distribution. Forestry practices can influence not only the amount of a specific resource, but can redistribute a given anount of a resource through space and tlme. Because they influence the animal differently, we make a further distinction between resources that are ingested by the animals and resources whose structure is exploited, such as conffer stands which intercept snowfall or otherwise provide shel ter.

GENERAL EFFECTS OF PLANTATION ON WILDLIFE

The potential packages in which individual wildlife species seek the requirements of Table l are cnomously diverse. Fortunately, natural succession lends sone predictability to the pattern in wich the requirements appear over time (Bunnell \& Eastman 1976). We can document how the se requirements vary during natural succession following complete or partial removal of the overstory. Frow this knowledge, together with information on spatial patterns of application we can posit the manner in which particular management practices such as thinning or fertilizing modify the pattern of avallability of particular requirements. Bunnell \& Eastman 

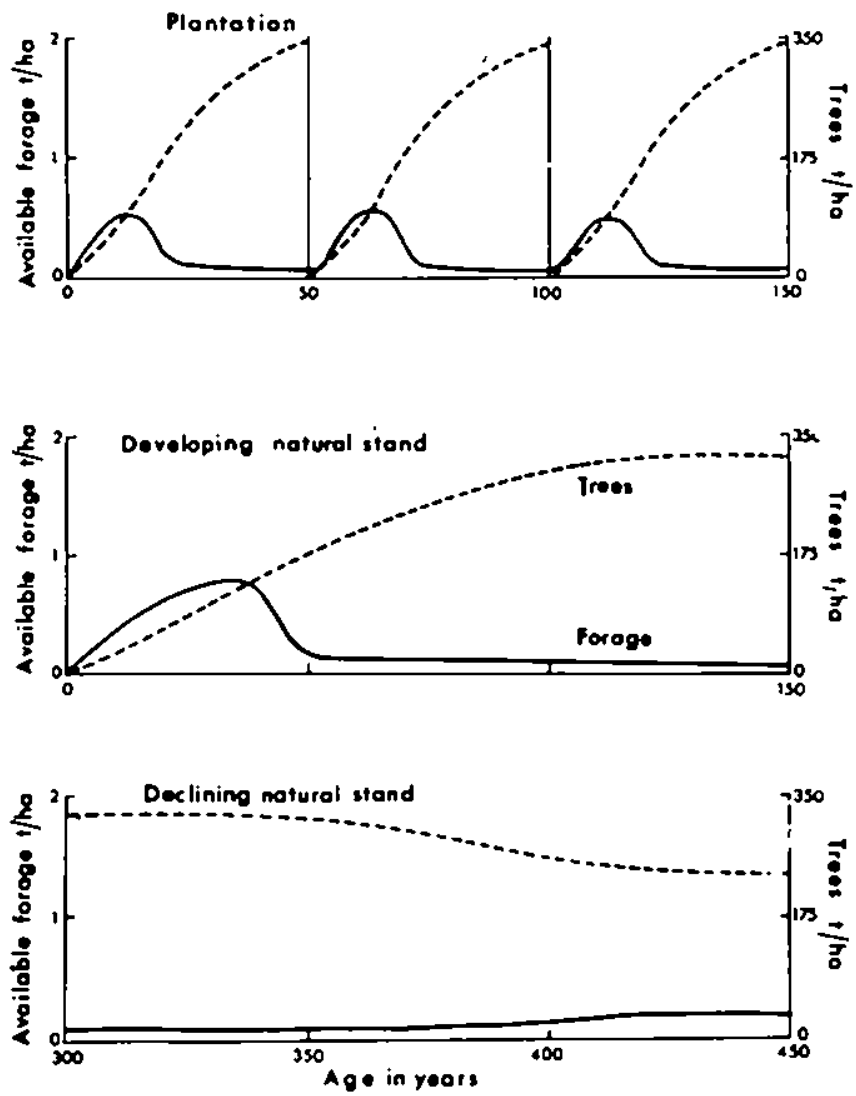

F1g. 1. Idealised responses of tree and shrub blomass

in plantation management as compared to a natural stand.

(1976, their Table 1) noted the temporal patterns of the requirements following clear-cutting, but concentrated on extensive forestry practices rather than plantation management.

Fig. I 1llustrates idealized development patterns of tree and shrub blomass under extensive forestry. The patterns Indicated are those which browsing ungulates would experience when fire or storms or disease followed by fire destroyed old growth forests which were replaced with new forests. Plantation management truncates the natural sere at both ends. Early seral stages are eliminated by rapid control of the site through practices such as scarification, brush control, 


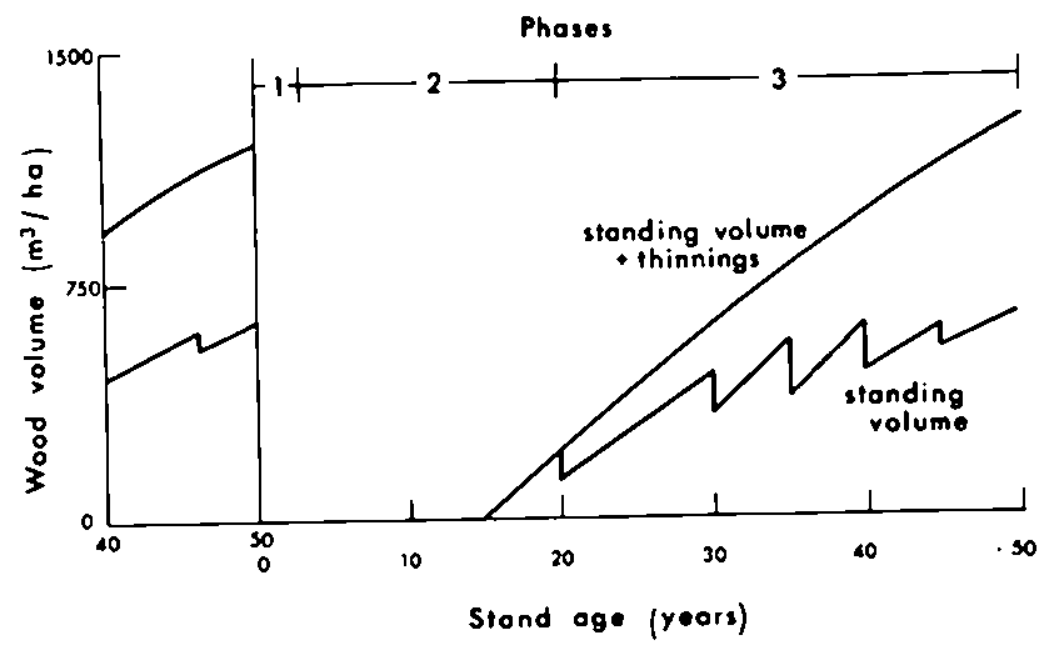

Ffg. 2. Phases of the management regime in a plantation. Phases: (1) harvest and site preparation, (2) establishment to first thinning, (3) fertilization and commercial thinning.

prescribed burning and dense stocking rates for planted stock. Later seral stages, which have proven valuable to wintering ungulates in some areas (e.8. Jones 1974, 1975) are eliminated by the short rotation length.

Wh thin the general framework we discinguish three phases in the management regime for any plantation. The length and specific characteristics of each phase vary between stands with rotation length and with immediate economic constraints. The phases considered are:

1. harvest and sice preparation,

2. plantation establishments to first (pre-commercial) thinning, and

3. thinning and fertllization (most of rotation). These phases are illustrated in Fig. 2. Specific characteristics of each /phase influence the local wildife populations.

IMPACTS OF PLANTATION FORESTRY ON WILDLIFE

Specific examples

Acknowledging the conceptual framework presented above, we now consider spectflc cases to 11 lustrate the problens and opportunities encountered during plantation management. 

Practices associated with plantation forestry affect some
wildife species negatively and others positively. Reduction of wildife

Ungulates. Of the basic requirements we consider (Table 1), plantation forestry can seriously reduce the amounts of energy, nutrients and temporary shelter. Escape cover is commonly abundant. The ungulate's use of space may be modifled temporarily by forest activities, but usually they quickly adapt to the disturbance (Beall 1973; Hershey \& Leege 1976). A more important disturbance in the North American context is the increased network of roads which accompantes plantation forestry. An extended road network facilitates access, increases hunting pressure, and can lead to over-harvesting where forestry practices have altered the landscape so as to concentrate the ungulates.

Typically temporary shelter is affected adversely only in areas of high snowfall. Despite their light foot-loading, black-tailed deer are seriously impeded by snow cover deeper than $60 \mathrm{~cm}$. Plantations of forty to fifty years of age are likely to have sufficient crown density to intercept snow, so reducing the snowpack on the forest floor. However, plantations of this age have litcle understory beneath the canopy. In contrast, old-growth forests which have opened up somewhat (Fig. 1) both intercept snow and provide browse. For these reasons, ungulates throughout North Aderica exploit mature, typlcally old-growth forests when snow cover becomes deep (Prescott 1974; Telfer 1970; Edwards 1956; Kelsall \& Prescott 1971).

Rodents and lagamorphs. Within mature conifer forests in coastal Washington, Oregon and northern California, mountain beaver (Aplodontia rufa) are present, but confined to openings within the stands. Such breaks in the canopy are associated with stream courses, springs (Hooven o Black 1976) or sites of overstory tree mortality. In response to the increased light, openings typically support a greater blomass of herb and shrub species than the understory in general. Thus, mountain beaver populations are low at the time of forest harvest and may be further reduced by slash burning which can result in direct mortality of up to 50 per cent of the population (Motobu 1976). For several years following harvest, vegetative conditions slollar to those formerly assoclated with openings develop over the entire site, although their continued development is best in areas of greatest soll molsture. During this stage of the plantation cycle ( 1 and 2 of F1g. 2), mountain beaver populations expand to occupy a wuch greater portion of the site, though with further growth of planted trees and conconitant stand closure, the animal again becomes confined to drainage courses or slash accumulations which have caused a break in the canopy of the developing stand (Neal \& Borrecco 1978). With lmmediate regeneration of harvested 
areas, often coupled with a reduction in animal nimbers through direct control, populations decline to or telow the levels found in mature stands. Population levels in 25-50-year old managed plantations of Douglas fir will likely be higher than in natural stands of the same age, as commerclal thinning will produce more open stands, with increased light reaching the forest floor (Lawrence 1969). The larger mountain beaver populations associated with more diverse vegetation are further reflected in the greater levels of damage :0 planted scedlings wilch occur following rehabllitation of brushfields in constrast to the period after harvest of a conifer stand.

In western Oregon, snowshoe hare (Lepus americanus) populations were reduced by timber harvest which was atcributed to the removal of forest cover, i.e. escape cover of Table 1 (Hooven and BIack 1976). An additional factor may have been the absence of green branches which fall during winter and are used as food. Hare populations recovered as re-vegetation took place and populations of up to 12.5 hare per hectare were documented ten years after a fire (Black 1965). These observations reflect the influence of removal and subsequent recovery of vegetation corresponding to the periods of (1) harvest and site preparation and (2) establishnent to first thinning described in Fig. 2. In plantations 3-4 years old, Borrecco (1976) demonstrated the importance of vegetative cover to snowshoe hares. Removal of tall herbaceous cover including fireweed (Epllobium angustifolium) and foxglove (Digitalis purpurea) in the spring, significantly reduced both trap catches and damage to Douglas fir seedlings during the following winter. Population data are lacking for the other two phases of plantation developrent. Hooven \& Black (1976) recorded hare densities of 0.5 to 5.0 per hectare in 125-year-old Douglas fir stands, and it is likely that similar levels will be present in younger thinned and fertilized plantations. Increased production of understory vegetation is anticipated as a result of fertilization (Lawrence 1969) but, to date, this response has not been quantified.

Birds. The specialized habltat requirements of many species of forest birds result in a variety of interactions with plantation forestry. As with mamals, different successional stages (Fig. 2) will be more or less favourable to different groups of birds. A corresponding successional pattern in the avian fauna reflects these changes in forest vegetation (Thomas et al. 1975).

Concerns for birds expressed by blologists (Thomas et al. 1975; Meslow \& Wight 1975) note three major results of plantation forestry:

(1) truncated succession

(2) loss of old-growth habltat

(3) removal of snags, i.e. isolated dead standing trees. All concerns revolve around the fact that the forests which 
develop under a regime of intensive management will be vegetatively less diverse and will contain correspondingly fewer specialized habitats than unmanaged forests. Frequent thinning will recover trees which die and crop trees will be vigorous with rapid rates of growth.

During the initial stages of development of a plantation (Fig. 2) habitat conditions will be essentially the same as those which occurred naturally following deforestation through wildfire, windthrow or disease, or timber harvest without artificial regeneration. The use of herblcides to control vegetation competing with crop trees modifies this patcern somewhat. The major difference will be the reduced period of time certain habitat conditions persist, e.8. the grass-forb and shrub-sapling stages of Heslow \& Wight (1975). These investigators listed chirty-eight and seventy-two species of birds in Western Oregon that prefer or are restricted to the grass-forb and brush-sapling stages, respectively.

While numbers of individuals wll probably be reduced as a result of this contracted perlod of preferred vegetative conditons, it is probable that species diversity will not change. An additional consideration is that the reduction in rotation lengths from 100 to approxlmately fifty years weans that twice the area wll be in these early successional stages at any point in time. As a result total numbers of these species of birds in a forest reglme will probably be comparable to those occurring prior to intensifled plantation management.

The implications of intensive management to specles of birds which require large dead trees, such as the pileated woodpecker (Drycopus plleatus) (Bull \& Meslow 1977), or large areas of old-growth forest, such as the spotted owl (Strix occidentalis caurina) (Wight 1974) are more direct. Short rotation forestry directly eliminates the mature forests (1.e. $>125$ years) and the large dead trees which are components of these stands. The red-cockaded woodpecker (Dendrocopts borealis presents a similar situation in the southeastern United States (Jackson 1971). This species, offlcially classifled as endangered by the U.S. Fish and Wildlife Service, requires living old-growth southern pines, preferably infected with red-heart fungus (Fomes pini), in which to excavate nesting and roosting cavities. Although the specles commonly occurs in even-aged stands, trees more than fifty years old are required as cavity trees. In the southeastern United States, plantation forestry employs rotation periods substantially less than fifty years in length. Thus, the options for management to accommodate the specles are 1 inited.

The degree of dependence of these specles on conditions of mature forest has not been tested experimentally, but their specialized habltat requirements suggest they will probably not be able to adapt to the changed conditions resulting from 
plantation forestry. Balda (1975) has deronstrated experimentally that breeding densitles and specles diversicy of secondary cavity nesters, $f_{e} e$ species utilizing cavities in snags excavated by other species, were reduced by snag removal in pinus ponderosa stands in Arizona.

In these exarples, the key resource which becomes limiting is that of habitation (Table 1). In the case of the spotted owl, mature conffer forests provide a feeding area and escape cover from predators such as the great horned owl (Bubo virginianus) The management options avallable to provide for these species are 1 imited. Basically they require a departure from the standard plantation management approach, at least on selected areas.

Management schemes to provide for these species are begining to ewerge (Thowas et al. 1975; Lay \& Swepston 1975; oregon Endangered Species Task Force 1977) and are discussed later.

Enhancement of wildife - damage

we noted earlier that plantation forestry creates conditions favourable for many vertebrate species and unfavourable for others. Further, a particular species will fare more or less well during the various stages of the plantation management regime. In the concext of plantation management, considering production of wood fibre as the primary objective of management, increased population growth of certain vertebrate species has detrimental effects. Where production of wood fibre is not the rajor objective, 'damage' would simply be animal feeding activity.

With the exception of damage to pole-sised trees by black bear (Poclker \& Hertwell 1973) and porcupine (Erithizon dorsatum) (Lawrence 1957) most wildlife damage to forest trees In North America occurs during phases 1 and 2 of the management regime (Fig. 2). These are periods of maximum increase in the population of sone animal species and, at the same time are periods during which the small size of planted seedlings renders them vulnerable to injury by wildiffe feeding.

Ungulates. With the exception of coastal areas of high snowfall, populations of black-tailed deer and Roosevelt elk (Cervus canadensis roosevelti) increase as a result of forest harvesting (Cowan 1945; Brown 1961; Harper 1971). This statement is made with the assumption that other resources required (Table 1) are present. Ungulates have the ability to respond quickly to increased nutrient supplies. Although Crouch (1974) did not determine population densities, he found that the peak of black-talled deer damage to Douglas fir seedlings in western oregon occured within four to six years of sice preparation. Effects of deer population levels were illustrated by Hines \& Land (1974) who achleved approximately a 50 per cent reduction in damage to Doulas fir with a 50 per 
cent reduction in deer numbers.

It is clear that forest management activities, particularly harvesting, set the stage for browsing damage by ungulates. At the same time, the advent of plantation management with its shortened rotations and reliance on high rates of seedling survival and growth, results in increased lmportance being assigned to ungulate damage. In the case of black-tailed deer, it is expected that the rapid restocking of logged areas and early dominance of the site by plantation trees will reduce overall damage levels. These practices should help ensure that seedlings wlll pass through the period of vulnerability to browsing of cerminal shoots in advance of peaks in deer populations.

Rodents. Populations of rodent species which damage plantation trees expand with the fmproved energy and nutrient supplies associated with vegetative succession imediately after logging. Most damage is associated with early stages of plantation development. A second period of damage occurs at the time of stand closure and coincides approximately with stocking control operations. This latter damage period appears to be a function of declining food supplies and is manifested in basal girdling of saplings.

In the pine region of the western United States, pocket gophers (Thomorays spp) damage seedlings during the initial stages of plantation development (Barnes 1973). Removal of overstory timber and the accompanying soil disturbance (Phase 1 of Fig. 2) result in dranatic increases In herbaceous vegetation (Hedrick et al. 1968; Garrison 1961). pocket gophers present in low densities in the forest and at high denstifies in forest openings rapidly occupy this newly available habitat and quickly reach high population densities (Barnes 1974). That increased forage permits this response was shown by Black \& hooven (1974) who signiflcantly reduced gopher populations through herbicidal removal of herbaceous vegetation.

Birds. In western fiorth America, the only instances in which significant damage by blrds to plantations have been recorded are with blue grouse (Dendrogapus obsurvus) on Vancouver Island, B.C. (Fowle 1960; P. Affleck personal commination). The response of blue grouse to development of second-growth forest on Vancouver Island was documented by Reffield, Zwickel \& Bendell (1970). Population densities rapidly increase from those of wature forest upon removal of the overstory. Densities remain high for a perlod of five to twenty years post-harvest in a pattern which is similar to, but extended somewhat longer than that observed for rodents and deer. Subsequently, as conlferous cover becomes dense, at about twenty-five years, populations decline rapidly, to levels approximately those in old-growth forests. As with deer and rodents, damage by blue grouse is important only during 
the first few years after planting.

Bears. Few data are avallable on the response of bear populations to the harvest of old-growth forest. Lauckhart (1955) indicated that populations increase after forest harvest, probably due in a large part to improved forage conditions. In several areas of the northwestern United States, black bear cause mortality on a number of conifer species through basal bark strippling (Levin 1954; Childs \& Worthington 1955; Poelker \& Hartwell 1973). Typically trees selected in natural stands by bears are in the range of 15 to $40 \mathrm{~cm} d \mathrm{bh}$ and are the more rapidly growing trees which occur in wide spacings (Levin 1954). Experience with bear damage in plantations is limited, but is increasing as the area occupied by plantations of susceptible sized trees increases. Since plantation management emphasizes the production of rapid-growing trees at wide spacings, through fertilizaton and thinning, it is likely that damage will increase in importance in the future.

Despite several studies, the reasons why bear damage trees in some areas and not others are unclear (Radwan 1969; Poelker \& Hartwell 1973). It appears that there are individual differences in tree-feeding patterns among bears even in areas where damage occurs, suggesting that behavioural factors are involved. It is likely that the patern of variation in carrying capacity through time (Fig. 1) influences bears as it does other species discussed above. With a decline in carrying capacity, manifested primarily through a reduction in food supply, bears may turn to conifer sapwood as a food source (Lauckhart 1955).

In each of the examples discussed above, overstory removal is the mechanism of major importance in enhancing wildife populations which in turn damage plantation trees. The major effect of plantation developrent is in modifying the length of time that vegetative conditions favouring high populations of these species persist.

From the foregoing discussion, we conclude that the mechanisms through which plantation managenent wll operate to reduce populations vary with the species involved and include: (1) reduction in the period of availability or the spatial arrangement of forage and cover responsible for high carrying capacity, and

(2) elimination of preferred or required habitats.

For species whose populations are enhanced, with the result that damage to forests occurs, the mechanisms of plantation management responsible are:

(1) increased carrying capacity through practices which promote favourable forage or cover conditions and

(2) provisions of trees with characteristics which render them higher in feeding preference than 'wlld' trees, e.g. rapld 8 rowth. 


\section{MANAGEMENT APPROACHES}

The approaches taken to integrate the management of plantations and wildlife have been developed in view of the varied mechanisms described above. Selected examples follow.

Ungulates. The conceptual approach developed by Thomas et a1. (1976) provides the only comprehensive framework avallable within which foresters can quantitatively relate timber and wildife interactions. The framework includes timber types, successional stages within these types, arrangement of managed stands in time and space and the occurrence of wildlife as affected by these criteria. The objective of developing this framework was to provide the forest manager with the means to identify widlife trade-offs associated with a particular forest management decision.

In the Blue Mountains of northeastern Oregon, the ratio of forage to cover and its arrangement in time and space are the primary factors determining potential levels of use of forest land by Rocky Mountain elk (Cervus canadensis nelsoni) (Thomas et al.) 1976. Several types of cover, having specific dimensions are required in defined amounts. The framework permits the forest manager to forecast potential increases or decreases in elk use as a result of a management activity. Plantation management alternatives, such as rotation length, can be evaluated using this system which is specific to the land types or 'ecolasses' that occur on the area. Thus, the system provides a planning tool which can be employed along with timber management planning to achieve simultaneous timber-elk production goals.

The interaction of black-talled deer, snowfall and mature forests in coastal British Columbla was discussed earlier The approach being employed to accommodate deer in forest management to-date involves reservation of mature forest in critical winter areas and provision of travel corridors. These areas are set aside permanently and in this regard, are not part of an active plantation management program, except that they must be incorporated into sustalned yield planning.

Where plantation management enhances ungulate populations with browse damage as a result, operational management activities are basically limited to use of repellents or physical barriers to protect seedings. Recognising that black-talled deer use of plantation is highest in the area 45 to $60 \mathrm{~m}$ from the forest edge (Willms 1971) and Roosevelt elk similarly make greatest use of the area within 200 m of standing $t$ laber (Swanson 1970) then increased size of clearcuts whll reduce the amount of area subject to browsing damage within a plantation.

An alternative approach that 18 under test in Washington and Oregon is the establishment of preferred forbs as a means of relieving deer and elk browse pressure on planted seedlings (Campbell \& Evans 1975). Th1s approach combines habltat 
iroprovement and damage control during phase 1 of the plantation management regime (Fig. 2). A potential hazard is that in the absence of population control through adequate harvests by hunting, increases in deer numbers could offset the effect of providing preferred forbs as an alternative to conifer seedlings as forage. Campbell \& Evans (1975) also pointed out the possibility of abundant herbs increasing snowshoe hare populations, creating an additional damage problem.

Rodents. Opportunities to influence rodent and hare populations in early stages of plantation developrent are limited. Cover and forage are the key habitat components that can be manipulated. Work referred to earlier indicates that herbicidal removal of vegetation that provides cover for snowshue hares (Borrecco 1976) or forage for pocket gophers (Black \& Hooven 1974) will reduce populations and damage caused by these species.

Bears. Opportunities to modify the plantation management regime to reduce bear damage also are limited. The characteristics of individual trees on which bcar damage is concentrated are identical to those that the silvicultural practices of thinning and fertilization attempt to produce. Perhaps early dominance of the site by conifers after logging will have some influence on the carrying capacity for bears, but it appears that the current practice of direct control through sport hunting will continue to be the primary means of damage reduction.

Birds. The most serious conflicts between plantation forestry and birds concern those species requiring old-growth habitats. To overcome these conflicts and accommodate the species requires departures from the plantation management regime, at least on some portion of the land area.

For the red-cockaded woodpecker a recovery team has been appointed to develop plans for maintenance and enhancement of the species (Red-cockaded Hoodpecker Team 1977). The team's primary focus is to ensure continued availability of habitat. Thus, they have recomended maintenance of forty ha of contiguous pine stands around existing colony sites to protect the colony and provide feeding areas and replacement trees. Minimum rotation length recommended is eighty years. Forest management practices that maintain the open character of stands, such as thinning and prescribed burning and that remove part of the associated hardwoods, are of some benefit. The establishment of modified plantation management regimes effective in providing for the long-term survival of the species depends on integrating these modified regimes into the overall management plan for the forest property.

Management plans have recently been developed for spotted owl (Oregon Endangered Species Task Force 1977) and are being implemented by the U.S. Forest Service and U.S. Bureau of Land 
Management in Oregon. They are an additional example of a departure froo a standard plantation management regime in order to maintain a species. The task force plan has the objective of maintaining 400 pairs of spotted owls. Management areas about 500 ha in size will be established for each pair. At least 120 ha of this area will be maintalned in old-growth forest (i.e. $>200$ years) with the remainder managed to provide at least 50 per cent of the area in stands at least thirty years old. Along with this program of habitat maintenance, which clearly involves an extensive area of land, will go experimental habitat manipulations directed at assessing the species' adaptability to conditions other than old-growth forest.

The approach to integrated forest and wildlife management discussed with regard to elk (Thomas et al. 1976) considers all vertebrate species occurring in the geographic unit. Management for snag-dwelling birds and mammals requires a departure from standard plantation management regimes since young even-aged stands will not contain snags. Bull \& Meslow (1977) have outlined an approach for meeting habltat needs of the pileated woodpecker. Since this species requires the largest snags and is likely to be one of the first species affected by plantation management, they reasoned that if its requirements were met, other woodpeckers would benefit as well. They recommend establishment of management units of at least 130 ha for each palr of woodpeckers. Within each sq.km containing a pilcated woodpecker management unit, chirty-six snags, plus trees which will provide replacement snags (all greater than $50 \mathrm{~cm} \mathrm{dbh}$ ) should be retained following silvicultural treatments. This approach, like the spotted owl management plan, utilizes a modified management scheme on selected areas within an area covered by an overall management plan. Obviously, wood yields will be different than in a forest managed primarily for fibre production, with the absolute change a function of the numer of special management areas deemed necessary. It is clear that socio-economic, as well as ecological considerations will influence the extent to which these management options are implemented. Calish, Fight \& Teeguarden (1978) outline an approach for assessing effects on wood yields of managing for non-timber resources, with specific regard to rotation length for Douglas fir. These kinds of assessments will be Increasingly necessary in making resource management decisions.

\section{REFERENCES}

Balda,R.(1975). The relationship of secondary cavity nesters to snag densities in western coniferous forests. United States Department of Agriculture Forest Service Southwest Region. Wildlife Habitat Technical Bulletin 1.37 pp. Al buquerque, New Mexico. 
Barnes,V.G.(1973). Pocket gophers and reforestation in the Pacific Worthwest: a problem analysis. U.S. Department of Interior, Special Sclentific Report Wildife 155, 18 pp.

Barnes,V.G.(1974). Response of pocket gopher populations to silvicultural practices in Central Oregon. Wildife and forest management in the Pacific Northwest" (Ed by H.C. Black) pp.167-177. Oregon State University, Corvallis, U.S.A.

Beall,R.C.(1973). Winter habitat use in the Sapphire Mountains of western Montana. Proceedings Western States Elk Worksnop, Bozeman, Montana, U.S.A.

Black,H.C.(1965). An analysis of a population of snowshoe hares (Lepus americanus washingtonii Baird) in western Oregon. Ph.D. thesis. Oregon State University, Corvallis, U.S.A. 285 pp.

Black,H.C. \& Hooven,E.F.(1974). Response of small-mammal communities to habilat change. Wildlife and forest management in the Pacific Northwest" (Ed. by H.C. Black) pp. 177-186. Oregon State University, Corvallis, U.S.A.

Black,H.C., Scherzinger, R.J. \& Thomas,J.W.(1976). Relationships of Rocky Mountain elk and Rocky Mountain mule deer habitat to timber management in the Blue Mountains of Oregon and Washington. Transcript of the elk - logging roads symposium (Ed. by J. Peek) pp. 11-31. University of Idaho, Moscow, U.S.A. December 1975.

Borrecco, J.E.(1976). Controlling damage by forest rodents and lagomorphs through habitat manipulation. proceedings Seventh Vertebrate Pest Conference pp. 203-210.

Brown,E.F.(1961). The black-tailed deer of western washington. Washington Department of Game. Biological Bulletin 13 . $124 \mathrm{pp}$.

Bul1,E.L. \& Meslow,E.C. (1977). Habitat requirements of the pileated woodpecker in northeastern Oregon. Journal of Forestry, 75, 335-340.

Bunnell,F.L.(1976a). Forestry-wildlife: whither the future. Forestry Chronicle, 52, 147-149.

Bunnell,F.L.(1976b). The myth of the omntscient forester. Forestry Chronicle, 52, 150-152.

Bunnel1,F.L. \& Eastman,D.S.(1976). Effects of forest management practices on wildife in the forests of British Columbia. Proceedings of Division I, XVI ILFRO World Congress, Oslo, Norway. pp.631-689.

Bunnell,F.L., Ellis,R., Stevenson,S. \& Eastman,D.S. (1978). Evaluating ungulate populations and range in $\mathrm{British}$ Columbia. Transactions North American Wildife and Natural Resources Conference, 43 , in press.

Calish,S., Fight,R.D. \& Teeguarden,D.E.(1978). How do non-timber values affect Douglas fir rotations? Journal of Forestry, 76, 217-221. 
Campbell,D.L. \& Evans,J.(1975). Improving widlife habltat in young Douglas fir plantations. Transactions North American Wildlife and Natural Resources Conference, 40, 210-218.

Childs,T.W. \& Worthington,N.P.(1955). Bear damage to young Douglas fir. Pacific Northwest Forest and Range Experiment Station Research Note 113. U,S, D, A, Forest Service. Pp. 4.

Cowan,I.Mct.(1945). The ecological relationships of the food of the Columbian black-tailed deer, Odocolleus hemionus columbianus (Richardson), in the Coast Forest Region of southern Vancouver Island, British Columbia. Ecological Monographs, 15, 110-139.

Crouch,G.L.(1974). Interaction of deer and forest succession on clearcuttings in the Coast Range of Oregon. "Wildlife and forest management in the Pacific Northwest" (Ed. by H.C. Black) Pp. 133-139. Oregon State University, Corvallis, U.S.A.

Edwards,R.F.(1965). Snow depths and ungulate abundance in the mountains of western Canada. Journal of Wildlife Management, 20, 159-168.

Fowle,C.D.(1960). A study of the blue grouse (Dendrogapus obscurus (Say)) on Vancouver Island, British Columbia. Canadian Journal of Zoology, 38, 701-713.

Garrison,G.A.(1961). Recovery of ponderosa pine range in eastern Oregon and eastern Washington by seventh year after logging. Society of American Foresters Proceedings, Washington. pp. 137-139.

Harper,J.A.(197l). Ecology of Roosevelt elk, Oregon State Game Commision, Portland, Oregon. U.S.A. 14pP.

Hedrick, D.W., Young, J.A., Mc Arhur, J.A.B. \& Ken1ston, R.F.(1968). Ef fects of forest 8 razing and grazing practices on mixed coniferous forests of northeastern oregon. U.S. Agricultural Experimental Station Technical Bulletin \#103. Oregon State University, Corvall1s, U.S.A. 24pp.

Hershey,T.J. \& Leege,T.A. (1976). Influences of logging on elk on summer range in north central Idaho. Transactions of the elk - logging roads symposium (Ed by J.Peek) pp.73-80. University of Idaho, Hoscow, U.S.A.

Hines,W.W. \& Land,C.F. (1974). Black talled deer and Douglas fir regeneration in the coast range of Oregon. "Wildilfe and forest management in the Pacific Northwest"(Ed. by H.C.Black) pp.121-133. Oregon State University, Corvallis, U.S.A.

Hooven,E.F. \& Black H.C.(1976). Effects of some clearcutting practices on small mammal populations in western Oregon. Northwest Science, 50,187

Jackson,J.A.(1971). The evolution, taxonomy, distribution, past populations and current status of the red-cockaded woodpecker. Proceedings Symposium on Fcology and 
Management Red cockaded woodpecker. pp4-29. U.S. Department of Agriculture Forestry and Wildife Service. Jones,G.W.(1974). Influence of forest development on black-tailed deer winter range on vancouver Island. Proceedings Symposium on Wildlife and Forst Management in the Pacific Northwest (Ed. by H.C. Black). Oregon State University, Corvallis. 236 pp.

Jones,G.W.(1975). Aspects of the winter ecology of black-talled deer (Odocolleus herionus columblanus) on northern Vancouver Is $\overline{l a n d, M . S C}$. thesis. University of British Columbla. $78 \mathrm{pp}$.

Kelsall,J.P. \& Prescott,W.(1971). Moose and deer behavlour in snow in Fundy National Park, New Brunswick. Department of the Environment, Canadian Wildlife Service Report 15. 25 pp.

Lauckhart,J.B.(1955). The effect of logging old-growth tiaber on bear, Society of American Foresters proceedings, pp.128-130.

Lawrence, H.H.(1957). Porcupine control; a problen analysis. Weyerhaeuser Company Forestry Research ikte. 43 pp.

Lawrence,W.H.(1969). The impact of intensive forest amnagement on wildlife populations. "Wildlife and reforestation in the Pacific Northwest" (Ed. by H.C. Black). Pp.72-74. School of Forestry, Oregon State University, Corvallis.

Lay,D. \& Swepston,D.(1975). The red-cockaded woodpecker. Texas Parks and Wildlife Department Publication. Austin, Texas $7 \mathrm{pp}$.

Levin,0.R.(1954). The South olyopic tree farm. Journal of Forestry, 52, 243-249.

Meslow,E.C. \& Wight,H.M.(1975). Avifauna and succession in Douglas fir forests in the Pacific Northwest. Proceedings Symposium on management of forest and range habitats for non-game birds. pp.266-271. U.S. Department of Agriculture Forest Service General Technical Report Wo-l.

Motobu,D.T.(1978). Effects of controlled slash burning on the mountain beaver (Aplodontla rufa rufa). Northwest Science, 52, 192-199.

Neal,F.D. \& Borrecco,J.E.(1978). Distribution and relationship of mountain beaver to openings in sapling stands. Submitted to Northwest Science.

Oregon Endangered Species Task Force (1977). Spotted owl management plan. Oregon Department for Fish and Wildlife, Portland, Oregon. 3 pp mimeo.

Poelker,R.J. \& Hartwell, H.P.(1973). Black bear of Washington. Blological Bulletin 14 Washington State Game Department $180 \mathrm{pp}$.

Prescott,W.H.(1974). Interrelationships of moose and deer of the genus Odocoileus. Naturaliste Canadien, 101, 493-504. Radwan,M.A. $(196 \overline{9})$. Chemical composition of the sapwood of four tree species in relation to feeding by black bear. Forest 
Science, 15, 11-16.

Red Cockaded Woodpecker Recovery Team.(1977). Red-cockaded woodpecker plan. 17 pp mimeo.

Redfield J.A., Zwickel,F.C. \& Bendell,J.F. (1970). Effects of fire on numbers of blue grouse. Proceedings Annual Tall Timbers Fire Ecology Conference, 10, 63-83.

Swanson, D.0.(1970). Roosevelt elk - forest relationships in the Douglas fir region of the southern Oregon Coast Range. Ph.D. thesis. University of Michigan. $173 \mathrm{pp}$.

Telfer,E.S.(1970). Winter habitat selection by moose and white-talled deer. Journal of Wildlife Management, 34 , 553-559.

Thomas,J.W. Grouch,C.L., Bumstead,R.S. \& Bryant,L.D.(1975) Silvicultural options and habltat values in coniferous forests. Proceedings Symposium on management of forest and range habltats for non-game birds. pp.272-287. U.S. Department of Agriculture Forest Service General Technical Report wo-1,

Thomas,J.W., Miller,R.J., Black,H., Rodiek,J.E. \& Maser,C. (1976). Guldelines for maintaining and enhancing wildlife habitat in forest management in the Blue Mountains of Washington and Oregon. Transactions of the North American Wildlife and Natural Resources Conference, 41, 452-476.

wight,H.M.(1974). Non-game wildldfe and forest management. "Wildife and forest management in the Pacific Northwest", (Ed. by H.C. Black), pp. 27-39. Oregon State University, Corvallis.

Willos, W.D.(1971). The influence of forest edge, elevation, aspect, site index and roads on deer use of logged and mature forests, northern Vancouver Island. M.Sc. thesis. Faculties of Forestry and Agriculture, University of British Columbia. 184 pp. 
Institute of Terrestrial Ecology, Penrhos Road, Bangor, Grynedd, LLS7 2LQ, Wales, U.K.

\section{SUMMARY}

Large-scale afforestation of uplands in Britain has particularly affected parts of southern Scotland. Breeding song-bird populations were censused using the mapping method on selected plots at different stages of forest development, from the original use of the woorland for grazing until forty years after planting.

Song-bird densities were least on the unplanted moorland, where only skylark and meadow plpit were common. At the young and pre-thicket plantation stages, a variety of species such as chats and willow warbler colonized the plantation. Some of these prefer scrub and were displaced when the canopy closed. In thicket and thinned plantations only species typical of conifer forests, such as goldcrest, chaffinch and wren remained. Total breeding song-bird densities were about chree times greater in pre-thicket plantations than on moorland, and four to six times greater in thinned plantations.

Tree species, soil fertility, the diversity of vertical structure, and breaks in the forest cover may all influence bird populations. In particular, spruce supported more song-birds than pine, and communities were diverse where foliage profiles covered a wide range. Areas within the forest replanted after wind-blow held the same species as the first rotation at the same stage. Pre-existing hardwood remnants within the plantation made little difference to the spectes present.

Several species use the forest as a refuge, but also require other habltats, e.g. the sparrowhawk, which nested in forests and other wodlands but often hunted outside plantations. 
In sourhwest scotland sparrowhawks bred more successfully in valley woods than in hill forestry plantations. In the interfor of a large plantation growth rates of nestings were lower and their mortality was considerably higher than on its lower edge and nearby valley woods. Differences were attributed to differences in the food supply, which was abundant in some woods in the valley, but sparser and more difficult to catch in plantations.

The controversy surrounding the wildife in large forestry plantations is discussed. Against the gains in total song-bird densities when moorland is afforested, several open country species have been displaced, and the raven is declining due to affurestation and consequent loss of sheep carrion.

RF́SUMÉ

Le reboisement à grande échelle des hautes terres de Grande Bretagne a pris place en particulier dans de nombreuses régtons du sud de l'Ecosse. Des populations d'oiseaux chanteurs ont été resencés en utilisant des relevés dans des endroits choisis pendant des étapes différentes du développement de la forêt, de la lande d'origine, utilisée comme pâturage jusqu'à quarante ans après la plantation.

La population d'oiseaux chanteurs était la plus mince dans les landes avant la plantation ou $l^{\prime}$ on ne trouvait que l'alouette et la farlouze. $\mathrm{Au}$ stade de fourré, différentes espéces, tels que le tarier et la fauvette, colonisaient la plantation. Certaines préféraient les buissons et s'en allaienc au 'moment de la fermeture des cimes. Dans les plantations au stade de gaul is ct de perchis eclairci il ne restait plus que les especces typiques des forêts de conifères, tels que le roftelet huppé, le pinson et le troglodyte mignion. La concentration d'oiseaux chanteurs étalt environ trois fois plus grande dans les plantations avant l'état de fourrés, que dans 1 es landes et quatre a six fois plus grandes dans les plantations éclaircies.

Les essences, la fertilité des sols, la diversité des structures verticales et des coupures dans le couvert peuvent aussi influer sur les population d'olseaux. En particulier 
les épicéas possédaient plus d'olseaux chanteurs que les pins et la diversité des feuillages entramait une diversité des communautés d'oiseaux. Des partles de la forêt replantés après des coups de vent possédalent les mênes espèces que pendant la prenière rotation à stade identique. Des feuillus préexistants $n^{\prime}$ ont que peu $d^{\prime}$ influence sur les especes présentes.

Plusiers especes utilisent la forêt comme refuge mais ont besoin aussi d'autres habitats, comme l'épervier, par exemple, qui fait son nid dans les forêts et autres régions boisées mais quil chasse en dehors de plantations.

Dans le sud-ouest de l'Ecosse, les éperviers se wultiplient mieux dans les bols de vallées que dans les forêts sur les hauteurs. A l'intérieur d'une grande plantation, le taux de crolssance des oisilions est plus bas et leur mortalité bien plus élevée que dans les lisieres plus basses ou dans les bols proches des vallées. On a attribué cette différence aux différences de nourriture plus abondante dans les bols de vallées mais plus rare et plus difficile a attrapper dans les plantations. Il y a beaucoup de controverses au sujet de la faune sauvage dans les grandes plantations forestières. Blen que la densité totale d'olseaux chanteurs ait été plus grande au moment du bolsement de la lande, plusieurs especces de rase campagne ont été déplacées et le nombre de corbeaux est en déclin à cause du boisement qui a eu comme consequence une diminution des carcasses de mouton.

\section{ZUSAMMENFASSUNG}

Durch die grossrāumigen Aufforstungsmassnahmen tm britischen Hügelland wurden insbesondere welte Telle Südschottlands erfasst. Dabel wurde elne Kartlerung brütender Singvögelbestände in ausgewählten Gebleten während verschiedener Fntwlcklungsphasen des Waldes von der ursprünglichen Nutzung des Moorlandes als Welde bis vierzig Jahre nach der Bepflanzung durchgeführt.

Im Moorland, wo nur Lerche und Wiesenpieper verbreltet waren, gab es die wenigsten Singuögel. In den ersten unterholzfreien Stadien der Pflanzung, siedelte sich eine 
Vielfalt von Arten, wie beispielsweise Steinschätzer und Weidenlaubsänger an. Einlge von thnen bevorzugten Buschwerk und wurden verdrängt, als sich das Blatterdach schloss. In Pflanzungen mit Dickicht und lichten Bestanden bleiben nur Arten zurück, dle für Nadelwälder typisch sind, wie sum Beispiel Goldhahnchen, Buchfink und 7aunkơnig. Insgesamt gab es in noch unterholzfreien pflanzungen dreimal so viel brütende Singvögel whe im Moorland und in lichten Pflanzungen vier- bis sechsmal so viel. Faktoren wie Baumart, Bodenfruchtbarke1t, Dichte und vertikaler Aufbau des Bestandes können die vogel populationen beeinflussen. Zum Beispiel war die Singrogeldichce in Fichtenbeständen hoher als in Kiefernbeständen. In elnem vielfach gegliederten Kronendach von Laubbarmen war die Zusamensetzung der Vogelwelt artenreich. Windbruchflachen wiesen nach Auspflanzung dieselben Arten auf, wie die Erstaufforstung im gleichen Stadium. In den verbl lebenen

Harthol z-Bestandesresten natürlichen

Unterschiede wurden kaum vorhandenen Arten festgestellt.

Einige Arten suchen in Wald Schutz, brauchen aber auch andere Habitate. Ein typisches Beispiel hierfur ist der Sperber, der in wăldern und anderen Baugebleten nistete, aber hăufig ausserhalb der Pflanzung jagte.

In Südwestschottland brüteten Sperber in Auewäldern mit grösserem Erfolg als in Bergwăldern. Im Inneren Tell elner grossen Pflanzung war die Wachstumsrate von Nestlingen geringer und thre Sterblichkelt betrāchtlich höher als at Waldrand und in nahen Auewäldern wit geringerer Hohe iber NN. Der Unterschied wird dem Nahrungsangebot zugeschrieben, das in einigen Auewäldern relchlich, in pflanzungen jedoch spärlicher und schwleriger zu erbeuten ist.

Die Kontroverse un das Tierleben in grossen Auffortstungsgebieten wird diskutiert. Dem Gewinn einer il ganzen grösseren Singvogelverbreltung bel Aufforstung von Moorland steht die Vertrelbung verschiedener Arten gegenüber, die offenes Gelände brauchen. Zum Befspiel verschwindet der Rabe immer mehr infolge der Abnatme von Schafkadavern nach Auf forstung. 


\section{INTRODUCTION}

During the past sixty years a policy of large-scale afforestation has been put into practice in Britain. The areas affected have been chiefly the uplands of Northern England, wales and Scotland, where moorland previously used for the grazing of sheep and cattle, has bees planted with conlfers. Two introduced species, Sitka spruce (Picea sitchensis) and lodgepole pine (Pinus contorta) form the bulk of the plantations, which, because of their planting regimes, can be described as 'even-aged' .

Such plantations of exotic trees have often been popularly condemed as being virtually devoid of wildlife, but there have been few quantitative assessments in which changes due to afforestation have been measured. The work reported here was done under a contract from the Nature Conservancy Council.

\section{SONG-BIRD COMMUNITIES OF PLANTATIONS}

Study areas and methods

Plots were established in three forests in the Dumfries and Galloway region of southwest Scotland. These were Ae Forest, situated on the edge of the Lowther Hills; Clatteringshaws Forest, entirely on upland in the Galloway Hills; and Eskdalemulr, a large young forest also on upland. Most of the study plots were on infertile hill ground, between 150 and 350 m above sea level, except at Eskdalemulr where they were at up to $425 \mathrm{~m}$.

Within $A e$ and Clatteringshaw Forests the range of study plots encompassed habitats categorlzed as unplanted sheep walk under grass and heather (Calluna vulgaris), and young, pre-thicket, thicket and thinned plantation. Only unplanted heather and young trees were studied at Eskdalemulr.

With the exception of one and one half plots of Norway spruce (Picea ables), the plots were planted with Sitka spruce, sometimesmixed will small percentages of lodgepole pine or larch (Larix spp.). They were chosen for uniformity within their boundaries whenever this was possible.

Territorial song-birds were censused on each plot using the mapping method, following williamson (1964). The plot, from 10 ha in chinned plantation to 25 ha on unplanted 8 round, was first mapped accurately. Each census consisted of ten early morning visits to the plot between late March and mid-June on which all song-birds observed, elther by sight or sound, were marked on a copy of the large scale map. At the end of the season, these maps were used for the construction of further maps, one for each specles, showing its occurrence on the plot over the series of ten visits. These species maps were used to estimate the position of territories, using well-established procedural rules, such as a requirement for at least three clumped observations to consticute one 
territory (International Bird Census Commitcee 1969). Numbers of territories on the plots were counted, and divided by the area of the plot to give densities, standarized as the number of breeding pairs/sq.km for each species occurring on cach plot.

The densities of more sparsely distributed non-passerines,. such as waders, grouse and raptors, were not estimated due to shortage of time and manpower, although they were present on the plots.

\section{RESUI.TS}

A summary of the census results is given in Table 1 , where scientific names of bird species are listed.

The succession of song-bird communties can be examined by considering the densities of the commoner species in relation to tree height (Fig. 1).

The skylark, dependent on grassy habilats for food and nest, sites, was the only specles to be at its highest density on unplanted grassland, and was the first to disappear as tree cover developed. By comparison, meadow pipit densilies increased markedly when exclosure of the land from grazing animals allowed ground vegetation to flourish, and these birds were more tolerant of the developing tree, remaining in openings and along firebreaks until the canopy closed.

Two species typical of open bushy habitats, the stonechat and whinchat, cook up cerritories in the plantations as soon as the trees suitable perches for then, and while they could still nest in the tussocks of grass below the trees. Their period of tenure in any particular plantation area would be short, perhaps only five years.

Willow warblers which take their insect food from the needles of trees, remained in the plantations until a later stage than the ground-feeding chats. At the pre-thicket stage this was the commonest specles, but their numbers dwindled as the canopy closed and their ground nesting sites were lost. They were not found in thinned plantations.

The wren was the first of the species present in mature plantations to appear on the plots of young trees planted on heather. Its requirements for food and nesting are found in cover close to the ground, and the density of wrens in thinned plantations was related to the abundance of brash and fallen trees. Other colonists of pre-thicket plantation were chaffinch and robin, which became most numerous at the thicket stage, and the canopy feeding and -nesting goldcrest, which reached high densities in the thinned plantations. The common species to occupy the plantations last was the coal $t 1 t$, a hole-nesting specles which frequently uses crevices at the bases of trees for its nest sites in plantations. They did not establish themselves until the trees reached the thicket stage. It is thus apparent that over a forty year period of 


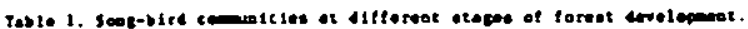

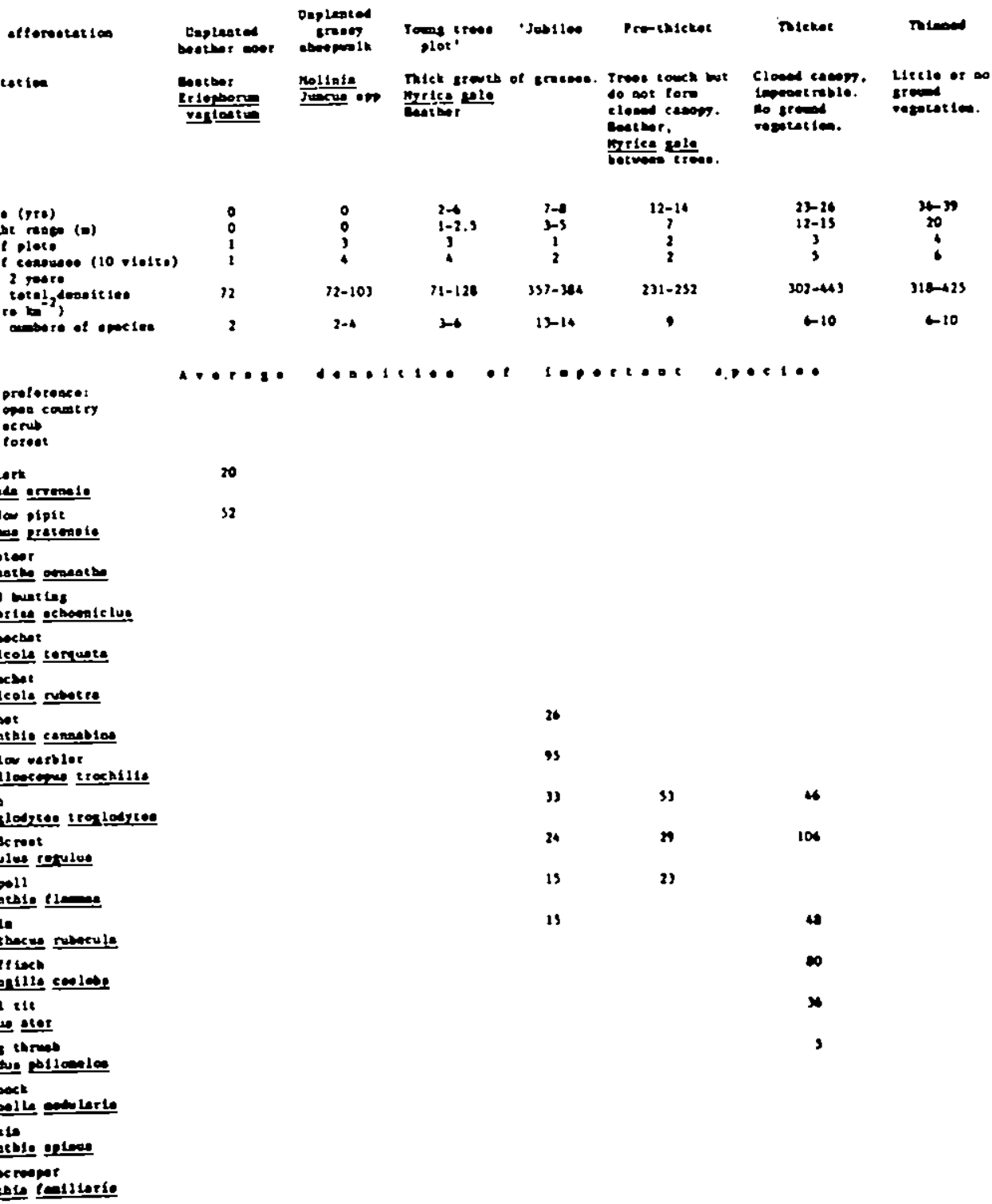

seck alle 
forest growth, the composition of the song-bird community changes entirely as all the species initially present lose their required habltats, and are replaced by others, some of which are themselves only present for a transitory period. The same observation can be made of the non-passerine birds, as species such as lapwing (Vanellus vanellus), curlew (Numenius arquata), redshank (Tringa totanus), snipe (Galiinago gallinago), red grouse (Lagopus 1. scoticus) and merlin (Falco columbarius). are replaced in young forest by black grouse (Lyrurus tetrix), short-eared owl (As1o flammeus) and kestrel (Falco tinnunculus), and later in mature plantations by woodcock (Scolopax rusticola), woodpigeon (Columba palumbus). sparrowhawk (Accipiter nisus) and tawny owl (Strix aluco).

FEATURES OF FOREST STRUCTURE. WHICH INFLUENCE BIRD POPULATIONS Tree species

The tree species forming the forest are an Important influence on song-bird communtiles. The greatest difference occurs between broad-leaved and conlferous wods, each of which has its characteristic species, although the majority of Britlsh woolland birds are found in both. Studies in Finland (reviewed by van Haartman 1971) showed that there were consistently wore breeding birds in birch (Betula spp.) than In spruce, and in spruce than in pine. Even-aged plantations in Britain are almost entirely of conffers, particularly spruces and pines. When studying plantations at the thinned stage, it was found that total song-bird densities were approximately twice as great in spruce as in pine, when there were also fewer species (Moss 1978a). In this context Newton \& Moss (1977) pointed out that pine has less foliage per unit area than spruce, and hence less habltat for insects. In Finland the differences between spruce and pine were of a lower magnitude (von Hartman 1971).

Sot1 fertility

Within forests of a particular tree species, soll fertility influences many aspects of productivity, including that of subsidiary vegetation and of insects. Thus it was noted earlier that in Ae Forest the 'Jubilee plot' pre-thicket plantation, where growth of trees and other vegetation was vigorous, supported a much more abundant and diverse bird population than might have been expected from the age and structure of the trees alone. Again finnish studies showed that bird densities decreased with decreasing soil fertility, as ind lcated by the type of vegetation of the forest floor (Haapanen 1965).

Diversity of structure

In North American, woodlands MacArthur \& MacArthur (1961) found that diversity of song-bird populations was directly related to the diversity of the helght structure of the vegetation, so that the more layers of trees and shrubs a wood 

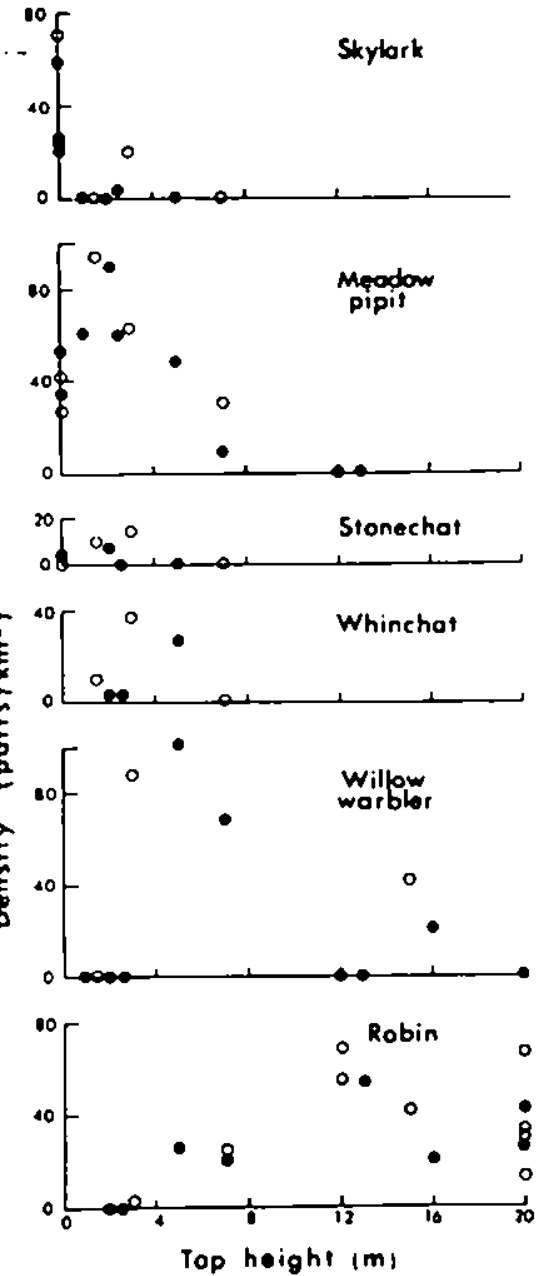
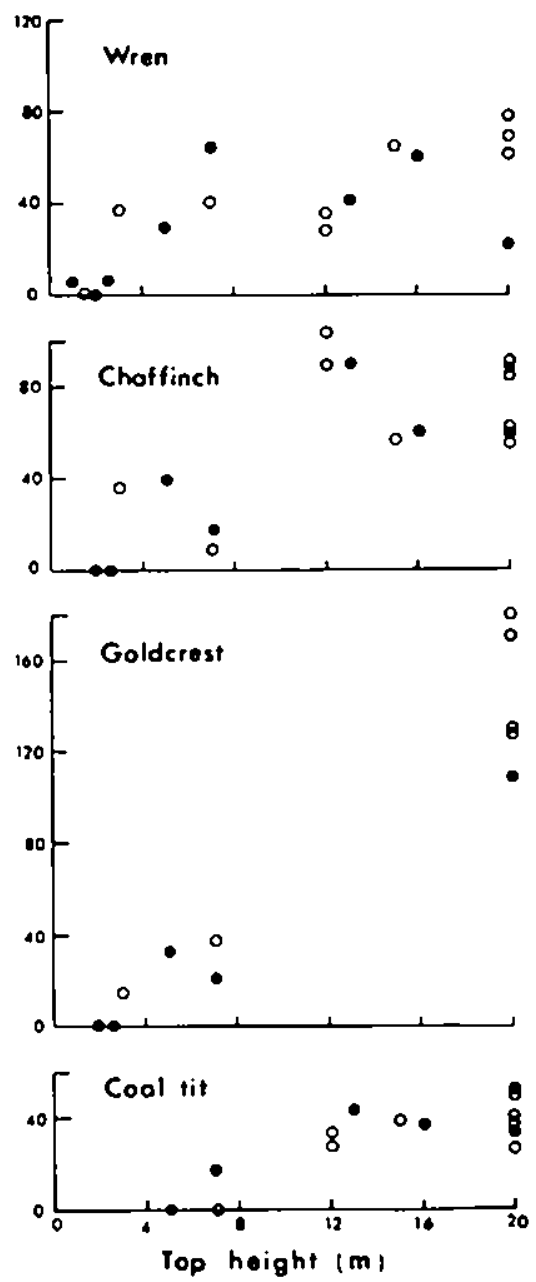

Fig. 1. The denslty of song birds in even-aged plantation in relation to the top height of the trees. 1976 data O, 1977 data O N.B. Not all zero densities are shown. 
contained, the more bird specles were found there. The same relationship was found in scotland when a sample of woods, both planted and semi-natural, coniferous and broad-leaved, was considered (Moss 1978b). This observation is easily understood, since a wood with a great diversity of vertical structure contains sufficient ecological 'niches' for a large variety of wondland bird species to find terricories there. When the structure is simple, only a few species occupy all the available niches. No similar result was obtained for plantations which had not yet reached the thicket stage, probably because of the presence of a number of species adapted to scrub, rather than understory.

The implication for even-aged plantations is that because they have an artificially low diversity in their height structure, their bird populations are low in species diversity. For example, thinned spruce plantacions described earlier held six to ten breeding species, whlle a neighbouring multi-structured mixed wood supported eighteen species (Moss 1978a).

However, a relationship between total numbers of pairs of song-birds and structural diversicy was not found, since for example plantations with low diversity provided excellent habitat for a few species and so total densities there were not particularly low.

Breaks in the forest structure

The most frequent breaks occurring in the structure of an even-aged plantation are due to rides and firebreaks, to clearfelling, windblow and the practice of leaving remants of original woodland during planting, usually in the form of hardwood fringing watercourses or on valley sides.

The large scale clearfelling of plantation blocks followed by subsequent replanting is only just beginning in Brition, and few areas exist where its effect on bird populations can be studied. However, a similar situation has occurred where large areas have been windthrown and subsequently cleared and replanted and a brief survey of some such areas was made in Ae Forest. The species present among young trees and at the pre-thlcket stages of replantings were the same as on the first rotation though meadow pipits were by comparison sparsely distributed. Cleared ground before replanting appeared to be completely devold of birds, unlike the sheepwalk before intilal planting.

It has occastonally been the practice among foresters to leave existing remnants of hardwoods along stream sides or in steeply sloping gullies, and these breaks might be though to provide a refuge for hole nesting bird specles such as blue and great tits (Paru caeruleus and $\underline{p}$. major) or redstarts (Phoenicurus phoenicurus) which favour mature broad-leaved trees. Such a gully approximately $50 \mathrm{~m}$ wide crossed one of the plots studled in Ae Forest, but there was no evidence that its 
old oaks (Quercus spp) attracted any extra breeding birds. As an added inducenent, nest boxes were provided in this gully but none was occupied in two breeding seasons. Similarly, S.J. petty (pers. comm.)- found - that a belt of alder. (Alnus glutinosa) approximately $50 \mathrm{~m}$ wide within a plantation in Galloway had no effect on the composition of the bird population there. However, a belt of rank heather, approximately 100 m wide containing rocky bluffs which had been left beside a stream in Kielder Forest, Northumberland, allowed merlins to continue nesting.

\section{THE PLANTATION AS A REFLUGE.}

So far, the plantation has been considered only as a habitat for those birds which are cotally dependent on it for nesting, feeding and roosting, at least during the breeding season. However, for a number of species it is used as a refuge for one or more of these activities, while not usually providing all their requirements. In the majority of such species, the forest is used as a nesting habitat but the bird finds part of its food elsewhere. For example, wistle thrushes (Turdus viscl vorus) nesting in the plantations often feed on adjacent pastures, and buzzards (Buteo buteo) nest in forests but hunt over surrounding open country. This type of use of the plantation can be lllustrated by describing the relationship between the sparrowhawk and its habitat, a spectes which has been studied intensively in recent years.

The sparrowhawk is a relatively small, agile woodland predator whose prey consists almost entirely of birds. It bullds its nest by preference in a coniferous tree whin a forest block, but for clear access the nest is usually close to a break such as a stream or ride. It typically hunts along woodland edges, including those formed by clearings, rides or rivers, and hedgerows in more open country, and relles on a surprise attack rather than a prolonged chase in order to capture its prey. Recent research into the ecology of the sparrowhawk in southwest scotland has investigated its relationships with the environment and with its food supply. Newton (1972) found that in continuous woodland, sparrowhawk nest sites were regularly spaced, but that the mean distance between them differed by a factor of three to four between Annandale in southwest Scotland and Speyside in the central Highlands. Data from further study areas in different parts of Britain were used (Newton et al. 1977) to show that nesting density was inversely proportional to altitude and proportional to land quality. Both these relationships were thought to arise as the result of variations in food supply with altitude and land quality.

Newton (1976) compared a number of aspects of sparrowhawk' breeding success between small valley woods, hillside forestry plantations, and the large plantations at Ae 
Forest. In valley woods, compared to hill forests, mean laying dates were earlier, mean clutch and brood sizes were larger, a greater proportion of nests produced young, and more nestings survived.

These differences were consistent in the three years studied, though not all statistically significant in every year. The net result was that sparrowhawks nesting in the valley woods were considerably more productive of young than those in the hill forests. It was chus difficult to understand why birds occupied the hill forests when there were vacant territories in the valley, unless the plantation habitat offered them some advantage balancing the reduced nesting success.

My own studies of sparrowhawks (Moss 1976, 1978c) also compared aspects of breeding performance between birds nesting in the large Ae forest and in small woods in the adjoining Annan valley. Dally growth rates of the nestlings were measured and the causes of mortality were assessed. The results showed that the study area could be divided between nests in the valley woods and the lower edge of the plantation as one group, and those in the higher and remoter parts of the plantation in another. Nestlings gained weight at rates which were on average 20 per cent lower in the interior of the forest than in the valley and forest edge, and the birds wh lower growth rates also suffered greated fluctuations in weight.

Differences in mortality were also marked, 48 per cent of nestings in the forest interior died when aged between two and twenty-four days compared to only 5 per cent in the valley and forest edge. Only 22 per cent of forest interior broods survived without any mortality, while in the remainder of the study area 87 per cent of parents all ralsed their young to fledging. The major causes of mortality were starvation as a result of competition within the brood ( 37.5 per cent of all deachs), exposure in wet weather ( 25 per cent) and predation by tawny owls ( 17.5 per cent).

Almost all the differences observed within the study area could be atcributed to the food supply. Censuses of song-bird populations in woodlands (Moss 1978a) showed that in the valley woods there were abundant sources of prey within easy reach, if not in the coniferous woods actually preferred by sparrowhawks for nesting. The specles present in the valley woods, such as thrushes (Turdus spp) tended to be larger on average than those predominating in the plantations, so enhancing their attractiveness as sources of prey for hawks. Valley woods were also easily accessible to the birds breeding along the edge of Ae Forest. By contrast, birds in the interior of the forest could elther hunt for the sparser prey there, for example on the edges of windblows and stream sides, or they had to fly relatively long distances to the valley 
woods in search of $r$ icher sources of prey. Radlo-telemetry studies showed that the birds frequently followed the latter course, and one ferale regularly travelled $9 \mathrm{~km}$ to hun when she hajd large young in the nest.

The consequences for broods in the interior of the forest were that competition occirred within broods wich were too large to be supported by the poor food supply, and the weaker nestlings died. The ferale was forced to hunt away from the nest and the nestings died because of exposure in we weather or were eaten by predators. Those nestlings which did survive had reduced growth rates which may well have left them less fit to survive the difficult perlod after fledging.

The conclusions of both Newton's and my own studies were that the large even-aged plantation offers extensive areas which are attractive to sparrowhawks as habitats in wich to nest, presumably with a minimum of disturbance from other birds due to the regular spacing of nests. However, from the studies of breeding success there appears to be a selective disadvantage in nesting in the intertor of the plantations, and one might expect birds to show a greater preference in choice of nest site for the valley woods than was observed. The optimum environment from the polnt of view of both food supply and nest site would appear to be close to a forest edge which borders the valley.

\section{DISCUSSION}

In recent years there has been frequent debate, sometimes heated and too often 1/1-informed, on the merits and demerits of the afforestation of Britain's uplands. As a starting point, the detractors of forestry plantations often describe the moorland which has been lost as the 'natural' vegetation of the uplands, whereas it is often the consequence of centurles of over-grazing by sheep and of burning, resulting in the removal of the natural forest cover of scots pine (Pinus sylvestris). birch and oak. These circustances should be borne in mind when comparing the effects of afforestation on bird populations in Britain with its effects elsectere in the world where plantations have replaced natural forests; in the latter case one wight expect a decline in diversity and number of birds.

Even-aged plantations as habitats for birds have both gains and losses by comparison wh moorland. On one side, there is an increase in song birds, both in numbers and species. Total song-bird densities in plantations were four to six times as high after twenty-five years as they were on moorland. In the course of 1 ts developnent, the plantation provided sultable habitats for a range of other song-bird species typical of scrub so that the total breeding species list of a forest containing areas at each stage of 8 rowth would far exceed that of moorland alone. 
In addition, plantations provide refuges for a number of other species although, as in the case of the sparrowhawk, it may be those parts of the forest which are close to outside sources of food which are of greatest value. This is an example of the classic 'edge effect' (Odum 1959), where the boundary between two ecological zones proves richer than the pure habitat of either.

Against the gain in song-bird numbers with afforestation must be balanced the loss of moorland species, which was underestimated in this study restricted to song-birds. Al though they are sparse in cerms of pairs/sq.km many species of waders are dependent on unplanted uplands as their breeding habital.

Populations of other species have also suffered from afforestation, sometimes indirectly as in the case of the raven (Corvus corax). Marquiss, Newton \& Ratcliffe (1978) have atcributed a per cent decline in the raven population over fifteen years in southern Scotland and Northumberland to the removal of sheep, their main food source, following afforestation. Ravens often deserted traditional breeding sites concurrently with planting in the surrounding area. The merlin may also be suffering a similar reduction due to loss of its preferred moorland habitat, and deserves more detailed research.

It is often evident from arguments used by the opponents of large-scale afforestation that their aesthetic considerations favour the open moorland landscape rather than 'regimented rows of trees'. A certain amount of claustrophobla is experienced once the canopy closes, views are lost, and rides become 'tunnels through the spruce needles'. Appreciation of the birds is probably more difficult for the visitor when he is in a forest than when he is on the moor, since although they are present in the plantations at greater densities, the birds are less obvious to the observer, hidden as they often are by the tree canopy. It is much easier to see a skylark singing overhead against a blue sky than a goldcrest lost up among the spruce needles.

In conclusion, the best management of upland forestry for birds appears to be a policy favouring soall, even-aged plantations forming a pacchwork of blocks of differing ages within any one forest area, rather than large-scale cover by forests of uniform age. Some valleys and moorlands should be left entirely free of planting, since many species are dependent on unplanted uplands for breeding. Forest managers may plan their planting programmes to achieve such a forest containing the full range of growth stages, and unincentionally they may often be helped towards such a pattern by the occurence of wind throws. 


\section{REFERENCES}

Haapenen, A. (1965). Blrd fauna of Finnish forests in relation to forest succession. Annales Zoologici Fennici, 2 , 153-196.

Haartman, L.von(1971). Population dynamics. "Avian biology" (Ed. by D.S. Farner and J.R. KIng), pp. 391-459. Academic Press, London and New York.

International Bird Census Comittee (1969). Recomendations for an international standard for a mapping method in bird census work. Bird study, 16, 248-255.

MacArthur,R.H. \& MacArthur,J.W.(1961). On bird species diversity Ecology, 42, 594-598.

Marquiss, M., Newton, I. $\delta$ Ratcliffe, D.A.(1978). The decline of the raven (Corvus corax) in relation to afforestation in southern scotland and northern England. Journal of Applied Ecology, 15, 129-144.

Moss,D.(1976). Woodland song-b1rd populations and growth of nestling sparrowhawks. Unpublished PhD thesis, University of Edinburgh.

Moss,D. (1978a). Song bird populations in forestry plantations. Quarterly Journal of Forestry, 72, 5-14.

Moss, D. (1978b) Diversity of woodland song-bird populations. Journal of Anfmal Ecology, 47, 521-527.

Moss,D. $(1978 \mathrm{C})$. Growth of nesting sparrowhawks (Acclpiter nisus). Journal of Zoology (London), in press.

Newton, I. (1972). Birds of prey in Scotland: some conservation problems. Scottish Birds, $7,5-23$.

Newton, I.(1976). Breed 1ng of sparrowhawks (Acc1plter nisus) in different enviroments. Journal of Anfmal Ecology, 45, $831-849$.

Newton, I. \& Moss,D.(1977). Breeding birds of Scottish pinewoods. Symposium on Native Pinewoods of Scotland, Aviemore, $1975 \mathrm{pp} .26-34$. Institute of Terrestial Ecology.

Newton, I., Marquiss,M., Weir D.N. \& Moss,D.(1977). Spacing of sparrowhawk nesting territories. Journal of Animal Ecology, 46, 425-441.

Odum, E.P.(1959). Fundamentals of Ecology., Saunders.

Willamson,k.(1964). Bird census work in woodlands. Bird Study, $11,1-22$. 

By E. KÖNIG* and H. Gossow**

* Forstliche Versuchs- und Forschungsanstalt, Abt. Waldschutz, D-7801, Stegen-Wittental, West Germany.

* Universität fúr Bodenkultur, Institut für Wildbiologie, A-1190 Wien, Peter Jordan-Strasse 82 , Austria.

\section{SUMMARY}

This paper deals with roe deer and red deer as inhabitants of Cencral European forests whether of mixed age or managed as even-aged plantations. It discusses to what extent they meet the deer's most important habitat requirements, nanely adequate food, cover and shelter. The most critical factor, particularly for roe deer, is energy supply; cover, whether for hiding or shelter, seems to differ in importance between the various age classes of trees. Carrying capacities of forests can be improved where stands of one to ten year-old crees, for food, and eleven to twenty year-old trees, for cover, are well-mixed to increase the edge-effect. Therefore, even-aged plantations should have significantly higher carrying capacities than natural forests because they contain larger numbers of trees in the age classes favourable for deer. However, in most cases high deer densities also mean much browsing and bark strlpping damage as well as poor body condition of the decr because of comperition for a limited supply of food which is reflected in their growth and reproduction. It appears that especially roe deer, as a 'succession specles', uses plantation forests wore for cover, which encourages colonization and territorialism, than as a supply of food since the diversity and digestibllity of the vegetation are reduced.

liethods, some still in a developmental stage, to assess deer condition in, as well as deer damage to plantations are discussed.

Roe deer and red deer differ in theit 
soclobiology, demands for food and cover, as well as in their effect on forests. Therefore, a deer habitat management, whether from the point of view of forestry or wildlife, will have to differentiate between them, in reconciling the various purposes for which the forest is grown.

\section{RÉSUMÉ}

Cette exposé traice des forets d'Europe Centrale, qu'elles soient équiennes ou d'âge mixte, en tant qu'habitat du cerf et du chevreuil. Ces forêts procurent aux cervidés leurs besoins les plus importants: nourriture, couvert et gite. Le facteur critique, surtout pour le chevreuil, est l'approvisionnement d'énergie; le gite, qu'll soit abri ou cachette, diffère en importance selon l'âge des forêts. Le rôle d'abri des forêts peut être amélioré lorsqu' on juxtapose des peuplements de la 10 ans, pour la nourriture, avec des peuplements de 11 à 20 ans, pour l'abr1, quí augmentent l'effet de bordure. C'est pourquoi les forêts équiennes peuvent avoir des densités de cervidés plus élevées que les forêts naturelles puisqu'elles contiennent des arbres de classes d'âges favorables aux cervidés. Cependant dans bien des cas les densités élevées topliquent des dégâts (broulage et ecorçage), et la condition physique des cervidés (poids) est également mauvaise à cause de la quantité limitée de nourriture à laquelle lls peuvent prétendre, refletéc par une mauvaise crolssance et une mauvaise reproduction. C'est surtout le cas du chevreull, 'espèce de succession', qui ut 11 ise les plantations comme abri, ce qui encourage la colonisation et le territorialisme, plutôt que pour sa nourriture car la variété et la digestibilité de la végétation sont réduites.

Nous discutons des wéthodes, dont certaines sont encore à l'état de dévelopement, pour évaluer la condition de vie des cervidés ainsi que les dégâts qu'ils causent dans lẹs plantations.

Le cerf diffère du chevreuil de façon soclobiologique, par son besoin différent de nourriture et d'abri. Ces deux anfmaux ont aussi une influence differente sur la foret. c'est pourquoi une gestion de. l'habitat des 
cervidés, qu'elle soit orientée vers la forestrie ou la protection de la faune sauvage, devra traiter les problènes du cerf et du chèvreuil sépārément én essayānt de cōncilier les besoins variés de la forêt.

\section{ZUSAMMENFASSUNG}

Diese Arbeit befasst sich ait den beiden in Mitteleuropa wichtigsten Wild-Wiederkäuern, Reh und Rothirsch, sowle der Frage, wieweit deren Asungs- und Deckungsanspriche it Altersklassen-Wirtschaftswald bzw. In künstlich verjüngten, altersglelchen Reinbeständen befriedigt werden. Es wird die Bedeutung energiereicher, vor allem aber gut verdaulicher Xsung und deren Zugänglichkelt in nfcht zu grosser Entfernung von den Deckung bietenden Einständen betont (Ze1t - Energie - Budgets). Insofern sollten die Altersstufen 1-10, fur Xsung sowie 11-20, für Deckung - insbesondere bei grenzlinien-reicher Gemengelage - auch hohe Tragfähigkeiten bzw. eher wohl hohen Besiedlungs-Anreiz bieten 'edge-effect'. Vor allem Rehwild, als 'Sukzessions-Art' findet in 'Plantagenwàldern' oft allerdings mehr Deckung und damit Anreize für Besiedlung und Territorialverhalten, als den asungsmässig insbesondere in qualitativer Hinsicht (Vergrasung bzw. Herbizideinsatz auf Kulturflăchen, Nahrungsmangel in Stangenholizern) - entspricht. Elne fruher, unter Urwald(nahen)-Verhältnlssen, vlellefcht besser aufeinander abgestimnte Relation von Tragfăhigkeit (siehe Kondition des Wildes wile auch des Waldes) und Besiedlungsanrelz (siehe Wildvertellungsdichten bzw. Waldstrukturen) klaffen Im Altersklassen-Reinbestand also mehr oder winder auseinander. So besehen ist eine a) tersklassenwe ise Waldbewl rtschaftung ind Irekt auch ein sehr wirksames Habitat Management für Schalenw1ld, ganz besonders fur Rehe, bel denen damit $z$ war hohe widdichten provoziert, aber nur mindere Konditionen (slehe Gewicht, Zuwachs, Trophäen u.a.) errelcht werden dürften.

Möglichkeiten, die Wild-Kondition whe auch den Wald(verjüngungs)- zustand als Folge von Wildschäden $z u$ bewerten, werden erórtert, insbesondere solche Methoden, de sich derzelt noch im Entwicklungsstadium befinden. Da sich 
Reh und Rothirsch in threr Sozloblologie, ihren Habitatsansprichen und hinsichtlich der von ihnen verursachbaren Waldschäden tell weise doch recht erheblich unterscheiden, sollte eine 'Schalenwldbewirtschaftung' dies entsprechend differenzlert berücksichtigen. lnd ebenso misste dle Forstwirtschaft sich ihrer habitat beeinflussenden Nebenwirkungen mehr bewusst werden und diesen unstand zum Belspiel bei der mittelfristigen Planung auch konsequenter einbeziehen.

INTRODUCTION

If antmals living in the wild are to thrive they must make very specific demands on their environment. Because of the diverse and frequently major encroactment by man on the forest, ranging from exploticion and devastation to the transforwation of these devastated areas into plantations of fast growing trees, prevalling ecological conditions have been transformed so drastically in certain areas that varlous species such as hazel grouse, capercalllie and woodpeckers have undergone a signiflcant decline (cf. Eiberle 1976, 1977). However, other species have managed to thrive in these changed conditions. Amongst the species that do continue to thrive in many countries in Europe are the two most dominant ruminant specles, roe and red deer, two species which present particular problems for the forester, who often also acts as the gamekeeper responsible. The areas in which these species can now be found in Central Europe and their numbers have multiplied in the last twenty to forty years (cf. Schroder 1976a; Konig 1976b; Donaubauer 1977) 1mplying by definition productive population densities as well as increased carrying capacities.

As a rule, fundamentally wrong management decisions are thought to be responsible for these explosive increases in stock (Figs $1 a+b$ and 2 ). They include the extermination of the larger predators, too low harvest quotas, especially of roe and red deer does, exaggerated winter, and on occasion even summer feeding. These policles are practised because all too often insufficient attention is paid to the changing ecological conditions of the countryside. This is particularly true of even-aged forest stands and the effects they have on the growth potential of hoofed game, especially for so-called 'succession species'.

WHAT ARE THE MAJOR DEMANDS PLACED ON THE HABITAT BY HOOFED GAME?

The primary - and therefore often also most easily limiting - ecological requirements of game are food and cover. Food has to satisfy the demand for energy as well as particular nutritional requirements; the digestibility of vegetation $1 \mathrm{~s}$ a limiting factor in this respect. High demands 


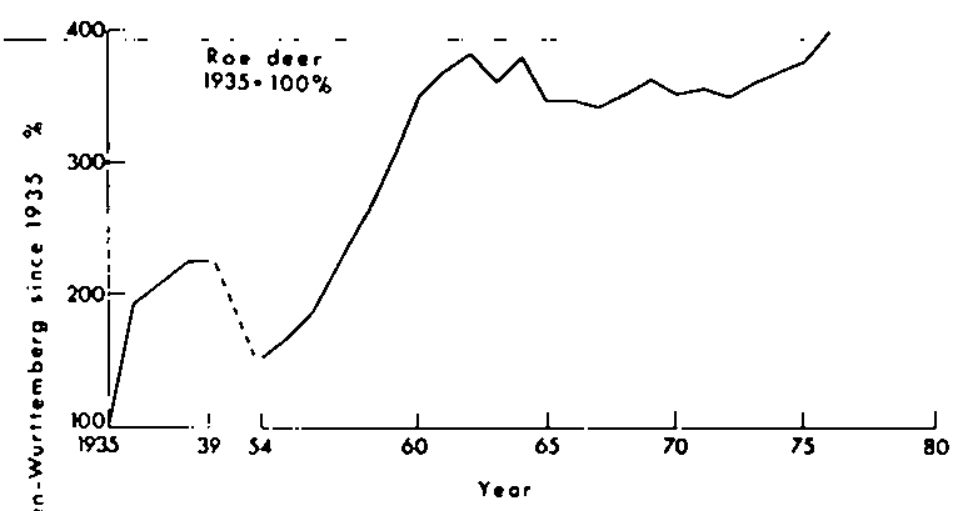

(a)

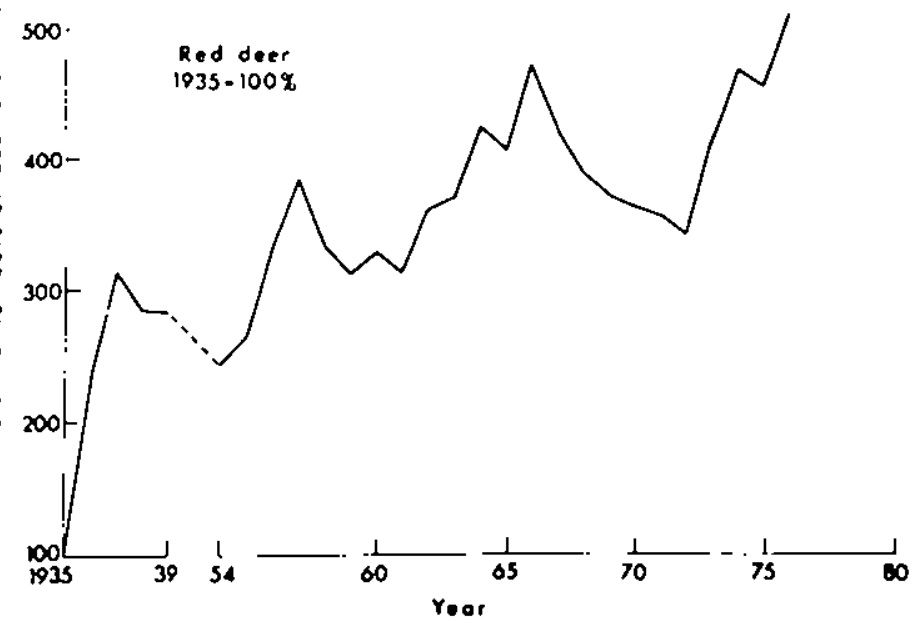

(b)

Fig. 1. Relative numbers of (a) roe and (b) red deer shot in Baden-Würteberg since 1935.

on the digestibility of food and on its energy value are made by

- females during pregnancy and, especially, during lactation;

- young animals while they are growing;

- bucks and stags defending their territory and during rutting (Eisfeld 1976; Ellenberg 1977, 1978; Geist 1974).

Availability of raw protein is highest in the late spring (Drozdz \& Osiecki 1973; Elsfeld 1975a, 1976) and since this coincides with the greatest perlod of need for roe deer, 

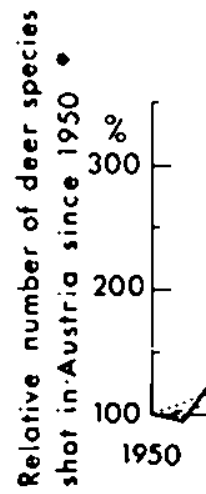

- ofter Donaubover 1977

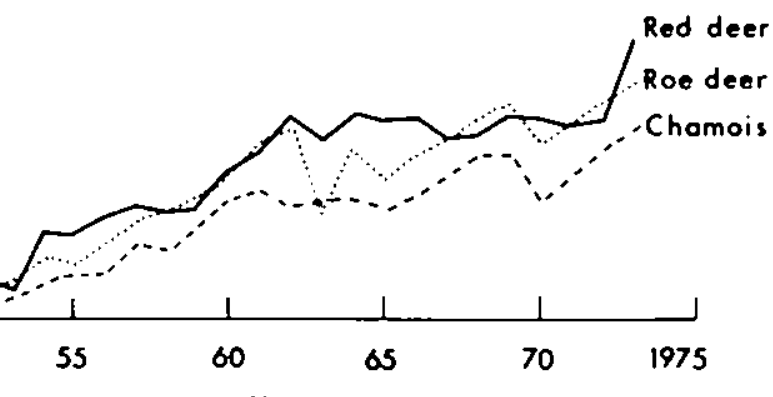

Year

Fig. 2. Relative number of each of three deer species shot in Austria since 1950 (after Donauber 1977).

Elsfeld (1974, 1976) considers protein deflctencies to be unlikely. On the other hand, the cotal supply of digestible food with the necessary energy content avallable, threatens to become critical at this time and may be barely sufficient to maintain existing stock. At first sight the ability of ruminants to digest cellulose as well as, in quantitative terms, the slight amount of the cotal available vegetation they consume, makes a nutritlonal shortfall in terms of energy requirement seem unlikely (Bobek, Weiner \& 21elinsky 1971; Bobek, Borrowsky \& Dzieciolowski 1975). Nevertheless, this is a possibility, especially for the smaller ruminants and for young animals during perlods of high energy demands. The limited capacity and digestive capability of the rumen are the limiting factors to an animal's abllity to make use of available vegetation (Campling 1970), since it may be prevented from taking advantage of nutritious vegetation because its rumen is already filled with relatively indigestible food. Thus, depending on the level of digestibility of food, it is possible for a ruminant to starve, or at best, suffer a deterioration in physical condition. Critical digestibility thresholds change with the seasons depending on avallable vegetation and the calorific needs of the animal. Roe decr require light, easily digestible food If their energy requirements are to be met, more so than graminivorous ('grazer') species, such as moufflon, chamois, sheep and cattle, and much more than red deer (Hofmann \& Geiger 1974; Feustel 1967; E1sfeld 1976; Ellenberg 1978; 
Gossow 1976). Roe deer are very selective feeders in comparison with red deer and chamois. Of the 113 plant cypes which occurred in twelve test areas studied by volz (1975), only thirty-five specles ( 31 per cent) were used, namely six out of twenty-two available grass species ( 27 per cent), nine out of twelve wood specles (75 per cent) and twenty out of seventy-nine herb species ( 25 per cent).

Differences in the composition of food in the rumen between red deer and chamois were also found by Schröder (1977b) and Drescher-Kaden (1977) and these differences were themselves found to vary according to season (Fig. 3); also compare Ahlen (1965) and Cossow (1976) for red deer versus moose.

Feeding and selection pressures of roe deer on the available plant types fluctuate considerably during the year and vary from area to area. Data on rumen contents is of little use for broad generalizations; its value lies in application to specific areas and in the demonstration of trends. This is because the available vegetation, type of hoofed game and their population density can cause varying selection pressures on the most disparate plant cypes (Esser 1958; Klotzli 1965; Ellenberg 1974, 1978).

Where feeding pressure is great, we are frequently confronted with untypical food preference lists and a blurring of the usual dietary differences found between species. Onderscheka \& Jordan (1974) found shifts in specific food pacterns during winter months in an alpine area where there had been a high grazing and browsing impact by roe deer, red deer, chamois and moufflon (Table l).

This stemmed from an increased depth of snow and concomitantly, an impaired accessibility of grass and dwarf shrubs, but was also affected by increased feeding competition. The differences between these species in their choice of food disappeared: "Red deer manage to assert themselves in this unusually strong feeding compecition by supplementing the shortfall in their preferred food at the expense of the roe deer (taking herbs and deciduous follage). Roe deer in turn have to compensate for their food shortfall by an increased intake of reeds and conifers. Chamois, although not to the same extent as roc deer, are also victims of this increased competition and increasingly make do with reeds, shrubs and conifers."

In addition to food, the availability of cover and shelter plays an equally and sometimes even more important role. For it has been demonstrated in several cases that peaks in animal abundance do not necessarily coincide with certain times of the year or even the locations of most plentifui food. This phenomena is not confined to ruminants. Numbers of black and red grouse, for example, increase up to two years after high polnts in food digestibility. Moose and deer 


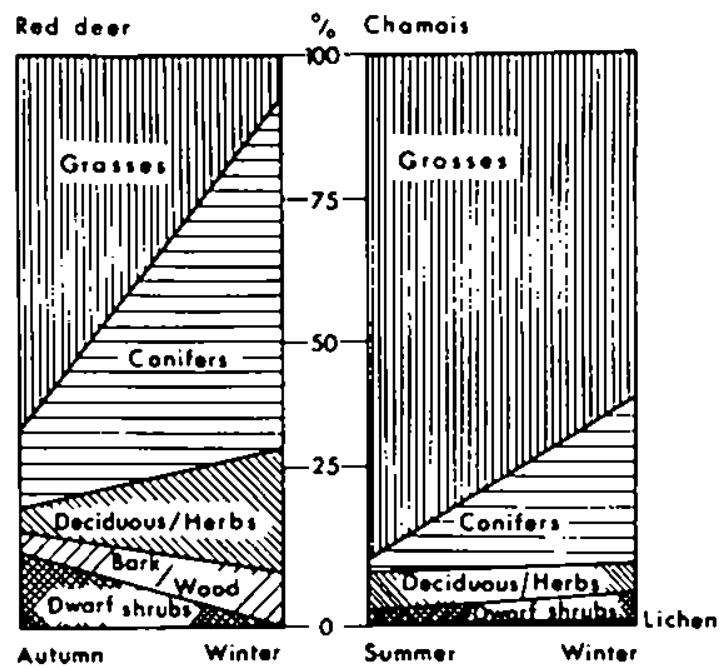

Fig. 3a. Composition of food in the rumen of red deer and chamois in different seasons (after Schröder 1977c).
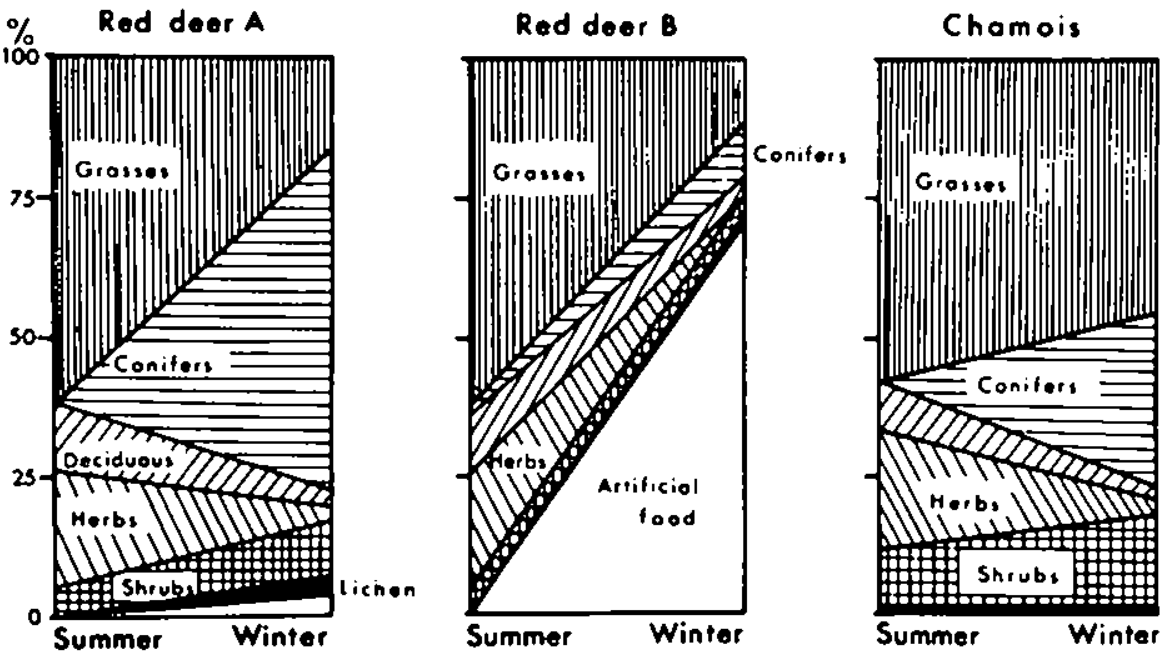

F1g. 3b. Composition of food of red deer and chamois in the months of July/August (summer) and December (winter). A - artificial food rarely accepted (deep snow), B - artificial food readily accepted in winter (afcer Drescher-Kaden 1975). 
Table 1. Percentage of plants in the rumen of roe deer, red deer and chamois, killed in the district of Langau (Onderscheka \& Jordan 1974).

\begin{tabular}{|c|c|c|c|c|c|c|}
\hline & $\begin{array}{l}\text { Roe } \\
\text { deer }\end{array}$ & $\begin{array}{l}\text { u m } \\
\text { Red } \\
\text { deer }\end{array}$ & $\begin{array}{l}\text { e r } \\
\text { Chanois }\end{array}$ & $\begin{array}{l}\text { Roe } \\
\text { deer }\end{array}$ & $\begin{array}{l}\text { W } \mathbf{i} \\
\text { Red } \\
\text { deer }\end{array}$ & $\begin{array}{c}\text { e } r \\
\text { Chamols }\end{array}$ \\
\hline Herbs & 45 & 18 & 12 & 11 & 2 & 2 \\
\hline Grasses* & 5 & 11 & 26 & 1 & 1 & 6 \\
\hline Reeds** & 0 & 15 & 18 & 6 & 26 & 25 \\
\hline Shrubs & 9 & 8 & 9 & 26 & 1 & 15 \\
\hline Mosses & 3 & 11 & 1 & 0 & 2 & 1 \\
\hline Conifers & 12 & 14 & 16 & 24 & 15 & 45 \\
\hline Deciduous & 22 & 5 & 4 & 18 & 1 & 1 \\
\hline Undefinable fibre & 4 & 18 & 14 & 5 & 3 & 5 \\
\hline Additional feed & 0 & 0 & 0 & 9 & 49 & 0 \\
\hline
\end{tabular}

* Nardus stricta, Lolium perenne, Dactyl is glomerata, Deschampsia caespitosa, Festuca pratensis, Bromus erectus and Poa pratensis.

**Juncus filiformis, Juncus effusus, Sesleria varia, Carex flacca, Carex remota, Scirpus silvaticus.

numbers increase with a lag of five to eight years. The length of the 1 ag appears to be related to the size of the game (Eygenraam 1957; Komarek 1971; Rendell 1974; Gossow 1977, 1978a).

Roe deer, living on the edge of forests, are primarily Inhabitants of thickets, although Ellenberg (1978) does not consider cover to be of decisive importance in controlling numbers when there is sufficient fcod avallable. Red deer are also regarded as inhabitants of the border areas between wood and steppe biotypes (Flerov 1952; Dzieciolowski 1969). For game to feel totally at home, a definte vegetational structure scems to be necessary to ensure settlement and breeding. Ellenberg (1978) has shown that roe deer does in even-aged stands, consisting primarily of saplings and thickets, had a home range of 19.4 ha, markedly smaller than that of roe deer in stands of mature and above all pole stage forest, whose home range was, on average, 35.7 ha. Obviously, roe deer react positively to some ecological types, e.g. clearings, the edges of stands and areas of restricted visibility, and negatively to others, e.g. large open areas of pole stands and areas with 1 imited undergrowth. In red deer, both sexes react differently to their environment (Jackes 1973; Gossow 1978b). The degree to which deer feel at home in their enviroment influences the extent to which they are prepared to defend 1 t (roe deer) or to remain and concentrate there (red deer) (Gossow 1977). 
Vegetation structure as cover has a number of very different functions. Il acts as a retreat and hiding place from predators and as protection from competition from its own or different species. Protection afforded against climatic influences is also important, as are protected rest areas and areas for giving birth, ruminating, wallowing and suitable observation. (cf. Noen 1973; Geist 1974; Bunnell \& Bastman 1976; Gossow 1977).

If too large a distance has to be covered between stands affording sufficient cover and feeding areas, then the risk of confrontation with predators, competitors and ocher sources of disturbance and danger (e.g. hunters, tourists, traffic, agriculture and forestry) rises. At some point the energy required to reach these feeding grounds will exceed the energy galned from feeding (Moen 1973; Gossow 1976; Eisfeld 1976; Ellenberg 1977). In an alpine area of predominantly even-aged stands populated by red deer, but also with localized pasture areas for grazing by cattle, red deer population quality varied greacly from home range to home range in terws of condition, including differences in milk production, aggressive behaviour, percentage of calves born, proportion of barren animals, etc. More negative effects were experienced with high altitude pastures used as nightly feeding ground by deer, since they were either too far away, making it necessary for the deer to cover great distances and variations in height or were no Ionger grazed by catcle and so decreased in nutritional value for red deer (Cossow 1978b).

What conclusions can be drawn from these habitat demands for the creation of :-

optimu guidelines for a habitat management in favour of red and roe deer?

As the varying demands of large game such as food, rest, protection, procreation, wallowing etc. can seldom be fulfilled in a single biotype, it is in the interest of a optimized economic time - energy budget (Moen 1973; Gossow 1977; Bunnell \& Farr 1978) to be in a position to offer the respective essential biotypes for food and cover within an operational radius appropriate to the animal species and number. In wildlife habitat management this so-called edge effect is a primary aim (Leopold 1933; Dasmann 1964; Telfer 1974; Thomas et al. 1976; Gossow 1976 and 1978a). As a result of the increase of even-aged stands and also the extent to which forests are being opened up by construction of forest paths, changes have occurred in the distribution of forest biotypes.

1 The proportion of open spaces and regeneration areas has increased (age group 1).

ii The proportion of thickets has increased (age group 2).

i11 There has been a tendency towards smaller felling areas, i.e. between 0.5 and 2 ha. 
All these changes should be favourable to the habitat demands of roe and red deer, at least in comparison to more naturally developed forests or even the primeval forests in which the breed $s^{\prime}$ unique morphological, physiological and behavioural peculiarities developed ( $c f$. Hofmann 1977; KLein 1970; Knapp 1966; Pimlott 1967; Klein \& Strandgaard 1972; Mayer 1975).

It is typical of forest ecosystems to have. a pre-ponderance of long-lived primary producers, trees and shrubs, which only in part - and this during the early growth stages - have a secondary productive function for ground dwelling game species, 1.e. they are eaten (cf. Dasmann 1964; Schröder 1974). When compared with the climax, primeval forest which has a relatively high proportion of mature crees, the plantation is ideal in respect of accessible feeding areas (Fig. 4). It is also superior in terms of cover, i.e. thickets and young, closely planted pole stage woods. The shorter the cutting cycle, the greater the suitability for gane, as this increases the proportion of avallable food as well as the areas of cover (

In addition to the effect of shortening the rotation length, the trend towards small felling areas now propagated in Central Europe has proved particularly beneficlal in satisfying the habitat demands of red and roe deer. Although these species prefer to feed at the edges of forests or chickets, they apparently 1 ike a distance of $20 \mathrm{~m}$ (roe decr) or between 30 and $50 \mathrm{~m}$ (red deer) from the forest edge before they actually begin feeding. This is less possible where blended felling is practised, as in a selection forest, while in areas of radical deforestation we frequently have the opposite problem of large areas of potential food - at least from the point of view of deer management - and therefore waste (e.g. Rochelle \& Bunnell, this volume, in respect of wapiti and black-tailed deer). In addition, the pioneering papers of Thomas et al. (1976) and Bunnell \& Eastman (1976) have raised these very points in discussing guidelines for the maintenance and improvement of wildlife habitat within the framework of forest management. Unfortunately, any real practical groundwork on this for Central Europe is still lacking. But a comparison between Middle European and North American forest and game 11 terature does show that there must be a substantial influence of forestry on the habitat of hoofed game in Europe.

Decisions about the magnitude of the cutting cycle, cholce of the regeneration method, i.e. natural or by planting, size of area to be felled, method of felling, etc. can all have a dominant influence on the population dynamics of hoofed game.

Possibilities and problems in assessing carrying capacity.

once established, forest plantations attract a range of plants, animals and insects, which compete for the favourable 
conditions. The forester not only manages the forest or the plantations as a timber resource, but he also produces though as a rule not intentionally - numerous habitats (Vile 1978). The strip cut system practised in North America in the interest of deer and grouse habitat management has exactly this aspect in mind (e.g. Telfer 1974). Many forests in Central Europe are also felled by the strip cut system. Though this is not always done in the interest of game habitat improvement, but rather for storm protection and the prevention of damage by drought, frost etc., the effect on game is favourable.

It is often the case that in these structurally and texturally more variegated even-aged stands the available food and its quality have declined. This is a combined result of increasing quantities of spruce and pine or beech, the eradication of undergrowth and other competitive vegetation, fencing, poor ground vegetation due to a dense overstory in the thickets, and feeding grounds being difficult to reach because of obstacles. Finally the increase in numbers and concentration of game leads to greater competition for available food which causes a loss of condition in game and increases damage to the forest because natural regeneration, cultivatibility, the survival chance of mixed tree specics and general quality of the stand are all reduced. Thus we have the other side of the coin, a high population density of ruminant game and a correspondingly high level of damage to the forest. This results in poor quality of game and, particularly in even-aged stands and plantations, puts the economic viability of forestry into jeopardy.

How is it possible to establish crlterla to gauge both the biotic carrying capacity for game and the economic viability of forestry by producing silviculturally sustainable forest stands.

Game

As a result of various studies (Andersen 1953; Strandgaard 1972, 1975; E1lenberg 1974, 1978; Schroder 1975, $1976 \mathrm{~b})$ it is clear that the numbers of roe and red deer cannot be counted accurately enough to collate concrete data ( 1 .e. In terms of the animal numbers per 100 ha of forest) in harvest planning. But we require such figures to establish what constitutes a viable or tolerable population density, irrespective of whether this is in the interest of the condition of the game or of the condition of the forest. As indicators for the relative carrying capacity of forest biotypes it is necessary to take into account not only the condition of the game but also the condition of the vegetation, its regeneration, etc.

In hoofed game deficlencles in nutrition are manifest in corresponding reproduction rates. The degree of fertility and the age at which the animals are capable of reproduction, the 


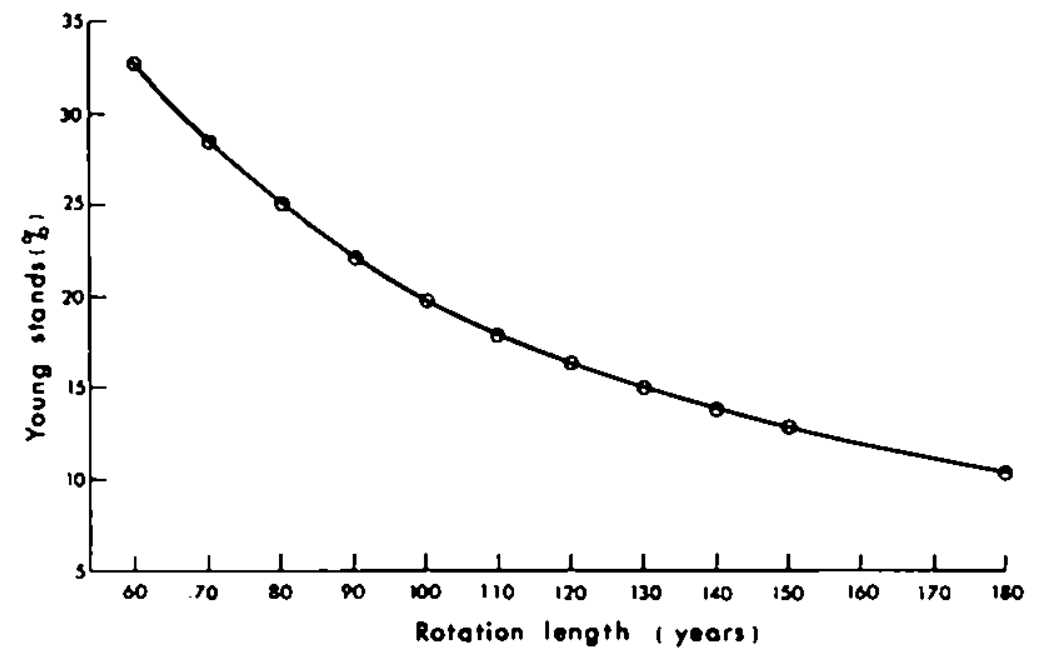

F1g. 4. Effect of rotation length on the percentage of young stands ( $1-20$ years old) in the total forest.

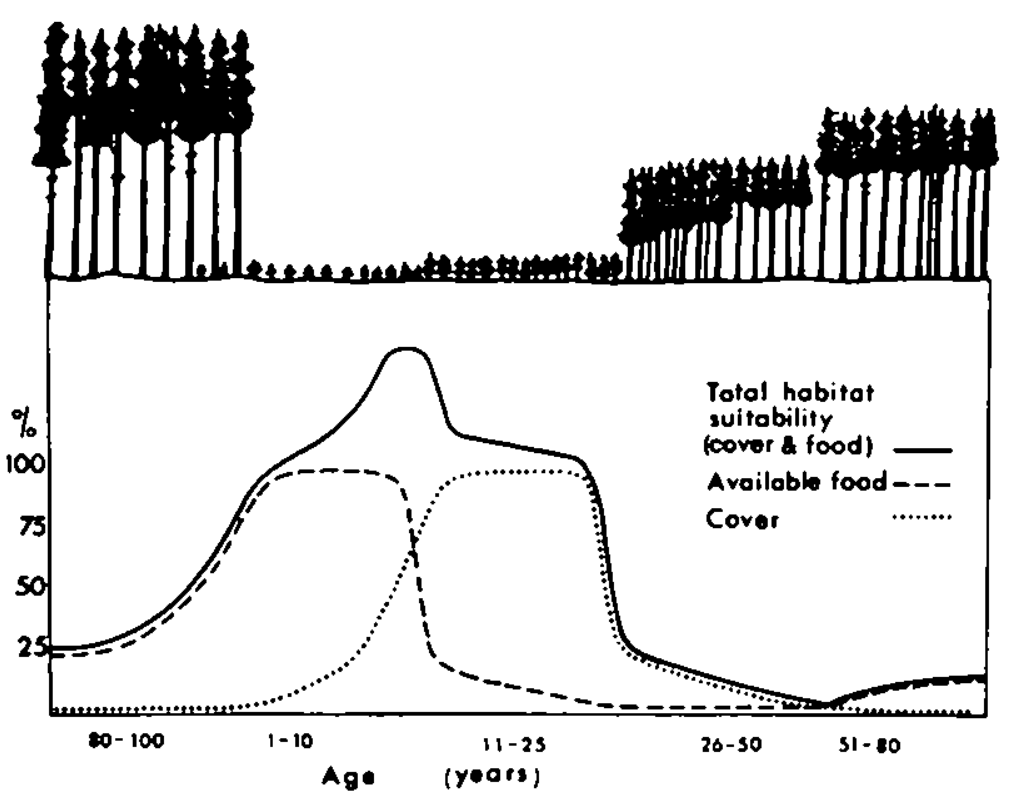

F18. 5. Schemat1c representation of the sultability of the forest habitat for deer during the course of the rotation. 
number of twin births, the degree of barrenness and the number of still-born fawns and calves (Mitchell \& Brown 1973; Mitchell, Staines \& Welch 1977; Ellenberg 1978) are all influenced by the nutritional plane of the animal as are the prerequisites for successful rearing, such as plentiful tilk supply (Ge1st 1971; Bunnell \& Farr 1978; Gossow 1978b). Gathering of evidence on reproduction requires time-consuming field work and/or examination of reproductive organs, as well as of fat reserves (e.8. kidney fat index). Animals not freshly killed but found dead supply simpler, if not quite such accurate indicators. Tests can be made on bone dimensions, e.8. measurements of the skull, lower jaw or the extremities (Eisfeld 1975b; Ellenberg 1975) which have the advantage that they do not require complicated preservation or preparation procedures. In West Germany, Eisfeld \& Ellenberg (1974) recommended that the carrying capacity for roe deer should be determined by a substitute parameter of assessing body size, for which, as a result of allometrically verified correlations, the lower jaw length of adult animals, measured from the first incisor's root to its condyle, can be used (Ellenberg 1975).

A completely different starting point, although as yet hardly ready for practical application, can be made by assessing the border areas of even-aged stands that are particularly beneficial to game (Schürholz 1974). Two forest areas have been compared with reference to the influence of the edge effect on roe deer (Table 2). For roe deer the most attractive area - biotype combinations include young growth (planted in the case study) and thickets, but exclude pole stands (see above). In areas $A$ and $B$, of a similar size, the number of edges and their total length were twelve and $1150 \mathrm{~m}$ (A) and twenty-eight and $3600 \mathrm{~m}(\mathrm{~B})$, respectively. Thus area $B$ had a much higher amount and interspersion of edge and very probably also a higher carrying capaclly. However, carrying capacity was intensifled by all-year round feeding just in the edge of the poorer area A. With its already sparser population density this led to a further food surplus, which of course made any direct comparison with the more densely populated area $B$ difficult and inconclusive. This example has been mentioned in order to demonstrate the relationships of some critical forest parameters for deer carrying capacity.

Forest

The second possible way of gauging the carrying capacity of a particular environment is by assessing the conditions and changes of the available vegetation ( $c f$. the concept of increasing vs decreasing invader plant species in range management). (ritical damage to vegetation is usually apparent long before any decrease in the condition of the game. A forest can only satisfy the multiple demands made on 1 t by society when, and if, its function as a source of protection, 
Table 2. Comparison of two adjacent forest areas with regard to the biotic carrying capacity of deer (after Milad 1977).

(1) Forest (z)

(2) Field, pasture (z)

(in $z$ of $(2)$ )

(4) Roads (n looha ${ }^{-1}$ )

(5) Forest paths (a $100 \mathrm{ha}^{-1}$ )

(6) Total forest area (ha) of which

- young trees (ha)

- thickets (ha)

- pole-stage (ha)

- mature forest (ha)

(7) Edge lengths* (m)

(8) Edge factor (a ha ${ }^{-1}$ )

(9) Edge areas within the forest between

young trees and thickets
pole-stage and young trees
pole-stage and thickets
tature wood and young trees
mature wood and thickets
mature wood and pole-stage
Total edge areas

Reproduction observation data (as indicators of game conditions): -average number of fauns born in May

- number of does leading fawns May-December

Mean date of birth

\section{Area A}

26.60

73.40

9.30

Area B

35.70

64.30

12.55

82

103

137

148

37.5

32.6

41.4

30.5

32.5

10,200

18.35

11,400

29.69

\begin{tabular}{|c|c|c|c|}
\hline Edge & $\begin{array}{l}\text { Length } \\
\text { (ब) }\end{array}$ & Edge & $\begin{array}{l}\text { Length } \\
\text { (a) }\end{array}$ \\
\hline 4 & 450 & 9 & 1200 \\
\hline 3 & 300 & 8 & 400 \\
\hline 4 & 600 & 10 & 1000 \\
\hline 3 & 600 & 7 & 1100 \\
\hline 5 & 100 & 12 & 1300 \\
\hline 4 & 500 & 10 & 1100 \\
\hline 23 & 2550 & 56 & 6100 \\
\hline
\end{tabular}

2.0

1.3

1.8

1.4

7 May

24 May

* Refers only to borders becween forest and fields, other': cultivated areas and forest and uncultivated areas and forest. 
its soctal function and its role as a supplier of timber remains sustainable. The aim of modern forest management must therefore be to create secure ecosystems which are capable of withstanding abiotic and biotic hazards such as storm, snow, drought and diseases and pests. The demand for such stabilization becomes more comprehensible if one considers the fact that, for example, in the state forest of Baden-Wurtemberg in the last twenty years approximately 25 per cent of the year's prescribed yields was unplanned and brought about by discases and pests (König 1976b). Mixed stands of trees suited to their particular environment fulfil these demands better than large stands of a single type. The regenerative capacity of nixed stands $c a n$, however, be threatened if the density of hoofed game is too high. This happens for two reasons:

1 certain types of tree are chosen in preference to others by game, above all fir and deciduous trees;

ii because of the better regenerative ability of certain tree types such as spruce.

Regulation of the numbers of game in accordance with the silvicultural carrying capacity of the forest is one of the most important steps in the creation of a suitable forest ecosystem (Konig 1976a, b). There are as yet no firm criteria with which to determine the amount of game to be shot in the interest of forest preservation. Fixing criteria will obviously not be possible on a country-wide scale because of very specific local differences in forest and game management. For this reason, Baden-wurtemberg conducts an annual series of spot checks on thirty-four regeneration areas, both natural and planced, to determine the amount of browsing by game. To isolate the possibility of any influence by game, approximately 30 per cent of the sample plots in every regeneration area is fenced in. Through such checks over a number of years it is hoped to determine a damage threshold. possibly these same figures will be of use in assessing the extent of damage in regeneration areas in edaphically similar locations and in establishing a corresponding deer density chrough an adequate kill quota in the interest of forestry preservation. Finally, it is possible that these test areas will enable us to check the influence of hunting on the degree of browsing or even of the influence of the structure of the forest on the efficiency of hunting (Sperber 1975). These figures could also be helpful for a large scale inventory (Speidel 1975), to make the influence of ruminant game on the forest clearer.

The level of bark danage by red deer varies greatly from area to area and only intensive investigations will produce reliable data. These data can be applied to a whole country, as In the case of Austria (Fig. 6; Plattner 1978), or to single forest districts, as in the case of Baden-Wurtemberg 


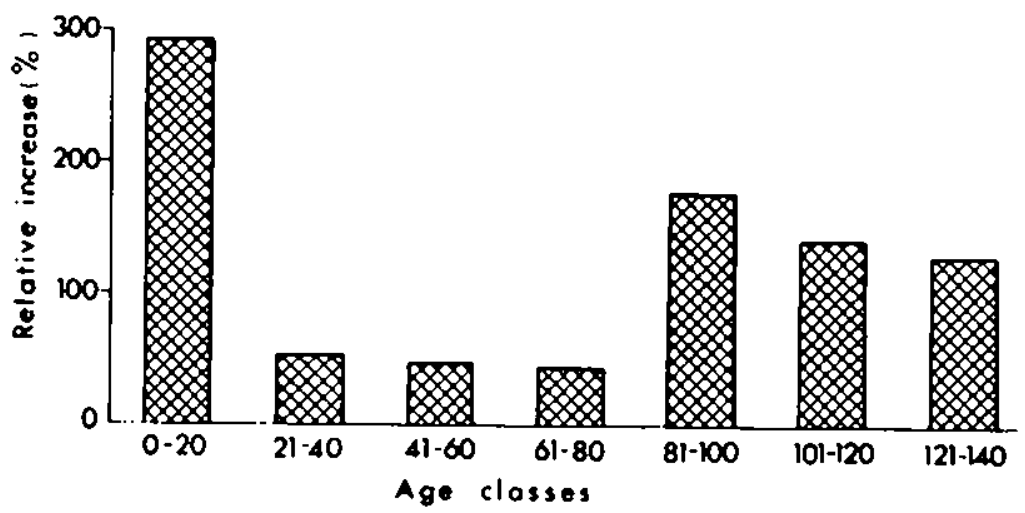

Fig. 6. Percentage increase of bark stripping danage in Austria from 1961/70 $(=100 \%$ ) till 1971/75 (after Plactner 1978).

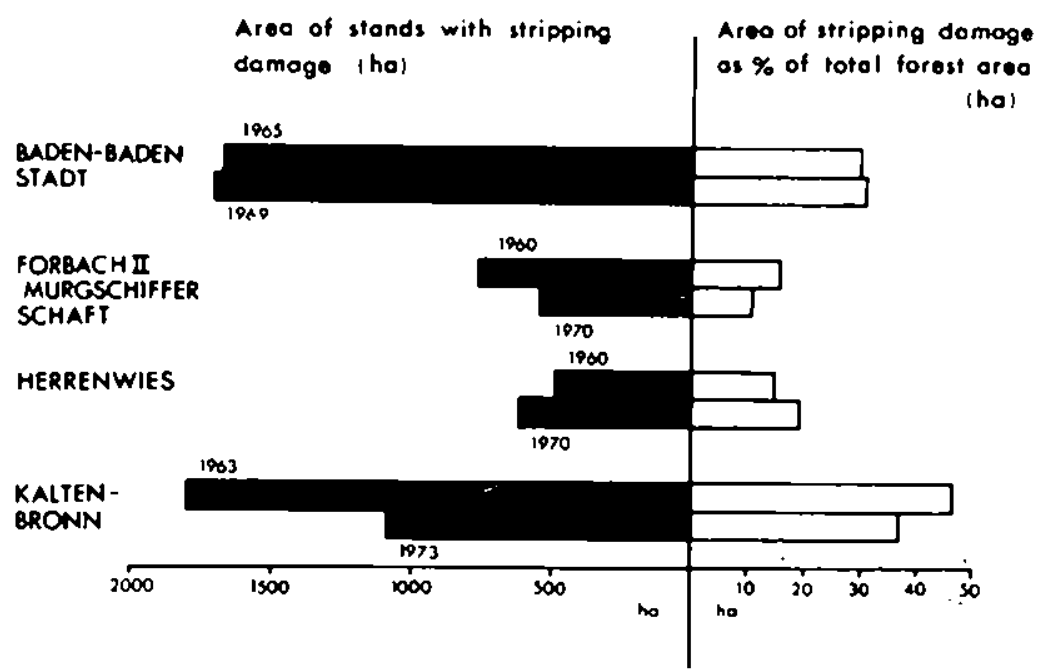

Fig. 7. Stripping damage in the Karlsruhe (BadenWurcemberg) area. 
(Fig. 7). Repeating the survey of such data over the space of ten years supplies us with an indication of trends in damage by bark stripping. On this basis the evaluation of the final Inventory perlod covering the whole of Austria showed a wean increase of 66 per cent in such damage, with ind Ividual states fluctuating strongly from this figure in either direction. In the two areas populated by red deer in the $\mathrm{Black}$ Forest the trend is also irregular. While damage in certain areas declined over the last decade, it has increased in others. Knowledge of such developrents is, however, a precondition for the implementation of the necessary measures to achleve the aims of a multiple use forest management.

For the evaluation of damage by bark stripping, fundamental investigations are required into the influence of bark stripping on the growth rate of trees (Roeder 1973) as well as the correlation between the wounds caused by stripping and the extent and intensity of woodrot (Roeder knigge 1972). As an ald to making decisions on the treatment of spruce stands damaged by bark stripping, e.g. to cut or fell prematurely or to reduce the cutting cycle, the reader is referred to a case study by Beisel (1973).

In future, forest management will become increasingly multi-purpose and $1 t$ will not be suffictent for long-term planning or management to consider only those vegetation types directly relevant to production forestry and the game damage done to them. There are important interactions both between different vegetation types and between use made by different animals. On the basis of present knowledge (Konig 1976; Cossow 1975, 1978c; Schroder 1976a, b; 1977a) one is forced to conclude that it is unlikely that the condition of game and the condition and development of the forest can be optimized at identical densities of game stocking ( $c f$. also Caughley 1976).

\section{REFERENCES}

Ahlen,I.(1965). Studies on red deer in Scandinavia. III. Ecological investigations. Viltrevy, $3,177-376$.

Andersen,J.(1953). Analysis of a Danish roe deer population. Danish Review of Game Biology, 2, 121-155.

Beisel,R.(1973). Auswirkungen von Beschädigungen der unteren Stamabschnitte auf den wert und die Produktionsdauer von Fichten-Betrlebsklassen und von Fichten-Beständen. Micteilungen Forstliche Versuchs- und Forschungsanstalt Baden-Württemberg, 48 .

Bendell,J.F.(1974). Effects of fire on birds and mammals. "Fire and Ecosystems". (Ed. by T.T.Kozlowski and C.E.Ahlgren), pp.73-138. Academic Press, New York.

Bobek, B., Borrowskd,S, \& Dzleciolowsk1,R.(1975). Browse supply in varlous forest ecosystems. Polish Ecological Studies, 1 , 17-32. 
Bobek,B., Weiner,J. \& Zielinski,J.(1971). Fond supply for deer in the deciduous forests of southern Poland. Transactions International Congress on Came Biology, 10, 271-276.

Bunnell,F. Eastman,D.(1976). Effects of forest management practices on wildlife in the forests of British Columbia. Proceedings 16th I.U.F.R.0. World Congress, Oslo. Division I. pp.631-689.

Bunnel1,F. \& Farr,A.C.M.(1978). Activity budgets of Dall's sheep during lambing. II. International Theriological Congress, Brno. (manuscript).

Campling,R.C.(1970). Physical regulation of voluntary intake. "physiology of digestion and metabolism in the ruminant." (F.d. by A.T.Phillipson), PP.226-234. Onel Press, Newcastle.

Caughley,G.(1976). Wildlife management and the dynamics of ungulate populations. Applied Biology, $1,183-246$.

Dasmann, R.F.(1964). Wildlife biology. New York. 231 pp.

Donaubauer,E.(1977). Zur Entwicklung der Rot-, Reh- und Gamswildbestände. "Wald und Wild 1977". (E.d. by H. Yayer), pp.35-45. Wien .

Drescher-Kaden,U.(1975). Nahrungswahl, mikrobielle Besiedlung und biochemische Leistungen der Mikroorganismen im Ruminoreticulum der Gemsen. verhandlungen der Gesellschaft fur Oekologie, Wien. pp.69-75.

Drescher-Kaden,U.(1977). Berechnungen über den Energiegewinn aus der Vergarung der Naturäsung in Pansen des Ganswildes. Tagungsbericht 2. Internationales Gamswild-Treffen, Bled 1976. pp.158-165.

Drozdz,A. \& Osiecki,A.(1973). Intake and digestibllity of natural feeds in roe deer. Acta Therlologica, $18,81-91$.

Drieclolowski,R.(1969). The quantity, quality and seasonal variation of food resources available to red dect in varlous environmental conditions of forest management. Forest Research Institute Warsaw. (after Mitchell, Staines \& Welch 1977).

Eiberle,K.(1976). Zur Analyse efnes Auerwildbiotops in Schweizerischen Mittelland. Forstwissenschaftilches Centralblatt, 95, pp.108-124.

Eiberle,K.(1977). Beobachtungen an höhlenbrutenden Vogelarten. Schweizerische Zeitschrift fur Forstwesen, 128, 750-761.

E.1sfeld,D.(1974). Der Eiwelss- und Energlebedarf des Rehes, diskutlert anhand von Laborversuchen. Verhandlungen der Gesellschaft fur Dekologie, Erlangen, 4, 129-139.

Elsfeld,D.(1975a). Zusammenhànge zwischen Nährungsqual ităt und Stickstoffgehalt fm Panseninhalt und im Kot bei Rehen. Transactions International Congress on Game Biology, 12 (in press).

Fisfeld,D.(1975)b). Zur Regulation der Rehdichte und Vorschlag zur Neugestaltung der Abschussplanung. Allgemeine Forstzeitschrift, 30, 1123-1127. 
Eisfeld,D.(1976). Ernahrungsphysiologie als Basis fir die ökologische Beurtellung von Rehpopulationen. Revue Sulse de zoologin, 83, 914-928.

Eisfeld,D. \& Filenberg,H.(1974). Vorschlag einer neuen Abschuss- regelung für Rehwild. Die Pirsch - Der Deutsche Jager, $26,858-860$.

Ellenberg, H. (1974). Beiträge zur Ökologie des Rehes. Daten aus den Stammhamer Versuchsgehegen. Dissertation Universitat Kiel. 133 pp.

Ellenberg,H.(1975). Die Körpergrösse des Rehes als Bioindikator. Verhandlungen der Gesellschaft fur Okologie, Frlangen, 4, 141-154.

Ellenberg, H. (1977). Das Reh in der Landschaft. Jahrbuch Verein zum Schutze der Bergwelt, tunchen, 42, 1-22.

Ellenherg,H.(1978). Zur Populationsökologle des Rehes (Capreolus capreolus L., Cervidac) in Mitteleuropa. SPIXIANA, Supplement 2. Munchen. $211 \mathrm{pp}$.

Esser,W.(1958). Beitrag zur Untersuchung der Äsung des Rehwlldes. Zeitschrift für Jagdwissenschaft, $4,1-41$.

Eygenraam,J.A.(1957). Über die Behand Iung, des Birkhuhnbestandes. 7eitschrift für Jagdwissenschaft, $\underline{3}$, 79-87.

Feustel,G.(1967). Vergleichende Untersuchungen am verdauungstrakt von Rothirsch und Reh post morter unter besonderer Berücksichtigung der Gerdstkohlehydrate und des Ligningehaltes der Ingesta. Dissertation veterinär-Medizinische Fakultat, lniversitat Punchen. $79 \mathrm{pp}$.

Flerov,K.K.(1952). Fauna of the U.S.S.R., Mamals. Vol. 1. Muskdeer and deer. Acadery of Sclences of the U.S.S.R., Moscow. English translation: Office of Technical Services, U.S. Department of Commerce, Washington. (after Mitche11, Staines \& helch 1977)

Geist,v.(1971). Mountain sheep. A study in behaviour and evolution. University of Chicago Press. 383 pp.

Gelst,v.(1974). On the relationshlp of social evolution and ecology in ungulates. American Zoologist, 14, 205-220.

cossow,H.(1975). Tragfahigkeitskriterien und Schalenwildregul ierung. Forstarchiv, 46, 254-258.

Gossow, H.(1976). Wildökologie. Bayerischer Land wirschaftsverlag, Funchen. $316 \mathrm{pp}$.

Gossow,H.(1977). Waldstrukturen und Wildstandsentwicklung . "Wald und Wild $1977^{\circ}$. (Ed. by H.Mayer), pp.1-27. Wien.

Gossow, H.(1978a) Feuer im Habitat Management. VW-Symposium. "Feucrökologie". Freiburger Waldschutz-Abhandlungen, 1, 83-97.

Gossow,H.(1978b). Some specific features in alpine red deer population ecology. II. International Theriological Congress, Brno. (Manuscrlpt).

Gossow,H.(1978c). Die Waldpflege als Grundlage der 
Wildfaunaplege, insbesondere der Wildhege. Korreferat zu M. Kotar's gleichbetiteltem Vortrag. "Die Waldpflege in der Mehrzweckforstwirtschaft." I.U.F.R.O. Meeting Division I 1977. Mittellungen der Forstlichen Bundesversuchsanstalt Wien, $124,295-299$.

Hofmann,R.R.(1977). Wildbiolog1sche Erkenntnisse, ein Hilfsmitel zur Minderung von Wildschaden. Al igemeine Forstzeitschrift, 32, 111-115.

Hofmann,R.R. und Geiger,G.(1974). Zur topographischen und funktionellen Anatomie des Viscera abdominis des Rehes. Anatomia, Histologia, Embryologia: Journal der Weltvereinigung der veterinaranatomen, $3,63-84$.

Jackes,A.D.(1973). The use of wintering ground by red deer in Rosshire, Scotland. M.Phil. thesis, University of Fdinburgh.

Klein,D.R.(1970). Food selection by North American deer and their response to over-utilization of preferred plant species. "Anfmal populations in relation to their food resources." (F.d. by A.Watson), pp.25-46. BI ackwell Scientific Publications, Oxford.

Klein,D.R. \& Strandgaard,H.(1972). Factors affecting growth and body size of roe deer. Journal Wildlife Management, 36, 64-79.

Klötzlíl,F.(1965). Qual1tät und Quantitat der Rehäsung. Veroffentlichungen des Geobotanischen Instituts, Zürich, $38,182 \mathrm{pp}$.

Knapp,P.(1966). Grundlagen und Methoden von Untersuchungen über Wild, insbesondere seine Wirkungen auf die Vegetation. Geobotanische Miteilungen, 43 .

Komarek,E.V.(1971). Effects of flre on wildlife and range habitats. U.S. Department of Agriculture Forest Service. Proceedings Prescribed Burning Symposium, pp.46-52.

König,F.(1976a). Wildschadenprobleme bel der Waldverjüngung. Schweizerische Zeitschrift für forstwesen, 127, 40-57.

König,F.(1976b). Forstschutz, Wildbiologie und Jagd. "Die Forstwirtschaft in Baden-Wurt temberg." Schriftenreine der Landesforstverwaltung Baden-Worttemberg (Ed.),, $110-122$.

Leopold,A.(1933). Game Management. New York. 481 pp.

Mayer,H.(1975). Der Elnfluss des Schalenwildes auf die Verjüngung und Erhaltung von Naturreservaten. Forstwissenschaftliches Centralblatt, 94, 209-224.

Milad,K.(1977). Zur Wachstums- und Fortpflanzungsleistung von Rehwild (tm Westerwald) bel fehlender bzw. ganzjahriger Fut terung. Diplonarbeit Forstwissenschaftliche Fakultät, Universitat Freiburg. 92 pp.

Mitchell,B. \& Brown,D.(1973). The effects of age and body size on fertility in female red deer (Cervus elaphus L). Transactions International Congress of Game Blologists, 11, 89-98. 
Mitchell,B., Stalnes,B.W. \& Welch,D.(1977). Ecology of red deer. A research review relevant to their management in Scotland. Institute of Terrestrial Ecology, Cambridge. 74 Pp.

Moen,A.N.(1973). Wildlife Ecology. San Francisco. 458 pp. Onderscheka,K. \& Jordan,H.(1974). Einfluss der Jahreszeit, des Biotops und der Äsungskonkurrenz auf die botanische Zusammensetzung des Panseninhalts beim Gams-, Reh-, Muffel- und Rotwlld. Tagungsberichte 1 . Internationales Gamswild-Treffen, Oberamergau. pp.53-80.

Pimlott,D.H.(1967). Wolf predation and ungulate populations. American Zoologist, 7, 267-278.

Plattner,F.(1978). Neue Ergebnisse der Forstinventur in forstpolitischer Sicht. Algemeine Forstzeitung, $\underline{89}$, 43-46.

Roeder,A.(1973). Zur Durchesser- und Massenermittlung in rotwild- geschälten Fichtenbeständen. Allgemeine Forstund Jagdze1tung, 143, 144-150.

Roeder,A. \& Knigge,W. $(\overline{1972})$. Sind Rotwildschäden wirklich so schwerwiegend? Forstarchiv, 43, 109-114.

Schröder,W. (1974). Über elnige Fragen der ökologle der Cerviden im Walde. Forstwissenschaftliches Centralblatt, $93,121-127$.

Schroder, W.(1975). Brauchen wir den Abschussplan fur Rehwild? Al lgemeine Forstzeltschrift, 30, 1108-1112.

Schroder,W.(1976a). Reh- und Rotwild in der Bundesrepublik Deutschland. Internationaler Hol zmarkt, 67, 1-4.

Schröder,W.(1976b). Zur Populationsökologle und zum Management des Rothirsches. Dargestellt an einem Simulationsmodell und der Reproduktionsleistung des Rothirschbestandes im Harz. Habilitationsschrift Fachbereich Forstwissenschaft, Universitat Munchen. $198 \mathrm{pp}$.

Schröder,W.(1977a). Gamswild in Nationalparks: Möglichkeiten einer naturlichen Populationsregulation. Tagungsberichte 2. Internationales Gamswild-Treffen, Bled. pp.28-37.

Schroder,w.(1977b). Räuml1che Vertellung und Nahrungsauswahl von Gans und Rotwild im Hochgeblrge. Forstwissenschaftliches Centralblatt, 96, 94-99.

Schürholz,C.(1974). Quantitative evaluation of edge from aerial photographs. Journal of Wildlife Management, 38 , $913-920$.

Spetdel,G.(1975). Grundlagen und Methoden zur Bestimmung der wirtschaftlich tragbaren wildichte beim Schalenwild. Forstarchiv, 46, 221-227.

Sperber,G.(1975). Einfluss der Altersstruktur und Mischungsform von Waldern auf Bestand und Bejagbarkeit des Rehwlides. Allgemeine Forstzeltschrift, 30 , $1119-1122$.

Strandgaard,H.(1972). The roe deer population at Kal $\phi$ and the factors regulating its size. Danish Review of Game 
Biology, $7,1-205$.

Strandgaard,H.(1975). Rehbestand und Regulation der Rehdichte auf Kalö (ost-Jütland). Al lgemeine Forstzeitschrift, $\underline{30}$, $1129-1131$.

Telfer,E.S.(1974). Logging as a factor In wildlife ecology in the boreal forest. Forestry Chronicle, 50, 186-190.

Thomas,J.W., Miller,R.J., Black,H., Rodiek,J.E. \& Maser,C.(1976). Cuidelines for maintaining and enhancing wildife habitat in forest management in the Blue Mountains of Oregon and Washington. North American Wildlife Conference, $41,452-476$.

vité,J.-P.(1978). Forstschutz I (Pest Managerent). Unpublished manuscript . $60 \mathrm{pp}$.

Volz,F.(1975). Der Einfluss des Rehwlldverbisses bei der Begründung von Nadel- und Laubholz-Mischbeständen auf der Schwàbischen Alb. Diplomarbeit Forstwissenschaftliche Fakultät, Universität Frelburg. 

THE MANAGEMFNT OF RED DF.E.R IN PLANTATIONS

A.B. COOPER and W.E.S. MUTCH

Department of Forestry and Natural Resources, University of Edinburgh, The King's Bulldings, Mayfield Road, Edinburgh FH9 $3 \mathrm{JU}, \mathrm{U.K}$.

\section{SURMARY}

It is recognised that plantation forestry in much of Scotland will not proceed in deer-free conditions. Current research is aimed at designing control schemes which will reduce deer damage to acceptable levels. The effectiveness of these schemes in controlling red deer resident in forests will be severely limited, owing to a steady inflow of deer from the reservoir of adjacent hill areas. Outside the forests, 2,500,000 ha of deer range are maintained partly or primarily for sporting purposes, with 270,000 red decr stocked at densities of up to fifteen per 100 ha.

The high cost of fencing and deer control within the forest is usually borne by forestry, but continued forest expansion with further loss of deer range will escalate the deer problem, and the sporting estates may have to accept a greater responsibility for their deer. The confrontation of deer incerests and forestry will not be resolved until private estates adopt more positive management policies, and the diffuse expertise in deer, forestry and hill land use is concentrated to consider alternative allocations of hill land resources.

RÉSUMÉ

Le cerf sera toujours présent dans les plantations forestières de la majorité de l'Ecosse. Des etudes actuelles cherchent à etablir un systeme de contrôle du cerf qui réduirait les dégâts causés par ces animaux à des proportions acceptables. L'efficacité de ces systèmes de contrôle sera minimisée à cause de $1^{\prime}$ afflux constant de cerfs des collines 
avoisinances. Fin dehors des forets, 2,500,000 heclares de terres sont des réserves de cerfs, destinées partiellement ou totalement à la chasse et où la population de cerfs est de 270,000 à raison de quinze par 100 hectare.

Le coût très élevé des clôtures et des mesures de contrôle du cerf au sein de la forêt revient aux forcstiers, mais à l'avenir l'expension de la forêt, qui emplétera sur les réserves, ne fera qu'aggraver la situation et les propriétalies de cerrains de chasse devront assumer une plus grande responsibilité de leur cerfs.

Le conflit entre les intérêts de la foret et ceux de la chasse du cerf ne pourra Etre résolu que lorsque les propriétaires privés adopteront une politique de gestion plus positive et que les connalssances diffuses dans la gestion et l'aménagement du gibier, de la forêt et de l'espace rural seront mises en commun pour considérer les alternatives possibles d'une redistribution de $1^{\prime}$ espace rural.

\section{USAMMENFASSUNG}

In grossen Teilen Schotclands können sich Aufforstungen nicht unter 'wildfrelen' Bedingungen entwickeln. Gegenwärtig zielt die Forschung darauf $a b$, pläne $z u$ entwerfen, dic Wildschäden auf eine wirtschaftliche Schadensschwelle zu reduzieren. Die Effektivität, mit der diese Plane das in Wäldern lebende Rotwild vermindert, wird durch den stindigen Zugang von Wild aus den angrenzenden Berggebieten ausserhalb des Waldes stark eingeschränkt. 2,500,000 Hektar Wildreservoir werden zum Teil oder ganz zu Jagdzwecken unterhalten, wobei der Rotwlldbestand bei 270,000 , also 15 pro 100 ha 1 legt .

Die hohen Kosten der Errichtung von Täunen und der Wildschadensverhütung in den wäldern trägt gewohnlich die Forstverwaltung, aber mit der zunchmenden Ausdehnung der walder und der damit verbundenen Einbusse an Äsungsfläche wird auch das Wildproblem grosser werden, und die Jagdbesitzer werden wohl mehr verantwortung fur ihr Wild übernehmen müssen.

Der Interessenkonflikt 'Wild und Wald' kann erst dann gelost werden, wenn der Privatbesitz slch zu einer positiveren Wirtschaftspolitik 
bekennt und die diffuse Sachkenntnis in bezug auf Wild, Wald und Waldnutzung sich auf alternative Möglichkeiten der Verwendung des Berglandes konzentriert.

\section{INTRODUCTION}

Three quarters of the land area of scotland are classified as rough grazing. The primary use of this land is hill farming, with extensive grazing by sheep and cattle. Because of severe ecological constraints the output per hectare is low, and so it is in this area that plantation forestry can make its strongest claim as an alternative $l$ and use .

of the five willion ha of rough grazing, over half are occupied by red deer (Cervus elaphus L.) at varying densities, and on approximately a million ha deer are the primary product, providing sport shooting and venison. Even on those sporting estates where deer are run at relatively high densities, the level of physical output is considerably lower than that of sheep. On one estate where the aim is to maximize venison output, up to $1.4 \mathrm{~kg} / \mathrm{ha} / \mathrm{yr}$ of meat is removed, whereas in similar conditions sheep would be expected to yield at least $3 \mathrm{~kg} / \mathrm{ha} / \mathrm{yr}$. It is in areas reserved primarily for deer that the challenge from forestry is particularly clear and effective, given that environmental conditions make tree growth feasible.

In practice, however, the afforestation of deer range is far from simple. Forestry can entirel y supplant hill farming by excluding sheep and cattle, but it is now clear that it cannot hope to exclude red deer. When the forester acquires deer range he also acquires a deer problem.

It is a measure of this problem that forest planting in Scotland is virtually never attempted within deer range without deer fencing. From the outset protection measures are necessary to establish deer free conditions, but these are short-lived. Although the forester may continue to live and work in the bellef that his plantations are deer-free, deer generally become established.

A concerted programe of research in Scotland, involving the Institute of Terrestrial Ecology, Forestry Commission, Red Deer Commission and others is now under way to provide information on how this endemic deer problem can be brought under management control.

The damage which red deer can do in plantations is well known. Seedlings are destroyed, growth is checked by heavy browsing, and stems are stripped of bark. The ideal plantation would develop by rapid and even growth but this is seldom possible and an uneven age or growth structure in a forest offers red deer a desirable habitat, with shelter and cover in thickets and clearlngs which they will maintaln for. themselves 
by preventing further tree establishment.

It may seem that if deer were fully recognized as a site factor before plantations were attempted, then properly planned deer control, including concessions in the lay-out of the plantations, could accommodate the deer problem. Indeed this is worthwhile and many foresters are now thinking along these lines, but it does not take account of the wider problem which exists in Scotland and is not paralleled in any country we know. We have a vast reservoir of red deer outside our forests.

To review the implications of this for Scottish plantation forestry one should consider:

1. The scale of the red deer problem.

2. The nature of afforestation in relation to the rest of the deer range.

3. Land tenure and the responsibility for deer.

\section{THE SCALE OF THE RED DEER PROBLFM}

The national red deer herd numbers between 270,000 and 300,000 . These are almost entirely located on sporting estates or other privately owned Iand. The population has been allowed to increasc by about 40 per cent in the last ten years (RDC reports), largely in response to a dramatic rise in the value of the deer products of sport shooting and ventson. Currently (1978) the price charged for shooting an average stag is between $\Sigma 80$ and $\Sigma 100$ and a 12-pointer more than $\mathcal{E} 160$ (Forestry Commission, pers. comm.) and its carcase will fetch about $\boldsymbol{E} 80$. The increase in the per caplta value of red deer has encouraged land owners to increase the 1 r deer stock and there are now probably more red deer than ever before in historical times.

Owing to the mountainous nature of the terrain that deer occupy and the wide dispersion of the resources they need, particularly shelter, red deer on the open hillside have to be extremely mobile. In contrast to woodland deer which can find most of their habitat requirements within easy reach, hill deer may have home ranges as large as $60 \mathrm{sq.km}$. This in conjunction with the large scale topography of the Highlands and the increased numbers of deer, cause long distance movement of large herd groups. Although the average estate extends to about 7000 ha, the deer usually move freely over the estate boundaries, so that the effective deer management unit can seldom be identifled as the responsibllity of one estate alone (itutch, Lockie \& Cooper 1976).

Most of the land which deer use is unsultable for afforestation. Whereas the main mountain ridges lie at elevations between 1000 and $1300 \mathrm{~m}$, the limit of economic tree planting is approximately $600 \mathrm{~m}$. It is estimated that 450,000 ha lie above this contour, which is 6 per cent of the land surface of Scotland. 
Red deer make good use of high ground, but they need low 8 round within their range, particularly in winter. The average density of red deer in the Highlands is about 10 per 100 ha, but in heavily stocked areas fifteen per 100 ha is not unusual (Mitchell, Staines \& Welch 1977). Snow frequently covers all range above $300 \mathrm{~m}$ betweer November and April and deer are then concentrated for lengthy periods on low ground; in these conditions densities may exceed ten to the hectacre.

It is into this widespread and intensifying matrix of deer use that plantation forestry is being inserted. Although it is unwise to consider continental management as being directly applicable in Scotcish conditions, it is worth noting that foresters there generally aim to balance deer stocks against a level of damage which is regarded as acceptable (i.e. financially less than the revenue the deer bring in). In practice this means maintaining deer densities of only two or three per 100 hectares (Phillips \& Mutch 1974).

\section{AFFORESTATION IN RELATION TO DEER RANGE}

Of managed woollands and those due to be planted (by Forestry commission and private owners), 70 per cent of the total area lies within red deer range (Fig. 1). New forests wust be protected by deer fences which wight present an obstacle to hundreds of deer in their attempt to make full use of their accustomed range. But once the plantation is established it is improbable that the fence will remain an obstacle for very long.

Firstly, there is a strong incentive for deer to get through the fence from a generally inhospitable, exposed and 'hungry' environment to an increasingly hospltable, sheltered and 'well-fed' environment.

Secondly, fences deteriorace. Even in apparently good fences small weaknesses such as slack wires or faulty water gates are quickly discovered by deer.

Thirdly, in exceptional but forsecable conditions, fence lines will be bridged by snow drifts allowing hundreds of deer to walk over.

It is Inevitable that deer will take up residence in plantations. While we agree that rescarch to determine acceptable densities of resident deer is urgently needed, we believe that the presence of the large reservoir of transient hill deer is a problem which will continually thwart attempts to bring about proper management and control of deer in forests. As long as foresters underestimate the dimension of the deer problem or pin their faith on the inadequate technology of the deer fence and the rifle, the greater that problem will become.

The present forest structure is attractive to deer and vulnerable to damage. 56 per cent of all managed woodland in Scotland has been planted since 1960. Most of this, and most 
of future planting, which could amount to 1.8 million ha (Locke 1976) is, or will be, in deer range. Lodgepole pine, which is particularly susceptible to bark stripping, will probably constitute the largest proportion of first rotation planting in red deer range.

Foresters are rapidly creating a habitat which a quarter of a million red deer would like to get into.

\section{LAND TENURE AND RESPONSIBILITY FOR DEER}

Because most of the national deer herd is maintained under private control, foresters have little influence on the source of their deer problem. The land use objectives of estate deer management and plantation forestry are directly opposed.

When the deer range and forest plantation are in single ownership, the issue may be resolved by the owner deciding which objective is to be sacrificed. An issue seldom mentioned is that of the 'private' plantation which takes second place to deer but which has been committed to the dedication scheme and supported by planting grant and management grants.

Usually, however, the forest and the deer range are in seperate ownerships. Difficulties and bad feeling frequently arise. In contrast to the situation in, for example, Germany and Austria, there is in Scotland a very slight requirement for the proprictors of deer ranges to collaborate in management. Estate owners can pursue their own objectives regardless of the needs of their neighbours.

It is largely due to the use of the hill areas as grazing for sheep and deer that practically all of the range available to them is devold of trees. The grazing pressure has intensified in the last 150 years but neither sheep farming nor deer management as now practised can be regarded as a truly indigenuus land use. So it is ironic that forestry in trying to re-establish tree cover, should be regarded as an innovation.

As an innovator, the forester has to labour under many disadvantages. Although he might acquire a complete sheep farm, it is unlikely he would ever acquire, fence and afforest an entire deer management un $1 \mathrm{t}$, even in a large scale state forest. It is very seldom that all the deer in an afforestation area will 'belong' to the new foresty proprietor; some will 'belong' to nelghbours.

The burden of deer on forest management is six-fold:

1. The presence of deer as a site factor restricts the cholce of tree species that can be planted. An increasing level of deer population progressively precludes the planting of the more vulnerable and palatable species though these may be the most productive or the most sultable in other respects. At later stages of 8 rowth such species as lodgepole pine and spruce are at risk due 


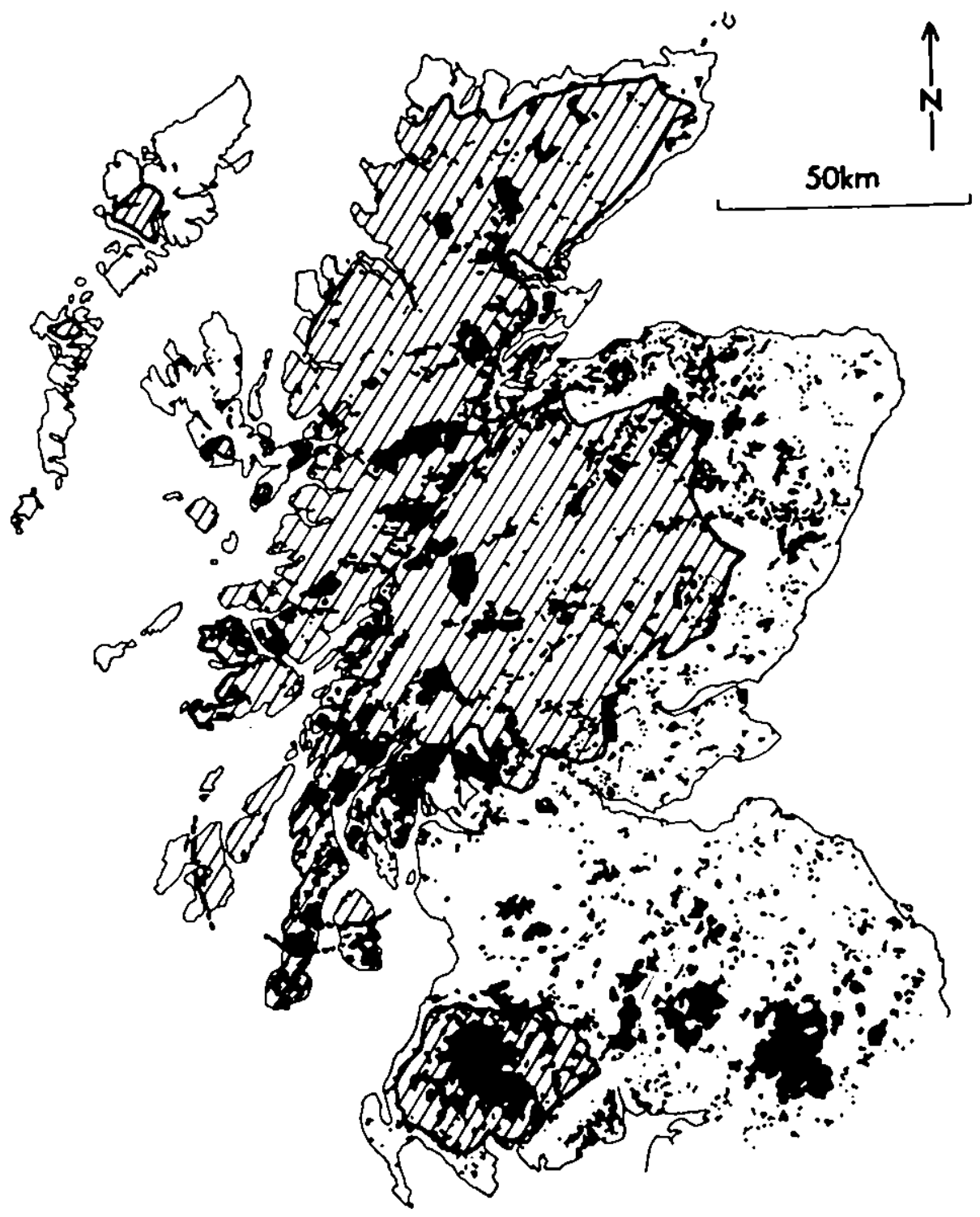

Fig. 1. The red deer range in Scotland (hatched area) and the currently planted areas of forest (solid black). $70 \%$ of the land due to be planted lies within the red deer range. 
to bark stripping.

2. On the basis of experlence on the European Continent deer densities of more than two or three per 100 ha may impose a browsing pressure which reduces early growth, and extends the rotation. Conseqently there is a delay in the receipt of cash from intermediate and final fellings. 3. While a small population of deer in an easily accessible forest of reasonable fertility and diversity, such as Grizedale in Cumbria, can offer the possibility of quite lucrative sport shooting to continental standards, the need to control resident populations in large and remote forests requires the employment of a professional cadre of rangers. At a unit cost of about $\not 5000 / y r$, even the time spent on deer control, excluding other duties, cannot be met by revenue from venison and occasional fees for sport stalking.

4. The pressure of deer at high densities iroposes restrictions on forest management options by precluding the planting up or regeneration of small clearings in the forest, as might be deslred in a group selection system or required by patches of windblow. The forest must then be re-established in relatively large units, and experience with roe deer in northeast England suggests that each of these may have to be fenced separately, even though the forest as a whole is ring-fenced. In this way the deer can be shot out frow the regeneration area to re-create the deer-free conditions required for the first few years of the tree's life. This procedure is very expensive.

5. Fencing represents a continuing cost, a carrying charge to scrvice the captal cost, plus raintenance.

6. A forest boundary fence is needed to keep out animals frow neighbours' properties and is crucial where these are stocked at rates infmical fo forest establishment. But in addition, the forester is forced into further cost and compromise. In deer range he is obliged to break up large forest blocks to provide corridors for movement of deer herds. This reduces the amount of plantable land he can put under trees, and signiflcantly increases his fencing costs; these are now $\angle 2 /$ m for erection. Owing to the break-in of deer from the outside reservolr forestry has to provide more labour for deer control than would be needed for the control of an endemic population.

\section{OPTIONS}

The costly constraints forestry must accept in deer range, and the compromises it must make, are a recognition that deer production is a major land use. However, this is measured more in terms of geographical scale than output or of employment. The national output of red deer meat is only in 
the region of 1500-2000 tons/yr, compared with 23,500 tons derived from hill sheep (Cunningham et al. 1978). It is questionable whether forestry diminishes that output. We estimate that from managed woodlands between 0.3 and 0.6 $\mathrm{kg} / \mathrm{ha} / \mathrm{yr}$ of venison is produced. This includes roe venison, not normally a product of hill range and compares favourably with our estimate of $0.6 \mathrm{~kg} / \mathrm{ha} / \mathrm{yr}$ from a sample of deer estates covering 200,000 ha.

In terms of employment, a similar comparison shows that about 69 ha of sustained yield forest currently supports one worker (Wolfe \& Caborn 1973) 4000 ha of open deer range would be needed to offer the same job opportunities (Mutch, Lockie \& Cooper 1976).

We question the ability of the wood producer to practise effectively in the teeth of the present deer problem. It is becoming clear that management practices which are based on prior decisions of choice, are not always effective either in forestry or animal production. Flexibilicy is needed in the selection of management strategies in view of regional differences in the relative importance of wood and deer production.

Where forestry is identified as the major land user, then the problem presented by deer outside the forest should be reduced to at least the level found to be acceptable in the management of resident forest deer. This means that the reservoir of hill deer should be reduced so relieving the pressure on the forest. A two-way traffic could possibly be allowed, with the forest as part of the nomal deer range, and control of numbers could be more easily effected on the open hill. Ultimately the successful application of the principle of equating deer densities in the forest and on the hill would allow the forester to work without deer fencing his plantations with a great saving of cost.

In other regions planting would be secondary to the primary use by deer, and this particulary where the cimber potential is limited or where there are marketing difficulties. Here forest developent would be judged by 1 ts contribution to deer as the major use, by providing shelter, etc.; new planting and regeneration would certainly require protection by deer fences and the forester would accept the cost implications of protection and of periodic damage.

With the true dimension of the deer problem now becoring apparent, however, it also appears that where production forestry is the major user, it should not be required to compromise in favour of low output deer management. In the present situation deer estates should accept some responstbility for the problem they exacerbate. If they cannot sustain or contain their deer they should participate in the cost of forest protection.

Responsibilicy for red deer in Scotland does not lie with 
the national forest authority, as it does in most countries, but with the Red Deer Commission. This is a very small organisation in relation to the size of the red deer population and the area it occupies, and it is scarcely effective in influencing the decisions of individual private estates. There is hardly any sanction which can be applied if a proprietor acts irresponsibly. Sharp conflicts can arise when, for instance, excessive numbers of deer are maintained on land adjacent to forest or agricultural development.

Considerable research effort has been applied to red deer ccology and management but there is a wide dispersion of expertise and a division of research responsibility. Research has been undertaken, or financed, by the Natural Environment Research Counc11, the Institute of Terrestrial Fology, the Red Deer Commission, Forestry Commission, Highland and Islands Development Board and several universitles. There is a need for coordination to ensure that only desirable overlaps occur. There is also an urgent need for a thorough review to determine the division of administrative responsibilities and to rectify the divorce of those with responsibility for deer and those with responsibility for the major land uses of farming and forestry.

\section{REFFRENCES}

Cunningham,J.M.M., Eadie,J., Maxwell,T.J., \& Sibbald,A.R. (1978). Inter-relations between agriculture and forestry; an agricultural view. Scottish Forestry, 32, 182-193.

Locke,G.M.L.(1976). The place of Forestry in Scotland. Forestry Commision, Edinburgh.

Mitche11,B., Staines,B.W. \& Welch,D.(1977). Ecology of Red Deer. Institute of Terrestrial Ecology, Cambridge.

Mutch,W.E.S., Lockle,J.D., \& Cooper,A.B.(1976). Red Deer in South Ross. Department of Forestry and Natural Resources. University of Ed Inburgh.

Phillips,J. \& Mutch,W.E.S.(1974). Red Deer in Woodland. Published by the Authors, Edinbrugh.

R.D.C. Red Deer Commission Annual Reports 1967-77. Her Majesty's Stationery Office, Edinburgh.

Wolfe,J.N. \& Caborn,J.M.(1973). Some considerations regarding forest policy in Great Britain. Forestry Commitcee of Great Britain, London. 
September 8, 1978

\section{FOREST DESIGN: THE FUTURE DEVELOPMENT OF F.VEN-AGED PLANTATIONS}

Chairman: C.J. Taylor

The future development of even-aged plantations:

Management implications.

E.J.M. Davies

The future developwent of even-aged plantations:

Silvicultural implications.

D.C. Malcolm

Tropical forests - comparisons and contrasts.

P.G. Adlard 
THF. FUTURE DEVELOPMFNT OF EVEN-AGED PLANTATIONS: MANAGEMENT IMPLICATIONS

BY E.J.M. DAVIES

Conservator for Southern Scotland, Forestry Commission, 55 Moffat Road, Dumfrles, U.K.

\section{SUMMARY}

This paper argues that British foresters have been slow to emulate good agricultural practice and outlines the standard regime-based silviculture that has been evolved in the Southern Scotland Conservancy.

It is suggested that with higher inputs of fertilizer, timber yields may be greatly increased to considerable economic advantage. It stresses the need for further research as being a matter of urgency.

RÉSUMÉ

Nous montrons dans cet exposé que les forestiers britanniques ont été lents à utiliser des systèmes agricoles convenables et nous décrivons la gestion et la sylviculture que nous pratiquons au sein de la Forestry Commission dans le sud de l'Ecosse.

Nous suggérons qu'une fertilisation ä des doses plus èlevées d'engrals amélioreralt la production en bols qui deviendratt economiquement plus rentable. Nous considérons aussi que des recherches plus poussées sont non seulement urgentes mals aussi necessalres.

\section{ZUSAMMENFASSUNG}

In dieser Arbelt wird die These aufgestellt, dass die britlschen Forstleute nur sehr langsam neue Entwicklungen in der landwirtschaftlichen Praxis auf ihre forstliche Bedeutung hin überprüfen werden. In grossen zùgen werden dle von der südschottischen Forstverwaltung entwickelten und standardisierten Waldpflegemassnahmen erlāutert.

Es wird darauf hingewiesen, dass bel verwehrtem Elnsatz von Dingemitteln die Holzerträge erheblich gesteigert und somit eine 
beträchtliche

Verbesserung

der

Betriebsergebnisse erziclt werden konnten.

Ferner wird betont, wie dringend es ist, dic

Forschungsarbeit auf diesem Gebiet zu

intensivieren.

\section{INTRODUCTION}

I felt very honoured when the organising comattee asked me to contribute to this Conference, but I must erphasize from the beginning that the views which $I$ am putcing forward are personal and have been formed as a result of some twenty years experience of afforestation, firstly in the upland of Wales and then on the mountains and hills of western and southern Scotland.

One is acutely aware that although the science of forestry is still in its infancy, it is somewhat handicapped by tradition. Perhaps some of the reasons for this can be found in the academic background of university lecturers in Europe. Most of the great teachers, men like Brandis and Schlich, in Victorian times, were concerned for the management, maintenance and conservation of the great forests of the world and trained students to lonk after these. There was litcle plantation forestry taughe and, in scotland in particular, this crait persisted until recent years. Therefore, those of us who were in the afforestation business were launched into British forestry somewhat inadequately trained and unaware of the tremendous agricultural and horticultural innovations which were current and which were of great significance to us. Over 80 per cent of the sites that had been planted in Scotland in the last twenty-five years had not grown timber crops for more than 300 years, and it has taken British foresters a very long time to realise the dowintion they have over their sites using techniques developed from aglcultural practice. My outlook, therefore, it that of the tree farmer (Davies 1971).

Furthermore, it is clear that the future lies largely in plantation forestry and, unless foresters become more involved in inproving the yield of their man-made woodlands, the rapidly increasing demand for timber from an exploding world population cannot possibly be satisfied.

Now I must admit that this particular tree farmer has been fortunate to practise his forestry in areas where the heavily yielding Sitka spruce (Picea sitchensis) grows fast and well, and as a manager my prime purpose is to grow spruce sawlogs for industry. Most of these will be grown on a thinning regime with a rotation of between thirty-five and fifty years, and wll reach a height of between 20 and $25 \mathrm{~m}$ with a mean diameter at breast height of $30 \mathrm{~cm}$. 
THE POTENTIAL OF SITKA SPRUCE.

There are huge opportunities to increase productivity way, way beyond the dreams of the early pioneers. Most of the Forestry Comission woodlands in my particular parish luckily consist of Sitka spruce and at a recent re-assessment we found that their average yield class was $12 \mathrm{cu} . \mathrm{m} / \mathrm{ha}$.

The recorded range of growth for Sitka spruce in the U.K. runs up to yield class 24 , a very heavy yielder indeed, and I believe that $1 \mathrm{t}$ may be exceeded. I recently measured some plantations growing at yield class 30 and these were on a far from fertile, exposed site 250 m above sea level. And fust before that I had the pleasure of re-editing the journals of that great hotanist, David Douglas (1914). 150 years ago he wrote of Sicka spruce:

"The appearance of this species closely resembles Picea douglasil; although neither so large nor so plentiful as that species, it may nevertheless becoue of equal if not greater importance: it posseses one great advantage by growing to a very large size on the northern declivities of the mountain in apparently poor, thin, damp soils; and even in rocky places where there is scarcely a sufficiency of earth to cover the horizontal wide-spreading roots, their growth is so far from being retarded that they exceed one hundred feet high and eight feet in circumference. This unquestionably has great clatms on our consideration as it would thrive is such places in Britain where even Pinus sylvestris finds no shelter. It would become a useful and large tree".

In the last fifty years Douglas' prescience has been vindicated, but we are still a very long way from maximizing our investment in the species.

\section{THE. RF.QUIREMENT FOR FERTILIZER}

I have an obsession with tree nutrition. For fifty years research work in nutrition was concentrated on the infertile lands and not on the moderate or good lands which farmers had learned by long experlence were far more remunerative. It was not until the 1970 s that any worthwhle research effort was undertaken on the better sites, and we still do not know their true potential. Recent re-assessments have been promising in many instances and in pole-stage crops there have been some remarkable reactions to fertillzers in timber volime (Davies 1969; Miller \& Cooper 1973; Dannatr, Davies \& McCavish 1971; Macintosh 1978).

In the late ' 60 s some extraordinary responses to phosphate were recorded in Argyll on surface water gleys and brown earths. Macintosh (1978) recorded an increase in leader length of 48 and 80 per cent for brown earths and surface 


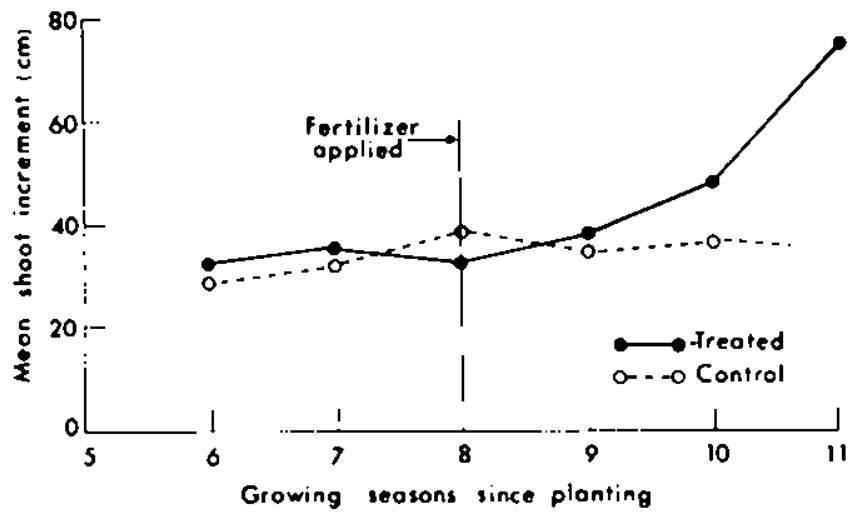

Fig.1. Tree leader increment after planting on a brown earth soil. Phosphate fertilizer was applied at year 8 .

water gleys respectively over controls in Glentrool Forest (Figs, 1 and 2).

An example of how British foresters have been slow to follow agricultural practice may be seen in their attitude to forest nutrition. The early research workers were men of considerable vision and they considered that the frontiers of plantabilfty were a major challenge. Good land was to be had in abundance, but much of their excltement lay in extending the tree line further up the hill, and in developing techniques to afforest the mfllions of hectares of deep, infertlle peat land that is such a feature of our British uplands. For nearly fifty years nutrition research was 


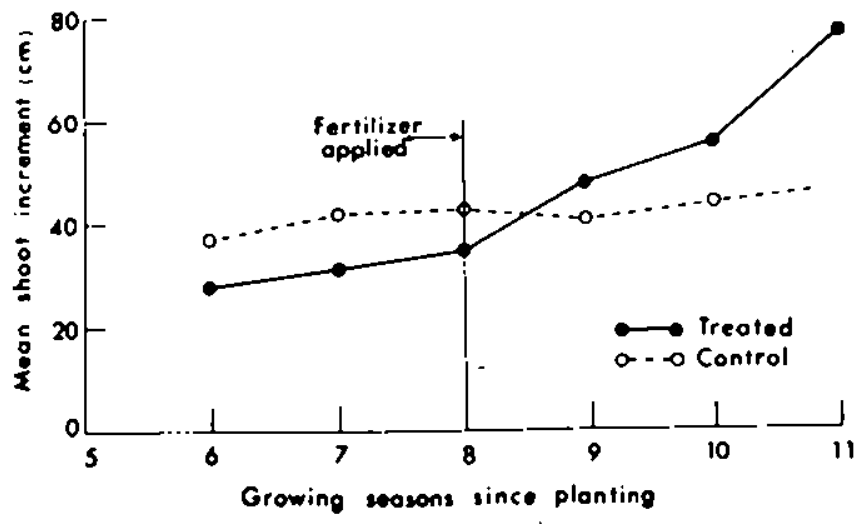

Fig. 2. Tree leader increment after planting on a surface water gley soll. Phosphate was applied at year 8 .

concentrated on these infertile lands, and the nutritional needs of richer ground ignored. The commerclal farmer on the other hand maximizes his yleld on his good ground before he breaks in the marginal land. Thus, at the present time, al though we have learned to establish plantations on very poor land, we are still unaware of what can be done to Improve the richer 1 and $s$.

The need to get trees to start well was quickly recognized, but once established, crops were of ten neglected, and because regimes had not been worked out, $g$ rowth became slower and slower. 


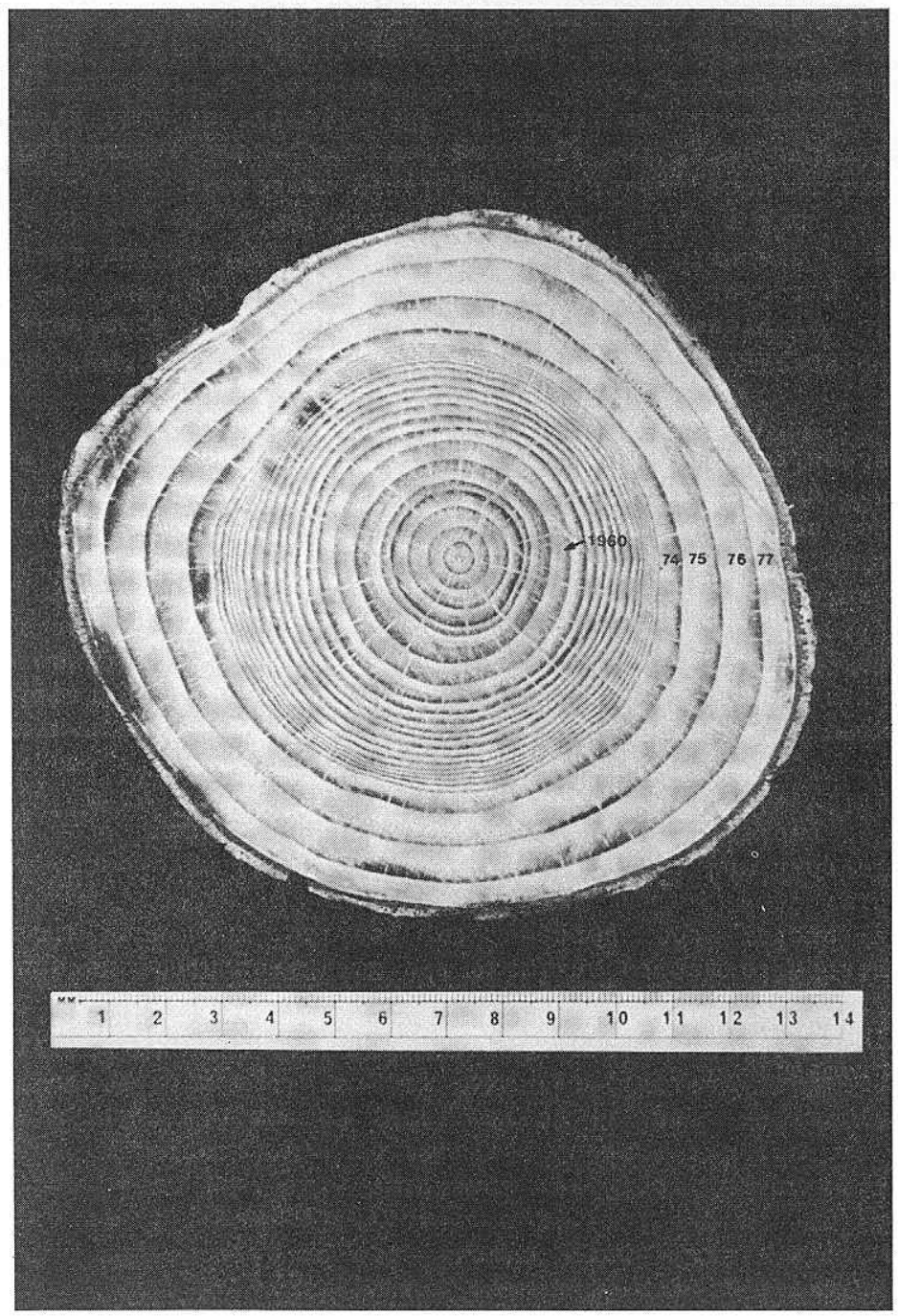

Fig. 3.

Figure 3 illustrates this. It is a disc taken from a Sitka spruce plantation grown on deep unflushed peat in Glentrool. Planted in 1952, it received a standard dose of phosphate in the first year. By 1960 growth had slowed right down because the nutrients had become exhausted. In April 1973 the crop was treated with PK and by 1977, when the specimen was taken, the basal area had increased from 60 to $140 \mathrm{sq} . \mathrm{cm}$. At least ten years have been lost though. Would any good farmer neglect his permanent grassland in such a manner? 


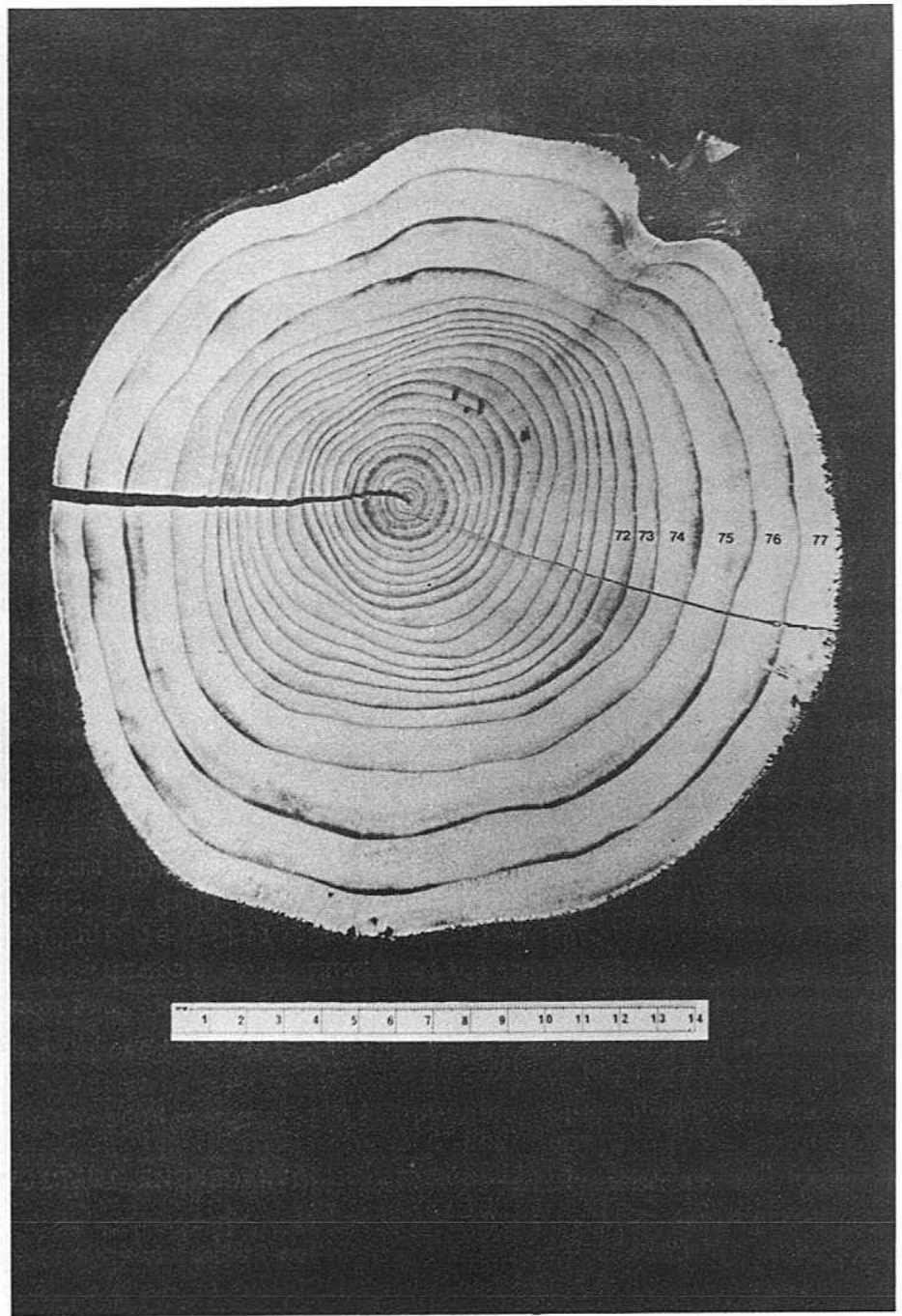

Fig. 4 .

Figure 4 is also from Glentrool. It comes from a low-lying, deep flushed peat site, which is reasonably fertile. Planted with Sitka spruce in 1954, when it received a standard dose of phosphate, it grew away moderately well and kept going. In April 1973 it received PK fertilizer and there has been a remarkable response. Cut in November 1977, the basal area had increased by 280 per cent in five years. This illustrates how foresters may easily be satisfied by moderate growth on a potentially high-yielding site. 


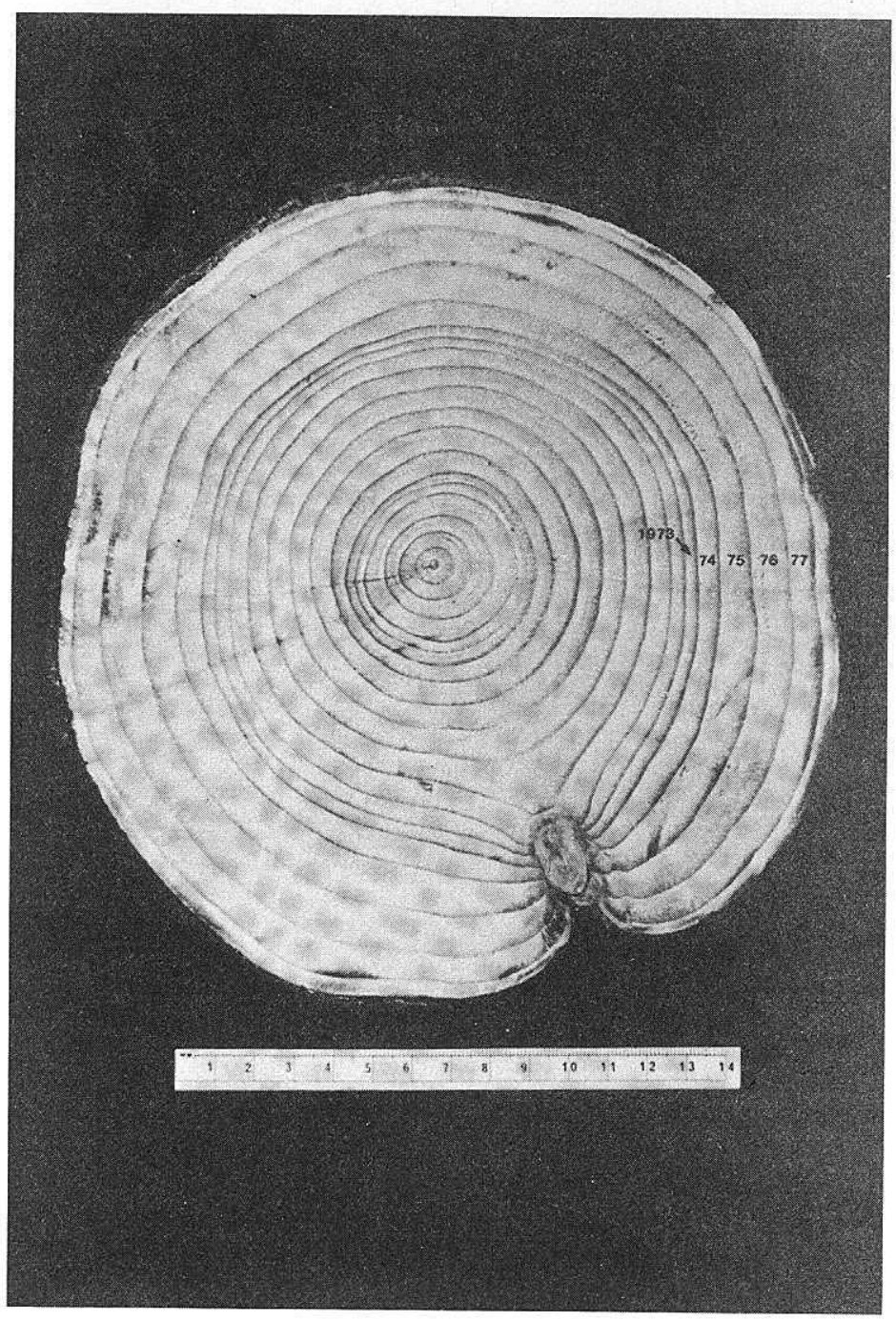

Fig. 5 .

Figure 5 comes from Arecleoch Forest, Ayrshire, about ten miles to the northwest of Glentrool. Sitka spruce on a surface water gley, planted in 1958, there is no record of it receiving any fertilizer at planting. In 1973 it was growing well and had reached thicket stage. Nevertheless the foliage colour was not very good and it was decided to treat it. In October 1973 it received $575 \mathrm{~kg} / \mathrm{ha}$ of $\mathrm{P}$ and this was followed in May 1974 with a nitrogen dressing ( $350 \mathrm{~kg} / \mathrm{ha}$ of prilled urea). In November 1977 the plantation was thinned (yielding 
$50 \mathrm{cu} . \mathrm{m} / \mathrm{ha}$ ) and leaders of over 1 m long were not uncomon amongst the felled trees. This specimen was cut in June 1978. The plantation, which is now managed on a regime basis, is due for a further PK dressing next year. Examination of $r$ ing width indicates that there was a falling off in growth in the carly 1970 s and makes one apprciate that we could have had even betcer growth from the beginning if we had been using a suitable fertilizer regime from the start.

\section{EVOLUTION OF A SILVICULTURE FOR INCREASF.D PRODUCTION}

Since 1972 we have been managing Arecleoch Forest on a high input regime and the results are already dramatic. For example, a 1966 Sitka plantation growing at 320 above sea level in considerable exposure is growing at yield class 20 following standard treatments of P, PK and nitrogen. With old low-input regimes the predicted yield class would be about 10 or 12 .

In another compartment at $220 \mathrm{~m}$ above sea level, 1969 Sitka spruce has recelved $P, P K$ and $N$ and has leaders in excess of $100 \mathrm{~cm}$. This crop will, if it keeps going, have to be thinned at fifteen years old. It is due for a further treatment with PK next year. With traditional methods it is unlikely that yield class 14 would have been exceeded.

We can demonstrate that this intensive silviculture is highly profitable (Edwards 1974). The Net Discounted Revenue calculations show substantial profits for the tree farmer if at the cost of four extra treatments of $P, N, P K$ and $N$ one can raise yield class 12 to yfeld class 18 . In one can raise yield class 14 to yield class 24 the net gain is of the order of 500 per hectare.

During the last fifteen years I have been carrying out large programmes of aeral fertilization in western and southern Scotland. Since 1972 in South Scotland we have treated over 84,000 ha of established plantation with fertilizers (Davies, Garforth \& Macintosh 1978).

$$
\text { ha }
$$

$$
\begin{array}{lr}
\text { P } & 48,759 \\
\text { PK } & 31,302 \\
\text { N } & \frac{3,971}{84,032}
\end{array}
$$

In addition some 5,000 ha of Calluna dominated sites have been treated with weedklller to release nitrogen during the period. The responses that we have had greatly exceeded our expectations and I have come to certain conclusions and generalizations based on our own investigations and on research work in the U.K. and abroad. As far as Sitka spruce is concerned:

1. Virtually all the soll types being afforested in south and west Scotland are phosphate deficlent for optimum 
tree growth.

2. Virtually all the soll types being afforested that have a humus layer of more than $15 \mathrm{~cm}$ in the same regions are deficient in potassiom for optimum tree growth.

3. One may expect greater returns from fertilizer applications in the wetter parts of these reglons than in the drier, eastern parts where rainfall is less than $800 \mathrm{~mm} / \mathrm{yr}$. Soll molsture in spring and carly sumer seems critical to effective nutrtent uplake in many crops.

4. It is wasteful to add nitrogen to a tree crop unless its PK status is right.

5. Pole-stage crops of Sitka spruce are frequently highly responsive to the addition of fertilizer, but this response should be recorded by volume measurements, as height increments at this stage can be misleading.

6. Moreover, the older the tree, the less 1 fkely it is to show basal area response. Response is to be looked for on the trunk just below and in the live crown, with a valuable improvement in form factor.

- I believe that fertilizers applied to spruce crops before canopy closure tend to result in more uniform crops. After canopy closure. I believe that the reverse applies, competition increases, and the big dominants tend to accelerate away from the rest. If one dares not thin a crop because of the probability of wind damage, one normally ends up with a high stocking of rather small trees with low sawlog concent. If one fertilizes after canopy closure one should end up with a number, perhaps $200 /$ ha, of big trees scattered through a matrix of pulpwood and small sawlogs, with a higher out-turn of valuable material, besides, of course, shortening the rotation.

8. There is no reason why trees growing fast when, say, 5 m high, cannol be kept on a high growth curve provided that there is no biological disaster, e.g. Insect attack, and that nutrients and soil moisture requirements are met. This is the most important concept of all and is central to regime fertilization.

There is, of course, still a huge amount to be learned about tree nutrition and the inter-reactions of soll moisture, temperature, provenance, sunlightetc. Nevertheless, could it be that we are, as I believe, on the edge of a major breakthrough in the economics of investment in forestry? What are the implications to our silviculture? Could it be, as I believe, that in the wetter west of Britain we can already grow crops of an average yield class of 20 or better? If so, we should cut our rotation by twenty years and, provided that a site is properly rootable, the investor would only be buying a climate! I feel sure the future I.U.F.R.O. meetings will become increasingly concerned with climatic limitations on 
tree growth.

If one accepts that one now has a rewarkable dominion over the site, except for cilmate, we must seek, in the cconomist's terms, to maximize the Net Discounted Revenue. I rather prefer the phrase to realize the econimic site potencial'.

To this end foresters in south Scotland have been issued with a table to enable them to judge current tree growth cricically. We have taken yield class 16 as the norm, and if current leader lengths fall below the appropriate length for the age of the crop, foresters should ascertain the reason. It is only a beginning but it is a step in the $r i g h t$ direction.

We have a multiplicity of experts and researchers investigating their own subjects in depth, and not always being able to relate their work to the whole. I believe that the time has come for the general manager to weld all these together and, like the great victorian scientists such as Darwin, who could see all creation as one, prescribe a comprehensive, if somewhat imperfect treatment, simple and clear.

\section{A STANDARD SILVICULTURF.}

In my present area, which is the south of Scotland, less than 10 per cent of the solls are free draining, and we have evolved a standard silviculture. During each of the last five years we have planted between 5000 and 6000 ha using these standard methods, which are regularly reviewed.

Firsty, after the land has been acquired, a detailed soil map is prepared. We recognize six significant soll groupings and three elevation zones which, multiplied cogether, mean eighteen possible sites (sce Toleman, this voluge). With this knowledge actual treatment types are decided on and defined by markers on the ground. The area is fertilized from the air with either $375 \mathrm{~kg} / \mathrm{ha}$ of course rock phosphate (ca. 13 per cent P) or $575 \mathrm{~kg} / \mathrm{ha}$ of rock phosphate/muriate of potash mixture (PK) if the soil has a noticeable peat content. It will then be cultivated by double mouldboard ploughs, which may or may not be fitted with tines designed to penetrate into the subsoll, and cross-drained. The area will normally be planted with Sicka spruce transplants at ca. 2m spacing, and little or no weeding is needed on all but the sites with the most vigorous growth of ground vegetation. We may have to apply more fertilizers before canopy closure and certainly should late in the $11 \mathrm{fe}$ of the crop. For example, on the most infertile site that we encounter, the deep unflushed peats whlch account for some 22 per cent of our plantable reserve, we expect to add PK at planting; nitrogen at year 4; PK at year 6; PK at year 12; nitrogen at year 16 and NP at year 20. our object is to get the crop growing fast from the very start and keep it growing fast. Regimes have been worked out for 
each of the elghteen sites.

When the crop reaches about $10 \mathrm{~m}$ in helght, we carry out a first thinning. This is what we call mechanical - plus worker selection: in the simplest terms we remove one row in every nine and thin some of the trees between these rows. Five years later, at perhaps age twenty-five, we carry out a second chinning and this is aimed at evening up the crop and removing any dominant, mis-shapen trees. It is done selectively and the marking is done by a forester or skilled worker. Five years later we thin the crop again. This may be the ultimate thinning or there may be even a fourth thinning. Both these latcer chinnings are 'low' thinnings almed at making the crop as even as possible and simplify the final product mix. Cleafelling would nomally follow ten years after the last thinning and we tend to favour large coupes of 10 to 100 ha where landscape and conservation interests permit. large coupes reduce edge effect losses from wind and grazing. After clearing we plant straight through the lopped branch waste left on the ground and the whole process starts again.

\section{A SPFCIFIC EXAMPLE OF THE STANDARD SILVICULTURF.}

Let me illustrate what I mean by reference to a bare grass/heather moorland site in a forest in southwest Scotland, $250 \mathrm{~m}$ above sea level, south-facing; solls mixed, but chiefly flushed and unflushed deep peat, moderately exposed. A modern regime would mean:

Year 0 Apply PK fertilizer at $575 \mathrm{~kg} / \mathrm{ha}$. Cultivate with double mouldboard plough $40 \mathrm{~cm}$ deep, 4 m centres; remove puddled water only by drainage. Plant say Washington provenance Sitka spruce at 2 m spacing.

Year 4 Add $\mathrm{N}$ as $350 \mathrm{~kg} / \mathrm{ha}$ prilled urea. In autumn re-space, cutting ca. 400 trees/ha concentrating on vigorous trees showing poor genetic qualities.

Year 6

Year 12

Add PK at $575 \mathrm{~kg} / \mathrm{ha}$.

Year 14

Add PK at $575 \mathrm{~kg} / \mathrm{ha}$.

Year 15

Road area for extraction

Thin mechanically with worker selection to

1100 trees/ha. Yield $50 \mathrm{cu} . \mathrm{d} / \mathrm{ha}$ chlefly pulp wood.

Year 16 Add $\mathrm{N}$ at $350 \mathrm{~kg} / \mathrm{ha}$ prilled urea.

Year 20 Thin selectively to 800 trees/ha. Yield $50 \mathrm{cu} . \mathrm{m}$. Add $P K$ after thinning at $575 \mathrm{~kg} / \mathrm{ha}$.

Year 25 Low thinning reducing crop to 500 trees/ha. Yield $100 \mathrm{cu} . \mathrm{d} / \mathrm{ha}$. This will contain at least 75 per cent of sawlog material, the rest pulpwood.

Year 26 Add $\mathrm{N}$ at $350 \cdot \mathrm{kg} / \mathrm{ha}$ prilled urea.

Year 35 Clearfell. Height $20 \mathrm{~m}$. Volume $500 \mathrm{cu} . \mathrm{m} / \mathrm{ha}$ Mean diameter $30 \mathrm{~cm}$.

Those conversant with our Forestry Commission Forest Management Tables (Hamilton Christle 1971) will note that 
the total production per hectare at thirty-five years old, under normal regimes, some 790 trees, is not reached. Under the regime advocated, total volume would be reduced, but individual trees removed in thinnings and clearfelling would be larger and obtained more quickly.

\section{HAZARDS TO FOREST PRODUCTION}

This standard silviculture is siople and straightforward but one would be idle to assume that it will not be tailored to meet special circumstances. For instance, some of our areas will not be planted with spruce, but with larch and hardwoods for amenity and wildife purposes. Some of the areas which have been planted on unstable solls will not be thinned, bit the great thing is this: to impress on managers at all levels concerned with the production of wood, the simple central concept that they are in business to produce standard spruce sawlogs for industry, and the skill of the forester can be measured in the way that he succeeds in dominating the environement and, most important, leaves casily managed forests to his successors. All of us have experienced the due consequences of over-elaborate management systems which can be so vulnerable to changes of circumstances or staff.

I know that the charge is often made against the tree farmer that life is not as sinple as he would have you believe. But a senior manager must simplify and whereas a research worker may well be concerned in detecting and recognizing differences, the manager is concerned in consonance and transmiting sensible concepts and precepts to his staff.

I admit that great technical difficultics beset the British forester. Just to plck out three: and of these three I think that wind and exposure will dominate our silvicultural thoughts and actions for as long as men try to cultivate trees in these extraordinary windswept islands. Those of you who are new to the British scene are possibly unaware of the extent of this problem. The Western Isles are said to be the fifth most exposed inhabited place in the world, ranking not far below Cape Horn, the southern t1p of New Zealand and Spitzbergen in average wind velocity.

In the carly years of the century there was an observatory on. the summit of Ben Nevis, Britain's highest mountaln, a mere $1360 \mathrm{~m}$ above sea level. During the twenty or so years of its existence 262 gales per annum were recorded. And periodically, perhaps every twenty or thirty years, we endure a great stort which, if it is sustalned for a few hours, lays trees over whole tracts of the countryside.

Since I have been practising forestry, we have had the great gale of 1952 which laid waste huge arcas of forest in northeast Scotland, and in 1968 central Scotland was subjected to a sustained six hour storm during which wind speeds of well 
over $160 \mathrm{~km}$ per hour were recorded. Wind will create irregularity whether we like it or not and my rather simplistic view Indicates that large, rather than small felling coupes will becone the order of the day so as to reduce the edge effect. One of the most exciting aspects of current research work has been on windthrow prediction and it was clear that the work of Dr. Calvin Booth and his exposition of it during our visit to the Forest of Ae has made a deep impression upon all of us at this meeting. You will recall that he divided our plantations into six hazard classes and predicted that thinned spruce stands will start to blow (i.e. over 3 per cent of the living trees will be thrown) at top heights as follows:

$\begin{array}{cc}\text { Hazard Class } & \text { Top Height } \\ & \text { m } \\ \text { I } & 25 \\ \text { II } & 22 \\ \text { II } & 19 \\ \text { IV } & 16 \\ \text { V } & 13 \\ \text { VI } & 10\end{array}$

In southern Scotland we have decided not to thin about 20 per cent of our plantatlons because of this wind hazard and new regimes involving respacing are being evolved. If only research workers could develop a height regulating hormone so that after a tree has reached say 20 m it ceased to grow in height but devoted all its energy to putting on girth, like certain human beings! In the meantime we have to devise means to get the maximum volume of sawlog on the ground before the wind-determined rotation expires.

And then there are the red deer. The red deer is a woodland animal and is native to the Highiands of Scotland. The recreation of its old habitat has enabled it to increase its numbers and range very extensively. It is difficult to control in a woodland setting and can be very dangerous to certain tree specles rlght through their lives.

And a further example, perhaps is entirely man-made. It is obvfous when one looks abroad that the pace of mechanization is accelerating, but some of the heavy, complex and expensive machines that are being developed can be very damaging to the forest and its solls. This is a huge subject and it would be idle to ignore its implications.

So much for three typlcal problems that will beset the manager of even-aged plantations in Britain.

\section{RESEARCH QUESTIONS}

It would be totally misleading to imagine from what I have sald that the tree farmer has no need for research because he knows $1 \mathrm{t}$ all anyway. Thls is very far from the 
truth. This particular tree farmer is in urgent need of advice on many subjects, but just take nutrition as an example. I should like to know:

1. What are the best regimes for each site type and predicted yields on these sites?

2. How sensitive are fertilizer regimes to provenance, thinning techniques and drainage intensitics?

3. What are the possibilities of using fertilizers to change form factors and stand assortment?

4. What response can be expected to pole-stage fertilizing on the various sites?

5. What opportunities has one got to put extra increment on the last ten years of a crop's life?

6. How to evolve an early warning system to alert the forester that growth is falling of

7. How to check readily on inputs 11 kely to maximize Net Discounted Revenue.

8. How to improve foliar analysis techniques and increase their reliability.

9. How to monitor aerial application of fertilizers more effectively.

10. How seriously do wide ring width and fast growth limit timber utilization?

11. The most effective and economic rates of application of common fertilizers and the periodicity of their application.

12. The long-term effects on high input sites.

\section{CONCLUSIONS}

1. The future of the timber using industry will involve a huge expansion and intensification of plantation management.

2. We are still ignorant and inward looking and have been slow to learn from the best agricultural and horticultural practices.

3. Management must be kept simple and in forestry small is seldom beautiful .

4. There is need for a great deal of research investment into increasing wood yields.

Finally, may an inexpert general forester be very impudent and suggest that senior research staff are in charge of the most difficult site of all: the research resource? I belfeve that most of the original thinking comes from the young and often from scientists from different disciplines working together. Encouraging young, lively minds and trying to prevent them going up dead limbs is not easy. Once. again climate is all important!

\section{REFERENCES}

Dannatt, N. Davies,E.J.M. \& McCavish,W.J.(1971). K11mory 1971An Investigation into fertilizer response. Scotish 
480

MANAGEMENT IMPLICATIONS

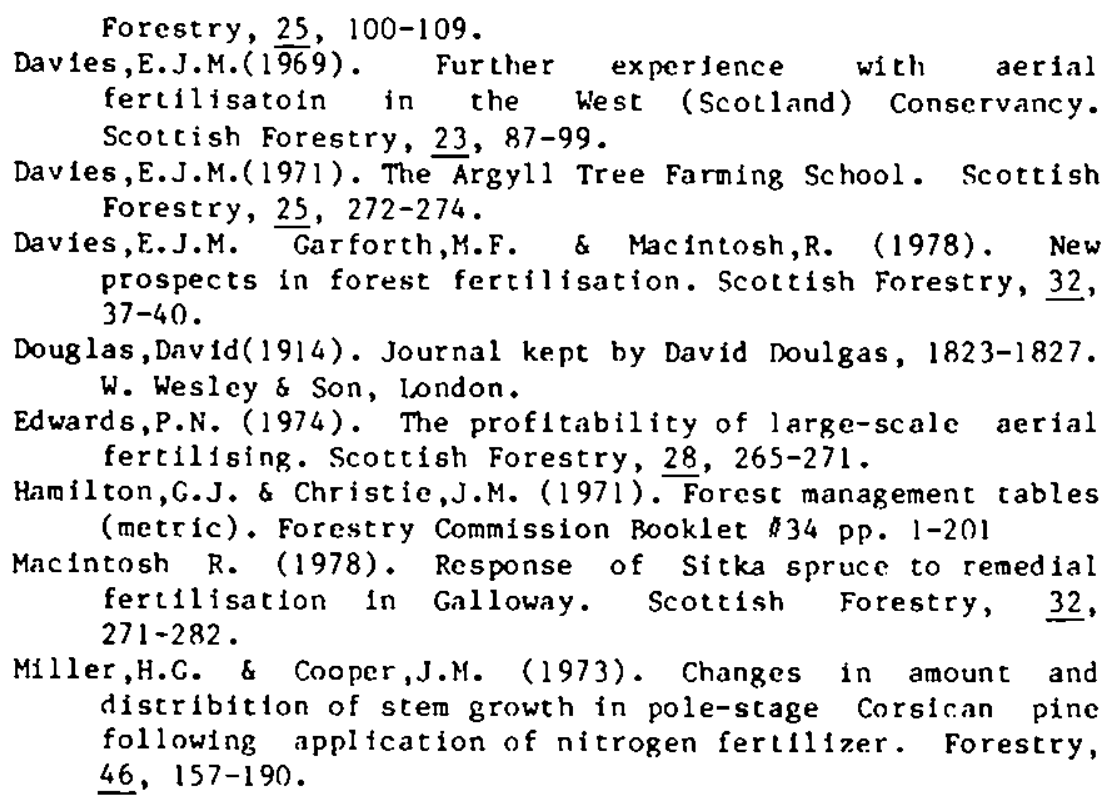


THE FUTURF. DEVELOPMENT OF R.VEN-AGED PLANTATIONS: SILVICULTURAL IMPLICATIONS

BY D.C. MALCOLM

Department of Forestry and Natural Resources, University of Edinburgh, Kings' Buildings, Mayfield Road, Fdinburgh, U.K.

\section{SUMPARY}

Plantations are distingulshed silviculturally by uniformity of stand age, structure and specific composition. Recent developments of culcural techniques allow site amelioration to accommodate desired species while mechanisation of harvesting methods promotes clearfelling systems.

The structure and development of the unmanaged forests, from which the main species used in British plantations are drawn, detonstrate their dependence on periodic disturbance. The longevity of the main species emphasizes the importance of regeneration conditions for ultimate stand composition rather than conventional ideas on succession. Windblow and fire disturbance lead to mainly even-aged stands distributed in relation to site conditions. Fcological 'stabllity' of these natural forests is doubtful, but they show considerable 'resillence'.

Analogies between unmanaged, indigenous forests and intensively managed, exotic plantations can only provide possible guidelines for silvicultural treatments. The design of plantation forests should take account of the existing varlability of the environment by linking forest structure to the scale of site heterogeneity, Identifled through terrain classification for extraction. Greater varlation in plantation forests will enhance their ability to respond to changes in the physical, bfological or social environments.

Du point de vue de la sylviculture, les 
plantations se distinguent des forêts
naturelles par l'uniformite de l'age du
peuplement, de la structure et des essences
qu'elles comprennent. Rémment, le
dévioppement des techniques de culture a
engendre une amélioration des stations
permettant de cultiver des essences voulues
tandis que la mécanisation des méthodes de
recolte encourage les systêmes de
coupes-a-blanc. La structure et le développement des forêts non aménagées, quí sont la source des essences principales utilisés dans les plantations de Grande Bretagne, prouvent que celles-ci dépendent de perturbations périodiques. La longevite des essences principales met en relief l'importance des conditions de régénération en vue de la composition finale du peuplement, bien plus que les idées conventionnelles concernant la succession. Les vents et les incendies donnent des peuplements plus ou moins équiens, distribués selon les conditions du terrain. On peut mettre en doute la' 'stabilité' ecologique de ces forêts naturelles, mais elles font preuve d'une plasticité considérable.

Les analogies entre foréts autochtones non aménagées et plantations d'essences exotiques, gërées intensivement, ne peuvent fournir que les grandes lignes d'un trattement sylvicole possible.

L'établissement d'une plantation forestière dolt tenir compte des condilions variables de $l$ 'environnement: la structure de la forêt dolt etre like au caractère héterogène du terrain, que $1^{\prime}$ on peut identifler par une classlfication du sol en vue du débardage. Des plantations très variées permettront aux forêts de mleux affronter les changements de l'environnement, qu'ils soient d'ordre physique, biologique ou social.

\section{ZUSAMMENF ASSLNG}

In der Forstkultur werden Pflanzungen nach der Zusammensetzung der Altersklassen, nach Bestandesaufbau und nach der Artenzusammensetzung unterschieden. Neuere Fntwicklungen in der Forstechnik erröglichen Standortsverbesserungen, ul erwïschte Baumarten elnzubringen, während die 
Mechanisterung der Holzernte Kahlschlagsysteme fördert.

Die Struktur und Entwicklung nich planmässig bewirtschaftecer walder, aus denen grơsstenteils das Anzuchtmaterial für die britischen Aufforstungen stamm, zeigt deren Abhänglgkeit von periodischen Störungen. Die Langlebigkeit der Hauptgattungsarten macht deutlich, dass die Bedingungen bel der Verjüngung für die zusammensetzung des Altbestandes wichitiger asind als konventionelle Sukzessionsmodelle. Windbruch und Feuerschaden führen zu hauptsächlich glelchaltrigen Bestànden, dle je nach Standortbedingungen vertellt sind. Die okologische 'Stabilität' dieser naturlichen walder ist zweifelhaft, aber sie zelgen beträchtliche 'Zähigkeit'.

Analogien zwischen nicht bewirtschafteten, einheloischen wäldern und intensiv bewirtschaftecen, exotischen Pflanzungen können nur grobe Leillinien für forstwirtschaftliche Massnatmen liefern.

Die Anlage von Aufforstungen sollte die bestehende Vielfalt der Ungebung berücksichtigen, indem die Bestandeszusammensetzung der durch Geländeklassifikation erfassten Standortheterogenltät Rechnung trägt. Grobsere vielfalt in Aufforstungen wird deren Pufferungsvermögen gegenüber veränderungen in der physischen, biologischen oder sozialen Unwel $t$.

\section{INTRODUCTION}

Plantations of tree species nay be established for a variety of purposes, chlef anong which is the production of industrial wood. Af forestation is also undertaken as a means of soll protection or for agricultural shelter or amenity. None of these objectives are exclusive of others and most afforestation schemes have multiple alms but in temperate countries generally, and in Britain in particular, the prime objective of afforestation is timber production.

In economic terms, af forestation involves a considerable Intial investment of resources in the purchase of land, site preparation, provision of planting stock and Its subsequent protection and management. Competition for scarce resources implies that investment in afforestation must be justified elther in narrow financial terms or, wore usually, in a broader economic view, by the provision of a range of benefits. In north temperate forests timber production alone 
does not appear to be able to achieve a return of much more than 3 per cent on the capital invested in planting (Johnston 1975). In Britain this rate of interest is now used as a target against which to measure the performance of the national forestry enterprise; the difference between costs at this rate and the prevailing Government rate of interest is considered a subsidy to forestry for the provision of a range of social benefits (Forestry Commission 1978). To encourage the investment of private funds in afforestation many countries adopt fiscal inducements such as preferential tax rates, subsidies or planting grants.

Large scale afforestation schemes are most often government inspired to make good a deficiency in either present or future raw materlal supplies. The deficiency may arise from carljet profligate destruction of indigenous forest (e.g. New Zealand or Britain) and/or a lack of desirable native species. The aim of increasing land productivity has sometimes motivated large planting schemes. The afforestation of 900,000 ha in Les landes, France, in the 19th century is a good example of this and a similar approach is being taken today in Spain. Sometimes, however, it has requited a near critical situation to generate sufficient political will to divert funds to afforestation.

Once determined upon, afforestation programmes tend to be carried out rapidly with emphasis on the economic benefits of large scale operation, simplictity of structure and the use of relatively few species. The resource, once created, soon attracts the attention of other interests so that the forester then has to reconcile the aim of attaining the highest yield from each land unit or money unit invested, with the other justifiable demands of society for such secondary benefits as conservation, recreation and amentity.

Although these features of afforestation have been touched upon already (holmes, this volume), it is worth refterating them as they are the reason why 1 t is necessary to consider the design of the forest. The term design acknowledges the man-made nature of the forest and implies an organised structure adapted to attaining defined management objectives, which include continuing high productivity. In the long term this requires a balance between the economic demands on production and the maintenance of site potential. The design of such plantation forests, so that they are also ecologically 'stable', is inevitably a speculative subject and is not susceptible to normal research methods. This paper, therefore, concentrates on the silvicultural characteristics of plantation forestry that influence long-term productivity and discusses measures that might be taken to maintain the resillence of the forest to changes in market demands, energy supply and social attitudes. Although the topic is discussed mainly in the context of the British situation, the principles 
involved are applicable el sewhere.

\section{PLANTATION FORESTS IN BRITAIN DISTRIBUTION AND RATE OF FORMATION}

The historical development of afforestation in Britain has been summarized by Holmes (1975). The planting programme, which expanded dramatically after 1945, has resulted in a marked trbalance in the age class distribution on a national scale (Holmes, this volume F1g. 2). As land was acquired, without respect to any formal land use policy, plantations were distributed more or less at random in the first place. Nevertheless large concentrations of plantations have developed in several regions such as Galloway, the Borders and parts of west Scotland. In a few instances planned integration with agriculture has been attempted (Stewart 1978), with 1 and purchase releasing capital for agricultural improvement but in general the aim has been to coalesce existing land holdings into larger units. The current rate of planting of about $29,000 \mathrm{ha} / \mathrm{yr}$, although relatively small compared with New zealand or Brazll which have programmes of 40,000 ha/yr and over 250,000 ha/yr (McConchle 1977; Palmer 1975), wlll, if continued, gradually balance the age class distribution nationally. On a more local scale this will not be posstble and positive steps will be required $1 \mathrm{f}$ management desires sustention of yield and labour requirements.

Kilmichael Forest in west Scotland provides an example of the Iocal management problems that may arise (F1g. 1). Here the fifteen planting years from 1946-60 account for about 70 per cent of the forest area and some 3400 ha, 40 per cent, was planted in a flue year perlod. As the land avallable for further planting in this district is limited, adjustments to the age class distribution will have to be made by planned fellings. The estimated percentage distribution of yleld classes (cu.m/ha/yr) of YC 20:20 per cent, YC 14: 45 per cent, YC 8: 30 per cent, YC 2: 5 per cent, only indicates the range of productivity present in the forest and conceals the extent of the variation.

The stands of lowest productivity can doubtless be Improved by remedial treatment but considerable site induced varlation will remain a feature. Varlation in Itthology (Dalradian site region, Toleman 1978) and glaclal geomorphology expressed in differential erosion and deposition, has resulted here, as in much of the uplands, in a complex of site types having differing aspects," slopes, soll proflles and very varlable shapes and areas.

\section{SILVICULTURAL CHARACTERISTICS OF FIRST ROTATION PLANTATIONS.} Species

The establishment of new plantations on land devold of tree cover, demands the use of specles that possess 'ploneer' 
characteristics. These species are easy to handle in the nursery, tolerate transplanting and are capable of withstanding climatic stress, vegetation competition and other adverse agencies. They should also show rapid early growth, quick occupation of the site and be of high productivity. If successful in plantation culture, economic and marketing conditions then will ensure their management on short rotations so that they will be still relatively juvenile when harvested.

In British conditions all these 'ploneer' qualities are found in the main specles used, Sitka spruce (Picea sitchensis (Bong.) Carr.) and lodgepole pine (Pinus contorta Dougl.). Although nationally they form 44 per cent and 11 per cent, respectively, of the groqwing stock (Locke 1978), their proportion in recent planting 1 s much greater.

Monocul ture

As planting has moved on to progressively poorer sites, species selection inevitably has become more restricted. On the site types avaflable formation of stands of mixed specles is possible, but does not often enhance survival or productivity. and may lead to complications in cost-effective management. The result is the developrent of extensive monocultures in which the stand structure is uniform, with variation existing only through differential rates of growth on different site types.

Cultural techniques

Much of the land now being afforested could not have been planted without the remarkable development of cultivation and drainage techniques over the last twenty-flve years. These techniques now allow planting and sucessful establishment on almost any site. The capacity to alter the site through cultivation, fertilization and the use of herblcides has also had an influence on species selection. Whereas it used to be obligatory to use species that were adapted to the extsting vegetation and soll conditions, it 18 now possible to alter the stte to neet the establishment requirements of the main species.

Harvesting

The cost of harvesting timber efther as intermediate or final yields, forms an important part of the overall economic performance of plantations. A balance must be struck between the costs of road construction and those of haulage from sturop. The trend has been to increase the payloads of extraction machinery and reduce roading intensity. on negotiable terrain the size of machine used is still increasing and dictates less frequent interventions but with greater individual yields. For final fellings large scale mechanization entails clearfelling as the trees left in successive felling systems (e.g. shelterwod) are liable to damage on both stem and roots (Braate 1976). Risk of windthrow 


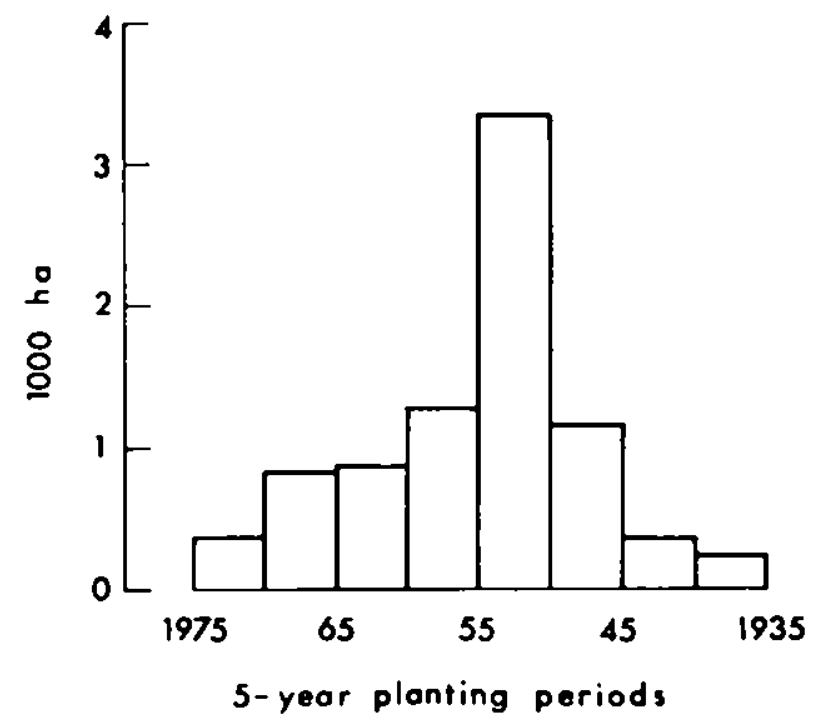

Fig. 1. Age class distribution of the forest area of Kilmichael Forest, west Scotland.

al so militates against systems other than clearfelling, except in a few favoured localities. On steep or broken terrain extraction systems are based on cable cranes which are relatively expensive to set up and so become more cost-effective with increasing volumes removed. Ease of management, concentration of labour and machinery and the control of herbivores all tend to favour felling coupes of large size. This trend is tempered by the need to take account of the effects of felling on the landscape.

To sumarize, upland plantation forests are developing as uniformly structured stands over relatively large areas, utilising few species of high productivity, the early site requirements of which have been met by increasingly intensive cultivation and fertilization. At economic maturity they will be clearfelled, restocked and the process started again.

From an ecological point of view the question may be asked whether these plantations forests can ever be more than aggregations of long-lived crops, managed on an agronomic basis. Can plantation forest, as described, be given a structure which is robust enough to ensure persistence in the face of enviromental or blological impacts? Because of the need to limit investment of resources to the minimum consistent with an adequate return, these are questions of economic as well as sllvicultural importance. Their answers are by no means clear but it is instructive to consider the development and structure of the forests from which the exotic 
species in common use have been drawn.

\section{STRUCTURE AND DEVELOPMENT OF NORTH TEMPERATE FOREST} General

There are not many detalled studies of the dynamics and development of unmanaged forest in the north temperate zone. Jones' (1945) critical review concluded that in foresis of shade tolerant species a small scale group structure develops due to patches of trees being windthrown. A recent study in Italy of Ables alba/Picea abies forest found a mosaic of small even-aged patches about 0.1 ha in extent (Patrone 1975). Examples of true selection forest structure seem to be infrequent and mainly confined to nixed conifer - leaf-tree forests with a predorinance of intensely shade-tolerant species (e.g. Abies alba Mill). In forests of less shade-tolerant species, the more usual structure secms to be a wide range of age classes with a continuous canopy, much $11 \mathrm{ke}$ a uniform crop but often with a more or less pronounced storied structure (Jones 1945). Closer to the Arctic, simpler, more extensive, uniform stands of relatlvely shade-fntolerant species occur which originate from catastrophic windblow or devastating fires. The importance of catastrophic disturbance of these northern ecosystems for adequate regeneration is well-known and application of fire to release accumulated nutrients in the organic soil has been a standard silvicultural treatment in Scandinavia (Nordstrom 1976 Paavanen, this volume). An extreme example of the need for this treatment is described for spruce in Finnish Lapland by Siren (1955) where without fire restarting the succession, spruce regeneration stagnates.

A form of stand in which regeneration proceeds in 'waves' with a cycle of about sixty-five years has recently been described by Sprugel (1976) for Ables balsamea (I..) Mill. forest in the northeastern United States. The 'waves' which advance into the older stand, appear to be initiated by wind damage and continue partly as a result of wind and frost accumulation on the exposed edge. The forest structure overall in this locality is reminiscent of a strip clearfelling distributed over several felling series.

In general it appears, that for forests dominated by coniferous species, conventional concepts of succession leading to a climatic climax, which remains 'stable' and self-perpetuating, are unrealistic. Dramatic disturbance on elther a local scale e.8. patch windblow, or more extensive catastrophes create changing spatial patterns of forest structure. Perry (this volume) has made the interesting suggestion that soll surface lftter accumulation may be an adaptation for excluding successional species. It is certainly clear that many spectes are adapted to periodic disruption of the forest. The interval between disruptive 'events' may be 
quite short as in Sprugel's (1976) exanple or much longer as In the case of the 300-year-old Tsuga canadensis (L.) Carr.

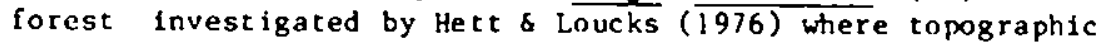
position and low deer populations had allowed small all-aged stands to develop of this shade tolerant specles. In oceanic climates the return periofs of catastrophic gales may be quite short, e.8. seventy-five years in Britain (Fraser 1971), while in more continental conditions, man- or lightning-induced fire has occurred in random patterns at intervals rarely exceeding 350-400 years (Heinselman 1971).

Northwest American forests

of particular interest are the forests of coastal northwest America, where the Pacific acean currents result in an equable oceanic climate not dissimilar to that in western Britain, with the exception of the continual wind pressure experienced here and, away from the west coast, the prevalence of late and early frosts. North of Seattle, Washington, the solls have evolved on glaclally derlved materlals and show many features similar to those in Britain but without extensive areas of climatically induced peats. Most of the species occurring in northwest America have populations that are well adapted to conditions in Britain. Provenance selection is most advanced with Sitka spruce and lodgepole pine, less precise with Douglas fir (Pseudotsuga menziesii (Mirb.) Franco) and grand fir (Abies grandis Lunde.) while little known of variation in western hemlock (Tsuga heterophylla (Raf.) Sarg.), Noble fir (Ables nobilis Lindl.), Paciftc fir (Ables amabilis Dougl. ex Ford.) or western red cedar (Thuja plicata D. Don.).

Franklin \& Dyrness (1973) have described the synecology of the coastal forest in Washington and Oregon, and Krajina (1969) in British Columbla. The former authors describe the Picea sitchensis zone forests as "typically dense, tall and among the most productlve in the world" and above ground biomass accumulations of over 2000 tonnes/ha are not uncommon.

Successional trends have been identifled for seral stands of either coniferous mixtures (S1tka spruce, western hemlock, western red cedar, Douglas $f(r)$ or Alnus rubra Bong. which is slowly Invaded by conffers (Frankl th \& Dyrness 1973). The shade-tolerant western hemlock is thought to ultimately dominate the forest but only after the longer-lived and taller spruce or Douglas fir deterlorate. The time span involved may be up to 500 years so that frequently the succession is set back by disturbance before this stage is reached. Day (1957) conducted detalled ecological investigations in mixed spruce, hemlock and cedar forest in the Queen Charlotte Islands, the most common seed origin of Sitka spruce in British plantations. He describes a similar development towards an uneven-aged canopy dominated by hemlock after long perlods but usually interrupted by storm or fire damage which results in 


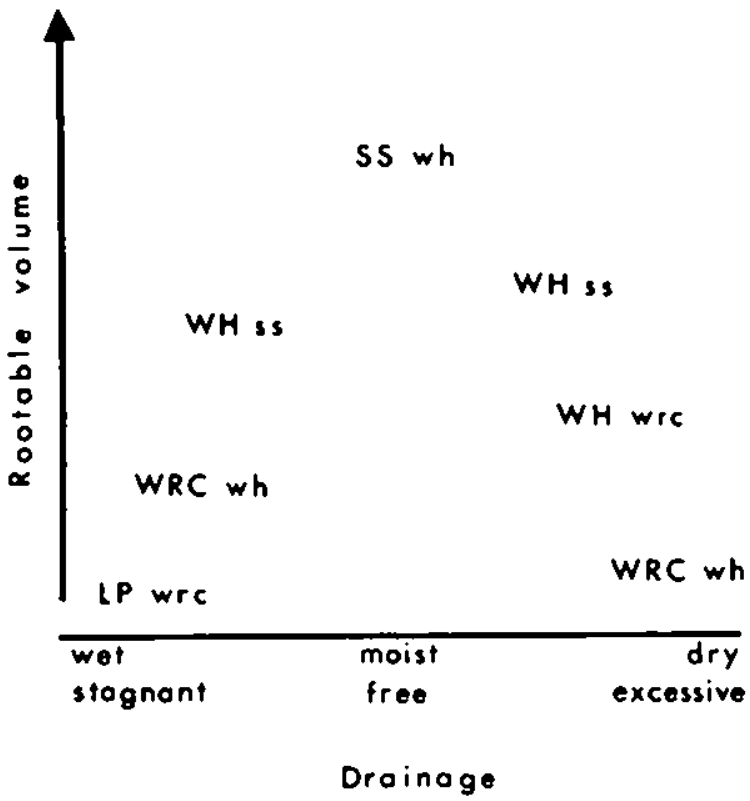

Fig. 2. Species dominance in relation to the soll conditions of rootable volume and drainage on Graham Island: SS - Sitka spruce, WH - western hemlock, WRC - western red cedar, LP - lodgepole pine, (after Day 1954).

an even-aged young stand. The specles composition of this new stand appears to be determined by the physical conditions of the seed bed as much as by the availability of seed from different species. Sitka spruce in particular regenerates well on exposed mineral surfaces, whereas hemlock and red cedar seem well-adapted to organic seed beds. The proportional species composition of the upper canopy subsequently appears to depend on the site tolerances of the individual species. A simplified version of Day's (1957) findings on the competitive ability of these specles, on a range of site types, is given in Figure 2. Sitka spruce is best able to maintaln a dominant position, through its lnherent 8 rowth potential; on moist, freely drained sites with adequate rootable volume; elsewhere it is progressively replaced by hemlock or cedar. In the area on Graham Island that Day studled, lodgepole pine only maintained a dominant position on muskegs but at Terrace on the Skeena River, in a much drier clfmate, this spectes is present also on the driest sites.

Two other features of this forest are of lmmedlate interest. First, the ability of sitka spruce to maintain some 
representation in the upper canopy on solls with root restricting mineral horizons, efther indurated till or fine textured gley, beneath a relatively thick organic (peaty) layer. Former windblown stems create 'hums' of mixed organic and mineral soll thereby providing the additfonal rootable volume necessary for Sitka spruce to conpete effectively with hemlock, the betcer adapted species for this site type.

The second, related, feature is the inability of sitka spruce to malntain a closed canopy beyond the stage when soil conditions effectively restrict further root expansion (Day 1957). There are several factors involved, such as the nutrient status of the soll, but the main effect seems to be the capacity of the soll to continue to supply water to meet the demands of increasing crown slze. After canopy closure the redistribution of leaf area between dominant and suppressed stems implies a simflar redistribution of soll resources but when these are fully exploited, the canopy must break up if Individual healthy stews are to increase in size. Death of non-suppressed trees occurs either through their having inadequate leaf area to support net photosynthesis or through the dieback of the root system with concurrent invasion of pathogens, windthrow often expediting the process. The total stand leaf area for a number of northwest American forest types has recently been related to simple measures of seasonal evaporative demand (Fig. 3) (e.8. Grier \& Running 1977) and there is no reason to suppose that sitka spruce in Britain will perform differently when soil conditions cannot meet even the limited demands of evaporative stress experienced in high rainfall areas.

THE SILVICULTURE OF UPLAND PLANTATION FORESTS

Analogies with ind igenous forest

The successful application of silvicultural techniques to the cultivation of Sitka spruce in plantations shows some similarity to the fashion in which this specles performs in its native habltat. The perlodic disruptions of the forest with regeneration of even-aged stands are simulated by clearfelling and restocking. Cultivation and drainage attempt to extend the area of those soll types which can meet the rooting requirements of the specles, repeating on a large and mote controlled scale the pattern of windblow generated soll 'humps' on shallow solls. The differences between the two ecosystems are equally obvious and reside malnly in the time scales involved. In the unmanaged forest there is a virtually closed nutrient cycle where accumulated nutrlents in the organic soll horizon are released in pulses after major disruption, loss of $N$ being made good by stimulated mircobial activity. The losses in drainage are either made good by fresh rock weathering and atmospherlc deposition (Miller, this volume) maintaining general levels of productivity or, on poor 


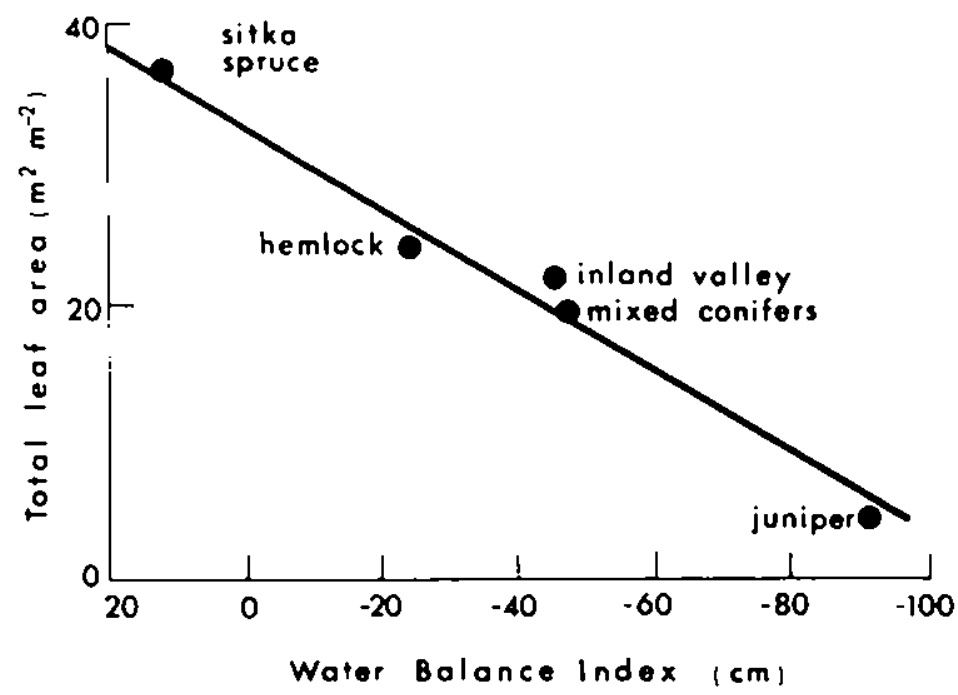

Fig. 3. Relationship between total stand leaf area and estimated water balance index for northwest American forest types (after Grier \& Running 1977).

Iithologies, there may be a slow decline in the productivity of successive generations and an increase in the proportion of specles more tolerant of low levels of nutrition. In managed plantations the relatively frequent removal of the stand, in many cases established on already impoverished solls, demands that the losses are made good through fertilization.

In the unmanaged forest natural selection emphasizes the ability of various species to survive and reproduce in competition. The competition for regeneration niches is eliminated in the plantation and considerable effort is directed to selection for productivity, wood quality and stem form.

Clearly the analogies that can be drawn from the natural forest are 1 imfted and can provide only an indication of the likely performance of cultivated populations particularly where these have been subject to considerable artificial selection. Research effort has therefore been focussed on the autecology of the species in plantations, particularly Sitka spruce. Intensive studies of particular stands comblned with work in controlled environments have elucidated many of the 
physiological responses of this species to its environent. Species performance and spectes selection

Although wuch empirical information on species performance has been obtained from the wany field experiments established by the Forestry Commission, this has only recently begun to be systematised through the recognition of silvicultural site reglons and an altitudinal stratification within these (Toleman 1978). The impact on practice of the more fundamental studies referred to above has to far been slight.

For most species there appears to be a slight trend for productivity to decrease from south to north in Britain but this is confused by local site variation and changes in the afforestation techniques used (Locke 1978). Actempts to relate productivity to readily avallable meteorological data have been disappointing and clearly local climatic variation related to topography and expressed by indirect parameters, such as elevation, is overriding (Malcolm 1976). In the few studies that have attempted to relate productivity of Sitka spruce to a range of site variables, elevation has proved the dominant factor emphasizing, the fmportance of temperature and exposure to wind (Page 1970; Malcolm 1976). A high proportion of vartability in productivity can be accounted for by elevation alone so that the altitudinal limit for economic planting of Sitka spruce can be predicted at about $550 \mathrm{~m}$ (Malcolm \& Studholme 1972; Mayhead 1973). These studles were mainly on unfertilized and uncultivated soils and indicated the importance of soll rootable volume, as well as site phosphorus status (Malcolm 1976). No doubt early growth rates can be enhanced by soll cultivation and fertilization but the extent of the improvement apparently falls of rapidly as limiting elevations are approached (Freezaillah 1974).

Comparisons between the productivity of different species are extremely difficult to make because of the obvious tendency to allocate species according to known site preferences, and the variability within sites. A further problem lies in making valid comparisons on first rotation plantings where one species acts as a 'ploneer' and the other may be more typical of later seral stages. There is no doubc that in the afforestation of exposed upland solls of generally low fertility the specles in common use, Sitka spruce or lodgepole pine; have distinct advantages. On sheltered, more sertile situations the initial cholce is wider. This is 1llustrated by the comparison (Aldhous \& Low 1974), by means of palred plots, between the main specles in use and four specles from northwest America (grand $f 1 r$, noble fir, western hemlock, western red cedar). The majortty of plots were on fertile, brown earth or surface water gley sites. In terms of productivity three of these specles were generally superior to Sitka spruce even though established in open non-forest 


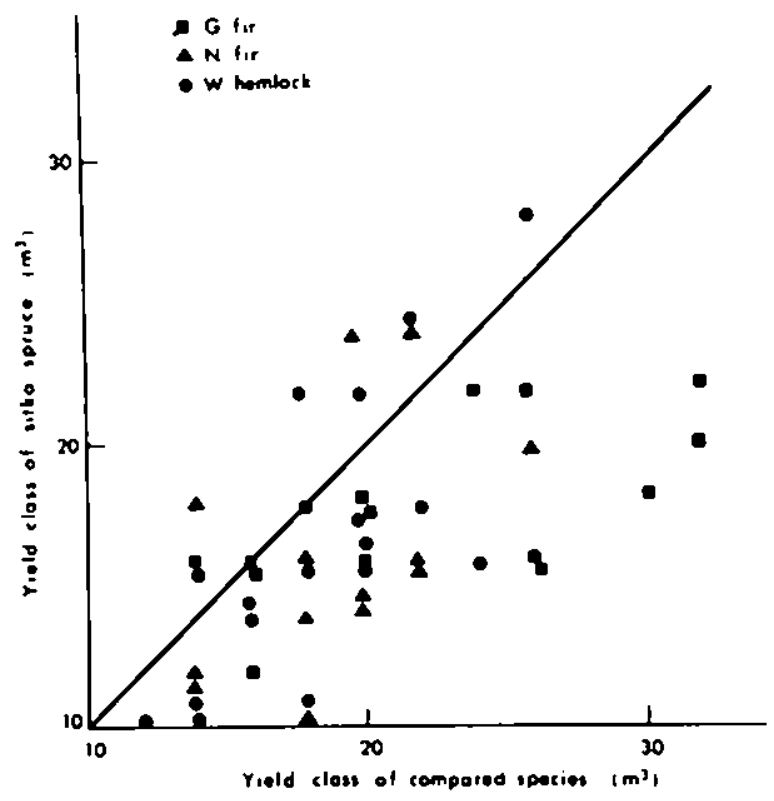

Fig. 4. The yield of Sitka spruce in relation to the yield of three other plantation specles in the U.K.

$G$ Fir - A. grand Is, N Fir - A. nobilis and

Whemlock - T. heterophylla, (after Aldous \& Low 1974).

conditions ( $F 1 \mathrm{~g} \mathrm{4.)}$ ). Western red cedar was compared in ten plots only and the growth rate was not correlated with that of Sitka spruce. Whether these comparisons can be extrapolated to more extreme "sites is doubtful but there is evidence that noble fir can withstand 'exposure' at least as well as sitka spruce. 'Western hemlock is most sensitfve to 'exposure' in youth and appears to require shelter at chis stage; unfortunately; it also apears particularly prone to fungal decay (Fomes annosus). Grand $f 1 r$, however, is resistant to Fomes, 18 more site tolerant than its present distribution suggests and has the silvicultural advantages of shade tolerance in youth and rapid litter breakdown.

If the range of opecies used in upland forests is to be extended, then $1 \mathrm{t}$ is likely that, on present knowledge, alternatives to Sitka spruce are likely to be drawn from the species noted above. Other factors, such as timber quality and marketing requirements are important in assessing the autabllity of alternative species but for many end uses the differences are slight.

So far, with the majority of plantations in the 
establishment and small pole-stage phase, serious biological problems have not arisen with spruce, except possibly the outbreak of Gilpinia hercyniae in wales (Billany \& Brown 1977). Problems are more likely to arise where one species has been extended on to sites which are incapable of supporting vigorous growth for the length of the rotation or where the genetic base is allowed to become too narrow. It is not always clear what combination of circunstances gives rise to population explosions of pests, but once they are present in sufficient numbers, they can be fairly indiscriminate in food preference (e.8. Panolis flammea, Stoakley 1977). The need for prudence is frequently mentioned (Seal 1978; Johnston 1978; Newhook 1977) but, for the reasons mentioned before, has not yet been recognized in the proportions of species currently being planned. There is an urgent need for appraisal of the possibilities for species diversification as plantation forests begin to move into their second rotation. Particular attention should be paid to the range of variation obtainable in northwest American silver firs (Ables grandis, A. nobilis, A. amabilis) and western hemlock.

Cultural treatments

The development of cultivation techniques has culminated in the ability to transform mineral solls which have root restricting horizons less than $90 \mathrm{~cm}$ deep (Neustein 1977). These solls are consequently freely drained or, at least after canopy closure, are unlikely to require drain maintenance. Complete cultivation is now quite common and results not only in improved soil physical status but in a flush of released nutrlents fron the incorporated organic mater. On coarse textured material of poor 11 thology, however, there is some doubt whether the resultant improved growth can be maintained either through loss of nutrient exchange capacity or available water capacily (Van Goor 1954; Thomson \& Neustein 1973). Nutrients may be added as long as it remains economic to do so.

In the climatically wetter areas gleys, peaty gleys or deep peats predominate. These form the rajor problem for site improvement. The restriction of rooting to the organic horizon due to impermeable, fine textured or compact mineral horizons beneath is critical to the maintenance of closed forest stands. This has led to the doubling of the distance between plough drains (Thompson 1977). in an attempt to widen the rooting 'platform' and, on an experimental basis, the sculpturing of the whole soll surface in an attempt to increase the rootable volume and delay windblow. Where first rotation stands have been blown down, the disturbance of the peaty layer often results in its partial disappearance through irreversible drying and oxidation. Where such stands are clearfelled the water table rises to near the surface leading to problems in establishing the next stand. Many of these 
sites are technically undrainable due to the pore size distribution as well as the occurrence of stumps. Nutrient status will have to be maintained be fertilization but the factor limiting productivity in second and subsequent rotations is more likely to be water supply in periods of low rainfall, due to the srall rootable volume and its low water capacity.

on the true peat soils, where root systems will never reach mineral horizons, initial drafnage permits canopy closure followed by a gradual drying of the peat to at least drain depth or deeper with lodgepole pine. Irreversible drying of peat here results in shrinkage and cracking (Pyatt 1976) so that these sites probably will be very different in later rotations. Some types of peat appear to have low retention capacity for added nutrients (Malcolm, Bradbury \& Freezaillah 1977), are already very low in available nutrients and may thus require frequent inputs of fertllizer. Although once drained they are physically suitable for vigorous tree growth, the nutrient regimes required way not be economic for demanding species (Dickson \& Savill 1974).

Fertilization of established plantation forest is becoming more frequent and, where nutrients are limiting, has achleved striking increases in growth rate. Pecently more attention has been paid to volume increment and changes in tree form which might be important in utilization. The increased growth is attained by increasing leaf area and net assimflation rates in the lower canopy, and, as in other monocultures, will be 1 imlted ultimately by mutual shading in closed canopies. In brief, fertilization accelerates the development of the stand; if unthinned, the mortality rate wlll be enhanced; if thinned, leaf area expansion of released trees will continue, although individual crowns may become less efficlent in wood production (Kramer 1966). End use of the timber is also Important and too fast growth rates will result in down-grading of sawnwood products. Miller (this volume) has shown that the forest soll is normally an effictent 'sink' for added nutrlents and $t$ t may be that ultimately interest in phosphate levels in mineral soll will dimlnish relative to nitrogen, as in most temperate countries, which might make the economics of fertilization less attractive.

Stand structure

The effect of inter-plant competition in regularly spaced monocultures is the creation of a hierarchy of dominance which in terms of tree size approximates a log-normal distribution, which in the managed stand tends to become nomal towards the end of the rotation. The distribution found in all-aged stands, best described by a power function of size or age (Dawkins 1971; Hett \& loucks 1976), is essentially the even-aged distribution perpetuated in the same space. In the 
even-aged stand by comparison, the reduction in stem number with increasing size is a progression in time. Valid comparison of utilisable productivity between the different structures is very difficult but for unlform sites the balance of advantage would appear, on theoretical grounds, to be wh the even-aged system. This is mainly due to the inefficiency of much of the leaf area in the lower parts of an irregular canopy, which 18 poorly illuminated despite the wide spacing of dominant trees that themselves develop inefficlent crowns. Differences in transfer and interception processes, that might be more beneficial in an irregular canopy, are unlikely to counteract the main disadvantage, (Malcolm \& Taylor 1979).

In reality, uniform sites do not exist and in more extreme environments there may be a case for developing an irregular structure, which wust depend on shade-tolerant species and natural regeneration. The ecological 'stability' clatmed for irregular forest structures is often confused with the bencfits of mixed species in nutrlent cycling, effects on tree form and so on. Increased physical stabllity in a windy climate is even more problematic, where effective rooting space is the factor limiting the size of stable trees. Catastrophic gales cannot be countered silviculturally by irregularity of structure but less damage from more normal winds might accrue in stands of a rather open structure in which the dominants were widely spaced from an early age to allow adequate root spread. Such treatment would entall loss in cocal production but wight allow larger individual stems to develop. Day (1962) studied the root systems of sitka spruce on sites with impenetrable mineral horlzons under shallow peat and concluded that there was a cholce between removal of the stand at an age before it broke up (1.e. at small pole size) or, by allowing a more open and irregular canopy to form, to take small scale varlability in root penetration into account. on rather simflar soll types at elevations of about $500 \mathrm{~m}$ in the Belgian Ardennes, plantations of spruce have been undergoing transformation to mixed stands of irregular structure (Roisin 1959) since about 1935. The alm here has been to increase resistance to possible insect attack and ioprove ecological conditions generally.

Stand size and distribution

Catastrophic stand destruction in unmanaged forests may be simulated by large scale clearfelling, which in cooler, humfd climatic conditions may be justified on ecological grounds. In managed forests, however, there are other constraints that influence the scale of regeneration fellings. These may include visual amenity, maintenance of widlife habitat including stream protection, and so on. The distribution of stands in relation to thelr demands, just as for forest age class distribution, are the province of forest managment. The slivicultural interest is that their 
distribution should optimize forest productivity by maintaining, and where possible, increasing site potential. At the same.time stand distribution should minimize the risks of environmental or blological damage. Some of these are predictable, others are not, so that the imposition of any idealized spatial pattern of stand distribution is unlikely to persists for long.

The logical procedure is to link stand distribution with site type distribution, that is to acknowledge the varlation in the physical resources. Different sites have different potencials which can be exploited more efficiently by some species than others. Different sites require different cultural treatments which, while increastng their potential, may reduce but not eliminate the variation. This varlation can be used to design a forest structure that reflects the ecological realities for healthy tree growth. The scale of the stand distribution patern will vary with that of the site types. Paterson (1975) has described how species selection, cultural treatment and harvesting might be fitted into the small scale but highly differentiated site patterns found in areas of fluvio-glacial deposits in upland Scotland. With more extensive site types like those in the southern uplands or in north England, some variation in stand slze might have to be imposed by wanagement. Stand slze might need to be limited to maintain forest conditions for regeneration. This becomes of particular importance at the altitudinal limits where moderate yields of slow grown timber must be taken at long intervals.

The basis for stand differentiation already exists in the process of site mapping within silvicultural site regions but felling coupe size has also to relate to mechanised systems of harvesting. In some cases the apparently most economical extraction technique will not be appropriate to the site conditions, particularly where heavy machinery is used on poorly draining soils thereby possibly reducing the future production potentlal. In general, however, extraction methods can be made to match desirable silvicultural objectives and the two related through terrain classification (Fig. 5) (Rowan 1978). There is a need for the development of machinery which can cope with rough terrain, of a slze which enables economic operation and yet not so large as to cause serious site damage on wet or peaty solls (Brate 1976). The cost of imported machinery may in itself slow progress towards increasing size of extraction equipment (Mconchie 1977).

The silvicultural system adopted will be in most cases clearfelling with replanting. Apart from its ecological desirability on many sites and the requirements of most of the species in use, econouic presures in harvesting alone would lead to its retention. The introduction of superior genotypes from tree breeding programmes will require a clearfeling system, although techniques of handing and tending these 


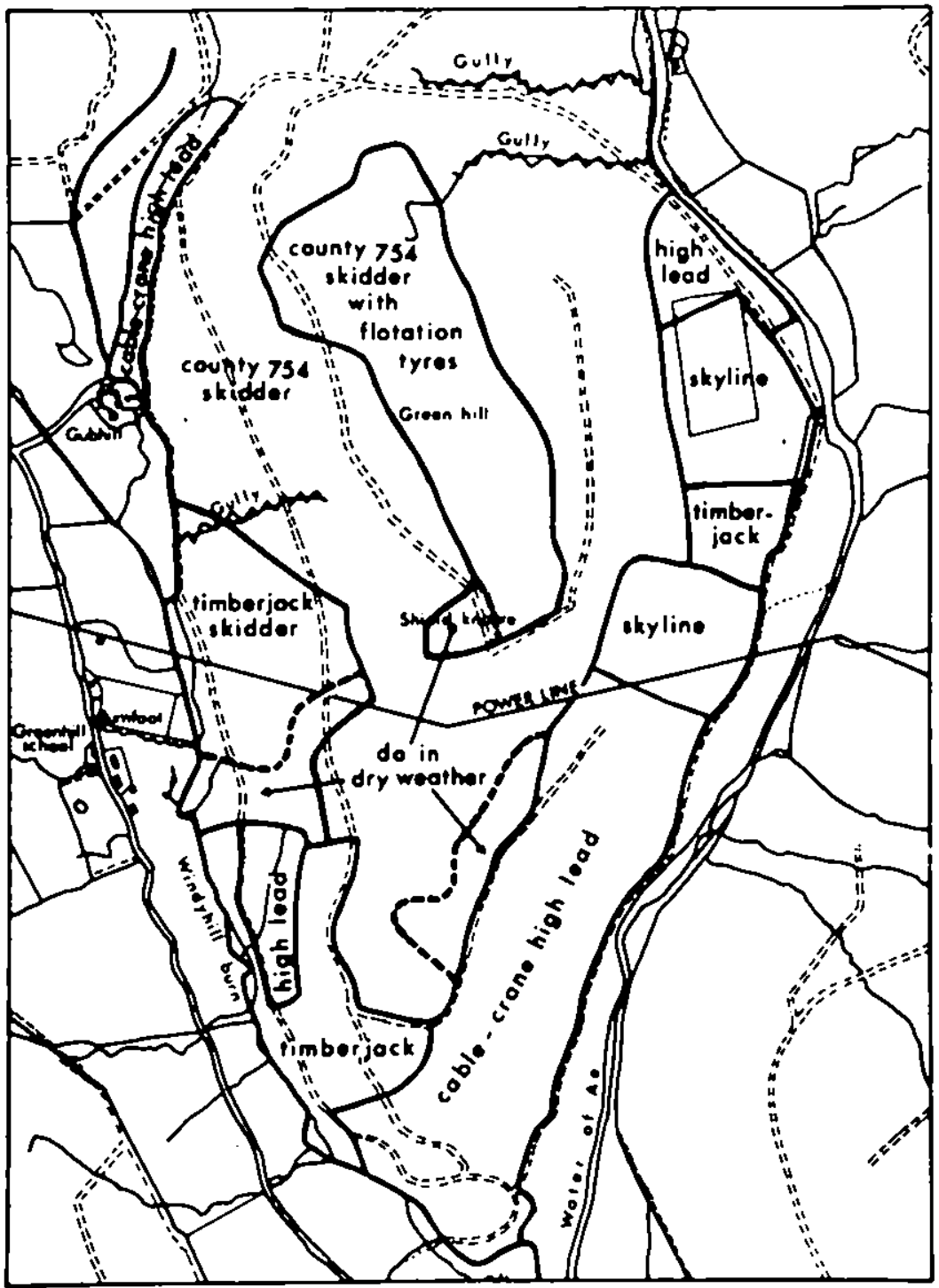

Fig. 5. A terrain classiflcation of part of the Forest of Ae, south Scotland, Indicating which of varlous timber extraction techniques should be used. 
improved trees have not yet been developed. Other systers, such as shelterwood or irregular working, may be desirable in areas which are particularly sensitive either environmentally or for amenity and conservations reasons.

Natural regeneration may occur even where it is not desired; if it is of acceptable species and genotypes there is no real probler and suitable tending techniques are avallable. Almost all the species that have been used in plantations have demonstrated a capacity to regenerate naturally but, for the reasons already discussed, little effort has been made to develop sllvicultural techniques to ensure 1 ts reliability.

At present, the presence of large deer populations forms a further constraint on specles selection, stand size and structure. The creation of forest habltat has led to large increases in the populations of these animals which browse restocked areas and strip bark in pole-stands. More is known of the management of roe deer (Capreolus capreolus) than of red deer (Cervus elaphus) in British forests (Loudon 1978) but both are difficult to census so that culling programes tend to be somewhat speculative. There is no doubt that control of these animals forms one of the biggest management problems as first rotation stands are felled for replanting. Policies of exclusion are too expenstve and probably ineffective (Cooper \& Mutch, this volume).

\section{CONCLUSIONS}

Thls paper has tried to assess the way the large scale plantations established in the British uplands might develop in future and in particular how they might be structured to minimize the influence of environmental and blotlc hazards. The physical resource or environment for tree growth $c$ an be thought of as the combination of two gradients. The range of soll conditions in respect of rootable volume and nutritional status is one and the other is climate as an expression of heat and water balances. These gradients interact at many levels to form a complex system or framework within which the biological elements vary in space and tree. The generalization of these concepts is the purpose of systems analysis (Bakuzis 1976). Systems analysis, however, depends' on an apprectation of the functioning of ecological processes and 1 it is here that detalled physiological studies find an application. A clearer understanding of the forest $x$ site interactions will result in a greater abllity to predict the consequences of sllvicultural and management decislons. Added to the ecological complexities are the economic constraints on the use of the forest. Sundberg (1976) identified conflicts at two levels: one between silvicultural objectives and economic operational methods and the other between the needs of the forestry system and other 'systems' with demand on the forest. The solution he proposed to the first was a managerial structure which could 
balance long and short term benefits and costs and, for the second, the application of systems analysis to avoid too narrow an approach to management problems. Whether we are yet In a position to adopt the second approach is doubtful.

At a more practical level the forester has to design the forest to meet as many of the demands on it as possible through the allocation of species to sices and the distribution of stands within the forest landscape. This he can do elther by:

1. attempting to stabilize a production system based on one or two species with complementary inputs of cultivation and fertilizer to homogenize the environment as much as possible, with cosmetic adjustments of species composition and stand boundaries to provide the secondary benefits of amenity and recreation; or by

2. accepting that even with cultural treatments the enviroment is not homogeneous, particularly in respect of climate, that the existing heterogeneity can be used to provide varlation, without necessarily reduced production, while meeting the other demands on the forest without strain.

The first option assumes stability, or at least small fluctuations, in the enviroment, the possibility of control of blological hazards and a continuing demand for a particular combination of physical and soclal benefits. The latter option assumes that future events affecting the forest are unpredictable and that change is inevitable. variation in species composition, size and distribution of stands within the forest gives flexibllity to management.

The two approaches outlined are akin to those assoclated with 'stable' and 'resillent' ecosystems as defined by Holling (1973). Stability is the abllity of a system to return to its previous state after disturbance, while resillence is the ability of a system to persist despite disturbance.

This paper has contended that neither the unmanaged forest nor the newly created plantation in the Britloh uplands can be expected to function as 'stable' ecological systems. It is certain that their future developent wlll be against a background of change, in energy costs, labour supply, warket demand and social attitude and use. The artificlal, managed forest presents an oppurtunity to design a system with resilience capable of absorbing such changes.

\section{REFERENCES}

Aldhous,J.R. \& Low,A.J.(1974). The potential of Hestern Herlock, Western Red Cedar, Grand Fir and Noble fir in Britain Bulletin of the Forestry Commission, London, 49, 1.105 . 
Bakuzfs,E.V.(1976). Outline of systems analytic approach to forest growth and site evaluation. Research on site factors Section 21, XV World IUFRO Conference Gafnesville 1971. pp. 156- 82. Wageningen, Netherlands.

Billany,D.J. \& Brown, R.M.(1977). The geographical distribution of Gilplnua hercyniae (Htg.) (Hymenoptera: Diprlonidae) in the United Kingdom. Forestry, 50, 155-160.

Braate,P.(1976). Silvicultural practices in modern plantation forestry. Ways and means of reconcting silvicultural and operational methods in modern forestry. Joint IUFRO/FAO Mecting XVI World Congress IUFRO, Os10, 1976. pp. 16-26.

Dawkins,H.C.(1971). Techniques for long-term diagnosis and prediction in forest communties. "The scientific management of animal and plant communities for conservation". Proceedings lith Symposium of the British Ecological Society, (Ed, by E. Duffey and A.S. Watt), pp. 33-44. Blackwell Scientific Publications, Oxford.

Day, W.R. (1957). Sitka spruce in British Columbia, Bulletin of the Forestry Commission, London, 28, 1-110.

Day,W.R.(1962). The development of Sitka spruce on shallow peat. Scottish Forestry, 16, 219-236.

Dickson,D.A. \& Sav1ll,P.S. $(1 \overline{974})$. Early growth of Picea sitchensis (Bong.) Carr. on deep oligotrophic peat in Northern Iteland. Forestry, 47, 57-88.

Forestry Commission.(1978). $57 \mathrm{th}$ Annul Report and Accounts for the year ended 31 March 1977. pp. 102. Her Majesty's Stationary of $f$ ce, London.

Franklin,J.F. \& Dyrness,C.T.(1973). Natural vegetation of oregon and washington. U.S. Department of Agriculture, Forest Service, General Technical Report PNW 8,1-417.

Fraser,A.I.(1971). Meteorology. "Windblow of Scottish forests in January 1968". Bulletin of the Forestry Comission, London, $45,3-7$.

Freezaillah,B.C.Y.(1974). Climatic influences on the growth and uptake of phosphorus by Sitka spruce. Unpublished $\mathrm{Ph} . \mathrm{D}$. thesis, University of Fdinburgh.

Goor,C.P. van(1954). De invloed van de bodembewerking op een aantal efgenschappen van de droge, bruine bosgronden. Landbouwkund 18 Tijdschrift, 66, 175-181.

Grier,C.C. \& Running, S.W. (1977). Leaf area of mature Northwestern coniferous forests: relation to site water balance. Ecology, 58, 893-899.

Heinselman,M.L.(1971). The natural role of fire in northern conifer forests. Fire in the northern enviroment (Ed. by R.J. Slaughter, R.J. Barney and C.M. Hansen), pp.61-72. U.S. Department of Agriculture, Forest Service, Portland, oregon.

Hett,Joan M. \& Loucks,O.L.(1976). Age structure models of bal sam fir and eastern hemlock. Journal of Fcology, 64, 1029-1044. 
Holling,C.S. (1973). Resilience and stability of ecological systems. Annual Review of Ecology and Sytematics, $\underline{4}$, $1-23$.

Holmes,G.D. (1975). History of forestry and forest managenent. Discussion of forests and forestry in Britain. Philosophical Transactions of the Royal Society, London, B. $271,69-80$.

Johnston,D.R. (1978). The constraints against irregular forestry. In: Dewar,J. The case for regional silviculcure. Forestry $51,1-19$.

Jones,F.W. (1945). The structure and reproduction of the virgin forest of the North Temperate Zone. New Phytologist, 44, 130-148.

Krajina,V.J. (196) . Ecology of forest trees in British Columbia. Ecology of Western North Amer1ca, Volume 2 (Fd. by V.J. Krajina) pp. 1-146. Department of Botany, University of British Columbia.

Kramer,H. (1966). Crown development on conifer stands in Scotland as influenced by initial spacing and subsequent thinning creatment Forestry, 39, 40-58.

Locke,G.M.L. (1978). The growing stock of regions. In Dewar, J. The case for reglonal silviculture. Forestry, 51, $1-19$.

Loudon,A.D.I. (1978). The control of roe deer populations: a problem in forest management. Forestry, $\underline{51}, 73-83$.

Malcolm,D.C. (1976). Site factors and the growth of Sitka spruce. Research on ste factors. XV World Congress IUFRo, Gainesvi11e, 1971, pp.269-283. Wageningen, Neherlands.

Malcolm,D.C. \& Studholme,W.P.(1972). Yield and form in high elevation stands of Sitka spruce and European larch in Scotland. Scottish Forestry, 26, 296-308.

Malcolm,D.C. \& Taylor,C.J. (1979). The place of 1rregular forestry in North Britain. In Thallow, K. Yield control and production planning. Forestry, $\underline{52}$ (in press).

Malcolm,D.C.,Bradbury,I.K. \& Freezalliah,B.C.Y.(1977). The loss of nutrients from fert111zed peats in an artificlal system in the fleld. ForestEcology and Management, 1 , 109-118.

Maycad,G.J.(1973). The effect of altitude above sea-level on the yield class of Sitka spruce. Scotcish Forestry, 27, 231-237.

McConchie,B.D.(1977). Plantation forestry: The future - an Industry viewpolnt. New Zealand Journal of Forestry, 22 , 226-228.

Neustein,S.A.(1977). A history of plough development in British forestry. Scottish Forestry, 31, 2-12.

Newhook,F.J.(1977). Plantation forestry: the reservations. New Zealand Journal of Forestry, 22, 246-248.

Nordstrom,L.(1976). (Forest regeneration in the past). (Seen in abstract). Kungliga Skogs- och lantbrukakademiens 
t1dskrift, 115, 303-314.

Page,G.(1970). Quantitative site assessment. Forestry, 43 , 45-56.

Palmer,F. (1975). Wood supply and demand - the medium term prospects for Britain. A discussion on forests and forestry in Britain. Philosophical Transactions of the Royal Society, London, B. 271, 81-89.

Paterson,D.B.(1975). Silvicultural practices on extensive areas of complex sites. Scottish Forestry, 29, 140-145.

Patrone,G.(1975). (Studies on even-aged forest in Cadore Belluno). (Seen in abstract). Academia Italiana di Sclenze Forestali, $1975,1-109$.

Pyatt,G.(1977). Site studies (north). Forestry Commission, Report on Forest Research, London. P 24.

Roisin,P. (1959). La transformation des Pessieres. Bulletin de Soclete des Forets Belges, 66, 153-190.

Rowan,A.A.(1978). Terrain classification. Forest Record of the Forestry Commission, London, $114,1-23$.

Seal,D.T.(1978). A sumary of the case for regional silviculture. In Dewar, J. The case for regional silviculture. Forestry, $51,1-19$.

Siren,G. (1955). The developrent of spruce forest on raw humus sices in N. Finland and its ecology. Acta forestalia fennica, $62,1-405$.

Sprugel,D.G. $(1 \overline{976})$. Dynamic structure of wave regenerated Ables balsamea forests in N.E. United States. Journal of F.cology, 64, 889-911.

Stewart,G.G. $(1 \overline{978})$. Inter-relations between agriculture and forestry in the uplands of Scotland: a forestry view. Scottish Forestry, 32, 153-181.

Stoakley,J.T.(1977). A severe outbreak of the pine beauty moth on lodgepole pine in Sutherland. Scottish Forestry, 31 , 113-125.

Sundberg,U.(1976). Forest management affected by mechanisat on and environmental concern. Ways and means of reconciling silvicultural and operational methods in modern forestry. Joint IUFRO/FAO Meeting. XVI World Congress IUFRo, Oslo, 1976. Pp.27-47.

Thompson,D.A.(1977). Cultivation. Forestry Commission Report on Forest Research, London. 19pp.

Thomson,J.H. \& Neustein,S.A. (1973). An experiment in intensive cultivation of an upland heath. Scottish Forestry, 27, 211-221.

Toleman,R.D.L.(1978). The site regions of upland Britain. In Dewar $J$. The case for reglonal silviculture. Forestry, 51, 1-19. 
TROPICAL FORESTS - COMPARISONS AND CONTRASTS

By P.G. ADLARD

Unit of Troplcal Silviculture, Commonwealth Forestry Institute, oxford, U.K.

\section{SUMMARY}

Forest plantations in the tropics include those established in the lowland rainforests, highland grasslands and arld zones. Most concern is felt over the effects of replacement of complex rainforest ecosystems by uniform, monospecific plantations. Problems of afforestation of grasslands, arid zone savannas and shrublands are mentloned but not discussed in detail.

After a brief revlew of the methods of regeneration and replacement of rainforest which are used to increase the yields of food and wood products, the resillence and stability of the artificial ecosystems created are considered. The importance of stand structure and succession, the effects of changes in the physical and chemical properties of the soll and nutrient cycling in a. forest ecosystem suggest that more care and sensitivity in site selection for plantations than has been shown so far is essential if serious fallures are to be avolded.

Recommendations for more extensive ecologfcal research as a basis for plantation management are made and guldelines suggested in the $11 \mathrm{ght}$ of existing knowledge.

RESUMÉ

Les régions tropicales comprennent trols zones de plantations forestières: - les forêts pluviales a basse altitude,

- les savannes des hauts plateaux,

- les zones arides.

on a exprimé beaucoup d'inquiétude sur les effets du remplacement des écosystèmes complexes des forêts pluviales par des 
plantations d'essences uniformes. Les problèmes du boisement des prairies, des savanes arides et de la brousse sont mentionnés dans cet exposé mais ne sont pas traités en detail. Nous decrivons brièvement tout d'abord les méchodes de régénération et de remplacement des forêts pluviales qui ont pour but d'améliorer les rendements en nourriture et en bois. Nous passons ensuite au sujet de la resistance et de la stabilité des éco-systemes artificlels. L'importance de la structure et de la succession des peuplements, les effets du changement des propriétés physiques et chimiques du sol et du cycle des éléments nutritifs dans l'éco-systeme forêt montrent que le choix du terrain doit être accompli soigneusement et raisonnablement, ce qui n'est pas toujours le cas, dans le but d'éviter des echecs sérteux.

Nous pensons que des recherches solides en écologle devraient être menées à bien, qui seraient le fondenent de la gestion d'une plantation. Nous en donnons quelques grandes lignes en nous basant sur des faits existants.

\section{ZUSAMMENFASSUNG}

Forstpflanzungen

unterliegen

den

Produktionsbedingungen so unterschiedlicher Naturräume wie z.B. tropische Regenwaldzone, montanes Grasland und Trockengebiete. Die meisten Bedenken bestehen bei der Umwandlung von korplexen Regenwald-ökosystemen in gleichaltrige Reinbestände. Probleme der Aufforstung von Graslandgebieten, Savannen und Buschwaldern der Trockenzonen werden zwar erwähnt, aber nicht ausführlich diskutiert.

Nach elnew kurzen Überblick über Methoden zur Verjüngung und Umwandlung von Regenwald zur Steigerung der Nahrungs- und Holzproduktion werden die Resistenz und Stabilität der küntlich geschaffenen Ökosysteme diskutiert. Die Bedeutung von Bestandes- aufbau und -entwicklung, die Auswirkungen durch Veränderung bodenphysikalischer und-chemischer Parameter sowle deren Einfluss auf den Nährstoffumsatz in elnew Wald-Ökosystem lassen vermuten, dass mehr Sorgfalt und bkologisches Bewusstsein als bisher bei der Standortwahl für Pflanzungen notwendis ist, wenn ernste Fehlschlage vermleden werden sollen. 
In Anbetracht des derzeftigen Kenninisstandes werden Empfehlungen fur extensivere ökologische Forschungen vorgeschlagen, die als Grundlage und Richtinie der Bewirtschaftung von Pf lanzungen dienen sollen.

\section{DEF INING THE CONTRASTS}

The range of habitats found within 'tropical forests' is so great that any useful comparisons with temperate forests, themselves variable, require extensive qualification.

Comparisons in this paper relate to those forest formations listed in Table 1 that are currently subject to greacest interference either through planned management or indiscrininate clearing for food production by land-hungry people living under stresses caused by a rapid increase in population.

Yangroves and fresh water swamp forests which contain large timber reserves but are not under immediate threat of destruction or conversion to plantations for obvious technical reasons, do not receive consideration.

In the context of this meeting we corpare the ecological and economic role of plantations both in the lowlands and highlands of the tropical zone, with the natural communities they replace, and with their analogues in temperate regions where these occur. Several forest formations grouped as tropical rainforests call for attention:

(1) Tropical lowland rainforest and semi-evergreen rainforest, together comprise the complex - structured dry-land communities and are dominated by hygrophilous tree species characterized by the frequency of buttressing, cauliflory and leaves with driptips, abundance of climbers and epiphytes and a degree of deciduousness that increases with seasonal water stress (R1chards 1952; Baur 1964; Whitmore 1975).

(ii) Where a distinct dry season occurs, the stature, structural complexity and species diversity of the forest is reduced, though, as with the monsoon forests of reak and pine, they may still yield much of value to man. It way be noted that it was in the tropical monsoon forests in India early in the 19 th century that intensive tropical silviculture was first applied and natural forest was replaced by plantations on a significant scale.

(iii) As we move away from the optimum conditions of continuous high humidity and temperature in the ralnforest zone, elther to the hot, arld habltats with xerophllous woodland and grassland of higher latitudes, or to mesophilous woodland, montane forest or fire induced grasslands at higher altitudes, the problems of plantation silviculture change. 
The importance of re-establishing a forest cover in the arid tropics to protect the soil and supply wood to local cormunities will have a long-term significance in terms of human welfare quite as great as the econonically more impressive pulpwod plantation projects in the rainforest zone and on the montane prasslands.

The validity of comparisons between plantations in temperate and tropical regions must, however, be questionable even with careful definition of the ecosystems in which they are established. Economic, social and political faciors frequently dominate ecological judgenents unless, or until, an event occurs to reveal an instability in the plantation ecosystem, such as extenslve windthrow, accelerated soil erosion or mineral deficiency. Perhaps the most useful question to ask is whether tropical plantations lead to site degradation or, put another way, whether the energy inputs to maincain the artificial ecosystem are greater than the energy yields. Have we reason to belleve that there are essential differences between temperate and tropical habitats which render application of temperate silvicultural and, probably of greater significance, agricultural methods essentially unstable in the tropical dry lands? Other comparisons, e.g. of productivity, quality and diversity of products and of methodology must all be secondary. Alternative management options for existing areas of natural vegetation are not restricted to total replacement by a completely artificial system but include various degrees of enrichment and partial replacement leading to mosaic patterns of land use. The incensity of management that can be tolerated in a tropical and a temperate ecosyster cannot be assumed to be identical. There is still tioe in many tropical areas to plan and control development to ensure a resiltent pattern of land use which maintains calculated proportions of rainforest under permanent management in association with agricultural development and plantations. Shifting agriculture at appropriate intensity is a resilient system, but under short rotations it becomes destructive. The rainforest may be a stable system but is not necessarily resilient to drastic interference on a large scale, using 'stable' and 'resilient' in the sense of Holling (1973). The spatial scale of man's interference may well be a key factor in the success or failure of land development in the tropies.

THE RISKS OF FOREST CONVERSION

Our ignorance of the ecology of tropical, compared with temperate communities confounds simple comparions. As Janzen (1975) puts it: "We understand almost nothing of the adaptive significance of the behaviour and morphology of most tropical plants, (... nor of ...) the population structure of each species." 


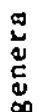

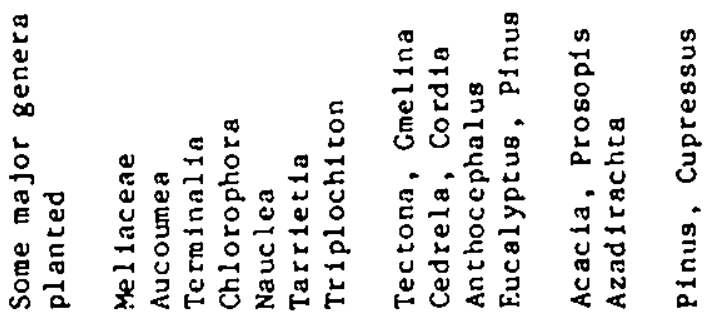

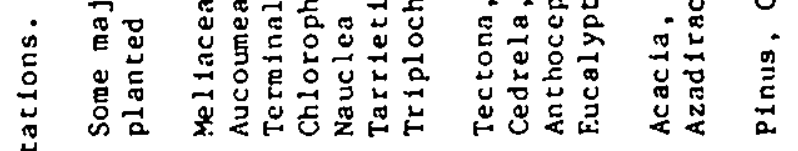

苞

$\stackrel{0}{0}$ ङ

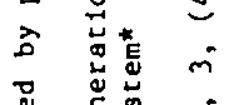

苞 壱

न1 $\stackrel{0}{2}=$

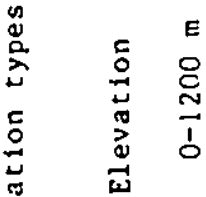

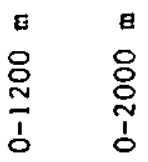

焉离

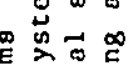

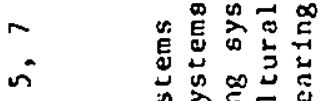

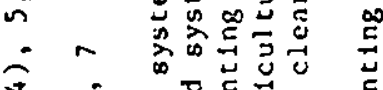

i i

$\therefore \quad \sim$

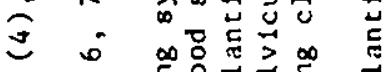

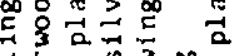

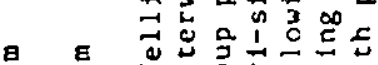

8 प

ก

I I

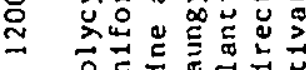

$\stackrel{\square}{\infty}$

竞

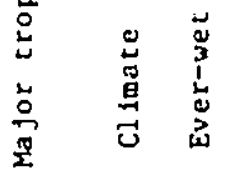

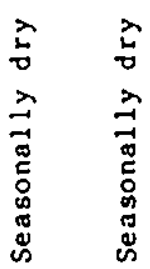

$\underset{n}{2}$

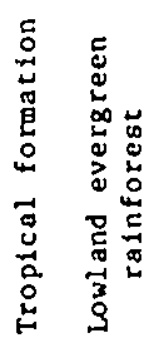

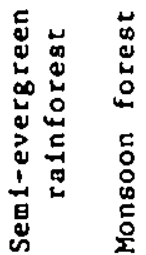

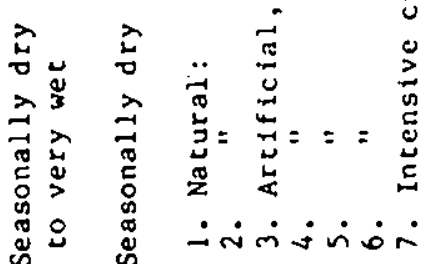

㒸

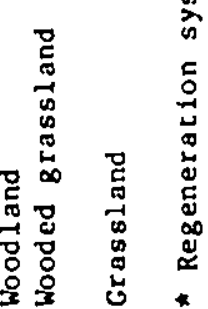


The value of the Man and Biosphere (MAB) project 1 in rectifying this imbalance should not be underestimated, but there is an urgent need for many more field studies by forest researchers in the rainforest zone. Carefully designed experiments that attempt to answer the questions with which we are here concerned need not be sophisticated or costly but do require the active participation of field rather than laboratory biologists.

Anong the rost urgent questions this paper was invited to answer are:

1. what are the genetic, physical and biological effects of replacing complex-structured forests by even-aged plantations;

2. what are the long-tern site derands of industrial wood production and can they be met;

3. is the natural forest performing an essential function by protecting soil, water and microclimate that is endangered when forest is replaced by plantations?

These questions have been frequently discussed and irportant reviews, to which this paper owes much, have been prepared recently. Whitmore (1975) and Ashton \& Brunig (1975) discuss large and small scale variation within tropical lowland forests in relation to climate, soils, topography, alcitude and regeneration patterns. They find that large scale differences in structure and floristic corposition between spatially separated soil types or climatic zones are well-known and documented but knowledge of the causes of small-scale variation, on which good silvicultural treatment must depend, and by extension, the effects of substitution "by plantations predicted, is Inadequate. Synnott (1975) considers the physical, enviromental and biological effects of logging and silvicultural operations in tropical, motst forests. He concludes that due to lack of quantitative information on floristic changes, growth processes and soll dynamics induced by forestry operations, "major mistakes wlll continue to be made both in forest management and in conversion of forests to other forms of land use".

The effects of interference by man with the tropical moist forest are also discussed by Brunig et al. (1975) and Brunig (1977). The former paper includes references to the few studies on litter breakdown, nutrient cycling, physical properties of the soll and erosion when forest is cleared, burnt and replanted with exotic or other specles not necessarily adapted to the ste. These authors, as all ecologically-minded writers discussing the managewent of the rainforest, again emphasize "the uncertainty of success due to the yet largely unpredictable reactions of the sensitive tropical, moist forest ecosystem to interference by man ... which makes any long-term land-use development project economically extremely risky. ... To reduce this risk... very 
much more knowledge on the ecology of the tropical woist forest is needed".

The considerable data on biomass and nutrient content of forest comunities collected by Rodin \& Bazllevich (1967) include relatively few results from studies in tropical rainforests and none on which direct compartsons can be made between the forest and plantation (see also Golley \& Medina 1975). Colley et al. (1975), in a study prompted by the interoceanic canal project in eastern Panama, provide the most complete information avallable on mineral cycling in tropical, moist forests, while making comparisons with studies in other tropical areas. Poore (1976a) considers the broader implications of interference with moist forest ecosystems by reference to climatic, phystcal, genetic and social consequences. He concludes that the success of sustained agriculture and plantation forestry depends on careful assessment of land capability, choice of species, methods of clearing, erosion control and tending and $a$ sustained application of skill and investment in fertilizing and pest control.

\section{RFGENERATION METHODS IN THE TROPICS}

The major cropical formations which are being modified or replaced on a large scale either by agriculture, perennial crops or forest plantations are summarized in Table 2, cogether with an indication of the regeneration methods used for some economically important tree species. The abrupt changes between existing communities and the plantations that replace them, are often more striking than in those temperate areas where the primary forest had been rodified by man millenia before modern silviculture was practised. Rainforest replacement

Within less than a century almost all the rainforest of Nigerfa has been selectively logged. The intensity of logging has increased at a rapid rate in recent years. Then, because the logsed forest with 300 or more species no longer contained enough trees of commerclal value, extensive areas were cleared and burnt and replaced by plantations of teak, Geelina arborea and, on a smaller scale, Indigenous 'pioneer' hardwoods e.8. Triplochiton scleroxylon, Terminalia superba and fvorensis, and Nauclea diderrichli. A rich, multi-species forest ecosystem, the result of millions of years of evolution has been suddenly destroyed and the dynamic process of regeneration and adaptation to catastrophic events or climatic change halted. Does this matter? To what extent can or should the plantations reproduce these processes? Is it possible to convert existing forest into high yielding stands without this abrupt alteration? Can artiflclally created forests be managed so that they not only produce a high sustalned yield of products needed by soclety but also protect the soil and 
maintain sat 1 sfactory water relations within the ecosystem? Such questions as these can only be answered on the basis of a better understanding of the ecology of the natural and artificial systems. An indication of some of the effects of rainforest modification or replacement is given in Table 2. Explotition, conversion, replacement or destruction of tropical rainforests is going on apace. It cannot be delayed on the grounds that we do not yet understand its processes fully. We can apply certain principles provided wo are sure that these 'principles' have not been based solely on studies in the rold-latitudes (Poore 1976b). Methods of enrichment and improvement of the African rainforests have been reviewed by Catinot (1965) and an account of methods of conversion to plantations by artificial methods is given by Lamb (1967).

More often than not, sllvicultural treatments, aimed at modifying but not destroying the rainforest structure, are widely believed to have failed to increase yields sufficiently to justify their cost. Low cost systems with natural regeneration and little silvicultural treatment may produce an adequate return on expendlture, but low wood ylelds per hectare; more expensive systems with natural regeneration and much treatment frequently increase growth races and may increase yields of certain categories of trees, but they may not be economic and their use is widely challenged for many reasons. More intensive systens that do not, however, involve the complete destruction of all the mixed forest vegetation, such as line and group planting can be highly productive and show a good return on investment, especlally when the standing timber in the pre-existing forest is fully ut 11 ized. Fxamples of successful enrichment plantations are to be found in Ivory Coast with Terminalia, in the Gabon with Aucoumea and in Uganda wi th Mesopsis (Synnott 1977).

Where the demand for wood products is becoming acuce, it is for replacement of the natural forest by intensive plantation. Lowe (quoted by Synnote \& Kemp 1976) calculates that in Nigerla it will be necessary to convert the whole forest estate, of whtch $20,000 \mathrm{sq.km}$ are in the forest zone, the balance being savanna woodland, to intensive production within fifty years. The potential yields from treated forest are not considered high enough to provide for expected demand. Conversion wil be mainly to plantations, sometimes by agri-silvicultural methods and less frequently by enrichnent planting. However, problems of supervising agri-silvicultural schemes mean that intensive planting under full control of the forest authority following clearfelling has greater likelihood of succes in practice.

Recent studies in Nigerla present a case for second thoughts on dismissing entirely silvicultural management of natural forest for sustained yield production (KIo 1978). Leslie (1976) discusses the issues involved in increasing 


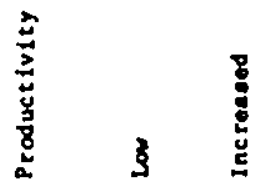

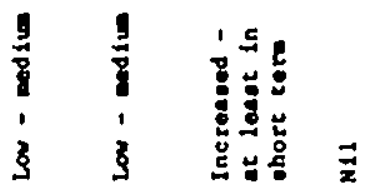

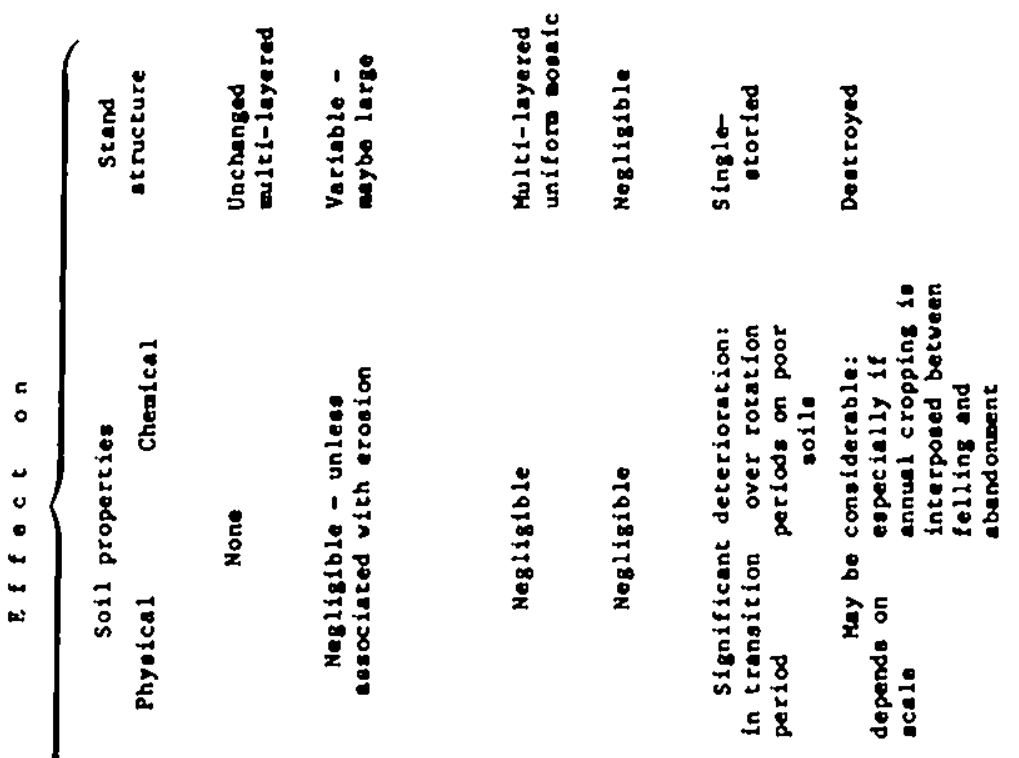

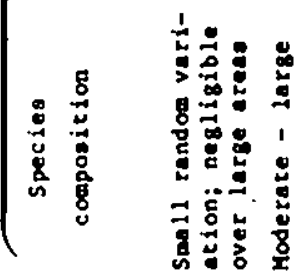

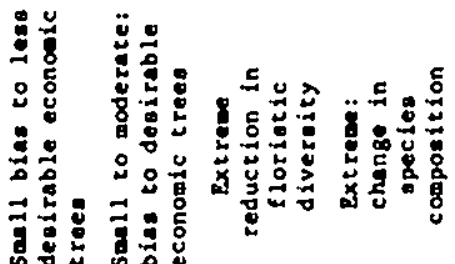

苟。

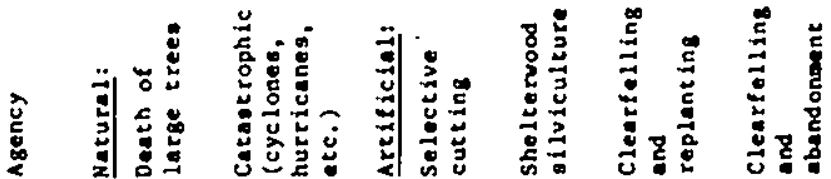


production by management of the natural forest $r$ ather than its replacenent.

Afforestation of montane grasslands

The large scale plantations of conifers on grasslands and open woodlands in tropical and subtropical highlands appear to have many similarities with terperate afforestation projects. The origin and persistence of the disclimax grassland or moorland are explained by fire rather than impeded drainage, and the length of the growing season is 1 imited by a dry season rather than by low temperatures, except at higher altitudes. Techniques of management are not dissimilar and productivity, despite sone striking exceptions on small areas, is not very much greater, even though rotations are usually shorter.

A typical example is the Viphya plateau in Malawi, latitude $12^{\circ} \mathrm{s}$, altitude $1200-3000 \mathrm{~m}$, rainfall 900-1300 mm. 40,000 ha of grassland and wonded grassland have been planted with pines for supplying the raw material for a proposed 150,000 con/year pulpmill. Yield of pulpwood is estimated as $17.5 \mathrm{cu} .0 . / \mathrm{ha} / \mathrm{yr}$ on a sixteen year rotation. The produrtivity of these plantations compared with that of the fire-climax vegetation they replace is greatly increased. Previous yields were confined to casual cutcing of fuelwood in the woodland areas providing a maximum of 2-3 cu.m/ha/yr. The grasslands provided little more than grazing for a sparse population of wild game. The use of such areas for ralsing domestic cattle or sheep wight provide similar increases in productivity under al ternative land use. This invites comparisons relevant to the planners but outside the scope of this discussion.

Afforestation in arid zones

High temperatures and low humidity restrict the choice of species and necessitate specialized establishment methods in the arid zones. Comparisons may be made with plantations on shifting sands, such as Culbin and the Landes. The social and technical problems of large scale plantations in arid zones are perhaps greater than the ecological ones. Once again, to keep the discussion within bounds, we must be content merely to recognize the existence of a different set of questions.

PRODUCTIVITY UNDER NATURAL AND ARTIFICIAL SILVICLLTURE Predictive models

Predictive productivity models, using the relation between growth and a component of water balance such as actual evapotranspiration can predict net primary production (NPP) for geographical regions (Sharpe in Lieth \& Whittaker 1975). Such models are an acknowledgement of the fact that plants tend to grow faster at higher temperatures and light intensities in the presence of adequate moisture supplies and to some extent quantify observed yield differences between major tropical ecosystems. Provided growth is predicted from 


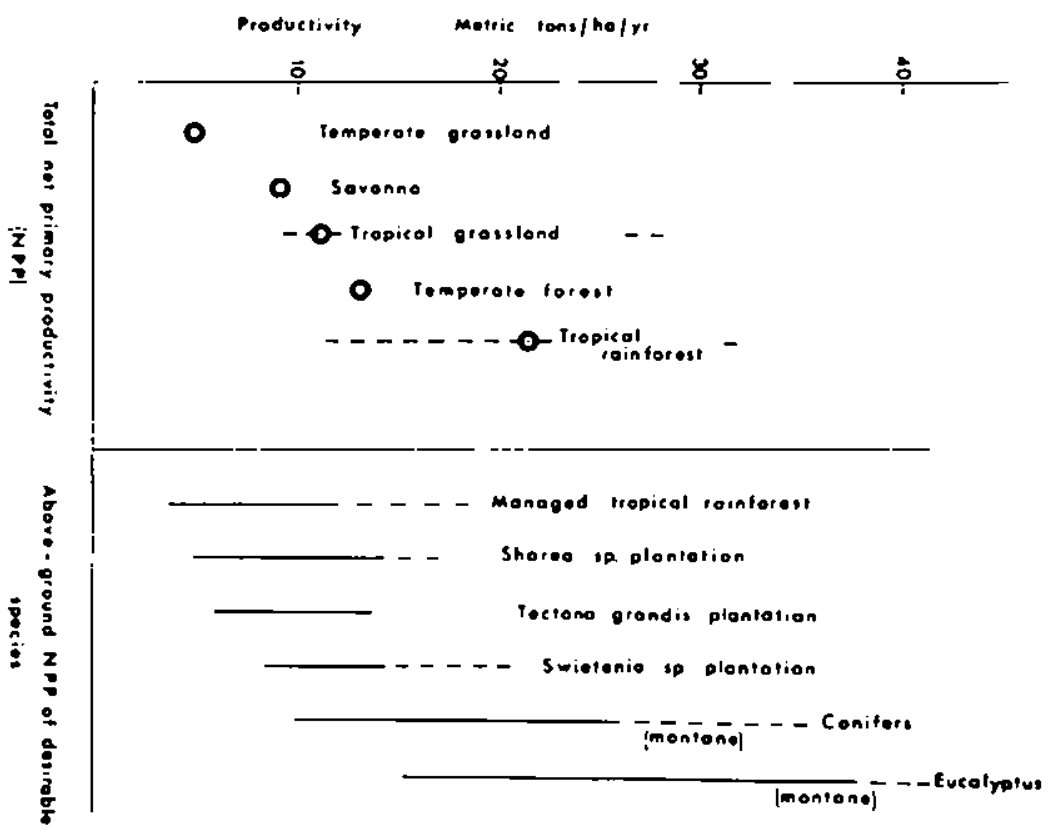

Fig. 1. Estimated productivity in some natural and artiflcial ecosystems (after colley et al. 1975, Dawkins 1963, Whitmore 1975).

estimates of potential evapotranspiration, taking into account periods of water deficit, and provided such calculations are based on actual measurements on site of temperature, rainfall and motsture capacity of the soll, such predictions can be of value in making reglonal comparisons of potentlal forest yield.

Obviously, to explain growth varlation within a region, we need to quantify other factors, not integrated by even such a complex parameter as actual evapotranspiration. For useful comparisons between natural forest and plantations to be made we shall briefly consider some effects of structure, succession and soil on productivity. The range of dry mater productivity lllustrated in Figure l draws attention to the striking difference between NPP and useful wood yields and between wood yields from natural rainforest and plantations. Where the complex-structured rainforest has a mean annual NPP of over 22 tons/ha/yr (Murphy in Lieth \& Whittaker 1975), the 
wood yield of silviculturally treated forest on better sites has been estimated as rarely more than 8 tons/ha/yr, ranglng frow 3.6 to 12 (Dawkins 1963), yet plantations of even-aged exotics way produce up to 40 tons/ha/yr or more, when planted at medium alticudes on good sites. These are maximum ylelds estimated on small plots. Average production over large management areas tends to be much less. The ylelds for exotfc species are usually based on data from first rotation stands with no certainty of long-term sustained yields at these levels (see Boardman, this volume).

The effect of structure and succession

It has been estimated that it would take from 200-400 years after clearing, for a lowland, evergreen, tropical rainforest to reconstruct the multi-layered and species-heterogeneous structure of the primary forest (Jones 1955; Golley et al. 1975). Brunig (1973) has shown how varlation in structure is related to successional development and site differences, suggesting how structure can be interpreted by its phystological and ecological function. More research is needed on the function of structure as a factor in the stability of the rainforest ccosystem. The evolution of a complex-structured community can be seen as the result of selection of groups of genotypes developing different survival strategies. The ploneers rapidly colonize clearings, may have short $11 \mathrm{fe}$ cycles and grow to the largest size in the shortest time to reproduce competitively. Shadebearers are adapted to survival and regeneration under canopy but at the expense of making sub-optimum use of incoming energy (Loucks 1970), though the evidence that there are any significant differences in carbon utilization between ploneers and shadebearers is slight (Whitmore 1975).

Neither strategy necessarily optiolizes wood production. Wood merely provides the mechanical structure necessary for the support of a crown that must extend towards the light, ahead of coopetition, for successful reproduction and survival of Individuals of some specles, while other species are equipped to complete their life cycles within the lower storeys and never reach the full $11 \mathrm{ght}$. The rate of ind Ividual tree growth and physical characteristics of the wood produced are related to the ecological characteristics of the species and seral stage of the community in which it grows but the extreme cases of ploneers and shadebearers typlfy patcerns of growth found also in plantations (F1g. 2).

Replacement of the multi-layered forest by a uniform population of light demanding individuals makes sense in teros of productivity and economics, as a simflar volume of tiober can be grown and harvested in a shorter period. Felling an even-aged plantation at the age when maximum mean annual increment is attalned, is analogous to harvesting a natural system at the late ploneer stage of a succession when net 


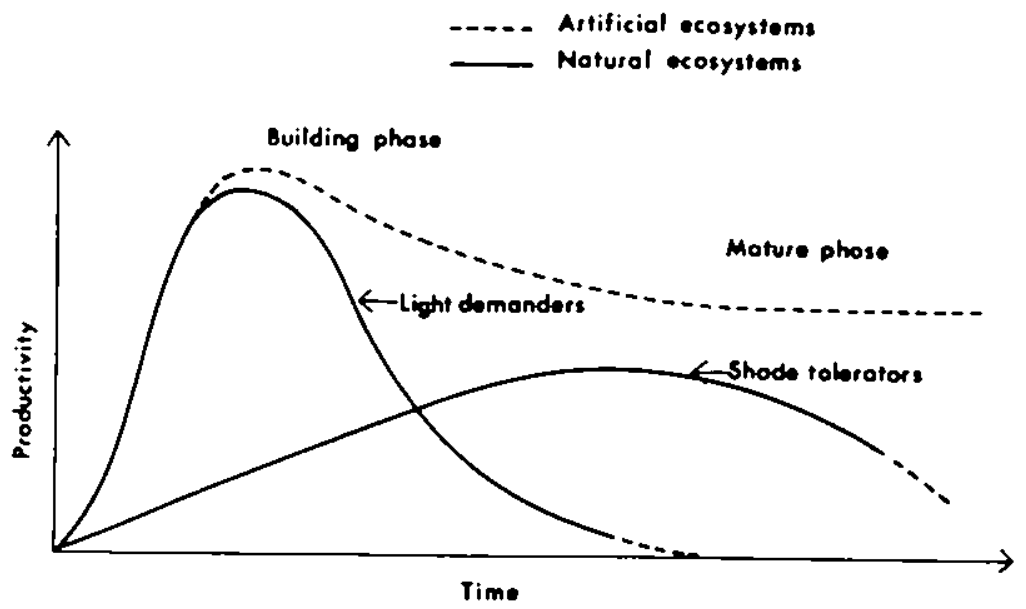

Fig. 2. Idealized diagram of the relation between productivity and successional stages in natural and artiffctal ecosystems.

primary production, NPP, is at a maximum (K1ra \& Shidei 1967). By contrast NPP in the climax forest may be entirely utilized in the maintenance of a dynamic equilibrium with a net yield of zero.

The losses incurred by replacement with a simpler artifictal system are less easy to assess. The loss of 'Information' In the form of genetic diversity, if the process of forest destruction continues, must be a cause of concern. Is 1 t wise to rely on production systems that have lost the power of self-regulation and regeneration?

Solls factors

Productivity estimates based on climatic models Indicate the potential growth for a region, and assume adequate supplies of avallable molsture and nutrients during the growing season; this applies as much to temperate as tropical areas but fallure to account for these factors in productivity estimates in the tropics is likely to be more Important. Soll processes, for example, differ in the troplcs to the cxtent that higher temperatures and intensity of rainfall increase the rate and depth of leaching and weathering. Assoclated with rocks of older age, such developments have resulted in extensive areas of forest solls of great depth but low wineral content within the rooting zone. In the ever-wet zones, 
biomass production is closely dependent on the amount of nutrlents returning to the soil in litter. Stark (1972) has hypotheslzed that there are special mechanisws for the utilization of minerals from litter with possibly direct transfer to root systems with mycorrhizas playing an important part. Also, the role of nitrogenous plants is probably more significant in the rainforest than in many temperate forest ecosystems. Some of the more extensive areas of existing rainforest occur on poor soils, yet carry as much biomass as any vegetation type. Data from Rodin \& Bazllevich (1967), summarized by Golley (1975), show tropical ralnforest with 564 tons/ha as having two and a half times the vegetative biomass of temperate deciduous forest and four times that of northern coniferous forest. The irportance of the closed nutrient cycle is well-known and frequently quoted in accounts of humld tropical forests, yet just as frequently ignored by 1 and use planners, although a full awareness of the consequences of forest destruction is highly relevant when selecting soll types on which to develop plantation forestry. Hall (1977) has Indicated the importance of soll types in the Nigerian rainforest, for explaining part of the floristic variation and for selecting sites for indigenous and exotic tree plantations (see also Ashton \& Brunig 1975; Whitmore 1975).

The problem of the $6 \mathrm{calc}$ of interference

This problem arises in rainforest management because silvicultural treatments, including logging, which are severe enough to result in useful increases in growth rates and yields of favoured species, way be so severe that the composition and structure of the forest are drastically altered and the habitat endangered. The risk depends very much on how much of the forest is commerclally valuable and hence on the flexibility of management.

There appears to be an analogy between the large scale destruction of rainforest as a result of cyclones and the destruction of extensive areas of temperate hardwood forests in North America by fire. The comerclally most valuable forests in the Solomon Islands are believed to be old seral stages resulting from cyclones up to 100 years previously, composed of long-lived ploneer species now being line-planted. The Nigerlan rainforest is probably a late seral stage resulting from wide-scale destruction 400 or so years ago and certain Caribbean forests owe their spectes composition to past cyclones (T.C. Whitrore pers. comm.). The role of fire in maintaining a proportion of a forest area in a youthful ploneer stage and the dangers to the ecosystem of fire control have been convincingly described by Loucks (1970) for Wisconsin hardwood forests. Where the destroyed areas are of such a pattern as to allow rapid colonization by pioneer species and re-establishment of soil cover, the ecosystem, far from belng destroyed, may actually be rejuvenated. Where the 
scale and pattern is wrong and ground cover is not re-established, or where climbers and undesirable secondary weed species prevent the germination of pioneer forest species, a particular ecosystem may be irreversibly changed and this can result in site deterioration. This way occur when the forest is cleared and burnt, especlally where heavy machinery is used on fragile solls in high rainfall areas. The scale and pattern of clearing in such cases will be inportant. Replacement of rainforest by even-aged plantations in other circumstances may, however, not be such an unnatural process as is sometimes supposed. Hcwever, we belleve there are dangers here and wany foresters and ecologists have $g$ tven warnings of the risks involved (Brunig 1974; Gonez-Pompa \& Wlechers 1976; Poore 1976b; R1chardson 1977).

Such views are a challenge to research and management; a challenge to reach an understanding of the functioning of cropical ecosystems and the ecology of cropical forest plants, but also, before many of the answers to further research are avallable, to apply management methods that, without prejudicing economic objectives, do not violate basic ecological princtiples.

One approach is to leave ecologlcally viable blocks of natural vegetation between areas cleared for plantations. At La Sabana in the State of Veracruz, Mexico, natural forest left in valleys during clearing for pine plantations comprise 40 per cent of the total area of nearly 8000 ha. On the Viphya Plateau in Malaw pionecr species of relict montane rainforest patches tend to regenerate in the grassland at their edges when protected from fire. Such protection is provided when stall forest pacches with fringing grassland are included within plantation areas. On the other hand, 'viable', i.e. self-regulating, balanced and reproduceable, areas of rainforest may have to be of considerable size, probably at least $10 \mathrm{sq} . \mathrm{km}$ and urgent research into acceptable patterns of rainforest developoent is needed while some optlons are still open. It is dangerous to plant extensive areas of single indigenous or exotic species before sowe understanding of thelr sultablitiy for the site is obtalned. Fallure of early plantations of Mellaceae, including spectes of Cedrela and Khaya, in many countries of tropical America and Africa provide examples of misdirected stlvicultural practices. Hore extensive were the results of shoot borer attack on Hevea brasiliensis in Surlnam when grown in pure plantations alchough both host and Insect were endewlc in the natural wixed forest (Gonggry 1948).

The Importance of organic matter

The loportant role of organic mater in tropical solls under forest is not confined to the ever-wet zones. An example way be given from the monsoon forest 6 of southern Ind 1 . Jose \& Koshy (1972) correlated the soll organic matter content at 


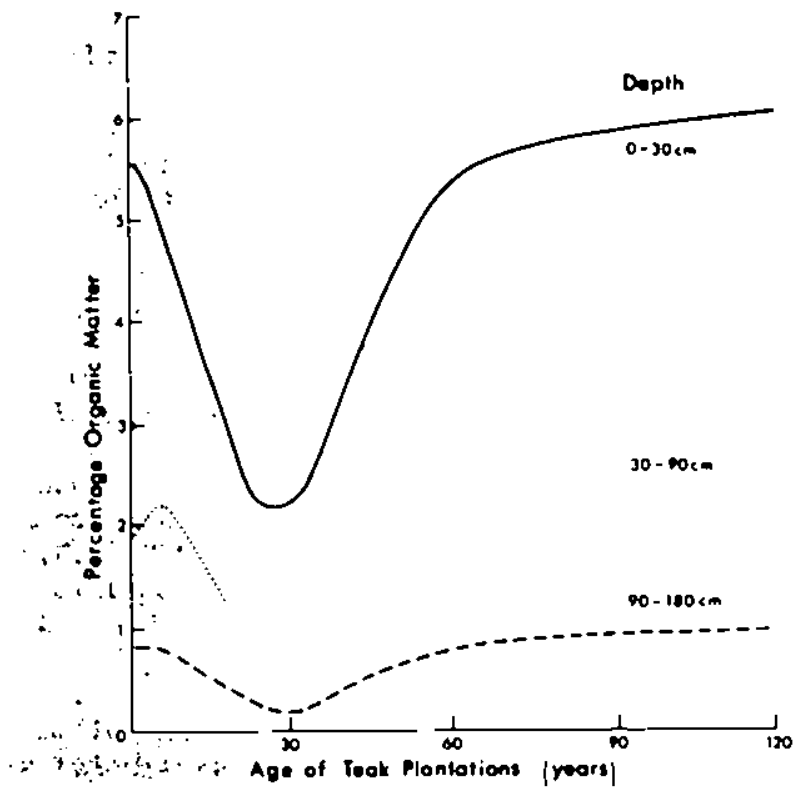

F1g. 3. Changes in organic matter content of solls under natural forest and teak plantations.

Nilambur (lattiude $11^{\circ} \mathrm{N}$, altitude $200 \mathrm{~m}$, mean annual rainfall $2500 \mathrm{~mm}$, mainly falling in June and July) under teak forest and under teak plantations of different ages (Fig. 3). A distinct'surface horizon $10 \mathrm{~cm}$ deep, rich in organic matter with a good crumb structure as found under the natural forest, was seen, only in the oldest teak plot, planted in 1846.

Bunvong. Thatutsa et al. (1976) studied the soil of forest in Thailand. treated by three silvicultural systems: clearfelling, strip-felling and selection cutting. Organic matter showed.a short-lived increase immediately following clearfelling, while dispersion ratios - a measure of structure stability obtained by wet sleving - increased from 21 to 34 per cent and porosity decreased from ca. 40 to 31 per cent. The dangers. of soll erosion under pure teak plantations have long been "recognized and underplanting and crop rotation suggested as remedies. The earliest teak plantations which are probably the earliest plantations of tropical trees, date from the beginning of the 19th century. At Nllambur, well over 100 years passed before the soll under plantations approached that under und 's'turbed forest. However, when timber was grown on the site" under good management and on an 80-year rotation, 
danger of site deterioration was slight. We lack data on the effect of short rotation silviculture of Gmelina arborea on soils and nutrient cycling but it is 11 kely to be less favourable under the same condtions, owing to the almost complete suppression of an understorey and ground flora, and a succession of lo-year rotations wll require careful monitoring.

Nutrient cycling

Lundgren (1978) has studied the nutrlent cycling and soll physical properties under pinus patula plantations at an altitude of $1800 \mathrm{~m}$ in Tanzania, with the object of determining the effect of a monoculture on site condtrions. After clearing the natural forest and during the first fifteen years under plantation, organic matter in the soll declined and bulk density increased. The effect on potassium was striking: the total amount of potassium removed in logs of thinnings and at clearfelling was approximately $700 \mathrm{~kg} / \mathrm{ha}$ - only 61 ightly less than the total reserve of potassium in the top $50 \mathrm{~cm}$ of soll at the time of clearfelling. This was on a cool and comparatively dry site where leaching and erosion may be expected to be less than in lowland plantations. The solls were humic ferrosols of the latosolic group. The effects are very different on the more fertile andosols derived from volcanic ash, on which aany coniferous plantations are established in East Africa, and which are well supplied with avallable ofineral nutrients (Lundgren 1978).

colley et al. (1975) found that calclum and potassium were the most abundant wineral elements in the vegetation of the natural lowland forest of East Panama but, whilst phosphorus occurred in relatively small amounts in the soll, calcium was relatively abundant. These elements are considered wost likely to be in short supply following conversion to plantations. Both have a high rate of blological cycling, 1 .e. between soll and vegetation and are in balance in the forest ecosystem. Blological cycling is 17-21 times greater than chemical cycling, 1.e. between soll and streams. After interference the amounts avallable to the new crop may become critical (see also Malkonen 1976), because of the inability of the geochemical cycling process to replenish the blological cycle at a fast enough rate. To rely on artificlal fertilizing to replace the lost nutrients may be too simple a solution, not only because of the costs Involved when natural supplies are not readily avallable, but also because of the high rates of leaching in tropical solls and risks to the functioning of nitrogenous bacterla and mycorrhizae that play a more important role in tropical than in temperate ecosystems.

Not all tropical solls have low fertility. Replacement of natural forest on solls with high cation exchange capacities by plantations under efficient management, need cause no significant loss of nutrients during the sensitive transition 
perlod. Plantations on ferrugenous solls in areas of moderate rainfall in Nigeria would be unlikely to cause soll degradation (Hall 1977), though those on ferralitic solls would carry greater risks. We are thus reminded of the importance of site, and especially soil studies in the preparation of planting plans and the importance of basic ecological studies before large scale conversion of forest is permitced. Studies on changes in soll properties under successive rotations of plantations, especially when related to dry watter yield, such as those of Evans (1975), are essentlal as a basis for the long-term planning of large-scale plantation schewes.

\section{CONCLUSIONS}

It has not been possible to answer the questions this paper was invited to discuss. Thls is seen to be inevicable when the state of ecological knowledge of tropical ecosystems is reviewed and one becomes aware of the limited number of completed detailed studies on the effects of changes in 1 and use on cropical forest ecosystems. The scale of the problem becones apparent when the range of variation in tropical habitats is appreciated as being far greater than that found in the mid-latitudes, where so much more intensive, ecological work has been done. This is the situation that the Man and Biosphere project lis designed to remedy, but much more than is already planned needs to be done. Subjects suitable for master's and doctor's degrees should be proposed that would challenge students from tropical countries to direct research effort to the fundamental problems of sustained yleld of natural resources, without which long-term planning is an illusion.

Such research would not require sophisticated equipment but could make significant contributions to ordered development in tropical countries out of all proportion to 1 ts cost. Many thesis topics being submitted today appear to have prestige value to the student or his supervisor, but have litte relevance to sclence and his country. Subjects for ecological research that would comblne prestige and relevance for students of physical as well as bfological sciences are surely not hard to define (Brun18 1974; Farnworth \& Golley 1974; Janzen 1975).

Growth models of even-aged plantations based on observed growth in permanent sample plots and current growing stock inventories have been developed for use in management control systems (e.g. Alder 1977), but relations between growth and environmental factors are less well understood. Physical and blological studies on the dynamics of artificial forest ecosystems, especially over successive rotation, are needed. The establishment of permanent sample plots, not only for continuous inventory but as microsites for ecological studies, 
provides the most reliable data for studying the dynamics of plantation growth. Without such data the questions before us will be answered only when evidence of site degradation has progressed so far as to be causing serious loss in yields or worse. In comparison to the cost of restoring site fertilicy in such cases, the cost of maintaining a network of growth monicoring plots as an insurance policy is small.

In the light of current knowledge of the effects of interference on a large scale on the rainforest, it is possible to draw up certain guldelines for increasing productivity, while minimizing the risk of ste degradation.

(1) On fragile sites maintain a mosaic of natural forest to ensure the potential for regeneration of forest conditions.

(2) When evaluating the feasibility of a plancation scheme include the cost of replacing the nutrients removed in harvesting, leaching and burning, and the cost of protection against pests and diseases.

(3) Convert forest to plantation with minimum habitat disturbance and soll exposure; the transition period is the perlod of greatest risk.

(4) Conserve stgnificant areas of natural forest for conservation of genetic varlability of flora and fauna within each region.

Forest management, like politics, is the art of the possible. Social, political and economic pressures on land development must be balanced by ecological realism to alleviate the effects of misuse of natural resources.

\section{ACKNOWLEDGEMENTS}

I am indebted to my colleagues in the Unit of Tropical Silviculture for assistance in the preparation of this paper and to H.C.Dawkins, T.J.Synnott and J.R.Palmer for criticism and advice.

\section{REFERENCES}

Alder,D.(1977). A growth and management model for confferous plantations in East Africa. D. Phil. Thesis, University of Oxford.

Ashton,P. \& Brunig,E.F.(1975). The variation of tropical moist forest in relation to environmental factors and 1 ts relevance to land-use planning. "Troplcal molst forest". Mitcilungen der Bundesforschungsanstalt fur Forst- und Holzwirtschaft, Reinbek bei Hamburg, \#109, pp.59-86.

Baur,G.N.(1964). The ecological basts of rainforest management. Ministry for Conservation, Sydney, New South Wales.

Brunig,E.F.(1973). Species richness and stand diversity in relation to site and succession of forests in Sarawak and Brune1. Amazoniana, 4 , 293-320. 
Brunig,E.F.(1974). Ökosysteme in den Tropen. Umschau, 13 , 405-410.

Brunig,E.F.(1977). The tropical rain forest - a wasted asset or an essential biospheric resource. Ambio, 6 , 187-191.

Brunig,F.F., Buch,M.von, Heuveldop,J. \& Panzer,K.F.(1975). Stratification of the troplcal molst forest for land-use planning. "Trupical molst forest". Mitteilungen der Bundesforschungsanstalt fur Forst- und Holzwirtschaft, Reinbek bei llamburg 109 , pp.1-58.

Bunvong Thafutsa, Wisut Suwannapinunt, Wasan Kaitpraneet \& Somsak Sukurung(1976). Changes in soil properties in teak forest under different silvicultural systems. Forestry Research Bulletin 39. Kesetsart University, Thailand.

Catinot,R.(1965). Silviculture tropicale en foret dense Africalne. Bols et Forêts des tropiques, fillo0-104.

Dawkins,H.C.(1963). The productivity of troptcal high forest trees and their reaction to controllable environment. D. Phil. Thesis, University of Oxford.

Evans,J.(1975). Two rotations of Pinus patula in the l'sutu forests, Swaziland. Commonwealth Forestry Review, 54 , 69-81.

Farnworth,G. \& Golley,F.B.(F,ds) (1974). Fragile ecosystems: evaluation of research and applications in the Neotropics. Springer Verlag, Berlin, Heidelberg, New York.

Golley,̈̈.B. \& Medina,F.(Eds) (1975). Tropical ecological systems. Springer Verlag, Berlin, Heldelberg and New York.

Golley,F.B., McGinnis,J.T., Clements,R.G., Child,G.I. \& Duever,M.J. (1975). Mineral cycling in the tropical moist forest ecosystem. University of Georgia Press, Athens, Georgia.

Gomez-Pompa,A. \& Wiechers,B.L.(1976). Regeneracion de Ins ecosistemas tropicales y subtropicales. "Investigaciones sobre la Regeneracion de Selvas altas en Veracruz, Mexico." Comp. Editorial Continentalia, Mexico.

Gonggry,J.W.(1948). Quelqeus remarques sur l'emploi d'essences exotiques et indigenes dans les silviculture tropicale. Bols et forets des tropiques, $7,251-257$.

Hall, John B.(1977). Forest types in Nigeria: an analysis of pre-exploitation forest enumeration data. Journal of Ecology, 65, 187-199.

Holling,C.S.( $1 \overline{97} 3)$. Resilience and stability of ecological systems. Annual Review of Ecology and Systematics, 4 , $1-25$.

Janzen,D.H.(1975). Fcology of plants in the tropics. Institute of Biology, Studies in Biology \#58. Arnold, London.

Jones,E.h.(1955). Ecological studies on the rainforest of southern Nigeria. IV. The plateau forest of the Okomu forest reserve. Journal of Ecology, 43, 564-594; 44, 
83-117.

Jose,A.I. \& Koshy,M.M.(1972). A study of the morphological, physical and chemical characteristics of solls as influenced by teak vegetation. Indian Forester, 98, 338-348.

Kio,P.R.(1978). Stand development in naturally regenerated forest in southwestern Nigeria. Ph.D. Thesis, Ibadan.

Kira,T. \& Shidei,T.(1967). Primary production and turnover of organic matter in different forest systems of the western Pacific. Japanese Journal of Ecology, 17, 70-87.

Lamb,A.F.A. (1967). Artificial regeneration within humid lowland cropical forest. F.A.O. Commission on Forest Development in the Tropics. Report of lst session. F.A.0., Rome. pp.73-86.

Leslie,A.J.(1976). A note on the economics of the management of the tropical molst forests. F.A.O. Commission on Forest Development in the Tropics. Report of $4 \mathrm{th}$ session. F.A.0., Rome. 7 pp.

Lieth, H. \& Whittaker,R.H.(Eds) (1975). Primary productivity of the biosphere. Springer Verlag, Berlin, Heidelberg and New York.

Loucks,0.L.(1970). Evolution of diversity, efficiency and community stability. American Zoologist, 10, 17-25.

Lundgren,B.(1978). Soll condtions and nutrlent cycling under natural and plantation forests in Tanzanian Highlands. Reports in Forest Ecology and Forest Soils, 31 . Swedish University of Agricultural Sciences, Uppsala.

Malkonen,E.(1976). The effect of fuller blomass harvesting on soll fertility. Symposium on Harvesting of a larger part of the forest biomass. Volume 1. F.A.O./F.C.E./I.L.0., Ceneva.

Poore,D.(1976a). Ecological guidelines for development in tropical rainforests. International Union for the Conservation of Nature, Morges, Switzerland.

Poore,D.(1976b). The values of the tropical moist forest ecosystems and the environmental consequences of their removal. F.A.0. Commission on forest developrent in the tropics. Report of 4 th session. F.A.0., Rome. 39 pp.

Richards,P.W.(1952). The tropical rafnforest, an ecological study. Cambridge University Press.

Richardson,D.(1977). A Faustian dilemma. Lnasylva, 29, 12-14.

Rodin,L.E. \& Bazflevich,N.I.(1967). Production and mineral cycling in terrestrial vegetation. Oliver and Boyd, Ed Inburgh.

Stark,N.(1972). Nutrlent cycling pathways and litter fung1. Bioscience, $22,355-360$.

Synnott,T.J.(1975). The impact, short and long-tern of silvicultural, logging and other operations on tropical molst forest. Commonweal th Forestry Institute, Oxford. Synnott,T.J.(1977). Final report on tropical high forest 
management project. Commonwealth Forestry institute, Oxford.

Synnott,T.J. \& Kemp,R.H.(1976). The relative merits of natural regeneration, enrichment planting and conversion planting in tropical molst forests, including agrisilvicultural techniques. F.A.0. Commission on forest developwent in the troplcs. Report of 4 th session. F.A.O., Rome. 12 pp. Whitmore,T.C.(1975). Tropical ralnforests of the Far East. Clarendon Press, Oxford. 
September 9, 1973

\section{FOREST PRACTICFS AND RF.SEARCH REQUIREMENTS -} TODAY AND IN THF. FUTURE

Chairman: J.D. Mat thews

The way ahead in research and practice

- J.D. Matthews, F.T. Last and D.T. Seal 
THE WAY AHEAD IN RESEARCH AND PRACTICE.

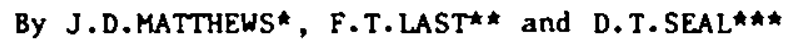

* Department of Forestry, University of Aberdeen, St. Machar Drive, Old Aberdeen, $A B 92 U U, U . K$.

** Institute of Terrestrial Ecology, Bush Estate, Penicuik, M1dlothlan, EH26 OQB, U.K.

*** Forestry Commission, Northern Research Station, Rosiln, Midlothlan, EH25 9SY, U.K.

\section{SUMMARY}

Never doubting that timber production is, and wll remain, the prime purpose of plantation forests, it was accepted that yields assessed in terms of quality and quantity must be related to, and be compatible with, the effective use and maintenance of soll and water resources, the effective capture and exploitation of solar energy, the conservation of wldiffe, the prevention of environmental impalrment and the provision of employment. Because of their diversity and complexity, the concurrent consideration of these different criteria necessitates a systems approach.

In seeking improvement, the meeting was concerned with design, as related to the architecture of individual trees before canopy closure, the canopy structure of tree stand 8 subject to between-plant competition and the mosaics of large blocks of trees of different ages, the latter being important not only for harvesting but also for wildlife, notably the control of deer. With these considerations in mind, attempts were made to define ideotypes, including trees with large harvest indices, 1.e. harvestable yield as a proportion of total blomass. When doing this, 1 t was agreed that the conservation of genetic resources was of prime importance to ensure the continuing avallability of material for the production of improved trees, whether propagated vegetatively or grown from seeds from controlled crosses.

The continuing appropriateness of existing methods of land classification was questioned. 
Those based on past performance are likely to underestimate future ylelds, whereas others based on site characteristics are better indicators of the need for site preparation than of potential yields. Other methods are needed, recognizing that (1) wind is a major determinant of growth and (ii) crop improvenent is an terative process with the introduction of new variants increasingly warranting a reconsideration of silvicultural practices. Tree nutrition 15 of fundamental importance. In the future, nutrient turnover should be budgeted, incerrelating the application of artificial fertilizers with nutrients released during litter decomposition. The appreciable benefits of mycorrhiza were stressed in relation to events during establishment rather than in the longer term. It was foreseen that increasing amounts of nutrients might be applied in the future. But, because the production of artificial fertilizers uses appreciable amounts of energy, the need to quantify the role of nitrogen-fixing microbes and others involved in mineralization was stressed.

Plantations of different ages provide different habitats for pests, both vertebrate and Invertebrate, pathogens, and also for desirable wildlife, both plants and animals. In studying the population dynamics of these plants and animals, it was stressed that the $r$ incidence should be judged against indices of damage, with the recognition of acceptable thresholds.

RÉSUMÉ

on salt que la production du bois est, et restera, la raison principale des plantations forestières; 11 est admis que la production definie en termes quantitatifs et qualitatifs, dolt être reliêe, et doit être compatible, avec une utilisation efficace des ressources du sol et des eaux, la capture et l'explotition de 1'énergie solalre, la protection de la faune sauvage et de l'environnement physlque et dolt constltuer une source d'emplofs. De par leur complexité et leur diversité ces différents critères demandent une approche systématique du sujet.

Le concept d'amélioration a été un des thème-clés de ce congrès, surtout en ce qui 
concerne l'architecture; celle des arbres avant la fermeture du couvert, celle de la structure du couvert des peuplements sujets a une competition entre individus, celles des mosalques formes par de larges groupements d'arbres d'age divers (celle-ci étant importante non seulement pour la récolte, mals aussi pour la faune sauvage et notament le contrôle ducerf). En tenant compte de ces considérations, nous avons été tentés de definir des idéotypes, comprenant des arbres a Indices de récolte importants, c'est à dire un rendement récoltable proportionnel a 1 a biomasse totale. De cette façon il apparât evident que la conservation des ressources génétiques est d'une importance primordiale pour assurer la disponibilité continuelle du matériaux producteur d'arbres meilleurs, qu'ils solent générés végétativement ou qu'on alt utilisé des semis provenant de croisements contrôlés.

Nous avons discuté les methodes existantes et prévalantes de classifications des stations: celles qui se basent sur le rendement futur, celles baskes sur la production autérfeure sousestimeront probablement les productions futures, tandis que d'autres basées sur des caracteristiques de la station conviennent d'avantage à 1ndiquer les améliorations de la station que sa production potentlelle. Il est nécessaire d'utiliser d'autres méthodes en tenant compte du falt (1) que le vent a une Influence capitale sur la croissance et (11) que l'amélioration de la plantation est un procédé trératif: plus on introdult de varlantes nouvelles, plus on a besoln de remettre en question les techniques sylvicoles. La nutrition de l'arbre est d'une Importance primordiale. A 1 'avenir, 11 faudra calculer exactement l'apport total d'éléments nutritifs, en essayant de relier 1 'introduction d'engrais artiflclels avec les éléments nutritifo liberés pendant la décomposition de la litière. Les avantages appréclables des mycorrhizes ont éte signales et soulignés pendant la période de creation plutôt qu' à long terme. Nous prévoyons $1^{\prime}$ ut 1 lisation de plus en plus étendue d'engrais à l'aven1r. Malgré cela, à cause de l'énergle considérable ut 11 fóee par leur production, 11 faut essayer de quantifier le rôle des oficrobes 
fixateurs d'azoce et d'autres, présents au cours de la minéralisation.

Les plantations d'age mûr sont la demeure d'une sérle de parasites, vertébrés ou invertébrés, de pathogenes et aussi d'une faune et d'une flore sauvages désirables. Nous soulignons que toute étude de la dynamique de ces populations animales et végétales devra être mesuréc et pesée contre les dégats possibles, dans des limites acceptables.

\section{Z.USAMMENFASSUNC,}

Da man nie in Frage stellte, dass die Holzproduktion der lauptzweck von Forstpflanzungen ist und bleibt, wurde akzeptiert, dass der qualtiative und quantitative Ertrag von folgenden Parametern abhängt, bzw. sich tit ihnen vereinbaren lassen muss: Ausnutzung und Erhaltung der Bodenkraft und des Wasserpotentials, Ausnutzungsgrad der Sonnenenergie, Erhalt der Fauna, Verhütung von Uwweltschäden und Schaffung von Arbeitsplätzen. Wegen der Unterschiedlichkeit und Komplexität der genannten Kriterien fst es nötig, sie systematisch zu untersuchen.

Auf der Suche nach Ansatzen zur Produktion besserer Genotypen beschaftlgte slch die Tagung mit äusseren Baumerkmalen elnzelner Bäume vor Kronenschluss, mit dem Aufbau des Kronenbereiches in Abhängigkeit von der Wettbewerbssituation und wit der heterogenen Struktur grosser Komplexe verschledenaltriger Bäume. Letztere sind nicht nur für die Ernte wichtig, sondern auch für das Tierleben, insbesondere für Rehwild. Aufgrund dieser Uberlegungen versuchte man, Ideale Bestandestypen unter Finbezlehung ertragretcher Baumarten $z$ definieren, wobei die verwertbaren Erträge proportional zur Gesamtblomasse sein sollten. Dabel kam man zu der übereinstimmenden Auffassung, dass de Erhaltung genetischer Ressourcen von vorrangiger Bedeutung für die Sicherstellung der Produktion von genetisch 'besseren' Bäumen sel, die entweder vegetativ oder aus defintertem Satgut hervorgehen kònnen.

Es wurde gefragt, ob die bestehenden Mechoden der Standortsklassifikation weiterhin angemessen selen. Diejenigen, die auf ertragsgeschichtlichen Daten basieren, 
unterschatzen leicht kunftige Erträge, wăhrend andere, die sich auf physische Standortselgenschaften stützen, zwar gute Ind ikatoren for notwend ige Standortsvorbereltungen liefern, aber nur beschränt Ertragsprognosen erlauben. Man braucht andere Methoden, da man erkannt hat, dass (1) Wind ein wichtiger Wachotumsfaktor lat, (11) die verbesserung der Samen ein fortlaufender Prozess ist und die Elnfunrung never Varianten ein Uberdenken forstwitschafticher Praktiken zunehmend erforderlich macht.

Dle Nährstoffversorgung der Baume ist von $g$ rundlegender Bedeutung. In Zukunft sollte der Nahrelementumsatz wirtschaftlich dahingehend überdacht werden, dass man die Anwendung von Mineraldungern und die naturliche Nahrelementfreisetzung durch Streuzersetzung sinnvoll kombinfert. Der beachtliche Nutzen von Mykorrhizen wurde wehr in bezug auf das Geschehen wahrend der Pflanzung, und nicht 80 sehr unter langfristigem Aspekt betont. Man konnte davon ausgehen, dass in Zukunft zunehmende Mengen an Dïnger verwendet wurden. Da Jedoch deren Produktion beträchtliche Energiemengen verbraucht, gewinnt die mengenmäsige Erfassung stockst of fbindender und anderer mineralisierender Mikroben immer mehr an Bedeutung.

Alternde Pflanzungen bleten hinterelnander verschiedene Habltate fur Schädinge und Krankheftserreger, aber auch fur erwinschte Pflanzen und Tiere. Die Untersuchung von deren Populationsdynamik soll im Zusammenhang mit Schadensverzelchnisen erfolgen, wobe 1 für die Praxis bestimmte Schwellenwerte erarbeltet werden müssen.

\section{EPILOGUE}

This meeting took place at a time when many pressures are forcing foresters to take stock of the clrcumstances in which they work. The world demand for timber and timber products is continually increasing yet the unremitting 108 s of natural forest 18 becoming recognized as unacceptable by an ever-increasing number of people. Without doubt the demand, if it 18 to be wet, will only be satiofied by the large scale establishent of plantation forests, but this 18 not to minimize the contribution frow natural forests managed for sustained yields. 
Although the main purpose of even-aged plantations is to produce timber, thetr managers work and take decisions in complex circumstances. They are responsible for managing large tracts of land, the tree crops on those lands and the plants and animals dependent on the habitats so provided. They must protect water supplies, meet economic and social goals by producing timber in sultable quantities and qualities, and directly or indirectly provide employment often in remote rural areas. The concept of multiple use of forests is not new. What is new, is the increased interest in this concept taken by people living in towns and cities, and the increasing pressures that they apply, forcing foresters to re-assess their management objectives. As pressures to control the use of fossil fuels become stronger, so will the demand, already strong in some parts of the world, for plantations as renewable resources of fuel. Forest managers will also need to become accustoned to assessing costs, not only in monetary terms but also in terms of energy inputs and outputs, relating yields to energy used during silvicultural and harvesting operations.

The problems can be stated readily, but their solutions are more difficult necessitating a greater understanding of forest ecology. At some sessions, particlpants were concerned with applied aspects of silviculture, in others with fundamental ecology. Even-aged plantations are becoming increasingly productive with improved cultivation procedures, including soil drainage, the greater use of exotic spectes, the increasing avallability of better cultivars with larger harvest indices; the chemical control of weeds after planting, the application of inorganic fertilizer, the limproved control of damaging insects and fungl and less wasteful and more complete methods of harvesting. Moreover, the potential for further improvement appears great. However, if large yields of $t$ imber are to be sustained from even-aged plantations, silviculturists and ecologists must be able to Identify and control processes that could damage their plantations and soils, and deleterlously affect non-damaging populations of wildlife, both plants and animals. Four aspects, of outstanding importance, were stressed:

(a) the long-term effects on the ecological stability of even-aged plantations of selecting restricted numbers of productive specles, provenances and cultivars, with the consequent narrowing of their genet lc base;

(b) the effects on tree growth of soll amelloration by drainage, cultivation and the application of fertilizers, the effects of even-aged plantations on the organic layers of soils and their combined influences on the prediction of tree growth by stie indices;

(c) the effects of afforestation on catchment water yields and (d) the need for more information about the ecology of 
insects, birds and other animals, of microbes, including mycorrhizal associates, and plants, so that their effects, beneficial or damaging, can be more accurately predicted.

\section{GENETIC BASIS OF EVEN-AGED PLANTATIONS}

Throughout the world extensive even-aged plantations are forwed with exotic species. The search for increased yields of timber and other forest products has progressed inexorably to the selection of those species that are easy to propagate, are sulted to 'pure', even-aged plantations, can adapt to a wide range of climates and sites, are relatively free from damaging pests and pathogens, and produce above average ylelds of useful timber. As tree tmprovement programes develop, some provenances are identified which give important improvements in quality and quantity of timber, with some selections being confined to one of a few individuals instead of populations. Species of Pinus, Picea, Larix, Betula, Eucalyptus, Cryptomeria, Tectona and many others are being subjected to selection that progressively narrows the genetic base of the stocks ultimately used for even-aged plantations. The process is well recognized, the benefits are great but experlence in agriculture has amply demonstrated possible long-term hazards.

Although beneftis are likely to accrue from the selection of progenies able to tolerate stresses attributable to severe cold, soll molsture deficits etc., larger yields are likely in most instances to be obtalned sooner by selecting trees whose harvestable ylelds form increasing proportions of total blomass. Tree breeders and silviculturists must continually modify the characters of the ideal tree, or idcotype, to take account of the Improved understanding of ways in which trees in plantations interrelate one to another at different stages of development; those that show promise before canopy closure may not continue to succeed afterwards. For the future, it is also desirable to know how genetically less heterogeneous stands of improved trees respond to severe corpetition for limited resources of water and nutrients as compared to their unimproved progentiors, remembering that sites, with improved preparation, will inevitably be less varlable.

\section{SITE CLASSIFICATION, SITE AMELIORATION AND NUTRIENT CYCLING.}

Participants at the meeting recognized that site classification is an essential basis for silvicultural dectsions when establishing even-aged plantations. Because of their importance, the different types of site Indices, designed to predict fucure production of $t$ imber, were critically reviewed. Some are based on yields of previous tree crops, others focus on soll types which incidentally integrate influences of climate on soll processes. Site ind ices based on past yields tend to underest imate what can be achieved in the future with improved silvicultural practices, whereas those 
based on soll types tell more about what needs to be done to prepare sites for planting than they do about potential yields. From our limited knowledge of forest climates - which needs to be greatly strengthened particularly for remote upland and mountain sites - assessments of exposure to wind can be made simply and effectively using standardized tatter flags. But how can the observations obtained be related to mechanisms and processes controlling stomatal behaviour and water loss? How can this information be used in early selection i procedures?

Many speakers emphasized the importance of soll organic matter for the continuing success of even-aged plantations. Some suggested that large yields of $t$ tmber may have been gained from the first generation of plantations at its expense, while others mentioned the development of fissures following the irreversible drying and contraction of peats in some areas after having been planted wt th lodgepole pine. The importance of organic matter decompostition was discussed in relation to amounts of nutrients released and relative to (1) applications of artificlal fertilizers and (1i) the requirements of forest trees at different stages of their development.

A consideration of basic aspects of nutrient cycling in even-aged plantations lead to another closely related subject considered important by participants. Frequent reference was made to the knowledge and experlence gained frow agricultural research and practice. Farmers amellorate their solls by drainage and ploughing; foresters have also achieved improvements in this way. Fatmers amend their solls by adding organic and inorganic fertilizers and the amounts of these often are finely adjusted to the needs of individual species and cultivars; an iterative procedure with amounts of fertilizer and the nature of other agricultural practices being reconsidered and adjusted $a s$, and when, new cultivars are introduced. For instance, the dramatically increased applications of fertilizers following the replacement in the early $60^{\circ} \mathrm{s}$ of long- by short-otrawed cultivars of wheat. This approach can also take account of local variations in climate and soll and could therefore be regarded as an example upon which to base regional silvicultural prescriptions. Silviculturists working in protection forests and with long rotations accept that their silvicultural systems must be well-buffered against hazards, but in even-aged plantations this attitude may not be 80 appropriate as soll scientists and engineers continue to find ways of reducing edaphic site variations by dralnage, cultivation and the application of fert1lizers.

In addition to discussing the use of fertilizers and the release of nutrients from decomposing litter, two other aspects of tree nutrition were debated. For some conditions it 
would appear profitable to study the use of mixtures, including trees such as Alnus species, with root colonizing, nitrogen- fixing microbes and additionally there could be mertt in identifying within-species variants that more efficiently explot avallable nutrlents. These ideas lead to a renewed interest in mycorrhizas which, at this meeting, centred on their beneficiai effects on the rapid establistment of trees after planting.

\section{EFFECTS OF AFFORESTATION ON CATCHMENT WATER YIELDS.}

on many occasions during the meeting there were references, direct and Indfrect, linking trees and water: the need for drainage to facilitate establishent, the inter-relation between water avallabllity and stomatal behaviour, the abllity of trees to withstand stress whether attributable to drought or waterlogging and very importantly the water ylelds from afforested catchments. The latter are of particular significance with afforestation and the conservation of water being regarded, in some areas, as incompatible land uses. Although some catchent studies have been made there is a need for more 60 as to be in a position to predict the effects of trees, compared with those of other types of vegetation, in a diverse array of environments. These studies should include estimates of water quality in addition to quantity.

\section{ECOLOGY OF THF. FAUNA AND FLORA OF EVEN-AGED PLANTATIONS.}

The importance to the continued success of even-aged plantations of knowledge about damaging populations of pests and pathogens is self-evident. Less obvious but equally essential in the long term, is the need to learn more about organisms that at present appear Insignificant but may be potentially valuable or dangerous. If the meeting had been held in 1975 this statement would have been applicable to the pine beauty woth (Panolis flamea), whose normally quiescent populations in Scots pine growing in the U.K. have, in the interim, increased in a few plantations of lodgepole pine to damaging proportions. The large yields of even-aged plantations may justify some risks and the acceptance of limited losses, but must seek to minimize the occurrence of large infestations and epidemics which may be uncontrollable or require the use of extensive and expensive control measures with possible side effects on wildife and other forest assets. It is necessary to recognize that the study of associated plants and animals, Including pests and pathogens, is an integral part of forest ecology. If their behaviour and population dynamics were better understood, control could be exercised with increased discretion. 


\section{RESOLUT IONS}

After the main purpose of the meeting had been successfully achleved, namely the provision of a form for discussing the ecology of even-aged plantations, participants agreed the following resolut lons:

I. Projections of world wood production and supply and of world wood demand, indlcate that sooner or later, and probably by the turn of the century, there will be a world shortage of wood which will becone Increasingly severe.

II. To meet this shortage it is inevitable that the use of intensive plantation forests will be extended.

III. Fconomic production through plantations will only be sustained so long as foresters are fully aware of the direct and indirect effects that plantations have on the environment.

IV. To ensure that production:will be sustained at economic levels, it is essential to augment the amount and range of fundamental research upon which applied research and management can draw.

v. In particular, the following. are recognized as key research fields:

(a) Plantation forestry often leads to a reduction in numbers of species grown, dependence on a limited genetic base and probably, in an increasing number of instances, to the use of clones. To safeguard the future, international action is required to conserve tree species in the $1 \mathrm{r}$ natural habttats, an important part of the work already - belng done by F.A.O. through its Panel of Experts on Forest Cene Resources; signiflcant and fully representative areas of natural forest must be conserved with equal emphasis on trees, soil and assoclated fauna and $f$ lora.

(b) By analogy with agriculture, the use of exotic species, the narrowing of the genetic base and the intensification of management increase the risks from pests, invertebrate and vertebrate, and pathogens. Research on spectes, which may affect forests of the future, is needed.

(c) Fertilizer requilements need to be linked to nutrient budgets. In particular, the possibility of exhausting the store of soll organic matter, and hence of nitrogen, needs attention.

(d) Too little is known of the effects on (1) so11s and (11) yields of water catchents; the latter deficlency reflecting an loperfect appreclation of the water relations of trees in different sttuations, particularly when comparing evapotranspiration from forests and grasslands.

(e) Experience in many parts of the world has shown that damaging populations of herblvorous animals, e.g. small 
rodents and deer, of ten develop in plantation forests. Their behaviour, reproductive ability and patterns of dispersal need to be invest 1 gated so as to define what constitutes a potentially damaging population.

CONCLUDING REMARKS.

Productive even-aged plantations are now distributed chroughout the world. They include plantations of Pinus taeda in southeastern United States, Pinus radiata in New Zealand and Australta, the clonal plantations of Cryptoneria japonica In Japan, the second and third generation plantations of Tectona grandis at Nilambur in southern Ind $1 \mathrm{a}$, the Pinus oocarpa plantations on the Jos plateau of Nigeria and the picea sitchensis stands of Galloway and Eskdalemuir in southern Scotland. In his opening paper, Mr G.D.Holmes emphasized the contribution that even-aged plantations must make to world supplies of timber and in his closing remarks, Professor D.Mlinsek, Coordinator of Division l of I.U.F.R.0. emphasized three main qualities of the forest resource, namely timber production, site protection and soclal benefits. Furthermore, Professor Minkek stressed that managers of plantation forests st 111 had much to learn from those tending naturally regenerating forests, as in Central Europe, where there is concern for site protection, in its broadest sense, in addition to timber production. 


\section{OFFERED PAPERS}

Malntenance of productivity in successive rotations of radiata pine in South Australla.

R. Boardman

Socioeconomic evaluation of the

recreational use of $f$ ish and wildife resources in Alberta, Canada.

W.E. Phillips and M.R. Carroll

Variation in tropical tree spectes

P.J. Wood 
MAINTENANCE OF PRODUCTIVITY IN SUCCESSIVE ROTATIONS OF RADIATA PINE IN SOUTH AUSTRALIA

Woods and Forests Department, 135 waymouth Street, Box 1604 G.P.O., Adelaide 5001, South Australla.

\section{SURMARY}

Investigation of site and silvicultural factors related to a decline in productivity in second rotations of pinus radiata suggested no simple causal factor; rather that many factors were acting in concert.. The establishment phase of developing even-aged plantation became pre-eminent for growth development, then had a profound influence on long-term productivity within the rotation. A long-term investigation has been established of two direct comparisons of first and second rotations. The whole experiment has a high level of positively-imposed site homogeneity and 8 rowth-promoting input with the aim of producing near-optimum growth rate, limited only by climatically induced factors.

\section{RESUME}

Les recherches effectuées sur les facteurs liés à la station et à la sylviculture et rellés au déclín de la productivité du pinus radiata pendant la deuxlème révolution n'ont misen évidence aucun facteur de cause à effet mais plutót une série de facteurs interd́pendants. La phase de creation pendant le développement des plantations equiennes est d'une importance prééminente pour le développement de l'arbre et Influe de facon captale sur la productivité à long terme pendant la révolution. Une étude à long terme établissant des comparaisons directes entre première et seconde révolution a étè mlse en route. Le sujet entler se base.sur une homogénéité imposée de la station et des données capables de produire un taux de croissance presque optioum, limité seulement 
par des facteurs climatiques.

ZUSAMMENFASSUNG

Eine Untersuchung des Standorts und der waldbauliche Faktoren it Hinblick auf den Produktivitatsrückgang in der zweiten Generation bel pinus radiata ergab, dass nicht nur ein elnziget Faktor die Ursache 18t; es wirken vielmehr eine Reihe von Faktoren zusammen. Die Begründungsphase in der Entwlcklung gleichaltriger Pflanzungen hat te hervorragende Bedeutung für die Wachstumsentwicklung der Bäume und hatte einen nachhaltigen Einfluss auf die Produktivität während der Utrtrlebsze1t. Man führte elnen Langzeitversuch durch in Form zweler direkter Vergleiche von Erst- und Zweltgeneration. Der ganze Versuch ist gekennzelchnet durch einen starken positiven Einfluss der Standortshomogenltät und wachstumbfördernder Dingerzufuhr. Durch dlese sollte eine nahezu optimale Wachstursrate erreicht werden, die nur durch kimatische Faktoren eingeschränkt wird.

\section{INTRODUCTION}

South Australla has a very limited area which possesses the climatic and edaphic conditions sultable for forestry and capable of meeting the timber-based needs of the population. Negligible areas of vigorous natural forest growth survived the first decades of colonization (1830-1970) (W1111ams 1974) and plantation forestry, from small beginnings in. 1875 has been strongly developed (Lewis 1975). These areas are dominated by a single specles of pine, radiata pine, singularly well-guited to the soils and clituate. At the present time the plantation estate is close to 100,000 ha (Bednall 1968; Lewis, Keeves of Leech 1976).

Most land sultable for pine afforestation has already been created as "Forest Reserves" by Act of Parllament and only uinor parcels can be acquired, and these indirect competition with agriculture. Consequently yield.is regulated on the 'sustained yield' principle on a median site quality area equivalent basis (Lewis, Keeves \& Leech 1976).

Evidence for a decline in productivity in second rotation plantations has acculated. This has been posed as a critical problem in forestry management as it reflects on the capacity of the forest to supply the wood-using industries, encouraged by the stability offered by. sustalned yleld. As Bednall (1968) has stated: "... evidence ... Indicates quite clearly that second rotations of Pinus radiata are overall producing less wood per acre per annum than they did in the first rotation at 
similar ages and at similar stocking. A remedy for this wust be found."

There are two levels of remedial condition: a relative one and an absolute one. The relative solution applies when cultural techniques applied, regardless of cost, to the second rotation raise 1 ts productivity to at least that of the historical performance of the first crop on that site. The absolute solution is more complex and requites the removal of growth-1 lolting factors under identical environment constraints, so far as they are known.

In this context, long-term mafntenance of productivity refers to sustained developoent of growth rate in relation to site fertility over time, with time measured in decades rather than years. It includes the physlological changes that occur during the life of long-lived tree specles in a forest-like situation and the accumulation of blomass by young trees when they replace old moribund ones. The practice of silviculture imposes more regimented systems of change upon natural systems of replacement, and these all affect the expression of site fertility in some wanner.

Research into the nutritlonal aspects of long-term productivity, or more particularly, the maintenance of opt imum rates of productivity, has been associated with the march of growth with tlue during the history of single stands. We have reached the point at which we can diagnose stress for, or growth limiting levels of, major nutrients and many trace elements over the life of a forest stand (Raupach 1967; Raupach, Boardman \& Clarke 1969; Boardman 1973).

In comparison, the logical extension of these studies into the nutritional situation when one forest stand 18 replaced by another in direct succession, has been slow. The occurrence of large depressions in productivity (20-25 per cent average) in second crops of the same species on the same site, has been necessary to insplre any investigation at all. The most notable investigations which have proceeded, are the now classical case of spruce in Saxony (Wledemann 1923), the citrus replant problew in California (Martin \& Ervin 1958), similar 'soll sickness' problems associated with frult tree orchards (Savory 1966) and, more recently, in the forest sphere, plne replant problems in South Australla (Lew18 1967; Lewis \& Boardman 1969, 1973; Keeves 1966; Lew1s \& Harding 1963; Mu1r 1969).

The first significant factor which relates all these latcer studies is that adequately precise knowledge of productivity in the first crop at a given time or atage of growth has been avallable for comparative purposes. Appreciation of the significance of any difference found is difficult nonetheless, for production with time 18 influenced by many factors cumulative in their effect.

A second significant factor in common is that the method 
of establishing a second or successive crop of the same species, In silvicultural terms, is termed the clearfelling system and one that falls at one extreme of the posstbilities encompassed by silvicultural regeneration systems (Troup 1955). H.T. Odum (1960), when describing chis system ecologicaliy in terws of energy-flow analogue circuitry, has likened $1 \mathrm{t}$ to an ecological short-circuit.

In Australia and New Zealand concern has been expressed at the demonstrated decline of pinus radiata in successive crops of this species over a wide range of sites and solls throughout the gengraphical range over which it is grown. In South Australia, subsequent remeasurements on plots reported by Keeves (1966) have confirmed concurrent studies in young stands, that :

(a) there is often a considerable growth rate depression in the early years of the second crop;

(b) that older stands, in particular stands which have passed the so-called canopy-closure stage, regardless. of rotation, show that little opportunity exists for rapld growth rate acceleration, either by 'natural recovery' or frow artificial means of stimulation, such as fertilizing except in cases of readily diagnosed deficlency of a lioliting nutrient.

This situation has shown strong affinity with the concepts of Maruyama (1960, 1963), which relate to self-regulating and equilibriating systems. Maruyama has recognized two aspects of these mulci-varlate systems with mutual causal inputs. The deviation-counteracting or equilibriating process he calls 'morphostatis'; the deviation-amplifying process he calls 'morphogenesis'.

Deviation-amplifying systems are ubiquitous and relate to all sicuations where an initlal 'low energy' input bullds up a deviation which diverges from the initial condition. Positive feedback between the elements of the situation can lead to maximization of the efflciency of development resulting from the Initial 'kick' or Investment.

Th1s conceptual framework appears to offer large gains in seek1ng remedies to long-term maintenance of productivity. The basic 'growth development' features are present of morphogenesis, in the so-called free growth stages, and morphostatis, during the later closed-stand stages. Silvicultural treatments offer opportunity to provide initial investments in growth producing stimult and to reinforce the initial deviation in such a direction and with such an intensity.to achieve optimization in the efficient use of them. During morphogenetic stages of growth swall differences in growth-promoting and growth-retarding factors can, through combination and amplification, due to the logaritholic aspects of growth, assume najor significance though minor in actual magnitude. This concept has been central to the development of 

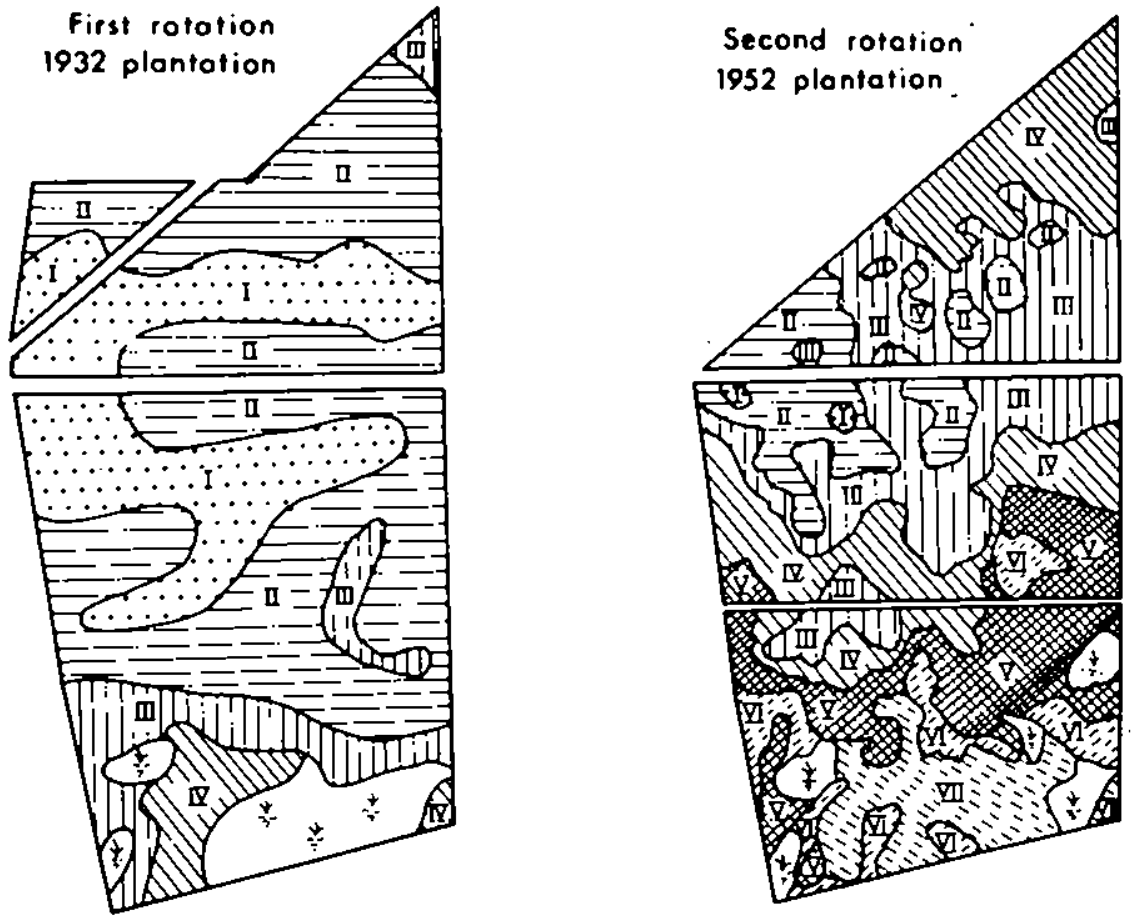

Fig. 1. Mappings of site class for an area of Penola Forest Reserve, South Australia, for the first and second rotations of radlata pine.

a comprehensive experiment allowing the examination of a wide range of site varlables.

There is a considerable amount of circumstantial evidence that factors of this kind are operative in the pine replant problem. Friedel \& Attiwl11 (1968), Friedel (1972), DeVries, Raupach \& Boardman (1972) were unable to demonstrate consistently the second rotation effect in pot trials, although it was present in the field situations where the test solls were collected. In none of the cases Investigated could gross nutrient deficiencies be detected, nor was any expected from the growth rates realized.

Current annual increments were measured on young, above-average sites from the second to the tenth years. 
Assessment of site class in the tenth year has shown that first rotation plots ranged from site class I to III. Figure 1 is an example. Increments in second rotation stands which demonstrated site classes I-III in the first crop have shown differences of the following magnitudes in basal area:

3 rd year increment - $2 / 3$ reduction

4 th year increment $-1 / 2$ reduction

5 th year increment $-1 / 2$ reduction

6 th year increment - $1 / 10$ reduction

7 th year increment $-1 / 12$ reduction.

The seventh and later years' reduction is of the same order as the difference found between the two site classes attained in the one rotation, e.g. the difference between site classes II and IV. That is, once the morphostatic stage is reached, increment is most closely associated with the site class attalned at the 7-8th year and this persists.

The cumulative difference by the eighth year in the above series amounted to $12 \mathrm{sq} . \mathrm{m} / \mathrm{ha}$ deficit, equivalent to the difference between site classes II and IV. Th1s places the problem area mainly in the morphogenetic or formative stages of stand development.

An experiment where first and second rotations are matched has shown that opportunity to stimulate growth rates in the morphostatic (post canopy closure) stage is considerably less than in the formative stage. The best improvement in rate was with $\mathrm{NH}$ Pt trace elements and amounted to an additional $0.5 \mathrm{sq} . \mathrm{m} / \mathrm{ha} / \mathrm{yr}$ average increase over $\mathrm{P}$ alone. This can be compared with the 50 per cent difference in the fourth year mentioned above whlch amounted to $4.5 \mathrm{sq} . \mathrm{m} . /$ ha in that year alone.

The interesting feature of this fertilizer experiment was that there was no significant difference in increment between rotations for a given treatment, including $P$ in $1 t$, although the total production with time has remained significantly different at each year's end. With the increased increment from NPt trace element applications, it would take about twenty-five years to elloinate the difference between the second crop and the original crop (loods and Forests Department, unpublished data).

The fertilizer treatments used here do not shed any clear light on the problem for sites not expected to show limiting phosphate. Sall positive differences in response to NPKt trace element supplements, sowetimes not statistically significant, have been recorded on both first and second rotation sites of the high site classes over a range of ages. Small positive, statistically significant responses of $N+P$ fertilizer \pm traces have been recorded consistently in pot trials conducted on sandy solls from matched native hardwood forest; and plne first and second rotation sites, where water has been non-1imiting (Devr1es, Raupach \& Boardman 1972). 
There is reason to believe that this may be more closely assoclated with soll texture than with pine species or cropping histories (R.G. Florence, personal communication).

The water or soil molsture aspects are more intriguing. DeVries, Raupach \& Boardman (1972) were able to eliminate many factors involved in the failure to reproduce the second rotation depression in pots leaving factors strongly associated with the soll moisture regiue as dominant among the remainder. Non-wetting behaviour of the sandy substrate has been found but it is not noticeably associated with cropping history.

The behaviour of a series of growth plots established in 1924 has been examined in relation to rainfall. Three of the seven plots were clearfelled and replanted and all three showed depressed productivity; one showed $P$ deficiency but the other two did not. Using a basal area index it was shown, with the sole exception of the $P$ deficient plot, that within a rotation the changes in index with age were closely correlated with the five-year running mean of rainfall. The four remaining first rotation plots, the oldest trees sixty-nine years, showed no tendency to decline in productivity with increasing age and behaved similarly to other yield plots on above site class $V$ sites in this respect (Woods and Forests Department, unpublished records).

Yet the disturbing fact remains that actempts to correlate soll water parameters with tree growth are notoriously difficult and these have been associated with usually less that 40 per cent of the variance in dependent growth variables (Woods and Forests Department, unpublished records).

Scudies of the microflora development and composition at different stages in first and second rotations have been examined from several points of view. Simpson (1967) showed that the fingal flora in young, first rotation stands was changed considerably by the fifth year and that a similar flora existed at the same age in second rotation. There were variations depending upon the stte preparation, e.g. Whether slash was burned or not, but differences between the expected site classes, borne out by subsequent measurments, were insignificant. At canopy closure and later mature stages differences between rotations and site classes were insignificant.

J.D. Ovington (personal communication) investigated fine root and fungal hyphae densities on matched sites and found highly significant differences between rotations at ages up to fifteen years. Second rotation solls possessed much greater dry welght of fungal matter and also of fine roots.

Theodorou \& Bowen (1970) have demonstrated in forest crials the different growth rates assoclated with different species and strains of mycorrhizae on pinus radiata. 
Howard (1967), concurrently with Simpson (1967) investigated the microfauna regimes and found that the microfauna changed rapidly from cypical pasture or cucalypt forest type to pine forest type, by nature of genera and abundances typical of populations reported for pine forests in the northern hemisphere. This change was virtually complete by the third to fifth years of the first rotation and persisted thereafter, including second rotations. The microfauna was found to ve controlled to a remarkable extent by the microfloral distribution and composition, even within the $F$ layer of the litter (J.A. Simpson, personal communication).

Florence \& Lamb (1973) have Investigated litter decomposition and nutrient release in first and second rotations, high and low site classes in South Australla and have found more rapid turnover of litter-held nutrients in the high slte classes. The net litter development between rotations was, however, similar in size at any particular time. Differences between rotations and site classes in the rorphostatic stages were oinfmal and lacked any consistent trends. Litter decomposition rate was correlated with nutrient element concentrations which,' in turn, were closely correlated with soll types.

It seers likely that our assessment of growth-dependent factors is too crude or gross and simplistic. Whilst 1 t may be sensitive enough to delineate the nature of nutrient problems within one rotation, there is a distinct possiblity that these are gross in the biological sense of growth-limfting singleor multivariate factors.

In 1970 we began to prepare for an experiment which would allow for manipulation of site factors in such a way as to impose close to opt Imum positive inputs.

Differences produced by the experimental treatments are over and above those produced by a basic silvicultural package which promises to lift early growth rates considerably when compared with the very low intensity, low cost treatments which were applied to the stands which showed the second rotation decline.

The experlmental treatments have been almed to influence ecologically significant aspects of 'site' and specific methods have been selected to produce distinct effects on site. The aspects upon which information is being sought can be considered as follows:

- genotype of crop species

- rhlzosphere flora

- native microflora

- humus

- soll moisture regime

- growth-1imiting nutrients

- soll physical state

- soll alr-temperature regime. 
We have attempted to take the pline plantation ecosysten apart and examine some of the consequences. This is where we believe the results obtained in this project are so profound and potentially useful.

A number of initial difficulties had to be overcome, of which the worst was to find a satisfactory way to apply fertilizer containing ammonium sulphate to seedlings one to two nonths after planting.

This was solved by a colleague, R.V. Woods in 1976 in a series of studies almed at increasing productivity on narginal soils and sltes. He commenced on first rotation land and in moving on to second rotation sltes with the same soil types, produced a relative solution to the second rotation which, by careful fertllizer placement, related to the buffering capacity and leaching characteristics of the sandy soils and bonsted productivity by what appears to be several site quality classes.

\section{AC.KNOWLF.DGEMENTS}

The magnitude of the study which we prepared has led to a major cooperative effort which, besides the Research Branch of the Woods and Forests Department (D.W.F.), includes three Divisions of C.S.I.R.O.: Forest Research at the South Australian Regional Station (D.F.R.), Solls (D.S.) and Mathewatics and Statistics (D.M.S.).

Responsibllity for various aspects of the studies has been distributed among the following research sclentists and their technical teams:

Conceptual aspects of the multifactor study into tree growth and nutrition: author and D.B.Boomsma (D.W.F.) in consultation with cooperators.

Experimental design and analysis of statistical data: K.M.Cellier and R.A.Correll (D.M.S.)

Preliminary soll and groundwater investigations: B.A.Mitchell (D.F.R.) and G.Blackburn (D.S.).

Raising of planting stock, planting, application of field treatments, collection of tree growth data, including perfodic whole-tree sampling: author, D.B.Boomsma and P.G.Zed (D.W.F.).

Monftoring of water tables, soll wolsture and climatic data including specific tree measurements associated with particular aspects: B.A.Mitchell (D.F.R.).

Microblological studies, Including developoent of mycorrhizal associations and soll nitrification studies: G.D.Bowen and C. Theodorou (D.S.). Soll compaction surveys: R.Sands (D.S.) and G.Vogt (D.W.F.).

Chemical analysis of solls: M.Raupach and the late A.R.P.Clarke; following the death of Mr. Clarke, transferred to Agricultural Chemistry Division of South Australian Department of Services and Supply (D.L. 
Harvey).

The author gratefully acknowledges the considerable and active cooperation which this major project has stimulated and produced. The results will be reported elsewhere.

\section{REFERENCES}

Bednall,B.H.(1968). The problem of lower volumes assoctated with second rotations in Pinus radiata plantations in South Australia. Woods and Forests Department, South Australfa, Bulletin 17 .

Boardman,R.(1973). Experience with phosphatic fertilizers in the southeast of South Australfa. Woods and forests Department, South Australia, Bulletin ${ }^{\circ} 21.2$ volimes.

DeVries,M.P.C., Raupach,:4. \& Boardman,R. (1972). Some glasshouse experiments to investigate the second rotation effect on three forest solls from South Australia. Proceedings Australian Forestry Tree Nutrition Conference (E.d. by R.Boardman), pp.301-307. Forestry and Timber Bureau, Canberra.

Florence,R.G. \& Lamb,D.(1973). Influence of stand and site on radiata pine litter in South Australla. New Zealand Journal of Forestry Sclence, 4 , 502-510.

Friedel,M.H.(1972). The decline in productivity of second rotation pinus radiata (D. Don) plantations in southeastern South Australia. University of Melbourne, $\mathrm{Ph} . \mathrm{D}$. Thesis.

Frledel,M.H. \& Att1will,P.M.(1968). Studies on respiration rates of pinus radiata litter. Australian Forest Research, 3, 33-38.

Howard,G.W. $(196 \overline{7})$. Arthropods inhablting pine litter in the southeast of South Australia. M.Sc. thesis, University of Adelaide.

Keeves,A.(1966). Some evidence of loss of productivity with successive rotations of pinus radiata in the southeast of South Austral1a. Australian Forestry, 30, 51-63.

Lewls,N.B.(1967). Regeneration of man-made forests. Paper F.A.O. World Symposium on man-made forests. Canberra, Austral1a. 14 pp.

Lews, N.B.(1975). A hundred years of state forestry in South Australia: 1875-1975. Woods and Forests Department, South Australia, Bulletin 22 .

Lewis,N.B. \& Boardman,R.(1969). The maintenance of productivity under successive forest crops. Paper Symposium ANZAAS $41 \mathrm{st}$ Congress, Adelaide. 9 pp.

Lewis,N.B. \& Boardman,R.(1973). The second rotation problem in South Austral1a. Paper APPITA Congress, New zealand. pp 5 .

Lewis,N.B. \& Harding, J.H.(1963). Soll factors in relation to pine growth in South Australia. Australian Forestry, 27, 27-34. 
Lewis,N.B., Keeves,A. \& Leech,J.(1976). Yield regulation in south Australian Pinus radiata plantations. Woods and Forests Department, South Australia, Bulletin 23.

Martin,J.P. \& Ervin,J.o.(1958). Greenhouse studies on influence of other crops and of organic materlals on growth of orange seedlings in old citric soll. Soll Science, $85,141-147$.

Maruyama,M.(1960). Morphogenesis and morphostasis. Methodos, 12 .

Maruyama,M.(1963). The second cybernetics: deviation-amplifying mutual causal processes. American Sclentist, 51, 164-182.

Muir,W.D.(1969). The problems of maintaining site fertility with successive croppings. Australian Journal of Science, $32,316-324$.

Odum,H.T.(1960). Ecological potential and analogue circuits for the Ecosystem. American Sclentist, 48, 1-8.

Raupach,M.(1967). Solls and fertilizer requitements for forests of Plnus radiata. Advances in Agronomy, 19 , 307-355.

Raupach,M., Boardman,R. \& Clarke,A.R.P.(1969). Growth rates of Pinus radiata (D. Don) in relation to follar levels of nitrogen and phosphorus for plantations in the southeast of South Australla. C.S.I.R.0., Australla, Soll Publication 26 .

Savory,B.M.(1966). Specific replant diseases. Comonwealth Bureau of Horticultural Plantation Crops. Research Review A1, Commonwealth Agricultural Bureau, Farham Royal. vi + $64 \mathrm{pp}$.

Simpson,J.A.(1967). Mycological aspects of decomposition of pine litter. M.Sc. thesis, Unfversity of Adelaide.

Theodorou,C. \& Bowen,G.D.(1970). Mycorrhizal responses of radiata pine in experiments with different fungl. Austral1an Forestry, 34, 183-191.

Troup,R.S.(1955). Stlvicultural systems (F.d. by E.W.Jones). 2nd Edition. Clarenden Press, Oxford. vili + $216 \mathrm{pp}$.

Wledemann,E.(1923). (Regress in increment and growth interruptions in spruce in middle and lower altitudes of the Saxon State Forests.) Translation by U.S. Forest Service 302. 1936.

Williams,M.(1974). The making of the South Australian landscape. Academic Press, London. 

;

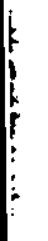


SOCIOECONOMIC EVALUATION OF TKF. RECREATIONAL USE OF FISH AND WILDLIFE RESOURCES IN ALBERTA, CANADA

By WILLIAM E. PHILLIPS and MICHAEL R. CARROLL

Department of Rural Economy, The University of Alberta, Edmonton, Alberta, T6G $2 \mathrm{Hl}$, Canada.

\section{SUPMARY}

In managing forest resources all benefits and costs, both market and extra-market must be taken explicitly into account in order to make comprehensive socioeconomic evaluations. Recreational uses of fish and wildlife resources by resident Albertans have a value of approxinately Can $\$ 100,000,000$ which is comparable to values from major comercial uses of resources. There are also other values such as those associated with conservation of the gene pool, option values to non-users who value having the option, whether or not acted upon, and heritage values.

Timber benefits are glven prominance over fish and wildlife benefits in the determination of how resources are used. This is because of the occurrence of direct financial benefits in timber related industry whereas non-timber benefits are, to a large extent, non-financial. With inventories of all types of forest resources and an understanding of the trade-offs between these resources, it would be possible to carry out an economic analysis. Changes in the administrative structure away from single-resource orientated departments could then lead to land use decision making which would maximlze net benefits from all resources to society.

RÉSUMÉ

Quand on considère la gestion des ressources de la forêt, il est nécessaire de tenir compte, de façon explicite, des avantages et des coût 8 , du marché et autres, pour pouvoir arriver à une évaluation socioéconomique complète. 
L'utilisation, dans un but récréatif, des ressources animales - poissons et faune sauvage - de 1'Alberta par sa population rapporte environ Can $\$ 100,000,000$, ce qui est comparable aux sommes rapportées par une utilisation commerciale de ces ressources. Aux valeurs financières 11 faut aussi ajouter d'autres valeurs telles que la conservation du réservolr génétique, la posslbllité d'en profiter, pour ceux qui ne la prendront peut-être pas, d'en avoir la possibilité et la préservation de I'heritage historique et naturel.

Les avantages associés au bois ont priorité sur ceux qui sont associés au milieu antmal quand 11 s'aglra de déteminer la wanière dont les ressources naturelles seront utilisées: les industries du bois apportant des avantages financiers directs, tandis que $l^{\prime}$ utilisation de ces ressources en dehors du cadre de $1^{\prime}$ industrie du bols $n^{\prime}$ ayant la plupart du temps aucun avantage financler. Il seralt possible de faire une analyse économique des ressources de la forêt en en inventoriant les ressources et en exploitant les relations réciproques entre ces ressources mêmes. Des changements dans la structure administrative de la gestion forestière, à savoir le passage d'une gestion à orientation unique vers une orientation wixte, pourratent amener à des décisions au niveau de l'utilisation du terrolr qui amélioreralent les avantages de toutes les ressources pour la soclété.

\section{ZUSAMMENF ASSUNG}

Bel der Nutzung von Waldressourcen wüssen sowohl Gewlnne als auch markt- und warktabhänglge Kosten einzeln berücksichtigt werden, um elne umfassende sozioökonomlsche Bilanz geben zu können. Die Nutzung des Fischund Wildbestandes als Freizeltbeschäftigung der Einwohner Albertas enspricht ungefahrt einem Wert van 100 Millionen kanadischer Dollar. Dieser Betrag ist verglelchbar mit dem Gewinn aus dem Wald ale Rohstofflieferant. Ausserdem gibt es noch andere Werte, wle zum Belspiel die Konservierung des 'Gen-Kapltals' durch den Wald, potentlelle werte, die je nach Lage und unabhängig von der sonstigen Nutzung realisiert werden konnen und schllesslich Traditlonswerte. Bel der Rohstoffnutzung 8 lbt man Holzerträgen 
den vorrang vor Fisch- und Wildertragen. Der Grund dafür liegt in den direkten finanzielien Cewinnen der holz- und holzverarbeitenden Industrie, wahrend die vom Holz unabhänglgen Ertrage grösstenteils nicht finanzieller Art sind. Mit einer vollstandigen Erhebung der Waldrohstoffe und dem Verstandnis der Wechselwirkungen zwischen diesen Rohstoffen auf dem Markt waren unfassende ökonomische Analysen möglich. Änderungen in der Verwal tungsstruktur, welche die auf Einzelrohstoffe ausgerichtete Bestandesgliederung beseftigt, könnten dann zu neuen Nutzungsformen führen, in der die Nettogewinne aus allen Ressourcen für dfe Gessellschaft optimiert sind.

\section{INTRODUCTION}

Fish and wildife resources in North America are public goods by ownership. Historically, their value and availability has led to widespread depletion of many species. Through public legislation and enforcement continued deplecion was arrested or reversed. As part of this process, fish and wildife resources were placed in the public trust and have remained so regardless of ownership and control of land surface rights.

Two issues have energed which are of particular inportance regarding resource allocation. First, privately owned land provided habitat for publicly owned wildlife which has led to a potentially inefficient distribution of wlldlife benefits and costs. Second, non-commercial use of fish and wildlife on public land has often been displaced by comercial uses. This implies that market values of commercial uses are emphasized whilst values external to the market system are ignored.

Boch issues result in patterns of resource use which favour commerclal rather than non-commerclal uses of resources such as fossil fuels, forest land, agrlcultural 1 and and hydropower. These commerclal uses of resources may not be in society's best interest now or in the future. If an Improvement in net social benefits to to be realized, then both non-commercial and commerclal resource uses must be balanced by government. All benefits and costs, both market and extra-market, must be taken explfcitly into account. Socioeconomic evaluations of the non-commercial uses of resources can assist in this endeavour. The focus of chls paper is on such an evaluation of the recreational use of Alberta's fish and wildife resources. 
RECREATIONAL USE OF FISH AND WILDLIFE RFSOURCES Evaluation procedures

Socloeconomic information is essential in the assessment of recreational activities. When combined with physical and biological information, it is possible to ascertain the importance of recreational uses of fish and wildife in relation to other uns, and in relation to other patterns of resource use which may alter fish and wildlife habitats. Two recent studies in Alberta provided such socioeconomic information (Phillips, De Pape and Ewanyk 1977; Phillips and McEl haney $1977 \mathrm{a}, \mathrm{b})$. The $1 \mathrm{r}$ objectives were:

1 To ascertain the socioeconomic characteristics, e.g. age, income, family size, residence, occupation, etc., of particlpants in recreational uses of $f$ ish and wildlife.

11 To establish datailed profiles of recreational activities, e.8., hunting fishing and informal nature study. Information was collected regarding location and duration of activities, expenditure on activities and numbers and species of fish and wildife taken in hunting and fishing.

11 To estimate the value of Alberta's fish and wildlife resources used for recreational purposes.

The information required to meet these objectives was obtained using mall questionnaires during 1976 and 1977 from random samples of resident and non-resident anglers and resident and non-resident hunters in Alberta.

Survey results

There are an estimated 1.39 million residents of Alberta who annually engage in observation and informal nature study of Alberta's fish and wildlife resources. Amongst these residents, 308,500 persons fish and 102,600 hunt. In addition to residents, there are annually 10,620 licensed anglers and 8,000 licensed hunters who reside in other provinces in Canada or abroad, notably the United States (Table 1). The total number of recreational users is 1.4 million persons anually.

Alberta's fish and wildife resources provide all licensed anglers and huncers with 5,9000,000 fish, 23,700 big game, 276,300 upland birds and 1,166,000 waterfowl annual1y.

The annual benefits on a per day basis for hunting and fishing were much higher than for observation and informal nature study. These benefits include licence fees (hunting and fishing) plus extra-market benefits, which are the sum of Individuals' willingness to pay over-and-above recreation expenses actually incurred for fish and wildlife recreation activities. The benefits from hunting and fishing are equal to the benefits from observation and informal nature study, al though the numbers of days spent in hunting and fishing were much lower.

Willingness-to-pay values are a type of estimate of market values Fish and wildlife values may be nore 


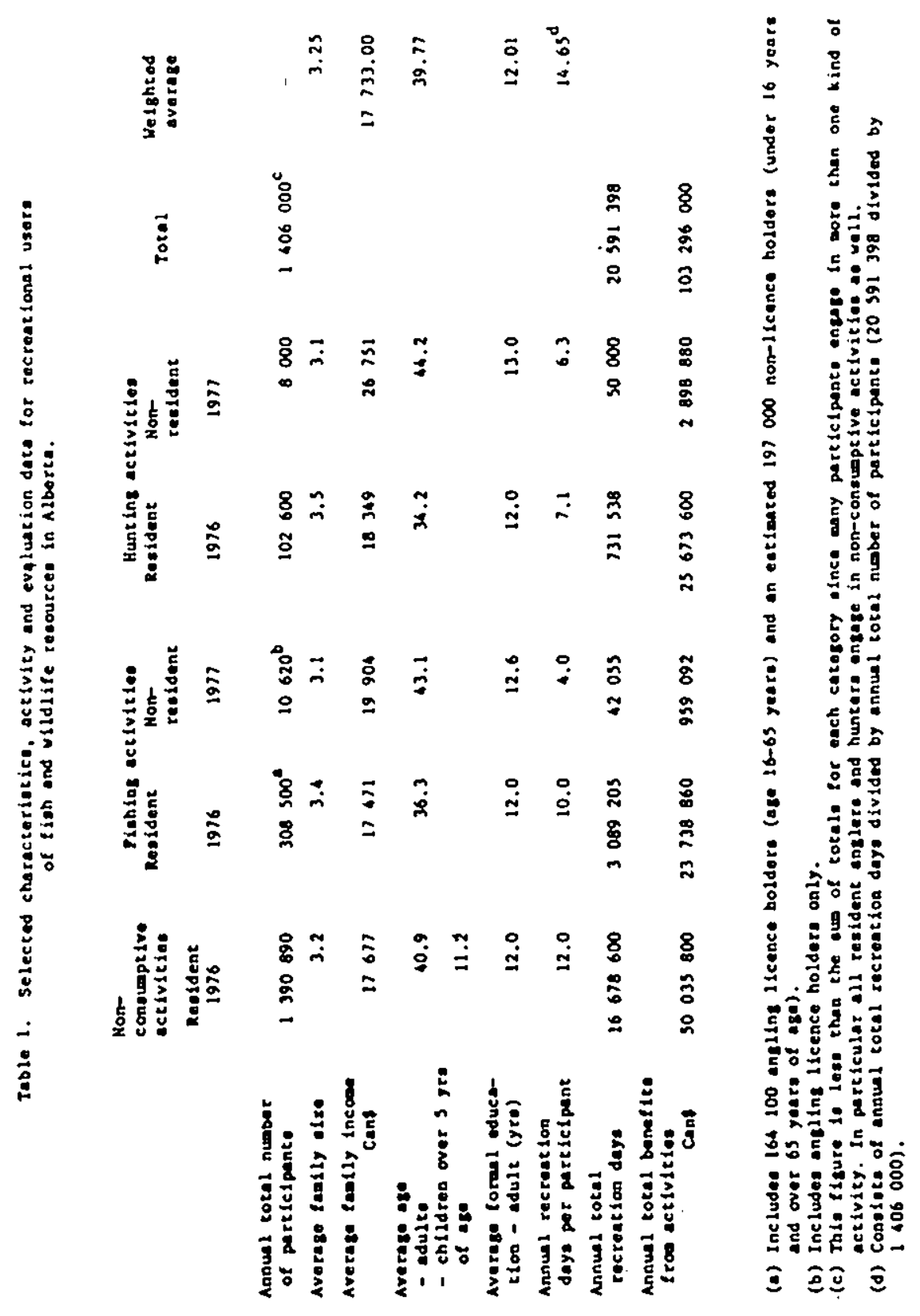


approptiately expressed in terms of compensation values. If recreational uses of fish and wildlife are considered as 'rights to use' by residents, then compensation values should be used instead of willingness-to-pay values. For instance, to the extent that fish and wildlife resources are displaced by other resource uses, then there is an erosion of the rights of residents to fish and wildlfe use for which compensation entitlement therefore exists. If one recognizes a right to be compensated then one should accept the compensation values which at present in Alberta amount to Can $\$ 300,000,000$ annually or three times the willingness-to-pay values of Can $\$ 100,000,000$ annually. An Individual's willingness-to-pay is constrained by that individual's income, whereas compensation to be received in lieu of $r$ ight to use does not have this constraint.

Regardless of which value figure is used, recreational uses of $f i s h$ and wlldlife resources by resident Albertans have values associated with them that are comparable to values from major commercial uses of resources for example, the value of timber products from Alberta forests is Can $\$ 85,149,000$ annually and the value of coal supply is Can $\$ 334,00,000$ annually. (Alberta Forest Service, 1976; Alberta Energy Resources Conservation Board, 1977).

Concluding comment

Non-commercial uses of fish and wildlife resources are important and should be considered explicitly in social accounting. Commercial fish and wildlife harvests also provide annual beneftis of course. For example commerclal fur harvest by both registered and native trappers amounts to about can $\$ 7,100,000$ annually. There are also other values such as those associated with conservation of the gene pool, option values to non-users who value having the option whether or not acted upon, and heritage values held by present generations knowing that future generations will have simllar opportunities to use fish and wildife resources.

Any activity that displaces the fish and wildlife habitat reduces the present and future use of fish and wilfilfe resources. The values so displaced should be accounted as a social cost againit the activity which influences the habitat. Current direct annual costs for fish and wildlife protection and management amount to about Can $\$ 10,000,000$. This amount is a small proportion of annual benefits wether expressed as wlllingness-to-pay (10 per cent) or as compensation values ( 3.3 per cent).

\section{POLICY ISSUES}

Impact of valuation on trade-offs

It has been observed above, that the total value of $f 1 s h$ and wildife resources may be evaluated using market values, willingness-to-pay or compensation values. The cholce of type 
of value which is most appropriate to use in decision making for resource allocation depends upon who is making the decision and for what purpose.

For example, one wight examine the decisions made by the Alberta Provincial Government in making a disposition of timber harvesting rights over a specific area to a private corporation (a Forest Management Agreement). This would typically involve the delineation of an area of 4000 square miles which would be managed for $t$ imber input to a wood fibre pulp mill. The harvesting system would be designed in collaboration with the Alberta Forest Service so as to protect fish and wildife, water and soll. The firrs will pay royalties for the timber harvested and the government normally recognizes the additional benefits of the creation of regional incones. The total benefits to the province are evaluated and the Forest Mnagement Agreement will be entered into if these benefits are considered close to the maximum likely to be available from any. other competitive firm entering a similar agreement. Now, the question of evaluation of $f i s h$ and wildife resources should be dealt with in deciding how much total benefit is required from the Forest Management Agreement and what type of harvesting system should be used. The benefits from timber harvesting should be weighed against the changes in fish and wildife values, and a tlober harvesting system designed which maximizes the joint values of $t$ imber and fish and wildife. The actual negollated exchange point in the Forest Management Agreement would depend upon the way in which fish and wildlife were evalauted.

In fact, the process of weighing resource values against each other is carried out in an excremely rudimentary and unsophisticated way. Generally, the non-timber resource values are given very litcle weight in deciding whether or not to enter into a Forest Management Agrement. Then the harvesting sytem is determined by making marginal changes in the timber harvesting rules which apply throughout the province and which have been determined on the basis of achteving some level of impact on fish and wildife which is acceptable to the Alberta Fish and Wildife Division.

In view of the high flsh and wildiffe values which have been discussed in preceding sections, it is clear that this fragmented, institutional approach should be replaced by an evaluation system which makes a trade-off between timber and non-timber resource values. Obviously, this trade-off will be affected by the valuation method which is used. A simple example is given in Table 2. Th1s shows that the optimum level of joint benefits under the assumptions given will depend upon the relative values of the timber as opposed to non-timber resources. If the willingness-to-pay approach is used, the opt imum level is achleved in harvesting system $D$ and the Forest Management Agreement should be entered into, using that 
harvesting system. When compensation values are used, the emphasis is much more on wildlife, the optimum harvesting system is no harvesting at all (F), and the Forest Maragement Agreement should not be entered into. The more general case of this trade-off would be represented by a production possibility curve for the products i.e. timber and wildlife, and the maximim revenue combination would occur where the slope of the iso-revenue curve was equal to that of the production possibllity curve. This would show the combination of products ylelding the maximum value for any given situation. Thus an increase in wildlife prices would shift the optimum comblnation towards wildlife.

political implications of value systems

Timber benefits have been given prominence in the past and are still given prominence in current decision making. A major reason is that there has been a concentration of direct financial benefits in the forest industry whereas the non-timber valuations included a large proportion of non-financlal benefits. The highly visible cash and jobs in the forest products industry carry a great deal of political influenic, especially because of the way these benefits are concentrated in specific communities.

Fish and wildife resources certainly contribute to the economy of the specific communities and the further north one goes, the more obvious this becomes, until one reaches the situation in the Northwest Territories, in which hunting and trapping incomes are the most important primary sector in certain communities. In Alberta, however, the actual incomes generated by fish and wildlife resources have to be ranked in comparison with the ruch higher incomes from the oil and gas industry, agriculture and forestry. This can rake the management of forest land primarily for fish and wildlife resources difficult to justify in a political framework. However, despite this difficulty zoning policies have been decided upon in the eastern slopes of the Rocky Mountains, which identify large areas, the primary use for which is to be recreation-oriented activity. Predictably, this has raised a good deal of alarw and protest in the forest industry, as was brought out in the recent public hearings on the environmental effects of forestry operations in Alberta conducted by the Environmental Council of Alberta (Parching 1977).

One might summarize by observing that the fish and wildife resources have a poor data base. Of ten there are mixed objectives from the resource users and there is a diffuse pattern of economic benefits as compared with a high degree of technical and economic knowledge in timber harvesting, and a single-minded and concentraced resource user $g$ roup of forest industry operators.

As an example of a possible future conflict one might consider an argument put forward by the Fish and Wildife 


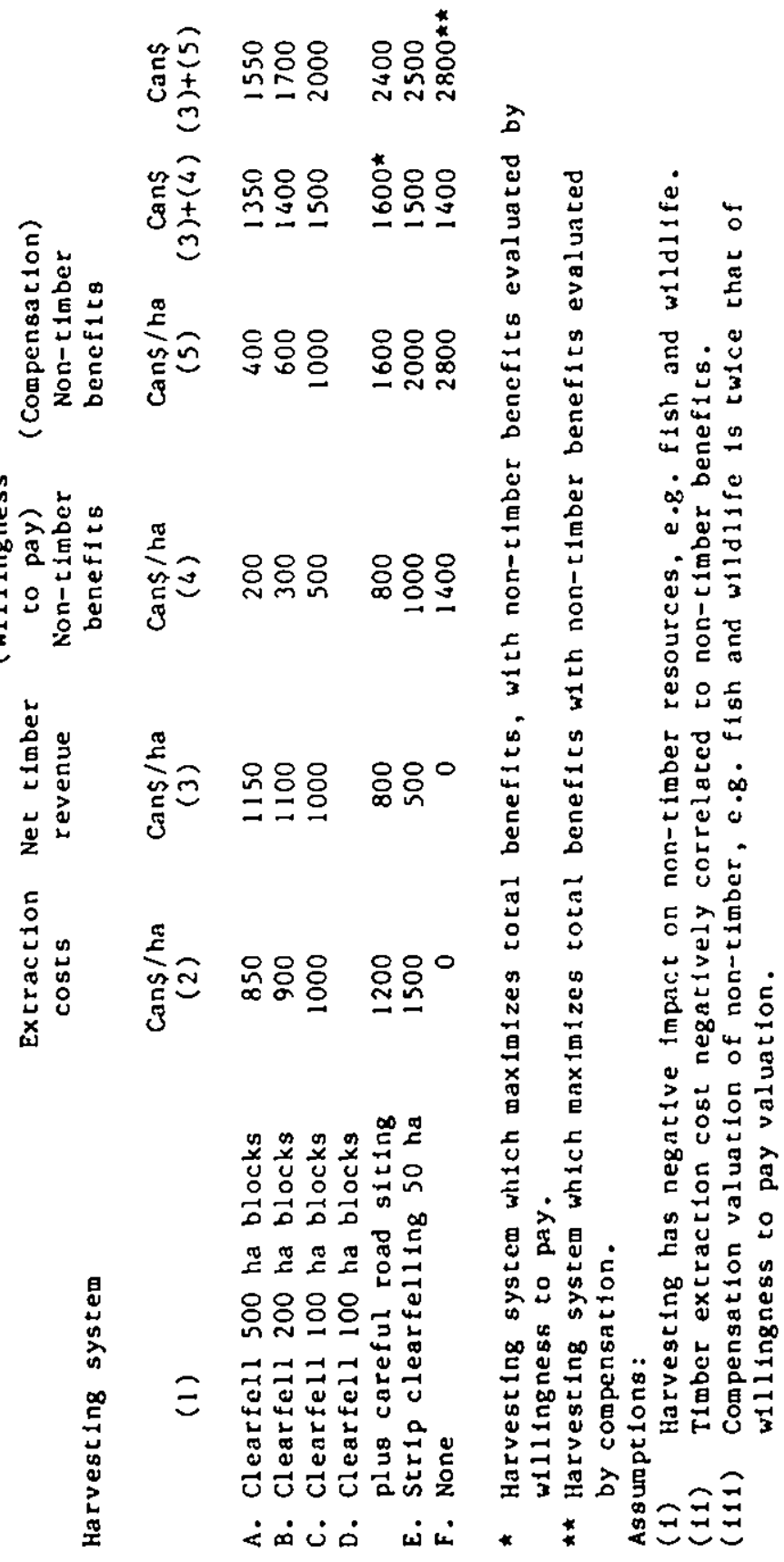


Division of the Provinclal Governenent and the various citizen-user-group associations, which maintains that greater net benefits could be obtained by altering timber management in favour of wildlife. For example, careful siting of logging roads to avotd disturbance in areas which provide natural grazing could well be desirable and controlled burning of open areas and deciduous cover types may provide better browse than cut-over, logged areas. However, road location decislons, non-optimute frov the point of view of transport and construction costs will never be made by the forest industry unilaterally, since they have to bear the entire construction and maintenance cost of roads, but gain none of the benefits from any wildlife habitat improvement. Controlled burning involves risks to the timber resource which the forest industry and the Alberta Forest Service are unwilling to take. Obviously, if wildlife management is going to be integrated with timber management so that regulations are set out which provide the possibility of reaching an optimum trade-off between increased costs to the forest industry and increased benefits to hunting and recreation activities, then dectstons must be taken by a body whlch transcends any single resource (see al so Cooper and Mutch, this volume).

Areas have been fdentified in Alberta which are soon to be subjected to detailed feasibility studies for pulp mill development. The forest land will be considered first in terms of timber; an environmental impact assessment will be made of the impact of effluent of human population and fish imediately downstream of the proposed pulp mill sites, and proposed logging practices will be discussed in terms of their Impact on erosion and wildlife. There will be emphasis on imposing regulations which reduce imrediate physical impacts rather than devising a total management system that provides an optimum level of combined timber, fish and wildifie and indeed other forest resources. The aggregate valuations of recreation and fish and wildlfe resources certainly indicate the general level of attention which should be glven to the varlous forest and wildlife resources in Alberta and provide justificaton for spending Provinctal funds on multi-resource planning exercises.

With full and accurate inventories of all resources, including fish and wildlife, an understanding of the relationship between different types of renewable resources and estimates of the total value of resources, the stage would be set for a comprehensive economic analysis. If all that were obtained, then changes in the administrative structure away from single resource oriented departments which deternine the disposition of timber independently of $f$ ish and wildlife could eventually lead to land use decision making whlch would maximise net benefits from all resources to soclety. 


\section{REFERENCES}

Alberta Energy Resources Conservation Board(1977). Coal industry annual statistics \$77-29. Calgary: Energy resources Conservation Board. Alberia Forest Service(1976). Forest statistical review 1975-76. ENR Report 15. Alberta Department of Energy and Natural Resources, Edmonton.

Parching,D.E.(1977) Public hearings on the environmental effects of forestry operations in Alberca. Fnvironment Conservation Authority Information Bulletin 1 , Edmonton.

Phillips,W.F.e \& McFlhaney,E.R.(1977) A socioeconomic evaluation of non-resident sport hunting activity in Alberta. I.M.P.A.C.T. Environomics l.td for the Alberta Fish and Wildife Division, Edmonton. $118 \mathrm{pp}$.

Phillips,W.F.. \& McFlhaney,F.R.(1977). A socioeconomic. evaluation of non-resident sport fishing activity in Alberta. I.M.P.A.C.T. Envoronomics Ltd for the Alberta Fish and Wildlife Division, Edmonton. 91 pp.

Phillips,W.E., De Pape,D. \& Ewanyk,L.(1977). Socioeconomic evaluation of the recreational use of $f i s h$ and wildife resources in Alberta with particular reference to the Athabasca ofl sands area: summary and conclusions. Volume I. Department of Rural Economy, Faculty of Agriculture and Forestry, Unfversity of Alberta. $125 \mathrm{pp}$. 


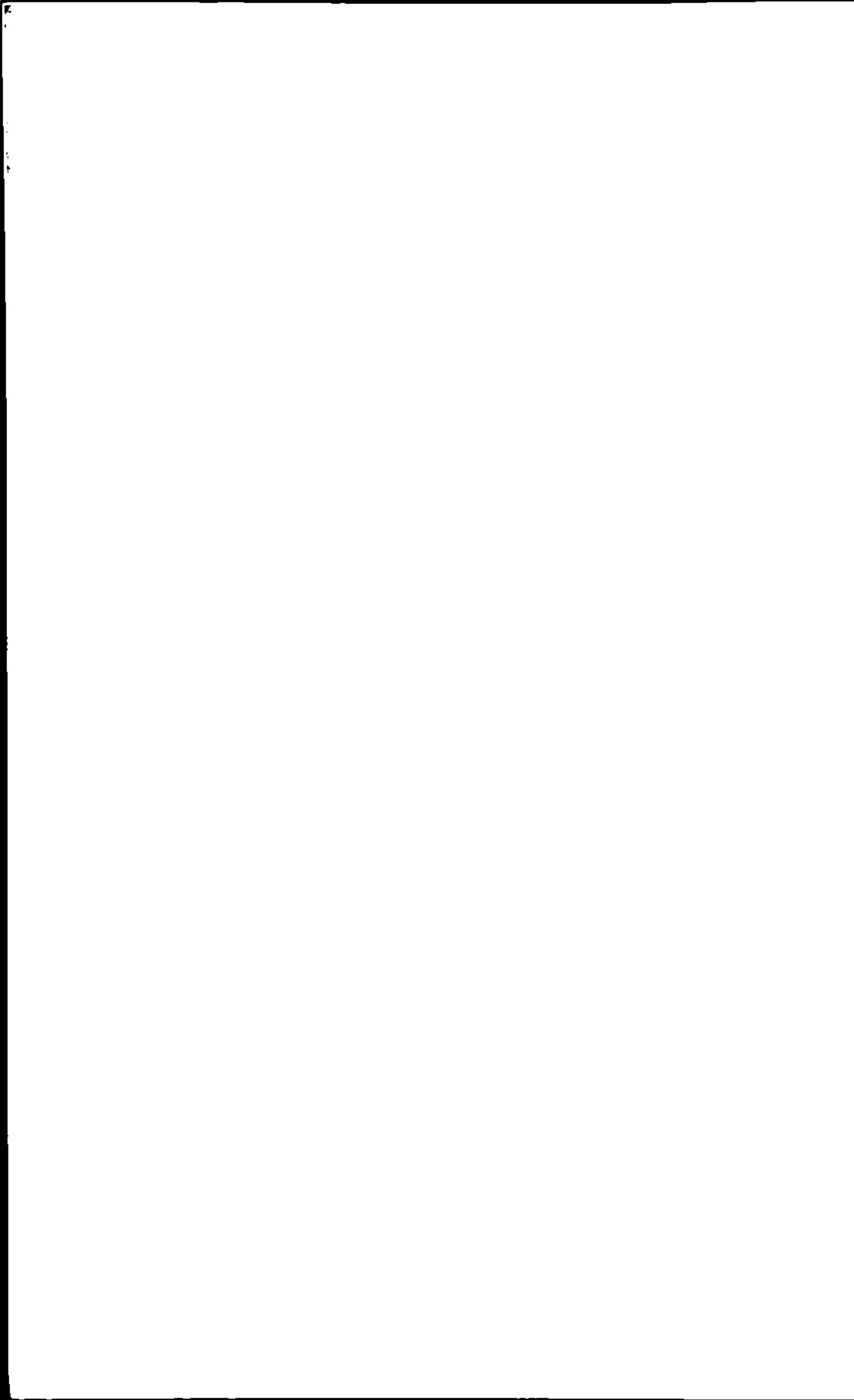


VARIATION IN TROPICAL TREE SPECIES

By P.J. WOOD

Unit of Tropical Sllviculture, Commonwealth Forestry Institute, Oxford, U.K.

\section{SUMMARY}

Although areas of plantation in the cropics are smaller than in temperate regions, most countries have one or more planting programmes and these are generally more important than those involving the management of natural forests. The F.A.O. panel of experts on forest gene resources coordinates lists of species for research, with printitice which currently enbrace tropical pines notably pinus caribaca,

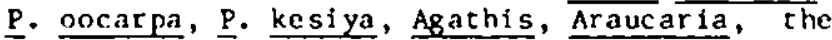
eucalypts and other hardwoods, including Gelina arborea and Tectona grandis. Less is known of the blology, reproductive systems, variation patcerns or even the natural occurrence of some of these spectes than of toportant temperate species, and current studics include provenance trials and investigations of genetic variation. Meanwhile, large planting schemes continue to use seeds from natural populations. The erosion of genetic variation through the disappearance of natural populations is serious in many countries and programmes for in situ and ex situ conservation of endangered populations have been started, though much remains to be done.

The response of genotype to site is at present still under study, though some information exists, notably for $\underline{P}$. carlbaea and $\underline{T}$. grandis.

\section{RESUME}

Bien qu'lls ne possèdent que des plantations plus petites que les réglons tempérées, les pays tropicaux $n^{\prime}$ en ont pas moins un ou plusleurs programmes de bolsement et ceux-c1 sont généralement plus importants que les programmes concernant la gestion de forêts 
naturelles. Les experts de la F.A.O. responsables des ressources génétiques forestières dressent des listes d'essences destinees à des recherches concernant tout d'abord les pins tropicaux notarment le pinus carlbaea, le $\underline{p}$. oocarpa, le $\underline{p}$. kesiya, I'Agathis, l'Auracaria, les eucalyptus et autres feufllus, y compris le Gmelina arborea et 1e Tectona grandis. On n'a que peu de notions des systemes reproductifs, de la biologle, des variations ou même de la présence dans la nature de quelques unes de ces especes en comparaison avec les espèces des zones tempérées et des études actuelles sont en cours et traitent d'essats de provenance et de recherches sur leur variation génétique. Cependant, des programes de plantations importants continuent a utiliser des graines provenant de populations naturelles. L'erosion des variations génétiques dủe à la disparition des populations naturelles est un probleme sérieux dans bien des pays et des programmes pour la protection in situ et ex sicudes populations en danger ont été mis en route bien qu'il reste encore beaucoup à faire de ce coté 1à.

La rélation entre génotype et station est encore au stade de la recherche, bien que $I^{\prime}$ on ait dejà quelques renselgnements sur pinus carlbaea et le Tectona grandis.

\section{ZUSAMMENFASSLUNG}

Obwohl die Flachen von Forstpflanzungen in den Tropen geringer sind als in den gemässigten Zonen, haben die meisten Länder ein oder mehrere Programme für Anpflanzungen. Sie sind in allgemeinen wichtiger als die für die Bewlrtschaflung natürlicher Wälder. Der FAO-Expertenausschuss für Gen-Reserven des Waldes koordiniert die Untersuchung verschiedener Arten und setzt Prioritäten. Zur Ze1t gilt die Aufmerksameit den tropischen Kiefern vor allem Pinus caribaea, P. oocarpa, P. kesiya, Agathis, Araucarta, Eukalyptus-Arten und anderen Harthölzern einschl iesslich Gmel ina arborea und Tectona grandis. Über die Biologie, die Reproduktionssysteme, dic Variationsmuster und sogar über das natürliche Vorkommen einiger dieser Arten ist wenlger bekannt als iber wichtige Arten der gemässigten Breiten. Die 
derzeitigen Untersuchungen schliessen Herkunftsversuche und Analysen der genetischen variation ein. In der $2 w i s c h e n z e i t$ werden bei grossen pflanzungsvorhaben weiterhin Samen von naturlichen Populationen benüzt. Die Abnabme genetischer vielfalt durch das Verschwinden natürlicher Populationen ist in vielen Ländern bedenklich. Man hat Programme för die Erhaltung gefährdeter Populationen in situ und ex situ entwickelt. Es bleibt jedoch noch viel zu tun. Die Reaktion der Genotypen auf den Standort wi-d zur ze1t noch untersucht. Man verfügt berefts liber elnige Informationen, besonders fGr Pinus cartbaea und Tectona grandis.

\section{PLANTATION FORESTRY IN THE TROPICS}

plantation forestry in the troplcs is still very wuch less widespread than in subtropical and temperate reglons. The approximate area under plantations in 1976 was twelve million ha although several countries included in this total extend from tropical to subtropical zones e.8. Australla, Brazil. Increasing pressures on remaining areas of natural forest necessitate the extension of fast growing plantations to supply the demand for forest products, but the management of existing ecosystems, especially rainforests, still has a valuable role to play in supporting rural communities and in maintaining fragile ecosystems and sites, including solls and water supplies.

The largest areas of plantations use surprisingly few species. Four pines and a cypress account for nearly all the softwood planting: Plnus patula and Cupressus lusitanica in the highlands and $p$. carlbaea, $p$. kestya and $\underline{p}$. oocarpa in the lowlands. Other softwods with a great potential include Aracauria and Agathis $8 \mathrm{pp}$. but these are not yet widely planted. Among hardwoods, the eucalypts are the rost widely planted group, though the number of specles Involved is also small. Notable are Eucalyptus camaldulensis, E. tereticornis, E. grandis, E. urophylla and E. deg lupta.

The other hardwoods in use are a more diverse group, although genera in the Verbenacaea represented by Tectona grand is and Gmelina arborea are probably the most widespread. Varlous Terminalia species mahoganles (Meliceae), Acacla and Albizia species make up the bulk of the other plantings, but other important species, e.8. Iriplochiton scleroxylon, Pericopsis elata and Cordia alliodora under study and development in several parts of the tropics: In future one way expect more interest in what are still described as "minor forest products' e.8 - gut arabic in addition to wood-producing spectes. 
PRIORITIES IN THF, STUDY OF VARIATION IN TROPICAL TREES

The F.A.O. panel of experts on forest gene resources publishes and periodically revises, a list of species used in plantation developrent for priorlty study. The latest of these (F.A.0. 1977) includes all the specles mentioned above, plus a nuber of others of more local interest. Table l gives a selection of these.

Table 2 gives a list of spectes included currently in international provenance trial programmes (See also Wood 1976).

From the standpoint of variation, these programes may be expected to yield ever increasing arounts of data on the individual species on a wide variety of sites in the tropics. At the same time attempts are being made to conserve provenances efther in situ or ex situ in exotic conservation plantations (see also Kemp \& Burley 1974; F.A.O./U.N.F.P. 1975). It will be noted firstly that much less is known of variation and distribution of tropical species than of temperate oncs, and that secondly few of the provenances, land races and individual genotypes have yet been tested exhaustively. Relatively short periods are needed to obtain the information because of the speed with which commercial and sexual maturity are attained.

Table 1. Trec species used in plantation development.

CENTRAL \& SOUTH AMERICA

Borabacopsis quinatam

Cedrela odorata

Cordia alliodora

Cupressus lusitanica

Nothof agus spp.

pinus caribaea (all vars.)

P. montezumae

P. occidentalis

P. oocarpa

P. pseudostrobus/tenuifolia

P. chiapensis

P. tropicalis

Prosopis spp.

Swictenla spp.

AFRICA

Acacia spp.

Aucoumea klalneana

Entand rophragma spp.

Khaya spp.

Nauclea diderrichí

Terminalia spp.

Triplochiton scleroxylon
SOUTHFAST ASIA

Acacia ninilotica

Agachis spp.

Albizia falcataria

Anthocephalus chinensis

Araucaria cunninghamil

A. hunsteini1

Bambusa spp.

Dipterocarpus spp.

Eucal yptus deglupta

E. urophylla

Gelina arborea

Pinus kesiya

P. merkusti

Tectona grand is

Toona spp.

AUS TRALIA

Acacia spp.

E. camaldulensis

E. citriodora

F. cloeziana

E. grand is 
Table 2. Species included in incernational tropical provenance trials either in progress or in preparation.

\section{SPECIES}

Araucaria angustifolia

Araucaria cunninghani

Cedrela odorata

Cordia alliodora

Eucalyptus camaldulensis

F. déglupta

E. urophylla

Gmelina arborea

Pinus caribbaea

P. kesíya

P. merkusil

P. oocarpa

P. patula

P. tenuifolia/pseudoscrobus

Tectona grand is

\author{
AGENCY * \\ F.A.O. \\ Queensland Forest Department/ \\ Papua New Guinea. \\ C.F.I., Oxford \\ C.F.I., Oxford \\ C.T.F.T., France; \\ C.S.I.R.O., Melbourne \\ C.S.I.R.0., Australia \\ C.T.F.T., France \\ Danish/F.A.0. Seed Centre \\ C.F.I., Oxford and \\ F.A.0./C.F.I./C.S.I.R.0./ \\ Thai-Danish Centre \\ C.F.I. and C.S.I.R.O. \\ F.A.O./C.F.I./I.N.I.F., Mexico \\ I.N.I.F. Mexico \\ C.F.I. \\ Danish/F.A.0. Seed Centre
}

* C.F.I. Comonwealth Forestry Institute

C.S.I.R.O. Commonwealth Scientific and Industrial

Research Organization

C.T.F.T. Centre Technique Forestier Tropical

F.A.0. Food and Agriculture organisation

(of the United Nations)

I.N.I.F. Instituto Nacional de Investigaciones Forestales

U.N.F.P. United Nations Environment Programe

Features of tropical tree variation

The lack of knowledge relating to tropical spectes which are already known to have lmportance for development in tropical countries is well seen in the difficulty experienced in obtalning seed from properly characterlzed populations or seed sources. Floral blology and reproductive behaviour are still poorly understoud, even in species which are widely planted (Styles 1972). However, several studies have been made and are in progress to detemine. patterns of genetic varlation, in addition to provenance trials; both may often use Identical material for study. Such studies Involve the use of numerical and classical taxonomy (e.g. Burley \& Burrows 1972; Styles, Stead \& Rolph, in press), cytologlcal study (e.g. Styles \& Khosla 1976), enzyme electrophoresis (Burley 1976; Bawa 1976) and resin analysis (Burley \& Green 1978, private communication).

In many of the countries where important species grow, valuable genetic material is being lost at a rapid rate 
through forest destruction, often before the levels of variation present within and between populations are even partly understood, and certainly before they are adequately quantified. Genetic conservation is therefore urgent in many areas, and guidelines for action have been published (U.N.E.P./F.A.O. 1975). Although new genetic materlal continues to be discovered in the wild for many important species, the variation present in the established plantations and provenance crials is increasingly becoming the basis for breeding and selection for the wide variety of planting sites found in tropical countries. Massive seed purchases by commercial planting companies have been made independently of the scicntific collectors of provenances, parlicularly of Pinus caribaea. Although they do not cover the same genetic base, the very large areas of plantation that have been raised from these seed lots wlll become lmportant gene pools in their own: right, both from the polnt of view of genetic improverent and 'of gene conservation.

Review of species groups for plantations

There is no space here to consider the detailed information on varlation in tropical spectes that already exists. Reference should be made to Burley \& Styles (1976); vikles, Burley \& Barnes (1978) and to other publications relating to variation in tropical species sponsored or supported by the I.U.F.R.0, working parties $52.03-01$ and S2.02-08.

However, some important points covering widely planted speries are out Ined below.

Tropical conifers. Pinus caribaca with its three varleties

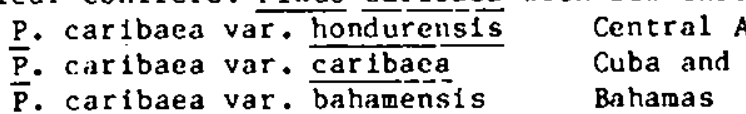

is undoubtedly the most important single pine species at present being planted in the tropical lowlands. Seed collections and explorations carried out by the Commonwealth Forestry Institute, Oxford, since 1962 are now producing much information on patterns of variation present in the natural populations and their growth interactions with site (for details of origin see Greaves 1978). P. oocarpa is, on many tropical lowland sites, even more promising, though its taxonomy and that of the closely related $\underline{P}$. patula is still under study (e.g. Styles 1976).

Much of the seed collected has been distributed in the form of International provenance trials. Table 3 shows the numbers of trlals and countries involved in this programme, and further collections of Mexican pines have been made by the Insticuto Nacional por Investigaclones Forestales, Mexico (I.N.I.F.) and are being made avallable through F.A.O., which has also coordinated the other trials. Other studies on pines are summarized in Table 2... 
Table 3. The international provenance trials coordinated by the Commonwealth Forestry Institute.

Species

Pinus caribaea

Pinus oocarpa

Pinus oocarpa

Pinus pseudostrobus/ tenuifolia

Cedrela odorata

Cordia alliodora

$$
\text { Number of }
$$

provenances

collected

36

45

20 *

25

14

13
Number of

countries

participating

49

35

12

11

20

18

* In collaboration with I.N.I.F., Mextco.

Results for these trials show differences in survival and carly growth that are difficult to relate directly to the factors of the seed collection site, and the position is further complicated by the apparent occurrence of intermediate forms, e.g. between $\underline{P}$. car ibaea and $\underline{p}$. oocarpa and between $\underline{P}$. oocarpa and $\underline{P}$. teñufol $\overline{l a} /$. pscudostrobus in Centră America. The latest positions are reported in ikles, Burley \& Barnes (1978). Breeding programmes with $\underline{P}$. carlbaea are well developed in Queensland, Fij1, Malaysla and Congo. The Asian pines have been under study longer, though crlals are less widespread but the characteristics of the island and mafnland sources of pinus merkusil are now well understood. A 'grass-stage' In which the young trees remain very small whilst buflding up reserves for rapld height growth is characteristic of the mainland provenances. This is a useful adaptation to a fire-prone environment, but it makes it of doubtful economic value as a plantation tree on sites where weed growth is a problem as the phase may last for two or three years and lead to excessive weeding costs. pinus keslya has been studled in detall in Zambia and Madagascar particularly, and $p$. patula in east and central Africa.

other conifers which are of some importance include Araucaria spp. (Ntima 1968) under study particularly in Queensland and Papua New Guinea, and Agath1s (Whitmore 1977). Troplcal Eucalypts. As ind icated above a small number of species form the bulk of the planting in troplcal countries. of these, important provenance trials have been carried out or are in progress with E. camaldulens1s: Eldridge 1975; Karschon 1974; 0jo \& Jackson 1973; E. deglupta: Davidson \& Fa1riamb $1974 ;$ E. grandis: Burgess $1974 ;$ E. tereticornis; E. urophylla: Martin and Cossalter $1975 / 6$.

Very considerable variation in all these species has been demonstrated both between and within populations. $\underline{E}$. 
tereticornis, with its tendency for wind pollination, appears to be a constituent of a number of hybrids found in exotic populations and is the basis of various land races adapted to local conditions, e.g. '12ABI' (Nadagascar, Congo), ' $\mathrm{C}$ ' (Zanzibar), 'Mysore hybrid' (India).

other tropical hardwoods. An excellent sumary of vartation and breeding! work in tropical hardwoods has been compiled by Ashton, Bawa, Whitmore and others in Burley \& Styles (1976). Studies of variability in plantations are few, and teak, Gmelina arborea and Triplochiton scleroxylon are the main species on which work has been done.

Teak has been the subject of provenance trials organized by the Danish/F.A.O. Forest Tree Seed Centre, sixty-five prove- nances being under trial in fourteen countries (Hedegart 1976; Keiding 1973). Among the most important characters determined to be under genetic influence is the age at which flowering comences, hecause this generally puts an end to monopodial growth. In Gmelina arborea variation may be less, although most large scale plantations (e.g. in Brazil) have used a narrow range of seed sources; information from provenance trials suggests that there is more variation in newly collected provenances.

\section{REFERENCES}

Bawa,K.S.(1976). Brecding of tropical hardwoods; an evaluation of underlying bases, current status, future prospects. "Tropical trees: varlation, breeding and conservation." (Ed. by J.Burley \& B.T.Styles), pp. 43-59. Academic Press, London.

Burgess, I.P.(1974). Eucalyptus grand is improvement programmes, Coffs Harbour. Australian Forestry Research Council Research Working Group 1. Proceedings of 4 th Heeting, Melbourne.

Burley,J.(1976). Genetic systems and genetic conservation of tropical pines. "Tropical trees: variation, breeding and conservation." (Ed. by J.Burley \& B.T.Styles), pp. 85-100. Academic Press, London.

Burley,J. \& Burrows,P.M.(1972). Multivariate analysis of provenance variation in needles of Plnys kesiya. Silvae Genettca, 21, 69-77.

Burley,J. \& Styles,B.T.(1976). Tropical trees; variation, breeding and conservation. Academic. Press, London.

Davidson,J. \& Falrlamb,J.(1974). Provenance trials of Eucalyptus deglupta in Papua New Guinea. Australian Forest Research Counc1l Research Working Group 1. Proceedings of $4 \mathrm{th}$ Meeting, Melbourne.

Eldridge,K.G.(1975). An annotated bibliography of genetic vartation in Eucalyptus camaldulensis. Tropical Forestry Papers 08. Commonwealth Forestry Institute, Oxford and C.S.I.R.0. Division of Forest Research, Canberra. 
F.A.0.(1977). Report of the fourth session of the F.A.O. panel of experts on forest gene resources. F.A.O. Rome.

F.A.0./U.N.E.P.(1975). Report of a pilot study in the methodology of conservation of forest genetic resources. Report FO:MISC 75/8. F.A.0. Rome.

Greaves,A.(1978). Descriptinns of seed sources and collections for provenances of pinus caribaea. Tropical Forestry Papers 12 , Commonweal th Forestry Institute, Oxford.

Hedegart,T.(1976). Breeding systems, varlation and genetic impovement of teak (Tectona grandis 1.f.) "Tropical trees; variation, breeding and conservation" (Ed. by J.Burley \& B.T.Styles), pp. 109-123. Academic Press, London.

Karschon,R.(1974). The relation of seed origin to growth of Fucalyptus camaldulensis in Israel. Israel Journal of Agricultural Research, 23, pp. 159-173.

Keiding,H.(1973). Status of the incernational provenance trials of teak, Tectona grandis L., October 1973. "Tropical provenance and progeny research and international cooperation" (E.d. by J.Burley \& D.G.Nikles), pp. 300-308, Commonwealth Forestry Institute, Oxford and Queensland llepartment of Forestry, Brisbane.

Kemp,R.H. \& Burley,J.(1975). Depletion and conservation of forest gene resources. Symposium Man and his envorinment. Birming ham University. $14 \mathrm{pp}$.

Martin,B. \& Cossalter,C.(1975-6). The Fucalyptuses of the Sunda Islands. Translations from Bols et Forets des tropiques nos. 163-166 by the New Zealand Forest Service.

Nikles,D.G., Burley,J. \& Barnes, R.D.(1978). Progress and problems of genetic improvement of tropical forest trees. proceedings Joint Workshop I.U.F.R.O. Working partles 2.02.08 and 2.03.01, Brisbane. Commonwealth Forestry Institute, oxford, in press.

Ntima,0.0.(1968). The Araucarias. Fast growing timber trees of the lowl and troplcs. 3 Commonwealth Forestry Institute, Oxford.

0jo,G.0.A. \& Jackson,J.K.(1973). Eucalyptus camaldulensis provenance trials in Nigeria at six years. "Tropical provenance and progeny research and international cooperation." (Ed. by J.Burley \& D.G.Nikles), pP. 273-283. Commonweal th Forestry Institute, Oxford.

Styles,B.T.(1972). The flower blology of the theltaceae and 1 ts bearing on tree-breeding. Silvae Genetica, 21, 149-204.

Styles,B.T.(1976). Studles of variation in Central American pines. I. The tdentity of Pinus oocarpa var. ochoterenat Martinez. Silvae Genetica, 25, 109-117.

Styles,B.T. \& Khosla,P.K.(1976). Cytology and reproductive blology of Meliaceae "Troplcal trees; variation, breeding and conservation." (Ed. by J.Burley \& B.T.Styles), pp. 
61-67. Academic Press, London.

Styles,R.T., Stead,J.W. \& Rolph,K.J.(In press). Studies of variation in Central. Americall Pines. II. Putative hybridization between Pinus caribaea var. hondurensis (Senecl.) Rarr. \& Golf and P. Oocarpa Schiede. Silvae Genetica.

Whitmore,T.C.(1977). A first look at Agathis. Tropical Forestry Papers :11. Commonwealth Forestry Institute, Oxford.

wood,P.J.(1976). The development of tropical plantations and the need for secd and genetic conservation. "Tropical trees: variation, breeding and conservation." (F.d. by J.Burley and B.T.Styles), pp.11-18. Academic Press London. 
SUBJECT INDEX 

Adaptation 76,124

Aerosol 224

Ageing of trees 126

Agro-forestry 9, 512

Animal populations 393, 537 assessment of 440

Bears 404, 406

Benefits, social and environmental 9, 484, 557

Biomass 4, 44, 518 rate of production 132

Birds 403, 406, 417 sungbirds 417

Bryophytes 178, 227, 235, 437

\section{Carrying capacity 437}

Calastrophies $167,489,497$, 518

Clearfelling $13,186,211$, $214,230,267,281,355$, $360,363,399,403,476$, $486,498,520,563$

Climax 82,488

Cline 76

Clone $17,103,112,131$

Competition 82, 132, 157, 201,496

models 158

Conservation $18,189,425$

Cover

animal requirement 435 438

Crown form $85,105,108,125$ 130

Cultivation $32,63,372,377$ techniques $64,486,495$

cuttings 112

\section{Damage}

animals, general 402

deer $403,442,443,455$

Deer 402,500

densicy 460

effects on

establishment 460

home range 437,456

red $432,455,479$

roe 432 venison 461

Digestibility of

vegetation 434

Disease resistance 79, 110

Diversity $14,83,86,181$, $420,426,507$

Dralnage 59, 371, 378, 381

techniques 60

Drought resistance 77,132

Ecosystem 4, 5, 84, 150, 508

estimated productivity 515

resilience 501

stab1lity $86,444,501$, 534

tropical 522

Ecotype 78

Elite tree 103

Epidemics 210, 215, 216

Establishment 26, 197, 457

Evapotranspiration 31,267 , $331,355,356,357,515$

Excraction machinery 478 , 499

Felling

coupe size $394,476,497,498$

effects on vertebrates 394 , 439

effects on insects 214

Fertllization (see also

Nutrient)

$32,65,315,361,467$, 496,548

economics 319

methods of 319

rates of 317,473

retention of 228

supply of 320

time of application 318

tree response to 319,472

types 317

Foliar analysis 51, 240, 320

Forest

age classes within 10,485 497

area in Britain 9

national pollcy 9, 560

Frost resistance 77 
Genetic

base 86

diversity 81,87

gain 105,108

variability $76,106,570$

Geochemical cycle 224

Grazing pressure 435

Ground vegelation 15,178 , $227,400,406,438$

competition with trees 29 , 64

Growing scason, utilization of 85

Growth models 160,522

Harvest index 135

Heredilabilily 106

Humus 63, 274, 474

moder 268

mor 238,268

mull 268

Hybrids

production of 110

Ideotypes $84,86,129$

Intensive culture 18, 125 ,

$168,363,364,401,473$

Interest, rate of 484

Isoenzymes 80

Land

tenure and management 458 use 13

lichens 299

Litter decomposition 230. 261,550

different materials 270 , 272

during plantation cycle 273,280

factors controlling 262

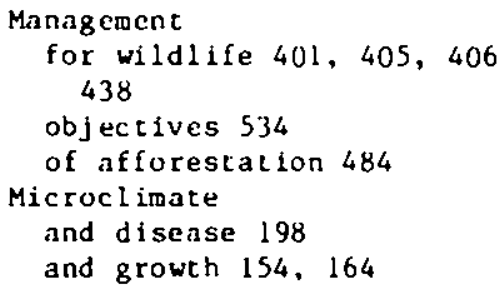

of the forest floor 263

Monoculture 3,486

Mycorrhizae 78, 130, 227,

$279,296,299,549$

ecto- 300

influence on plant

nutrition 301

Natural stands

develuproent of 468

loss of 533

Net discounted revenue 475 N1che $81,83,113,422,492$

Nitrogen fixation 88,227 , $296,297,315$

Nursery, forest 197, 303

Nutrient

accumulation $234,239,268$

availability 28,382

cycle $88,231,238,521$, 535

deficiency 240

input from acrosols 225

leaching of $230,234,262$, 360,364

quantily of uptake 233

release $64,232,234,261$, 274

removal at harvest 230

second rotation

problens 545

supply 42

translocation 238

Pathogens 196, 241

Peat

characteristics for tree growth 59

classification 29,380 , 471

Penman-Monteith equation 331

Photosynthesis 84,132

C3-C4 plants 85,134

Pioneer species $4,83,486$, 511

Planting stock 62, 111, 197

Ploughing 62, 372

Plus tree 103

selection 104

Pollution 
atmospheric 231

in water supplies 229,281

Production

capacity 43,49

potential 42

softwood in U.K. 13

of second rotation 545 , 546

Propagation 111

Provenance $76,77,111,124$. 125, 382, 573

Regeneration $17,186,189$, $403,444,491,511$

Respiration

plant 85

soil 264

Rodents 399, 406

Root

growth $29,59,63,130$, $166,167,238,372$

and resistance to

wind throw 166

Second rotation 199, 211 , 544

Seed $77,107,111$

Seeding, direct 65, 199

Selection forest 488,520

Selection of trees

criterta for $104,124,297$

evaluation of 128

genotypic 107

intensity 107

mass 83,104

phenotypic 78, 106

$r$ and $K 83$

Shade, effect on ground vegetation 182

Shelterwood 3, 500, 509

Short rotations 168, 206. 476

Site

assesswent 26

definition of 41

factors 28,42

index $43,51,151$

prediction 46

speed of 'capture' 127

unit 42,51 utilization 131

Site classification

climatic 26, 535

examples of 35,475

multivartate 48

objectives 27

problems of 53, 152

region 32,48

topographic 29

by vegetation 29,46

wind 31,478

Soil 17, 78, 370, 517, 534

aeration $29,58,61,264$, 279,376

changes in 238

effects on 8 round

vegetation 181

erosion 36

fercility and bird

populations 420

moisture $28,51,58,59$,

$61,165,261,267,279$,

370,490

organic matter 261,519

organisms 237, 261, 276

water storage capacity 355

Soiltypes

brown earth 32,468

gley $377,469,472$

iron pan 33, 371

podzol 32

tropical 520

Stand structure 45, 496, 516 effects on:

assessment of yield 43

bird populations 420

pathogens 196

water economy 338,344

362

wildife habitat 396,398 , 437

yield 156,548

mixed species 87

Stem form 107, 474

Stomata 332,334

Succesion 489,516

Terpene 79

Thicket stage 198, 201, 211

Thinning 13,204, 212, 280, 
$363,398,475,476$

Transpiration $333,357,376$

Tree growt h $62,65,66,152$

Trce selection $27,493,572$

Tropical forests 507, 569

conversion to

monoculture 508, 569

Ungulates 399, 402, 405

Water economy

interception loss 342,356 358

yield $355,358,537$

Water quality 229, 359, 361

Whole tree harvesting 65 , 230

Wildlife requirements 395 , 432

Wind $31,163,331,477$

wind throw $13,17,384,478$, 491,508

causes of 162

hazard classification 33 , 478

effect on wildlife

habitat 426

Winter feeding 442, 558

Wood

consumption 9

ind ustrial demand 12

structure 104, 109, 155

Yield

class 152

harvestable 135

prediction $48,152,160$,

162

tables 44,476 



18 

